BIBLIOGRAPHY OF THE GEOLOGY AND

\title{
MINERALOGY OF TIN
}

-RRANK L. HESS AND EVA HESS

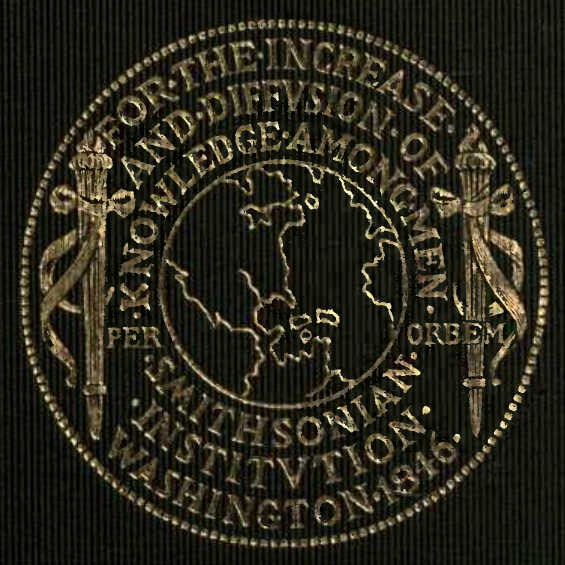




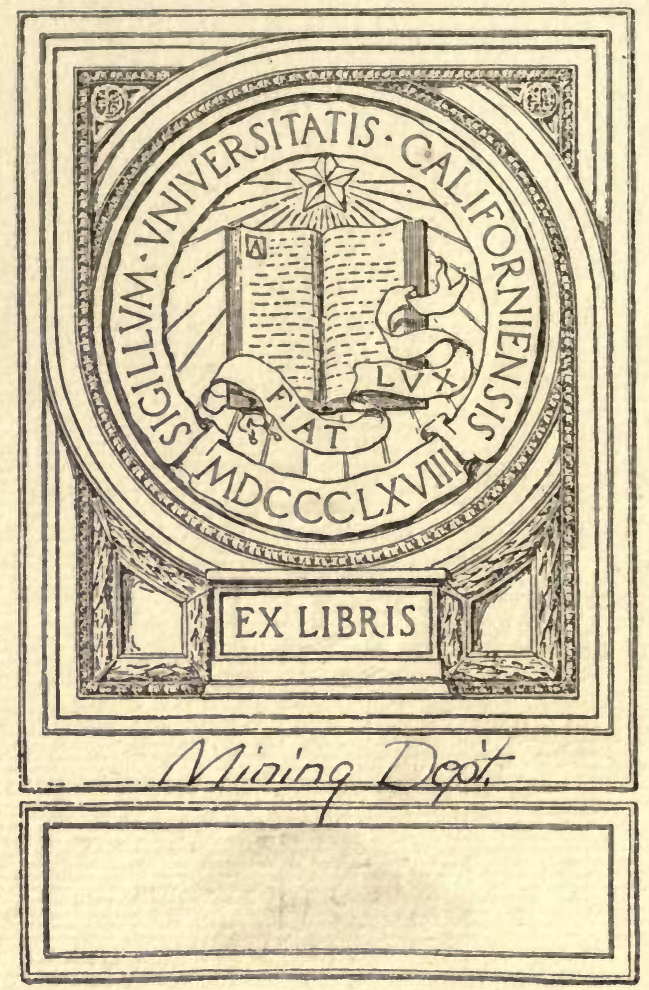




$$
\begin{aligned}
& \text { APtiftomas } \\
& \text { ofpt 4, 19/2 }
\end{aligned}
$$




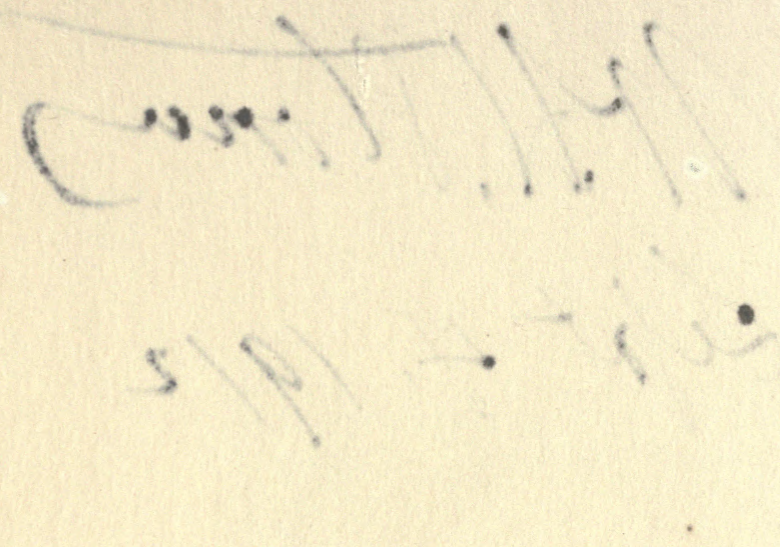




SMITHSONIAN MISCELLANEOUS COLLECTIONS

VOLUME 58 , NUMBER 2

\title{
BIBLIOGRAPHY OF THE GEOLOGY AND MINERALOGY OF TIN
}

\author{
BY \\ FRANK L. HESS and EVA HESS
}

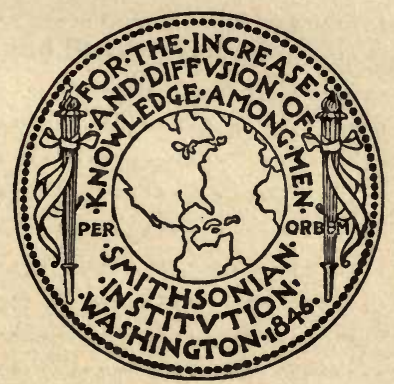

(Publication 1987) ?

CITY OF WASHINGTON

PUBLISHED BY THE SMITHSONIAN INSTITUTION 1912 
$T N 470$

$\mathrm{HA}$

mans over

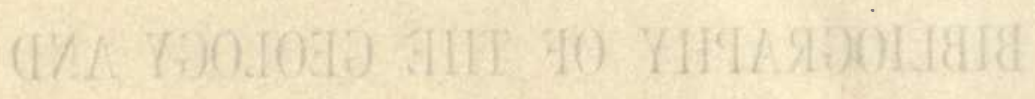

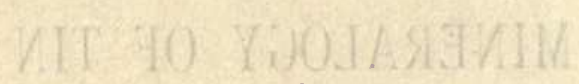

E Be Lord baltimore (Press

Mining Dept.

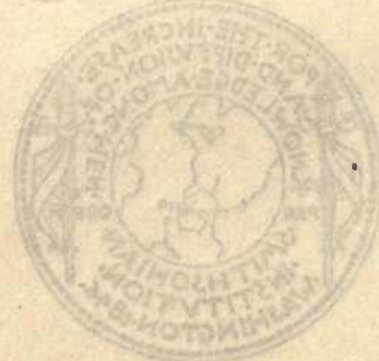

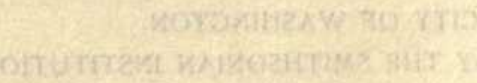

sing 


\section{CONTENTS}

PAGE

Introduction

List of journals and other publications to which reference is made, with

abbreviations used.

I. Bibliography arranged by countries:

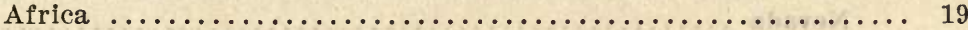

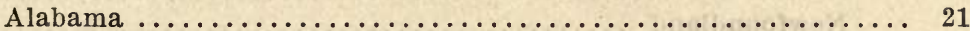

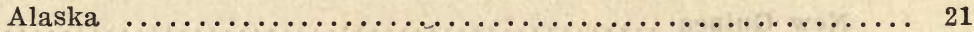

Argentine Republic ........................... 25

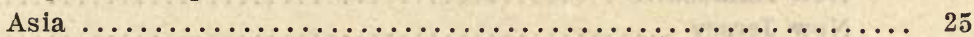

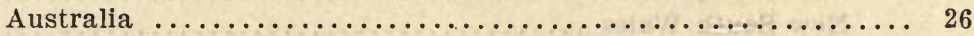

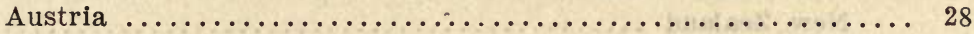

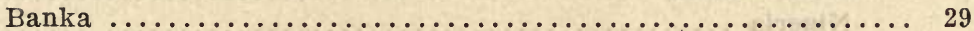

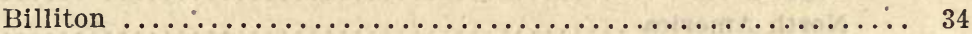

Bolivia ....................................... 36

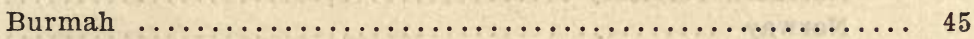

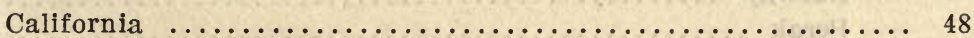

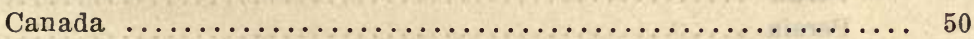

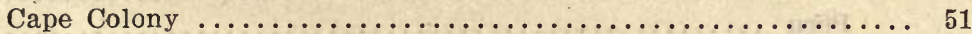

Carolina, North and South..................... 52

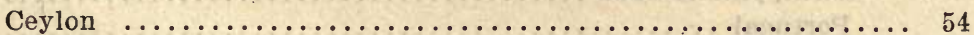

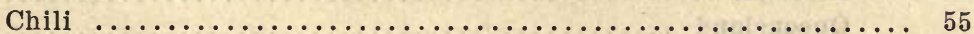

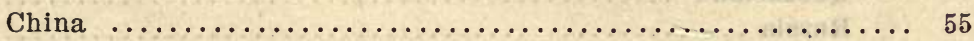

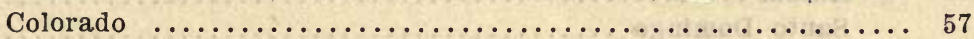

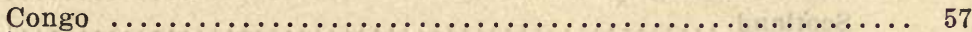

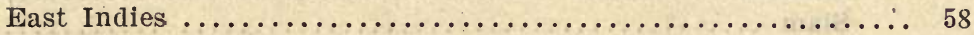

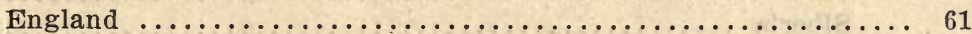

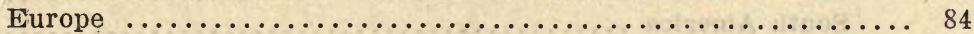

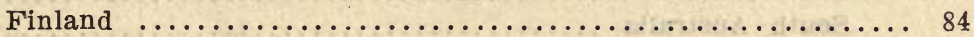

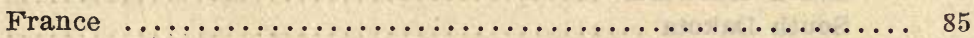

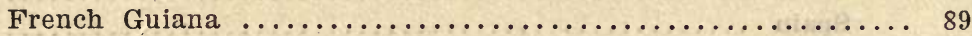

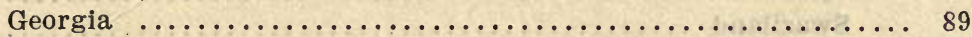

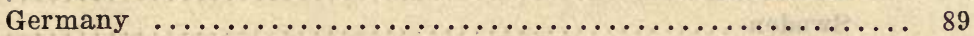

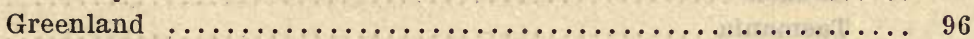

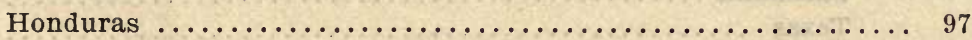

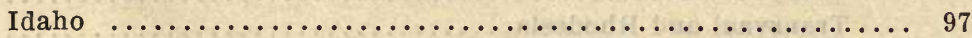

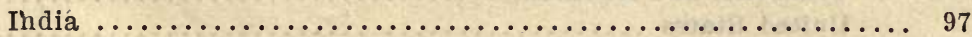

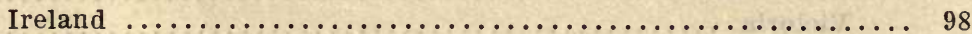

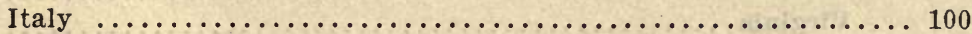




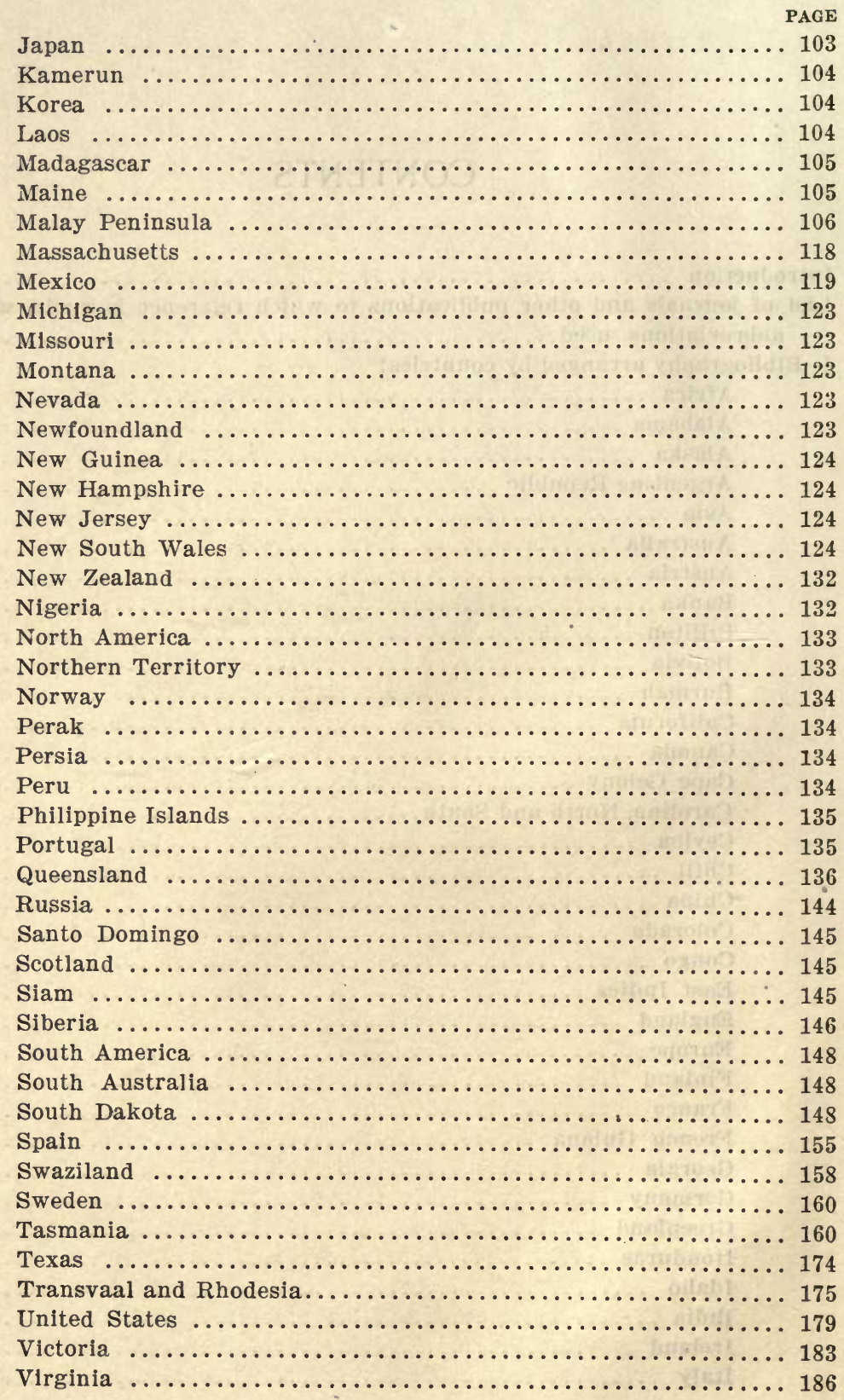




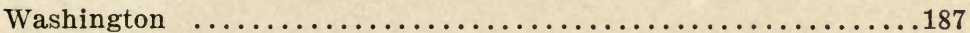

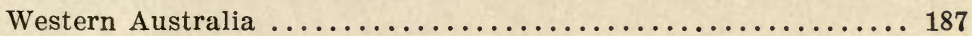

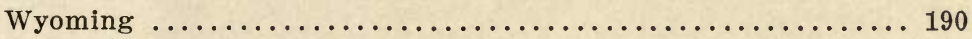

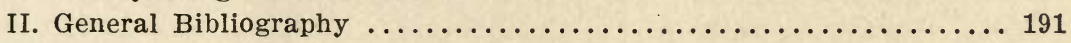

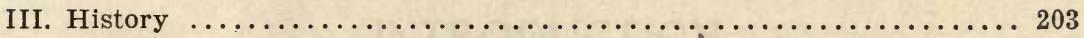

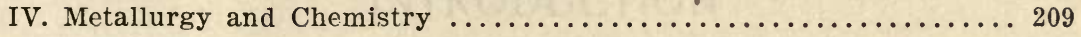

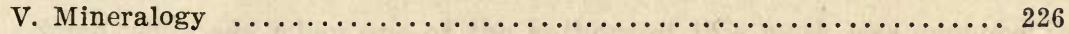

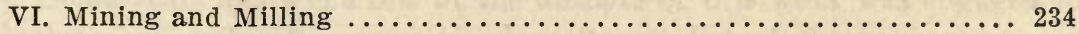

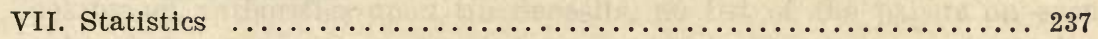

Index (prepared by Lancaster D. Burling) .................. 241 



\section{INTRODUCTION}

Some years ago when one of the authors of this work was engaged in looking up authorities upon tin deposits, no list of the papers on even such noted occurrences as those of Great Britain, Germany, or the Malay Peninsula was to be found, while it required much effort and continued search to find what had been written upon Bolivia and the lesser known localities.

No monographic work covered the field, for many discoveries and great developments had taken place since the appearance of the only comprehensive book, E. Reyer's “Zinn," in 1880, and his bibliographic references were often indefinite and far from complete. There seemed to be real need for an extensive bibliography, and during five years one or both authors have been engaged a considerable part of the time in the collection and digestion of material for such a publication. Since the work was begun Sydney Fawns" "Tin Deposits of the World" has appeared, but the list of authorities given is not extensive.

Owing to the circumstances under which the work was done the notes upon the papers listed do not consistently follow one plan. Little attempt has been made to digest works in foreign languages. Of those in English, some are digested, some have the contents noted, and, in a few cases, where it conveys a good idea of the matter treated, only the title is given.

In digesting articles upon the geology of tin deposits it has been aimed to give, where possible, (a) the country rocks, (b) age, (c) origin of the deposits, (d) accompanying minerals, (e) economic importance, and (f) other details of value.

When desiring to consult the literature of tin deposits it is believed that as a rule persons will wish to know about the tin-bearing veins, dikes, or placers of a particular country or district, and in the arrangement of this bibliography the works are, where possible, placed under the names of the countries in which are located the tin deposits of which they treat. The names of the countries follow each other in alphabetic order, and under each heading names of authors are in similar order. 
Anonymous articles are listed under "Anon." which takes its place in the alphabetic sequence. Where more than one article occurs under "Anon." they are arranged chronologically.

Where deposits in a number of countries are treated in one article, the title is placed under the heading "General."

Works treating preponderantly of the extraction, handling, and reduction of tin ores are placed under "Mining and Milling" and "Metallurgy." The lists given under these subjects are not published with the idea that they are complete and no effort has been made to make them so, but as important articles were met, it seemed best to note them, in the hope that even an incomplete list might be of use to many persons who desire only a certain amount of general knowledge upon the subject. The lists may serve, also, as a nucleus for some who wish to pursue the subject further.

Headings other than "General" and names of countries form a second alphabetic list which follows the list of countries.

In the geological portion of the bibliography it is believed that no important paper upon tin appearing up to the middle of 1908 has been omitted. Following this prefatory note will be found the abbreviations used for journals referred to in the work. The bibliography is classified as follows: I, By Countries; II, General; III, History; IV, Metallurgy and Chemistry; V, Mineralogy; VI, Mining and Milling; VII, Statisties. It is thought that the exhaustive index prepared by Mr. Lancaster D. Burling will supplement the arrangement of articles under countries and make the finding of particular papers comparatively easy.

Frank L. Hess. Eva Hess. 


\section{LIST OF JOURNALS AND OTHER PUBLICATIONS TO WHICH REFERENCE IS MADE, WITH ABBREVIATIONS USED}

Abh. math. phys. Classe kön. bay. Abhandlungen der mathematischAkad. Wiss. physikalischen Classe der königlich bayerische Akademie der Wissenschaften, München.

Actes Soc. sci. Chili...............Actes de la Société scientifique du Chili, Santiago.

Amer. Chem. Journ..............American Chemical Journal, Baltimore.

Amer. Geol............................ Incorporated in 1906 with Economic Geology, Lancaster, $\mathrm{Pa}$.

Amer. Inst. Mg. Eng.............American Institute of Mining Engineers, New York.

Transactions of the American Institute of Mining Engineers, New York.

Bulletin of the American Institute of Mining Engineers, New York.

Bi-monthly Bulletin of the American Institute of Mining Engineers, New York.

Amer. Journ. Sci. Arts.............American Journal of Science and Arts, New Haven. American Journal of Science after Vol. 19, 1880.

Amer. Journ. Mg. Mill. Oilb. Geol. American Journal of Mining, Milling, Min. Met. Oilboring, Geology, Mineralogy, Metallurgy, New York. In 1866 title changed to Engineering and Mining Journal, New York.

Amer. Mfr. Iron World.............American Manufacturer and Iron World, Pittsburg.

Amer. Mg. Rev..................merican Mining Revlew (now Mining Review), Los Angeles.

Amer. Philos. Soc...................... sophical Society, Philadelphia.

Ann. Brit. Geol................... Annals of British Geology. By J. F. Blake, London.

Ann. Chem. Pharm..................nnalen der Chemie und Pharmacie, Heidelberg. 
Ann. Chim. Phys...................nnales de Chimle et de Physique, Paris.

Ann. Gén. Civ............................ du Génie Civil, Paris.

Ann. Indust. nat. étr................nnales de l'Industrie nationale et étrangère, Paris.

Ann. Mines...............................

Ann. New York Acad. Sci...........Annals of New York Academy of Sciences, New York.

Ann. Philos. Mag. Chem. Min. Mech. Annals of Philosophy or Magazine of Nat. Hist. Agr. Arts.

Chemistry, Mineralogy, Mechanics, Natural History, Agriculture and the Arts, London.

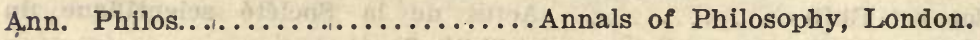

Ann. Physik. Chem...............Annalen der Physik und Chemie, by Julius C. Poggendorff, Leipzig.

Ann. Progr. Rep. Geol. Surv. West- Annual Progress Report of the Geoern Australia. logical Survey of Western Australia, Perth.

Ann. Rep. Board Reg. Smithsonian Annual Report of the Board of ReInstitution. gents of the Smithsonian Institution, Washington, D. C.

Ann. Rep. California State Min.......Annual Report of the Callfornia State Mineralogist, Sacramento.

Ann. Rep. Dep. Mines, New South Annual Report Department of Mines, Wales.

New South Wales, Sydney.

Ann. Rep. Dir. U. S. Geol. Surv........Annual Report of the Director of the United States Geological Survey, Washington, D. C.

Ann. Rep. Geol. Surv. Canada........Annual Report of the Geological Survey of Canada, Ottawa.

Ann. Rep. Geol. Surv. Texas..........Annual Report of the Geological Survey of Texas, Austin.

Ann. Rep. Roy. Cornwall Polyt. Soc...Annual Report of the Royal Cornwall Polytechnic Society, Falmouth.

Ann. Rep. Roy. Inst. Cornwall.........Annual Report of the Royal Institution of Cornwall, Truro.

Ann. Rep. School Mines Zeehan.......Annual Report of the School of Mines Zeehan, Zeehan, Tasmania.

Ann. Rep. Secr. Mines Water Supply.. Annual Report of the Secretary for Mines and Water Supply, Melbourne.

Ann. Rep. Trans. Plymouth Inst. Annual Report and.Transactions of Devon and Cornwall Nat. Hist. Soc. the Plymouth Institution and Devon and Cornwall Natural History Society, Plymouth.

Ann. Rep. Under-Secretary for Mines, Annual Report of the Under-Secretary Queensland.

for Mines, Queensland, Brisbane. 


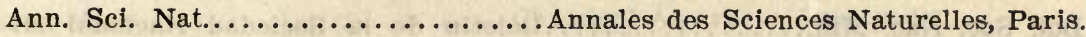
Ann. Soc. géol. Belg..............Annales de la Société géologique de Belgique, Liége.

Ann. Voy................................ Paris. Title changes: Nouvelles Annales des Voyages et des Sciences Geograph1que, Paris.

Arch. Bergb. Hütt...................... für Bergbau und Hüttenwesen.

- By C. J. B. Karsten, Breslau und Berlin. Title changes: Archiv für Mineralogie, Geognosie, Bergbau und Hüttenkunde.

Arch. Miner. Geogn. Bergb. Hütt......Archiv für Mineralogie, Geognosie, Bergbau und Hüttenkunde. By C. J. B. Karsten und H. v. Dechen, Berlin. See also Arch. Bergb. Hütt.

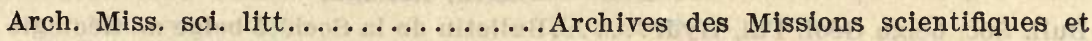
littéraires, Paris.

Atti R. Accad. Lincel. (Trans. or Atti della Reale Accademia dei Lincei Mem.) (Transunti or Memorie), Roma. Ausland. ............................. Austr. Ass. Adv. Sci..............Australasian Association for the Advancement of Science, Sydney.

Austr. Mg. Eng. Rev..............Australian Mining and Engineering Review, Melbourne and Sydney.

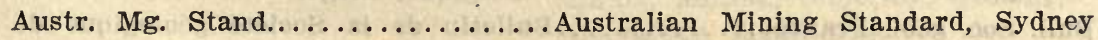
and Melbourne.

Berg. Hütt. Zeit................... und hüttenmännische Zeitung, Leipzig.

Bi-mo. Bull. Amer. Inst. Mg. Eng..... Bi-monthly Bulletin of the American Institute of Mining Engineers, New York.

Bol. Com. Mapa Geol. España.........Boletin de la Comision del Mapa Geologico de España, Madrid.

Bol. Inst. Geol. Mexico.............Boletin del Instituto Geológico de México, Mexico.

Bol. Min. Indust. Constr............ Boletin de Minas Industria y Construcciones, Lima.

Bol. R. Com. geol. Italia............Bollettino Reale Comitato geologico d'Italla, Roma.

Bol. Secr. Fom....................... Mexico.

Bol. Soc. esp. Hist. Nat............Boletin de la Sociedad española de Historia Natural, Madrid.

Bol. Soc. Ing......................... Lima, Peru. 
Bol. Soc. Nac. Min................ Boletin de la Sociedad Nacional Minería, Lima.

British Columbia Mg. Rec...........British Columbia Mining Record, Victoria.

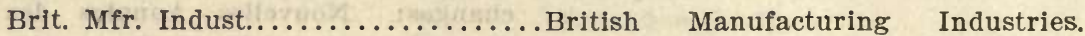
Edited by G. Phillips Beven, London.

Bull. Imp. Inst. Great Britain........ Bulletin of the Imperial Institute of Great Britain, London.

Bull. Inst. Mg. Met............ Bulletin of the Institution of Mining and Metallurgy, London.

Bull. Geol. Surv. Alabama...........Bulletin of the Geological Survey of Alabama, Montgomery.

Bull. Mines Indust. or.............. Bulletin des Mines et de l'Industrie de l'or, Tomsk.

Bull. North Carolina Geol. Surv.......North Carolina Geological Survey, Bulletin, Raleigh.

Bull. Soc. belge Géol. Pal. Hydr....... Bulletin de la Société belge de Géologie de Paléontologie \& d'Hydrologie, Bruxelles.

Bull. Soc. franc. Min.............. Bulletin de la Soclété française de Minéralogie, Paris.

Bull. Soc. Géogr......................tin de la Société de Géographie, Paris.

Bull. Soc. géol. Belgique............Bulletin de la Société géologique de Belgique, Liége.

Bull. Soc. géol. France.............Bulletin de la Société géologique de France, Paris.

Bull. Soc. Híst. nat. Toulouse..........Bulletin de la Sociêté d'Histoire naturelle de Toulouse, Toulouse.

Bull. Soc. Indust. min.............. Bulletin de la Société de l'Industrie minérale, Saint-Etienne.

Bull. Soc. sci. méd. Ouest...........Bulletin Société scientifique et médicale de l'Ouest, Rennes.

Bull. South Dakota Geol. Surv.........South Dakota Geological Survey Bulletin, Vermillion.

Bull. U. S. Geol. Geogr. Surv. Terr.... Bulletin of the United States Geological and Geographical Survey of the Territories, F. V. Hayden, U. S. Geologist-in-charge, Washington, D.C.

Bull. Western Australia Geol. Surv....Western Australia Geological Survey Bulletin, Perth.

Calcutta Journ. Nat. Hist...........Calcutta Journal of Natural History, by McClelland, Calcutta.

California Journ. Techn. .........California Journal of Technology, Berkeley.

Can. Mg. Rev................ The Canadian Mining Review, Montreal. 
Chem. Abs.............................. Eheal Abstracts, Easton, Pa.

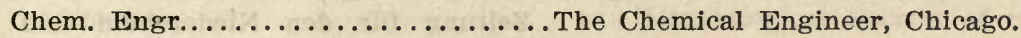

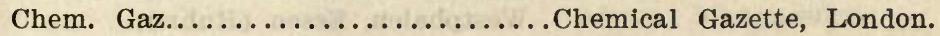

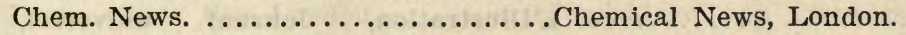

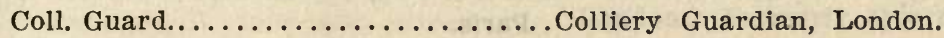

Cienc. Indust..................... Ciencla é Industrias, Buenos Aires.

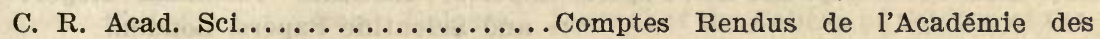

Sciences, Paris.

Dep. Mines Geol. Surv., New South Department of Mines, Geological SurWales.

vey of New South Wales, Sydney.

Dublin Univers. Mag............ Dublin University Magazine, Dublin.

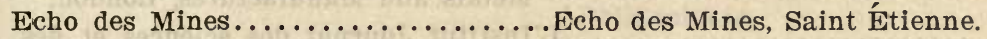

Econ. Geol............................. corporated the American Geologist, Lancaster, $\mathrm{Pa}$.

Edinburgh New Philos. Journ........Edinburgh New Philosophical Journal, Edinburgh.

Electr. Eng................... Electrical Engineer, New York.

Engineer. $\ldots \ldots \ldots \ldots \ldots \ldots \ldots \ldots$ The Engineer, London.

Engineering. . . . . . . . . . . . Engineering, London.

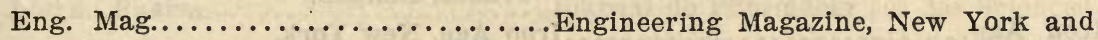
London.

Eng. Mg. Journ...............Engineering and Mining Journal, New York. See American Journal of Mining, Milling, Oilboring, Geology, Mineralogy, Metallurgy.

Eng. News Amer. Railw. Journ.......Engineering News and American Railway Journal, New York.

Erl. geol. Specialkarte Kön. Sachsen.Erläuterungen zur geologischen Specialkarte des Königreichs Sachsen, Leipzig.

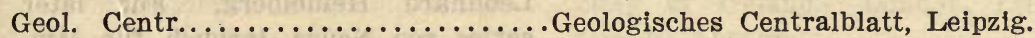

Geol. För. Stockholm Förh..........Geologiska Föreningens i Stockholm - Förhandlingar, Stockholm.

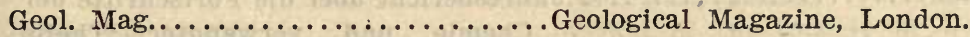

Geol. Minas. ......................... Gía y Minas, Buenos Aires. Title changed in 1909 to Ciencia é Industrias.

Geol. Rec. .................. The Geological Record. Edited by Wm. Whitaker, London.

Ges. Nat. Freunde Berlin Mag. neuest. Der Gesellschaft naturforschender Entd. Ges. Nat. Freunde $z u$ Berlin Magazin für die neuesten Entdeckungen in der Gesammten Naturkunde, Berlin.

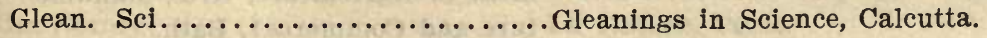


Glück. Berg. hütt. Zeit. Nied. Westph. Gltickauf; Berg- und hüttenmännische Zeitung für den Niederrhein und Westphalen, Essen (Ruhr.).

Illustration L'Illustration, Journal universel, Paris.

Imp. Inst. Tech. Rep. and Sci. Papers. Imperial Institute Technical Report and Scientific Papers, London.

Ind. Eng.................................. Engineering, Calcutta.

Indust. Iron................. Industries and Iron, London. Formerly Iron, the Journal of Science, Metals and Manufactures, London.

Institut L'Institut Journal des sciences et des Sociétés savantes en France et à l'étranger, Paris.

Iron ....................... The Journal of Science, Metals and Manufactures. Continued from 1893 as Industries and Iron, a Journal for the Engineering, Electrical, Chemical and Metallurgical Trades, London.

Iron Age................... Iron Age, New York.

Jaarb. Mijnw. Ned. Oost-Indië.........Jaarboek van het Mijnwezen in Nederlandsch Oost-Indië, Amsterdam.

Jahrb. Berg. Hütt. Kön. Sachsen......Jahrbuch für das Berg- und Hüttenwesen im Königreiche Sachsen, Freiberg.

Jahrb. k. k. geol. Reichs...........Jahrbuch der kaiserlich-königlichen geologischen Reichsanstalt, Wien.

Jahrb. Min. Geogn. Geol. Petr.........Jahrbuch für Mineralogie, Geognosie, Geologie und Petrefactenkunde; von Leonhard Heidelberg. For later series see Neues Jarbuch für Mineralogie, Stuttgart.

Jahr. Chem...................Jahresbericht über die Fortschritte der Chemie und verwandter Theile anderer Wissenschaften, Giessen.

Jern-Kont. Ann...............Jern-Kontorets Annaler, Stockholm.

Journ. Appl. Scl....................................

Journ. Asiat. Soc. Bengal............Journal of the Asiatic Society of Bengal, Calcutta.

Journ. Bath West England Soc.......Journal of Bath and the West of England Society (and Southern Counties Association for the Encouragement of Agriculture, Arts, Manufacture and Commerce), Bath. 
Journ. Chem. Met. Min. Soc. South Journal of the Chemical, Metallurgical Africa. and Mineralogical Society of South Africa, Johannesburg.

Journ. Chem. Soc. London............Journal of the Chemical Society of London. Formerly Quarterly Journal of the Chemical Society.

Jour. College Sci. Imp. Univers. Journal of the College of Science of the Tokyo. Imperial University, Tokyo.

Journ. Elisha Mitchell Sci. Soc. ......Journal of the Elisha Mitchell Scientific Society, Raleigh.

Journ. Franklin Inst............. Journal of the Franklin Institute, Philadelphia.

Journ. Geol...................Journal of Geology, Chicago.

Journ. Geol. Soc. Dublin............Journal of the Geological Society of Dublin, Dublin.

Journ. Indian Arch. East Asia........ Journal of the Indian Archipelago and Eastern Asia, Singapore.

Journ. Mines................................

Journ. Nat. Philos. Chem. Arts.......Journal of Natural Philosophy, Chemistry and the Arts, London.

Journ. Pharm..................Journal de Pharmacie (et des Sciences accessoires contenant le Bulletin des Travaux de la Société de Pharmacie de Paris), Paris.

Journ. prakt. Chem................Journal für praktische Chemie. Otto Linne Erdmann, Leipzig.

Journ. Print. Pap. Parl. Tasmania.... Journal and Printed Papers of the Parliament of Tasmania, Hobart.

Journ. Proc. Roy. Soc., New South Journal and Proceedings of the Royal

Wales. Society of New South Wales, Sydney. Journ. Roy. Geol. Soc. Ireland.........Journal of the Royal Geological Society of Ireland. London, Dublin and Edinburgh.

Journ. Roy. Inst. Cornwall...........Journal of the Royal Institution of Cornwall, Truro.

Journ. Soc. Arts............... Journal of the Society of Arts, London.

Journ. Straits Branch Roy. Asiatic Journal of the Straits Branch of the

Soc. Royal Asiatic Society, Singapore.

Kon. Nat. Tijdschr. Ned.-Indië........Koninklijk Natuurkundig Tijdschrift van Nederlandsch-Indië, Batavia.

Kön. Schwed. Akad. Wiss. Abh. Nat. Königlich Schwedische Akademie der Haush. Mech. Wissenschaften. Abhandlungen aus der Naturlehre, Haushaltungskunst und Mechanik, Leipzig.

La Nature........................... Nature, Paris. 
London, Edinburgh, Dublin Philos. London, Edinburgh and Dublin PhilMag. Journ. Sci. osophical Magazine and Journal of Science, London.

London and Edinburgh Philos. Mag. London and Edinburgh Philosophical Journ. Sci. Magazine and Journal of Science, London.

"Lotos" Zeitschr. Nat. ........... Lotos," Zeitschrift für Naturwissenschaften, Prag.

Mech. Eng.................. The Mechanical Engineer, London.

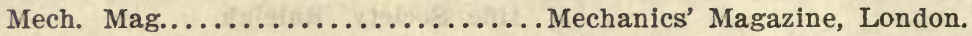

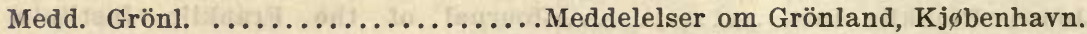

Mem. descr. Carta Geol. Italia..........Memorie descrittive della Carta Geologica d'Italia, Roma.

Mem. Com. Mapa Geol. España........ Memoria de la Comision del Mapa Geologico de España, Madrid.

Mem. Geol. Surv. Great Britain........Memoirs of the Geological Survey of Great Britain, London.

Mem. Geol. Surv. New South Wales.... Memoirs of the Geological Survey New South Wales, Sydney.

Mem. Geol. Surv. Summ. Progr. Memoirs of the Geological Survey. Geol. Surv. United Kingdom and Summary of Progress of the GeoMus. Pract. Geol. logical Survey of the United Kingdom and Museum of Practical Geology, London.

Mem. Soc. Sci. Nat. Arch. Creuse......Memoires de la Société des Sciences Naturelles et Archéologiques de la Creuse, Guéret.

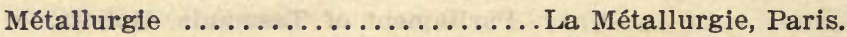

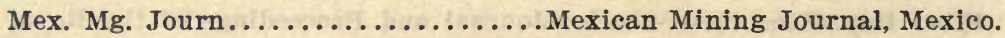

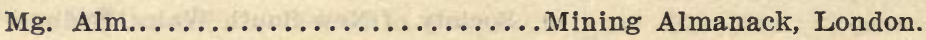

Mg. Ass. Inst. Cornwall............Mining Association and Institute of Cornwall, Truro. Report and Proceedings of Miners' Association and Institute of Cornwall, Truro.

Transactions of the Mining Association and Institute of Cornwall, Camborne.

Mg. Journ. Railw. Comm. Gaz.........Mining Journal, Railway and Commercial Gazette, London.

Mg. Mag. ................................ Magazine, New York.

Mg. Mag. .................................. Magazine, London.

Mg. Rec., British Columbia..........British Columbia Mining Record, Victoria.

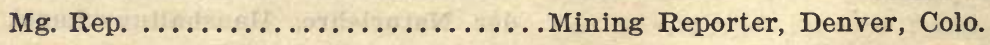

Mg. Rev. .............................. See also American Mining Review. 
Mg. Sci. ........................ Mining Science, Denver.

Mg. Sci. Press.....................nining and Scientific Press, San Francisco.

Mg. Smelt. Mag. Mo. Rev. Pract. London Mining and Smelting MagaMg. Quarry. Met. zine, a Monthly Review of Practical Mining, Quarrying, and Metallurgy, etc., H. C. Salmon, editor.

Mg. World. ...................... Wining World, Chicago.

Mg. World Eng. Rec...............Mining World and Engineering Record, London.

Mines and Min.................. Mines and Minerals, Scranton, Pa.

Min. Ind. ........................neral Industry, New York and London.

Min. Mag. Journ. Min. Soc............Mineralogical Magazine and Journal of the Mineralogical Society, London.

Min. Mitth. .Mineralogische Mittheilungen, von G. Tschermak, Wien.

Min. Proc. Inst. Civ. Eng............ Minutes of Proceedings of the Institution of Civil Engineers, London.

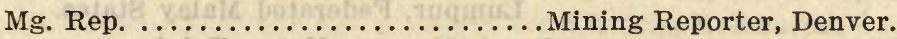

Min. Res. U. S. Geol. Sur............Mineral Resources of United States, published annually by the U. S. Geological Survey, since 1883.

Min. Surv. Ceylon Adm. Rep...........Mineralogical Survey, Ceylon, Administration Reports, Colombo.

Mitth. Jahrb. kön. ung. geol. Anst.... Mittheilungen aus dem Jahrbuche der königlich ungarischen geologischen Anstalt, Budapest.

Mitth. k. k. Techn. Gewerbe-Museums Mittheilungen des kaiserlich-königlichin Wien. en Technologischen Gewerbe-Museums in Wien.

Monatsb. deutsch. geol. Ges........... Monatsberichte der deutschen geologische Gesellschaft, Berlin.

Monogr. U. S. Geol. Surv............Monographs of the United States Geological Survey, Washington, D. C.

Mo. Bull. Int. Bur. Amer. Repub..... Monthly Bulletin of the International Bureau of American Republics, Washington, D. C.

Nat. Hist. Journ. School Rep. ........ Natural History Journal and School Reporter, York.

Nature. ...................... Nature, London.

Neues Jahrb. Min. ...............Neues Jahrbuch für Mineralogie, Stuttgart. For earlier series see Jahrbuch für Mineralogie, Geognosie, Geologie und Petrefactenkunde; von Leonhard, Heidelberg. 
North Carolina Geol. Surv. Bull.......North Carolina Geological Survey, Bulletin, Raleigh.

Northwest Mg. Journ..............Northwest Mining Journal, Seattle.

Not. Indian Archipelago Adj. Countr.. Notices of the Indian Archipelago and Adjacent Countries. By J. H. Moor, Singapore.

Nouv. Ann. Voy. Scl. géogr............ Nouvelles Annales des Voyages et des Sciences géographiques, Paris. Formerly Annales des Voyages, Paris.

Oest. Zeitschr. Berg. Hütt........... Oesterreichische Zeitschrift für Bergund Hüttenwesen, Wien.

Pap. Proc. Roy. Soc. Tasmania....... Papers and Proceedings of the Royal Society of Tasmania, Hobart.

Pap. Proc. Roy. Soc. Van Diemen's Papers and Proceedings of the Royal Land. Society of Van Diemen's Land, Tasmania.

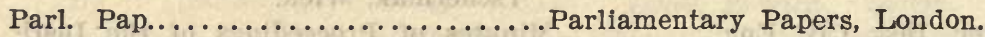

Perak Gov. Gaz........................ Kuala Lumpur, Federated Malay States.

Perak Mus. Notes.......................... Museum Notes, Taiping.

Petermanns Mitth................ A. Petermanns Mitthellungen aus Justus Perthes' Geographischer Anstalt, Gotha.

Philos. Mag...................The Philosophical Magazine, London. Philos. Trans. Roy. Soc. London......Philosophical Transactions of the Royal Society of London, London.

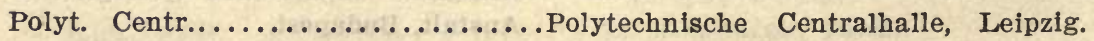
Polyt. Journ.................Polytechnische Journal, Dingler, Stuttgart.

Pop. Sci. Mo.................................. Science Monthly, New York.

Proc. Amer. Mg. Cong...............Proceeding of the American Mining Congress, Denver.

Proc. Amer. Philos. Soc.............Proceedings of the American Philo sophical Society, Philadelphia.

Proc. Boston Soc. Nat. Hist...........Proceedings of the Boston Society Natural History, Boston.

Proc. Chem. Met. Soc. South Africa...The Proceedings of the Chemical and Metallurgical Society of South Africa, Johannesburg. Title changed with Vol. 3, May, 1902, to Proceedings of the Chemical, Metallurgical and Mining Society of South Africa.

- Proc. Chem. Met. Min. Soc. South Africa.
The Proceedings of the Chemical Metallurgical and Mining Saciety of South Africa, Johannesburg. 
Proc. Colorado Sci. Soc.............Proceedings of the Colorado Scientific Society, Denver.

Proc. Geol. Soc. London.............Proceedings of the Geological Society of London, London.

Proc. Geol. Ass................. Proceedings of the Geologists' Association, London.

Proc. Inst. Civ. Eng............. Proceedings Institution of Civil Engineers, London.

Proc. Inst. Mech. Eng............. Proceedings of the Institution of Mechanical Engineers, Birmingham.

Proc. Liverpool Geol. Soc............Proceedings of Liverpool Geological Society, Liverpool.

Proc. Linn. Soc. New South Wales.... Proceedings of the Linnean Society of New South Wales, Sydney.

Proc. Roy. Soc. London.............Proceedings of the Royal Society of London, London.

Prog. Min. Ind. Tasmania...........The progress of the Mineral Industry of Tasmania, Hobart.

Prog. Rep. Geol. Surv. Victoria........Progress Report Geological Survey of Victoria, Melbourne.

Quart. Journ. Geol. Soc. London......Quarterly Journal of Geological Society of London, London.

Quart. Mg. Rev...............Quarterly Mining Review, London.

Queensland Gov. Mg. Journ.........Queensland Government Mining Journal, Brisbane.

Rec. Geol. Surv. India............Records of the Geological Survey of India, Calcutta.

Rec. Geol. Surv. New South Wales..... Records of Geological Survey of New South Wales, Sydney.

Rec. Geol. Surv. South Victoria.......Records of Geological Survey, South Victoria, Melbourne.

Rec. Mines South Australia.........Record of the Mines of South Australia, Adelaide.

Rep. Brit. Ass. Adv. Sci............ Report of the British Association for the Advancement of Science, London.

Rep. California State Mg. Bur.......Report of California State Mining Bureau, Sacramento.

Rep. Dep. Min. Western Australia.... Report of the Department of Mines of Western Australia, Perth.

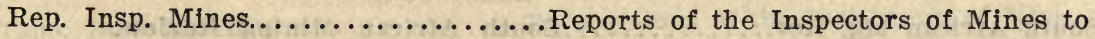
Her Majesty's Secretary of State, London.

Rep. Proc., Min. Ass. Cornwall and Report and Proceedings of Miners' Devon. Association of Cornwall and Devon, Truro. Now Mining Association and Institute of Cornwall, Falmouth. 
Rep. Roy. Inst. Cornwall.......... Report of the Royal Institution of Cornwall, Truro.

Rep. Roy. Cornwall Polyt. Soc........Report on the Royal Cornwall Polytechnic Society, Falmouth.

Rep. Rugby School Nat. Hist. Soc..... Report of the Rugby School Natural History Society, Rugby.

Report Secretary of the Immigration Commission, to the Finance Minister of the Province, No. 119, Buenos Aires.

Rep. Secr. Mines Tasmania..........Report of the Secretary for Mines, Tasmania, Hobart.

Rep. South African Ass. Adv. Sci.... Report of the South African Association for the Advancement of Science, Cape Town.

Rev. Min................................ Minera, Madrid.

Rev. Univ. Mines Mét. Trav. Publ. Revue Universelle des Mines, de la

Sci. Arts Appl. Indust. Métallurgie, des Travaux Publics, des Sciences et des Arts Appliquées à l'Industrie, Liége and Paris.

School Mines Quart................School of Mines Quarterly, New York. Science. $\quad \ldots \ldots \ldots \ldots \ldots \ldots \ldots \ldots$. . . . . . Nence, New York.

Sci. Amer. Suppl................ Scientific American Supplement, New York.

Sci. Proc. Roy. Dublin Soc........... Scientific Proceedings of the Royal Dublin Society, Dublin.

Sel. Rec. Bengal Gov............... Selections from the Records of the Bengal Government, Calcutta.

Sel. Rec. Gov. India............... Selections from the Records of the Government of India, Public Works Department, Calcutta.

Sitz. Kön. bayer. Akad. Wiss.......... Sitzungsberichte der Königlich bayerischen Akademie der Wissen̉schaften, München.

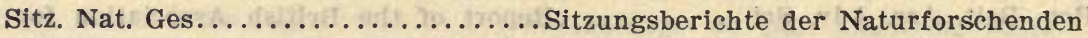
Gesellschaft, Leipzig.

Sitz. Abh. Nat. Ges. "Isis."..........Sitzungsberichte und Abhandlungen der Naturwissenschaftlichen Gesellschaft “Isis," Dresden.

South African Mg. Journ............South African Mining Journal, Johannesburg.

South African Mg. Rev............. South African Mining Review.

South African Mines............... South African Mines, Johannesburg.

South Dakota Geol. Surv. Bull......... South Dakota Geological Survey Bulletin, Vermillion.

Spec. Pub. U. S. Geol. Surv........... Special Publication United States Geological Survey, Washington, D. C. 
Special Report Department of Mines, Melbourne, Victoria.

Summ. Progr. Geol. Surv. United Summary of Progress of the Geological Kingdom. Survey of the United Kingdom, London.

Summ. Rep. Geol. Surv. Dep. Canada.Summary Report of the Geological Survey Department of Canada, Ot. tawa.

Tasch. ges. Min............... Taschenbuch für dle gesammte Mineralogie. Dr. Karl Leonhard, Frankfurt-am-Main. Zeitschrift für Mineralogie, Dr. Karl Leonhard, Heidelberg.

Tasm. Parl. Pap.......................... bart.

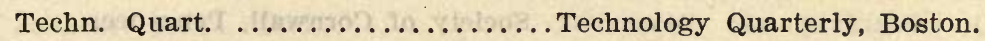

Tijdschr. Ned. Ind..............Tijdschrift voor Nederlandsch-Indië; door van Hoëvell, etc., Batavia.

Times Eng. Suppl. London. .........Times Engineering Supplement, London.

Trans. Amer. Inst. Mg. Eng..........Transactions of the American Institute of Mining Engineers, New York. (General.)

Trans. Austr. Inst. Mg. Eng. ........ Transactions of the Australian Institute of Mining Engineers, Melbourne.

Trans. Cornwall and Devon Min. Ass. Transactions Cornwall and Devon Miners' Association, Camborne.

Trans. Devonshire Ass. Adv. Sci. Lit. Transactions of the Devonshire AssoArt. ciation for the Advancement of Science, Literature and Art, Plymouth.

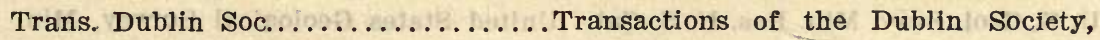
Dublin.

Trans. Fed. Inst. Mg. Eng.......... Transactions of the Federated Institution of Mining Engineers, Newcastle-upon-Tyne, and London.

Trans. Geol. Soc. Glasgow...........Transactions of the Geological Society of Glasgow, Glasgow.

Trans. Geol. Soc. London........... Transactions of the Geological Society of London, London.

Trans. Geol. Soc. South Africa........ Transactions of the Geological Society of South Africa, Johannesburg.

Trans. Inst. Mg. Eng............. Transactions of the Institution of Mining Engineers, London and Newcastle-upon-Tyne. See also Transactions of the Federated Institution Mining Engineers.

Trans. Inst. Mg. Met............. Transactions of the Institution of Mining and Metallurgy, London. 
Trans. Manchester Geol. Soc.........Transactions of the Manchester Geological Society, Manchester.

Trans. Mg. Ass. Inst. Cornwall.......Transactions of the Mining Association and Institute of Cornwall, Cam. horne.

Trans. North of England Inst. Mg. Transactions of the North of England Mech. Eng. Institute of Mining and Mechanical Engineers, Newcastle-upon-Tyne.

Trans. New York Acad. Sci......... Transactions of the New York Academy of Sciences, New York.

Trans. Proc. Roy. Soc. New South Transactions and Proceedings of the Wales. Royal Society of New South Wales, Sydney.

Trans. Roy. Geol. Soc. Cornwall.......Transactions of the Royal Geologlcal Society of Cornwall, Penzance.

Transvaal Mines Dep. Rep. Geol. Surv. Transvaal Mines Department, Report of the Geological Survey, Pretoria.

Trav. Scl. Univ. Rennes............Travaux Scientifiques de l'Université de Rennes, Rennes.

U. S. Geol. Surv..................... States Geological Survey, Washington, D. C.

For publications of, see Ann. Rep. Dir. U. S. Geol. Surv.; Monogr. U. s. Geol. Surv.; U. S. Geol. Surv. Prof. Pap.; U. S. Geol. Surv. Bull.; U. S. Geol. Surv. Min. Res. U. S. Cal. Year; Spec. Publ. U. S. Geol. Surv.

U. S. Geol. Surv. Bull............United States Geological Survey Bulletin, Washington, D. C.

U. S. Geol. Surv. Min. Res. U. S. Cal. United States Geological Survey, MinYear. eral Resources of the United States. Calendar Year, Washington, D. C.

U. S. Geol. Surv. Prof. Pap.......... United States Geological Survey, Professional Paper, Washington, D. C.

Verh. k. k. geol. Reichs............Verhandlungen der kalserlich-könig. lichen geologischen Reichsanstalt, Wien.

Verh. nat. Ver. preuss. Rheinl. Westph. Verhandlungen des naturhistorischen Vereins der preussischen Rheinlande, und Westphalens, und des Regierungs-Bezirks Osnabrück. Bonn.

Verh. russ. kais. min. Ges.......... Verhandlungen der russisch-kalserlichen mineralogischen Gesellschaft, St. Petersburg.

Vid. Medd. nat. Foren. Kjøbenhavn.... Videnskabelige Meddelelser fra den naturhistoriske Forening i Kjøbenhavn. Kjøbenhavn. 
No. 2

Virginias. .......................... Virginias, Staunton, Va.

Western Australia Geol. Surv. Bull... Western Australia Geological Survey Bulletin, Perth.

Zeitschr. Anorg. Chem.............. Zeitschrift für Anorganische Chemie, München und Leipzig.

Zeitschr. Berg. Hütt. Sal. preuss. Sta. .Zeitschrift für das Berg- Hütten- und Salinenwesen in dem preussischen Staate, Berlin.

Zeitschr. deutsch. geol. Ges. ........Zeitschrift der deutschen geologischen Gesellschaft, Berlin.

Zeitschr. Kryst. Min.............Zeitschrift für Krystallographie und Mineralogie, Leipzig.

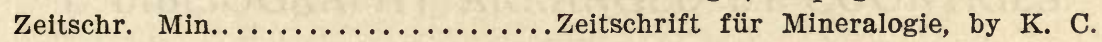
von Leonhard, Frankfurt-am-Main.

Zeitschr. prakt. Geol.............Zeitschrift für praktische Geologie, Berlin. 


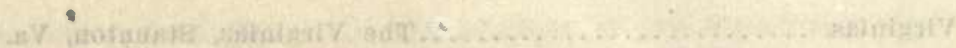

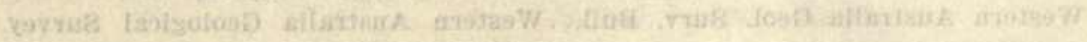
A)

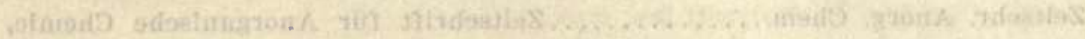

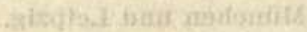

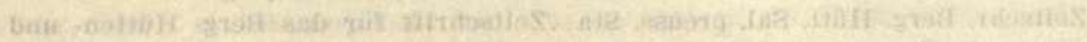

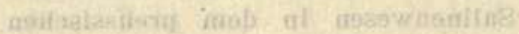

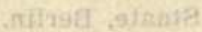

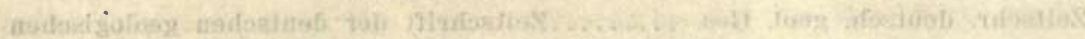

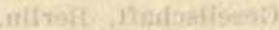

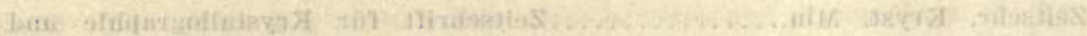

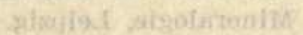

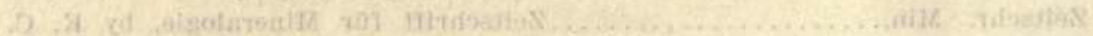

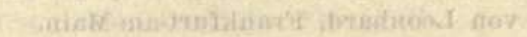

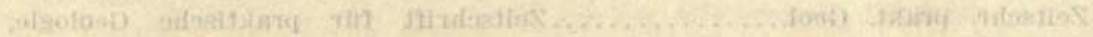
ath +oka 


\title{
BIBLIOGRAPHY OF THE GEOLOGY AND MINERALOGY OF TIN ${ }^{1}$
}

\author{
BY
}

\author{
FRANK L. HESS AND EVA HESS
}

\section{BIBLIOGRAPHY ARRANGED BY COUNTRIES}

\section{AFRICA}

1. BECK, R. Einige Bemerkungen über afrikanische Erzlagerstätten.

Zeitschr. prakt. Geol., Vol. 14, 1906, Berlin, pp. 205-208. 2 figs. of rock sections. The tin deposits of South Africa are treated.

2. Gibson, WALCOT. The geology of Africa in relation to its mineral wealth. Trans. Fed. Inst. Mg. Eng., Vol. 12, 1896-97, Newcastle-upon-Tyne and London, p. 307.

Tin merely mentioned as reported in metamorphic areas of South Africa.

2a. Jorrnson, J. P. The ore deposits of South Africa. Part 1, Base metals. 1908, London, pp. 30-37.

Describes briefly the Rooiberg, Weynek, Doornhoek, Potgietersrust, Welbeloond, Embabaan, and Langerwacht tin deposits.

3. Launay, L. DE. Les richesses minerales de l'Afrique.

1903, Paris, pp. 158-160.

Tin is found on the Benoue, an affluent of the Niger. In the French Congo it is found in the Crystal Mountains, on the Oubanghi and Ouelle Makua, also at Massinga (or Massinda) north of the village of Agapata in the upper basin of the Banghi in a region of Archæan rocks and granite with copper.

In the northeast part of Swaziland near the frontier of the Transvaal, tin has been known for a long time. Deposits at Embabaan only are promising. Though tin veins are present, only the alluvials have been worked.

There has been the following production:

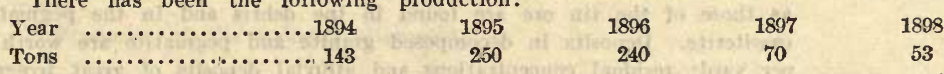

According to Dr. Molengraaff the region is one of mica, talc, chlorite, and amphibolite schists with some quartzites carrying magnetite, similar to the formation at Hospital Hill, Johannesburg. The cassiterite is found, not in the quartz, but in the pegmatite cutting the schists.

Louis, Henry. See No. 1340.

3a. ReckNaget, R. On the origin of the South African tin deposits.

Trans. Geol. Soc. South Africa, Vol. 12, 1909, Johannesburg, pp. 168-202.

Review: South African Mg. Journ., Vol. 7, pt. 2, 1909, Johannesburg, pp. 69-70, 111-112.

${ }^{1}$ It is believed that no important paper upon the geology or mineralogy of tin appearing up to the middle of 1908 has been omitted from this bibliography. 


\section{AFRICA (Continued)}

Holds that the pneumatolytic theory of tin deposits is untenable and attempts to explain the South African deposits on the hypothesis that they are formed by magmatic differentiation or by the combined action of magmatic differentiation and lateral secretion. The South African deposits are individually briefly reviewed.

3b. Rumbold, WM. R. The South African tin deposits.

Bi-mo. Bull. Amer. Inst. Mg. Eng. No. 22, 1908, New York, pp. 601-607, figs. 5. Trans. Amer. Inst. Mg. Eng., Vol. 39, 1909, New York, pp. 783-789.

Describes the Cape Town (Kuils River), Bushveld and Swaziland (Oshoek and Forbes Reef) tin deposits as they appeared in 1904.

At Kuils River crystallized pinkish-gray cassiterite occurs with wolframite in a 5-foot quartz vein cutting granite. Placers have been formed from the vein. At Bushveld cassiterite occurs with quartz in decomposed granite.

The Oshoek deposits are stanniferous hornblende pegmatites and placers derived from them. 'The pegmatites carry garnet, monazite, euxenite, reschynite, and large isolated crystals of cassiterite. In the Forbes Reef deposits cassiterite occurs in an aplite dike and in thin reins cutting schists which carry cinnabar, gold, scheelite, bismuth, monazite, euxenite, æschynite, copper and iron pyrites, pyrrhotite, margarite and tourmaline. Crystals from the veins when scratched, sometimes fly to pieces like Rupert's drops.

The description shows a marked resemblance between some of the South African deposits and some of those near Hill City, South Dakota.

Stokes, Ralph S. G. See No. 730.

3c. Vort, F. W. Uebersicht über die nutzbaren. Lagerstätten Südafrikas. Zeitschr. prakt. Gcol., Vol. 16, 1908, Berlin, pp. 191-216.

A geological study of the economically valuable mineral deposits of South Africa, including gold, diamonds, copper, graphite, tin, monazite, iron ores, magnesite, asbestos, etc.

3d. Weston, E. M. Tin mining and ore dressing in South Africa.

Eng. Mg. Journ., Vol. 89, 1910, New York, pp. 411-413, 470-472, 573-574, pls. 8, cross sections 5 , maps 2.

At Embabaan, Swaziland, tin occurs in "the older granite" cutting Archæan beds composed of mica, chlorite and talc schists, with some ampbibolite and quartzite. The granite shows dioritic phases. Where tin is most plentiful quartz is almost absent in the granite. The coarsest cassiterite occurs in the granite with pegmatite containing blue, white, or yellow quartz. Some cassiterite crystals appear monoclinic and, where twinned, orthorbombic. Pieces of cassiterite weighing $1 / 4$ to $1 / 2$ pound are not uncommon and masses of 8 pounds occur. Ilmenite, mostly in fine grains, corundum, monazite, xschynite, and euxenite in crystals as large as those of the tin ore are found in the debris and in the pegmatite with the cassiterite. Deposits in decomposed granite and pegmatite are worth up to $\$ 1.25$ per yard; residual concentrations and alluvial deposits of great irregularity as to distribution of values, are worked. The flelds are not as large as those of Australia or the Malay Peninsula. Suction dredges may prove profitable. Labor is cheap, material high. Between 1600 and 1700 tons of tin ore have been produced, at a profit of £33 5s.7d. per ton.

Second article describes mode of sluicing. Corundum and monazite are picked from the coarser concentrates.

Third article describes the Waterberg deposits, 100 miles north of Pretoria. Tin occurs in sandstone, granite, felsites and shales near contacts. In the northern part of the fleld the tin is in irregular impregnations in granite; in the southern part it is in pipes. At Zwartkloof decomposed granite carrying about 2s. worth of tin per cubic yard will be hydraulicked. Gives a description of the milling process at the Zaaiplats and Rooiberg mines.

See also Cape Colony, Congo, Kamerun, Nigeria, Swaziland, Transvaal, Madagascar. 


\section{ALABAMA}

4. Anonymous. Tin in Alabama.

Eng. Mg. Journ., Vol. 34, 1882, New York, p. 309.

A communication in which the writer is very hopeful of tin in paying quantities in Alabama.

5. Benedict, WM. de L. Tin in Alabama.

Min. Ind. for 1892, Vol. 1, 1893, New York, pp. 456-457.

Tin is found near Ashland, Clay County. The ore occurs both in lodes and as stream tin, and is reported to exist in considerable quantities. Metal produced from the ore seems to have been a mixture of iron and tin. Work began at the Broad Arrow mines March 1, 1883, but operations do not seem to have been successful, for in July of same year work was stopped.

6. Phillips, WM. B. Occurrence of tin.

Bull. 3, Geol. Surv. Alabama, 1892, Montgomery, pp. 27-30.

Author describes his visit and examination of the tin of Coosa County, Alabama. Crystals sent to A. R. Ledoux \& Co., New York, assayed 78.19 per cent tin.

\section{ALASKA}

7. AdAIR, JAmes B. Tin deposits of the York region, Alaska, and what development shows for the season of 1905 .

Northwest Mg. Journ., Vol. 1, No. 3, 1906, Seattle, pp. 3-5.

U. S. Geol. Surv. reports on the York tin region for 1904 are quoted and from these the results of the development during the season of 1905, are given.

8. Anonymous. Tin in Alaska.

Min. Ind. for 1901, Vol. 10, 1902, New York and London, p. 638.

Buhner Creek and Anikovik River are mentioned as localities where tin has been found. In the first locality stream tin has been concentrated on the bed rock with small amounts of magnetite, limonite, pyrite, fluorite, garnet, and gold.

9. Tin mining in Alaska.

Eng. Mg. Journ., Vol. 76, 1903, New York, pp. 879-880, 150 words.

Brief mention of the discovery of tin in the Lost River district.

10. Alaskan tin production.

British Columbia Mg. Rec., Vol. XI, No. 12, December, 1904, Victoria, p. 434, 300 words.

"Prospects of the industry discussed."

11.

Tin in Alaska.

Eng. Mg. Journ., Vol. 80, 1905, New York, p. 198, 150 words.

The discovery of tin on Seward Peninsula is very briefly mentioned.

12 Alaska.

Mg. World, Vol. 26, 1907, Chicago, p. 154.

The tin outlook in Alaska, which author seenss to think good, is discussed.

$12 \mathrm{a}$. Tin in Alaska.

Mg. Sci., Vol. 59, 1909, Denver, p. 428.

General.

$12 \mathrm{~b}$. Mining in United States during 1908.

Eng. Mg. Journ., Vol. 87, 1909, New York, pp. 101-102.

Brief description of manner of occurrence of Alaskan tin. 


\section{ALASIKA (Continued)}

12c. Tin deposits of Alaska.

Mg. Journ., Railw. Comm. Gaz., Vol. 85, 1909, London, pp. 607-608.

Describes the manner in which tin occurs at Ears Mountain, Buck Creek, Cape Mountain and Lost River.

Anonymous. See T-

13. Beales, R. L. Tin in Alaska.

Mg. Sci. Press, Vol. 89, 1904, San Francisco, pp. 395-396, illus. 3, 1050 words. Describes the occurrence of tin on Seward Peninsula; on Cape Prince of Wales, Buck Creek, and Lost River. Describes present method of working.

14. BeLl, Robert M. Tin ledges in Alaska.

Eng. Mg. Journ., Vol. 76, 1903, New York, p. 820 , 750 words.

Describes the discovery of ledges containing tin ore in the vicinity of Port Clarence, Alaska.

15. - Tin in Alaska.

Mg. Sci. Press, Vol. 87, 1903, San Francisco, p. 351.

Describes the occurrence of tin deposits. Since 1899 placer gold has been found in nearly all the streams of Seward Peninsula and miners in the west end of the peninsula have been finding stream tin in greater or less quantities in the concentrates. In July, 1903, a party of prospectors discovered and located a tinbearing ledge on Lost River, 20 miles west of Teller, which promises to carry good value.

16. BExL, R. N. Tin in Alaska.

Mines and Min., Vol. 24, 1904, Scranton, p. 328.

Reprint: Austr. Mg. Stand., Vel. 31, 1904, Sydney and Melbourne, p. 424.

An account of the tin deposits on Cassiterite Creek, a branch of Lost River, Seward Peninsula.

17. Brooks, A. H. A new occurrence of cassiterite in Alaska.

Science, Vol. 13, 1901, p. 593.

Also published in U. S. Geol. Surv. Min. Res. U. S. for 1900 (1901), Washington, pp. 267-271.

U. S. Geol. Surv. Bull., 213, 1903, Washington, D. C., pp. 92-93.

Reconnaissances in the Cape Nome and Norton Bay regions, Alaska, in 1900. Special publication U. S. Geol. Surv., 1901, Washington, D. C., pp. 136-137.

Extract: Mg. Sci. Press, Vol. 82, 1901, San Francisco, p. 203.

Extract: Mg. Journ. Railw. Comm. Gaz., Vol. 72, 1962, London, p. 1375.

Announces the discovery of stream tin in considerable quantities on Buhner Creek, which enters the Anikovik River from the west about three miles from Bering Sea. A sample of concentrates in one of sluice boxes was examined and yielded the following minerals: cassiterite, magnetite, ilmenite, limonite, pyrite, flourite, garnets and gold. Determination of percentage by weight: tinstone 90 per cent, magnetite 5 per cent, other minerals 5 per cent.

18. . Alaska.

Eng. Mg. Journ., Vol. 79, 1905, New York, pp. 16-18.

An article in which the mineral wealth of Alaska is discussed. Tin is mentioned as having been found in the York region, on Lost River, Cape Mountain, and Ears Mountain, "all of which shows that there is a legitimate field for the tin prospector."

19. Collter, Arthur J. A reconnaissance of the northwestern portion of Seward Peninsula, Alaska.

U. S. Geol. Surv. Prof. Pap. 2, 1902, Washington, D. C., pp. 49-51.

Short description of stream tin and the topography of the country, with theories as to the origin of the stream tin. 


\section{ALASKA (Continued)}

20. - Tin in the York region, Alaska.

Eng. Mg. Journ., Vol. 76, 1903, New York, pp. 999-1000, pl. 1, map.

Gives results of a trip made to investigate the mineral resources of this region. One tin ledge was found, also other minerals of value.

21. - Tin deposits of the York region, Alaska.

U. S. Geol. Surv. Bull., 225, 1904, Washington, D. C., pp. 154-167, map 1.

Extract: Mg. Journ. Railw. Comm. Gaz., Vol. 75, 1904, London, p. 505.

Describes the general geology of the York region and the occurrence and character of stream and lode tin deposits.

22.

\section{Tin deposits of the York region, Alaska.}

U. S. Geol. Surv. Bull. 229, 1904, Washington, D. C., pp. 61, pls. 7, maps 2, figs. 2. Digest: Mg. Mag., Vol. 10, 1904, New York, pp. 131-132.

Abstract: Mg. Sci. Press, Vol. 89, 1904, San Francisco, pp. 106, 125, 142.

Abstract: Neues Jahrb. Min., 1905, II [Ref.], Stuttgart, pp. 179-181.

Description of placers of Buck Creek and lodes of Lost River and Cape Mountain, Seward Peninsula, Alaska, with references to reported occurrences at other places.

Gives a short résumé of the occurrence of tin in other parts of the world.

An elaboration of the article in Bull. 225 (No. 21).

23. - Recent development of Alaskan tin deposits.

U. S. Geol. Surv., Bull. 259, 1905, Washington, D. C., pp. 120-127.

Describes the lode and placer deposits of Seward Peninsula, Alaska. Stream tin in the Fairbanks and Dawson regions is mentioned.

24. Courtis, W. M. Tin in Alaska.

Eng. Mg. Journ., Vol. 73, 1902, New York, p. 143.

A conmunication describing tin placers 12 miles northeast of York.

25. Fay, Albert Hill. Geology and mining of the tin deposits of Cape Prince of Wales, Alaska.

Bi-mo. Bull. Amer. Inst. Mg. Eng., 1907, New York, pp. 769-787, figs. 11, 4 of which are plates.

Abstract: Min. Sci. Press, Vol. 95, 1907, San Francisco, pp. 144-146, figs. 3.

General description of area; climate; vegetation; geology; tin deposits, which he does not consider payable at time of examination; a description of his methods of sampling and fire assaying with KCN. Mining-incomplete account of work done; economic conditions-with table of prices of provisions.

Bibliography of 13 articles on tin at end.

Fawns, Sydney. See No. 1320.

\section{Hess, Frank L. The York tin region.}

U. S. Geol. Surv. Bull. 284, 1906, Washington, D. C., pp. 145-157, fig. 1.

Editorial on same: Mg. World, Vol, 24, 1906, Chicago, p. 658.

Abstract: Iron Age, May 31, 1906, New York.

Digest: Mines and Min., Vol. 27, 1906, Scranton, p. 158.

Epitome of geology, mineralogy and mining development of the tin deposits of Seward Peninsula, Alaska, to the close of the season of 1905 .

27. The York tin region of Alaska.

Eng. Mag., Vol. 32, 1906, New York and London, pp. 352-369, pls. 7, fig. 1. Practically the same article as "The York tin region" in U. S. Geol. Surv. Bull. 284, 1906, Washington, D. C., pp. 145-157, fig. 1.

28. HILl, J. H. Tin deposits of the York region, Alaska.

Northwest Mg. Journ., Vol. 1, No. 4, 1906, Seattle, pp. 1-2.

General article. 


\section{ALASKA (Continued)}

28a. York tin mines.

Northwest Mg. Journ., Vol. 7, 1909, Seattle, p. 79.

"A short historical review of the prospecting and development of the placer tin deposits of Seward Peninsula, Alaska."

28b. JAcoBs, E. Alaskan Mineral Exhibit at A.-Y.-P. exposition.

Eng. Mg. Journ., Vol. 88, 1909, New York, p. 409.

The exhibit of tin ores, placer and lode, is believed to be the largest purely American production ever made on this continent. Quotes Adolph Knopf as saying that up to close of 1908 , the total production of the Seward peninsula tin region was 160 tons of cassiterite concentrates, all of which except a few tons from lode deposits, came from the placers of Buck Creek.

29. Kropf, Adolpr. The Seward Peninsula tin deposits.

U. S. Geol. Surv. Bull. 345, 1908, Washington, D. C., pp. 17.

"This paper summarizes the result of the geologic investigations which have been carried on in the Seward Peninsula since the close of 1906. The known Alaskan tin deposits that are of a character sufficiently encouraging to warrant prospecting, are limited to the extreme western part of Seward Peninsula, and are embraced in an area of abcut 400 square miles."

29a. Geology of the Seward Peninsula tin deposits, Alaska.

U. S. Geol. Surv., Bull. 358, 1908, Washington, D. C., pp. 71, pls. 9. (Including map of western end of Seward Peninsula) and figs. 7.

Describes the geology and mineralogy of the tin deposits of Seward Peninsula, Alaska; mining operations and development; and two new tin-boron minerals, hulseite and paigeite.

29b. - Some features of the Alaskan tin deposits.

Econ. Geol., Vol. 4, 1909, Lancaster, pp. 214-223.

Abstract: Mg. World, Vol. 30, 1909, Chicago, pp. 969-971.

Describes especially the occurrences of tin minerals at Ears Mountain and Lost River, and the occurrence of two new magnesian iron-tin-boron minerals, hulseite and paigeite at Ears Mountain. Stannite occurs at Lost River in an argentiferous vein. Metasomatic replacement has taken place with little regard to the nature of the country rock.

30. Newland, D. H. Tin.

Min. Ind. for 1902, Vol. 11, 1903, New York and London, p. 587.

Buck and Fillery creeks mentioned as containing alluvial tin. In the latter locality, the wash is about 16 inches in depth, and carries about 8 pounds of 60 per cent cassiterite to the cubic yard.

31.

Alaska tin.

Min. Ind. for 1903, Vol. 12, 1904, New York and London, pp. 326-327.

The discovery of lode tin in the Lost River district, about 30 (sic) miles east of Cape Prince of Wales, reported. It occurs in a dike of granite intersecting limestone. The description of tin ore and its occurrence is taken from A. J. Collier's report, U. S. Geol. Surv. Bull. 225, 1904, Waslington, D. C., pp. 154-167.

OHLY, J. See No. 1215.

32. Pavlov, A. W. Ueber die primären Zinnlagerstätten in Alaska.

Bull. Mines Indust. or, No. 2, Bd. 2, 1905, Tomsk, map 1.

Written in Russian. This description is based on A. J. Collier's articles.

33. Rickard, Edgar. Tin deposits of the York region, Alaska.

Eng. Mg. Journ., Vol. 75, 1903, New York, pp. 30-31.

Describes the geology of the region and occurrence of tin. 


\section{ALASKA (Continued)}

34. T- Die Entdeckung von Zinnerzlagern In Alaska.

Berg. Hutt. Zeit., Vol. 60, 1901, Leipzig, p. 434.

Digest: Geol. Centr., Vol. 3, 1903, Leipzig, p. 522.

"Auftreten von Gangen, die Schiefern aufsetzen und enthalten: Magneteisenstein, Titaneisenerz, Brauneisenerz, Schwefelkies, Flusspath, Granat, Gold und vor allem Zinnstein, der dem Gewichte nach 95 per cent der Gangmasse ausmacht. O. v. Linstow.",

Evidently taken from Brooks. Sce reference No. 17.

35. Walcott, C. D. Discovery of tin near York, Seward Peninsula.

25th Ann. Rep. Dir. U. S. Geol. Survey., 1903-1004, Washington, D. C., pp. 79.

\section{ARGENTINE REPUBLIC}

36. Anonymous. Tin in Argentina.

Écho des Mines, Dec. 30, 1907, St. Etienne.

Translated in Mg. Journ. Railw. Comm. Gaz. Vol. 83, 1908, London, p. 6.

Tin has recently been re-discovered in various parts of Argentina. Deposits were formerly exploited by Jesuits, who obtained tin from the outcrops of the veins for bell metal. Cassiterite occurs in small crystals in granulite near Tinogasta (Catamarca), at the village of Mazan. In La Rioja Province, close to the Catamarca frontier, a company is at work with 100 miners on a stockwerk of small veins occurring in altered granulite dikes. Surface ore gave 7 per cent tin, but in depth the per cent fell to 1 and 11/2. Mining is cheap and easy; the country is fairly watered, well wooded and fertile.

37. Castro, Mariano Salas. Mining in the Province of Salta.

Rep. Secr. of the Immigration Commission, to the Finance Minister of the Province. No. 119. Published in Spanish, English and German, Buenos Aires, [no date], pp. 1-16, map 1.

Tin, gold, silver, coppper and lead deposits reported in departments of Chicoana and La Poma, Province of Salta, Argentine Republic. Bismuth was worked in 1889 in a ravine called Agamillos. Vein said to be six and a half feet wide and forty-four yards deep.

38. Hoskold, H. D. Report upon the mines, mining, metallurgy and mining

laws, etc., etc., of the Argentine Republic.

Natl. Sect. Mining and Geology, 1904, Buenos Aires, pp. 142-143.

States that cassiterite was found some years since near Tinogasta, Catamarca. After a few tons were mined the vein pinched out. Stream tin had recently been found in a small stream at Mazan, northeast of Chilecito, 6 miles from the frontier line of Catamarca.

\section{ASIA}

39. Fiscier, H. Ueber Zinnerze, Aventuringlas und grünen Aventurinquarz aus Asien, sowie über Krokydolithquarz aus Grlechenland.

Neues Jahrb. Min., 1882, II, Stuttgart, pp. 90-92.

40. Hermans, [?]. Native tin.

Journ. prakt. Chem., Vol. 33, Leipzig, p. 300.

Abstract: Amer. Journ. Sci. Arts, ser. 2, Vol. 2, 1846, New Haven, p. 415.

"According to Hermann, native tin occurs in the gold washings of the Ural (Central Asia) in small gray metallic grains containing also some lead."

See also under Burmah, Ceylon, China, East Indies, India, Japan, Laos, Malay Peninsula, Siam, Persia, Philippine Islands. 


\section{AUSTRALIA}

41. Axoxymous. More Australian tin.

Iron, Vol. 5, 1875, London, p. 551. Digest from Geol. Rec., for 1875, London, p. 147.

" Records the discovery of a sample of stream tin ore, weighing about 10 pounds, intermingled with $1 / 2$ ounce of rough reef gold, at the foot of Mount Pilot, New South Wales. The geological formation consists of superficial deposits of granite."

42. Australian tin at the Philadelphia Exhibition.

Eng. Mg. Journ., Vol. 22, 1876, New York, pp. 72-73, 87.

An account of the development and description of the deposits of the tin producing districts.

43.

\section{Australia.}

Min. Ind. for 1899, Vol. 8, 1900, New York and London, pp. 620-621.

Description of alluvial tin deposits on northern coast of New South Wales. Herberton field, Queensiand, produced about $\$ 1,000,000$ worth of stream tin from 1883 to 1894 and nearly $\$ 5,000,100$ worth of lode tin. Discovery of lode tin reported at Sebastopol, Victoria.

44. The Planet tin mines.

Austr. Mg. Stand. April 5, 1900, Sydney and Melbourne.

Not available to the authors.

45. - Tin in Australia.

Min. Ind. for 1901, Vol. 10, 1902, New York and London, pp. 639-641.

New South Wales, Northern territory, Queensland, South Australia, Tasmania and Western Australia tin deposits briefly treated.

46. - Australian tin and tin mining.

Mg. Journ. Railw. Comm. Gaz., Vol. 72, 1902, London, p. 225.

Tin deposits are scattered widely over Australia, there being more than 120 known tin localities in New South Wales alone. Tin was discovered in 1851, but not until 1872 were mining operations begun. Native tin has been found in New South Wales. A brief description of occurrences on a number of creeks, and amount of tin mined and exported.

- See also $\mathrm{E}-\mathrm{C}$.

Beck, Richard. See No. 1299.

47. Bexedict, WM. DE L. Tin in Australia.

Min. Ind. for 1892, Vol. 1, 1893, New York and London, pp. 442-445.

General survey of the tin deposits of Australia, including New South Wales, Queensland, Victoria, Western Australia and Tasmania.

The tin bearing granite of Australia appears to be closely allied to that of other countries, and has been described as exactly corresponding to that of Cornwall.

48. Cogmuan, T. A. Tin. A statistical account of the seven colonies of Australasia, 1899-1900.

1900, Sydney, pp. 569-572, map 1.

Daubré, A. See No. 1314.

Diest, P. H. van. See No. 1478. 


\section{AUSTRALIA (Continued)}

49. E-, C. The Australian tin mines.

Mg. Journ. Railw. Comm. Gaz., Vol. 44, 1874, London, pp. 396, 507, 643, 751, 833, 973, 1057, 1281, 1394; Vol. 45, 1875, pp. 71, 287.

Mostly statistics of tin production.

50. English, A. G. On Australian and Tasmanian tin.

Mg. Journ. Railw. Comm. Gaz., Vol. 45, 1875, London, p. 19.

Stream tin has been worked in the neighborhood of Ovens, Victoria, for many years in conjunction with gold, also near Albany. Deposits light, would scarcely pay if not accompanied by gold. Stream tin has been found in creeks and rivers in Gippsland. Country is unexplored as yet; cannot predict as to lodes. In the Inverel district of New South Wales, considerable deposits of tin have been worked with varying success. In Queensland, at Stanthorpe, is the largest and most promising deposit of tin. Chief deposit of Tasmania is at Mount Bischoff, 35 miles from Emu Bay, on northwest coast, a mountain 3000 feet above sea level, evidently of volcanic origin, surface stone is composed of decayed granite, porphyry, and quartzose rock, through which tin is disseminated. Wash dirt varies from 3 to 40 feet deep. No overburden beyond a foot or two. Purely lode tin. Probably deposited by some volcanic action. Near the mountain pieces of lode weighing from 1 pound to $1 \frac{112}{\mathrm{cwt}}$. are found; not water worn, and very pure. Assays from 70 to 73 per cent.

FAwns, Sydney. See No. 1320.

Fuchs, E., and Launay L. DE. See No. 1323.

51. Johnson, J. C. F. Getting gold. A practical treatise for prospectors, miners, and students.

1897, Philadelphia and London, pp. 32-33, 600 words.

Short description of the occurrence of tin ore. Confined to Australian examples.

Lock, C. G. WARNFond. See No. 1338.

Louis, Henry. See No. 1340.

52. Mance, F. S. Eastern States of Australia.

Eng. Mg. Journ., Vol. 81, 1906, New York, p. 36.

Reviews tin mining in Queensland, New South Wales and Tasmania, during 1905.

53. Meunier, Stanislas. Sources minérales de l'Australasie (Minerais d'étain de formation actuelle).

Bull. Soc. belge Géol. Pal. Hydr., Vol. 5, 1891, Bruxelles, pp. 8-11.

54. Newland, D. H. Tin in Australia.

Min. Ind. for 1903, Vol. 12, 1904, New York and London, pp. 327-329.

Output and value of tin product during 1903.

55. Newton, E. Writon. The metalliferous minerals of Australia.

59th Ann. Rep. Roy. Cornwall Polyt. Soc., 1891, F́almouth, pp. 117-131.

Treats of the mineral resources of South Australia, New South Wales, Victoria, Queensland, Western Australia, Tasmania and New Zealand, including tin.

Phillits, J. A., and Louis, H. See No. 1350.

56, Plummer, Jorn. Australian tin and tin mining.

Iron Age, Feb. 6, 1902, New York, p. 9, 900 words.

Treats of the location of the deposits, and the extent to which they have been worked. 


\section{AUSTRALIA (Continued)}

57. REYer, EDUARD. Zinn in Australien und Tasmanien.

Oest. Zeitschr. Berg. Hütt., Vol. 28, 1880, Wien, pp. 47-49, 61-63, 74-76, 85-87.

- See No. 1354.

58. Robertson, J. R. M. The bismuth and tin deposits of Australia.

Trans. Geol. Soc. Glasgow, pt. 1, Vol. 7, 1881-1884, Glasgow, pp. 126-127, 133-142, map.

An account of the origin of the alluvial tin of Australia.

59. Stephen, D. Australian and Tasmanian tin ore.

Mg. Journ. Railw. Comm. Gaz., Vol. 49, 1879, London, p. 191.

Gives tin statistics for years 1877 and 1878, showing a decrease of production.

Thibault, P. J. See No. 1578.

60. Tregay, W. Australian and Tasmanian tin.

Mg. Journ. Railw. Comm. Gaz., Vol. 48, 1878, London, p. 212.

61. Vale, Stephen S. Australian tin deposits.

Trans. Mg. Ass. Inst. Cornwall, Vol. 1, 1887, Camborne, pp. 30-44, map.

General description.

Weeks, Josepri D. See No. 1372.

62. WoLfF, G. Australisches Zinn.

Berg. Huitt. Zeit., Vol. 34, 1875, Leipzig, pp. 2-3, 12-14, 24-26, 29-30.

Mit einer Plan-Skizze auf Taf. 1.

Abstract: Oest. Zeitschr. Berg. Hutt., Vol. 23, 1875, Wien, pp. 287-288.

63. Woops, J. E. T. Tin in Australia.

Mg. Journ. Railw. Comm. Gaz., Vol. 49, 1879, London, p. 225.

Extracts from two letters in which author states that he thinks Australian tin, aside from Mount Bischoff, is of little value.

See under New South Wales, Northern Territory, Queensiand, South Australia, Tasmania, Victoria, Western Australia.

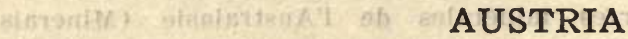

64. ANonymous. Tin in Bohemia.

Mg. World, Vol. 26, 1907, Chicago, p. 509.

A brief notice of the re-opening of an old tin mine in Bohemia, about 15 miles from Carlsbad. The lodes contain wolfranite as well as tin. The new operators are erecting a 100-ton mill, which will be equipped with a magnetic scparator and other appliances for recovering both the tin and wolframite.

Charleton, Arthur G. See No. 1310.

65. CotтA, B. von. Ueber die Zinnerzlagerstätten von Graupen in Böhmen. Berg. Hütt. Zeit., Vol. 23, 1864, Leipzig, pp, 117-118.

Daubree, A. See No. 1314.

66. Fuchs, E., and Launay, L. DE. Traité des gîtes minéraux et métallifères. Vol. 2, 1803, Paris, pp. 127-136.

Treats of tin in Saxony and Bohemia. 


\section{AUSTRIA (Continued)}

Groddeck, Albert. See No. 549.

67. Hallwicir, H. Geschichte der Bergstadt Graupen in Böhmen. 1868, Prag.

Schiller, Ph., and Lewald, P. The occurrence of tin ore at Graupen and Upper Graupen, and the manner of mining in ancient and modern times.

JARs, G. See No. 416.

68. Jokєц, Jor. Das Erzgebirge im Leitmeritzer Kreise in Böhmen. Jahrb. k. k. geol. Reichs., Vol. 9, 1858, Wien, pp. 549-574, geol. map 1.

1. Zinnerze. 2. Zinnerz gänge im grauen Gneiss. 3. Zinnerz gänge im Felsitpoiphyr. 4. Zinnerz im Greisen.

69. Laube, Gustav C. Mittheilungen über die Erzlagerstätten von Graupen in Böhmen.

Jahrb. k. k. geol. Reichs., Vol. 14, 1864, Wien, pp. 159-178, fig. 1.

LEWALD, P. See reference No. 67.

70. Newland, D. H. Tin in Austria.

Min. Ind. for 1903, Vol. 12, 1904, New York and London, p. 329.

Tin production for 1903 was 34 metric tons valued at $\$ 21,918$.

71. Nowicki, Constantin von. Das Vorkommen des Zinnsteins bei Schlaggenwald und Schönefeld.

“Lotos," Zeitschr. Nat., Vol. 7, 1857, Prag, pp. 106-112.

Phillips, J. A., and Louis, H. See No. 1350.

Schiller, Ph. See No. 67.

Schultz, - See No. 573.

72. Vogelsang, - Berg- und hüttenmännische Mitteilungen über Böhmen.

Zeitschr. Berg. Hütt. Sal, preuss. Sta., Vọ. 10, 1862, Berlin, pp. B-164-165.

Describes the mining and smelting of tin in Schlaggenwald Bohemia.

See also Bohemia, Saxony, etc.

\section{BANKA}

73. AkkeringA, J. E. Rapport van het distrikt Blinjoe, eiland Bangka.

Jaarb. Mijnw. Ned. Oost-Indië, 1863 (1872), I, Amsterdam, pp. 41-148, I kaart en vijf bijlagen,

\section{- See No. 110.}

74. ANonymous. The tin mines of Banca.

Mg. Journ. Railw. Comm. Gaz., Vol. 19, 1849, London, p. 178.

Amer. Journ. Sci. Arts, ser. 2, Vol. 8, 1849, New Haven, pp. 291-292.

Brief history of early tin mining in Banca, and mining methods used at time of writing.

75. - Exploitation du mineral d'étain a Banca.

Rev. Univ. Mines Mét. Trav. Publ. Sei. Arts Appl. Indust., ser. 1, Vols. 23, 24, 1868, Liege and Paris, pp. 411-412. 


\section{BANKA (Continued)}

76. The Banca tin mines.

Iron Age, Vol. 35, 1885, New York, p. 31.

Description of deposits and manner of working them by the Chinese.

77. The best deposits of tin.

Mg. Sci. Press, Vol. 66, 1893, San Francisco, p. 52.

The stanniferous deposits of Banca and Billiton are said to be the best tin deposits in the world. An analysis of Banca metal gave:

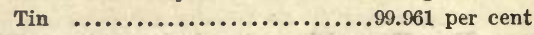

Iron $\ldots \ldots \ldots \ldots \ldots \ldots \ldots \ldots . . . . .00 .019$ per cent

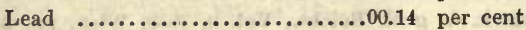

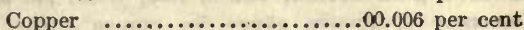

There are 200 mines worked in Banca by private companies, while $1 / 2$ of that number are exploited by the Dutch Government. Mines of Billiton are in possession of a private concern, which pays a royalty to the government of 3 per cent of annual yield.

78. Wetten, Gouvernements-Besluiten en Bepalingen betreffende het Mijnwezen in Nederlandsch-Indië.

Jaarb. Mijnw. Ned. Oost-Indië, 1894, Tech. and Admin., Amsterdam, pp. 211-239, Treats of the methods of tin mining in Banka.

79. —. Tin in Banka.

Min. Ind. for 1897, Vol. 6, 1898, New York and London, p. 640.

Verbeek (Zeitschr. prakt. Geol., 1897, Berlin, p. 428) is authority for the statement that the duration of the tin deposits of Banka and Billiton is limited. Up to the time of writing, Banka had produced $7,000,000$ piculs of tin, and the existing supply amounted to only about $3,000,000$.

80. - Tin in Banka.

Min. Ind. for 1899, Vol. 8, 1900, New York and London, p. 621.

Mines have been under government control since 1832. Output in 1897 was 9307, raising to 10,220 tons in the succeeding year.

81. - Toepassing van graafwerktuigen bij de tinwinning op Banka. 1907, Batavia, pls. 13.

Not available to the authors.

82. Веск, R. Die Zinnerzlagerstätten von Banka und Billiton.

Zeitschr. prakt. Geol., 1898, Berlin, pp. 121-127.

Review of R. Verbeek, Geologische Beschrijving van Bangka en Billiton. Jaarb. Mijnw. Ned. Oost-Indië, 1897, Amsterdam.

Beck's article digested: Neues Jahrb. Min., 1899, II, Stuttgart, pp. 266-267.

83. Benedict, WM. de L. Tin in East Indies.

Min. Ind. for 1892, Vol. 1, 1893, New York and London, pp. 445-446.

Occurrence of tin in island of Banca and Billiton described. Production from islands from 1880 to 1892 given.

84. BoEns, R. J. Over het gebruik van krachtinstallaties tot grondverzet bij de tinontginning op het eiland Banka.

(On the application of power machinery for the working of tin ground in the island of Banka.)

Jaarb. Mijnw. Ned. Oost-Indie,, Vol. 32, 1903, Batavia, pp. 190-218. With 3 Append.,

illus. 7, and pls. 5 .

85. BRedemeyer, W. Tin mining in Banca.

Mg. Sci. Press, Vol. 25, 1872, San Francisco, p. 21.

Digest: Oest. Zeitschr. Berg. Hütt., Vol. 21, 1873, Wien, p. 76. 


\section{BANKA (Continued)}

86. Condes, J. H. Rapport van het distrikt Pangkal-Pinang, eiland Bangka. Jaarb. Mijnw. Ned. Oost-Indië, 1876 (1878), I, Amsterdam, pp. 89-126. Met eene kaart en twee bijlagen.

87. - Rapport over het onderzoek naar het delfstoffelijk productief vermogen van het distrikt Koba eiland Bangka.

Jaarb. Mijnw. Ned. Oost-Indië, 1883 (1885), I, Tech. and Admin., Amsterdam, pp. 67-115. Met eene kaart en twee bijlagen.

88. Cretier, H. Tinhoudend metaal, tinslak en tinertszand van het zeestrand bij Soengei Liat, district Muntok, residentie Banka.

Jaarb. Mijnw. Ned. Oost-Indië, 1888, Weten. Ged., Amsterdam, pp. 113.

89. Croockewiт, J. H. Scheikundig onderzoek van tinerts, afkomstig v. $h$. eiland Banka.

1853, Batavia, pp. 14.

Not available to the authors.

See No. 1473.

90. Diest, P. H. van. Inleiding tot de geognostische mijnbouwkundige rapporten der distrikten van Bangka.

Jaarb. Mijnw. Ned. Oost-Indië, 1872, I, Amsterdam, pp. 3-40.

91. Rapport van het distrikt Soengeileat, eiland Bangka. Jaarb. Mijnw. Ned. Oost-Indië, 1862 (1872), II, pp. 3-71. 1 kaart en vijf bijlagen.

92. - Rapport van het distrikt Merawang, elland Bangka. Jaarb. Mijnw. Ned. Oost-Indië, 1861 (1873), I, Amsterdarn, pp. 3-75. Met eene kaart.

93. - Verslag der onderzoekingen aan den heuvel Sambong Giri, eiland Bangka.

Jaarb. Mijnw. Ned Oost-Indië, 1873, I, Amsterdam, pp. 187-193. Met eene kaart en twee platen.

94. - Banca and its streams works.

Translated from Dutch by Foster, O. Le Neve, 1867, Truro.

Not available to the authors.

95. DiJK, P. VAN. Uitkomsten der waarnemingen omtrent eenige onderdeelen der Chineesche ontginningswijze van het tinerts op Bangka, getrokken uit officieele nota's van het jaar 1878 en medegedeeld.

Jaarb. Mijnw. Ned. Oost-Indië, 1879, II, Amsterdam, pp. 55-91.

96. - Berekening van de verhounding tusschen de grens van ontginbaarheid der tinertsafzettingen op Bangka en het loon van den Chineeschen mijnwerker (tinprijs, inkoopprijs). Bepaling van beiden, zoodanig dat de te behalen winst op de tinontginning een maximum zij. Jaarb. Mijnw. Ned. Oost-Indie, 1882, II, Amsterdam, pp. 349-366.

97. DoRer, J. Vrijmoedige beschouwingen tegen het afstaan van de tinmijnen op Banka aan departiculiere industrie.

1850, Gravenhage.

Not available to the authors. 


\section{BANKA (Continued)}

98. EverwiJn, R. Verslag van een onderzoek naar tinaders in het distrikt Djeboes, elland Bangka.

Jaarb. Mijnw. Ned. Oost-Indië, 1873, I, Amsterdam, pp. 151-155. Met twee kaartjes.

99. Fraenket, S. Bljdrage tot de kennis der tinmijnen van Banka.

1843, Batavia.

Not available to the authors.

Foster, C. Le Neve. See No. 94.

Fuchs, E., and Launay, L. DE. See No. 1323.

100. Godefroy, W. Eene verbeterde steekboor (kogelklep-steenboor) voor het onderzoek op tinerts op Bangka.

Jaarb. Mijnw. Ned. Oost-Indië, 18s4, II, Tech., Amsterdam, pp. 324-333.

101. Groot, C. DE. Rapport over de tin-slakken (tra), welke op Bangka onbenuttigd worden weggeworpen.

Jàarb. Mijnw. Ned. Oost-Indië, 1854 (1878), II, Amsterdam, pp. 29-98.

102. Hooze, J. A. Graphische voorstelling der productie, veilingsprijzen en geldswaarde van Bangka-tin.

Jaarb. Mijnw. Ned. Oost-Indië, 1881 (1882), II, Tech., Amsterdam, pp. 83-87. Met 2 staten en 2 graphische voorstellingen.

103. Horsfeld, Thomas. Mineralogical description of the island of Banca. Journ. Indian Arch. East. Asia, Vol. 3, No. 7, 1848, Singapore, p. 398.

Review: Amer. Journ. Sci. Arts, 2d ser., Vol. 7, 1849, New Haven, pp. 86-101.

104. Huguenin, J. A. Rapport van het district Toboali, elland Bangka.

Jaarb. Mijnw. Ned. Oost-Indië, 1869 (1877), I, Amsterdam, pp. 81-186. Met eene kaart en vier bijlagen.

105. JoNGH, D. DE. Over het voorkomen van tinertsaders op het eiland Bangka.

Jaarb. Mijnw. Ned. Oost-Indie, 1883 (1884), II, Tech., Amsterdam, pp. 306-317.

Soengei-Liat. Pangkal-Pinang. Merawang.

106. - Over het voorkomen van goud en tinerts op en langs de oostkust van het district Merawang, eiland Bangka.

Jaarb. Mijnw. Ned. Oost-Indie, 1883 (1885), II, Amsterdam, pp. 161-175. Met twee kaarten.

(a) Over het voorkomen van goud op Bangka in het algemeen.

(b) De geologische gesteldheid der kuststreek van Merawang tusschen Tandjong Antoe en de monding der Merawang-rivier.

(c) Het voorkomen van stofgoud en tinerts op de riffen en in de langs het strand gelegene valleitjes.

107. - Vervolg op het rapport over het jaar 1883 betreffende het voorkomen van tinader-ertsen op Bangka.

Jaarb. Mijnw. Ned Oost-Indie, 1884 (1885), II, Amsterdam, pp. 176-181.

(a) District Soengei-Liat. (b) District Pangkal-Pinang. (c) District Merawang.

108. - Over de uitkomsten der tinwinning op Banka gedurende de ontginnings jaren 1882-83 tot en met 1899-1900 met zes staten en eenige graphische voorstellingen.

Jaarb. Mijnw. Ned. Oost-Indie, 1900, Amsterdam, pp. 51-93. 


\section{BANKA (Continued)}

109. LANGE. Het eiland Banka en szyne angelegenheder.

Hertzogenbosch. 1850, p. 59. ff.

Describes the tin deposits of Banka.

Not available to the authors.

110. Menten, J. H. Het boren en het boormateriaal op Bangka.

Jaarb. Mijnw. Ned. Oost-Indië, 1873 (1874), II, Amsterdam, pp. 163-189. Drie platen:

Hoofdstuk I. Eenige algemeene beschouwingen over het opsporen van stroontinerts. gronden.

II. Beschrijving van het boormateriaal, zooals dit werd ontworpen door wijlen den Mijningenieur J. E. Akkeringa.

III. Wijze waarop het boormateriaal bij de onderzoekingen wordt gebruikt.

IV. Verbeteringen welke het boormateriaal later heeft ondergaan.

Mulder, [?]. See No. 1538.

111. Oudemans, A. C., Jr. Over verontreiniging van Banka-Tin.

Jaarb. Mijnw. Ned. Oost-Indië, I, Tech. en Admin., 1890, Amsterdam, pp. XXIV. XLIV.

112. Posewitz, Tr. Die Zinninseln im indischen Oceane.

I. Geologie von Bangka. Mitth. Jahrb. kön. ung. geol. Anst., Vol. 7, 1885, Budapest, pp. 153-182.

II. Das Zinnerzyorkommen und die Zinngewinnung in Bangka. Ibid. Vol. 8, 1886, pp. 55-106.

Reviewed by A. Stelzner: Neues Jahrb. Min. 1887, II, Stuttgart, pp. 107-110.

113. Raffles, Thos. S. On the tin of the island of Banka.

Trans. Roy. Geol. Soc. Cornwall, Vol. 3, 1827, Penzance, pp. 247-255.

Short history of production of tin in Banka, ruling prices, brief description of placers, distribution of tin in the island and market conditions.

114. Renaud, G. P. A. Rapport van het district Soengeiselan, elland Bangka. Jaarb. Mijnw. Ned. Oost-Indië, 1780 (1874), I, Amsterdam, pp. 3-81.

Met eene kaart en twee bijlagen.

Hoofdstuk I. Vermelding van de wijze waarop de overzichskaart werd vervaardigd.

II. Beschrijving van de natuurlijke gesteldheid van het terrein.

III. Geologische en mineralogische beschrijving.

IV. Beschrijving van de tinertsvoerende valleien en den loop der ontginning.

v. Algemeene blik op het productief vermogen van het district.

115. - Overzicht der tinproductie van eenige mijnen in het district Pangkal-Pinang, elland Bangka.

Jaarb. Mijnw. Ned. Oost.Indië, 1880, II, Amsterdam, 81-82.

115a. - Overzicht der tinproductie van eenige mijnen en het district Soengeiselan, eiland Bangka.

Jaarb. Mijnw. Ned. Oost-Indië, 1880, II, Amsterdam, pp. 77-80.

116. - Over de Chineesche ontginningswijze van tinerts op het eiland Bangka en de eventueele toepassing daarop van Europeesche werktuigen.

Jaarb. Mijnw. Ned. Oost-Indië, 1882 (1884), I, Tech. en Admin., Amsterdam, pp. 5-121.

Hoofdstuk I. Administratieve regelingen volgens welke de betaling der mijnwerkers geschiedt.

II. De gevolgde methode van ontginning der tingronden en hare onderdeelen.

(a) Grondverzet. (b) Bemaling. (c) Ertswasschen. (d).Smeltkosten. (e) Tin en rijstkruien.

III. Bepaling van het dagloon van den Chineeschen mijnwerker. 


\section{BANKA (Continued)}

117. Reyer, Eduard. Banka und Bilitong.

Oest. Zeitschr. Berg. Hüt., Vol. 27, 1879, Wien, pp. 384-385, 395-397, 407-409.

Extract: Iron Age, Vol. 24, Nov. 20, 1879, New York, p. 3.

"Concise, though well-detailed notice of the nature and condition of tin-mining in Banka and Billiton, with geological sketch map of the northeast district of the former island, and full references to former observers and writers on these works and the structure of the islands."

- See No. 1354.

\section{SchuUrman, J. A. See No. 1415.}

118. VAN DER WYCK, O. H. The occurrence of tin ore in the islands of Banca and Billiton.

17th Ann. Rep. Dir. U. S. Geol. Surv. 1895-96, pt. 3, 1896, Washington, D. C., pp. 227-242.

Conditions of occurrence, method of mining and smelting tin ore on the islands of Banca and Billiton.

119. Verbeek, R. D. M. Ueber die Zinnerzlagerstätten von Bangka und Billiton. Zeitschr, prakt. Geol., 1899, Berlin, pp. 134-136.

Digest: Neues Jahrb. Min., 1901, I (Ref.), Stuttgart, pp. 422-423.

Verbeek's first article on this subject appeared in Jaarb. Mijnw. Ned. OostIndië, Vol. 26, 1897, and was reviewed by Beck in Zeitschr. prakt. Geol., 1898, Berlin, pp. 121-127.

\section{See No. 136.}

120. VlaAnderen, C. L. Schelkundig onderzoek van Bangka-tin.

Jaarb. Mijnw. Ned. Oost-Indië, 1874 (1875), I, Amsterdam, 233-235.

WEeks, Josepir D. See No. 1372.

See also Billiton and General.

\section{BILLITON}

121. Ak kerivgA, J. E. Verslag van een onderzoek naar tinertsaders op het eiland Billiton.

Jaarb. Mijnw. Ned. Oost-Indië, 1873, I, Amsterdam, pp. 3-72. Written in 1860. Met drie kaarten en een plaatje.

Hoofdstuk I. Beschrijving der kaarten.

“ II. De ontginbaarheid der tinaders.

“ III. Eenige opmerkingen omtrent geognosie, adererts en alluvialen tinerts.

122. Axonymous. Notlz über das Vorkommen von Zinn auf der Insel Billiton

[in der Nähe der Insel Banka].

Berg. Hitt. Zeit., Vol. 12, 1853, Leipzig, p. 609.

123. - Billiton tin mines.

Eng. Mg. Journ. Vol. 26, 1878, New York, p. 294.

Tin mines in four districts: Mangar (most important), Boeding, TandjangPadan, Dindang.

Percentage of pure tin is 40 to 70 per cent. Since 1854 produced 1000 pieuls for first year, and for the 20 years after 62,000 piculs. 


\section{BILLITON (Continued)}

124. - Verslag van het Mijnwezen in Nederlandsch Oost-Indië over het jaar 1880-1.

Jaarb. Mijnw. Ned. Oost-Indië, 1882, II, Tech., Amsterdam, pp. 116-132.

Tinontginningen.

a. Ontginning van Gouvernementswege.

b. Billiton-Maatschappij.

125. - Verslag van het Mijnwezen in Nederlandsch Indië over het jaar 1881-2.

Jaarb. Mijnw. Ned. Oost-Indië, 1883, II, Tech., Amsterdam, pp. 147-157.

Tinontginningen.

a. Ontginning van Gouvernementswege.

b. Particuliere ontginningen. Billiton.

126. - Verslag van het Mijnwezen in Nederlandsch Indië over het

jaar 1882-3.

Jaarb. Mijnw. Ned. Oost-Indië, 1884, II, Tech, Amsterdam, pp. 347-358.

Tinontginningen.

a. Ontginning van Gouvernementswege.

b. Particuliere ontginningen. Billiton.

c. Concessie-aanvragen.

$126 \mathrm{a}$.

Tin mining in the island of Billiton. A general sketch.

G. Kolff \& Co., Batavia (Dutch East Indies), 1908, pp. 31 .

Treats of the political, topographic, geological, and commercial aspects of Billiton, Dutch East Indies, and its tin mining industry. Describes in excellent manner the methods of working the deposits (from the commercial side rather than the mechanical) and handling the Chinese. Besides tin, iron is the only commercial mineral found in quantity. There are small quantities of tungsten, gold, lead, and copper.

Probably the most intimate English account of tin deposits and mining on Billiton Island.

BECK, R. See No. 82.

127. Cretien, H. Tinhoudend zand van Billiton.

Indische Gids, 1881, II.

Not available to the authors.

128. Diest, P. H. van. Bijdrage tot de geschiedenis van Billiton, gedurende de eerste 15 jaren onzer vestiging aldaar, bepaaldelijk met het oog op het reeds te dien tijde bekend zijn van het voorkomen van tinerts aldaar.

Jaarb. Mijnw. Ned. Oost-Indië, 1874, II, Amsterdam, pp. 193-240.

129. Ferrier, - Exploitation de l'étain a Billiton.

Rev. Univ. Mines Met. Trav. Publ. Sci. Arts Appl, Indust. Ser. 2, Vol. 9, 1881, Liége and Paris, pp. 458-460. (Extract.)

Fuchs, E., and Launat L. DE. See No. 1323.

130. Gвоот, C. DE. Die Insel Billiton durchforscht nach Zinnerz.

Kon. Nat. Tijdschr. Ned.-Indië, Jahr. 3, Lief. 2 u. 3, 1852, Batavia, p. 133, maps 2. Not available to the authors,

131. Tinader op Billiton.

Kon: Nat. Tijdschr. Ned.-Indië, 1870, Batavia.

Not available to the authors. . 


\section{BILLITON (Continued)}

132. - Herinneringen aan Blitong.

1887, Gravenhage. Tinerts, pp. 168-228, sketch 1.

Review: Neues Jahrb. Min., 1888, II (Ref.), Stuttgart, pp. 424-425.

1. Tinerts afgezet in het vastgesteente, p. 168.

2. Tinerts dat onvervoerd is blijven liggen op de plaats waar het door verweering van het vastgesteente, waarin het gelegerd was, daaruit werd losgemaakt, p. 189.

3. Laagvorming afgezetten stromtinertsgrond, p. 199.

4. Stroomtinerts, p. 208.

5. Mineralen, welke met het stroomtinerts in den ertsgrond worden aangetroffen, p. 218 .

133. MAIER, P. J., and LAUdon, J. Jets omtrent het voorkomen van tin op het elland Billiton.

Kon. Nat. Tijdschr. Ned.-Indie,, 1854, Batavia.

Not available to the authors.

134. Posewitz, TH. Die geologisch-montanistischen Verhältnisse der Inse] Billiton.

Petermann's Mitth., Vol. 33, 1887, Gotha, pp. 108-116. Map.

History of the discovery of tin ore in Billiton, geology of the island, the occurrence and mining of tin, statistics of production.

135. RaNt, H. F. E. Verslag van de bevinding en de vooruitzichten der aderontginning nabij den berg Tadjouw op het eiland Billiton. Jaarb. Mijnw. Ned. Oost-Indië, 1873, II, Amsterdam, pp. 73-91.

Reyer, Eduard. See No. 117.

136. VerbeeK, R. D. M. Geologische beschrijving van Bangka en Billiton.

Jaarb. Mijnw. Ned. Oost-Indie, 1897, Tech. Admin. en Weten. Ged., Amsterdam, pp. 1-220. Met 4 kaartjes, 2 bijlagen, en 4 platen.

Reviewed by Beck in Zeitschr. prakt. Geol., 1898, Berlin, pp. 121-127.

Beck's article digested: Neues Jahrb. Min., 1899, II [Ref.], Stuttgart, pp. 266-267. Largely devoted to the manner of occurrence of tin in the islands.

-. See No. 119.

WeEks, Joseph D. See No. 1372.

See also "General."

\section{BOLIVIA.}

137. Anonymous. Tin mine in South America.

Mg. Mag. No. 1, Vol. 1, 1853, New York, pp. 210-212.

Extract from "New York Courier" without date. A non-technical and rather careless description of a tin mine at Onero (Oruro ?) probably in Bolivia. Output said to have been 3000 tons per year.

137a.

\section{- Zinnvorkommen in Südamerlka.}

Oest. Zeitschr. Berg. Hutt.' Vol. 8, 1860, Wien, pp. $48-49$.

Brief mention of the very rich tin ore to be found in Bolivia, but location is such that the mining of it has not been very practicable.

138. - Tin in Bolivia.

Min. Ind. for 1895, Vol. 4, 1896, New York and London, p. 571.

Tin production while small, showing a steady increase, and in 1895 production was much larger than ever before. 


\section{BOLIVIA (Continued)}

139. Bolivian tin and the supply of the United States.

Eng. Mg. Journ., Vol. 66, 1898, New York, p. 632.

Editorial in which is discussed the devclopment of the tin plate industry in United States, and the increasing block tin importation. Why we do not import more raw material from Bolivia is also discussed.

140. L'étain en Bolivie.

Illustration, Vol. 116, 1900, Paris, p. 419.

Review: Berg. Hütt. Zeit., Vol. 60, 1901, Leipzig, p. 268.

141. Tin in Bolivia.

Min. Ind. for 1900, Vol. 9, 1901, New York and London, p. 639.

Tin is mined in the departments of Oruro, Potosi, La Paz and Cochabamba, of which Oruro is much the most important, containing within its borders 25 out of a total of 37 mines of the whole country.

141a. - Tin in Bolivia.

Min. Ind. for 1901, Vol. 10, 1902, New York and London, p. 641.

Most important tin mining district is that of Huanuni, where tin ore occurs in numerous veins and lodes, traversing the granite country rock.

142. Tin in Bolivia.

Eng. Mg. Journ., Vol. 73, 1902, New York, p. 218.

Answer to correspondent asking about Bolivia tin deposits. Gives recent production and some other data.

143. - Tin in Bolivia.

Mo. Bull. Int. Bur. Amer. Repub., Jan.-June, 1902, Washington, D. C., pp. 588-590.

In the Huanuni district in Bolivia on the mountain of Pozoconi, many of the tin veins run into tin pyrites at from 100 to 200 feet in depth. "Solid tinstone of variable width up to 2 feet." One vein at the Challa and Apacheta mines, 10 miles south of Huanuni is 25 to 30 feet wide, averaging 20 per cent tin. The vein is composed of grains of $\mathrm{SnO}_{2}$ in an argillaceous rock.

The Arecayo mine of the Oruro district, has lodes from 1 to 3 feet wide and has considerable masses of solid ore, averaging more than 40 per cent tin.

144. - A new tin mine, Bolivia.

Mg. Journ., Railw. Comm. Gaz., Vol. 74, 1908, London, p. 525.

Situated 57 miles south of Tupiza, anciently worked in a small way for silver, In 1901 opened as tin mine. Striking in an easterly and westerly direction, lodes cut decomposed clay, slate and shale. Principal lode over 800 feet in length, with an average width of 2 feet. With the rudest dressing machinery, about 23 tons of black tin of 55 per cent to 62 per cent is produced monthly.

145. - Tin mining in Bolivia.

Eng. Mg. Journ., Vol. 80, 1905, New York, p. 698.

Brief summary of report of the British Foreign Office. Since rise in price of tin, the famous silver mines of Oruro have depended for their prosperity more on their tin output than silver production. Bolivia now one of the largest producers of tin in the world. Total shipments in 1904 from Oruro district amounted to equivalent of 8000 tons of metallic tin, in 1903 the output was about one-half as large.

146. Tin mining in Bolivia.

Eng. Mg. Journ., Vol. 81, 1906, New York, p. 1137.

Tin deposits of La Blanca, San José and Quinsachata are briefly described, giving output, etc. 


\section{BOLIVIA (Continued)}

147. Rallway and mining development in Bolivia.

Eng. Mg. Journ., Vol. 82, 1906, New York, p. 2, map of S. Bolivia.

"Tin mines of the country are undoubtedly destined to become one of the world's chief sources of supply. Already the Bolivians aspire to the premier place in tin production. The conditions under which this metal is found show wide differences, but it is found throughout a large area, and is undoubtedly abundant."

148. - Tín in Bolivia.

Eng. Mg. Journ., Vol. 82, 1906, New York, p. 631.

The prevalent idea that tin ore is superficial in Bolivia, only time will prove or disprove. If there is no notable increase for some time in the output of Bolivian tin, it will not be through want of ore in lodes, but through scarcity of labor.

148a. - Producción de estaño en 1906 y 1907.

Geol. Minas, Vol. 2, 1907-1908, Buenos Aires, p. 630 .

Gives Bolivian production of tin for years 1906 and 1907.

148b. - The mining industries of Bolivia.

Journ. Soc. Arts, Vol. 57, 1909, London, pp. 721-722.

Reprint: Mg. World, Vol. 31, 1909, Chicago, p. 923.

Treats of the Bolivian tin output, market, machinery used, etc.

148c. The tin mines of Huanuni and Uncia, Bolivia.

Mg. Journ. Railw. Comm. Gaz., Vol. 87, 1909, London, p. 125.

Abstract from "El Comercio" (Uŷni, Bolivia).

Gives brief notes regarding output and improvements in the various mines of Huanuni and Uncia.

148d. Tin Mining in Bolivia.

Eng. Mg. Journ., Vol. 88, 1909, New York, p. 1284.

Extract from undesignated British consular report, giving the total production of barilla during 1908 as follows: Potosi, 18,139 tons; Oruro, 9620 tons; La Paz, 2008 tons; Cochabamba, 170 tons. Total, 29,937.

148 e. - La producción de estaño en Bolivia.

Cienc. Indust., Vol. 3, 1909, Buenos Aircs, p. 209.

148f. - Bolivia in 1909.

Mg. Journ. Railw. Comm. Gaz,, Vol. 88, 1910, London, p. 136.

Short account of the tin output for 1909 , showing an increase over the production of 1908 .

149. Arzruni, A. Ueber einige Mineralien aus Bolivia.

Zeitschr. Kryst. Min., Vol. 9, 1884, Leipzig, pp. 73-77.

Review: Neues Jahrb. Min., 1886, I (Ref.), Stuttgart, pp. 198-199.

150. Ballivián, M. V., and SaAvedra, Bautista. El estaño en Bolivia. Monografias de la industria minera, No. 3.

Oficina nacional de immigración, estadistica, etc., 1900, La Paz, pp. 133.

151. Barba, Alvaro Alorso. Arte de los Metales.

Madrid, 1630, chap. 32 .

Ref. from Frochot, L'étain in Bolivie, Ann. Mines, ser. 9, Vol. 19, 1901, Paris, p. 187.

"C Cost encore aujourd'hui une autorite en matiere de mines, et ses indications sur la géographie miniére de la Bolivie ont êté très rarement reconnues inexactes." Not available to the authors. 


\section{BOLIVIA (Continued)}

A translation was published in London in 1740, entitled: "A collection of searce and valuable treatises upon metals, mines and minerals. . . . Being a translation from the learned Albaro Alonso Barba, director of the mines at Potosi in the Spanish West Indies, and the observations of several ingenious persons of our own country, founded on many years experience." Tin, chap. 32, pp. 107-110.

Beck, Richiard. See No. 1299.

152. Benedict, WM. DE L. Tin in Bolivia.

Min. Ind. for 1892, Vol. 1, 1893, New York and London, pp. 450-451.

Tin at Potosi is found in large quantities in silver bearing veins. At Chorolque, bismuth and tin are found close together in distinct veins. A few deposits of alluvial or stream tin have been discovered, but only one that is of any importance.

152a. Berkey, Charles P. See Rumbold, William R. Origin of Bolivian tin deposits.

Descriptions of microscopic sections of Bolivian tin ores and rocks.

153. Bradley, D. H., JR. Mining in Bolivia.

Mg. Mag., Vol. 11, No. 1, 1905, New York, pp. 41-48, 9 illus.

As a tin producing country, Bolivia is second to Malay Peninsula. With the exception of that from Potosi, bar tin, the product of Bolivia is second in quality to none. Deposits rich, output increasing. Tin will undoubtedly be found in many other parts of Bolivia. Bolivian mines offer immense opportunities for investments paying 25 per cent premium within 3 or 4 years.

153a. Brown, Gilmour E. Present position of Bolivian tin mines.

Mg. Journ. Railw. Comm. Gaz., Vol. 85, 1909, London, p. 399.

Extract: Mg. World, Vol. 36, 1909, Chicago, p. 829.

$\Lambda$ few notes on the cost of mining and smelting, and the names of a few of the principal mines operating in Bolivia.

154. Conway, Sir Martin. Climbing and exploration in the Bolivian Andes. New York, 1901, pp. 291-299.

The tin mines of Huaina Potosi are treated from a literary rather than geological standpoint. Veins from 3 meters to 10 meters wide occur in "porphyry," slate and trachyte.

D'Achiardi, Antonio. See No. 1313.

Davies, D. C. See No. 1317.

155. Emmons, S. F. Geological distribution of the useful minerals.

Trans. Amer. Inst. Mg. Eng., Vol. 22, 1894, New York, p. 72.

"In Bolivia where tin ore forms an important part of the mineral product, it occurs in andesitic or trachytic rocks of Cretaceous or Tertiary age, is associated with sulphides of silver, copper, lead, zinc and iron and without the usual accompaniment of tourmaline, topaz, fluorspar or apatite.".

155a. Endter, Augusto. The tin mines of Llallagua, near Oruro, Bolivia.

Mg. Journ. Railw. Comm. Gaz., Vol. 86, 1909, London, pp. 52-53.

Abstracted from "Compañia Estañfera de Llallagua. Tercera Memoria del Directorio y Balance Jeneral al 31 de Diciembre de 1908." Santiago de Chile, 1909, 36 pages with five folding plates.

Treats of the geology, vein structure and mining methods, also announces and describes a newly found pocket of rich ore. 


\section{BOLIVIA (Continued)}

155b. Everding, - Unterlagen zu einer bergmännischen Lagerstättenbegutachtung in bolivianischen Zinnerzbezirk.

Glück. Berg. hütt. Zeit. Nied. Westph., 45 Jahr., 1900, Essen, pp. 1325-1335.

156. Fawns, Sydney. Tin deposits of the world.

Mg. Journ. Railw. Comm. Gaz., 1905, London.

Deposits of Bolivia, pp. 112-124. Small outline map.

No new material. Taken from Pasley's, Chas. S., "The tin mines of Bolivia."

Trans. Inst. Mg. Met.. Vol. 7, 1898-1899, London, pp. 70-90, 95; Roberts, Malcolm,

"Chorloque tin mines," op. cit., Vol. 9, 1900-1901; and Min. Ind., New York and London, 1903.

157. Forbes, David. Researches on the mineralogy of South America:

London, Edinburgh, Dublin, Philos. Mag. Journ. Sci., ser. 4, Vol. 29, 1865, pp. 133-136; Vol. 30 , 1865, London, pp. 139-142.

First article treats of the occurrence of tin ore in Bolivia; second article describes the different kinds of tin ore of Bolivia.

Frenzer, A. See No. 1611.

Describes cylindrite from Bolivia.

158. Frochot, Maurice. L'étain en Bolivie.

Ann. Mines, ser. 9, Vol. 19, 1901, pp. 186-222.

Extract: Bol. Min. Indust. Constr., Ano 18, Nos. 7, 8, 1902, Lima, Peru, pp. 51-53, 59-62.

Digest: Trans. Inst. Mg. Eng., Vol. 23, 1901-1902, London and Newcastle-upon-Tyne, pp. $715-716$.

Gcol. Centr., Vol. 1, 1901, Leipzig, p. 707.

35 tin mines at work; cost of production very heavy; no such deposits known in Peru or Chili; Oruro district largest producer; geological conditions extremely varied; Huanuni mine credited with two-thirds of output of State; situated in a sort of stockwork in Mount Posconi, 10,500 feet high; in most cases $\mathrm{SnO}_{2}$ gives way to stanniferous pyrites at depth of $13 n^{\prime}-160^{\circ}$, one vein is fllled with pure tinstone to a depth of $650^{\prime}$ or more; 9 miles south are mines of Challa and Apacheta where is a vein 25 to 30 feet thick which in parts can be dug with a spade (where pyritiferous). Many "veneros" in this neighborhood not well worked. Fifty miles north of Oruro is Colquiri, where the Spaniards used to work silver ores but neglected tin, as usual. Tin veins close at hand are still untouched. In the mountains of Tres Cruces, $\left(20,000^{\prime}\right.$ alt.) the Sayaquiri vein is 25 feet thick. Ore rather poor, associated with iron pyrites and wolframite, but some crystalline ore runs 70 per cent tin.

Avicaya mines are productive and rock is compact porphyry. In the department of La Paz, the mines of Milluni, Huayna Potosi and Chocaltaya are all on one ore belt 12 miles in length. Veins, appear to be of very recent origin, for they occur near fossiliferous gypsum-bearing beds and red clays which have been faulted by disturbances that raised the neighboring Andes. Are in slates of Silurian or pre-Silurian age. Many veins not worked. Bolivian tin ores are not connected with plutonic granite, but appear to be connected genetically with thermal springs, which hold metallic sulphides in solution and were the outcome of Cretaceous and Tertiary volcanic eruptions.

159. Fuchis, E., et Launay, L. DE. Traité des gites minéraux et métalliferes. Vol. 2, 1893, Paris, pp. 107-158.

Brief note upon the occurrence of tin in Bolivia.

160. Gautier, Ferdinand. Observation sur la formation des filons d'étain. Actes Soc. sci. Chili, Vol. 5, 1895, Santiago, pp. 82-84.

Theories on deposition of tin veins near Chorolque, Bolivia. 


\section{BOLIVIA (Continued)}

\section{Gmemling, Andreas. See No. 1497.}

161. Harrison, G. Tin in Bolivia.

Diplomatic and Consular reports (Bolivia). Trade of Bolivia for the years 1904-1905, No. 3600 , Ann. ser. 1906, London, p. 4.

Mentions tin mining as principal industry.

161a. Light, John. El estaño boliviano y la iniciativa chilena.

Geol. Minas, Vol. 1, 1906-1907, Buenos Aires, pp. 392-397.

Taken from "La Lei," Santiago, Chile.

General article upon tin, particularly of Bolivia.

Lours, Henry. See No. 1340.

162. Minchin, J. B. Tin mines in Bolivia.

Eng. Mg. Journ., Yol. 51, 1891, New York, pp. 586-587.

Good description of various tin mines of Bolivia, associated ores, manner of working, difficulties of transportation. Most important deposits are situated among the mountain ranges bordering the table-land to the east and northeast of Oruro and Lake Poopo, and are scattered over some 500 square miles. General country rock is shale, more or less highly inclined and contorted from eruptions of trachytic porphyry; the tin veins occur in the latter.

163. Minchin, J. B. Mineral resources of Bolivia. Iron, Vol. 37, No. 962, 1891, London, p. 536.

164. The mineral resources of Bolivia. (Tin mines.) Engineering, Vol. 51, 1891, London, p. 453.

Tin-bearing country extends along eastern border of Bolivian table-land from lake Titicaca to near the Argentine boundary. At Potosi and Oruro tin is associated with ores of silver, in other places, found alone or mixed with iron oxide and earthy matter. Country rock is shale, inclined and contorted from eruptions of trachytic porphyry; the tin veins occur in the latter rock. Mode of occurrence varies even in one group of mines. Country lacks adequate mining machinery.

165. Tin in Bolivia.

Mo. Bull. Int. Bur. Amer. Repub., No. 55, 1892. Revised to July 1, 1893, Washington, D. C., pp. 74-78.

Short, general, . descriptive article, probably taken from : his " Tin mines in Bolivia," Eng. Mg. Journ., Vol. 51, 1891, New York, pp. 586-587.

166. Notes on tin mining in Bolivia.

Eng. Mg. Journ., Vol. 75, 1903, New York, p. 31.

Reprint with additions: Mo. Bull. Int. Bur. Amer. Repub., 1904, Washington, D. C., pp. 107-116.

Mines are briefly described. Tin ore occurs chiefly at $\mathrm{La} \mathrm{Paz}$ on the north, Oruro in the middle, Chorolque on the south and Potosi on the east. Huanuni is richest tin district. Transportation by pack mules, llamas and wagons. The best tin is said to come from Berenguela, 45 miles east of Oruro. Mines were formerly worked for silver. Some of the tin ore is very hard to handle on account of the large amount of antimony and other sulphides. Tin mining develops as transportation becomes easier. 350 tons barilla (concentrates) estimated to give 210 tons of bar tin.

Output of barilla for 1902:

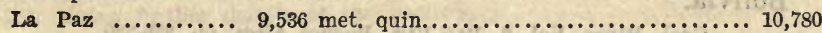

Oruro $\ldots . . . \ldots . . .996,981$ " " "

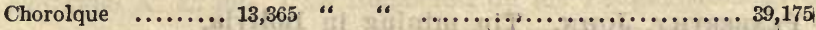

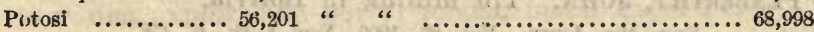

Total $\quad \cdots \ldots \ldots \ldots . .176,083$ 


\section{BOLIVIA (Continued)}

167. Tin in Bolivia.

Min. Ind. for 1902, Vol. 11, 1903, New York and London, pp. 588-590.

General description of tin deposits of Bolivia, methods of working, grade of ore, production, etc.

168. - Tin production in Bolivia.

Eng. Mg. Journ., Vol. 77, 1904, New York, p. 244.

Production of tin from mines in the neighborhood of Oruro. Description of the individual mines.

169. - Bolivian tin mines.

Mg. Journ. Railw. Comm. Gaz., Vol. 79, 1906, London, p. 361, 450 words.

Reprint: Eng. Mg. Journ., Vol. 81, 1906, New York, p. 810.

A letter dated Oruro, Bolivia, Jan. 26, 1906, giving a short general description of the Bolivian tin mining industry.

170. Newland, D. H. Production of Bolivian mines for 1903.

Min. Ind., Vol. 12, 1904, New York and London, pp. 329-330.

Mines in vicinity of Oruro briefly treated.

171. Ochsenrus, C. Die Silber-Zinnerz-Lagerstätten Bolivias.

Zeitschr. deutsch. geol. Ges., Vol. 49, 1897, Berlin, pp. 693-695.

171a. Olaechea, T. El estaño en Bolivia.

Bol. Min. Indust. Constr., No. 7, ano, 18, 1902, Lima, pp. 51-53 and No. 8, pp. 59-62.

"From an interesting article by Frochot, printed in "Annales des Mines," we extract the points which may be the most directly useful to national [i. e. Peruvian] mining; although the metal referred to has only been known to exist in the department of Puno, it will not be strange if some day, owing to the mineral wealth of the Peruvian soil, tin may be found as a result of new explorations, in conditions where it can be conveniently worked." Then follow extracts from Frochot's article.

\section{Pasley, Chas. S. The tin mines of Bolivia.}

'Trans. Inst. Mg. Met., Vol. 7, 1898-1899, London, pp. 77-90, 95.

Digest: Min. Ind. for 1898, Vol. 7, 1899, New York and London, pp. 707-718.

Abstract: Coll. Guard., Vol. 77, 1899, London, p. 18.

Fawns, Sydney.-Tin deposits of the world, pp. 112 et al.

Tin mines in East Cordilleras. Rocks Silurian graywacke, slate, shales, and sandstone, cut by granite and later "porphyritic rocks." Trachyte in south. Formerly worked at Huanuni by Spaniards down to 1000 feet carrying ore out on their backs, two trips a day, 75 pounds per trip. Many rich veins from 1 foot to 30 feet wide and carrying up to 50 per cent tin. Mines located at from 13,000 feet to 15,000 feet altitude. Freights high. Fuel scarce. Tourmaline found with ores. Much antimony, pyrite, bismuth, and arsenic, with some silver, copper, and gold.

Pearce, R. See No. 1630.

172a. Peña, Alfonso de LA. La explotación de minerales de estaño en Bolivia.

Geol. Minas, Vol. 2, 1907-1908, Buenos Aires, pp. 336-339.

173. Penberthy, John. Tin mining in Bolivia.

Eng. Mg. Journ., Vol. 82, 1906, New York, p. 458.

Deposits of Bolivia are both lode and alluvial. Principal centers of production are Chorolque, Potosi, Uncia and Huanuni. The transportation to shipping points 


\section{BOLIVIA (Continued̄)}

depends upon rainfall, since absence of grass paralyzes transport which is carried on by mules and llamas. The labor problem is one of great difficulty. With present price of tin, all mines are worked to limit; but it is improbable that there will be an increase in production in the near future owing to the excessive difficulties here encountered.

174: - Tin mining in Bolivia.

Amer. Mg. Rev., November 7, 1908, Los, Angeles, p. 1, pl. 1. Abstract of paper read beofre Roy. Cornwall Polyt. Soc. of England.

Briefly describes the tin mines and mining conditions existing in Bolivia.

- See No. 467.

Penfiem, S. L. See No. 1631.

Phillurs, J. A., and Lours H. See No. 1350.

175. Preumont, G. The Bolivian tin mining industries and railways.

Mg. Journ. Railw. Comm. Gaz., Vol. 83, 1908, London, pp. 5-6, 65-66.

Bolivia presents after the Malayan States the most interesting field for tin mining. Since ore occurs mostly in lodes, it has, in many respects an advantage over those countries depending on alluvial grounds, which are rapidly becoming depleted. Most of the mines are comparatively yet in virgin ground. The possibility of the output increasing rapidly, is largely dependent on better and cheaper methods of transportation. Hence the outlook for railway development is treated at length.

176. Northern tin fields of Bolivia.

Mg. Journ. Railw. Comm. Gaz., Vol. 83, 1908, London, pp. 160, 249, 314.

Gives location, geographic and climatic description of country in which tin deposits occur. The tin-bearing lodes seem to bear no direct relation to the granite core of the mountains, but occur in quartzite on their western flanks. This quartzite is neither very continuous nor very wide, but all areas of it have been found to be stanniferous. The tin flelds of Milluni, Quimsa Cruz, Araca and Ichoca occur in such areas. Describes in detail the Huaina-Potosi, Milluni, Araca, Quimsa Cruz, and Santa Vela Cruz fields.

PrIor, G. T. See No. 1636.

Describes teallite.

177. Punnetr, H. Macauley. The tin deposits of Bolivia.

Mg. Journ. Railw. Comm. Gaz., Vol. 33, 1863, London, pp. 403, 443, 479, 498, 554.

Enumeration and description of principal tin districts of Bolivia and modes of working mines, crushing and washing of ores.

Rolker, Chas. M. See No. 1357.

178. Roberts, Malcolm. Chorolque tin mines and alluvial deposits, Bolivia. Trans. Inst. Mg. Met., Vol. 9, 1900-1901, London, pp. 372-376.

Geography, geology, mineralogy; description of the mines and their working, also a description of the alluvial deposits.

179.

- Notes on Chorolque tin mines and alluvial deposits, Bolivia.

Trans. Inst. Mg. Met., Vol. 12, 1902-1903, London, pp. 404-405.

Additions to paper in Trans. Inst. Mg. Met., Vol. 9, 1900-1901, London, pp. 372-376, giving further details of the geology.

180. Romaña, Eduardo A. L. DE. Una inspeción de los yacimientos de estaño de Bolivia y una exploración por el mismo metal en el Perú.

Boletin Cuerpo de Ingenieros de Minas del Pera No. 57, 1908, Lima, pp. 99, figs. 26, maps 2 .. 


\section{BOLIVIA (Continued)}

Abstract: Mg. Journ. Railw. Comm. Gaz., Vol. 84, 1908, London, pp. 37-38, 91-92. Reviews the uses and production of tin to p. 31; describes Bolivian deposits and their production to p. 68 . The remainder of the bulletin describes investigations in the provinces of Huancane and Chucuito, department of Preno. Tin was found at but one place in Peru, on the mountain Calvario in Vilque Chico, where it occurs with lead.

180a. Rumboid, Whutam R. Origin of the Bolivian tin deposits.

Econ. Geol., Vol. 4, 1909, Lancaster, pp. 321-364, map, figs. 31.

Abstract: Mg. World, Vol. 31, 1909, Chicago, pp. 1063-1066. Map.

The tin ore occurs in Devonian quartzite and quartzite-schist and in quartz porphyry cutting these.

The Concordia lode is in a breccia in a fissure, part of which is occupied by quartz porphyry. Besides cassiterite, the lode carries siderite, tourmaline, sphalerite, and pyrite.

The Elisa and Coya lodes as exposed where worked, are similar to the Concordia.

The Monte Blanco mine, besides having lodes, has schistose quartzite, carrying cassiterite and tourmaline between the laminæ.

The Barrosa Cota Mine works white quartz veins, carrying pyrite, magnetite, and tourmaline, with cassiterite which in some places takes the form of wood tin.

The San Roque and La Boliviania mines work the "Gallofa " lode, which carries iron oxide and pyrite, arsenical pyrite, chlorite, and tourmaline. There is no igneous rock exposed in the mine.

At La Unificada Mine, Negro Pabellon, the lode carries cassiterite with iron oxide, quartz and barite.

Wolframite occurs in veins and pockets of the quartz porphyry.

In the Cataracagua lode at Huanuni, the writer thinks the cassiterite may have been deposited later than iron oxides. Little sulphide has been encountered along the lode.

The Morococala mines are in an inlier of quartzite schist in andesite. A great flow of andesite covers much of the tin-bearing rocks and many of the tin mines are located around the edge of the andesite which, however, has no relation to the origin of the tin ores.

The Antequera, Totoral, and Avicaya mines at Chualla Grande are on impregnation lodes in quartzite and carry cassiterite, quartz, tourmaline, iron pyrite, and less chalcopyrite.

In most of the Llallagua and Uncia veins, there is little impregnation but the walls are slickensided. The average width of the veins is about 2 feet. They carry much iron oxide in the upper portions; below that, sulphides of iron, bismuth, arsenic, antimony, a little silver, and traces of gold. There is no stannite. The writer considers these to be the richest tin mines in Bolivia and probably in the world.

The San Jose lode is 2 metres wide and carries 20 per cent tin.

The San Salvadora lode is 2 feet wide and is said to carry 25 per cent tin in dense sulphides. It also ccntains values in bismuth and silver. He claims that with proper handling, the barilla could be made as clean as the tin concentrates from the Malay Peninsula and cleaner than those from Cornwall.

Descriptions of numerous microscopic sections by Charles P. Berkey are quoted.

SPENCER, L. J. See No. 1641.

181. SteinmaN, G. Ueber die Zinnerzlagerstätten Bolivias.

Monatsber. deutsch. geol. Ges., No. 1, 1907, Berlin,.pp. 7-9.

Translation: Mg. Journ. Railw. Comm. Gaz., Vol. 81, 1907, London, pp. 453-454.

Translation: Informaciones y Memorias, Boletin de la Sociedad de Ingenieros, Vol. 10, 1907, Lima, pp. 133-136.

Gives geological data on the tin deposits of Bolivia, additional to that published by Stelzner. 


\section{BOLIVIA (Continued)}

\section{Stelzner, Alfred W. Zinnerzlagerstätten von Bolivia.}

Zeitschr. deutsch. geol. Ges., Vol. 44, 1892, Berlin, pp. 531-533. Also, Zeitschr. prakt. Geol., 1893, Berlin, pp. 81-82.

Digest: Min. Mag. Journ. Min. Soc., Vol. 10, 1893, London, pp. 261-262.

Digest: Neues Jahrb. Min., 1893, II (Ref.), Stuttgart, p. 81.

"Tin ores in South American Cordilleras are restricted to a zone extending from the 15th to the 21st degree of latitude. In paragenesis and mode of occurrence they offer a remarkable contrast to the tin ores of other countries. The ore is seldom in crystals but usually crypto-crystalline, kidney-shaped, or compact. The usual tourmaline, topaz, fluorite, apatite, etc., are almost entirely absent. Instead of these the tin ore is accompanied by stannite and other sulphides. Frequently the tin is restricted to the upper portion of a vein, its place being taken lower down by argentiferous fahlerz, pyrite, and (locally) galena and zinc blende. In its geological occurrence, the tin ore is remarkable, occurring in association, not with granite, but with trachytes and andesites referred to a late Cretaceous or early Tertiary age."

\section{3. - Die Silber-Zinnerzlagerstätten Bolivias.}

Zeitschr. deutsch. geol. Ges., Vol. 49, 1897, Berlin, pp. 51-142, map and bibliography.

Ein Beitrag zur Naturgeschichte des Zinnerzes.

Review: Neues Jahrb. Min., 1891, I (Ref.), Stuttgart, pp. 481-483.

\section{—. See No. 1642.}

\section{Wendt, A. F. The Potosí, Bollvia, silver-district.}

Trans. A mer. Inst. Mg. Eng., Vol. 19, 1891, New York, pp. 90-91.

"An almost constant accompaniment of the silver ores of Potosi, and of a great many of the silver ores of the plateau of Bolivia, is binoxide of tin, in the shape of gray or yellow oxide. Some of the silver veins are very rich in the oxide of tin, notably so the Tajo-polo and the Veta Estaño, which was named after its contents of tin."

The country rock is rbyolite.

\section{BURMAH}

185. ANonymous. Maliwan tin mines [Mergui district].

Ind. Eng. July 20, 1889, Calcutta, pl. 1.

Reprint: Eng. Mg. Journ., Vol. 48, 1889, New York, p. 182.

Digest: Proc. Inst. Civ. Eng., Vol. 98, pt. 4, 1889, London, pp. 468-469.

Description of the almost deserted tin mines of Mergui, near Renaung. Veins of tin-sand are found at the surface, mined in open workings by shallow pits from 10 to 12 feet deep. Sand is raised by ladders from the mines and washed. Two smelting furnaces are situated at Maliwan. Output per day is 15 to 16 blocks of tin of 106 pounds each, bringing about Rs. 60 at Penang.

186.

\section{Tin in Burmah.}

Min. Ind. for 1900, Vol. 9, 1901, New York and London, p. 639.

187.

\section{Tin in Burma.}

Mg. World, Vol. 24, 1906, Chicago, p. 96.

Tin occurs in alluvial deposits all along the water courses, covering an area nearly 200 miles in length, by an average breadth of 40 miles. At Maliwan both vein and alluvial tin mining is carried on. 


\section{BURMAH (Continued)}

188. Foss, K. Mackenzie. The occurrence of tin and gold in Lower Burma. Mg. Journ. Railw. Coinm. Gaz., Vol. 76, 1904, London, pp. 505-506.

Describes an alluvial tin deposit at Henzai. Assayed 73 per cent tin; one particular assay went 48 ounces of gold to ton, and 50 per cent metallic tin. Deposit contains considerable copper and wolframite. Worked by natives in crude manner. Some 28 miles inland from Mergui tin, coal and gold found. Mr. T. W. H. Hughes reported favorably on these deposits.

189. Fryar, Mark. Burma.

Indian Economist, 1872, Calcutta, pp. 445-459.

Not available to the authors.

190. Grundy, JAmes. Mineral production of India.

Trans. Manchester Geol. Soc., Vol. 28, 1902-1904 (1905), Manchester, p. 14.

Tin is mentioned as occurring in Lower Burma. Relatively of small economic importance. Trade is trifling. Practically all the tin mined is used in India.

191. Hetafer, J. W. Letter on tin, iron, etc., from Tenasserim.

Journ. Asiat. Soc. Bengal, Vol. 7, 1838, Calcutta, p. 171.

Expresses himself as "greatly satisfled" with tin mines of Tenasserim district.

"They are very rich and very extensive."

192. Holland, T. H. Tin ore in Burma.

Rec. Geol. Surv. India, Vol. 31, 1904, Calcutta, p. 43.

Note on discovery of a tin-bearing greisen in Tenasserim.

193. Hughes, T. W. H. Tin-mining in Mergui District.

Rec. Geol. Surv. India, Vol. 22, pt. 3, 1889, Calcutta, pp. 188-208. Sketch map 1. Partly reprinted in Sydney Fawns', "Tin deposits of the world," pp. 39-41.

Has but little hope for lode mining. Stream tin is generally distributed through the gravels. Jungle thick so that exploration is difficult. Mines worked by Chinese, and ore is smelted at the mines. List of mines given.

194. - Report on the prospecting operations, Mergui district.

Rec. Geol. Surv. India, Vol. 26, 1891-1892 (1893), Calcutta, pp. 40-53.

Confirms previous reports that tin deposits are large and accessible enough to be worked profitably under economical management. Geology of country gives reason to hope that both north and east of country prospected, other paying tin deposits may be found.

195. Kina, WiLL. Tin in Tenasserim.

Rec. Geol. Surv. India, Annual Report for 1888, Vol. 22, pt. 1, 1889, Calcutta, p. 11; for 1889, Vol. 23, pt. 1, 1890, Calcutta, p. 8; for 1890, Vol. 24, pt. 1, 1891, Calcutta, pp. 9-10; for 1891, Vol. 25, pt. 1, 1892, Calcutta, p. 8; for 1802, Vol. 26, pt. 1, 1893, Calcutta, p. 4.

Outlines progress in opening up this new district.

196. Lemon, Chas. and Tremenheere, G. B. Reports on the tin of Province of Mergui, in Tenasserim, in the northern part of the Malayan Peninsula.

Trans. Roy. Geol. Soc. Cornwall, Vol. 6, 1846, Penzance, pp. 68-75.

Description of the occurrences of stream tin in Mergui. States that cassiterite is also found in granite dikes which cut sandstone. Both forms of deposits said to be large, especially those of stream tin. 


\section{BURMAH (Continued)}

197. Lock, C. G. Warnford. Tin in Burmah.

Economic Mining, 1895, New York, p. 623.

"Burmah is the great source of Indian tin supplies. In the Tenasserim division, tinstone is very plentiful, every stream bed near Maliwun in Mergui yielding the metal when washed. Dr. Oldham states main source of all the Tenasserim tin is the granite range separating province from Siam, where it exists as an essential ingredient of the mass of rock."

198. Oldiam, T. Remarks on papers and reports relative to the discovery of tin and other ores in the Tenasserim provinces.

Sel. Rec. Bengal Gov., Vol. 6, 1852, Calcutta, pp. 33-44.

Also: Papers on the geology and minerals of British Burmah, 1882, Calcutta, pp. 366-375.

Not available to the authors.

199. Notes on the coal-fields and tinstone deposits of the Tenasserim provinces.

Sel. Rec. Gov. India, Vol. 10, 1856, Calcutta, pp. 31-67.

Also: Papers on the geology and minerals of British Burmah, 1882, Calcutta, pp. 375-406.

Not available to the authors.

Reyer, Eduard. See No. 1354.

200. Royle, $\rightarrow$. On the tin mines of Tenasserim province.

London, Edinburgh, Dublin Philos. Mag. Journ. Sci., ser. 3, Vol. 24, 1844, London, pp. 63-65.

In 1837 tin was discovered near Lake Loadut, about 110 miles north-northeast of Maulnain, and in 1840 the country north of the Pakchan River was reported to be the richest stanniferous district within the Tenasserim provinces. Ore is found in the debris of primitive rocks, and the range is said to be a continuation of the Siamese tin district of Rinowng. In an hour and a half 11,889 grains of tin were collected in the vicinity of the coal mines on Great Tenasserim River.

201. Snow, A. B. Tin mining in Lower Burma.

Mg. Journ. Railw. Comm. Gaz., Vol. 78, 1905, London, p. 247.

Describes alluvial tin-bearing ground as covering an area nearly 200 miles long with an average breadth of about 40 miles along the water courses. At Maliwan both lode and alluvial mining is carried on. Veins are from 1 inch to 6 feet wide. Mining is done in most primitive manner by natives. Climatic conditions are favorable.

202. Theobald, W. Metalliferous resources of British Burmah.

Rec. Geol. Surv. India, Vol. 6, pt. 4, 1873, Calcutta, pp. 91-93.

"Beyond some workings near Malee-wan on the Pakchan River, the ore is nowhere systematically worked on a large scale within British territory. South of the Pakchan stream the richness of the tin washings is derived from the degradation of a stanniferous granite, in which the tinstone occurs as one of the integral constituents of the rock."

203. Tremenheere, G. B. Report on the tin of the Province of Mergui.

Journ. Asiat. Soc. Bengal, Vol. 10, 1841, Calcutta, pp. 845-851. Additions to report, Vol. 11, 1842, Calcutta, pp. 24, 289.

Also, Calcutta Journ. Nat. Hist., Vol. 3, 1843, Calcutta, pp. 47-54. .

Sci. Rec. Bengal Gov., Vol. 6, 1852, Calcutta, pp. 5-11; papers on the geology and minerals of British Burmah, 1882, pp. 350-356.

Not available to the authors. 


\section{BURMAH (Continued)}

204. - Second report on the tin of Mergui.

Journ. Asiat. Soc. Bengal, Vol. 11, 1842, Calcutta, pp. 839-851.

Gives more complete description of the tin-bearing ground and of the methods of working, than in earlier report.

205. - Report of a visit to the Pakchan River, and some tin localities in the southern portion of the Tenasserim provinces.

Journ. Asiat. Soc. Bengal, Vol. 12, 1843, Calcutta, pp. 528-534, map.

Malewan is only spot in Province where people have located for the purpose of collecting tin. Do not work veins, stream tin alone is collected. Not possible to work except in rainy season, at which time one man can extract four rupees worth of tin per day. Mining done by Chinese. Country rock is granite.

206. - Report, etc., with information concerning the price of tin ore of Mergui.

Journ. Asiat. Soc. Bengal, Vol. 14, 1845, Calcutta, pp. 329-332.

207. WaRtH, H. Burmah tin deposits.

Eng. Mg. Journ., Vol. 54, 1892, New York, p. 449.

Reprint: Min. Ind. for 1892, Vol. 1, 1893, New York and London, p. 450.

The tin deposits are of two kinds:

1st. Tin gravels found in all or most of the valleys. Gravels are a mixture of quartz, garnet, black tourmaline and gray cassiterite.

2d. Tin-bearing deposits in original eruptive rock, which is weathered so that it is possible to wash out grains of whitish cassiterite which it contains.

The yield from deposits of second class near Malewan was only 0.04 per cent of impure wash tin.

\section{CALIFORNIA}

208. Anonymous. Sur les mines d'or, d'argent et d'étain récemment découvertes dan les environs de Los Angeles [Cal.].

Ann. Mines, ser. 6, Vol. 16, 1869, Paris, pp. 599-600.

209.

California tin.

Mg. Sci. Press, Vol. 64, 1892, San Francisco, p. 261.

Announcement of the first shipment of pig tin from Temescal, Cal., to New York, which consisted of 22,000 pounds, the output of two weeks. Said to be equal to Straits Settlement tin.

210. The California tin mines.

Eng. Mg. Journ., Vol. 53, 1892, New York, p. 49.

Short account of progress of San Jacinto tin mine during 1891. Outlook bright. Tin raised for 1891 placed at 123,366 pounds having a gross value of $\$ 24,673$.

\section{1. - Tin in California.}

Mg. Sci. Press, Vol. 82, 1901, San Francisco, p. 209.

"The metal from Bishop Creek, Inyo Co., Cal., is tin." (Given to show possible tin-bearing locality.)

212. Benedict, William, de L. The San Jacinto (Cal.) tin mines.

Eng. Mg. Journ., Vol. 50, 1890, New York, pp. 450-453. Editorial on same, p. 447. Briefiy reviews the unsuccessful attempts made to exploit tin mines in the United States, and the history of the San Jacinto deposits, the metal in which was long thought to be silver. Compares the deposits with those of Cornwall, and gives an epitome of the several reports upon the deposits from which he decides that the deposits should be developed before extensive works are erected. 


\section{CALIFORNIA (Continued)}

213.

\section{Tin in California.}

Min. Ind. for 1892, Vol. 1, 1893, New York and London, pp. 452-453

Descriptive, historical, statistical. 269,000 pounds pig tin produced to the time of closing down in September, 1892.

214. Blake, William P. Occurrence of tin [wood tin] in California, Idaho and Montana.

2d Rep. State Mineralogist, California, 1880-1882 (1882), Sacramento, appendix, pp. 216-218.

California: Tin specimens found in Feather River, Plumas Co.

Montana: Stream tin occurs in many streams of the granitic region of the Bitter Root Mts.; in some localities in sufficient quantities to justify the hope that washing for this ore may be profitable. The many points at which this ore is found in Montana and Idaho indicate that it has a wide and general distribution in the granite region of the Northwest.

215. Fairbanks, Harold W. Geology of the Temescal tin district.

11th Rep. Cal. State Mg. Bureau, 1893, Sacramento, pp. 111-118.

Describes the geologic features of the region and the system of tin veins.

216. - The tin deposits at Temescal, Southern California.

Amer. Journ. Sci., ser. 4, Vol. 4, 1897, New Haven, pp. 39-42.

Also, Mg. Sci. Press, Vol. 75, 1897, San Francisco, p. 362.

Digests: Neues Jahrb. Min., 1899, I (Ref.), Stuttgart, pp. 23-24, 86-87.

Geological description of the district, and of the occurrence of tin.

217. Garrison, F. LYNwood. Tin in the United States.

Eng. Mg. Journ., Vol. 78, 1904, New York, p. 830.

The Temescal tin mine is described.

218. Hanks, H. G. Cassiterite.

4th Rep. California State Mg. Bureau, 1884, Sacramento, pp. 115-123.

Gives a short general dissertation upon the occurrence of tin; describes its ores; gives a list of the alloys of tin and their uses; enumerates the principal localities where tin is found; and describes the Temescal mines.

219. JACKson [J. R. (?)]. Sur la découverte de 'minerais d'étain en Californie. (Extraits d'une lettre.)

C. R. Acad. Sci., Vol. 50, 1860, Paris, pp. 105-106.

220. KNight, ENoch. Temescal tin mines.

Eng. Mg. Journ., Vol. 53, 1892, New York, p. 276, pl. 3.

At writing (end of year 1891), Temescal tin mines (San Jacinto) have produced the first and only American tin ever sent to the market.

Description and reports of mine given.

OHLY, J. See No. 1215.

221. Roessler, - New California tin mine.

Eng. Mg. Journ., Vol. 8, 1869, New York, p. 371.

Editorial on same, p. 377.

Announces the discovery of tin near San Jacinto, California. Brief review of California tin mining.

222. West, H. E. Tin in California.

Eng. Mg. Journ., Vol. 79, 1905, New York, pp. 852-853.

History, occurrence, and milling and metallurgy of the Temescal mines. 


\section{CALIFORNIA (Continued)}

223. Whitney, J. D. Tin in Temescai range.

Geol. Surv. of California. (Geology), Vol. 1, 1865, Philadelphia, pp. 180-181.

Synopsis of the field work froin 1860-1864.

During 1860-1861 the Temescal range was a scene of great excitement on the subject of tin. Description of the ore and its occurrence given.

\section{CANADA}

224. Anonymous. Discovery of tin in Canada.

Mg. Journ. Railw. Comm. Gaz., Vol. 81, 1907, London, p. 305. Also, Can. Jg. Rev., Vol. 28, 1907, Montreal, pp. 39-40.

Reports discovery of tin near New Ross, Lunenburg County, Nova Scotia. Only slight development, and economic value is unknown. Tin is found in small quantities in numerous other localities in Canada. States that tin has been discovered in Laurentian rocks in Greenland.

225. Betts, A. G. Electrolytic lead-refining.

Trans. Amer. Inst. Mg. Eng., Vol. 34, 1903, New York, pp. 180.

Tin is found in electrolytically refined lead at Trail, B. C., to the extent of 0.02 per cent. A number of analyses given show from 0.0012 to 0.0140 per cent of tin. Small amounts of $\mathrm{Cu}, \mathrm{Bi}, \mathrm{As}, \mathrm{Sb}, \mathrm{Ag}, \mathrm{Au}, \mathrm{Fe}$ and $\mathrm{Zn}$ are found in the bullion.

226. Brock, R. W. Tin in British Columbia.

Summ. Rep. Geol. Surv. Dep. Canada for 1902 (1903), Ottawa, p. 130.

" Tin is reported to have been found near Long Lake, British Columbia, but no information could be obtained regarding the exact locality. It is quite possible that traces may occur in connection with the intrusions of granite rock in that part of the district. But no alterations of these rocks were observed, such as take place where tin occurs in commercial quantities." (Whole ref.)

227. Fairibault, E. Rodolphe. Lunenberg County, Nova Scotia.

Sunm. Rep. Geol. Surv. Dep. Canada for 1907 (1908), Ottawa, pp. 80-82.

Tin oxide was found in sand at Tangier in 1868, and later at Shelbourne, Rawdon and Country Harbour in drift.

On the Reeves claim at New Ross, tin is found in a pegmatite dike containing large quartz crystals, and is accompanied by scheelite, wolframite, and amblygonite. In the granites near New Ross, besides the minerals named there have been found monazite, one of thr columbite minerals, durangite, lepidolite, hübnerite, molybdenite, zinc blende, beryl, apatite, tourmaline, fluorite, pyrolusite, manganite, limonite, hematite, magnetite, siderite, bismuthinite, argentiferous galena, copper, iron pyrites, and arsenical pyrites. Quartz crystals reach 27 inches long and 10 inches thick.

The amount of tin so far shown seems to be insignificant. Traces of tin were found in pegmatite 6 miles south of Reeves claim. Bismuthinite and molybdenite were found in a dike of quartz and aplite 1 mile south of New Ross corner.

Tungsten and rare-earth ores were found 1 mile east of New Ross corner. (See Report for 1906, p. 91.)

228. Hoffman, G. C. Cassiterite, var. wood-tin.

Ann. Rep. Geol. Surv. Canada, n. 8., Vol. 12, 1899 [1902], Ottawa, pp. 16 R-17 R. Small pebbles of wood-tin found in all tributaries of the Klondike River, most frequently in Bonanza and Hunter creeks.

229. Ingalls, Walter Renton; Argall, Philip; and Garde, A. C. Report of the commission appointed to investigate the zinc resources of British Columbia and the conditions affecting their exploitation.

Mines Branch, 1906, Ottawa, pp. 15-16. 


\section{CANADA (Continued)}

Tin has been shown to occur to the extent of 0.17 per cent in zinc ore from the Payne mill, near Sandon, Slocan district, B. C., and traces of tin are reported in lead at the Trail smelter, the ore of which is supposed to have come from the Slocan district.

230. Osann, A. Oxide of tin.

Ann. Rep. Geol. Surv. Canada, n. s., Vol. 12, 1899 (1902), Ottawa, pp. 720-73o. A very small quantity of cassiterite was found in graphitic gneiss derived from limestone, at Graphite City in the Ottawa Valley, Canada.

Proved by this test: "It was dissolved in a borax bead colored slightly blue by copper monoxide; the bead assumed a ruby color or became opaque, resembling red sealing wax." Occurs with rutile, augite, quartz, titanite, pyrite.

231. Wolf, A. G. The Betts process at Trail, British Columbia.

A thesis submitted to the Colorado State School of Mines for the degree of E. M. Read before West. Assn. Tech. Chem. and Met., April, 1907.

Mines and Min., Aug., 1907, Scranton, pp. 11-15.

Mg. World, August 31, 1907, Chicago, pp. 355-356; September 14, 1907, Chicago, pp. 438-439.

States that the refined lead made contains .301 per cent of tin, with small quantities of $\mathrm{Ag}, \mathrm{As}, \mathrm{Sb}$ and $\mathrm{Fe}$.

232. Young, G. A. The tin-bearing locality at New Ross, N. S.

Summ. Rep. Geol. Surv. Dept. of Canada for 1907 (1908), Ottawa, p. 77.

Gives geologic description of the tin bearing area near New Ross.

\section{CAPE COLONY}

233. Anonymous. The Kuils River tin field.

Mg. World, Vol. 25, 1906, Chicago, p. 213.

Large extent of alluvial ground; estimated that there is in sight ten million dollars worth of ore. Even the overburden is highly payable. Abundance of water. Country rock mainly granite mostly of fine structure, in places passing into syenite, belonging to the Cape system. Hills are traversed in a north and south. direction by bands of greisen, with closely associated quartz lodes dipping to the east.

233a. - Kuils River tin mines.

Mg. Journ. Railw. Comm. Gaz., Vol. 82, 1907, London, p. 212.

Taken from "The Cape Argus," July 22, 1907. A newspaper description of the tin placers on the Kuils River, 13 miles from Cape Town.

States that much of the cassiterite is in very fine particles and that the tailings are being worked.

233b. - The tin deposits of Cape Peninsula.

South African Mg. Rev., December, 1908, Johannesburg, pp. 2.

Not available to the authors.

\section{3c. - Tin mining in the Cape Peninsula.}

South African Mg. Journ., Vol. 7, pt. 2, 1909, Johannesburg, p. 221.

Treats of new developments and promising outlook, with comments on Kuils River deposits.

- See No. 1047.

234. Griffiths, Harry D. Notes on tin mining in Cape Colony.

Journ. Chem. Met. Min. Soc. South Africa, Vol. 8, 1907-1908, Johannesburg, pp. 167. 181, figs. 6, illus. 2 . 


\section{CAPE COLONY (Continued)}

44 mastract: Mg. Journ. Railw. Comm. Gaz., Vol. 83, 1908, London, pp. 119-120.

Describes Kuils River tin deposits which are located some $17 \frac{1}{2}$ miles southeast of Capetown in hills composed of gray granite, coarsely porphyritic in structure with large quantity of biotite. Ore occurs both as lode and alluvial. Methods and cost of working given.

234a. - New methods of concentrating alluvial tin.

Mg. Journ. Railw. Comm. Gaz., Vol. 84, 1908, London, p. 56.

" Describes the new methods introduced at the Kuils River tin mines, Cape Colony, which consist in effecting a coarse concentration by means of a rotary pan similar to that used in diamond washing, and then cleaning the rough concentrates in a hydraulic separator to the grade required."

235. Keyzer, S. S. Tin in Cape Colony.

Mg. Journ. Railw. Comm. Gaz., Vol. 80, 1906, London, p. 8.

Description of lode and alluvial deposits occurring in Cape Colony, between Kuils River and Stellenbosch.

235a. Wagner, P. A. Notes on the tin deposits in the vicinity of Capetown. Trans. Geol. Soc. South Africa, Vol. 12, 1909, Johannesburg, pp. 102-111, pl. 1 and figs. 2.

Describes the lode tin deposits at Langverwacht, Hazendal, Welbeloond, Papkuilsfontein, and Hoogekrall and detrital deposits at Langverwacht (Kuils River).

The first two occur in quartz veins in white granite dikes cutting granite. The veins carry cassiterite, wolframite, molybdenite, arsenopyrite, pyrite and a little tourmaline. The other three are quartz veins cutting slates, and are accompanied by much more tourmaline, arsenopyrite and pyrite.

At Papkuilsfontein an assay trom one vein showed:

$$
\begin{aligned}
& \mathrm{Sn}=12.9 \text { per cent. } \\
& \mathrm{Bi}=0.27 \\
& \mathrm{Cu}=\text { trace. } \\
& \mathrm{As}=21.78 \\
& \mathrm{Au}=2 \text { dwts. } 3 \text { gr. per ton. } \\
& \mathrm{Ag}=1 \text { oz. } 12 \text { dwts. per ton. }
\end{aligned}
$$

Cassiterite impregnates the country rock, more or less, at all the places.

Fluorite and topaz are absent and no other fluorine-bearing minerals are noted.

\section{NORTH AND SOUTH CAROLINA}

\section{Anonymous. Tin in North and South Carolina.}

Mg. Sci. Press, Vol. 86, 1903, San Francisco, p. 300.

New tin veins have been discovered which give more promise than those formerly known. Manner of occurrence described. Ore strongly resembles the greisen of

237. some of the Black Hills tin mines, although usually more decomposed. Tin ore in North Carolina.

Mg. World, Vol. 21, 1904, Chicago, pp. 174-175, photos 3, sketches 2.

Treated under the heads: geology of the deposits; development work; description of veins; equipment; history of development.

238. - Tin in South Carolina.

Mg. Rep., Vol. 50, 1904, Denver, pp. 65-66.

Notice of the discovery of tin in South Carolina on the Ross place.

239. - Tin in the Carolinas.

Eng. Mg. Journ., Vol. 82, 1906, New York, p. 823.

" Tin is present in exceedingly irregular pegmatite dikes, as cassiterite, which occurs only as an original constituent of the pegmatite. This mineral is not evenly distributed through the dikes, but is generally segregated or concentrated along certain lines."

Unimportant. 


\section{NORTH AND SOUTH CAROLINA (Continued)}

239a. BaLL, S. MaYs. Tin deposits of the Carolinas.

Eng. Mg. Journ., Vol. 87, 1909, New York, pp. 1139-1140.

Gives brief history of the tin discovery, descriptions of the Ross Mine and other deposits and account of the tin produced in the Carolinas.

240. Benedict, WM. DE L. Tin in North Carolina.

Min. Ind. for 1892, Vol. 1, 1893, New York and London, p. 455.

King's Mountain tin deposit treated. The climate of district is very favorable to the disintegration of the rocks, as a result the small gullies running down sides of ledge contain much stream tin in places. Doubtful if ore can be mined at a profit.

241. Dabney, Chas. W. Note on cassiterite from King's Mountain, North Carolina.

February, 1884, Raleigh, N. C., 2 page pamphlet.

Also, Journ. Elisha Mitchell Sci. Soc., 1884, Raleigh, pp. 79-81; Geol. North Carolina, Vol. 2, 1888, Raleigh, pp. 347-349.

Brief outline of the discovery and author's examination of the tin deposits at King's Mountain. Two assays are given, one showing 74.41 per cent, the other 65.21 per cent tin.

242. Furman, John H. The tin deposits of North Carolina.

Trans. New York Acad. Sci., Vol. 8, 1889, New York, pp. 136-145, pls. 2, figs. 5. Discussion, pp. 145-151.

Location and history of the discovery of the deposits are given with a description of the geology of the occurrences.

242a. - The King's Mountain tin region.

The King's Mountain Flerald. Vol. 3, Aug. 3, 1905. States that cassiterite was discovered at King's Mountain by Robert Claywell in 1883. Describes the geology of the region, the efforts to mine tin, and the reasons for failure.

243. Garrison, F. Lynwood. Tin in the United States.

Eng. Mg. Journ., Vol. 78, 1904, New York, p. 831.

The tin deposits of the Carolinas are treated among other deposits of the United States.

244. Genth, Frederick A. The minerals of North Carolina.

U. S. Geol. Surv. Bull. 74, Washington, D. C., 1891, p. 35 .

Cassiterite found in 1882 near King's Mountain. Short description and partial analysis given.

245. Graton, L. C. The Carolina tin belt.

U. S. Geol. Surv. Bull. 260, 1904, Washington, D. C., 1905, pp. 188-196.

Digest: Mg. Mag., Vol. 11, 1905, New York, p. 477.

Abstract: Iron Age, Vol. 75, II, 1905, New York, p. 1519.

Aif.o. Development has not yet been sufficient to allow much valuable generalization or prediction regarding these deposits. The Carolina tin belt however, appears to offer a promising fleld for exploration.

"The tin ore occurs in pegmatite dikes which cut across amphibolites and metamorphosed sediments. There are two varieties of pegmatite. One composed almost exclusively of quartz and microcline, appears to carry no tin. The other, which is tin bearing, is characterized by muscovite in various forms, and plagioclase feldspar, when any feldspar is present. Author believes the pegmatites are of igneous origin, and that the cassiterite is a primary constituent. What caused the segregation of tin ore in certain parts of the dike is not known."-H. Ries.

246. Reconnaissance of some gold and tin deposits of the southern

Appalachians.

U. S. Geol. Surv. Bull. 293, 1906, Washington, D. C., pp. 31-57.

Extract: Mg. World, Vol. 25, 1906, Chicago, p. 634. 


\section{NORTH AND SOUTH CAROLINA (Continued)}

History of tin mining in the Carolinas; geology of tin belt; mining developments; economic importance of tin deposits.

Practically the same article as that in Bull. 260.

247. Hess, Frank L. The Carolina tin deposits.

Eng. Mag., Vol. 32, 1906, New York and London, pp. 10-20, plates 4, map 1.

General geology of the region, with detailed description of the mines and a short discussion of their probable future, which he considers an unsolved question. Believes cassiterite to be an original constituent of the pegmatite dikes in which it occurs.

248. Ledoux, Albert R. Tin in North Carolina.

Eng. Mg. Journ., Vol. 48, 1889, New York, pp. 521-522. About 2100 words.

Describes King's Mountain tin deposits, method of working and probable future.

249. See No. 254 a.

250. Phillips, W. B. Tin in North Carolina.

Eng. Mg. Journ., Vol. 43, 1887, New York, p. 111.

Short discussion on the probability of finding tin in paying quantities in North Carolina.

251. Pratt, Joseph Hyde. Carolina tin belt.

Min. Res. U. S., 1903, U. S. Geol. Surv., 1904, Washington, D. C., pp. 337-344.

Geographic location; geology; mineralogical and chemical character of ore; production of tin from Carolina belt.

An epitome of Pratt and Sterrett's "The tin deposits of the Carolinas." See No. 252 .

252. Pratt, Joseph Hyde, and Sterrett, Douglass B. The tin deposits of the Carolinas.

North Carolina Geol. Surv. Bull. No. 19, 1904, Raleigh, pp. 64, figs. 8.

Short abstract: Amer. Journ. Sci., ser. 4, Vol. 20, 1905, New Haven, p. 75.

Introduction; geographical location; geology; mineralogical and chemical character of the ore; associated minerals of the cassiterite; percentage of cassiterite in the veins; development work.

Besides a description of the Carolina ores, a brief resume is given of the other deposits of the world.

253. Sloan, Earl. Mineral Resources of South Carolina.

Rep. Proc. 7th Ann. Session, Amer. Min. Cong., Portland, Oregon, 1904, pp. 134-187.

Brief account 'of the discovery of the Ross tin mine, near Gaffney, with description of the vein as shown by work to date.

Sterrett, Douglass B. See No. 252.

254. Ulke, Trtus. The occurrence of tin ore at King's Mountain, North Carolina, and near Vesuvius, Virginia.

Min. Res. U. S. for 1893, U. S. Geol. Surv., 1894, Washington, D. C., pp. 178-182.

Describes the character of the country rock of the two localities and the manner of accurrence of the tin ore.

254a. VAN Ness, W. W., JR. Tin in North Carolina.

Eng. Mg. Journ., Vol. 44, 1887, New York, p. 344.

Short description of discovery and workings at King's Mountain.

\section{CEYLON}

255. Coomaraswamy, ANANDA $K$. Minerals containing rare elements, and associated minerals.

Min. Surv., Ceylon Adm. Rep., 1904 (1905), Colombo, p. E. 10. 


\section{CEYLON (Continued)}

Note stating that cassiterite had bcen identified in a specimen of "nambu" from Niriella, near Ratnapura.

256.

- Report on the occurrence of cassiterite (oxide of tin) in Ceylon. May, 1905, Colombo. 2 page paniphlet. About 450 words.

Digest: Neues Jahrb. Min., 1906, Stuttgart, I (Ref.), p. 166.

Small amount of stream tin found in gem washing at Niriella (Palle Pattuwa, Nawadun Korale, Sabaragamuwa). Of no commercial importance. Ilmenite occurs with it. Gives analysis.

257. Coomaraswamy, A. K., and Parsons, James. Cassiterite.

Min. Surv., Ceylon Adm. Rep., 1905 (1906), Colombo, pp. E. 9-10.

Report of investigation of stream tin at Niriella, Induwehena, near Dela, and in Kuruwita. None of the deposits are of economic importance. The cassiterite is supposed to come from the surrounding granite. Zircon, rutile, ilmenite, etc., are found with the cassiterite.

258. Dunstan, Wyndham R. Report on cassiterite from Ceylon.

1905, Colombo. About 150 words. Published with article on cassiterite by Coom. araswamy, Mineralogical Survey of Ceylon. Pamphlet of 2 pages.

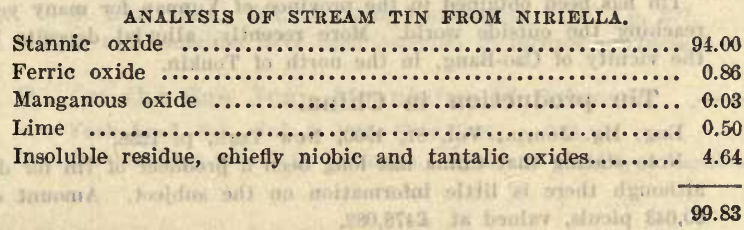

Equivalent to metallic tin 74.09 per cent.

259. Parsons, James. Additional report on an occurrence of cassiterite in Ceylon.

1905, Colombo. About 375 words published in pamphlet with article by Coomaraswamy.

Small occurrence of cassiteritc (stream tin) in gravels at Noragala. Occurs with sapphire, topaz, and large quantities of zircon.

Foullon, H. See No. 1322.

\section{CHILI}

259a. Götring, A. Die Erzgänge zu Punitaqui in Chile, mit besonderer Berücksichtigung der Zinnober führenden Lagerstätten.

Zeit. prakt. Geol., 1894, Berlin, pp. 224-230.

Cassiterite occurs in a diabase in which are also deposits of cinnabar, siderite, copper minerals and gold. The tin is apparently not in commercial quantity. Hornblende granite occurs not far away.

260. Möricke, W. Erzgänge zu Punitaqui in Chile.

Zeitschr. prakt. Geol., 1894, Berlin, pp. 282-283.

Discusses the occurrence of tin mentioned by A. Götting. See No. 259a.

\section{CHINA}

261. Anonymous. Zinn-Gruben von Johor in China.

Nouv. Ann. Voy. Sci. geogr., 1827, Paris, p. 418.

Extract: Tasch. ges. Min., 1828, Bd. 1, Frankfurt-am-Main, p. 47.

Original article not available to the authors.

Describes the alluvial deposit of tin near the town Gongong. 


\section{CHINA (Continued)}

262. - Tin mines in southwestern China.

Eng. Mg. Journ., Vol. 46, 1888, New York, p. 152.

Notes on a trip by Mr. F. S. A. Bourne, British Consular Agent at Chung King, quoted as stating that more than 1000 men are said to be employed in Southern Yunnan, Kuochinchang, in the tin mines of the region.

263. - The mineral resources of China.

Mg. Journ. Railw. Comm. Gaz., Vol. 67, 1897, London, p. 915.

Richest tin mines are located in department of Lingngau-fu, southeastern portion of Yunnan, whence the metal comes in shape of small truncated pyramids weighing about 2 catties each.

264. - Tin in China.

Min. Ind. for $1898,{ }^{\circ}$ Vol. 7 , 1899, New York and London, p. 711.

According to a report of the French Commercial Mission, the province of Yunnan now exports annually 2500 metric tons of tin. This is obtained from alluvial deposits at Kotchiou, 20 miles from Moung-tse.

265. - Tin mining in Indo-China.

Eng. Mg. Journ., Vol. 80, 1905, New York, p. 829, 200 words.

Tin has been obtained in the province of Yunnan for many years, most of it never reaching the outside world. More recently, alluvial deposits have been opened in the vicnity of Cao-Bang, in the north of Tonkin.

266. - Tin production in China.

Eng. Mg. Journ., Vol. 81, 1906, New York, p. 1238.

Note stating that China has long been a producer of tin for domestic consumption, although there is little information on the subject. Amount exported in 1904 was 50,043 piculs, valued at $£ 478,082$.

Beck, Richard. See No. 1299.

Browne, Frank. See No. 1458.

266a. Colurss, W. F. Tin production in Yunnan, China.

Bull. Inst. Mg. Met., Dec. 5, 1909, London, 3500 words, illus. 5.

Abstract: Mg. Journ. Railw. Comm. Gaz., Vol. 88, 1910, London, pp. 195-196, illus. Review: Eng. Mg. Journ., Vol. 89, 1910, New York, p. 781.

Treats of the occurrence and nature of the mines and ore; mining and concentration; mining laws and customs; dressing and smelting.

D’Achiardi, Antonio. See No. 1313.

267. Grosier, Jean Baptiste Gabriet Alexander. A general description of China.

1795, London, p. 400, English Edition.

Mentions that "iron, lead and tin mines must be very common, since these metals are sold at a low rate throughout the whole empire."

268. LECLÈRE, A. Étude géologique et minière des provinces chinoises voisines du Tonkin.

Ann. Mines, ser. 9, Vol. 20, 1901, Paris, pp. 345-348, 439-440, 474-476.

Digest and translation: Trans. Inst. Mg. Eng., Vol. 25, 1902-1903, London and Newcastle-upon-Tyne (1904), p. 823.

Tin occurs at Tomuko, Tsementong, Kotiou, and Malaken, in province of Yunnan. Some of the tinstone occurs in veins in Triassic limestones, but there are also secondary ore bodies, from the decomposition of the limestones and veins. Worked open-cast. "At Malaken the red clay veins worked for tinstone are proving more and more barren of that ore, while the proportion of copper in the inflling increases." The stuff thrown on the wasteheaps is really rich copper oxide. 


\section{CHINA (Continued)}

269. Pansner, Hofrath. Beiträge zu einem Handbuche der Mineralogie des chinesischen Reichs.

Tasch. ges. Min., Vol. 12, II, 1818, Frankfurt-am-Main, pp. 415-416.

Treats briefly of tin and its occurence in China.

269a. Willis, BaILEY. Mineral resources of China.

Econ. Geol., Vol. 3, 1908, Lancaster, p. 129.

At present mining and smelting of tin are the most important industrial developments of Yunnan. Metal occurs in veins, no alluvial deposits. Occurs always in red clay, contained sometimes in fissures of limestone, sometimes in the neighbor. ing accumulations of soils. Resources of district in tin cannot easily be estimated. Deposits liable to run out suddenly. Difficult to define probable depth. Production limited by small amount of available water.

\section{COLORADO}

270. Emmons, S. F. Geology and mining industry of Leadvilie, Colo.

Monogr. U. S. Geol. Surv., Vol. 12, 1886, Washington, D. C., p. 377.

"Tin, indium and cadmium have been detected in furnace products."

271. Stevens, R. P. On the San Juan Mountains of Colorado.

Trans. New York Acad. Sci., Vol. 5, 1886, New York, p. 128.

States that tin has been found in Colorado. Gives no locality or authority.

\section{CONGO}

272. Barrat, Maurice. Sur la géologie du Congo Français.

Ann. Mines, ser. 9, Vol. 7, 1895, Paris, p. 459.

" On soupconne depuis longtemps la presence de l'étain dans le massif cristallin qui apparait sur la côte occidentale d'Afrique, et $M$. Mizon a récemment attiré l'attention sur l'étain de la Bénoué, qui est l'objet d'un trafic considérable. Dans notre colonie, on n'a encore signalé que des traces de cassitérite dans les monts de Cristal." Whole reference.

273. Buttaenbaci, $H$. L'avenir industriel de l'état indépendant du Congo. Rev. Univ. Mines, Met. Trav. Publ. Sci. Arts Appl. Indust., ser. 4, Vol. 14, 1906, Liége and Paris, pp: 140-141, map and fig.

Taken from No. 274.

274.

L'avenir industriel du Katanga.

1906, Brussels, p. 21, 120 words.

Twenty thousand tonnes of tin said to be in sight in alluvial deposits, a short distance from navigable waters of the Lualaba.

275. La cassitérite du Katanga.

Ann. Soc. géol. Belg., Vol. 33, 1906, Liége, pp. M49-M52, flgs. 2.

Digest translation: Trans. Inst. Mg. Eng., Vol. 33, 1908, London and Newcastleupon-Tyne, pp. 722-723.

Cassiterite occurs in nearly vertical lodes at the junction of a massif of pegmatoid granite with tourmaline quartzites, mica schists, etc. Gold and copper deposits occur not far away. Stanniferous area is rugged and veins sometimes crop out in the ravines, but are usually hidden by debris containing cassiterite pebbles up to several pounds in,weight, which are frequently well crystallized. 


\section{CONGO (Continued)}

276. FARRELL, John R. The copper and tin deposits of Katanga.

Eng. Mg. Journ., Vol. 85, 1908, New York, pp. 747-753, maps 2, illus.

Remarkable deposits in the Congo are being developed, and will be largely productive when railway communication is available. The tin belt extends for a hundred miles in a northeast and southwest direction from the Lualaba to the Lufira rivers just north of a range of granite hills. Cassiterite has been found as alluvial wash in a number of places. Wash consists of angular fragments of pinkish quartz mixed with tourmaline, tourmaline schists and schorl rock. Cassiterite contains from 63.5 to 65 per cent tin, unmixed with other metals.

277. Fawns, Sydney. Tin deposits of the world.

London, 1905. Deposits of the Congo Free State, pp. 144-146.

Tin has been found both in alluvial drift and in ledges on the Tanganyika Concessions in the Congo Free State about lat. $10^{\circ} 20^{\prime} \mathrm{S}$., long. $25^{\circ} 13^{\prime} \mathrm{E}$., and at intervals for 60 miles northwest along the valley of the Lualaba River. Most important discovery at the Busanga Tin Mine, three-quarters of a mile from the junction of the Lufupa and Lualaba rivers. Cassiterite occurs in quartz veins too poor to work. It is also found scattered through the residual alluvium and in the stream gravels.

278. LACroix, Alfred. Minéralogie de la France et de ses colonies.

Vol. 3, 1901, Paris, p. 231.

Briefly states that tin has been found in the Congo region.

279. Stanier, X. The geology of the Congo.

Guide de la Section de l'État Indépendant du Congo a l'Exposition BruxellesTervueren, 1897, p. 269.

Trans. Fed. Inst. Mg. Eng., Vol. 15, 1898, Newcastle-upon-Tyné and London, p. 496.

"Commanders Van Gele and Roget have noticed the existence of stanniferous rocks on the Ubangi and Uelle [Djabbir], and they have also mentioned the presence of objects made from this metal in the hands of the natives. This fact would seem to indicate the presence of workable deposits, and deserves further study, for it is known that tin is a metal very easily extracted, and that its value is sufficiently high for it to support high rates of transport."

\section{EAST INDIES}

280. Anonymous. Tin in Singkep.

Min. Ind. for 1897, Vol. 6, 1898, New York and London, p. 641.

A paragraph stating that Singkep tin is to be smelted and sold as Straits tin.

281. Benedict, WM. DE L. Tin in Sumatra.

Min. Ind. for 1892, Vol. 1, 1893, New York and London, pp. 449-450.

Tin district described. In comparing the richness of the alluvial deposits of Sumatra with those of Banca it is stated that former yields at the rate of $0.348 \mathrm{lbs}$. of tin per cubic meter excavated, as against a yield of from 3 to $4 \frac{1}{2} \mathrm{lbs}$. in the latter. A number of assays given.

\section{Crawfurd, John. History of the Indian Archipelago, etc.}

1820, Edinburgh, Vols. 1 and 3.

Tin: Indigenous to the Archipelago, Vol. 1, p. 182; seldom used by natives in its pure state, Vol. 1, pp. 191-192; where found, Vol. 3, p. 450; history of mining, Vol. 3, p. 452; parallel between the mines of Banca and Cornwall, Vol. 3, p. 464; price and quantity exported, Vol. 3, p. 466; general reflections on the tin trade, Vol. 3, p. 466. 


\section{EAST INDIES (Continued)}

283. Cretier, H. Bijdragen uit het scheikundig laboratorium ven het hoofdbureau van het Mijnwezen in Nederlandsch-Indië te Batavia.

Jaarb. Mijnw. Ned. Oost-Indië, No. 15, 1881, II, Amsterdam, pp. 246-247.

Tinhouded zand van Billiton.

284. Dach, Robert. Ueber das Vorkommen und den Abbau von Zinnseifen auf der Insel Karimon.

Berg. Hüt. Zeit., Vol. 22, 1863, Leipzig, pp. 337-338.

Brief digest: Neues Jahrb. Min., 1864, Stuttgart, p. 365 .

285. Diest, P. H. van. Begrooting van het kapitaal benoodigd voor het in ontginning brengen van tinert bevattende terreinen op het eiland Sinkep, en der voordeelen welke van die ontginning mogen worden verwacht.

Jaarb. Mijnw. Ned. Oost-Indië, 18 2 , II, Amsterdam, pp. 127-152.

286. - Verslag der onderzoekingen aan den heuvel Salinta.

Jaarb. Mijnw. Ned. Oost-Indië, 1873, II, Amsterdam, pp. 145-149. Met eene kaart.

286a. Doonman, W. H. C. Die Gewinnung des Zinns in den niederländischöstindischen Kolonien.

Glück. Berg. hiutt. Zeit. Nied. Wesph.; 45 Jahr., 1909, Essen, pp. S44-\$46.

287. Everwyn, R. Forschung nach Zinnerzen in den Landschaften Sukandana, Simpang und Matam [westliche Abtheilung von Borneo] und nach Antimonerzen auf den Karimatainseln.

Kon. Nat. Tijdschr. Ned.-Indië, n. s., Theil 6, 1855, Batavia, S. is.

Not available to the authors.

288. - Forschung nach Zinnerzen in der Landschaft Kandawangan [Südwestspitze von Borneo].

Kon. Nat. Tijdschr. Ned.-Indië, n. s., Theil 9, 1856, Batavia, S. 449.

Not available to the authors.

289. EverwiJn, R. Verslag van een onderzoek naar tinerts, op eenige eilanden behoorende tot de residentie Riouw.

Jaarb. Mijnw. Ned. Oost-Indië, 1872, II, Amsterdam, pp. 73-126. Met eene kaart en drie bijlagen.

290. - Verslag van eene onderzoekingsreis in het rijk van Siak. Jaarb. Mijnw. Ned. Oost-Indië, 1874, I, Amsterdam, pp. 83-155.

Chap 2, Geological sketch of country visited; Chap 3, Report on alluvial deposits of Kampar River district. An appendix is added which contains list of the mines worked in Siak.

291. - Overzicht van de mijnbouwkundige onderzoekingen, welke tot $\mathrm{nu}$ toe door den dienst van het mijnwezen in de wester-afdeeling van Borneo werden verricht.

Jaarb. Mijnw. Ned. Oost-Indië, 1879, I, Amsterdam, pp. 58-82.

Investigation of the tin deposits of Soekadana, Simpang, Matan and Palo.

D'Achiardi, Antonio. See No. 1313.

Fawns, Sydney. See No. 1320. 


\section{EAST INDIES (Continued)}

292. Fennema, R. Onderzoek naar tinerts in het gebied der Boven Banjoeassin, residentie Palembang, naar aanleiding van een valsch bericht van een inlandsch hoofd, uitgevoerd door den opziener der $2^{\text {e }}$ klasse P. J. Tant.

Jaarb. Mijnw. Ned. Oost-Indië, 1878, II, Ainsterdam, pp. 233-235.

293.

- Topographische en geologische beschrijving van het noordelijk gedeelte van het gouvernement Sumatra's Westkust.

Jaarb. Mijnw. Ned. Oost-Indië, 1887, II, Amsterdam, Weten,, pp. 248-249.

Fuchs, E., and Launay, L. DE. See No. 1323.

294. Hamilon, Alexander. A new account of the East Indies.

1727, Edinburgh, Vol. 2, pp. 75, 121.

States that Perak produces more tin than any other district of India. Selangor and Parcelore are also large producers of tin. Gives an account of the discovery of tin in Sumatra.

295. Hochstetter, Ferdinand. Zinn in den niederländisch-östindischen Inseln.

Jahrb. k. k. geol. Reichs., Vol. 9, 1858, Wien, pp. 284-286.

Review: Zeitschr. Berg. Hüt. Sal., preuss. Sta., Vol. 8, 1860, Berlin, pp. XXIIXXIII.

296. Koperberg, M. Geologische en mijnbouwkundige onderzoekingen in de residentie Menado gedurende het jaar 1901 (Celebes).

Jaarb. Mijnw. Ned. Oost-Indiē, Vol. 31, 1902, Ansterdam, pp. 147-165. Pl. 4 (topogr. maps).

Lock, C. G. WarNFord. See No. 1338.

297. Menten, J. H. Verslag van een onderzoek naar tinerts op het elland Singkep.

Jaarb. Mijnw. Ned. Oost-Indië, 1876 (1877), II, Amsterdam, pp. 145-177. Met twee kaarten.

298. NEEB, E. A. Verslag omtrent het onderzoek naar tinert-safzettingen in een gedeelte van Midden-Sumatra.

Jaarb. Mijnw. Ned. Oost-Indië, Vol. 31, 1902, Amsterdam, pp. 113-145, pls. 1-3, geol. map.

299. Newbold, T. J. Account of Sungie Ujong, one of the states of the interior of Malacca.

Moor's Indian Archipelago. 1837, pp. $77(\mathrm{a})-84(\mathrm{a})$.

Brief outline of the tin mining conditions under Dutch occupation. Description of the miners, Malays and Chinese, their methods of mining, smelting, etc. Geological description of tin-bearing country. Quantity produced in Malayan Peninsula and Banca.

300. Posewriz, Tr. Das Zinnerzvorkommen auf den Inseln des RiouwLingga-Archipels.

Petermann's Mitth., Vol. 33, 1887, Gotha, pp. 366-368.

301.

Zinnerz auf den Inseln Sumatra, Flores and Borneo.

Ausland, No. 34, 18s8, Stuttgart und München, pp. 672-674. 


\section{EAST INDIES (Continued)}

302. - Borneo. Entdeckungsreisen und Untersuchungen. Gegenwärtiger Stand der geologischen Kenntnisse. Verbreitung der nutzbaren Minerallen.

1889, Berlin, pp. 344-345.

Describes the tin deposits of the island of Borneo.

303. Reyer, EduARd. Zinn in Birma, Siam und Malakka.

Oest. Zeitschr. Berg. Hütt., Vol. 27, 1879, Wien, pp. 563-564, 575-576, sketch map 1.

304.

Die Zinnerzlagerstätten von Perak, Malacca, und ihre Ausbeutung.

Berg. Hütt. Zeit., Vol. 47, 1888, Leipzig, pp. 181-183.

See No. 1354.

305. Rolker, Charles M. The alluvial tin deposits of Siak, Sumatra.

Trans. Amer. Inst. Mg. Eng., Vol. 20, 1891, New York, pp. 50-84.

Digest: Report on Mineral Industries in the United States at the Eleventh Census, 1890, Washington, D. C., 1892, pp. 257-264.

Reviews briefly the history of tin mining in the East Indies, prefatory to a description of the physical characteristics, rivers, climate, geology, distribution of tin, accompanying minerals, costs of mining, labor supply, tools and customs of the district of Siak, Sumatra. Gives present exports of tin from East Indies.

306. Schneider, C. F. A. Geologische Uebersicht über den holländischöstindischen Archipel.

Jahrb. k. k. geol. Reichs., Vol. 26, 1876, Wien, pp. 122, 134.

-

307. Tenison-Woods, J. E. The geology of Malaysia, Southern China, etc.

Nature, Vol. 33, 1886, London, p. 232.

States that he saw, tin ore brought from the Kinebetungen River, Borneo, by D.

D. Daly, private secretary of the governor.

308. Wmbman, (Consul). Tin in Java,

Eng. Mg. Journ., Vol. 55, 1893, New York, p. 231.

States that a Dutch company has erected works and a smelter at Singkep to test the tin ores discovered at that place. Reports discovery of tin at Jahor.

Original article not available to the authors.

See under Banka, Billiton, New Guinea.

\section{ENGLAND}

309. Аввотт, George, Jr. An essay on the mines of England; their importance as a source of national wealth and as a channel for the advantageous employment of private capital.

1833, London, pp. 227.

310. Anonymous. Tin mines. The whole history of the tin works in Cornwall, beginning with their manner of working in the times of the Saxons.

Harleian manuscript, No. 6380. Not available to the authors. Reference made from Boase, G. C., and Courtney, W. P., Bibliotheca Cornubiensis, Vol. 3, 1882, London, p. 1020 . 


\section{ENGLAND (Continued)}

311. Etwas über den Zinn- und Kupferbergbau in Kornwallis. Aus Briefen eines reisenden Deutschen vom October, 1783. Aus der handschrift.

Johann Bernouilli's Sammlung Kurzer Reisebeschreibungen, Jahrgang 1784, Vol. 13, Berlin, pp. 363-374.

Not available to the authors.

312. - Some observations on the mines of Cornwall and Devon, describing the art of training a load, the art and manner of digging the ore and the way of dressing and of blowing tin.

Philos. Trans. Roy. Soc. London, abridged, Vol. 1, 1809, London, pp. 565-574.

First published in Vol. 6, 1671, pp. 2096-2113.

The working of tin veins ("loads"), and the dressing and smelting of the ore.

313. - On the mining district of Redruth.

Quart. Mg. Rev., No. 6, 1832, London, pp. 201-225.

History of the mining and a description of the geology of the district.

314. Tincroft.

Mg. Journ. Railw. Comm. Gaz., Vol. 1, 1835, London, pp. 87, 108.

A history and description of the various lodes and working of the Tincroft mine.

314a.

- Cornwall and mines.

Dublin University Magazine, Vol. 58 (July), 1861, Dublin, pp. 32-45.

A popular description of tin mining in Cornwall.

315. Axonymous [Salmon, H. C. (?)]. The St. Ives and Levant tin-mining district, Cornwall.

Mg. Smelt. Mag., Mo. Rev. Pract. Mg. Quarry. Met., Vol. 3, 1863, London, p. 138.

Not available to the authors.

316. Axoxymous. The system of selling tin ore in Cornwall.

Mg. Sinelt. Mag. Mo. Rev. Pract. Mg. Quarry. Met., Vol: 5, 1864, London, pp. 6-11, 132-135.

317. - Cornish tin-mining. Great Vor district.

Mg. Journ. Railw. Comm. Gaz., Vol. 55, 1885, London, p. 987.

Discusses present mining conditions with special reference to the future of the Great Vor district.

318. - Working low grade tin ores.

Mg. Sci. Press, Vol. 65, 1892, San Francisco, p. 187.

The tin at Wheal Prosper, Cornwall, is doubtless the lowest grade of any in the world, yet is being worked with profit. Ore runs 3 pounds black tin per ton of ore, or about $\mathbf{0 . 1 3}$ per cent. Prof. C. Le Neve Foster gives following reasons:

1. Rock soft and friable, easily stamped.

2. Tin in large grains, hence fine stamping is not necessary.

3. The light specific gravity of substances nixed with tin, make separation by water easy.

4. There is water power at command.

319. - Tin mining.

Mg. Sci. Press, Vol. 67, 1893, San Francisco, p. 356.

Some curious statements about tin mining in Cornwall, taken from "Symon's Gazetteer" of Cornwall. 


\section{ENGLAND (Continued)}

320.

\section{Cornish tin mining in photograph.}

Eng. Mg. Journ., Vol. 58, 1894, New York, pp. 130, 154, 178, 202, 226, 298.

Eighteen excellent photos showing mines, and methods of working, probably taken by J. C. Burrows. See 467 .

321.

\section{Tin mining in Cornwall.}

Mg. Journ. Railw. Comm. Gaz., Vol. 64, 1894, London, p. 928.

Discovery of important tin deposits at the Park of Mines, near St. Columb. Country rock is entirely clay slate. Granite occurs within three-quarters of a mile of mine. Ore occurs in massive and crystallized form, in many small lodes.

322. Tin in England.

Min. Ind. for 1897, Vol, 6, 1898, New York and London, pp. 640-641.

Improvements and economies of Dolcoath mine. The mine shows increased quantity of ore as well as profits.

323.

\section{Tin in Great Britain.}

Min. Ind. for 1898, Vol. 7, 1899, New York and London, p. 711.

Abstract of report of directors for Dolcoath mine for half year ending June 30, 1898.

324.

\section{Tin in Great Britain.}

Min. Ind. for 1899, Vol. 8, 1900, New York and London, p. 621.

Treats briefly of Dolcoath mine. Statistics of production given.

325.

\section{Cornish tin mining,}

Engineer, Vol. 90, 1900, London, p. 172.

Considers reasons why this industry has not revived with the rise in the price of tin.

326. - Tin in United Kingdom.

Min. Ind. for 1900, Vol. 9, 1901, New York and London, p. 640.

Report of Dolcoath mine during first half of 1900 .

327. - Report of Dolcoath mine.

Min. Ind. for 1901, Vol. 10, 1902, New York and London, pp. 642-643.

Statistics of output from 1897 to 1901 given.

328. - Tin mining in Cornwall.

Eng. Mg. Journ., Vol. 74, 1902, New York, p. 335.

Rather unpromising outlook. One company paid dividends in 1900 but 1901 used profits in bettering plant. Ore $\mathbf{4 3 . 5}$ pounds of black tin per long ton of ore. Another is losing money with 27 pound ore.

329. - The tin mining industry of Cornwall.

Sci. Amer. Suppl., Vol. 63, 1907, New York, pp. 26189-26191, photos 8.

Mining conditions in Cornwall, difficulties to be overcorne, and the improvements being made. Writer claims there are yet several million tons of ore awaiting development.

\section{9a. - Cornish tin mining.}

Eng. Mg. Journ., Vol. 86, 1908, New York, p. 181.

A discussion of the costs of tin mining in Cornwall and reasons for loss at some mines.

329b. Cornish mining in 1908.

Mg. Journ. Railw. Comm. Gaz., Vol. 85, 1909, London, pp. 12-14.

"A brief account of the commercial conditions, together with tables of output and value of the ore mined in the different districts." 


\section{ENGLAND (Continued)}

329c. The tin alluvials of Restronguet.

Mg. Journ. Railw. Comm. Gaz., Vol. 85, 1909, London, pp. 175-176.

States, and gives reason for, the belief that tin alluvials of Cornwall are neither exhausted nor too poor to be profitably worked.

329d. - British Empire's tin output.

Mg. Journ. Railw. Comm. Gaz., Vol. 85, 1909, London, p. 384.

"Statistics showing output of tin, from 1893-1907 in tonnage and value. These statistics cover the United Kingdom and all the English colonies."

329e. - Cornwall and Devon.

Mg. Journ. Railw. Comm. Gaz., Vel. 88, 1910, London, pp. 12-13.

Gives mining conditions especially as to output in the various mines of Cornwall and Devon for year 1909.

329f. - Cornish tin alluvials.

Mg. Journ. Railw. Comm. Gaz., Vol. 88, 1910, London, p. 533.

Treats briefly of the possibility of alluvial tin mining in Cornwall.

329g. Camborne, Cornwall.

Mg. Sci. Press, Vol. 100, 1910, San Francisco, pp. 433-434.

Discusses the condition of South Crofty, Carn Brea, Tincroft, Dolcoath, and Wheal

Vor mines.

- See No. 1278 .

330. ARgall, WM. On the occurrence of wood-tin ore in the Wheal Metal lode at Wheal Vor in Breage.

Journ. Roy. Inst. Cornwall, Vol. 4, No. 15, 1874, Truro, pp. 255-256.

Description of the wood-tin found and condition under which it occurred.

331. Baldauf, Martin. Bergmännische Reisebriefe aus England.

Oest. Zeitschr. Berg. Hütt., Vol. 56, 1908, Wien, pp. 17-21, figs. 9.

"Describing the geology, and the methods of mining and dressing the ores at the Redruth, Dolcoath and East Pool mines."

331a. BALt, LIONEL C. The Dolcoath.

Queensland Gov. Mg. Journ., Vol. 10, 1909, Brisbane, pp. 58-61, illus.

The first of a series of articles on mining and milling in Cornwall, to allow a comparison of methods used there with those in Queensland.

331b. - Some Cornish mines and treatment works.

Queensland. Gov. Mg. Journ., Vol. 10, 1909, Brisbane, pp. 108-112, illus.

Describes the mining and milling methods, with short account of the geology of Botallack and Wheal Bassett mines also method of treatment of tin ores at South Crofty and Porth Ledden mills.

331c. Cornish mining.

Queensland Gov. Mg. Journ., Vol. 10, 1909, Brisbane, p. 274, illus. Briefly describes Cornish mining methods.

332. BARNetT, A. K. Observations on the elvan courses, greenstones and sandstones of Cornwall, with remarks on their associated minerals.

Rep. Proc. Min. Ass. Cornwall and Devon, 1873-1874, Falmouth, pp. 69-94, figs. 4.

Some of the elvans or rhyolitic dikes carry tin. 


\section{ENGLAND (Continued)}

333. Barrow, George. The high-level platforms of Bodmin moor, and their relation to the deposits of stream tin and wolfram.

Mg. Journ. Railw. Comm. Gaz., Vol. 83, 1908, London, p. 361. Discussion, p. 384. Describes three platforms; first, marine, of Pliocene age, at $\mathbf{4 5 0}$ feet above sea, second at 750 feet seen about Camelford, and at foot of Delabole Hill, third at a little less than 1000 feet, flrst recognized on Davidstow Moor. Superficial deposits which bear tin above 750 feet platform differ very much in places from those below. Here ancient wash is preserved, perhaps protected, from denudation which has destroyed them below this level. The deposits are not so concentrated as the stream-sorted material below. Deposits have been worked in the past, but on account of difficulty of separating wolframite, were abandoned. Since that difficulty has been removed, the industry is reviving, and the wolframite is more valuable than the tin ore.

334. Bartletr, Thomas. A treatise on British mining; with a digest of the cost book system, stannerie and general mining laws.

1850, London, pp. 112.

BATten, JoHn; JR. See No. 1377.

335. BAwDEN, S. Dislocation of lodes and strata.

Rep. Proc. Min. Ass., Cornwall and Devon, 1866, Falmouth, p. 29.

Not available to the authors.

Beck, Richard. See No. 1299.

336. Benedict, WM. DE L. Cornwall.

Min. Ind. for 1892, Vol. 1, 1893, New York and London, pp. 439-442.

Early history of tin mining in Cornwall. Statistics of production from 1742 to 1891 given. Geology of Cornwall tin veins described.

337. Bennetts, Geo. Tin lodes on Dartmoor.

Mg. Journ. Railw. Comm. Gaz., Vol. 56, 1886, Lonđon, p. 963.

338. Bennets, Samuel. The mining district of St. Agnes.

Trans. Mg. Ass. Inst. Cornwall, Vol. 1, 1887, Camborne, pp. 18-27, discussion, pp. 27-29, pl. 1.

Treats of the peculiarities of tin and other veins of the district, from a geological point of view.

339. Berger, J. F. Observations on the physical structure of Devonshire and Cornwall.

Trans. Geol. Soc. London, Vol. 1, 1811, London, pp. 93-184.

Treated under heads:

Tin forming one of the integrant parts of granite; p. 120.

Stream tin, where met with in Cornwall; p. 162.

Course of veins in Cornwall; pp. 163-166.

Estimate of the number of mines of Cornwall, of the different kinds of ore they contain and of their relative ages; pp. 167-175.

of the different matrices accompanying the mineral deposits in Cornwall and Devonshire; pp. 173-181.

340. Black, A. and C. Black's guide to the Duchy of Cornwall, 12th ed. 1883; Edinburgh, pp. 49-54.

A short description of Carclaze tin mine is given on p. 49, and a narrative explanation of tin mining and the handling of tin ores follows. 


\section{ENGLAND (Continued)}

341. Blake, WM. P. The Dolcoath tin mine, Cornwall.

Eng. Mg. Journ., Vol. 54, 1892, New York, p. 414.

Reprint, Sci. Amer. Suppl., Vol. 34, 1892, New York, pp. 14082-14083. Short general article.

342. Boase, G. C., and Courtney, W. P. Bibliotheca Cornubiensis, 3 vols. 1874-1882, London.

Contains a large number of references to Cornwall and Devonshire tin mines, to their geology, customs, laws, history, etc.

343. BoAse, HeNry S. On the tin-ore of Botallack and Levant.

Trans. Roy. Geol. Soc. Cornwall, Vol. 2, 1822, Penzance, .pp. 383-403.

Examination of the tin-ore found in some of the St. Just mines; method of dressing it preparatory to smelting; explanation of method of separating the tin and copper from ores of these mines; the result of some experiments on the ore by which it was hoped to find an improved process for separating the copper.

344. - Contributions towards a knowledge of the geology of Cornwall. Trans. Roy. Geol. Soc. Cornwall, Vol. 4, 1838, Penzance; pp. 166-474, pls. 3, 4. Description of the geology of Cornwall, with "numerous innovations," and deductions with which author has endeavored to disprove some accepted geological doctrines. The tin veins of Cornwall treated.

345. BonNard, A. H. Note sur le gisement, l'exploitation et le traitement de l'étain dans le Duché.de Cornouailles.

Journ. Mines, No. 84, Vol. 14, 1803, Paris, pp. 443-454.

"The author more particularly describes Polgooth mine, Carclaze mine and Pentowan stream work, near St. Austell, from personal observations."

346. Borlase, WM. Copeland. Natural history of Cornwall.

1758, Oxford.

Not available to the authors.

- See Nos. 1381, 1382, and 1383.

347. Borlase, Rev. Wm. Copeland, and Rosewarne, H. Extract of letters giving an account of a specimen of native tin found in Cornwall.

Philos. Trans. Roy. Soc. London, Vol. 12, 1769, London, p. 597-598.

Brown, A. Selwyn. See No. 1308.

348. Brunnich, Morten Tirkane. Beschreibung zweyer Zinnerze.

Kön. Schwed. Akad. Wiss. Abh. Nat. Haush. Mech., Vol. 40, 1778 (Pub. 1783),

Leipzig, pp. 307-310.

Treats of tin ores of Cornwall.

349. Buller, John. An account of the Parish of St. Just. 1842, Penzance.

Not available to the authors.

Burnard, Robert. See No. 1384.

350. Busz, K. Mittheilungen über den Granit des Dartmoor Forest in Devonshire, England, und einige seiner Contactgesteine.

Neues Jahrb. Min., Beilage-Band 13, 1899, Stuttgart, pp. 90-139, pl. 1, fig. 1. Page 100: Hornfels consists of light colored mica, quartz and tourmaline. Innumerable grains of cassiterite occur through it. Isolated by $\mathbf{H} \dot{F}$ and metallic tin obtained. Describes also a garnet-datolite hornfels and a hedenbergite hornfels with accessory garnet, datolite, axinite, and quartz. 


\section{ENGLAND (Continued)}

Carcanagues, - See No. 1651.

351. Carew, Richard. Survey of Cornwall.

1811, London, pp. 25-60.

The first edition of this work was issued in 1602. Description of stream works and lode-mines; names of mines; mode of working; ore dressing; sharing black tin; tin coinage (paying tribute in metal); ccmmercial practices; and courts.

352. Carne, Josepr. An account of the Relistian tin mine.

Philos. Trans. Roy. Soc. London, 1807, London, pp. 293-295.

Journ. Nat. Philos., Chem. Arts, ser. 2, Vol. 20, 1808, London, p. 24.

Short description of pebbles of chlorite schist cemented by crystallized tin, which occurred in this mine.

353. - On the relative age of the veins of Cornwall.

Trans. Roy. Geol. Soc. Cornwall, Vol. 2, 1822, Penzance, pp. 49-128, pls. 1, 2.

The tin veins, among other metalliferous veins, are treated with regard to their age in relation to the country rocks.

354. - On the mineral productions, and the geology of the parish of St. Just.

Trans. Roy. Geol. Soc. Cornwall, Vol. 2, 1822, Penzance, pp. 290-358. Map of Parish of St. Just.

Treated under heads:

The tin of the parish described, pp. 292-294; description of veins, pp. 321-323; tin floors, pp. 326-331; the stream works of Parish, pp. 331-333; tin mines, pp. 339-344; ancient modes of mining, pp. 345-350; ancient history of the "Cassiterides," pp. $354-358$.

355. - A description of the stream-work at Drift Moor, near Penzance. Trans. Roy. Geol. Soc. Cornwall, Vol. 4, 1838, Penzance, pp. 47-56.

Antiquity of diggings and proof of the deluge.

356. - An account of the discovery of some varieties of tin-ore in a vein, which have been considered peculiar to streams, with remarks on diluvial tin in general.

Trans. Roy. Geol. Soc. Cornwall, Vol. 4, 1838, Penzance, pp. 95-112.

Describes wood tin, toadseye tin, and sparable-tin found in Garth mine, or East Wheal Cock.

356a. Statistics of the tin mines in Cornwall, and of the consumption of tin in Great Britain.

Journ. Statis. Soc., London, Vol. 2, 1839, London, pp. 260-268.

Gives a brief history of tin smelting, the exports, imports and prices of tin from 1750 to 1837 .

357. - Pseudomorphous minerals of Cornwall.

Trans. Roy. Geol. Soc. Cornwall, Vol. 6, 1846, Penzance, pp. 29-30.

Crystals of feldspar and quartz wholly or partially replaced by $\mathrm{SnO}_{2}$.

358. Chaplin, G. P. Cornish methods of mine timbering.

'Trans. Fed. Inst. Mg. Eng., Vol. 13, 1897, Newcastle-upon-Tyne and London, pp. 200-210, pl. 11.

Some data about timbering. New Dolcoath shaft vertical and $181 / 2$ feet in diameter. It is bricked and expects to cut the lode at 2500 feet depth. The rocks of the mine are generally solid and need little timbering, but timbers 2 feet square and 30 feet long are sometimes used. 


\section{ENGLAND (Continued)}

Chapman, E. J. See No. 1597.

359. Codringtox, T. On some submerged rock-valleys in South Wales, Devon and Cornwall.

Quart. Journ. Geol. Soc. London, Vol. 54, 1898, London, pp. 269-278.

Treats of the stream tin deposits of Cornwall.

360. Colenso, Johr W. A description of Happy-Union tin stream work at Pentuan.

Trans. Roy. Geol. Soc. Cornwall, Vol. 4, 1838, Penzance, pp. 29-39.

Overburden 53 feet. Tin from finest sand to large pieces of 200 pounds. Averages about .9 of 1 per cent of the gravel.

361. Collins, J. H. A handbook to the mineralogy of Cornwall and Devon. With instruction for their discrimination, and copious tables of localities.

1871, Truro, pp. 108, pls. 10.

362. Note on a portion of the incrusted surface of a block of "Jews' Tin."

Journ. Roy. Inst. Cornwall, Vol. 4, 1872, Truro, pp. 83-84.

$\Lambda$ bstract: Chem. News, Vol. 25, 1872, London, p. 271.

Analysis of the crust which covered a part of a block of "Jews' Tin," and which appeared to be chiefly peroxide of tin, probably formed by the slow oxidation of the outer surface of the block of metallic tin.

363. - Note on the rocks and Goonbarrow mines near St. Austell.

Rep. Proc. Min. Ass. Cornwall and Devon, 1872-1873, Truro, pp. 66-69, figs. 2.

Description of the occurrence of tin at Goonbarrow mines.

364. - On the mining district of Cornwall and West Devon.

Proc. Inst. Mech. Eng., 1873, Birmingham, pp. 89-106. Discussion pp. 107-118. pls. 22-36.

Treated under the heads:

Mineral lodes; tin and copper mines; quantities and values of the ores.

365. Note on the occurrence of stanniferous deer horns in the tin gravels of Cornwall.

Trans. Roy. Geol. Soc. Cornwall, Vol. 10, 1887, Penzance, pp. 98-100.

Abstract: Amer. Journ. Sci. ser. 3, Vol. 22, 1881, New Haven, pp. 81-82, 175 words.

Description of deer horns which have been partly replaced by percolating stanniferous solutions. In some parts, the original horn structure is almost entirely preserved or reproduced in oxide of tin.

(Note: J. B. Scrivenor in a later examination of similar horns found the tin to be mechanically deposited and not a replacement. See $726 \mathrm{~b}$.)

366.

- On the geology of Cornwall.

Proc. Geol. Ass., Vol. 10, 1889, London, pp. 101-111.

Treated under heads: Mineral lodes, stockworks; tin stream work; lode workings.

367. - On the origin and development of ore deposits in the west of England.

Journ. Roy. Inst. Cornwall, Truro.

Chaps. I and II, Vol. 10, 1891, pp. 109-149, flgs. 13. Chap. III, Vol. 11, 1893, pp. 111-184, figs. 16. Chap. III, Vol. 11, 1893, pp. 327-377. Chaps. III and IV, Vol. 12, 1896, pp. 49-75. Chap. V, Vol. 13, 1899, pp. 283-312. 


\section{ENGLAND (Continued)}

Chap. I, Vol. 10, Formation of structural planes in rock masses.

Chap. II, Vol. 10, The mechanical phenomena of faulting.

Chap. III, Vols. 11 and 12, Rock-change as affecting the formation of ore deposits.

Chap. IV, Vol. 12, The formation and natural concentration of detrital deposits.

Chap. V, Vol. 13, The relative ages of the ore deposits of the west of England.

The tin deposits of England are treated in this series of articles, along with other metalliferous veins.

368. - Cornish mines and Cornish miners.

65th Ann. Rep. Roy. Cornwall Polyt. Soc., Vol. 65, 1897, Falmouth, pp. 64-96.

Journ. Soc. Arts, Vol. 47, 1899, London, pp. 359-376.

Treated under heads:

Antiquity of mining; the valley gravels; submarine tin gravels; the "Old Men"; copper and other minerals; deep mining; pumping machinery; winding apparatus; ore dressing; boring machines; the great extent of mining operations; tin; the first great collapse; the revival; the culmination; product of some leading mines; the future of Cornish mining.

369. - The precious metals in the west of England.

Journ. Roy. Inst. Cornwall, Vol. 16, pt. 1, 1904, Truro, pp. 103-119. ntal ans Article treats of the gold and silver of the West of England. Stream tin at Treloy frequently had mixed with it grains of gold, mostly about the size of wheat grains, sometimes as large as peas.

- See Nos. 1385 and 1598 (Cornish tinstones).

370. Combes, Chas. Mémoire sur l'exploitation des mines des comtés de Cornwall et de Devon.

Ann. Mines, ser. 3, Vol. 5, 1834, Paris, pp. 109-144.

370a. Conran, R. H. Tin mining in Cornwall.

Austr. Mg. Eng., Rev., Vol. 1, 1909, Sydney and Melbourne, pp. 279-282, illus.

Abstract: Mg. World, Vol. 31, 1909, Chicago, pp. 549-551, illus.

Brief history of early mining and geological description of the country with more detailed account of mining methods.

371. Cotta, Bernard von. A treatise on ore deposits.

Translated by F. Prime, 1870, New York, pp. 406-427.

Summary of the ore deposits of Cornwall.

372. Couch, R. Q. Notice of the occurrence of the horns and bones of several species of deer in the tin works of Cornwall.

Trans. Roy. Geol. Soc. Cornwall, Vol. 7, 1865, Penzance, pp. 185-191.

The author, describing a certain specimen, says, " the whole horn had undergone a change into tin ore." But thinks that possibly this may not imply solution of the tinstone.

D’Achiardi, Antonio. See No. 1313.

373. Daнцвцом, Тн. Ueber die Cornwaller Zinngruben.

Jern-Kont. Ann. 1890, Stockholm, p. 334.

Review: Berg. Hütt. Zeit., Vol. 50, 1891, Leipzig, p. 290.

Daubrée, A. See No. 1314.

Davey, Stephen. See No. 1603. 


\section{ENGLAND (Continued)}

374. Davies, Alfred T. The phenomena of heaves or faults in the mineral veins of St. Agnes, Cornwall.

Rep. Proc. Min. Ass. Cornwall and Devon, for 1879 (1880), Truro, pp. 12-33, figs. 21. Discussion of vein or lode formation, with a number of practical rules and diagrams for the guidance of miners showing how to follow the continuation of veins which have been faulted or heaved. Applies to the tin veins of the district.

Davies, D. C. See No. 1317.

375. Davy, Sir Humphry. Hints on the geology of Cornwall.

Trans. Roy. Geol. Soc. Cornwall, Vol. I, 1813, Penzance, pp. 38-50.

Notes on the occurrence of tin in Cornwall.

Dechen, H. von. See No. 545.

376. De la Beche, HeNry T. Report on the geology of Cornwall, Devon and West Somerset.

Mem. Geol. Surv. Great Britain, 1839, London, pp. 1-648, maps and plates.

376a. Dew, J. H. W. Cornish tin alluvials.

Mg. Journ. Railw. Comm. Gaz. Vol. 88, 1910, London, pp. 599-600.

Correspondence concerning tin bearing gravels in Cornwall.

Dietzsch, F. See No. 1479.

377. Drew, S. History of Cornwall. 1824.

Not available to the authors.

378. Dufrenoy, P. A., and Beaumont, Elie de. Notice sur le gisement, l'exploitation et le traitement des minerais d'étain et de cuivre du Cornouailles.

Ann. Mines, Vol. 9, 1824, Paris, pp. 827-908, Vol. 10, pp. 331-366, 401-426; Vol. 11, pp. 207-254.

Reprint: Arch. Bergb. Hütt. Vol. 13, 1826, Berlin, pp. 60-185.

Reviews: Zeitschr. Min., 1826, II, Frankfurt-am-Main, pp. 427-439.

Ann. Sci. Nat., Vol. 7, 1826, Paris, pp. 195-243.

Edmonds, Richard. See No. 1389.

379. ENGLISH, HeNRY. A compendium of useful information relating to the companies formed for working British mines, containing copies of the prospectuses, amount of capital, number of shares, names of directors, etc., with general observations on their progress, detailing their operations, mines in their possession and original information. 1826, London, pp. 124.

Fawns, Sydney. See No. 1320.

Ferguson, Henry T. See No. 1654.

379a. Feuvre, P. A. Cornish Mining.

Times Eng. Suppl., Vol. 1, 1905, London, pp. 250, 273, 274, and 309-310.

Discusses briefly economic conditions of tin mining in Cornwall. Quotes Robert Hunt to the effect that the tin lodes down to 600 feet in depth average 3.97 feet wide, and below that 3.36 feet, and Henry Louis as saying that the average tin content is 2 per cent. In the second article dues and royalties and their effect upon Cornish tin mining are discussed. The third article treats of working costs. 


\section{ENGLAND (Continued)}

380. FletT, J. S. On some brecciated stanniferous velnstones from Cornwall.

Mem. Gcol. Surv. Great Britain, for 1902 (1903), London, pp. 154-159.

Microscopic examination of tin-bearing veinstones from following mines: Dolcoath, Wheal Basset, South Crofty, Carn Brea, Wheal Kitty and West Kitty. Essential constituents of these tin ores are quartz, tourmaline, chlorite and cassiterite. Fluorspar, pale micas, iron oxides, copper pyrites, kaolin (?) are present also, but not universally, occasionally there are pieces of altered feldspar and fragments of granite or slate.

381. Foster, C. Le Neve. Notes on the Rosewarne mine.

Trans. Cornwall and Devon Min. Ass., 1866, Camborne, p. 26.

Not available to the authors.

382. - Report on the inspection of metalliferous mines in Cornwall, Devonshire and a part of Somersetshire for the year ended 31st December, 1873.

Rep. Insp. Mines for 1873 (1874), London.

Parl. Pap., Vol. 13, 1874, London, pp. 295-321.

Gives statistics regarding mines of district.

383. - The tin deposits of East Wheal Lovell.

Trans. Roy. Geol. Soc. Cornwall, Völ. 9, 1875, Penzance, pp. 167-176, pls. 1.4. Two mines are included in the East Wheal Lovell namely, Tregonebris and Flatwork. In this article the tin deposit and the peculiarities of the latter mine are. treated.

384. - On a deposit of tin at Park of Mines.

Rep. Proc. Min. Ass. Cornwall and Devon for 1875 (1876), Falmouth, pp, 22-26, figs. 5 .

Abstract: Rep. Brit. Ass, Adv. Sci., Vol. 45, 1876, London, p. 64. (Note and abs.) Digest: Geol. Rec. for 1876, London, p. 12.

The tin-ore occurs as lenticular layers generally one or two inches thick, between the planes of bedding of the killas. The layers appear to be the off-shoots from north and south veins.

385. - On the Great Flat Lode of Redruth and Camborne and some other tin deposits formed by the alteration of granite.

Quart. Journ. Geol. Soc. London, Vol. 34, 1878, London, pp. 640-653, figs. 10, pls. 30. Plan and section of tin mines on Great Flat Lode.

Abstract: Rep. Brit. Ass. Adv. Sci., 1877, London, p. 71.

It is worked for three and one-half miles, and consists of a leader or true fissure vein only a few inches wide carrying tin and copper ores; a lode from 4 to 15 feet wide on one or both sides of the leader, mostly of tourmaline rock, carrying 1 to 3 per cent of tin; a capel of only slightly stanniferous tourmaline rock separates the lode from the slate or granite. There is an absence of wall or plane of separation between the lode and capel or the capel and granite. Thinks the lode and capel are altered granite, and that most of the lodes in Cornwall are of similar origin.

386.

\section{On some tin stockworks in Cornwall.}

Quart. Journ. Geol. Soc. London, Vol. 34, 1878, London, pp. 654-659, figs. 3.

Abstract: Rep. Brit. Ass. Adv. Sci., 1877, London, p. 70.

Stockworks occur in killas (slate), granite and elvan (granite porphyry dikes). Gives a list of the stockworks occurring in each rock.

387. Fox, Chas. On a deposit of tin in Wendron.

Rep. Proc. Min. Ass. Cornwall and Devon, 1868, Truro, p. 35.

Not available to the authors. 


\section{ENGLAND (Continued)}

388. Fox, Robert Were. On mineral veins.

4th Ann. Rep. Roy. Cornwall Polyt. Soc., 1836-1838, Falmouth, pp. 81-141, figs. 1-21, colored.

General deseription of tin and copper veins in Cornwall. Says that where tin and copper occur in the same vein, they are inclined to occur on opposite sides of the vein. Lodes said to be more productive when nearly vertical.

389. Frecheville, R. J. Notes on great main lode of Dolcoath, Cook's Kitchen, Tincroft, and Carn Brea mines.

Trans. Roy. Geol. Soc. Cornwall, Vol. 10, 1887, Penzance, pp. 146-156, colored plates 2, showing cross section of mines.

General description of tin-bearing veins in these mines, with figures of production and remarks as to the probable continuance of the vein.

390. - The results obtalned by the Cornish system of tin-ore dressing. Trans. Mg. Ass. Inst. Cornwall, Vol. 1, 1887, Camborne, pp. 93-104. Reprinted in Eng. Mg. Journ., Vol. 40, 1885, New York, pp. 416-417. An examination into the actual loss of black tin experienced in dressing.

391. Fuchs, E., et Launax, L. DE. Traité des gîtes minéraux et métallifères. Vol. 2, 1893, Paris, pp. 112-127. Maps, figs. and bibliography.

Tin deposits of Cornwall treated.

392. Garby, JoHn. A catalog of minerals found in Cornwall with their localities.

Trans. Roy. Geol. Soc. Cornwall, Vol. 7, 1865, Penzance, p. 85.

Cassiterite, wood-tin, siliceous oxide and tin-pyrites given, the latter two unimportant.

Greg, R. P. and Letrsom, W. G. See No. 1614.

393. Gregor, WM. Observations on a remarkable change which metallic tin undergoes under peculiar circumstances, and on its partial conversion into a muriate of tin.

Trans. Roy. Geol. Soc. Cornwall, Vol. 1, 1818, Penzance, pp. 51-59.

" Some observations on a remarkable change which metallic tin undergoes that has long lain under the surface of the earth and on its partial conversion into a muriate."

394. HaNCOCK, RICHARD. On the mineral deposits of old Wheal Vor mine, Breage.

38th Ann. Rep. Roy. Cornwall Polyt. Soc., 1870, Falmouth, pp. 101-102.

This mine is eituated in a basin of killas, between two granite bills and has produced more than $\$ 3,000,000$ worth of tin and copper.

395. HAwkins, C. Observations on gold found in the tin stream works of Cornwall.

Trans. Roy. Geol. Soc. Cornwall, Vol. 1, 1818, Penzance, pp. 235-236.

Notes that gold was frequently found with stream tin in a moor near the church of the parish of Ladock.

- See No. 1395.

396. Hawkivs, JohN. On submarine mines.

Trans. Roy. Geol. Soc. Cornwall, Vol. 1, 1818, Penzance, pp. 127-142.

An account of the early working of Huel Wherry tin mine, near Penzance. It was about 720 feet out from shore, barely uncovered at lowest tides, 19 feet under water at highest. Very rich ore. In dike $18^{\prime}$ broad, $16^{\prime}$ very rich. $\mathrm{SnO}_{2}$ one of the constituent parts of the porphyry, so that it was called "stannifled granite." 70,000 pounds of ore removed. 


\section{ENGLAND (Continued)}

397. - On some remarkable phenomena attending the lodes of Polgooth tin mine.

Trans. Roy. Geol. Soc. Cornwall, Vol. 1, 1818, Penzance, pp. 143-153, pl. 5.

Description of the tin veins of Polgooth mine, which were observed by author or on which data were communicated to him, in 1791, by Capt. Phillips, director of mine, data being gathered as the working of - mine opened it up.

398.

. On the stratified deposits of tinstone, called tin-floors, and on

the diffusion of tinstone through the mass of some primitive rocks.

Trans. Roy. Geol. Soc. Cornwall, Vol. 2, 1822, Penzance, pp. 29-48.

A description of the Cornwall tin deposits known as tin-floors is given, also an account of the form of deposit known in Germany as "stockworks" and methods used by Germans in working such deposits.

399.

Pentuan.

Observations on the alluvial strata at Porth, Sandrycock and

Trans. Roy. Geol. Soc. Cornwall, Vol. 2, 1822, Penzance, pp. 285-289.

A paper in which the writer gives his views explanatory of alluvials of Porth and Sandrycock. Believes in deposition by a flood.

See No. 1396.

Headden, WM. P. See No. 1617.

400. Helmhacker, R. Allgemeines über das Zinnerzvorkommen in Cornwallis, nebst einlgen speciellen Beispielen.

Oest. Zeitschr. Berg. Hütt., Vol. 27, 1879, Wien, pp. 427-429, 443-445, 458-460, $466-470,473-475,490-492,500-503,509-511$, 524-527, 537-538, illus.

401. Henty, G. M. On the occurrence of wood-tin at the great Wheal Vor mines.

Rep. Proc. Min. Ass. Cornwall and Devon, 1867, Falmouth, p. 55.

402. Henwood, GEORge. Observations on certain tin stream works in the county of Cornwall.

Mg. Journ. Railw. Comm. Gaz., Vol. 22, 1852, London, pp. 607, 629; Vol. 23, 1853, p. 12. A series of three articles entitled the "Carnon," "Nancothan," and the "Bog," respectively treat of stream "tin deposits, their situation, appearance, production, antiquities discovered in the course of working, animal and fossil remains, and methods of working. Theories as to the probable sources from which these great deposits were derived. Briefly treats of the character, superstitions and peculiarities of the Cornish miner.

\section{Four lectures on geology and mining.} 1855, London.

(1) An introductory lecture, pp. 23; (2) Observations on certain tin stream works in the county of Cornwall, pp. 27; (3) On the metalliferous veins or lodes of Devon and Cornwall, and the methods of mining them, pp. 23; (4) On the manipulation of the ores of Devon and Cornwall, to render them marketable, pp. 21.

404. Henwood, W(ILLIAM) J(ORY). Deposits of stream tin ore in Cornwall with remarks on the theory of that formation.

Trans. Roy. Geol. Soc. Cornwall, Vol. 4, 1838, Penzance, pp. 57-69.

Overburden 14 to 53 feet. Gravel containing $\mathrm{SnO}_{2}, 4$ to 18 feet, on granite bottom. Believes in diluvial deposition. 


\section{ENGLAND (Continued)}

405. - On the metalliferous deposits of Cornwall and Devon.

Trans. Roy. Geol. Soc. Cornwall, Vol. 5, 1843, Penzance.

Treats of the quantity of tin mined in Cornwall and Devon; the form, displacement, and segregations of ore in the veins; the characteristics of tin veins in granite, slate and elvan; stream tin, wood tin and ordinary lode tin; and the minerals associated with cassiterite in the different country rocks.

406. - On a remarkable deposit of tin-ore at the Providence mines

near St. Ives, Cornwall.

Trans. Roy. Geol. Soc. Cornwall, Vol. 7, 1865, Penzance, pp. 179-184.

London, Edinburgh, Dublin Philos. Mfag. Journ. Sci., ser. 4, Vol. 4, 1852, London, pp. 538-541.

The Providence mines, in the parish of Lelant, comprise mines formerly known as Wheal Speed, Wheal Laity, Wheal Comfort and Wheal Providence. Observations on the eastern workings in the slate and on the western within the granite formation, have already appeared in Trans. Roy. Geol. Soc. Cornwall, Vol. 5, Penzance, pp. 16-20. The intermediate tract now described is wholly granite.

407. $\longrightarrow$ Observations on the metalliferous deposits of Cornwall.

- Journ. Roy. Inst. Cornwall, Vol. 4, 1871-1873, Truro, pp. ix-xxxix.

Reprinted with alterations and additions in Rep. Proc. Min. Ass. Cornwall and Devon, 1872-1873, Truro, pp. 1-20.

General description of veins of Cornwall, including tin-veins.

408. - On the detrital tin ore of Cornwall.

Journ. Roy. Inst. Cornwall, Vol. 4, 1871-1873, Truro, pp. 191-254. Read, May 16, 1873.

Abstracts: Geol. Mag. 1873, London, pp. 317-319; 1874, pp. 177-178.

Abstract translated by Zeiller, Ann. Mines, 7th ser. Vol. 6, 1874, Paris, pp. 114-130.

Contains summary of observations made at intervals during 45 years.

Four districts treated:

1. From Land's End to the eastern sources of Hayle River. 2. Included between the Camborne, Crowan, Wendron and Constantine granite, and the eastern tributaries of Restronguet, a creek of Falmouth. 3. Bounded on west by Truro River and the Gannel, on east by Fowey and lower part of the Camel. 4. From eastern part of third district to Tamar.

- See Nos. 1327 and 1656.

409. HiLt, J. B. Mining in southern district (Cornwall and Devon).

Summ. Progr. Geol. Surv United Kingdom for 1902 (1903), London, pp. 38-40.

Although areas surveyed have been extensive mining districts, few mines are still active. Tin streaming in original sense of the term, is practically a thing of the past. Mines operated with modern machinery. Last few years the debris from mine burrows have been put under stamps, more especially those mines originally worked for copper.

410. - The plutonic and other intrusive rocks of W. Cornwall in their relation to the mineral ores.

Trans. Roy. Geol. Soc. Cornwall, Vol. 12, 1905, Penzance, pp. 546-615.

Tin always found in minute quantities in lithia micas, and except in lepidolite, copper also. Favors first deposition by ascending meteoric waters.

411. Hinx, J. B., and MacAlister, D. A. Geology of Falmouth and Truro and of the mining district of Camborne and Redruth.

Mem. Geol. Surv. Great Britain, 1906, London, pp. 113-314, figs. 64.

Extracts: Min. World, May 11, 1907, p. 598; May 18, 1907, p. 626; June 1, 1907, p. 691 .

Geology of districts is treated with particulars relating to the mines. 


\section{ENGLAND (Continued)}

412. Hunt, Robert. A notice of the copper and tin raised in Cornwall.

Mem. Geol. Surv. Great Britain, Vol. 1, 1846, London, pp. 510-519.

Several tables given showing average production of various mines of Cornwall. Short early history of copper and tin production.

413. The economic geology of Devonshire and Cornwall in 1868.

Journ. Bath West England Soc., n. s., Vol. 16, 1868, Bath, pp. 75-78.

Treats briefly of the early history of tin, tin trade from 1858 to 1868 , and manner of working the mines at the time of writing.

414. - On the mineral production of Cornwall and Devon. Rep. Proc. Min. Ass. Cornwall and Devon, 1869, Truro, pp. 5-11. Not available to the authors.

415. British mining. 1884, London, pp. 1-944, illus. 230.

A treatise on the history, discovery, practical development and future prospects of metalliferous mines, including tin mines, in the United Kingdom.

See Nos. $1397,1688$.

Hutchin, H. W. Notes on tin dressing. See No. 1507a.

Hutchinson, A. See No. 1620.

JAMES, Henry. See No. 1398.

416. JaRs, G. Voyages Métallurigique.

Vol. 3, 1781, Paris, pp. 154-223.

Sur les mines d'êtain des hautes montagnes de la Saxe, celles de la Bohême, et de la province de Cornouaille en Angleterre, années 1757 et 1765 .

417. K-, W. Die Bergwerke von Devonshire und Cornwall.

Berg. Hutt. Zeit., Vol. 38, 1879, Leipzig, pp. 374-375.

418. Kerl, Bruno. Gewinnung von Zinnsteln und Chinathon in der Carclacegrube bei St. Austel in Cornwall.

Berg. Hutt. Zeit. Vol. 21, 1862, Leipzig, pp. 82-83.

419.

Zinngewinnung in Cornwall.

Berg. Hütt. Zeit., Vol. 21, 1862, Leipzig, pp. 144-148.

Treated under the heads: Ore occurrences; preparation of the tin ore; metallurgy of $\mathrm{tin}$.

420. Kitto, Benedict. On mineral veins.

37th Ann. Rep. Roy. Cornwall Polyt. Soc., 1869, Falmouth, pp. 48-52.

Treats of one of the oldest mines in Cornwall, the Great Work Mine, which is situated partly, in the parish of Breage and partly in Germoe. The three principal lodes, Great Work, Wheal Breage and South Wheal Breage are described.

421. Kudernatsch, Josepr. Ueber die Gewinnung und Darstellung des Zinnes, insbesondere in England.

Jahrb. k. k. geol. Reichs., Vol. 3, 1852, Wien, pp. 173-175.

Also. Berg. Hütt. Zeit., Vol. 12 (n. t. 7), 1853, Leipzig, pp. 162-164.

LE Grice, C. V. See No. 1518. 


\section{ENGLAND (Continued)}

422. LeIfCHILD, Jorn R. Cornwall, its mines and miners, with sketches of scenery. Designed as a popular introduction to metallic mines.

1855 , London, pp. 303.

A readable popular account of the scenery and mines of Cornwall, including both alluvial and lode tin mines, with a short summary of foreign tin mines known at the time. Contains a general account of the geology of the Cornish tin mines, including the faulting. It also covers, in a general way, the manner of operating the mines and metallurgical processes used. Gives cost of operating, production and wages.

422a. Linoton, T. Dolcoath copper and tin mine, Cornwall.

Mg. World, Vol. 32, 1910, Chicago, p. 107.

Treated geologically, also gives figures showing ore raised, outlay and profit.

Lewis, George Randall. See No. 1402.

423. LoBley, J. LogaN. Two days in a mining district.

Proce. Geol. Ass., Vol. 2, 1873, London, pp. 45-60.

Copper and tin mining district of East Cornwall is described. List of Cornish metallic minerals given. "All the Cornish tin is procured from the peroxide, for although tin pyrites or cupreous sulphuret of tin does occur in Cornwall, it is rare and not used for the production of metal."

424. Lock, C. G. WARNFORD.

Economic Mining, 1895, New York, pp. 622-623.

Treats of Cornish tin.

Louis, Henry. See No. 1340.

LOWER, T. See 489a.

425. MacAlister, Donald A. Vertical distribution of the commercially valuable ores in the Camborne lodes.

Summ. Progr. Geol. Surv. United Kingdom for 1903 (1904), London, pp. 26-28.

426. A cross section and some notes on the tin and copper deposits of Camborne, with special reference to the limits of productive ore ground.

Trans. Roy. Geol. Soc. Cornwall, Vol. 12, 1905, Penzance, pp. 773-795, figs. 5.

427.

- Geological aspect of the lodes of Cornwall.

Econ. Geol., Vol. 3, 1908, Lancaster, pp. 363-380. Geol. map.

Gives a short historical summary of the Cornish mines and their yield from early times. He then treats the general geology, the lodes, their structure and relations to the granite. The pneumatolytic and metasomatic action of vein forming solutions is treated with regard to granite, slate and greenstone. The genesis of the ores is ascribed to the solutions from a cooling granitic magma. The alluvial tin deposits are briefly described.

Sait See Nos. 449, 1659.

428. Maclaren, J. MaLcolm. The occurrence of gold in Great Britain and Ireland.

Trans. Inst. Mg. Eng., Vol. 25, 1903, London and Newcastle-upon-Tyne, pp. 438-439, 440, 494. 


\section{ENGLAND (Continued)}

The occurrence of gold in the tin placers of Cornwall is described. $3 \frac{1}{2}$ pounds of tin ore gotten from 150 pounds of gravel in Goldmine River, County Wicklow, Ireland. All wood-tin. Accompanicd by magnetite, ilmenite, homatite, iron-pyritcs, galena, wolframite, molybdenite, gold, copper-pyrites and oxides of manganese. Cassiterite was in grains up to $1 / 2$ inch in diameter.

Maclean, John. See No. 1403.

429. Maps of the Geological Survey of Great Britain.

Show tin-bearing veins and placers. Published previous to 1869.

430. Martin, Joseph S. The position and prospects of Cornish mining. Coll. Guard., Vol. 77, 1899, London, p. 943.

Notes from the author's annual report on the southwestern district for 1898. Urges that the mines be more properly equipped and wisely managed.

431. MAYNARD, JoHn. Remarks on two cross-sections through Carn Brea Hill and the neighboring mines.

Rep. Proc. Min. Ass. Cornwall and Devon, 1873-1874, Falmouth, pp. 43-54; pls. S. Sections through the principal tin mines and the intervening country.

432. Merret, C. A relation of the tinn mines and working of tinn in the county of Cornwall.

Philos. Trans. Roy. Soc. London, No. 138, Vol. 12, 1678, London, pp. 949-952.

Philos. Trans. abridged, Vol. 2, 1809, pp. 424-426.

Description of the manner of occurrence of tin ore, and brief account of methods of smelting.

433. Morssenet, Lłon. Du mineral d'étain dans le Cornwall.

Ann. Mines, ser. 5, Vol. 14, 1858, Paris, pp. 77-276.

Brief abstract in Neues Jahrb. Min., 1860, Stuttgart, p. 360 .

Sketch of Cornwall; description of tin veins and associated minerals; description of the working of the mines and economic results.

434. Étude sur les filons du Cornwall et du Devonshire.

C. R. Acad. Sci., Vol. 55, 1862, Paris, pp. 759-762.

Ann. Mines, ser. 6, Vol. 3, 1863, Paris, pp. 161-171.

Mg. Smelt. Mag., Mo. Rev. Pract. Mg. Quarry. Met., Vol. 3, 1863, London, pp. 20-23 and Vol. 4, 1864, p. 25.

435. Moissenet, L. L. Observations on the rich parts of the lodes of Cornwall.

Translated by J. H. Collins, 1877, London.

Not available to the authors.

MYRICK, C. M. See No. 1541.

436. Newland, D. H. Tin in United Kingdom.

Min. Ind. for 1902, Vol. 11, 1903, New York and London, p. 595.

Review of tin industry in Cornwall during 1902.

437. Tin in Cornwall.

Min. Ind. for 1903, Vol. 12, 1904, New York and London, pp. 332-333.

Review of tin mining in Cornwall during 1903. 


\section{ENGLAND (Continued)}

438. Oxland, R. The mineral resources of Devon and Cornwall.

Ann. Rep. Trans. Plymouth Inst., Devon and Cornwall Nat. Hist. Soc., Vol. 5, 1873-1874 (1874), Plymouth, pp. 485-493.

Not available to the authors.

At time of writing article, there was a great depression in Cornish tin and copper mining on account of market conditions. The article is an inquiry into the possibility of reviving the mining industries.

439. Paris, John Ayrton. A guide to Mount's Bay and the Land's End. 1824, London, 2d Ed.

Contains many semi-scientific allusions to the tin mines of Cornwall, with points concerning their history, origin of names, etc. "II"

Pearce, Gilbert B. See No. 1407.

440. Pearce, Richard. Notes on the occurrence of cobalt in connection with the tin ores of Cornwall.

Journ. Roy. Inst. Cornwall, No. 13, Vol. 4, 1872, Truro, pp. 81-\$3.

Author found an appreciable quantity of cobalt in a sample of dressed tin ore (black tin) from Dolcoath mine. Analysis of "hard-head" showed 4.40 per cent cobalt and 16.25 per cent tin. Concludes that cobalt might be extracted profitably from "hard-head" and at same time afford a means for recovery of large portion of tin which was then lost.

441. The anniversary address of the president. Hiamizo?) jo zista

Trans. Roy. Geol. Soc. Cornwall, Vol. 13, pt: 2, 1906, Penzance, pp. 97-112. Discussion of Cornwall's mineral resources and their future.

—. See No. 1629.

Penberthy, John. See No. 467.

442. Priluips, J. Arthur. The rocks of the mining districts of Cornwall, and their relation to metalliferous deposits.

Quart. Journ. Geol. Soc. London, Vol. 31, 1875, London, pp. 319-345, pl. 16.

Gives a description both from macroscopic and microscopic examination of the rocks in which mineral deposits occur in Cornwall, with analyses of a number of them. Also discusses the mineral deposits including tin.

- See No. 1632 .

Phillips, J. A., and Louis, H. See No. 1350.

443. Phillips, WM. On the veins of Cornwall.

Trans. Geol. Soc. London, Vol. 2, 1814, London, pp. 110-160.

History and description of veins of Cornwall, including the Tincroft mine.

Phillips, William. See No. 1633.

Plinius, Caius. See No. 1408.

Polwhele, R. See No. 1409.

444. Pryce, William. Mineralogia Cornubiensis. A treatise on minerals, mines and mining: Containing the theory and natural history of strata, fissures and lodes, with the methods of discovering and working of tin, copper and lead mines, and of cleansing and metallizing their products, 


\section{ENGLAND (Continued)}

showing each particular processing for dressing, assaying and smelting of ores, to which is added an explanation of the terms and idioms of miners.

1778, London, pls. 7, tables 2, portrait of author, pp. 331 .

Extract: Journ. Mines, No. 3, Vol. 1, 1795, Paris, pp. 91-126.

445. Punnett, H. Macaulay. On some peculiar deposits of tin in St. Aubyn and Grylls mine.

Trans. Roy. Geol. Soc. Cornwall, Vol, 7, 1865, Penzance, pp. 379-380.

A brief inquiry into the nature of the contents of peculiar shoots of tin ore. The ore is said to be different in chemical character from the tin ore in the main lode.

RAMmelsberg, C. See No. 1637.

446. Rance, Chas. E. DE. On the relative age of some valleys in the north and south of England, and of the various and post-glacial deposits occurring in them.

Proc. Geol. Ass. London, Vol. 4, 1876, London, p. 250.

Thinks stream tin deposits of South England are nearly synchronous with the West Lancashire post-glacial marine beds. Points out that there has been no glaciation in this region.

447. RAsineigh, P. An account of the alluvial deposition at Sandrycock. Trans. Roy. Geol. Soc. Cornwall, Vol. 2, 1822, Penzance, pp. 281-284.

Drawn up in 1792, communicated by J. Hawkins in 1819.

"Tin ground and loose stones of all sorts" from one foot to 6 feet thick overlain by 35 feet overburden.

RAY, JoHn. See No. 1554.

448. Reid, Clement, and Flett, J. S. The geology of the Land's End district. Explanation of sheets 351 and 358 , with contributions by Wilkinson, B. S. N., Dixon, E. E. L., Pollard, W. and a mining appendix by MacAllister, D. A.. Mem. Geol. Surv. Great Britain, 1907, London, p. 158, figs. 35, pls. 6.

Geology of district and mines, and their output of tin since 1852.

449. Reid, Clement, and Scrivexor, J. B. The geology of the country near Newquay.

Mem. Geol. Surv. Great Britain, 1906, London, pp. 72-80, and pp. 91-106, with map and figs.

Gives estimates of the amount of tin produced. Former work for stream-tin, now long ceased. Describe briefly the mines now working near St. Agnes, and some of those that are abandoned. Describe the microscopic appearance of the tin lodes. Also describe the geology of the lodes at Cligga head.

D. A. McAllister gives notes on the particular mines, their ores and geology on pp. 91-106, with figs.

\section{See No. 1638.}

450. REYer, E. Zinn.

1881, Berlin, pp. 102-156, figs. 3 .

Treats under heads: Geologische Beschreibung; die Erzgänge; Geschichte der Zinnprodukzion und des Zinnhandels von Cornwall.

450a. Rickard, Thomas. Fifty years in Cornwall.

Mg. Sci. Press, Vol. 1C0, 1910, San Francisco, pp. 795-797. 


\section{ENGLAND (Continued)}

Revlews the improvements in technical methods and appliances in Cornwall mining, and concludes that this improvement has not been inadequately translated into economic results.

451. Rowe, T. P., and Foster, C. LE Neve. Observations on Balleswidden mine.

Trans. Roy. Geol. Soc. Cornwall, Vol, 10, 1887, Penzance, pp. 10-17.

Short description of Balleswidden mine, situated about 1 mile from village of St. Just-in-Penwith, which was abandoned in 1873 . During the 36 years that the mine was worked, more than 12,000 tons of black tin were sold, valued at £694,094.

452. RudLER, F. W. Handbook to minerals of the British Islands. 1905, London.

Cassiterite and its associates, pp. 5-32.

Treats not only of cassiterite and stannite, with their accompanying minerals, but of the origin, form and other characteristics of the veins in which they are found.

453. Salmon, Arthur L. Cornwall.

1903, London, pp. 16-21.

A short general description of tin-mining in Cornwall, adapted to the needs of tourists not particularly interested in the subject.

454. Salmon, H. C. The mines and mining operations of Cornwall.

Mg. Sinelt. Mag. Mo. Rev. Pract. Mg. Quarry. Met., Vol. 5, 1864, pp. 257, 328. Not available to the authors.

Saunders, C. D. See No. 1414.

Scrivenor, J. B., and Rein, Clement. See No. 1638.

455. Simmons, WM. The metallic ores of Cornwall.

Proc. Liverpool Geol. Soc., Vol. 3, 1878, Liverpool, pp. 28-35.

Brief description of occurrences of the ores of tin, copper, iron and lead.

456. Skewes, Edward. Red river tin stream, Cornwall.

Eng. Mg. Journ., Vol. 74, 1902, New York, pp. 178-180, figs. 5.

Abstract: Min. Ind. for 1902, Vol. 11, 1903, New York and London, p. 653.

An article discussing the mode of operation of the Cornish tin mines, the loss of tin, etc.

Smith, George. See No. 1418.

457. Smyth, Warington W. Metallic mining (tin mines).

Brit. Mfr. Indust., Vol. 2, 1876, London, pp. 26-30.

Treats of the occurrence of copper and tin in certain districts of England.

Solly, R. H. See No. 1640.

Spargo, T. See No. 1699.

458. Stelzner, A. W. Das Zinnerzvorkommen auf der Grube East Wheal Lovell in Cornwall.

Mitth. Verh. Bergmånn. Vereins zu Freiberg. Sitzg., Vol. 2, Nov. 1876.

Digest: Neues Jahrb. Min., 1877, Stuttgart, pp. 416-417.

Berg. Hutt. Zeit., Vol. 35, 1876, Leipzig, pp. 417-419.

Based on "The tin deposits of East Wheal Lovell" by C. Le Neve Foster, published in Trans. Roy. Geol. Soc. Cornwall, Vol. 9, 1875, Penzance, pp. 167-176. First reference not available to the authors. 


\section{ENGLAND (Continued)}

459. Stephens, Francis J. Abstract of essay on the "Mineral resources of Falmouth."

54th Ann. Rep. Roy. Cornwall Polyt. Soc., 1886, Falmouth, p. 193.

Tin is mentioned as occurring at Pennance mine, Falmouth.

460. Stephens, F. J. The ancient tin mining districts of Cornwall.

72d Ann. Rep. Roy. Cornwall Polyt. Soc., 1904, Falmouth, pp. 101-114.

Notes on the geology, minerals and mines of Levant; St. Ives and Zennor.

461. Stephens, Hugh. Remarks on the mineral phenomena of Huel Rose in the parish of Sithney.

Rep. Proc. Min. Ass. Cornwall and Devon, 1871 (1872), Truro, pp. 47-49.

462. Symons, Brenton. Treatise on the geology of Cornwall.

1884, Penzance.

Not available to the authors.

463. Symons, R. On Carclaze tin and china clay pit.

Journ. Roy. Inst. Cornwall, Vol. 6, 1881, Truro, pp. 140-143, map 1.

Describes in a general way Carclaze mine which yielded 10 to 12 tons of tin ore per year from small veins in a decomposed granite (growan). Had for many years produced large quantities of china clay and workings covered over 15 acres.

464. TAYLoR, Chas. D. Description of the tin stream works in Restronguet Creek near Truro.

Proc. Inst. Mech. Eng. for 1873, Birmingham, pp. 155-166, pls. 58-59.

Discussion 162-166.

Extracts: Bull. Soc. Indust. min., ser. 2, Vol. 4, 1875, Saint Étienne, pp. 678-680. Berg. Hüt. Zeit., Vol. 35, 1876, Leipzig, pp. 443-444.

Description of methods used in recovering " a valuable deposit of stream tin which is found under the water in Restronguet Creek, and lies on the rock beneath the mud and silt that form the bottom of the creek."

TAYLOR, J. See No. 1663.

TAYLOR, JoHn. See Nos. 1419, 1576.

Thioluier, M. A. See No. 1579.

465. Thomas, Chas. Remarks on mining in Cornwall and Devon. 22d Ann. Rep. Roy. Cornwall Polyt. Soc.; 1854, Falmouth, pp. 28-35.

Treats of the geological and mineralogical character of the rocks that have been found most productive of metallic ores.

466. Thomas, C. Mining fields of the West, Cornwall and Devon. 1867. Not available to the authors.

467. Thomas, Herbert. Cornish mining interviews. Underground scenes

by J. C. Burrows.

1896, Camborne, pp. 351.

Treats of tin mining in a popular way, and contains an interview with Capt. John Penberthy on "Bolivia as a tin-producing country and its probable effect on Cornwall " (pp. 1-8).

The illustrations are good and have been widely reprinted. See 320 and 475 . 


\section{ENGLAND (Continued)}

468. The mineralogical constitution of the finer material of the Bunter pebble-bed in the west of England.

Quart. Journ. Geol. Soc. London, Vol. 58, 1902, London, p. 623.

Paragraph on cassiterite "Difficult to distinguish from rutile, but it occurs in small quantity in the heavy residues from some of these sands. Seem to be two modes of occurrence: (I) in pale-yellow, well-shaped crystals, and (II) in more or less rounded brownish grains."

469. Thomas, Josiaf. Description of the operations at Dolcoath mine.

Journ. Roy. Inst. Cornwall, Vol. 3, No. 11, 1870, Truro, pp. 191-197.

An account of the mine, and manner of working it. Author states that at time of writing he believes "we are working to a greater depth, and raising a larger quantity of tin, as well as making greater profits, than any other tin mine in the world.

"The mine has been producing of late about 87 tons of black tin per month, or 1050 tons per year."

470. - Description of Dolcoath main lode, illustrated by transverse section, and specimens from the lode and country.

Rep. Proc. Min. Ass. Cornwall and Devon, for 1882 (1883), Truro, pp. 13-15.

Dolcoath is the deepest metalliferous mine in Cornwall. The granite has become softer, and the tin lodes larger and more productive with depth; mine shows no sign of decay.

471. Thomas, R. Report on a survey of the mining district of Cornwall, from Chasewater to Camborne.

1819, London.

Not available to the authors.

472. Thomas, R. A. Notes on Cornish mines in 1896.

64th Ann. Rep. Roy. Cornwall Polyt. Soc., 1896, Falmouth, pp. 89-94.

Discussion of the decreased tin output of Cornwall, and of means for its increase.

Thomas, R. ARthur. See No. 1666.

473. Thomas, Richard A. Some observations on the "Great Flat Lode" in Wheal Uny mine, near Redruth.

54th Ann. Rep. Roy. Cornwall Polyt. Soc., 1886, Falmouth, pp. 184-188. 1500 words.

Calls Great Flat Lode a "true fissure vein," but says it reaches 72 feet (12 fathoms) in width with a small amount of tin distributed evenly through it. Dip varies. Slickensides occur where vein narrows. Many "cross-courses" break up the vein. Generally dips to the west. Occasionally rich enough to work 30 feet wide. Copper ores in upper part of vein and some chalcopyrite below.

474. Thomas, WM. Excursion to Cornwall.

Proc. Geol. Ass, Vol. 10, 1887, London, pp. 196-215, figs. 7.

Mentions a few general points about Carclaze, Cain Brea and other tin mines.

475. Thomas, WM., and Burrows, J. C. 'Mongst mines and miners, underground scenes by flashlight.

1883, London and Camborne, pp. 32, pls. 26. Colored section of Dolcoath main lode, $621 / 2$ fathoms per inch.

Written in popular style. The plates are excellent. See 467.

476. Tredinnick, $R$. Tin and tin mining.

Mg. Journ. Railw. Comm. Gaz., Vol. 46, 1876, London, p. 1388.

General article giving amount of ore raised and profits derived from some of the Cornwall mines. 


\section{ENGLAND (Continued)}

477. Tregaskis, James. Remarks on the geology of Cornwall and Devon in connection with the deposits of metallic ores and on the bearing of productive lodes.

(Two lectures.) 1857, Redruth.

Not available to the authors.

478. TWEeDY, W. M. Notices of minerals of uncommon occurrence recently found in Cornwall.

21st Ann. Rep. Roy. Inst. Cornwall, 1841 (1842), Truro, pp, 38-39.

Among other minerals which author mentions as uncommon are wood-tin and detached crystals of tinstone and sandstone in the form of crystals of feldspar.

479. - A description of the Lode at Wheal Coates Mine, in which the pseudomorphous crystals of tin occurred.

27th Ann. Rep. Roy. Inst. Cornwall, 1845, Truro, pp. 20-24.

Mineralogical and geological description of the tin deposits at Wheal Coates, with detailed descriptions of individual pseudomorphs of cassiterite after feldspar.

TYLOR, A. See No. 1420.

480. Unwin, George. Letters, remarks, etc., with a view to open an extensive trade in the article of tin from the county of Cornwall to India, Persia and China.

1790, London.

Not available to the authors.

481. Ussher, W. A. E., and MacAlister, D. A. Summary of progress of the geological survey of the United Kingdom.

Mem. Geol. Surv. Great Britain for 1903 (1904), London, pp. 22-23, 26-28.

Report on the progress of tin mining in Cornwall for year 1903.

481a. Vivian, Joseph. Reminiscence of mining in Cornwall.

Mg. Sci. Press, Vol. 100, 1910, San Francisco, pp. 743-745, map.

Treats of the early history of copper and tin mining in Cornwall.

482. WaIt, F. W. The tin mines of Cornwall.

Mg. Journ. Railw. Comm. Gaz. Vol. 54, 1884, London, p. 1423.

Report of a lecture delivered before the Menai Society. Begins with the early history of tin in Cornwall, tracing it down to the present time. Gives description of principal mines. Treats of tin itself, the manner of occurrences and working. The Cornish miner, his habits, characteristics and mining methods, with the difficulties encountered. Popular.

482a. Walker, Edward. The Red River, Cornwall.

Mg. Sci. Press, Vol. 97, 1908, San Francisco, p. 849. Map of Cornwall.

An account of the trouble caused in the Red River due to the tailings from the tin mines.

WARNER, RICHARD. See No. 1421.

483. Watson, J. Y. A compendium of British mining, with statistical notices of the principal mines in Cornwall; to which is added .... a glossary of the terms and usages of mining. London, 1843.

Mg. Journ. Railw. Comm. Gaz., Vol. 21, 1851, London, pp. 3, 22, 27, 39, 50, 62. Treated under heads: General features of a mine; on the nature of veins; the nature of lodes; the system of Cornish mining; on " bounding."

Reprinted with revisions and corrections up to 1851 . 


\section{ENGLAND (Continued)}

484. WebB, - and GeACH, - - History and progress of mining in the Caradon and Liskeard district. Not available to the authors.

WeEks, Joseph D. See No. 1372.

485. West, H. E. Cornish tin mining.

Mg. Sci. Press, Vol. 94, 1907, San Francisco, pp. 179-181, 213-214.

486. White, W. T. The south or main tin lode of Wheal Peevor. Trans. Min. Ass. Inst. Cornwall, Vol. 1, 1887, Camborne, pp. 81-84.

A description of a tin lode with its faulting. At one place the throw is 75 fathoms.

487. Williams, ARchibald. The romance of mining. The tin mines of Cornwall.

London and Philadelphia, 1905, pp. 258-273.

A popular and fairly accurate account of tin mining in Cornwall.

488. Whilams, JoHn. Account of some remarkable disturbances in the veins of the mine called Huel Peever, in Cornwall.

Trans. Geol. Soc. London, Vol. 4, 1817, London, pp. 139-145.

Huel Peever contains numerous examples of almost every species of interrup. tion known to Cornwall veins. Its tin vein was so heaved by other veins that it was not again discovered for forty years. Describes the disturbed condition of the veins.

489. Wriliams, R. H. Occurrence of tin in the St. Austell district.

Mg. Journ. Railw. Comm. Gaz., Vol. 80, 1906, London, pp. 276-277, 1200 words.

"A review of this district in Cornwall, England, describing the geological structure:",

489a. Woodward, J(oHN). A catalogue of English native fossils in the collection of J. Woodward, M. D.

1728, London, 3 vols., bound together. Vol. I, pp. 198-206. Vol. III, pp. 40-41. In the first reference 30 specimens of Cornish tin ores are briefly described with short, quaint descriptions, written by $T$. Lower, of most of the mines from which they came.

In the third volume, which treats of foreign specimens, 18 specimens of tin ore from Saxony and Bohemia are noted.

Worth, R. N. See Nos. 1425, 1426, 1427.

490. ZirkeL, Ferdinand. Bergmännische Mitthellungen über Cornwall.

Zeitschr. Berg. Hütt. Sal. preuss. Sta., Vol. 9, 1861, Berlin, pp. B 242-261, figs. 4. Treated under the heads: Ore in Cornwall, dressing, metallurgy and production.

\section{EUROPE}

Rolker, Chas. M. See No. 1357.

See under Austria (Bohemia), England (Cornwall and Devonshire), France, Germany, Ireland, Italy, Norway, Portugal, Russia, Scotland, Spain, Sweden.

See under Russia.

\section{FINLAND}




\section{FRANCE}

491. Anonymous. Apperçu de l'extraction et du commerce des substances minérales en France avant la Révolution.

Journ. Mines, Vol. 1, No. 1, 1794-1795, Paris, pp. 72-73.

Notes a report by M. Schreiber on the finding of bits of metallic tin in Pieux, Manche, France.

492. - Ueber die Auffindung des Zinns in Frankreich.

Tasch. ges. Min. für 1815, Vol. 9, II, Frankfort-am-Main, pp. 560-562.

Brief account of the discovery of tin veins in France in 1809.

493.

Tin mines in France.

Mg. Journ. Railw. Comm. Gaz. Vol. 1, 1835, London, p. 53.

Tin was not known to exist in France until 1809, and it was not until 1817 that a deposit was discovered. This was found by a marine officer, and Dufrenoy was sent to examine it. The tin ore occurs at the junction of granite and slate and the country bears a marked resemblance to Cornwall.

494. - Tin in Montebras, France.

Min. Ind. for 1899, Vol. 8, 1900, New York and London, p. 621.

Deposits of tin at Montebras are at contact of granite and feldspathic porphyry. Ore said to average 4 per cent, which would be above the grade of other European deposits.

495.

\section{Tin in France.}

Min. Ind. for 1901, Vol. 10, 1902, New York and London, pp. 637-646.

Small veins carrying cassiterite are known to occur near Vaulry and have been worked from time to time. Recently a company, the Societe des Mines de Vaulry et Cieux, secured a concession of alluvial ground near by, and some ore is being produced.

496.

\section{The mines of Montebras,}

Mg. Journ. Railw. Comm. Gaz. Vol. 84, 1908, London, p. 3.

A very general description of the developments, dressing plants, and tin deposits at Montebras in central France.

Antimony, amblygonite and montebrasite occur with tin ore said to average 2 per cent cassiterite.

497. Audibert, E. Sur le gîte d'étain oxydé de Maupas, Morbihan.

Ann. Mines, ser. 4, Vol. 7, 1845, Paris, pp. 181-186.

Review in Neues Jahrb. Min. 1847, Stuttgart, pp. $358-360$.

Description of tin veins of Maupas, France.

498. Baudot, F. Les mines d'étain de la Villeder (Morbihan).

Bull. Soc. Indust. min., ser. 3, Vol. 1, Livre 1, 1887, Saint Étienne, pp. 151-187.

Treats of the situation and size of the concession; history of the discovery of the veins and their former working by the Romans, and other attempts at working the veins. Describes the working of alluvial deposits of the locality, and geology. States that pyrite, mispickel, sphalerite, galena, quartz, emerald, muscovite and plogopite micas, gilbertite, tourmaline, topaz and feldspar are found with the cassiterite, all of which are described at some length, as are the veins. Much space is given to a description of the working of the mine, its machinery, etc.

BeCK, RICHARD. See No. 1299.

499. Blavier, Ed., and Lorieux, T. Sur un gîte d'étain nouvellement découvert, à la Villeder (Morbihan).

Ann. Mines, ser. 3, Vol. 6, 1834, Paris, pp. 381-388. 


\section{FRANCE (Continued)}

500. Burtire, M. P. L. Note sur les travaux de recherche exécutés à Meymac, (S. France).

Ann. Mines, ser. 9, Vol. 12, 1897, Paris, pp. 5-31.

Extract: Zeitschr. prakt. Geol., 1897, Berlin, pp. 418-420.

Deposit not important from commercial standpoint, but, geologically, has attracted attention because of peculiarities. The deposit is described in detail.

501. Cotta, Bernard von. A treatise on ore deposits.

Translated by F. Prime, Jr., 1870, New York, pp. 380-384.

Treats of tin deposits of Brittany.

502. Cressac, C. DE. Die Entdeckung des Zinns in Frankreich.

Ges. Nat. Freunde Berlin Mag. neust. entd. ges, Nat., Vol. 4, 1810, Berlin, pp. 239-240.

503. Cressac, C. DE. Notice sur la découverte de l'étain en France.

Journ. Mines, No. 198, Vol. 33, 1813, Paris, pp. 435-452.

(1) Reconnaissance et indication d'un second gisement d'etain dans le département de la Haute-Vienne.

(2) Traduction littérale de l'indication du gisement d'étain reconnu par le mineur saxon Schnor de Schnéeberg.

(3) Reconnaissance et indication d'un troisième gisement d'étain dans le département de la Haute-Vienne.

D—, C. H. See No. 1386.

D’Achiardi, Antonio. 'See No. 1313.

504. Daubré, Auguste. Note sur le kaolin de La Lizolle et d'Échassières, département de l'Allier, et sur l'existence de minerai d'étain qui y a été exploité à une époque extrêmement reculée.

O. R. Acad. Sci., Vol. 68, 1869, Paris, "pp. 1135-1139.

- See Nos. 1314 and 1316.

Davies, D. C. See No., 1317.

505. Davy, L. Sur l'ancienneté probable de l'exploitation de l'étain, en Bretagne.

C. R. Acad. Sci., Vol. 125, 1897, Paris, pp. 337-339.

Abstract: Lébesconte, P., Bull. Soc. sci. méd. Ouest, Vol. 7, 1898, Rennes, pp. 51-53.

Found slag with small grains of crystalline tin near old excavations. Considered to be product of ancient smelting. Found veins near by containing tin. Veins cut upper Silurian metamorphic rocks. They consist of quartz with muscovite, cassiterite, tourmaline, etc. Cassiterite where vein is most micaceous. Thinks work was done by Gauls before Roman conquest. Location: between Abbaretz and Vay in Lower Loire.

506. Dufrenoy, P. A. Sur le plateau central de la France, et particulièrement sur les terrains secondaires qui recouvrent les pentes meridionales du massif primitif qui le compose.

Ann. Mines, ser. 2, Vol. 3, 1828, Paris, pp. 55-57.

Short account of the occurrence of tin in granite and gneiss in France. 


\section{FRANCE (Continued)}

507. Dufrenoy, Pierre Armand, et Juncker. Rapport sur les recherches et les essais de la mine d'étain de Piriac, département de la Loire Inférieure.

Ann. Mines, Vol. 4, 1819, Paris, pp. 21-58. (See No. 513.)

508. Durociner, M. J. Observations sur les dépôts stannifères de la Bretagne et sur les métaux précieux qu'ils renferment.

C. R. Acad. Sci., Vol: 32, 1851, Paris, pp. 902-904, Vol, 45, 1857, pp. 522-525.

Digest: Neues Jahrb. Min., 1852, Stuttgart, pp. 498-499.

509. Fuchs, E., et Launay, L. DE. Traité des gites minéraux et métallifères.

Vol. 2, 1893, Paris, pp. 101-158.

A general article upon the tin deposits of the world with an especially good description of the French tin deposits at La Villeder, Montebras, Creuse, Vaulry, Cieux, Colettes (Allier), Chanteloube and St. Leonard. Gives general geology and list of accompanying minerals at each place.

510. Gouvenain, C. A. DE. Sur la dissémination de l'étain et sur la présence du cobalt et de diverses autres substances dans les kaolins des Colettes et d'Échassières situés dans le département de l'Allier.

C. R. Acad. Sci., Vol. 78, 1874, Paris, pp. 1032-1034.

511. Gúfdras, Marcel. Sur la presence de l'étain dans le département de la Lozére.

C. R. Acad. Sci., Vol. 138, 1904, Paris, p. 1121.

Digests: Trans. Inst. Ng. Eng., Vol. 27, 1903-1904 (1905), London and Newcastleupon-Tyne, p. 629.

Mg. Journ. Railw. Comm. Gaz., Vol. 75, 1904, London, p. 574.

Neues Jahrb. Min., 1906, I (Ref.), Stuttgart, p. 332.

Though department of Lozere is rich in metalliferous veins, tin ore has not hitherto been recorded there. Author discovered a vein close to Great Monastier fault, in parish of Barjac. Country rock is mica schist, vein dips $60^{\circ}$, and is $7 \frac{1}{2}$ feet thick at outerop. The gangue consists chiefly of barytes and quartz; between these is a thin band of cassiterite barely 1 inch thick with which are closely associated pyrolusite and wolframite.

512. Hersart, Crr. Sur une nouvelle découverte de minerai d'étain dans le département de la Loire-Inférieure.

Journ. Mines, Vol. 35, No. 208, 1814, Paris, pp. 293-308.

513. Juncker, - et Dufrénoy, P. A. Rapport sur les recherches et les essals de la mine d'étain de Piriac, département de la Loire Inférieure. Ann. Mines, Vol. 4, 1819, Paris, pp. 21-58.

Review: Tasch. ges. Min. 1824, Vol. 18, 1II, 1824, Frankfurt-am-Main, pp. 676-678. (See No. 507.)

514. Kerforne, F. Découverte d'un gisement d'étain et de wolfram dans l'Ille-et-Vilaine.

Bull. Soc. sci. mêd. Ouest., Vol. 11, 1903, Rennes, pp. 448-449.

Trav. Sci. Univ. Rennes, Vol. 2, 1903, Rennes, pp. 380-381.

Digest: Neues Jahrb. Min., 1905, II (Ref.), Stuttgart, p. 369.

515. Kerndt, C. H. Thdr. Ueber die neueren Zinngruben 7 .u Piriac.

Polyt. Centr., 1858, Leipzig, pp. 86, 106, 168.

Not available to the authors. 


\section{FRANCE (Continued)}

516. LACroIx, A. Minéralogie de le France et de ses colonies. Description physique et chemique des minéraux. Étude des conditions géologiques de leurs gisements.

1901, Paris. Cassiterite. Tome 3, pp. 217-235.

Crystallization and general description of cassiterite, pp. 217-220. In granites, Bretagne (Loire Inférieure), Plateau Central, p. 221. In quartz veins, pp. 221-231: Bretagne, pp. 223-227. Finistere, p. 223. Morbihan, pp. 223-227. Loire Inférieure, p. 227. Anjou, pp. 227-231. Maine-et-Loire, p. 227. Creuse, pp. 228-229. Correze (Meymac), pp. 229-230. Haute-Vienne, pp. 230-231. Charente, p. 231. Puy-de-Dôme, p. 231. Allier, p. 231. Maures, Congo (10 words), Madagascar, Tonkin, p. 231. In veins with sulphides, Indochine (Laos), pp. 231-233. Alluvial deposits, pp. 233-235. Bretagne (Morbihan \& Loire Inférieure), pp. 234-235. Plateau Central (Haute-Vienne \& Creuse), p. 235. An excellent article treating cassiterite from the mineralogical standpoint.

517. Lassalle, Th. Mines d'étain en France.

Métallurgie, Vol. 31, 1900, Paris, pp. 343, 345 .

Tin deposits of Montebras are on contact of granite and feldspathic porphyry. Ore said to average 4 per cent, which would be above the grade of other European deposits.

518. Launar, L. DE. Une mine de lithine en France.

La Nature, 2d ser., No. 1464, Vol. 29, 1901, Paris, pp. 43-44.

Digest: Geol. Centr., Vol. 1, 1901, Leipzig, p. 707.

"Le gisement d'étain de Montebras deja exploité par les anciens gaulois, fournit surtout maintenant de l'amblygonite (phosphate d'alumine et fluorure double de soude et de lithine) qui est utilisee pour la préparation des sels de lithine. Cette substance est accompagnée d'apatite et de plusieurs minéraux rares, tels que le niobium, la wavellite, l'urane, etc."-L. Pervinquière.

519. Limur (le comte), DE. La mine d'étain de la Villeder.

Bull. Soc. Hist. nat. Toulouse, Vol. 16, 1882, Toulouse, pp. 247-261.

520. Lopin, - - Note sur la constitution des gîtes stannifères de la Villeder (Morbihan).

Bull. Soc. geol. France, ser. 3, Vol. 12, 1884, Paris, pp. 645-666, map 1, figs. 3. Review: Neues Jahrb. Min., 1885, II (Ref.), Stuttgart, pp. 58-59.

521. - Étude sur les gîtes métallifères de Pontgibaud (France). Ann. Mines, ser. 9, Vol. 1, 1892, Paris, pp. 471-472.

Louis, Henry. See No. 1340.

522. Mallard, ERnest. Note sur un filon d'étain oxydé situé près du village de Montebras, commune de Soumans (Creuse).

Mem. Soc. Sci. nat. arch. Creuse, Vol. 3, 1862, Guéret, pp. 161-167.

Old excavations supposed to be ancient earthworks found to be over tin mines, to exploit which the work was done. Veins are in granite carrying black mica.

523. ㄴ. Note sur les gisements stannifères du Limousin et de la Marche, et sur quelques anciennes fouilles qui paraissent s'y rattacher.

Ann. Mines, ser. 6. Vol. 10, 1866, Paris, pp. 321-352.

Extrait par l'auteur, C. R. Acad. Sci., Vol. 62, 1866, Paris, pp. 223-225.

Tin ores were discovered at Vaulry (Creuse) in 1812 and exploited by the government but given up in the ' 60 's. Veins carried much columbite wolframite, mispickel, iron-arsenate, native copper, black oxide of copper, molybdenite, uraniumphosphate, fluorite, calcium phosphate, and barite. 


\section{FRANCE (Continued)}

524. Mazade, - Titan und Zirkonerde mit Molybdän, Zinn, Tungstein, Tantal, Cerium, Yttrium, Glycium, Nickel und Kobalt in den MineralWassern von Neyrac. [Ardèche]. Institut, Vol. 20, 1852, Paris, p. 198. Not available to the authors.

Patrison, S. R. See No. 1406.

Phillips, J. A., and Louis, H. See No. 1350.

525. Sénez, L. Des mines d'étain françals. (Etr. de l'Union bretonne.) 1856, Nantes. Not available to the authors.

526. Simonin, L. Sur les mines d'étain de la Villeder (Morbihan). Bull. Soc. géol. France, ser. 2, Vol. 23, 1866, Paris, pp. 371-373.

Simonin, L. See No. 1416.

\section{FRENCH GUIANA}

527. Damour, A. Note. sur la présence du platine et de l'étain métallique dans les terrains auriféres de la Guyane.

C. R. Acad. Sci., Vol. 52, 1861, Paris, pp. 688-690.

Reports metallic tin in a small specimen ( 2 grams) from the Approuague River, French Guiana.

\section{GEORGIA}

Rolker, Chas. M. See No. 1357.

U. S. Eleventh Census, 1890. See No. 1221.

\section{GERMANY}

528. ANoNymous. Zinngewinnung zu Altenberg in sächsischen Erzgebirge.

Eisenzeitung, No. 24, 1888.

Treats of the occurrence, mining, ore dressing and smelting of tin of Altenberg.

Not available to the authors.

529. Beck, Richard. Einige Beobachtungen im Gebiete der Altenberg-Zinnwalder Zinnerzlagerstätten.

Zeitschr. prakt. Geol., 1896, Berlin, p. 148.

530. - Ueber die Erzlagerstätten von Schwartzenberg im sächsischen Erzgebirge.

Zeitschr. Deutsch. geol. Ges., Vol. 52, 1900, Protok., Berlin, pp. 58-60.

Digest: Trans, Inst. Mg. Eng., Vol. 22, 1901-1202 (1903), London and Newcastleupon-Tyne, p. 700.

Near Schwarzenberg, in the Western Erzgebirge a dome of augen-gneiss forms the basement-rock which is mantled by mica-schist; on the north conformably overlain by phyllites but faulted against them on the south. All broken through by granite-dikes. In the altered schists occur two concentric ore belts intimately associated with crystalline limestone, dolomite and skarn (sahlite-actinolite-rock). Magnetite occurs in regular beds or inter-stratifled with the limestone. Red and brown hematite beds are altered from magnetite. Other ores are in two dis- 


\section{GERMANY (Continued)}

tinet groups: (1) pyrite-blende group, including iron-pyrite, zinc-blende, argentiferous galena and copper pyrite with some arsenical and magnetic pyrites, more rarely polybasite and native silver; (2) the stanniferous group, including tinstone in columnar crystals, molybdenite, specular-iron ore, etc.

The pyritic and stanniferous ores were the last constituents deposited from the siliceous solutions.

531. - Die Erzlagerstätten.

Erl. geol. Specialkarte Kön. Sachsen, 1903, Leipzig, pp. 40-57.

Digest: Trans. Inst. Mg. Eng., Vol. 27, 1905, London and Newcastle-upon-Tyne, p. 639.

(7) The Graupen tin deposits are described.

- See No. 1299.

532. Beust, - , vox. Ueber die Zinnerzlagerstätten von Schlaggenwalde.

Berg. Hüt. Zeit., Vol. 27, 1868, Leipzig, pp. 3-4.

533. Blöpe, Gottlon von. Versuch einer Theorie über die Bildung des Geyer'schen Stockwerkes.

Tasch. ges. Min., Vol. 10, I, 1816, Frankfurt-am-Main, pp. 1-32.

Not available to the authors.

534. BonnaRd, A. H. DE. Essai géognostique sur l'Erzgebirge ou sur les Montagnes métalliféres de la Saxe.

Journ. Mines, Vol. 38, 1815, Paris, pp. 261-318, 339-382, 415-452.

Also Tasch. ges. Min., Vol. 16, 1822, Frankfurt-am-Main, pp. 94-136, 508-538.

Treats of the Saxon tin mines.

535. Breithaupt, A. Die Paragenesis der Mineralien. Freiberg, 1849.

Said to treat of tin deposits of Germany.

Not available to the authors.

Brown, A. Selwyn. See Nos. 1307 and 1308.

Charleton, Arthur G. See No. 1310.

536. Charpentier, J. F. W. Mineralogische geographie der Thursachsischen Lande.

1778, Leipzig, geol. map, wood cuts 7.

Contains many references to the tin deposits at Altenberg and other places in Saxony.

537. CotTA, BERnaRd voN. Das Altenberger Zinnstockwerk. Berg. Hütt. Zeit., Vol. 19, 1860, Leipzig, pp. 1-2.

538. - Mineralien der Freiberger Erzgänge.

Berg. Hutt. Zeit., Vol. 19, 1860, Leipzig, pp. 301-305.

Gives a list of the tin and other minerals of the Freiberg ore deposits.

539. — Altenberg Zwittergestein Festschrift zum hundertjährigen Jubiläum der Königl. Sächs. Bergakademie zu Freiberg.

1866, Dresden, p. 156. (Not seen.)

Digest: Trans. Roy. Geol. Soc. Cornwall, Yol. 9, Penzance, p. 175.

"Prof. von Cotta proves that there is a gradual passage from fine grained reddish granite to the almost compact black stanniferous Zwittergestein. The Zwittergestein is an altered granite which has lost about 3 per cent of silica and 2 per cent of potash and has taken up 4 per cent of ferrous oxide, and $1 / 2$ per cent of stannic oxide."-C. Le Neve Foster. 


\section{GERMANY (Continued)}

540

A treatise on ore deposits.

Trans. by F. Prime, 1870, New York.

Treats of Altenberg tin stoekwerk, pp. 106-109; tin deposits of Zinnwald, pp. 109-110; tin deposits of Graupen and Poebel, pp. 111; tin deposits of Marienberg, pp. 114-115; tin deposits of Ehrenfriedersdorf and Geyer, p. 115; tin deposits of District of Johanngeorgenstadt and Eibenstock, pp. 123-124.

541. - Die Geologie der Gegenwart.

1872, Leipzig, pp. 154-159.

Describes the tin deposits of Germany, and more briefly the principal ones of other parts of the world.

D'Achiardi, Antonio. See No. 1313.

542. DALMER, KARL. Der Altenberg-Graupener Zinnerzlagerstättendistrict. Zeitschr. prakt. Geol., 1894, Berlin, pp. 313-322, with text figs.

Digest: Trans. Fed. Inst. Mg. Eng., Vol. 10, 1895-1896, Newcastle-upon-Tyne and London, pp. 588-589.

In district north of Teplitz, Archæan rocks of the Erzgebirge are cut by quartzporphyry, granite porphyry, and albite-granite intruded along fault lines. Tin closely connected with granite, which is youngest, but there are broad zones of impregnation around the granite, and these are the most important. Believes in pneumatolytic deposition. Seams contain chiefly quartz and lithia-mica with whieh are tinstone, wolframite and fluorspar, topaz being rarer. Chlorine shown to occur in the mieas of Zinnwald, Graupen and Altenberg. Thinks ehlorine played important part in the formation of the deposits. Stanniferous lodes near the "impregnation zones" contain galena, arsenical and copper pyrites and malachite. Tin lodes of Graupen district said to pass gradually southeastwardly into pyriteveins. Believes blende-bearing lead ores to be also in causal connection with granitic intrusion, but that the conditions that originated them, acted further away than those of the tin veins.

543. DALMER, K. Gänge der Zinnerz- und kiesigblendigen Bleierzformation im Schneeberger Kobaltfelde.

Zeitschr. prakt. Geol., 1895, Berlin, pp. 228-229.

544. - Die Erzlager von Schwarzenberg im Erzgebirge.

Zeitschr. prakt. Geol., 1897, Berlin, pp. 265-272.

DaubreE, A. See No. 1314.

Dagies, D. C. See No. 1317.

545. Dechen, H. von. Die Bildung der Gänge.

Verh. nat. Ver. preuss. Rheinl. Westpl., Vol. 7, 1850, Bonn., pp. 161-175.

Also, Neues Jahrb. Min., 1851, Stuttgart, pp. 210-220.

Tin deposits of Germany and England described.

Fawns, Sydney. See No. 1320.

546. Freiesleben, J. C. Das Kies-, Eisen- und Zinnsteinlager bei Breitenbrunn. Geognostische Arbeiten, Vol. ${ }^{\circ}$, pp. $47 \mathrm{ff}$.

Extraet: Tasch. ges. Min., 1820, Vol. 14, II, Frankfurt-am-Main, 1820, pp. $428-434$. Not available to the authors.

547. - Beiträge zur Geschichte, Statistik und Literatur des Sächsischen

Erzbergbaues.

1848, Freiberg.

Not available to the authors. 


\section{GERMANY (Continued)}

Fuchs, E., and LAunay, L. DE. See No. 1323.

Gätzschmann, M. F. See No. 1391.

548. Gmelin, J. F. Beyträge zur Geschichte des deutschen Bergbaues. 1783, Halle.

Not available to the authors.

549. Groddeck, Albert. Traite des gîtes métallifères. Translated from the German by H. Kuss.

1884, Paris, pp. 242-251.

Describes tin stockworks at Altenberg, Geyer, and Zinnwald, Saxony; and tin veins at Schalaggenwald and Graupen, Bohemia. Brief references to tin deposits are made at a number of other places in the book.

550. HaLLwich, H. Das Zinnerz-Vorkommen zu Graupen und Obergraupen und Art und Weise des Bergbaues daselbst in alter und neuer Zeit.

Oest. Zeitschr. Berg. Hütt., Vol. 16, 1868, Wien, pp. 150-151, first article.

Extract from Dr. Hallwich's " Geschichte der Bergstadt Graupen."

JARS, G. See No. 416.

551. KLIPSTEIN, A. Altenberger Zinnstocks.

Neues Jahrb. Min., Vol. 1, 1830, Stuttgart, pp. 256-261.

Lampadius, W. A. See No. 1516.

551a. Lepsius, Richard. Geologie von Deutschland und den angrenzenden gebieten.

Vol. 1, 1903, Leipzig, p. 66 et seq.

The tin deposits of the Erzgebirge are briefly treated.

Louis, Henry. See No. 1340.

552. Manès [-]. Mémoire sur les mines d'étain de Saxe.

Ann. Mines, Vol. 8, 1823, Paris, pp. 499-594, 837-886; Vol. 9, 1824, pp. 281-304, 463-476, 625-656.

Not available to the authors.

553. ManN, O. Zur Kenntniss erzgebirgischer Zinnerzlagerstätten.

Sitz. Abh. Nat. Ges. "Isis," 1904, Dresden, pp. 61-73, figs. 2, geol. map.

554. Miklucio-Maclay, M. von. Rutil und Zinnstein im Greifensteiner Granit. (Ehrenfriedersdorf.)

Neues Jahrb. Min., 1885, II, Stuttgart, pp. 88-90.

Occurrence of cassiterite as original rock making constituent: with rutile in lithia mica of "Greifenstein."

555. Müller, HermanN. Ueber die Bildung der Zinnstockwerke im östlichen Erzgebirge.

Berg. Hütt. Zeit., Vol. 24, 1865, Leipzig, pp. 178-180.

Neues Jahrb. Min., 1865, Stuttgart, pp. 866.868.

556. — Beiträgen zur geognostischen Kenntniss des Erzgebirges. Vol. 2, 1867, Freiberg,

Extract; Neues Jahrb. Min., 1867, Stuttgart, pp. 616-619.

Not available to the authors. 


\section{GERMANY (Continued)}

557. - Ueber die Erzlagerstätten in der Umgegend von Berggiesshübel. Erl. geol. Specialkarte Kön. Sachsen, 1890, Leipzig, p. 55. Gänge der Zinnerzformation.

558. Die Erzgänge des Annaberger Bergrevieres.

Erl. geol. Specialkarte Kön. Sachsen, 1894, Leipzig. Zinnbergbau in den Annaberger Revieren, pp. 32-36. Gänge der Zinnerz-Formation, pp. 67-71.

559. - Die Erzgänge des Freiberger Bergrevieres.

Erl. geol. Specialkarte Kön. Sachsen, 1901, Leipzig, pp. 129-141.

Treated under heads: Zinnerz und Kupfererz führende Gänge; Zinnstockwerk bei Seiffen; Zinnseifenablagerungen bei Seiffen; Zinnerz führende bei Freiberg; Zinnseifen in der Gegend von Freiberg und Dorfhain.

560. MüLler, H., und Richter [-]. Ueber das Vorkommen von Zinn in der Zinkblende der Freiberger Erzgängte.

Berg. Hütt. Zeit., 1851, Leipzig, pp. 353-356.

Nowicki, Constantin von. See No. 71.

561. OpPE, H. V. Die Zinn- und Eisenerz-Gänge der Eibenstocker Granitpartie und deren Umgebung inner halb der Bergamtsrefiere Johanngeorgenstadt und Schneeberg.

In Cotta (B.) Gang-studien, Vol. 2, Freiberg, 1854, pp. 133-195.

Digest: Neues Jahrb. Min., 1853, Stuttgart, pp. 725-726.

Phillips, J. A., and Louis, H. See No. 1350.

RAMMelsberg, C. See No. 1637.

562. Reuss, A. E. Die Umgebungen von Teplitz und Bilin, in Beziehung auf ihre geognostischen Verhältnisse. Prag und Teplitz, 1840.

Der Zinngänge bei Graupen, p. 4; ueber das Zinnwalder Stockwerk und die Zinngänge im Seegrunde, pp. 40-51.

563. REyer, EdUARD. Ueber die erzführenden Tieferuptionen von ZinnwaldAltenberg und über den Zinnbergbau in diesem Gebiete.

Jahrb. k. k. geol. Reichs., Vol. 29, 1879, Wien, pp. 1-60, figs. 4.

Digest: Oest. Zeitschr. Berg. Hütt., Vol. 27, 1879, Wein, pp. 494-495.

564. - Tektonik der granitergüsse von Neudeck und Karlsbad, und Geschichte des Zinnbergbaues im Erzgebirge.

Jahrb. k. k. geol. Reichs., Vol. 29, pt. 3, 1879, Wien, pp. 405-461.

"This memoir is divided into:

1. A study of the relations of the granite and schists.

2. A discrimination of the various local kinds of granite, as being necessary for a knowledge of the nature and origin of the granite masses; with both earlier descriptions of the several granites and the author's own researches.

3. The history of the nost important tin-bearing rocks and tin works of the districts. These chapters are illustrated with several wood cuts, among which is a plan of the country between Carlsbad, Ebenstock and Schwarzenberg." 


\section{GERMANY (Continued)}

565. The history of tin mining in Bohemia and Saxony. Iron Age, Vol. 24, Dec. 18, 1879, New York, p. 5.

Probably an abstract from Jahrb. k. k. geol. Reichs., Vol. 29, 1879, Wien, pp. 405-461.

566. - Beiträge zur Geschichte des Zinnbergbaues in Böhmen und Sachsen.

Oest. Zeitschr. Berg. Hutt., Vol. 28, 1880, Wien, pp. 349-350, 366-367, 374-377, $388-390,399-400,414-415,422-424$.

567.

\section{Zinn.}

1881, Berlin, pp. 6-101, figs. 7 .

I. Geologie von Zinnwald und Altenberg. II. Geschichte des Zinnbergbaues von Graupen, Zinnwald und Altenberg. III. Platten, Erenfriedersdorf, Geier. IV. Schlackenwald. V. Kronik des Zinnbergbaues in Bömen und Sachsen.

Rosenbusch, H. See No. 1639.

568. RÜCKER, ANToN. Beitrag zur Kenntniss des Zinnerzvorkommens bei Schlaggenwald.

Jahrb. k. k. geol. Reichs., Vol. 14, pt. 3, 1864, Wien, pp. 311-324.

Digest: Neues Jahrb. Min., 1864, Stuttgart, p. 362.

569. SANDBERGER, F. Ueber die Bildung von Erzgängen mittelst Auslaugung des Nebengesteins.

Zeitschr. deutsch. geol. Ges., Vol. 32, 1880, Berlin, pp. 350-370.

Schertel, A., and Stelzner, A. W. See No. 1643.

570. Schmidt, Albert. Die Frage nach dem Ursprung des Zinns in der vorhistorischen Zinnbronze und das Fichtelgebirge.

Montan. Ztg. Oest. Ungarn., Vol. 7, No. 19, 1900, Graz, pp. 479-482.

Not available to the authors.

571. - Das Vorkommen von Zinnstein im Fichtelgebirge und dessen Gewinning im Mittelalter.

Zeitschr. Berg. Hütt. Sal. preuss. Sta., Vol. 54, 1906, Berlin, pp. 377-382. Mit 11 text fig.

Abstract: Geol. Centr., Vol. 9, 1907, Leipzig, p. 297.

The Fichtelgebirge played a considerable role in the earlier historic and in prehistoric time as a source of tin. The tin bearing rocks appear in exactly the same relations and with the same paragenesis as in the cases of better known sources of tin. Most of the former mining operations were confined to the working of placers. At the villages Schönlind and Weissenhaid, six tin lodes were uncovered. There appears to have been a further vein-like occurrence which is shown by fioat ore at Seehause in the Schneebergkette. The prospect of again carrying on placer mining is very slight.

Translation of R. Bärtling's digest.

572. SchRöDER, M. Ueber Zinnerzgänge des Eibenstocker Granitgebietes und die Entstehung derselben.

Sitz. Nat. Ges., 1883, Leipzig, p. 70 ff.

Review: Neues Jahrb. Min., 1887, Stuttgart, I [Ref.], p. 268.

573. Schultz, - Bemerkungen auf einer bergmännischen Reise durch Sachsen und einer Theil von Böhmen.

Arch. Bergb. Hütt., Vol. 2, 1820, Breslau und Berlin, pp. b140-b142.

Treats of tin deposits of Saxony. 


\section{GERMANY (Continued)}

573a. Singewald, J. T., JR. The Erzgebirge tin deposits.

Econ. Geol., Vol. 5, 1910, Lancaster, pp. 166-177, 265-272, figs. 2. (geol. maps) and 1 plate.

The tin deposits are grouped around two belts of granite cutting across the Erzgebirge, between Saxony and Bohemia. Around the eastern belt are the tin mines of Sadisberg, Altenberg, Zinnwald, and Graupen, and around the western are those of Schneeberg, Annaberg, Joachimstahl, etc.

At Sadisdorf a stockwork of veinlets has made zwitter of the granite-the feldspars having been replaced by topaz and quartz. Cassiterite, fluorspar, pyrite, arsenopyrite, chalcopyrite, chalcocite and cuprite have been impregnated in the granite. An eighteen-foot quartz vein carrying fluorspar, wolframite, molybdenite, and zinnwaldite cuts the granite. At Altenberg is a similar zwitter which extends downward about 700 feet. It carries an average of about 0.3 per cent tin and 0.002 per cent of bismuth. At Zinnwald quartz veins $1 \frac{1}{2}$ to 2 feet thick carrying cassiterite and wolframite (which is more important), with zinnwaldite, are worked. At Graupen the Luxer vein, now worked, contains white quartz which in places gives way to coarsely crystalline orthoclase and albite and to fluorspar. Cassiterite, lithium mica, wolframite, chalcopyrite, and galena are the other vein minerals.

At Geyer zwitter bands are mined. At the Leier Mine north of Geyer a greisen dike 3 feet wide, locally carrying 1 per cent tin, and tin-bearing veins are worked. The ores carry nearly 30 per cent of iron and arsenic. At Sauberg, tin veins occur in gneissic mica schist. No granite has been encountered. There are five groups which consist of 3 to 15 parallel veins each, 1 to 3 feet apart, and from 2 to 10 inches wide. They carry much arsenopyrite and some wolframite. At one place they are faulted by a silver cobalt vein.

The deposits on the Austrian side are not described.

574. StedzNer, A. W. Beiträge zur geognostischen Kenntniss des Erzgebirges. Vol. 1, 1865, Freiberg, pp. 3-58.

Abstract: Die Granite von Geyer und Ehrenfriedersdorf sowie die Zinnerzlagerstätten von Geyer.

Neues Jahrb. Min., 1865, pp. 863-866; 1866, Stuttgart, pp. 229-230.

575.

Beiträge zur Entstehung der Freiberger Bleierz- und der erzgebirgischen Zinnerzgänge.

Zeitschr. prakt. Geol., 1896, Berlin, pp. 377-412.

Digest: Neues Jahrb. Min., 1898, II (Min), Stuttgart, pp. 72-74.

Thinks ore deposits due to ascending waters. No rutile present in deposits.

Stelzner, A. W., and Schertel, A. See No. 1643.

576. SterNberger, KARL. Die ärarischen Bergbau-Unternehmungen im böhmischen Erzgebirge.

Oest. Zeitschr. Berg. Hütt., Vol. 5, 1857, Wien, pp. 62-63.

577. Telk IN (Vice-Consul). Tin mining in Saxony.

Mg. Journ. Railw. Colnm. Gaz., Vol. 81, 1907, London, p. 624.

Notes a revival of Erzgebirge mines, which flourished in 16th and 17th centuries, "but began to be abandoned when the South American deposits were discovered."

578. VIEBIG, W. Die Silber-Wismutgänge von Johanngeorgenstadt im Erzgebirge.

Zeitschr. prakt. Geol., Vol. 13, 1905, Berlin, pp. 95-96.

578a. WeInschenk, ERnst. Die Kieslagerstätte im Silberberg bei Bodenmais.

Abh. Math. Phys. Classe Kön. Bay. Akad. Wiss., Vol. 21, München, 1901, pp. 349-410. 


\section{GERMANY (Continued)}

Digest Translation: Trans. Inst. Mg. Eng., Vol. 22, 1901-2 (1903), London and Newcastle-upon-Tyne, p. 694.

"Among other interesting minerals from this locality are graphite, tinstone, tourmaline, garnet, etc."

\section{GREENLAND}

579. Allen, Tho. Memorandums respecting some minerals from Greenland. Ann. Philos., 1813, London, p. 107.

Tin is briefly mentioned as being fouud among other minerals in Greenland.

580. ANonymous. Half hours in the far north.

Dodd, Mead and Co., New York, p. 145.

"We were happy enough to obtain a few minerals, some specimens of rough garnets, allanite, tantalite, molybdenite, etc., with copper, tin, and iron ores in small quantities (near Frederikshaabs, Greenland)."

581. BoggILd, O. B. Mineralogia Groenlandica.

Medd. Grönl., Vol. 32, 1905, Kjøbenhavn, pp. 89-91.

Mentions the finding of cassiterite in Greenland.

582. Flink, Gust. Berättelse om en mineralogisk resa i Syd-Grönland sommaren 1897.

Medd. Grönl. 14de hefte, 1898, Kjøbenhavn, p. 261.

(Résumé des Communications sur le Grönland p. 416.)

Briefly mentions cassiterite as having been found in small quantities during the trip.

583. Giesecke, K. L. Mineralogiske rejse i Grönland.

1878, Kjøbenhavn.

Cassiterite was found in the Christianshaabs district (p. 83); in the Frederikshaabs district on Arsuk Fjord (pp. 161, 180 and 338) and at Itivdliarsuk in the Godhavn district (p. 289).

Unimportant except as showing distribution and mineralogical occurrence.

584. HoFf, Tr. Om tinstenens forekomst ved Ivikaet ved Arsut Fjord i Syd-Grönland.

Vid. Medd. nat. Foren. Kjøøenhavn, for 1854 (1855), Kjøbenhavn, pp. 201-204, fig. 1 in text.

585. RINk, HENRY. Danish Greenland its people and its products. Edited by R. Brown.

1877, London, p. 391.

Merely states that "tinstone accompanies the cryolite."

586. TAyler, J. W. On the veins of tin-ore at Evigtok, near Arksut, Greenland.

Quart. Journ. Geol. Soc. London, Vol. 15, 1859, London, pp. 606-607.

Quoted in Fawns, Sydney, "Tin deposits of the world," 1905, p. 146.

About twenty veins through an area 80 by 1500 feet, also disseminated through rocks with fine grained galena and tantalite. One and one-half inches of cassiterite on one side of largest vein, which is ten inches wide. Gangue feldspar, quartz, fluorspar, and "sparry iron"; vein runs into white cryolite. Other accompanying minerals are "blende," copper, iron and arsenical pyrites, black cryolite, " molybdena," and zircon. No wolframite. 


\section{HONDURAS}

\section{6a. Montis, E. DE. Mining in Honduras.}

Mex. Mg. Journ., Vol. 7, 1908, Mexico, p. 24.

Makes bare statement that, among other metals, tin is found in Honduras.

\section{IDAHO}

Hanks, H. G. See No. 218.

586b. Lindgren, Waldemar. A geological reconnaissance across the Bitterroot Range and Clearwater Mountains in Montana and Idaho.

U. S. Geol. Surv., Prof. Paper No. 27, 1904, Washington, D. C., p. 89.

"Stream tin [wood tin, F. L. 11.] is frequently found with the gold in this [Hughes] creek."

\section{INDIA}

587. Anonymous. Occurrence of tin in India.

Mg. Journ. Railw. Comm. Gaz., Vol. 75, 1904, London, p. 605.

Note stating a new discovery of tin ore has been made at Hosainpura, State of Palanpur. Mineral occurs in large distinct crystals, together with the mineral gadolinite, as a constituent of tourmaline-pegmatite.

588. Mineral production of India.

Bull. Imp. Inst. Great Britain, Vol. 4, No. 2, 1906, London, pp. 156-164.

Brief review of mineral productions of India as given by Rec. Geol. Surv. India, Vol. 33, pt. 1, 1906, Calcutta, pp. 1-32.

"Tin ore is found in the Hazáribaigh distriet of Chota Nagpur and otler localities of India proper, but it has only been worked to any extent in South Burma. The total output in 1904 just exceeded 70 tons. It is sent to the Straits Settlements, from which the greater part of the tin imported into India is obtained. The metal is mainly employed in India to form a coating in the inside of copper cooking utensils, which is renewed from time to time. The consumption shows no signs of increase." (Whole Ref.)

589. BALL, V. A manual of the geology of India.

Geol. Surv. India, pt. 3, 1881, Calcutta, pp. 313-322.

The only localities (Indian) where tin ore occurs in sufficient quantities to be of commercial value are situated in the Tenasserim division of British Burma.

590. - The mineral resources of India and their development.

Journ. Soc. Arts, Vol. 30, 1882, London, p. 583.

Although ores of tin do occur in parts of the Indian Peninsula, there is at present time no deposit large enough to warrant working to any great extent. Localities where tin ore oecurs are numerous. Mostly ineluded in the strip of land in Tenasserim which extends from Ys to Maleewoon, a distance of about 400 miles. Sources of stream tin, which is found in the majority of rivers of this distriet, are in range of hills separating British Tenasserim from Siam. An attempt was made by a British company at Maleewoon to work deposits, but it resulted in loss. Working of ore is carried on by Chinese, Shans and Burmese.

D'AChiardi, Antonio. See No. 1313.

591. Holland, T. H. Tin ore and gadolinite in Palanpur.

Rec. Geol. Surv. India, Vol. 31, 1904, Calcutta, p. 43.

In Sept. 1903, tin ore was discovered at Hosainpura, Palanpur State. "Mineral occurs in distinct, large crystals as a constituent of tourmaline-pegmatite together with the mineral gadelinite." 


\section{INDIA (Continued)}

592. KING, W. Index of the local distribution of important minerals, etc., in India.

Rec. Geol. Surv. India, Vol. 22, pt. 4, 1889, Calcutta, p. 254.

Tin ores are mentioned as coming from Chota Nagpur; Nurgo or Nurunga, where there are grains of tinstone in gneiss; Phira, and at Simratari, where mere traces have been found.

593. Maliet, F. R. Geological notes on part of Northern Hazáribágh.

Rec. Geol. Surv. India, Vol. 7, pt. I, 1874, Calcutta, pp. 35-36, 43.

Cassiterite, is found at Nurgo, a village south of Baraka in grains thickly distributed through a thinly foliated gneiss containing some thin "seams of pegmatite." Also occurs in lepidolite in pegrnatite at Pihra, and in granite cutting mica schist at Simratari, west of Pihra.

Natives smelted tin ore for iron ore and when they saw the white metal, thought they had obtained silver.

594.

A manual of the geology of India. pt. 4. 1887, Calcutta, pp. 54-55.

"Tinstone has been reported from several parts of the peninsula of India, but nowhere has it as yet been found in any quantity."

595. Medlicott, H. B. and Blanford, W. T. Tin in India.

Manual of the Geology of India, Calcutta, 1879, pp. 19, 708.

Mr. Mallet found tinstone in the gneiss in district of Hazaribagh. Tinstone is found in some abundance in parts of the Tenasserim and in Martaban.

596. OAtes, RoBert. The copper and tin deposits of Chota-Nagpore, Bengal, India.

Trans. Fed. Inst. Mg. Eng., Vol. 9, 1895, Newcastle-upon-Tyne and London, pp. 445-451, pls. $24,25$.

Gives geology, account of the working, machinery used and results obtained, at Narungo tin-mine, 5 miles north of Baragunda.

Piilllips, J. A., and Louis, H. See No. 1350.

597. Rudra, SARAT C. Mineral resources of British India.

Trans. Amer. Inst. Mg. Eng., Vol. 34, 1904, New York, p. 828.

"Although no deposit of tin ore has yet been discovered in Peninsular India, stray samples have been found in Bengal, Chota-Nagpur, Bombay and Bastar. The only place in British India where this mineral is known to exist in a large quantity is in Lower Burma, at Amberst, Tavoy and Mergui."

598. Stephens, F. J. Geology and mineral resources of Kumaon and Garhval. Trans. Inst. Mg. Met., Vol. 10, 1901-1902 Iondon, pp. 394, 401, 411.

Tin is briefly mentioned as occurring in small quantities in India.

\section{IRELAND}

599. Anonymous. Tin ore and gold in Wicklow, Ireland.

Amer. Journ. Sci. Arts, ser. 2, Vol. 11, 1851; New Haven, p. 232.

Gives following analysis of tin ore made by W. Mallet:

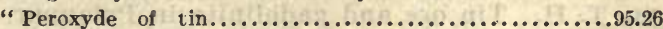

Peroxyde of iron..............................41

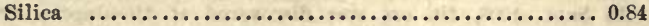

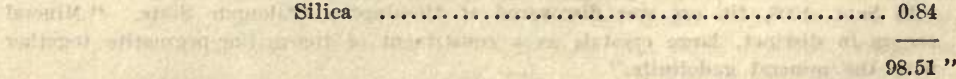

Fawns, Sydney. See No. 1320. 


\section{IRELAND (Continued)}

600. Fitton, Willia m. Notice respecting the geological structure of the vicinity of Dublin; with an account of some rare minerals found in Ireland. Trans. Geol. Soc. London, Vol. 1, 1811, London, p. 270.

Tinstone found in the gold mines of Wicklow.

601. Kinahan, G. H. On the mode of occurrence and the winning of gold in Ireland.

Sci. Proc. Roy. Dublin Soc., n. 8., Vol. 3, 1883, Dublin, p. 272.

Tinstone crystals are mentioned as occurring with the gold at Ballinvally. Found also in Monaglogh and Coolbawn.

602. Economic geology of Ireland.

Journ. Roy. Geol. Soc. Ireland, Vol. 18 (Yol. 8, new series), 1889, Dublin, pp. 11, $17,79,82,86,121,122$.

A collection of papers appearing in the Sci. Proc. Roy. Dublin Soc., from March 1886 onward. Three counties in which tin is said to be found:

1. County Dublin, Dalkey, at Kingstown with lead and zinc in granite. Only place in Ireland that it is known in a lode. Rumored at Kilcrohane (Sheep Head) County Cork, but not authenticated.

2. County Kerry, Lough Leane, Killarney. Questionably.

3. County Wicklow, Goldmine River, Woodenbridge, in gravels with gold and mag. netic sand. Suggests possibility of finding tin lodes at last place.

603. - Notes on mining in Ireland.

Trans. Inst. Mg. Fng., Vol. 26, 1903, London and Newcastle-upon-Tyne, pp. 279-280, 236.

Tin ore in the Ovoca district, County Wicklow, has not been found in place. Thinks it may occur in copper-bearing veins in the district and that copper may give way to tin in depth. Treats shortly of old bronze, showing that tin was known in Ireland long ago.

Only localities where tin is known are Dalkey, County Dublin, and the Goldmine Valley, County Wicklow. Said to have been found near the lakes of Killarney, County Kerry.

H. J. Seymour is quoted as crediting minute crystals of cassiterite to the Mourne Mountains.

604. MAClaRen, J. Marcolm. The occurrence of gold in Great Britain and Ireland.

Trans. Inst. Mg. Eng. Vol. 25, 1902-1903, Newcastle-upon-Tyne and London, p. 494.

States that in the Croghan Kinshelagh area, County Wicklow, Ireland, " the black sand is composed mainly of magnetite, ilmenite, hematite and iron pyrite, but cassiterite, galena, wolframite, molybdenite, gold, copper-pyrite and oxides of manganese also occur in the sand. The late Mr. W. Mallet records having obtained from a washing of 150 pounds, no less than $3 \frac{1}{2}$ pounds of stream tin, in all sizes from small grains up to pebbles $1 / 2$ inch in diameter and of the variety known as wood-tin."

605. Mallet, W. On the minerals of the auriferous district of Wicklow.

Journ. Geol. Soc. Dublin, Vol. 4, 1848, Dublin, pp. 272-273.

Abstract: London, Edinburgh, Dublin Philos. Mag. Journ. Sci., Vol. 37, 1850, London, pp. 393-394.

Brief abstract: Amer. Journ. Sci. Arts, 2d ser. Vol. 11, 1851, New Haven, p. 232. Tin in County Wicklow, Ireland, "Should this mineral be found in the mass of sand in a quantity at all approaching that in which it existed in the specimen examined, it would probably richly repay the labor and expense of collection and smelting. The fact of the existence of tinstone in such considerable quantity in these auriferous streams, would scem to indicate the probable existence somewhere in the surrounding district of masses of ore, and possibly forming the continuation of those vast deposits of Cornwall." 


\section{IRELAND (Continued)}

606. Seymour, H. J. On the occurrence of cassiterite in the tertiary granite of the Mourne Mts., County Down.

Sci. Proc. Roy. Dublin, Soc., Vol. 9, 1902, Dublin, p. 583, 584.

This occurrence of cassiterite in an undoubted Tertiary granite is of great interest, as tending to show the comparatively recent origin of some mineral lodes. First record of the occurrence of tin in Ireland dates from 1796.

607. Smith, Aquila. On Irish tin ore.

London, Edinburgh, Dublin Philos. Mag. Journ. Sci., ser. 3, Vol. 18, 1841, London, pp. 134-136.

Tin ore is said to have been found in Wicklow County about 1796, in some gold mines. Messrs. Mills, King and Weaver, published in Trans. Dublin Soc., Vol. 2, 1801, Dublin, p. 147, an announcement of the occurrence of tinstone crystals associated with the gold in Croghan Mts. in Wicklow County. This is first announcement of the existence of tin in Ireland. The author in examining some washed sand from the gold works in Wicklow County, found small particles of " native tin oxide."

608. Weaver, Thomas. Memoir on the geological relations of the east of Ireland.

Trans. Geol. Soc. London, Vol. 5, 1821, London, p. 135.

Mentions "tinstone" as having been found in granite, and stream tin at Croghan Kinshela, County Wicklow.

609. - On Irish tin ore.

London, Edinburgh, Dublin Philos. Mag. Journ. Sci., ser. 8, Vol. 19, 1841, London, pp. 27-31.

Mr. Weaver reviews the paper on Irish tin ore by Aquila Smith, printed in Philos. Mag., Vol. 18, 1841, London, pp. 134-13b. Mentions that tin, contrary to Mr. Smith's assertion, is found in three distinct localities in Ireland, two in the county of Wicklow, and one in county of Dublin.

\section{ITALY}

610. ANonymous. A tin mine in Tuscany.

Journ. Appl. Sci., Vol. 7, 1876, London, p. 56.

Notes the discovery of a vein of cassiterite near Campiglia, Tuscany. The vein is about 4 inches wide, between limonite and a Lias limestone. Believed to be the first time tin has been found unconnected with granite.

611. - The discovery of tin ore in Italy and its relation to the bronze manufacture of the ancients.

Iron, Vol. 14, 1879, London, pp. 166-167, 322-324.

612. Beco, Jean, and Thonard, LEon. L'industrie minérale en Italie depuis 1860 jusqu'en 1880 .

Rev. Univ. Mines Mét. Trav. Publ. Sci. Arts Appl. Indust. ser. 2, Vol. 14, 1883, Paris and Liége, p. 115.

The oxide of tin was discovered in Tuscany in $\mathbf{1 8 7 6 .}$

613. Bergeat, AlFred. Beiträge zur Kenntniss der Erzlagerstätten von Campiglia Marittima (Toscana) insbesondere des Zinnsteinvorkommen dortselbst.

Neues Jahrb. Min., Vol. 1, 1901, Stuttgart, pp. 135-156, text figs. 2, pl. 7.

Review: Zeitschr. prakt. Geol. 1901, Berlin, pp. 422-423.

Digest: Trans. Inst. Mg. Eng., Vol. 22, 1901-1902, London and Newcastle-uponTyne, pp. 705-706. 


\section{ITALY (Continued)}

These stanniferous deposits differ from all others known, for they do not appear to be associated with eruptives, but occur in limestone with hematite. Campiglia is $12 \frac{1}{2}$ miles from Massa Marittima, 18 miles from Elba and about same distance from borax-producing localities of Larderello and Castelnuovo. Ore deposits extend in belt of over 3 miles from Monte Valerio to Monte Calvi. 11/4 miles southwest of town are tin ores, 2 miles northwest are sulphide-ores-argentiferous-galena, pale and dark zine blende, pyrite and chalcopyritc. Ores intimately associated with cordierite-bearing quartz trachyte, epidote, chlorite, ilvaite, manganiferous pyroxene, quartz, and fluorspar, separated from tin-deposits by Marmi valley. These ores are eruptive and metasomatic. No tin in them. Tin deposits are on Monte Valerio and Monte Fumacchio. Country-rock gray or pinkish Inarble, probably Middle Lias, overlain by variegated Upper Lias slates, with quartz nodules. No eruptives to be seen here. Tin ore in limonite in fissures in slates and very irregular metasomatic masses in limestone. Thinks ores are not of secondary concentration and are not a stanniferous gossan. Gangue is calcite and kaolin. None of ordinary accompanying minerals of tin. Copper ores of Boceheggiano and Massa Marittima are stanniferous.

614. Blanchard, Fréd. Sur la découverte de la cassitérite à Campiglia Marittima.

Atti R. Accad. Lincei (Mem.), ser. 2, Vol. 3, 1875-1876 (1876), Roma, pp. 93-94.

615.

Sulla scoperta della cassitérite à Campiglia Marittima.

Bol. R. Com. geol. Italia, Vol. 7, 1876, Rome, pp. 52-54.

Digest: Geol. Rec. for 1876, London, p. 194.

At Cento Camerelle, on west side of Monte Fumacchio, a small tin-vein occurs, accompanied by limonite. Has east-westerly direction, with underlay to south. Country rock is Iower Lias limestone.

616. - Sulla miniere di stagno in Campiglia.

Atti R. Accad. Lincei (Trans.), ser. 3, Vol. 2, 1877-1878 (1878), Rome, pp. 186-191.

617. Braun, Max. Zinnstein in Italien.

Neues Jahrb. Min., 1877, Stuttgart, pp. 498-499.

A communication describing Italian tin deposits.

Brown, A. Selwyn. See Nos. 1307 and 1308.

618. Caillaux, Alf. Note sur la découverte de minerai d'étain en Toscane.

Bull. Soc. Geol. France, ser. 3, Vol. 4, 1875-1876 (1876), Paris, pp. 293-295.

Geologically, an important discovery on account of its rather unusual occurrence.

Two analyses were made of this tin by Hallway of London:

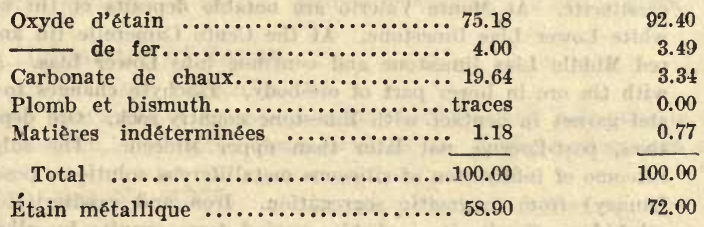

619. Charlon, E. Note sur la découverte de l'étain oxydé en Toscane.

Ann. Mines, ser. 7, Vol. 9, 1876, Paris, pp. 119-122.

620. Church, A. H. La scoperta del minerale di stagno in Italia, e sua relazione colla lavorazione del bronze presso gli antichi.

Bol. R. Com. geol. Italia, Vol. 10, 1879, Rome, pp. 382-394, 545-556. 


\section{ITALY (Cortinued)}

621. D’Achiard, Antorio. Entdeckung des Ziunsteins in Campiglia Marittima.

Neues Jahrb. Min., 1876, Stuttgart, p. 285.

Digest: Geol. Rec. for 1876, London, p. 222.

"Notes on the discovery of cassiterite, with brown iron ore, in the Cento Camerelle, where the Romans and perhaps the Etruscans, had important mines. The tinstone contains 72.45 per cent tin."

. See No. 1313.

622. DALMER, KARL. Zinnerzlagerstätten.

Zeitschr. prakt. Geol. 1894, Berlin, p. 100.

Additions made to a communication by Herr Gurlt concerning the occurrence of tin in Campiglia.

623. ERnst, C. von. Die Montanindustrie Italiens.

Oest. Zeitschr. Berg. Hutt., Vol. 31, 1883, Wien, p. 597.

Brief account of localities, and manner of occurrence of tin in Italy, also production from 1876 to 1880 inclusive.

Fawns, Sydney. See No. 1320.

Fuchs, E., and LAunAy, L. DE. See No. 1323.

624. GurLt, A. Zinn-Vorkommen im Kalkstein von Cava del Fumacchio bei Campiglia, Toscana.

Zeitschr. prakt. Geol. 1894, Berlin, pp. 324-326.

Remarks on this article by Karl Dalmer, p. 400.

625. Herter, Paul, and Rath, G. von. Zinnstein von Campiglia.

Zeitschr. deutsch. geol. Ges., Vol. 29, 1877, Berlin, pp. 194-196.

626. LANGER, J. H. Zinnsteinvorkommen in Toscana.

Oest. Zeitschr. Berg. Hütt., Vol. 24, 1876, Wien, p. 502.

627. Lotri, B. Súlla genesi dei giacimenti metalliferi di Campiglia Marittimi in Toscana.

Bol. R. Com. geol. Italia, Vol. 31, 1900, Rome, pp. 327-337, sections 2.

Digest Trans.: Trans. Inst. Mg. Eng., Vol. 22, 1901-1902, London and Newcastle-uponTyne, pp. 704-745.

Quartz-trachytes, some of them bearing tourmaline, and tourmaline-granite cut gray and white limestones of lower Liassic. Metalliferous deposits in more direct contact with trachyte than with granite. At Campo Alle Buche at the contact of the granite and gray limestone are masses of hematite, limonite, carbonate of lead and traces of cassiterite. At Monte Valerio are notable deposits of tin with the iron ore in the white Lower Lias limestone. At the Cento Camerelle tin and iron ores occur in the red Middle Lias limestone and continue into Lower Lias. Are in a horizontal vein with tin ore in lower part of orc-body. 'Trachyte changes to pyroxenite with epidote and garnet in contact with limestone country-rock. Ore deposits same age as intrusives, post-Eocene, not later than upper Miocene. The sulphides are probably the outcome of infiltration of siliceous metalliferous solutions, possibly (after Vogt and De Launay) from magmatic segregation. Iron and cassiterite come from oxidation of sulphides. Cassiterite probably carried from granite by alkaline carbonate solutions with carbonate of iron which was later decomposed into oxide.

628. Phillips, J. A., and Louis, Henry. A treatise on ore deposits. 1896, London, pp. 476-477.

In Italy tin was found in connection with hematite, near Campiglia Marittima, in 1875. In Lower Lias limestone in fissures in connection with hematite. 70 tonnes of ore produced up to 1894 , but none during that year. 


\section{JAPAN}

629. Anonymous. Les Mines du Japon.

Bureau des Mines, 1900, Paris, pp. 294-297.

Tin occurs in tertiary tuffs, with galena and pyrite at Taniyama. Ore said to carry 10 per cent of tin.

630.

\section{- Outlines of the geology of Japan.}

Imp. Geol. Surv. Japan, 1902, Tokyo, pp. 183-184.

Kiura mine, situated in Bungo province was discovered many hundred years ago, and was once prosperous. At present ore is almost exhausted. Tin ore occurs in cavities in limestone. Taniyama mine was discovered in 1655 , was most productive between 1848-1860, annually yielding froin 120,000 to 130,000 kin of tin. Ore occurs in veins. Stream tín is found in vicinity of Takayama and Hirukawa.

See No. 1672.

BeCK, RichaRd. See No. 1299.

D'Achiardi, Antonio. See No. 1313.

FAwns, Sydney. See No. 1320.

\section{Godfrey, J. G. H. On the geology of Japan.}

Quart. Journ. Geol. Soc. London, Vol. 34, 1878, London, pp. 542-555, 100 words.

Tin ore occurs only in small quantities. Found in province of Bungo and Satsuma (Taniyama). Estimate of total production per annum is $71 / 2$ tons.

632. Jiмво, Котова. Notes on the minerals of Japan.

Journ. College Sci. Imp. Univ. Tokyo, Vol, 11, 1899, Tokyo, pp. 224, 231.

Describes specimens of cassiterite from Mino, Satsuma, Bungo and Hitachi provinces. Brief.

633. Munroe, Henry S. The mineral wealth of Japan.

Trans. Amer. Inst. Mg. Eng., Vol. 5, 1877, Easton, Pa., pp. 297-299.

Reprint: Eng. Mg. Journ., Vol. 22, 1876, New York, p. 427.

Translated from the English by Leon Thonard, in Rev Univ. Mines, Met. Trav. Publ. Sci. Arts Appl. Indust., ser. 2, Vol. 2, 1877, Paris and Liége, pp. 273-275.

Tin is found in but three of the thirty-five ken of Japan, so far as author knows, only in veins. Nearly all tin produced comes from Taniyama mine. There are, here, 21 distinct veins of tin averaging $1 \frac{1}{2}$ feet in in thickness, but varying from a few inches to four feet. The ore is cassiterite, found in almost microscopic crystals - scattered through a gangue of quartz. Method of treating the ore is given.

634. ReIN, J. J. The industries of Japan.

English translation, 1889, London, p. 303.

Merely a note. Little tin in Japan; on island of Kinshin and Tani-yama in Satsuma; and in Ohira-tetsu-san, in Bungo. These localities are in the southern end of Japan.

Rolker, Chas. M. See No. 1357.

635. WAdA, Tsunashiro. The mining industry of Japan during years 18671892.

Mining Bureau Dept. Agriculture and Commerce, 1893, Tokyo, pp. 1, 300.

Tin has been mined since the end of the 7 th century. Production in 1820 , from Taniyama, 791 piculs. 


\section{JAPAN (Continued)}

636. - Minerals of Japan.

Translated by T. Ogawa, 1904, Tokyo, pp. 50-51.

Cassiterite sometimes occurs in fluviatile deposits, as in the provinces of Mino and Bungo, and sometimes in rocks as in the provinces of Satsuma, Hitachi, Suo and Hyüga. It occurs usually in small quantities, and the mineral is worked only in Satsuma and Hyüga.

\section{KAMERUN}

637. Anonymous. Tin deposits in Kamerun.

Mg. Journ. Railw. Comm. Gaz., Vol. 76, 1904, London, p. 405, 150 words.

Digest from Mg. Mag., Vol. 10, 1904, New York, p. 336.

"Brief confrmation of the truth of important discoveries of pure tin in British, French and German possessions in Northern Nigeria."

638.

Kamerun tin deposit.

Zeitschr. prakt. Geol., Vol. 12, 1904, Berlin, pp. $427-428$.

Paragraph stating that tin has been found in Kamerun along the British Nigerian boundary, and that two companies had acquired mining rights.

639. Macco, A. Die nutzbaren Bodenschätze der deutschen Schutzgebiete.

Zeitschr. prakt. Geol., Vol. 11, 1903, Berlin, pp. 28-33, 193-202, map.

Digest: Trans Inst. Mg. Eng., Vol. 24, 1902-1903 [1904], London and Newcastle-uponTyne, p. 712.

"Tin ore certainly occurs in that area [Kameroons] but how and where the natives work it is as yet unknown."

Fawns, Sydney. See No. 1320.

\section{KOREA}

640. Oppert, Ernest. A forbidden land: Voyages to the Corea.

1880, London, pp. 171-172.

Briefly mentions that quicksilver, lead and tin are found in province of Hoang-hai.

\section{LAOS}

641. Anonymous. L'étain au Laos.

Métallurgie, Vol. 32, 1901, Paris, pp. 891, 893.

642.

L'étain au Laos.

La Nature, Vol. 32, I, Dec. 26, 1903 (1904), Paris, pp. 58-59.

Short general article giving the location, general geology and mineral associations, of the tin deposits of Laos, and the manner of working.

643. Gascued, L. Gisements stannifères au Laos Français.

Ann. Mines, ser. 10, Vol. 8, 1905, mem., Paris, pp. 321-332, fig., sketch map.

Digest: Geol. Centr. Vol. 7, 1905-1906, Leipzig, p. 683.

La vallee du Nam-Patène montre un synclinal de grès argileux, flanqué de part et d'autre par des calcaires. Les grès paraissent d'age tertiaire. Ces grès renferment d'importants dépôts de limonite, parfois très manganésifere; l'oxyde d'étain y est en outre répąndu a l'êtat de fine division.-L. Pervinquière.

644. Lacroix, Alfred. Sur les gisements stannifères de Hin-boun (Laos).

Bull. Soc. franc. Min., Vol. 24, 1901, Paris, pp. 422-425.

Digest Translation: Trans. Inst. Mg. Eng., Vol. 25, 19C2-1903, London and New. castle-upon Tyne, p. 826. 


\section{LAOS (Continued)}

Mine located in Province of Kammun, Laos, in a small tributary valley of the Hinbun River. At present worked by French, has long been worked by natives. Ore occurs in limestone, no eruptives. Not.in place, but little water worn. None of the ordinary minerals accompanying tin are present. Cassiterite often resembles " needle ore" of Cornwall. Cassiterite supposed to be a primary constituent of a sulphide gossan, as at Campiglia, Italy.

645. Pelatan, L. Les richesses minérales des colonies françaises (Asie Française).

Rev. Univ. Mines, Mêt. Trav. Publ. Sci. Arts Appl. Indust., ser. 3, Vol. 54, 1901, Liége and Paris, pp. 247-249.

\section{MADAGASCAR}

646. Bouse, JoHno. Madagascar mineral and other resources.

California Journ. Tech., Vol. 4, No. 2, 1904, Berkeley, p. 61.

Copper and tin ores are mined in a small way. So far these ore deposits do not seem very extensive or rich. Some tin is exported.

647. Dunstan, Wyndham R. Tinstone from Madagascar.

Bull. Imp. Inst., Great Britain, Vol. 3, No. 1, 1905, London, p. 41.

The analysis of a specimen from Antananarivo gave $\mathbf{7 7 . 5}$ per cent metallic tin, but it is scarcely to be expected that when mined on a large scale such a high content of metallic tin will be maintained.

Lacroix, Alfred. See No. 516.

648. Pelatan, L. Les richesses minérales des colonies françaises (Madagascar).

Rev. Univ. Mines, Met. Trav. Publ. Sci. Arts Appl. Indust., ser. 3, Vol. 52, 1900, Paris and Liége, pp. 294-295.

Tin has long been.known to exist in region of Ambatofangehana, and recently tin has been found in the southern part of the district of Ambohimanga.

\section{MAINE}

649. Hiтcнсоск, C. H. State Geol. of Maine. Letter to D. W. Hendrickson. In prospectus bound in Mining Pamphlets, Vol. 69, U. S. Geol. Surv. Library. (Letter dated Aug. 8, 1865.)

States that tin ore at Mt. Mica, Paris, Maine, is in "a very coarse granite, in a finer granite, and this cuts a coarse mica schist, the oldest rocks in Oxford Co." "Largest known cut tourmaline in the world came from this hill, and is valued at $£ 300$. It is owned by Prof. C. U. Shepard of Amherst College." A crystal of cassiterite exceeding 5 pounds in weight had been taken out. Thinks the deposit and the one at Mt. Rubelite, in Hebron, worth exploring.

650. - Reputed tin discovery in Maine.

Eng. Mg. Journ., Vol. 30, 1880, New York, p. 173.

Quoted: Mg. Sci. Press, Vol. 41, 1880, San Francisco, p. 194.

Short article recording a recent discovery of tin ore at Winslow, Maine. The inclosing rock is described as a mica slate, adjacent to which is a hard quartzite band. Author states that mineralogical, geological, and physical features are identical with those common to the stanniferous districts of Europe. 


\section{MAINE (Continued)}

651. Hunt, T. Sterry. Remarks on an occurrence of tin ore at Winslow, Maine.

Trans. Amer. Inst. Mg. Eng., Vol. 1, 1871-1873, New York, pp. 373-375.

Remarks by Prof. Silliman and $\mathbf{R}$. W. Raymond.

Tin veins an inch or two in thickness, traverse an impure gray micaceous limestone. Gangue consists of purple fluorspar, and silvery white mica with quartz, through which the cassiterite associated with mispickel, is disseminated in small crystalline masses.

652. - Discovery of tin ore and emery at Winslow, Me.

Eng. Mg. Journ., Vol. 30, 1880, New York, p. 218.

Short communication regarding discovery of tin at Winslow, Me.

653. Jackson, C. T. Sur les mines de cuivre du lac Supérleur et sur un nouveau gisement d'étain dans l'État du Maine. (Extract d'une Lettre.)

C. R. Acad. Sci., Vol. 69 , 1869, Paris, pp. 1082-1083.

654.

Tin ore at Winslow, Me.

Proc Boston Soc. Nat. Hist., Vol. 12, 1869, Boston, p. 267.

An account of discovery of tin at Winslow. Rock in which veins exist is a compact mica slate or gneiss, and the vein matter consists of purple fluorspar, silvery radiated mica in hexagonal prisms, and quartz.

\section{MALAY PENINSULA}

655. Anonymous. Geology and mineralogy of the Malay Peninsula.

Mg. Journ. Railw. Comm. Gaz., Vol. 18, 1848, London, p. 197.

Amer. Journ. Sci. Arts, ser. 2, Vol. 6, 1848, New Haven, pp. 129-132.

656. - Tin in the Malay Peninsula.

Eng. Mg. Journ., Vol. 47, 1889, New York, p. 48.

Short review of a report of Belgian Consul-General.

657.

The production of tin in the Malay Peninsula.

Journ. Soc. Arts, Vol. 41, 1893, London, pp. 421-422.

Statistics of production for 1891. Description of Chinese methods of mining.

658. The Perak tin mines.

Eng. Mg. Journ., Vol. 56, 1893, New York, pp. 268-269, illus. 1, figs. 6.

Abstract from "London Engineer" describing the Chinese method of working tin mines. The mines are not profitable when worked by expensive western methods.

659. Mining in the Malay Peninsula.

Mg. Journ. Railw. Comm. Gaz., Vol. 66, 1896, London, pp. 277, 308-309. Editorials.

Description of Peninsula, geology and minerals. Tin and gold the only metals in deposits of commercial importance. Tin deposits mostly alluvial, bedrock is kaohin, or rarely, shale or limestone, upon which is the stanniferous gravel from a few inches to 80 feet thick. A little lode mining is being carried on in Kuantan; in Pahang and at Bundi, in Tringganu. At Kuchai, in Selangor, also at Sungei Rin in Jelebu leaders and veinlets of tin ore have been found in a "greisen" similar to occurrences in Saxony and Bohemia. Thinks discovery of veins may have great future results. 


\section{MALAY PENINSULA (Continued)}

660. - Tin mining in Perak.

Mg. Sci. Press, Vol. 76, 1898, San Francisco, p. 61.

Extract from report of the Commissioner of Lands and Mines of Perak, giving mining conditions, output, prices, etc., for 1896.

661.

\section{The Malay tin industry.}

Iron Age, Vol. 62, II, Dec. 8, 1898, New York, pp. 17-18.

Shows that federated Malay States will continue to be by far the largest tin producing country in the world; describes deposits, mining, etc.

662. Tin of Straits Settlements.

Min. Ind. for 1898, Vol. 7, 1899, New York and London, p. 711. See No. 1287.

663.

\section{Tin in the Malay Peninsula.}

Min. Ind. for 1900, Vol. 9, 1901, New York and London, pp. 639-640.

While river dredging for tin has not been seriously attempted, applications for water rights to follow this method of mining are being made. Progress has been made in the development of lodes, especially in district of Kuantan, Pahang.

664. Tin supplies.

Engineering, Vol. 72, No. 1872, November 15,.1901, London, pp. 684-685, 1300 words.

" Editorial on the tin supply in the Malay States, based on information given in the last annual government report and claiming that there is no cause for anxiety concerning the future supply."

Not available to the authors.

665.

\section{Tin mining in Malaya.}

Austr. Mg. Stand., Vol. 20, Dec. 26, 1901, Sydney and Melbourne. Serial. 1st part.

"Discusses the tin deposits in the Malay Peninsula, and the future outlook as a tin-producing region."

Vol. 21, 1902, p. 47, 2d part. Outlines advantages to be gained by the use of water power as a mining agent in Malaya. Describes the deep lead and lode mining.

First article not available to the authors.

666. - Tin in Malay Peninsula.

Min. Ind. for 1901, Vol. 10, 1902, New York and London, pp. 641-642.

667. - Mining in the Malay Peninsula.

Mg. Journ. Railw. Comm. Gaz.. Vol. 72, 1902, London, p. 754.

A statement of the production and a brief description of the tin deposits of four of the Federated Malay States: Perak, Selangor, Negri Sembilan and Pahang.

668. - Malayan tin mining.

Austr. Mg. Stand., Vol. 30, 1903, Sydney and Melbourne, p. 665.

Reprint from " Straits Echo."

A Chinaman has applied ground-sluicing to placer tin mining and it is described as a novelty.

669. - Malay mining; the tin duty.

Mg. Journ. Railw. Comm. Gaz., Vol. 76, 1904, London, p. 233, 420 words.

Digest: Mg. Mag. Vol. 10, 1904, New York, p. 336.

Extract from the "Malay Mail," incorporating protest of miners' association against high advalorem duty on exportation of tin. Statistics of production and costs are included.

670. - The Tambum tin mine, Perak.

Mg. Journ. Railw. Comm. Gaz., Vol. 76, 1904, London, p. 626.

Mine situated 5 miles from Ipoh; owned by Mr. Leong Fee; turns out 140 piculs of ore per day. Net profits for Sept. 1904, $\$ 60,000$. 


\section{MALAY PENINSULA (Continued)}

671. - Production de l'étain dans les États fédérés malais. Métallurgie, Vol. 35, 1904, Paris, p. 1493.

672. The Straits tin mines.

Eng. Mg. Journ., Vol. 80, 1905, New York, pp. 831-832.

Brief summary of Senior Warden of Mines' report. Output in 1904, 856,238 piculs. Perak continues the premier producer of tin in Federated Malay States. Brief accounts of progress in various mining districts.

673. Monazite tin ore in Federated Malay States.

Selangor Government Gazette, Sept. 14, 1906.

Review: Eng. Mg. Journ., Vol. 82, 1906, New York, p. 918.

Contains a report on a specimen of washed alluvial tin ore from the land worked by the Sempam Tin Mining Co., Pahang. The ore consisted principally of a mixture of cassiterite, ilmenite and monazite. An analysis of the ore is given.

Original article not available to the authors.

674. - See No. 673.

Quoted in Mg. Journ. Railw. Comm. Gaz., Vol. 80, 1906, London, p. 475.

675.

Tin production in the far East.

Eng. Mg. Journ., Vol. 82, 1906, New York, p. 963.

Treats mostly of the labor troubles in connection with mining in the Malay States and Dutch East Indies. Average output of tin in Malay States for 1905 was 4.09 piculs (534 pounds) per coolie.

676.

\section{Tin dredging on the foreshore in the Malay Peninsula.}

Mg. Journ. Railw. Comm. Gaz., Vol. 83, 1908, London, p. 237.

Description of the tin dredging operations in Tongkah Harbor, Siam.

$676 a$.

. Tongkah Harbor Tin Dredging Co.

Austr. Mg. Eng. Rev., Vol. 1, 1909, Melbourne, pp. 277-278. Illus.

Editorial on same. Austr. Mg. Eng. Rev., Vol, 1, 1909, Melbourne, pp. 347-348.

Very brief description of the tin bearing area of Tongkah Harbor, located on Puket Island, a Siamese possession on west side of Malay peninsula. Also describes work now being done by the dredging company.

$676 \mathrm{~b}$. - Tin ores from the Federated Malay States.

Bull. Imp. Inst., Vol. 6, 1908, London, pp. 155-157.

Describes placer tin samples containing corundum, rutile and a small amount of rare earths, besides tin. Lode stuff carried $\mathrm{Co}, \mathrm{Zn}$ and $\mathrm{As}$.

$676 \mathrm{c}$. Tin mining in Malaya.

Eng. Mg. Journ., Vol. 88, 1909, New York, p. 929.

$676 \mathrm{~d}$.

\section{Tin mining in the Federated Malay States.}

Austr. Mg. Stand., Vol. 43, 1910, Sydney and Melbourne, pp. 169-170, illus. 1.

Deals with mining and treatment methods.

677. BaLfour, JoHn F. Tin in the Malay Peninsula:

Journ. Soc. Arts, Vol. 55, 1907, London, pp. 505-507.

Treats of the general features of the peninsula, geology, and tin deposits. The tin is considered under: Lode mining, impregnations (contact deposits and stockworks) and alluvial deposits, as to the manner of occurrence and method of working.

678. Becher, H. M. Mining in the Malay Peninsula.

Trans. Inst. Mg. Met., Vol. 1, 1892-1893, London, pp. 78-107, discussion, pp. 131-141.

Treated under heads: The tin formation; the Malay gold-bearing formation; the Chinese system of mining; the character of the alluvial; modern methods vs. Chinese; pumping methods; the machinery employed; general conclusions; prospects of the Malayan tin fields. 


\section{MALAY PENINSULA (Continued)}

BECK, RichaRd. See No. 1299.

\section{Benedict, Wy. De L. Tin in the Malayan region.}

Min. Ind. for 1892, Vol. 1, 1893, New York and London, pp. 446-450.

Perak produces two-thirds of tin production of the Straits, and one-third of that of the world. Description of Perak deposits, methods of mining. Tin deposits of Island of Sumatra treated. Assays given.

Brown, A. Selwyn. See Nos. 1307 and 1308.

680. Clifford, Hugh. Tin in Malaya.

Austr. Mg. Stand., Vol. 29, 1903, Sydney and Melbourne, p. 259.

Extract of a lecture delivered before the Royal Colonial Institute, Dec. 9, 1902. Deals with tin resources of the Malay States.

681. Collett, Octave J. A. L'Étain. Étude minère et politique sur les Etats fédérés malais.

1903, Brussels, p. 196, map 1, and plates.

On tin in the Malay Peninsula. Divided into six parts: (1) Geography. (2) History. (3) Geology. (4) Methods of mining tin. (5) Methods of mining and smelting tin. (6) Legislation regarding tin. Production, prices, etc. Geology. General structure of the country. Popular explanation of formation of placers from veins. Very little description of the veins or of the placers themselves. Cassiterite accompanied by grains of quartz, hematite, fluorite, pyrite, tourmaline and feldspar.

681a. Connubian. Lode mining in the Malay States.

Mg. Journ. Railw. Comm. Gaz., Vol. 84, 1908, London, p. 622.

Letter in which a correspondent states that the lode mines of Pahang are among the big tin mines of the world, and gives figures to support his statement.

682. Cramer, Carl. Das Zinnerz und seine Gewinnung auf der Halbinsel Malacca.

Oest. Zeitschr. Berg. Hütt., Vol. 42, 1894, Wien, pp. 543-545, pl. 20.

Digest translation: Trans. Fed. Inst. Mg. Eng., Vol. 10, 1895-1896, Newcastle-uponTyne and London, p. 589.

Thickness of ore-bearing deposit (karang) up to $3 \frac{1 / 4}{4}$ feet. Overburden up to 33 feet, average $6 \frac{1}{2}$ to 10 feet. Tin ore in karang varies up to 15 per cent, may be barren. Pays with as little as 0.5 per cent. French company tried to dredge in river Muar, but failed. Impurities: iron, wolframite, ilmenite. 77.15 pounds tin per head per month average production.

683. Croockewit, $\mathrm{H}$. Tin mines of Malacca.

Journ. Ind. Arch. East. Asia, Vol. 8, 1854, Singapore, pp. 112-133.

Translated from Tijdschr. Ned. Ind., Nov. 1851, Batavia.

Not available to the authors.

D'Achiardi, Antonio. See No. 1313.

Davies, D. C. See No. 1317.

684. De LA Croix, J. ERrivgton. Some account of the mining districts of Lower Pêrak.

Journ. Straits Branch Roy. Asiatic Soc., June 1881, Singapore, pp. 1-10, section 1.

The region of Lower Pêrak comprises numerous mining districts, which can be placed under following heads: 1. Sungei Kinta District. 2. Sungei Batang Padang District. 3. Sungei Bidor Distruct. The geology of these districts is given, the 


\section{MALAY PENINSULA (Continued)}

occurrence of tin ore, and the manner of mining by Chinese and Malays. Author believes the minirg in all of the districts is in its infancy, and with better roads, and the clearing of streams, rendering transportation easier, many of the deposits now neglected could be worked with profit. There is at least 7,680 acres of actual alluvial ground, which under ordinary circumstances, will afford work to 25,000 miners for the next hundred years.

685.

\section{Les mines d'étain de Perak.}

Arch. Miss. sci. litt., ser. 3, Vol. 9, 1882, Paris, pp. 1-78.

Digests: Nature, Vol. 28, 1S83, London, pp. 202-203; Sci. Amer. Suppl., Vol. 16, 1883, New York, pp. 6368-6369.

Memoir result of seven months exploration in the Malay State of Perak. Perak, although only 95 by 50 miles in dimensions, having an area of less than 5000 square miles, has long been known as a tin producing country, but only since the influx of Chinese has it been of first rate importance. Mines worked at present, chiefly alluvial, water-courses being flled with sand and gravel deposits to a depth of 20 or 30 feet, resting upon a floor of pure china clay, apparently derived from decomposition of the granitic rocks. Geological description necessarily imperfect, owing to the dense tropical vegetation which covers the entire country. Author has been able to establish the presence of numerous quartz veins traversing the granite which is coarsely porphyritic in the center and largely charged with tourmaline at the edges of the masses, reproducing the conditions to be found in the northwestern tin districts of Cornwall. Ore very pure, free from wolframite, arsenic, etc., which is troublesome to the Cornish miner. No vein mines have yet been opened. Methods of working, very primitive. Great improvement of mining conditions under British rule.

686. - Le royaume de Pérak.

Bull. Soc. Geogr., ser. 7, Vcl. 4, 1883, Paris, pp. 333-354.

Describes the country in general, economic conditions, mines and miners.

687. Derrick, W..H. Notes on lode tin mining in the Malay Peninsula.

Trans. Inst. Mg. Met., Vol. 7, 1898-1899, London, pp. 12-16. Discussion, pp. 16-19. Abstract: Eng. Mg. Journ., Vol. 68, 1899, New York, pp. 784-785.

Description and cost of working the mines of Kuantan, Pahang, the principal lode mine of the Federated Malay States. These mines, so report says, were worked 100 years. The open cast system was the only one adopted by the old miners. Under native management (at least within recent years) the mines were not a financial success. Good outlook for increased output under European management.

688. Doyle, Patrick. Tin mining in Larut.

Mg. Journ. Railw. Comm. Gaz., Vol. 48, 1878, London, pp. 1191, 1219, 1247.

Reprinted in book form, 1879, London and New York.

A series of three articles giving a brief historical summary of Larut, a subsidiary district of Perak; description of the geological features of the country, and mincralogical productions. Describes miners (Chinese), modes of living, prosperity, manner of mining and its difficulties.

689. . On some tin deposits of the Mayalan Peninsula.

Quart. Journ. Geol. Soc. London, Vol. 35, 1879, London, pp. 229-232.

- "All the ore worked up to the present time has been found in the alluvium derived from the mountain ranges; that is, in mining language, in stream works. The ore has been traced up to veins in the rock, but these have not hitherto been worked. The tin beds are composed of the débris of granitic rocks mixed with the orę."

690. DiJK, P. vaN. Tinontginning in het district Larut Perak, Gouvernement Straits Settlements.

Jaarb. Mijnw. Ned. Oost-Indië, 1883, II, Gemengde, Tech., Amsterdam, pp. 115-116. 


\section{MALAY PENINSULA (Continued)}

691. Drkes, F. J. B. Tin mining in Malaya.

Austr. Mg. Stand., Vol. 32, 1904, Sydney and Melbourne, p. 137.

Extract from Senior Warden of Mines' report for 1903. Statistics of population employed in tin mining, output per annum, earnings of laborer, etc. Tronoh and Tambum are mentioned as the two richest mines in Malaya. Brief history of Tambum.

692.

- Report of the administration of the mines department, and on the mining industry for the year 1903.

Perak Gov. Gaz, Suppl., Vol. 17, No. 22, 1904, Kuala Lumpur, pp. 1-11.

Treats of tin mining and the output.

693.

Federated Malay States. Report on the administration of the mines department and on the mining industry for the year 1904. [Tin and gold.]

Perak Gov. Gaz. Suppl., July 14, 1905, Kuala Lumpur, pp. 1-9.

Ellis, Thos. F., and McKillop, John. See No. 1530.

694. Fawns, Sydney. Tin lode mining in Tringganu.

Mg. Journ. Railw. Comm. Gaz., Vol. 76, 1904, London, p. 377.

Abstract: Lakes, Arthur, Min. Rep., Vol. 50, 1904, Denver, p. 500.

"Describes the mode of occurrence and work done up to present time in this part of the Malay Peninsula."

- See No. 1320.

694a. FLower-ELuIs, T. A brief account of the Malay tin industry.

Proc. Chem. Met. Soc. South Africa, Vol. 2, February, 1897-September, 1899, Johannesburg, pp. 5-18.

Treats of the geology of the Malay Peninsula, properties of cassiterite, methods of mining, richness of deposits, purification of the ores, Chinese method of smelting tin ores, European method of smelting tin ores, refining the rough metai, tests for quality of tin, Swaziland tin fields.

695. Hampton, J. H. The tin deposits of the Straits.

Iron Age, Vol. 38, 1886, New York, p. 1.

Description of the country, the tin deposits, the Chinese methods of mining and smelting, and output from 1876-1884.

696. - Tin deposits of the State of Perak, Straits Settlement.

Trans. Min. Ass. Inst. Cornwall, Vol. 1, 1887, Camborne, pp. 143-152. Map.

A short descriptive article.

697. - On the occurrence of tin.

Trans. Geol. Soc. South Africa, Vol. 4, 1899, Johannesburg, pp. 37-40.

Malay Peninsula tin deposits were first visited by author in 1882 . The contour of country and existence of forests made geological observations difficult. Stanniferous gravels extend over a very large area. Tin was raised by Chinese as long ago as 1798. Lode tin is attracting attention in State of Pahang.

Hughes, T. W. H. See No. 1507.

698. Hume, W. J. P., and Dykes, F. J. B. Report of proceedings of the minIng conference held at Ipoh, Perak, Federated Malay States, Sept. 23 to Oct. 6, 1901. 1902, Taiping, pp. 1-64, pl. 5, fol.

Lakes, Arthur. See No. 694. 


\section{MALAY PENINSULA (Continued)}

699. Lock, C. G. Warnford. Tin mining and milling in Tringganu.

Mg. Mag., Vol. 13, No. 4, 1906, New York, pp. 290-294, pls. 7. 1400 words. Short general description of tin mining conditions in northeastern Malay States.

No productive mines in granite, but some in overlying slates. Tin veins often have no quartz in them, being solid cassiterite. No fluorite or tourmaline. Much monazite and xenotime with some zircon and ilmenite in the stream gravels.

700. - Tin in Tringganu.

Mg. Journ. Railw. Comm. Gaz., Vol. 79, 1906, London, p. 182.

Gives outline of geography and geology of Tringganu, and describes both the lode and alluvial deposits of the State. The veing are mostly in shales overlying granite. For original article see No. 699.

701. Mining in Malaya for gold and tin. 1908, London, Not available to the authors.

702. Louis, Henry. Tin in the Malayan region.

Min. Ind. for 1895, Vol. 4, 1896, New York and London, pp. 571-573.

Digest of article from Mining Journal Railway and Commercial Gazette. See No. 1340.

703. - Die Zinnseifen der Halbinșel Malakka.

Zeitschr. prakt. Geol., 1896, Berlin, pp. 233-234.

Taken from "Western Daily Mercury," March, 1895.

- - See No. 1340 .

704. Low, JAMEs. Observations on the geological appearances and general features of portions of the Malayan Peninsula and of the countries lying betwixt it and $18^{\circ} \mathrm{N}$. lat., pp. 128-162.

Book not available to authors, but a brief digest is found in Glean. Sci., Vol. 1, 1829, Calcutta, pp. 223-224.

Tin-bearing ground extends in a continuous line from the southern extremity of Peninsula to about $15^{\circ} \mathrm{N}$. lat. No mines discovered beyond this. Mines are pits of from twelve to twenty feet deep. Ore generally in round or oblong masses, with well-defined crystals, in matrix of quartz, or bedded in masses resembling half decomposed granite. Brief description of metallurgical processes used.

704a. Marks, E. SEABorn. Mining in the Malay States.

Mg. Sci. Press, Vol. 98, 1909, San Francisco, pp. 31-36, illus.

"A description of the climatic conditions of the country and the method of mining and concentrating tin ore."

McKillop, JoHn, and Ellis, Thos. F. See No. 1530.

705. Meunier, Stanislas. Examen chimique d'eaux minérales provenant de Malaisie minerai d'étain de formation actuelle.

C. R. Acad. Sci., Vol. 110, 1890, Paris, pp. 1083-1085.

Author " found 0.5 per cent of $\mathrm{SnO}_{2}$ in an opaline depcsit, resembling geyserite, from a thermal spring in Selangor." See No. $726 \mathrm{~b}$.

705a. Miles, Edward T. Notes on Tongkah tin dredging.

Austr. Mg. Stand., Vol. 42, 1909, Sydney and Melbourne, p. 60.

Describes the deposits of tin and difficulties experienced in dredging in Tongkah Harbor, situated on northeast side of Tongkah Island (Junk Ceylon). 


\section{MALAY PENINSULA (Continued)}

706. Morgan, J. DE. Note sur la geologie et sur minière du royaume de Perak et des pays voisins.

Ann. Mines, ser. 8, Vol. 9, 1886, Paris, pp. 368-442, pls. 8, 9, 10.

Discusses the geography, the geology and the tin mines of Perak. Also treats the main workings individually, the manner of exploitation, metallurgy, the Chinese companies, the mining laws and the statistics.

707. Moss, E. W. Observations on the distribution and economic value of tin ores in the Malay Peninsula.

Rep. Rugby School Nat. Hist. Soc. for 1890 (1891), Rugby, pp. 17-21, map.

Digest from Ann. Brit. Geol., 1891, London, p. 377.

"A general notice of the stream tin of Banca and the vein tin of Perak."

708. Newland, D. H. Tin in Malay States.

Min. Ind. for 1903, Vol. 12, 1904, New York and London, pp. 330-331.

Short article dealing with the Malayan tin trade during 1903.

709. Noyes, H. Herbert. Tin deep leads in Selangor.

Mg. Journ. Railw. Comm. Gaz., Vol. 79, 1906, London, p. 690.

Reprint: Eng. Mg. Journ., Vol. 82, 1906, New York, p. 1.

Gives a description of the alluvial tin deposits of the Serendah Valley, Selangor. The writer states that these once famous fields have been practically abandoned by the Chinese. They leave as soon as the shallow and easily worked deposits near exhaustion. Believes Europeans will have to take up the work in the deep deposits.

710. Osbeck, Peter. A voyage to China and the East Indies.

1771. London, Vol. 1, p. 244 (English edition); p. 204 (German edition).

Briefly mentions that " tin comes in small pieces from Pegu and Jahor."

711. Owen, Frank. Mining in Perak.

Trans. Inst. Mg. Met., Vol. 6, 1897-1898, London, pp. 51-87.

Abstract: Min. Ind. for 1897, Vol. 6, 1898, New York and London, pp. 611-644.

Extract: “Chinese tin smelting," Coll. Guard., Vol, 74, 1897, London, p. 931.

Area, population, statistics, manner of mining, etc. Describes the Chinese system of smelting tin in a blast furnace.

712.

A review of the tin industry of the Malay Peninsula (up to the end of 1889).

Min. Ind. for 1900, Vol. 9, 1901, New York and London, pp. 646-656, map 1.

Describes the occurrence of tin ore in the Malay Peninsula, the general geology of the country, and the prices obtained for tin. Also treats of the mining conditions and the future prospects of the industry.

713. Parkes, Chas. R. Surface tin mining in the Malay Archipelago.

Proc. Inst. Civ. Eng., Vol. 115, pt. I, 1894, London, pp. 352-354. Abridged.

Malay alluvial tin deposits are briefly described, and methods of mining are given in considerable detail.

714. Penrose, R. A., Jr. Tin deposits of the Malay Peninsula, with special reference to those of the Kinta districts:

Journ. Geol., Vol. 11, 1903, Chicago, pp. 135-154, figs. 9, pls. 4.

Digest: Zeitschr. prakt. Geol., Vol. 11, 1903, Berlin, pp. 278-279. Neues Jahrb. Min., 1905, I (Ref.), Stuttgart, p. 100.

Abstracts: Min. Ind. for 1902, Vol. 11, 1903, New York and London, pp. 590-593;

Eng. Mg. Journ., Vol. 75, 1903, New York, pp. 926-928, map, illus. 3. 


\section{MALAY PENINSULA (Continued)}

4he The geographical position of the Malay tin regions is given and the general geology of the Malay Peninsula. The Kinta district is then taken up, its location described, and the occurrence and nature of alluvial tin ores of the district are treated. The accompanying minerals are also noted. The occurrence of tin ore in the rocks, the origin of the deposits and the commercial features are discussed.

Phillips, J. A., and Louis, H. See No. 1350.

715. PrKE, E. R. Mining in Perak, Straits Settlements.

Trans. Mg. Ass. Inst. Cornwall, Vol. 3, 1892, Camborne, pp. 194-201, discussion pp. 201-206.

Gives a brief general description of Perak, the location of the tin-placers and the mining methods of the Chinese. Also describes the Kinta tin lodes and Malayan tinsmelting practice.

716. Place, John. Tin mining in the Malay States.

Engineering, Vol. 82, 1906, London, pp. 281-284, pl. 1.

A very general article giving a description of the country and trade conditions, with short descriptions of mines and smelting. Prophesies further development and increase of output.

717. Rathiorne, Ambrose B. Camping and tramping in Malaya, fifteen years' pioneering in the native States of the Malay Peninsula.

1898, London, pp. 117-166, 333-334.

Pages 117-166: General description of mines (wholly untechnical), labor, social, economic conditions, fuel supply, roads, etc. 333-334, geology: "Upheaval of the granite"; "more violent" between $3^{\circ}$ and $6^{\circ}$ than between $1^{\circ}$ and $3^{\circ}$. Limestone occurs in the northern half of the country. Near Thaiping, borings show country to have recently sunk over a hundred feet. Old cannon found at Larut 30 fect below surface in tin mine. Stone implements frequently found, but no mammalian bones in the gravels. A hoard of Portuguese coins of the 15th century was dug up at Kinta.

718. RitTer, CarL. Die Erdkunde.

Vol. 5 (Die indische Welt), 1835, Berlin, pp. 77-79, 246.

Treats of the in of the Malayan Peninsula.

719. Roliker, Charles M. The tins of Banca and Billiton.

Eng. Mg. Journ., Vol. 28, 1879, New York, p. 338. An abstract from an article by E. Reyer. See No. 117 .

\section{See No. 1357.}

720. Ross, D. Notice of some tin ore from the coast of Tenasserim.

Glean. Sci., Vol. 1, 1829, Calcutta, pp. 143-144.

Description of some stream tin from Chanda, half way between Mergui and Tavoy.

721. Rumbord, WM. R. The tin deposits of the Kinta Valley, Federated Malay States.

Amer. Inst. Mg. Eng., Vol. 37, 1906, New York, pp. 879-889, figș. 1-4.

Reprint: Mg. Journ., Vol. 80, 1906, p. 460.

General description of Kinta Valley; alluvial tin deposits; lode deposits; (a) those in granite, (b) those in limestone; origin of the deposits.

States that this district is probably, at the present time, the richest alluvial tin district in the world. 


\section{MALAY PENINSULA (Continued)}

722. Saunders, W. T. Tin mining in the Straits Settlement.

Trans. Inst. Mg. Eng., pt. 4, Vol. 27, 1904, London and Newcastle-upon-Tyne, pp. 343-350.

Digest: Mg. Mag., Vol. 11, No. 1, 1905, New York, p. 71.

Reprint: Mg. Journ. Railw. Comm. Gaz., Vol. 75, 1904, London, p. 661.

About 60 per cent of the world's supply of tin comes from Straits Settlement. In the past most of it has been obtained from alluvial deposits, and while the placers appear to be unfailing, much attention is now given to lode mining. Alluvial mining is carried on largely on the west side of the Peninsula, while lode mining is confined to east side.

723. Scrivenor, J. B. A preliminary report on the geology of the neighborhood of Taiping, Perak.

Perak Gov. Gaz., Suppl., Vol. 17, No. 3, January 15, 1904, Kuala Lumpur, pp. 1-14, 13,000 words.

Part I. Physical features, igneous rocks, sedimentary rocks, alluvial deposits, faults and mineral lodes, weathering.

Part II. Geological history, mining prospects.

724. — Federated Malay States. Geologist's Report for 1904 (Tin).

Perak Gov. Gaz. Suppl., July 14, 1905, Kuala Lumpur, pp. 7.

The material in this article appears in the same author's "Geologist's Report of Progress," September, 1903-January, 1907. See No. 726.

Not available to the authors.

725.

\section{Alluvial and lode tin in Malaya.}

Mg. Journ. Railw, Comm Gaz, Yol, 78, 1905, London, pp, 273, ano words.

" From the annual report of the Federated Malay States. Describes three mines of detrital tin associated with limestone, gives information of the tin lodes, and briefly discusses the origin of the deposits."

726. - Geologist's report of progress, Sept., 1903-Jan., 1907.

Federated Malay States Government Press, Kuala Lumpur, 1907, pp. 1-44, sketch map 1.

Reprint: Mg. Journ. Railw. Comm. Gaz., Vol. 81, 1907, London, pp. 781-782, 793, 843-844, 866-867.

A summary of work done embracing that published in the Perak Government Gazette except report on geology of Sarawak. First 18 pages deal with structural geology. Describes tin lodes of Kuantan (Sungei Lembing); Bundi, Kemaman; Machi tin field; mines in the Main Range, including the Telom district, Tras, Bentong, Gunong Gapis, Bukit Fraser and neighboring places; Chin Chin and Tanjong Serai, Malacca; stockworks at Bruseh and Tanjong Malim; tin ore in limestone at Changkat Pari, Ayer Dangsang; Siak and Jesophat's Valley; alluvial mines of Tronoh and Sungei Besi, Perak.

$726 \mathrm{a}$.

- Geologist's annual report for 1908.

Federated Malay States, Kuala Lumpur, 1909, pp. 2-7.

The Ayer Dangsang pipe changed at a depth of 170 feet to a vein 5 to 6 feet thick with the same mineral association-abundant sulphides in a calcite matrix, with fluorite and a little quartz. In the Lahat pipe the original calcite and sulphides were dissolved and after a partial concentration the pipe was recemented with calcite from the limestone walls.

Scheelite with abundant tourmaline, a little pyrite, traces of copper and arsenic, occur in a quartz vein at Salak North, Perak. Scheelite occurs in a number of Pahang tin mines.

Cassiterite occurs with tremolite in a pipe at Lahat. Describes a stockwork of minute veins which is a type of many deposits in the Kledang Range. 


\section{MALAY PENINSULA (Continued)}

Some of the alluvial tin ore contains metallic copper in fine sharp crystals.

Small seams of lignite standing vertically, occur in the tin gravels. Leaching of the underlying limestone has let the gravels down until they are, in places, on edge, and have been covered over by horizontal beds.

$726 \mathrm{~b}$. The origin of tin deposits.

1909, Kuala Lumpur, pp. 11.

Also, Mg. Journ. Railw. Comm. Gaz, Vol. 85, 1909; London, pp. 3n7, 340.

Reviews the commonly accepted theories concerning the deposition of tin minerals. He doubts the analysis of Meunier showing tin oxide in siliceous sinter from Ayer Panas (see No. 705), and states that his examination of deer-horns similar to those supposed by J. H. Collins to have been partly replaced by $\mathrm{SnO}_{2}$, showed no tin.

Numerous tin deposits of the Malay Peninsula are in limestone or clay-slate, but granite is supposed to be close at hand in each place. At Bundi, in Kemaman, a tin deposit in which the $\mathrm{SnO}_{2}$ is in small yellow needles, carries no tourmaline, but there is some axinite.

Most of the deposits are veins, large or small, but there are a few tin-bearing pegmatites in the Malay Peninsula.

Shows that in many places in the Malay Peninsula, especially in the limestone region, there is very little tourmaline, but generally mucb fluorspar with the tin deposits. He believes fuorine to be more important than boron in the genesis of tin minerals. There is also much arsenopyrite in the limestone, more than when the deposits are in granite.

727. Slack, W. E. Malay tin mines. Handbook giving particulars of mining companies working in the Malay Federated States.

1907 (?), London.

Not available to the authors.

728. Stephens, F. J.' Mineral features of Pahang, Malay Peninsula.

Trans. Inst. Mg. Met., Vol. 9, 1900-1901, London, pp. 419-424.

Describes the physical conditions under which mining must be carried on, trans. portation facilities and economic details; the geology of the country; the vein systems; the workings of individual companies; tin and gold ores, and their richness.

729. Stokes, Ralph, S. G. A series of articles on Malay tin fields.

Mg. World, Vol. 25, 1906, Chicago. Illustrated.

1. Industrial position of Malay tin fields. Sept. 1, 1906, pp. 234-235.

2. Geology of Malay tin fields. Sept. 8, 1906, pp. 262-263.

3. Malay tin fields. Oct. 6,1906, pp. $424-425$.

4. Geology and treatment of tin in the Malay fields. Nov. 10, 1906, pp. 572-573.

730 .

Mines and minerals of the British Empire. Being a description of the historical, physical and industrial features of the principal centers of mineral production in the British Dominions beyond the seas.

1908, London, pp. 65-75 and others, with a number of plates.

The Malay States tin fields are treated in chapters 6 and 7. A review of the world's sources of tin supply is given, after which he discusses the labor available, the production of tin in the different states; taxation and other heavy charges of the government; the geology, and the different classes of deposits, both in place and alluvial. Chapter 7 is devoted to methods of mining and a description of the alluvial mines.

A chapter is devoted to the Mt. Bischoff tin mine, Tasmania, and another to the northeastern tin fields of that Province. The tin deposits of New South Wales, Transvaal, Cape Colony and Northern Nigeria receive passing mention. 


\section{MALAY PENINSULA (Continued)}

731. Swettenham, Frank. About Perak.

Published by "Straits Times." 1893, Singapore.

Book not available to the authors.

732. Swettenham, F(rank) A. Annual report of the State of Perak for the year 1893.

Taiping, Perak, pp. 53. Progress of tin mining in Perak, and information concerning output.

733. TAYLOR, Wirliam. Tin mining in the Federated Malay States.

Eng. Mg. Journ. Vol. 82, 1906, New York, p. 529.

Short extract from Ann. Rep. for 1905.

Figures given, showing output from various mines. "The acting Senior Warden sees no cause for alarm in the decreased output, and is of the opinion that no evidence is forthcoming to show that the stanniferous deposits of the country are nearing exhaustion."

734. Tenison-Woods, J. E. Geology of the Malayan Peninsula.

Nature, Vol. 30, 1884, London, p. 76.

Notes caves in limestone with deposits of "tin sand," which are 1000 feet above the plain; now exposed in precipices and reached by steps cut in the rock. Show extent of erosion.

735. - Physical geography of the Malayan Peninsula.

Nature, Vol. 31, 1884, London, pp. 152-154.

"The tin deposits hitherto found are all stream tin, no lodes have yet been worked .... Though tin has been worked for centuries, only a comparatively small portion of the country has been worked out or worked at all. I consider that the deposits in Perak are practically inexhaustible."

736. - Explorations in Pahang.

Nature, Vol. 33, 1885, London, p. 32.

Refers to a peculiar coinage of tin "shaped for the most part like an old fashioned square ink-stand."

Short reference to tin-bearing gravels.

737. — Report on the geology and physical geography of the State of Perak.

Proc. Linn. Soc. New South Wales, Vol. 9, 1885, Sydney, pp. 1176, 1186, 1189, 1190, 1192, 1203. Tin mines at Thaiping, Assam Kumbang, Kamunting, Salak, Pappan, Poussin, Lahat, Goping, Tecca, Kiampar River, Kuala Diepang, Dindings and Selama are described.

738. Treacher, W. H. Mining tin.

Perak Gov. Gaz. Suppl., Vol. 17, No. 22, 1904, Kuala Lumpur, pp. 1-9. Report for 1903. 3 charts showing output of tin and iron ore pp. 40-43.

Reprinted: Board of Trade Journal, Vol. 66, 1904, p. 17.

Description of labor conditions and supply, manner of working, wages, contracts, etc., and mode of operating mines.

739. Tremenheere, H. Seymour. Tin in Tenasserim.

Mg. Journ. Railw. Comm. Gaz., Vol. 40, 1870, London, p. 919.

Extract of address delivered before Royal Geological Society of Cornwall. The matter is largely the same as that in the report of his brother, Geo. Borlase Tremenheere, on the "Tin of the Province of Mergui in Tenasserim, in the northern part of the Malay Peninsula."

Besides the stream tin found along the banks of the creeks, there is a rich vein of tin 3 feet wide in the side of an isolated hill, about eleven miles from Mergui. The hill consists almost entirely of decomposed granite. Crystals of cassiterite occur thickly imbedded in pure kaolin. 


\section{MALAY PENINSULA (Continued)}

740. Vercoe, Chas. Tin deposits in the Malay Peninsula.

Mg. Journ. Railw. Comm. Gaz., Vol. 50, 1880, London, p. 904.

Brief description of the mines near Malacca, at Qualla Lumpor and Laroot, and of methods used by Chinese in working them.

741. Vercoe, H. B. Tin deposits of the Straits.

Mg. Journ. Railw. Comm. Gaz., Vol. 56, 1886, London, p. 1277.

Treats briefly of alluvial deposits of Muntaha District of Johore, expresses a belief that tin lodes exist in the surrounding hills, which would prove very productive.

742. Viator. A trip to the Johore River (tin mines).

Not. Indian Archipelago Adj. Countr., 1837, Singapore, pp. 265-266, map.

Popular article. Visited tin mines at village of Gongong, which were formerly worked by followers of the Sultan. Smelting furnace now in ruins. Ore about 12 feet under surface, in a stratum of coarse "quarry sand," mixed with white clay. Did not seem to be very productive mines. Country very unhealthful.

743. W-. Der Zinnhandel der malayische Halbinsel.

Oest. Zeitschr. Berg. Hütt., Vol. 51, Wien, 1903, p. 645.

744. Wray, LEONARD, JR. Tin in the Straits of Malacca and Tenasserim.

Mg. Journ. Railw. Comm. Gaz., Vol. 44, 1874, London, p. 378.

Extract from his lecture "The Settlement on the Straits of Malacca," delivered before Royal Colonial Institute, March 24, 1874. Discussion as to whether the early Phœnicians first got their tin in India or Cornwall.

745. Physical geography of the Malayan Peninsula.

Nature, Vol. 31, 1885, London, p.' 459.

A communication correcting what he considers to be errors in an article by J. E. Tenison-Woods in "Nature," Vol. 31, pp. 152-154, 1884.

- Bears upon the geology of the tin deposits.

746. - Alluvial tin prospecting: including tables for checking the accuracy of bore holes, and for estimating the amount, richness and value of the ore obtained from them.

Perak Mus. Notes, No. 2, 1893, Taiping, pp. 1-114.

747. - Some account of the tin mines and the mining industry of Perak.

Perak Mus. Notes, No. 3, 1894, Taiping, pp. 1-24, table 1, pls. 4, 5, giving diagrams. The first three chapters of a continued article upon tin in Perak, the other numbers of which are not available to the authors. In this installment the history and statistics of the Malayan tin trade, the geology of the deposits, a description of old mines, and native uses of tin are given.

\section{MASSACHUSETTS}

748. HitchCock, ED. Tin in Massachusetts.

Amer. Journ. Sci. Arts, ser. 1, Vol, 16, 1829, New Haven, pp. 188-191.

Brief review: Jahrb. Min. Geogn. Geol. Petr., 1830, Heidelberg, pp. 316-317.

Letter written to editor of Amer. Journ. Sci. Arts. Writer sent specimen from Goshen, Mass., of what he thought to be first tin found in the United States.

749. HiTchCock, EDWARD. Report on the geology of Massachusetts examined under the direction of the Governor of that state during the years 1830-1831.

Amer. Journ. Sci. Arts, ser. 1, Vol. 22, 1832, New Haven, pp. 62-63.

Tin at Goshen described. 


\section{MASSACHUSETTS (Continued)}

750. Teschemacher, J. E. Description of the oxide of tin found at the tourmaline locality, Chesterfield, Mass.

Report Association American Geologists and Naturalists, 1840-1842 (1843), Boston, pp. 296-297.

A. A. Hayes, to whom a portion was submitted for examination, says: "From these experiments it appears that the mineral is a nearly pure oxide of tin, its hardness and closeness of texture, as indicated by its high lustre, exceed those of any specimen I ever examined."

\section{MEXICO}

751. Aguilera, José G. Bosquejo geológico de Mexico.

Bol. Inst. Geol. Mexico, Nos. 4, 5, 6, 1897, Mexico, pp. 234-235.

A note in which he states that tin ore occurs in small veins in rhyolite, accompanied by hematite, topaz, and durangite. Rhyolites of Upper Tertiary age.

752. - Catálogos sistemático y geográfico de las especies mineralógicas de la República Mexicana.

Bol. Inst. Geol. Mexico, No. 11, 1898, Mexico, pp. 83-84.

Tin is found in the following states: Aguas Calientes, Guanajuato, Jalisco, Querétaro, Sonora, Durango, Hidalgo, Puebla, San Luis Potosi, Zacatecas.

753. - Geographical and geological distribution of the mineral deposits of Mexico (tin).

Trans. Amer. Inst., Mg. Eng., Vol. 32, 1902, New York, pp. 506-50'7.

"The tin deposits of Mexico are of two classes: Those of the Tertiary, and the alluvial placers of the Quarternary. .... In Mexico the characteristic association of minerals and rocks is, so we might say, that of the latest tin-veins of the Tertiary, in which are found crystallized hematite, topaz and in some cases wolframite and durangite. The associatcd rocks are Pliocene rhyolites and rhyolitic tufa."

754. Allen, D. K. Tin in Baja California, Mexico.

Mg. Journ. Railw. Comm. Gaz., Vol. 54, 1884, London, p. 1194.

Gives an account of a piece of cassiterite weighing 314 pounds broken from ledge, brought in by Indians, source unknown. Another vein said to give 18 to 38 per cent tin from picked samples. Pay streak 2 to 4 feet wide. Found in same range or belt 'with same formation as that of the Temescal (Cal.), tin mines.

755. Anonymous. Tin deposits of Mexico.

Mg. Journ. Railw. Comm. Gaz., Vol. 54, 1884, London, p. 1412.

Deposits occur at small town of Coneto, about 90 miles northwest of Durango. Ore is principally red and black cassiterite of extreme purity, found both in veins and placers. "Sulphuret of tin," similar to that of Cornwall has been found in one part of the mountains, while arseniate of tin, also very finely divided red ophite of tin, are found in many veins.

756

\section{Tin deposits of Durango, Mexico.}

Eng. Mg. Journ., Vol. 48, 1889, New York, p. 80.

Describes briefly the tin deposits near Coneto, Durango.

757. - Mines in the State of Guerrero, Mexico.

Mg. Journ. Railw. Comm. Gaz., Vol. 76, 1904, London, p. 556.

Extract from Bull. Official Ministerio de Fomento. In describing the mines in the district of Taxco, tin is mentioned as occurring at Acamistla and Coapango. 


\section{MEXICO (Continued)}

758. - Tin in Mexico.

Eng. Mg. Journ., Vol. 80, 1905, New York, pp. 519-520, 1500 words.

“The tin properties now under development are 5 in number: La Esperanza, Tinnit, La Santa (sic) Francisco, La Minita and Los Dos Amigos. The tin at La Bsperanza occurs in threads or stringers in the vein. When development work was started on property, the first stringer discovered was only 1-64 inch thick, but in uncovering the vein, stringers ranging from $1 / 4$ to $\$ / 4$ inch thick were encountered and about 800 pounds of tin ore running 75 per cent tin was taken out. An assay across the vein runs from 2 to 4 per cent tin, while the ore as sorted by natives runs from 55 to 65 per cent and by concentration it can be brought up to 75 or 85 per cent tin.

759. Mexico's first tin ingot.

Mo. Bull. Int. Bur. Amer. Repub., Vol. 21, Sept. 1905, Washington, D. C., p. 802. States that although stream tin has been produced in Mexico for many years, the first ingot of lode tin has only recently been smelted. Gives a few details of a tin deposit at Aguas Calientes.

760. Tin in Mexico.

Mg. World, Vol. 25, 1906, Chicago, p. 301.

"The tin-bearing area extends from south of Aguas Calientes to north of Durango on the eastern side of the Sierra Madre range. The localities are widely separated and according to reports, quite different in geology and ore occurrence."

761. Barcena, Mariano. Tratado de geologia elementos aplicables á la agricultura, á la ingenieria á la industria.

Bol. Secr. Fom. 1886, Mexico, p. 146.

Tin occurs in veins in Mesa de los Caballos in Zacatecas, and in alluvium in Lagos and other localities.

762. Barriga, Manuel Diaz. Mining in Mexico.

Mg. Journ. Railw. Comm. Gaz., Vol. 77, 1905, London, p. 631.

Tin bearing ground is found in many portions of the Republic, but the deposits of the Coneto region in Durango are the most important. Occur in calcareous trachite. Concentrated ores, mostly in form of oxides, yield from 35 to 75 per cent of metal.

Beck, Richard. See No. 1299.

763. Benedict, WM. De L. Tin in Mexico.

Min. Ind. for 1892, Vol. 1, 1893, New York, pp. 451-452.

"Tinstone has been found in Mexico at numerous widely separated localities. None of the deposits have been systematically or extensively exploited except those of Durango, where the ore is found to occur in small but frequently very rich pockets in ill-defined veins in trachite-porphyry, which is the common country rock."

764. Bergemann, C. Zinnstein von Xeres in Mexico.

Neues Jahrb. Min. 1857, Stuttgart, p. 395.

Gives an analysis of tin ore from Xeres, Mexico.

765. Bretherton, H. G. The tin deposits of Mexico.

Mg. World, Vol. 27, 1907, Chicago, pp. 685-686.

"Notes on the history and present standing of the tin deposits which are situated in and about the border region between the states of Jalisco and Aguas Calientes."

766. Bromly, A. H. Tin mining and smelting at Santa Barbara, Guanajuato, Mexico.

Trans. Amer. Inst. Mg. Eng., Vol. 36, 19c6, New York, pp. 227-233, figs. 2.

Mg. Journ. Railw. Comm. Gaz., Vol. 78, 1905, London, pp. 121, 139. 


\section{MEXICO (Continued)}

Describes deposits and method of producing ore. Ore formation is of an "unusual nature consisting of cracks in the rhyolite which have been filled with clay." These clay stringers carry a mixed mineralization, particularly in the form of iron and tin oxide. Deposits not considered of commercial value.

Data showing results from smelting various classes of ore given. Methods of treatment of the ore are described.

767. Chandere, C. F. On tin ore at Durango in Mexico.

Amer. Journ. Sci. Arts, 2d ser., Vol. 39, 1865, New Haven, p. 349.

The cassiterite is in form of wood-tin and is accompanied by topaz. Gives crucible assay.

768. Collins, J. H. Specimens of tinstones from Durango.

Journ. Roy. Inst. Cornwall, Vol. 13, pt. 1, 1895-1898, Truro, p. 129, about 150 words. Describes specimens of tin ore from Durango, Mexico.

769. Del Mar, Alex. History of the precious metals.

2d edition, revised. 1902, New York, p. 206.

States Cortes reported that " chisel-shaped" tin money was used in Mexico, and that specimens are in the "Paris collection."

770. Fawns, Sydney. Tin deposits of the world.

Published by the Mining Journal, 1905, London. Tin deposits of Mexico, pp. 154157,1300 words.

Compilation from Ingalls' "Tin deposits of Durango, Mex."; Louis' "Production of tin "; and Nevius' "The Sain Alto tin deposits."

771. Genth, F. A. On the occurrence of tin ores in Mexico.

Proc. Amer. Philos. Soc. Vol. 24, 1887, Philadelphia, pp. 23-35.

Description of specimens of tin ore from Sierra de Catalan, State of Durango, Mexico. Small crystals of hematite are replaced by cassiterite. Also mentions wood tin and other forms from various Mexican localities, which contain much iron and arsenic. Quotes from Wm. Semmons, concerning a deposit of $\mathrm{SnO}_{2}$ upon bismuthinite.

772. Grose, Joseph. Tin discovery in Mexico.

Mg. Journ. Railw. Comm. Gaz., Vol. 43, 1873, London, p. 863.

Alluvial tin ore washed down from the mountains is found scattered over an area of several square miles, 250 miles southwest of the city of Mexico.

773. HALse, Ed. The occurrence of tin ore at Sain Alto, Zacatecas, with reference to similar deposits in San Luis Potosi and Durango, Mexico.

Trans. Amer. Inst. Mg. Eng., Vol. 29, 1900, New York, pp. 502-511, figs. 1-6.

Abstract: Eng. Mg. Journ., Vol. 68, 1899, New York, p. 428.

Describes occurrences of tin ore in other localities than Durango, and compares them with the latter. Description of tin smelting at Las Cuevas.

774. Hanks, Henry G. On the occurrence of durangite in the tin-bearing region of Durango, Mexico.

Amer. Journ. Sci. Arts, ser. 3, Vol, 12, 1876, New Haven, pp. 274-275.

Description of the tin deposits of Durango. Durangite is found only in the "Barranca " tin mine, eighteen miles northwest fron Coneto, State of Durango.

775. Humboldt, Alexander de. Essai politique sur le royaume de la NouvelleEspagne.

1811, Paris, Vol. 3, pp. 203, 299, 306-307; Vol. 4, pp. 105-106, 194-195.

Extract: Arch. Bergb. Hutt., Vol. 17, 1828, Breslau and Berlin, pp. 358-359.

Extract by A. J. M. Brochant, Notice sur les Mines du Mexique. Journ. Mines, Vol. 30, 1811, Paris, p. 104.

Briefly treats of tin occurrences in Mexico. 


\section{MEXICO (Continued)}

776. Ingalls, Walter Renton. Tin deposits of Durango, Mexico.

Eng. Mg. Journ., Vol. 59, 1895, New York, p. 293.

This paper is based on a study of mines of Mexico in 1892. Deposits at Potrillos and Cacária are dscribed. A table of 10 analyses made by Dr. Genth on Mexican tin ore-half from Potrillos, remainder from Cacaria-is given.

777. - The tin deposits of Durango, Mexico.

Trans. Amer. Inst. Mg. Eng., Vol. 25, 1896, New York, pp. 146-163, nap 1, figs. 2. Treats of early tin mining in Mexico, and especially of the physical characteristics, geology, and occurrence of tin at Potrillos, Cacaria and Cerro de Iglesia de los Remedios, tin regions of Durango.

Discussion by C. W. Kempton, pp. 997-998. (See No. 779.) Additional notes, Vol. 27, 1897 , pp. $428-429$.

778. - Notes on the tin deposits of Mexico.

Trans. Amer. Inst. Mg. Eng., Vol. 27, 1897, New York, pp. 428-429.

Some additional notes on tin localities in Mexico, mentioned in paper " Tin deposits of Durango" in Trans. Amer. Inst. Mg. Eng., Vol. 25, New York, p. 146.

KeMP, JAS. F. See No. 1213.

779. Kempton, C. W. The tin deposits of Durango, Mexico.

Trans. Amer. Inst. Mg. Eng., Vol. 25, 1896, New York, pp. 997-998.

In discussion of paper on same subject by W. R. Ingalls (No. 777), mentions an occurrence of tin placers at Sain Alto, Zacatecas, Mexico.

Lock, C. G. Warnford. See No. 1338.

Louis, Henry. See No. 1340.

780. Manzano, Jesus P. The mineral zone of Santa Maria del Rio, San Luis Potosi, Mexico.

Trans. Amer. Inst. Mg. Eng., Vol. 32, 1901, New York, pp. $481-482$.

Description of tin ores and occurrences, and output of several mines. Deposits generally small. Country poorly forested.

781. Nevius, J. Neuson. The Sain Alto tin deposits (Mexico).

Eng. Mg. Journ., Vol. 75, 1003, New York, p. 929, fig. showing tin smelter.

Digest: Geol. Centr., Vol. 5, 1904, Leipzig, p. 437.

The cassiterite occurs in rhyolite, associated with chalcedony. As the rock weathers the cassiterite nodules are washed out and concentrated in the ravines where they are collected. The method of smelting the ores is also described.-H. Ries.

782. Newland, D. H. Tin in Mexico.

Min. Ind. for 1903, Vol. 12, 1904, New York and London, pp. 331-332.

Sain Alto deposits described. Output amounts to a few tons a year. Grade of ore as smelted is about 40 per cent metallic tin.

Pinsson, L. V. See No. 1635.

Pratt, Joseph Hyde, and Sterrett, Douglass B. See No. 252.

783. Richtrofen, F. Ueber das Aiter der goldführenden Gänge und der von ihnen durchsetzten Gesteine.

Zeitschr. deutsch. geol. Ges., Vol. 21, 1869, Berlin, p. 737.

A foot note describes the tin ore at Durango.

Rolker, Chas. M. See No. 1357.

784. Wilson, Geo. Tin and petroleum in Mexico.

Eng. Mg. Journ., Vol. 34, 1882, New York, p. 280. 


\section{MEXICO (Continued)}

Tin in veins and alluvial. One tract of over 200 square miles, hastily prospected, shows stream tin in every water course, yielding by washing, from 5 to 20 per cent tin ore. Can be worked by hydraulicking at small cost. Vein tin yields from 60 to 70 per cent metallic tin; very free from injurious impurities. Country granite.

\section{MICHIGAN}

785. Stevens, Holrace J. Tin in Michigan.

Mg. Journ. Railw. Comm. Gaz., Vol. 76, 1904, London, p. 233.

Sketch of desultory attempts at tin mining in United States, with brief mention of recent discoveries of deposits in Keeweenaw County, Michigan.

(These " discoveries" proved false.)

\section{MISSOURI}

786. Dunstan, R. W. Discovery of tin in Missouri.

Mg. Journ., Railw. Comm. Gaz., Vol. 37, 1867, London, pp. 699, 731.

A letter giving very encouraging outlook for the tin in Missouri, 100 miles south of St. Louis, in a mountainous district of granite, trap and porphyritic rock. States that lodes run nearly north and south. Tin also occurs in alluvial floors, decomposed granite and black sand.

787. Genth, F. A. Tin ore in the United States.

U. S. Railroad and Mg. Journ., May 4, 1870, Philadelphia.

Reprint: Eng. Mg. Journ., Vol. 9, 1870, New York, p. 322.

Mg. Journ. Railw. Comm. Gaz., Vol. 40, 1870, London, pp. 486-487.

Extract: Ann. Mines, ser. 6, Vol. 17, 1870, Paris, pp. 572-575.

Treats briefly of the tin deposits in the United States. Tells of the pretended discovery of tin in Missouri and the resulting excitement; gives analysis of supposed tin ore sent from Madison County, Mo., and states that traces of tin were found in one specimen; also gives analyses of two concentrates from San Jacinto, Cal.

WHEELER, H. A. S'ee No. 1423.

HANKs, H. G. See No. 218.

\section{MONTANA}

787a. RAymond, Rossiter W. Statistics of mines and mining in the states and territories west of the Rocky Mountains.

Fourth annual report of Rossiter W. Raymond, United States Commissioner of Mining Statistics [for the year 1871], Washington, D. C., 1873, pp. 288-289.

"A Mr. Hall has several bars of tin, weighing a couple of pounds each, reduced by himself from ore picked from the gravel at the adjacent bar [Big Prickly Pear Creek]. The ore is very pure, and similar to the float tin found in Durango, Mexico. Some prospecting has been done for the ledge that this ore is evidently derived from, but so far without success." Entire reference.

\section{NEVADA}

788. HoFFMAN, W. J. On the mineralogy of Nevada.

Bull. U. S. Geol. Geogr. Surv. Terr., Vol. 4, 1878, Washington, D. C., p. 734.

The only locality in Nevada where stream tin occurs is at the Tuscarora placer mines where small crystals are occasionally found.

\section{NEWFOUNDLAND}

789. MrLne, J. Notes on the physical features and mineralogy of New Foundland.

Quart. Journ. Geol. Soc. London, Vol. 30, 1874, London, p. 745.

States that tin is found in New Foundland, but whether in paying quantities is not yet determined. 


\section{NEW GUINEA}

790. Anovymous. Tin on Ferguson Island.

Eng. Mg. Journ., Vol. 75, 19c3, New York, p. 623.

Rich tin lodes and gravel have been recently discovered on Ferguson Island on the northeast coast of New Guinea. No details given.

\section{NEW HAMPSHIRE}

791. Jackson, Charles T. Description of the tin veins of Jackson, N. H.

Report Association American Geologists and Naturalists, 1840-1842 (1843), Boston, pp. 316-321, figs. 2 .

Describes the occurrence of small tin-bearing veins near Jackson and the minerals associated with the tin and discusses the origin of the veins.

792.

Final report on the geology and mineralogy of the State of New Hampshire, with contributions toward the improvement of agriculture and metallurgy.

1844, Concord, N. H., pp. 139-145, figs. 2.

Review: Amer. Journ. Sci. Arts, ser. 1, Vol. 49, 1845, New Haven, p. 34.

Tin ore at Jackson, N. H. Description of tin veins, crystallization, association. Short translation from Daubree on description and theory of tin veins. With the tin occurs arsenic pyrites, black sulphuret of copper (rare), carbonate of copper, native copper, tungstate of manganese and iron (rare), black tourmaline and quartz.

\section{NEW JERSEY}

793. Leslex, J. P. The iron manufacturers' guide to the furnaces, forges and rolling mills of the United States, with discussions of iron as a chemical element, an American ore, and a manufactured article, in commerce and in history.

1859, New York and London, p. 428.

Trace of tin (.18 per cent $\mathrm{SnO}_{2}$ ) found in "garnet rock," about $1 \frac{11 / 2}{2}$ miles northeast of Andover, New Jersey.

794. SchNabel, CarL. Handbook of Metallurgy.

Translated by Louis, Henry, 1898, London, Vol. 2, p. 3.

"Tin has only been found by Eliot and Storer in American zinc from New Jersey, and English zinc made by Vivian \& Co., of Swansea."

\section{NEW SOUTH WALES}

795. AdAMs, RoBert. Mining in New South Wales.

Mg. Journ. Railw. Comm. Gaz., Vol. 43, 1873, London, p. 1009.

Working only alluvial deposits. Not more than one-tenth of mines are paying, owing to poor management.

796. A-, R. D. Tin mining in Australia.

Mg. Journ. Railw. Comm. Gaz., Vol. 49, 1879, London, pp. 909-910.

Description of the tin mining at Vegetable Creek, New South Wales.

797. ANDREws, E. C. The geology of the New England Plateau, with special reference to the granites of northern New England.

Rec. Geol. Surv. New South Wales, pt. 1; Vol. 7, pt. 4, 1904, pp. 281-300, pls. 55-56. Parts 2 and 3, Vol. 8; pt. 2, 1905, pp. 108-152, pl. 20. Parts 4 and 5, Vol. 8, pt. 3, 1907 , pp. $196-250$, pl. 39. 


\section{NEW SOUTH WALES (Continued)}

Part 1 describes the physiography; part 2, the general geology; part 3 treats of the genesis of the ore deposits; part 4, of the petrology, and part 5 contains additional notes on the ore deposits.

Permo-carboniferous slates were intruded by granite accompanied by pegmatite, eurite, micrographic dikes and quartz veins and masses. Many of the younger accompanying rocks carry tin, tungsten, and bismuth minerals, molybdenite, monazite, gold and allied minerals. Most of the New England ore deposits are considered to have been formed by magmatic segregations, in which are included those formed from heated gases or waters. The ores are arranged peripherally around acid granite massifs. The Gulf tin deposits occur as pipes formed at the intersection of fissures some of which are of very irregular form. The deposits contain arsenical pyrites, tourmaline, fluorspar, beryl, monazite, bismuth, and wolframite. At Kingsgate, pipes 18 inches to $\mathbf{4 0}$ feet in diameter carry molybdenite in masses up to one ton in weight, bismuth, bismuthinite, and bismuth carbonate, and at Tabletop, Timbarra, pipes carry gold in sufficient quantity to pay for working, but at neither place are they tin bearing. The pipes are all formed through replacement of the granite by solutions following very small cracks. At Tingha tin occurs in " 2 eurite vein," pegmatite and pipes, with chalcedony, and quartz; in the Emerald mines at Emmaville, in quartz veins with white mica, emeralds, and fluorspar cutting carboniferous (?) slates; at Giant's Den, in quartz veins with tourmaline, topaz, and chalcopyrite, cutting greisen; at Pheasant Creek with wolframite, in greisen and " mica rock"; in the Inverell District with abundant topaz, in greisen; at Deepwater with wolframite and iron pyrites in greisen; at Wilson's Downfall with huge quartz crystals and platy wolframite in greisen and granite; at Bald Nob in flssure veins; at Silent Grove in a granular quartz vein with bismuth and galena. At Howell stannite occurs in the Conrad and King Conrad reefs with argentiferous galena and sphalerite.

798. ANonymous. The discovery of tin in New South Wales.

Mg. Journ. Railw. Comm. Gaz., Vol. 42, '1872, London, pp. 45, 398.

799.

\section{More Australian tin.}

Iron, Vol. 5, n. s. 1875, London, p. 551.

A very brief description of some stream tin from foot of Mount Pilot, New South Wales. The region is described geologically.

800. - Tin in New South Wales.

Min. Ind. for 1900, Vol. 9, 1901, New York and London, pp. 636-637.

Brief epitome of the tin mining conditions in New South Wales.

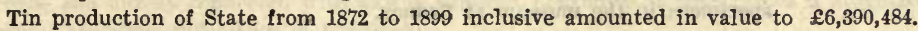

The lodes have scarcely been touched. Principal lode mine is the Oetery in the Emmaville district.

801. - Tin in New South Wales.

Min. Ind. for 1901, Vol. 10, 1902, New York and London, p. 639.

Very brief general remarks about tin deposits in New South Wales.

802.

Tin and tin mining in New South Wales.

Journ. Soc. Arts, Vol. 50, 1902, London, pp. 285-286.

- Brief history of tin discovery in New South Wales; localities and manner of occurrence; production.

803. - Tin in New South Wales.

Journ. Franklin Inst., Vol. 161, 1906, Philadelphia, p. 384.

A note. "At Tingha, Inverell district, there are fifteen or sixteen dredges working for tin, all doing well. Reported that they have work for six to ten years ahead of them." 


\section{NEW SOUTH WALES (Continued)}

804. - Beach mining in New South Wales.

Queensland, Gov. Mg. Journ., Vol. 8, 1907, Brisbane, p. 175.

Refers to report on beach mining in Queensland, made by L. C. Ball in 1905, and states that under similar conditions to those he described a French company intends to work the 13 miles of beach, from one mile south of Evans or Little River, ac the mouth of Richmond River, running northerly to McAuley's Lead. "The sands are said to contain gold, platinum, tin, monazite, and other minerals," but the richness is not known.

805. - Beach mining in New South Wales.

Queensland Gov. Mg. Journ., Vol. 8, 1907, Brisbane, p. 275.

The Byron Bay correspondent of the "Town \& Country Journal," under date 8th May, writes: A new mining plant has been set up at Broken Head, on the northern end of Seven-mile Beach, that was formerly very rich in gold, tin and platinum. A Sydney syndicate has just completed a plant, to treat the black sands for six or more kinds of minerals, which have a good market value. All previous work along this foreshore was confined to the recovery of gold and tin. It has now been found that minerals of equal value exist in the concentrates. Other parties are also working the beach sands.

806. BEER, AdoLF. Geschichte des Welthandels.

1864, Vienna, pp. 210-211.

Short notice of the tin production in New South Wales and Queensland.

807. Benedict, WM. DE L. Tin in New South Wales.

Min. Ind. for 1892, Vol. 1, 1893, New York, p. 443.

Principal alluvial deposits in New South Wales are situated about 400 miles north of Sydney, on western slope of the great dividing range. Alluvial deposits said to be practically exhausted. Tin has been found in veins in the Emmaville district, the principal one being the Oetery inine.

\section{Brown, A. Selwyn. See Nos. 1307 and 1308.}

808. Card, George W. Minerals of economic value, New South Wales (tin). Handbook to the Mining and Geological Museum, Sydney, 1902, Sydney, pp. 66-67, 113-115.

General description of tin ore and its manner of occurrence, with 2 list of tin specimens in the museum at Sydney.

809. Carne, J. E. The auriferous beach sands of the Esk River and Jerusalem Creek, in the parish of Esk County, Richmond, New South Wales.

Rec. Geol. Surv. New South Wales., Vol. 5, 1898, Sydney, pp. 71-86.

A number of assays of the sands are given, nearly all showing presence of tin. The possible sources of the gold, platinum and tinstone in the sands are:

(1) The underlying Siluro-Devonian rocks which contain poor quartz reefs.

(2) The Clarence coal measures.

(3) Drifts under basalt, known to occur and to be slightly auriferous.

(4) The basalt, doubtfully gold bearing.

(5) The draining channels from New England.

810. ClakKF, W. B. Leading article on mining containing a prognostication of the discovery of tin in New South Wales.

April 16, 1849, Sydney Morning Herald.

Not available to the anthors. 


\section{NEW SOUTH WALES (Continued)}

811.

\section{Mines and mineral statistics of New South Wales.}

May 7, 1853, p. 71.

In author's report to the Colonial Secretary, he drew attention for the first time to the probable occurrence of extensive deposits of tin ore. He then stated that "wolfram and oxide of tin with tourmaline, occur near Dundee and in Paradise Creck, and it is probable that this ore of tin is plentifully distributed in the alluvial of other tracts as I have found it amidst the spinelle, rubies, oriental emeralds, sapphires, and other gems of the detritus from granite."

812. Researches in the Southern gold fields of New South Wales, 1860.

Tin, pp. 109, 128.

813. - Anniversary Address.

Trans. Proc. Roy. Soc. New South Wales, for 1873 (1874), Sydney, pp. 1-39.

Address contains notes on tin in New South Wales.

814. - Remarks on the sedimentary formations of New South Wales, etc.

Edition 3, 1875, Sydney, pp. 61, vertical sections.

Digest: Geol. Rec. for 1875, London, p. 148.

Tin mines of New South Wales and Queensland occur in Devonian rocks.

815. Coglan, T. A. The wealth and progress of New South Wales for 18861887.

Sydney, 1887, pp. 82-84. Ibid., for 1890-1891 (1891), pp. 84-86. Ibid., for 1894 (1896), pp. 210-212. Ibid., for 1895-1896, Vol. 2, 1897, pp. 493-1023.

816. Conder, Hartwell. The occurrence of stannite in Australasia.

Austr. Mg. Stand., Vol. 40, 1908, Sydney and Melbourne, p. 577.

Gives a description of stannite and mentions localities in which it has been found. States that it occurs in considerable quantity in the Conrad mines, New South Wales, and the Oonah Mine (Zeehan) and at Heemskirk, Tasmania. In the Conrad mine stannite occurs in a quartz vein cutting granite and is accompanied by argentiferous galena, zinc blende, chalcopyrite and arsenical pyrites. Cassiterite occurs in the granite, but rarely if ever in the vein. At Oonah stannite occurs with bismuthinite, wolframite, galena, pyrite, and zinc blende in a vein between quartzite and graphitic schist, and closely connected with galena deposits. Stannite at both places is argentif. erous. Discusses difficulties of treatment.

816a. Cotton, Leo A. The tin deposits of New England, New South Wales. Part 1, Proc. Linn. Soc. New South Wales, Vol. 34, 1910, Sydney, pp. 733-781, pls. 59-62, figs. 13 , geol. map.

Describes the country rocks in detail, the distribution of the lodes, their direction and causes of trend. The deposits are divided into eleven classes which do not appear to be very distinctive. The veins under the different classes are described and eomparisons made with occurrences in other countries.

817. Cox, Herbert S. Tin deposits of New South Wales.

Journ. Proc. Roy. Soc. New South Wales, for 1886, Vol. 20, 1887, Sydney, pp. 93-112, figs. 7 .

General description of both lode and alluvial deposits with geology of district. Accompanying minerals are wolframite, copper pyrites, arsenical pyrites, fluorspar (not in large quantities), tourmaline, fluorine bearing micas, and topaz; at Gulf mine, near Bendemeer, beryl forms a rock in which cassiterite is impregnated. In the Inverell district, diamonds, sapphires and zircons occur with stream tin. Cassiterite is iridescent at Silverton. 


\section{NEW SOUTH WALES (Continued)}

\section{Davies, D. C. See No. 1317.}

818. David, T. W. Edgeworth. Geology of the Vegetable Creek tin-mining field, New England District, New South Wales.

Dep. Mines Geol. Surv., New South Wales, No. 1, 1887, Sydney, pp. x and 169, figs. 12 , and map.

Review: Amer. Geol., Vol. 1, 1888, Minneapolis, p. 122.

Gives a history of tin-mining in New South Wales; physiography, meteorology; geology; mineralogy, etc. Much of the country is covered by basalt up to 300 feet thick, averaging 200 feet. In places, stanniferous stream gravels covered by the basalt have to be crushed before the tin can be obtained.

Siluro-Devonian sediments are intruded by quartz felsite dikes and granite, probably of Permian age. The tin deposits are associated with this granite. The stanniferous gravels both exposed and lava-covered are described in detail. 'Some of the stream tin is only $1 / 70$ of an inch in diameter but shows sharp crystal edges. Sapphire, topaz, zircon, spinel, garnet, magnetite and ilmenite are found in the placers. Gold is also found in small quantities.

Ninety veins and stockworks are described.

Quartz is found in 69 veins; chlorite in 29; feldspar in 20; mica and arsenopyrite each in 8; pyrite and fluorspar, each in 4; tourmaline and wolframite, each in 3; zinc blende, galena, chaloopyrite, bismuth, molybdenite, vesuvianite and stilbite, each in 2; hematite, pyrrhotite, manganese, scheelite and beryl, each in one vein.

The veins range up to 3 feet in thickness.

- 28270 Gold, silver, lead and copper occur in veins of the neighborhood. Silver is in commercial quantity.

\section{Department of Mines, New South Wales, Annual Reports from 1875.}

Sydney.

Since 1875, the Department of Mines of New South Wales has issued annual reports upon mines and minerals of the State, with the statistics of production and progress of the industry as shown by reports from the wardens of the various districts, mine inspectors and geologists.

\section{- Fawns, Sydney. See No. 1320.}

820. Genth, F. A. Contributions to mineralogy.

Proc. Amer. Philos. Soc. Vol. 23, 1886, Philadelphia, pp. 30-31.

Treats of some specimens of tin ore and their associated minerals from Aberfoil and Sam rivers, New South Wales.

821. Gower, Grorge H. Report on the Vegetable Creek tin field.

Ann. Rep. Dep. Min. New South Wales, for 1874, Sydney, pp. 63-70. (With plan of the dressing machinery designed by W. H. Wesley.)

822.

New England and Clarence district. Vegetable Creek division.

Ann. Rep. Dep. Mines New South Wales for 1876 (1877), Sydney, pp. 110-114, pls. 2, Giving progress of each mine of the district with total yield from 1872-1876; also a description of new machinery used for washing gravel for tin.

823.

\section{Report on the New England and Clarence Mining District.}

Ann. Rep. Dep. Min. New South Wales, for 1878, Sydney, pp. 126-130 (with a sketch plan of the Vegetable Creek mining district, showing the approximate position of the creeks, and the localities of the principal mines working for stream tin under basaltic formation, and of the tin lodes. Scale: 4 miles to 1 inch). 


\section{NEW SOUTH WALES (Continued)}

824. - Report on the condition and prospects of the Vegetable Creek tin mining district for the year 1879.

Ann. Rep. Dep. Min. New South Wales for 1879 (1880), Sydney, pp. 149-156. (With plan and section of Messrs. Wesley Bros. workings, two plans of machinery, and a table showing total yield of tin ore from the Vegetable Creek tin mining district.)

825. JAQUET, J. B. Tin bearing dykes (?) of Eurlowie and Waukeroo.

Geol. of the Broken Hill Lode and Barrier Ranges Mineral Fields, New South Wales, Mem. Geol. No. 5, 1804, Sydney, pp. 128-131, pl. 1.

After general description of the ore and accompanying rocks, the following subjects are treated:

Analogous occurrence of tin in Dakota; Huel Byjerkerno mine; Mount Euriowie mine; Badjerican mine; Calorla (Euriowie Tin-mining Co.); Barrier Bischoff mine: Thistle mine.

826. KJERULF, Th., and BrögGER, W. C. Zinnsteinvorkommniss aus New South Wales.

Neues Jahrb. Min., 1879, Stuttgart, pp. 566-567.

827. Liversidge, A (rchibald). The minerals of New South Wales.

Trans. Proc. Roy. Soc. New South Wales, Vol. 9, 1876, Sydney, pp. 177-179.

Description of tinstone; its occurrence in veins and alluvial deposits, and the adt 10 vo localities where found.

828. - Minerals of New South Wales.

Thall wasmen:

1st edition, 1876, Sydney, pp. 25-27. 2d edition, 1882, Sydney, pp. 39-41. 3d edition, 1888, Sydney, pp. 76-84.

Treats of: Tin (chemical composition, appearance, specific gravity of ores); tin deposits; localities.

829. - Map of the minerals of New South Wales. 1888, Sydney, pp. 3-32. Min. map.

An alphabetical list of mineral localities, including the tin deposits of the state.

830. - On some New South Wales and other minerals.

Journ. Proc. Roy, Soc. New South Wales, Vol. 29, 1895, Sydney, pp. 323-324.

Analyses of some cassiterite crystals from Elsmore mine, Inverell, New South Wales.

Louis, Henry. See No. 1340.

831. Mingaye, John C. H. Notes on the occurrence of platinum, gold and tin in the beach sands in the Richmond River district, New South Wales.

Journ. Proc. Roy. Soc. New South Wales, Vol. 26, 1892, Sydney, pp. 368-370.

Sand from the Richmond River district was examined and a few of the results obtained given. Tin was present in all the samples, but percentage was not determined in every case.

832. Newland, D. H. Tin in New South Wales.

Min. Ind. for 1902, Vol. 11, 1903, New York and London, p. 593, 250 words.

Gives the tin output of New South Wales during 1902 and reviews conditions of mining.

833. - Tin in New South Wales.

Min. Ind. for 1903, Vol. 12, 1904, New York and London, pp. 327-328.

Gives the tin output of New South Wales during 1903 and notes that there was a marked increase in the use of dredges, the recovery by this means amounting to 244 long tons. Considerable abandoned ground has been worked profitably, owing to the increased price obtained for tin and to improved methods. 


\section{NEW SOUTH WALES (Continued)}

Phillips, J. A., and Louis, H. See No. 1350.

834. Pittman, E(Dward) F. Tin deposits of New South Wales.

Published by the Government, giving a full description of the mines and methods of working. 1899.

Not available to the authors.

835. - The mineral resources of New South Wales.

Geol. Surv. New South Wales, 1901, Sydney, pp. 130-150, pls. 3, figs. 4.

Tin: History of development, occurrence and places where mined.

Largely a digest of T. W. E. Davids' "Geology of the Vegetable Creek Tin-mining Field."

836. Plummer, John. Tin mining in New South Wales.

Eng. Mg. Journ., Vol. 73, 1902, New York, p. 212.

General description of tin deposits of New South Wales and a more detailed account of Vegetable Creek tin fleld, the leading one of the State.

837. Mining in New South Wales.

Mg. Journ. Railw. Comm. Gaz., Vol. 76, 1904, London, p. 375.

Dredgers for tin not properly equipped for saving tin ore.

838. REID, G. H. An essay on New South Wales, the mother colony of the Australias.

1876, Sydney, pp. 72-73.

A very brief sketch of the tin industry at that date. Tin production from 1872 1875 given.

Reyer, Eduard. See No. 1354.

839. SueE, W. H. J. Mineral deposits, etc., in New South Wales.

Report of Mining Conference, New South Wales, 1896, p. 6.

Not available to the authors.

840. Stephen, G. Mminer. Discovery of tin in New South Wales. Mg. Journ. Railw. Comm. Gaz., Vol. 42, 1872, London, pp. 45, 398. Also, Quart. Journ. Geol. Soc. London, Vol. 28, 1872, London, p. 42. Announcement by letter of great deposit of tin ore in district of New England. The tin ore is said to be in " pepitas crystals, and beds of conglomerate, especially in micaceous granite more or less decomposed."

Stokes, Ralph S. G. See No. 730.

841. Stonier, G. A. Report on tin-bearing country in the county of Bourke. Mg. Journ. Railw. Comm. Gaz., for 1889 [1890], London, pp. 234-235.

842. TAYLOR, N. Report on the property of the Pheasant Creek tin syndicate, New England.

New South Wales Leg. Ass. Papers, 1883-1884, 796-A, pp. 20-21.

Not available to the authors.

843. Thibault, P. J. Tin mining in New South Wales.

Austr. Mg. Stand., Vol. 33, 1905, Sydney and Melbourne, pp. 444-445, 465-466. Serial. "A summary review covering the period from 1900 to 1904 inclusive."

844. - Tingha tin dredging industry, New South Wales.

Austr. Mg. Stand., Vol. 38, 1907, Sydney and Melbourne, pp. 128, 148-149, 174-175, 197-198, 222-223, 246-247, 265-266, 292. Illustrated. 


\section{NEW SOUTH WALES (Continued)}

Gives methods of dredging and results obtained by following companies: Melbourne Cope's Creek Tin Sluicing Co., Tingha Consolidated Tin Mines, Elsmore Tin Sluicing Co., The Tingha Tin Dredging Co., Cope's Creek Central Tin Dredging Co., The Amalgamated Tin Dredging Co., Cope's Creek Dredging Co.

- See No. 1644.

844a. Trenchard, H. G. Recovery of tin from alluvial deposits.

Austr. Mg. Stand., Vol. 41, 1909, Sydney and Melbourne, pp. 37-38.

" Notes on the strean sluicing plants at Tingha, New South Wales, for recovering tin from the abandoned workings and leads too poor for hand treatment."

845. UlRICH, G. H. F. Observations on some of the recent tin ore discoveries in New England, New South Wales.

Quart. Journ. Geol. Soc. London, Vol. 29, 1873, London, pp. 5-11, figs. 2.

Abstracts: Mg. Journ. Railw. Comm. Gaz., Vol. 42, 1872, London, p. 1105; Geol. Mag., Vol. 9, 1872, London, pp. 569-571.

District described is in northern part of colony of New South Wales, almost immediately adjoining tin region of Queensland.

846. Changed to $578 \mathrm{a}$.

847a. Wrikinson, C. S. Report on the discovery of tin and other metals in the Burra Burra district, between the Bogan and Lochan rivers.

Queenslander, Vol. 12, 1876.

Not available to the authors.

$847 \mathrm{~b}$.

- Report on tin bearing country, New England.

New South Wales Leg. Ass. Papers, 1872, 181-A (Folio, Sydney, 1873. By authority), p. 10 , pls.

Not available to the authors.

847c. - Report on tin bearing country, district of Inverell.

Enclosing Rev. W. B. Clarke's report on Geological Surveys, May 7, 1853, pp. 11, New South Wales Leg. Ass. Papers, 1872-1873, 176-A (Folio, Sydney, 1873. By authority).

Not available to the authors.

$847 \mathrm{~d}$. Tin deposits of New South Wales. Iron, Vol. 3, 1874, London, pp. 267, 296, 325.

$847 \mathrm{e}$. - Tin deposits of New South Wales. Mg. Journ. Railw. Comm. Gaz., Vol. 44, 1874, London, p. 200.

847f. - Report of Progress (Vegetable Creek tin fields). Ann. Rep. Dept. Min. New South Wales for 1883 [1884], Sydney, pp. 148-152.

847g. - Report on mineral reserves, Molong district. (Gumble tin lodes.)

Ann. Rep. Dept. Mines New South Wales, for 1886 [1887], Sydney, p. 132.

847h. - Report on tin lodes near Poolamacca, in the Silverton district, New South Wales.

Ann. Rep. Dept. Mines New South Wales, for 1887 [1888], Sydney, pp. 141-144.

848. - Report on the Mount Euriowie tin properties, New South Wales, 1887.

Not available to the authors. 


\section{NEW SOUTH WALES (Continued)}

849. Wilkinson, C. S., and DAvid, T. W. E. Geological map showing the principal stanniferous leads in the Tingha and Elsmore districts, 1895. Scale, 80 chains to 1 in.

Not available to the authors.

850. Wood, Harrie M. Tin.

Min. Products of New South Wales, 1882, Sydney, p. 27, Ibid., 1887, p. 34.

Brief very general articles upon the occurrence and production of tin in New South Wales.

\section{NEW ZEALAND}

851. ANoNymous. Tin on Stewart Island (N. Z.).

Austr. Mg. Stand., Vol. 18, 1900, Sydney and Melbourne, p. 310.

A note stating that tin exists on Stewart Island in vein and alluvial deposits. The latter are worked in a small way at Half Moon Bay. The deposits are not extensive.

852. BELL, JAMES M. The salient features of the economic geology of New Zealand.

Econ. Geol., Vol. 1, 1906, Lancaster, p. 750.

"Cassiterite has been found in the form of 'stream tin' in some of the streams amid the rugged hills of Stewart Island, and has been reported to occur actually in granite." Whole Reference.

853. Binns, George J. Mining in New Zealand.

Trans. Fed. Inst. Mg. Eng., Vol. 4, 1892-1893, Newcastle-upon-Tyne and London, p. 67.

Tin ore has been known for some years in auriferous conglomerates at the base of the coal measures at Lankey's Creek, Reefton, Milford and Dusky sounds on the west coast of Otago. In 1888 tin ore was found in gravels, and in situ " associated with gneissic granitoid rocks" in the Rcmarkable Mountains, Stewart Island. Deposits small, climate wet. In April, 1892, stream tin was found in the gold wash at Humphrey's Gulley, near Hokitika, on the west coast of the South Island.

Fawns, Sydney. See No. 1320.

854. Launay, L. DE. Les richesses minérales de la Nouvelle-Zélande.

Ann. Mines, se:. 9, Vol. 5, 1894, Paris, pp. 549-550.

855. McKay, Alexander. On the geology of Stewart Island and the tin deposits of Port Pegasus district.

Reports of Geological Explorations during 1888-89, New Zealand Geological Survey, Publication No. 20, Wellington, 1890, pp. 74-85. Sketch map of tin fields of Pegasus Dist., figs. 6.

Stream tin was found in shallow gravels with gold, but was not rich enough to work except with the gold. It averaged less than 1 ounce of stream tin to the "tindishful " (sic). In the Tin Range on Port Pegasus tin occurs in "quartz rock" 6 inches to 1 foot thick, with " mica rock" above and below. More wolframite than cassiterite is carried by the " quartz rock." Granular topaz, gahnite, sphalerite with "blue faces," and pyrites, accompany the cassiterite.

\section{NIGERIA}

856. ANONYMous. Alluvial tinstone deposits of Northern Nigeria.

Bull. Imp. Inst. Great Britain, Vol. 5, No. 2, 1907, London, pp. 179-183.

Extract: Mg. World, Vol. 27, 1907, Chicago, p. 562.

Description of alluvial tin deposits along the River Delime, tributary to Lake Tchad, 220 miles northeast of Lokoja. In highest land of Northern Nigeria. Country 


\section{(bovidi) NIGERIA (Continued)}

rock is gneiss cut by basalt, dolerite and pegmatite dikes. No tin ore is found in place. Metallic tin reported as native, is always near native furnaces. An analysis of a specimen of stream tin is given showing about 67 per cent $\mathrm{SnO}_{2}$. Ilmenite and some monazite and zircon occur with the stream tin.

Gives an account of the native method of working stream tin. The Niger Co. in 1905 produced one ton of "black tin" per day.

857. Dunstan, Wyndham R. Tin ore from the Bautshi tin fields, Northern Nigeria.

Imp. Inst. Tech. Rep. and Sci. Papers, London, 1903, p. 53. Same, Bull. Imp. Inst. Great Britain, Vol. 1, 1903, London, p. 21.

. Chemical examination of a tin specimen weighing 1 pound which came from a depth of 6 feet from the surface of a plain lying to the north of a range of hills about 70 miles southwest of Bautshi in Northern Nigeria. Analysis showed 81.30 per cent tin dioxide. Extent of deposit not known.

858. Report on a series of mineral and vegetable products from Northern Nigeria.

Colonial Reports (Miscellaneous), No. 26, 1904, London, pp. 17-18.

Tin ore from the Tilde area about 15 miles southwest of Badika, alsa gravel carrying tin, from the River Gimpu, three miles west of Tilde, are analyzed and described.

859.

1904 and 1904-1905.

Colonial Reports (Miscellaneous), No. 33, 1906, London, pp. 22-29.

Extract: Mg. Journ. Railw. Comm. Gaz., Vol. 78, 1906, London, p. 546.

Digest: Eng. Mg. Journ., Vol. 81, 1906, New York, p. 992.

Describes alluvial tin occurences of Uwet and Akwa-Ibama districts. Only the latter contained tin deposits rich enough to warrant working, but these are described as poor in comparison with other alluvial deposits. Associated with columbite, garnet, ilmenite and tourmaline, with a small amount of quartz and occasionally magnetite. Conclusions drawn from examination are not of a definite character.

860. Nicolaus, R. C. Tin deposits of Northern Nigeria. In tin deposits of the world, by Sydney Fawns.

1905, London, pp. 139-141. Written Dec. 1904.

Found in the Naraguta and Shere Hills, outliers of the Gura Mountains in the Badiko district, Province of Bauchi, 600 miles northeast of Lokoja, situated at the confluence of the Niger and Benue rivers. Occurs as coarse and fine stream tin along the Gimpy or Kogin-Delume (" river tin"). Hills of granite with intrusions of diabase and porphyry. Near river is a contact with coarse gray gneiss. Tin thought to come from stockworks in granite. Metallic tin in nodules about the size of a bean, thinly coated with $\mathrm{SnO}_{2}$, is found 15 feet below the surface of the gravels. Gravels said to avcrage 36.66 pounds stream tin per ton. Smelted with charcoal in small local furnaces. The product is $99.40 \mathrm{tin}$.

\section{NORTH AMERICA}

See under Canada, Greenland, Mexico, Santo Domingo, United States and separate States.

\section{NORTHERN TERRITORY}

861. Anonymous. Tin at Port Darwin, Northern Territory, Australia.

Mg. Sci. Press, Vol. 89, 1904, San Francisco, p. 273.

A shipment of tin ore from Port Darwin is said to have carried 75 per cent tin and worth about $£ 80$ per ton, it is said this was taken from an area of ground not covering 25 yards (square), depth 4 feet. Open cut work; is below an outcrop of quartz thickly studded with tin ore. 


\section{NORTHERN TERRITORY (Continued)}

861a. Playford, E. C. Tin in Australia.

Mg. Journ. Railw. Comm. Gaz., Vol. 85, 1909, Lontan, p. 577.

Notice of same. Eng. Min. Journ., Vol. 87, 1909, New York, p. 1272.

Gives an account of, and outlook for a new discovery of alluvial tin at a place bearing the native name of Warra, close to Pine Creek, Northern Territory.

Tin ore is black, with a little brown, ruby, amber and wood tin. Country rock consists of a gray granite and sandstone, with a little, quartz. Small amount of monazite has been found with tin.

862. TAte, Ralph. Report on the Northern Territory.

Geol. Surv. South Australia, No. 63, 1882, Adelaide, p. 4, map.

Two alluvial deposits have been located, along one of the tributaries of McKinlay River, and the head waters of a stream near Mt. Wells. The deposits are of comparatively little importance. Neither of these deposits of tinstone seemed to be associated with granite.

863. Tenison-Wood, J. E. Report on the geology and mineralogy of Northern Territory.

Geol. Surv. South Australia, No. 122, 1886, Adelaide, p. 7.

Ore occurs in the form of reef tin. Is abundant and rich. Spread over wide area. Metalliferous country resembles that of Cornwall. "The Northern Territory may be emphatically pronounced to be a tin country."

Brögger, W. C. See No. 1596.

\section{NORWAY}

\section{PERAK \\ See Malay Peninsula \\ PERSIA}

864. Hennecke, Ludwig. Die Bodenschätze Persiens.

Zeitschr. Berg. Hutt. Sal. preuss. Sta., Vol. 47, 1899, Berlin, pp. 272-274.

Digest trans: Trans. Inst. Mg. Eng., Vol. 18, 1899-1900, London and Newcastle-uponTyne, p. 509.

"Rich occurrences have been certifled in many parts of Persia, of mercury, copper, tin, and antimony-ores, realgar, native sulphur, brown iron ore, manganese and cobalt-ores, kaolin, borax and alum."

865. MACTEAR, JAs. Some notes on Persian mining and metallurgy.

Trans. Inst. Mg. Met., Vol. 3, 1894-95, London, pp. 2-3. .

Quotes from a letter of Dr. Riach to Lord Palmerston in 1837 concerning a supposedly very large deposit of tin ore on Anngert Creek near the village of Juwaa, 60 miles northeast of Tabriz, but when visited in 1893 or 1894 by Mactear, nothing was known of the tin.

\section{PERU}

866. Anonymous. Nuevos yacimientos de estaño y bismuto en el Perú.

Bol. Soc. Nac. Min., No. 87, 1905, Lima, pp. 103-105.

Extract: Mo. Bull. Int. Bur. Amer. Repub., Vol. 21, July, 1905, Washington, D. C., p. 131.

Until recently tin ores were considered rare in Peru, the only deposits known to exist being those described by Prof. Raimondi in the district of Moho, Province of Huancané, Dept. of Puno. Mineral veins and veinlets containing tin were afterwards described by Carlos Posth as existing in quartz in the Pataoca and Accaobina spurs of the Andes in the Vilque district. Tin is now known to be widely distributed in Peru. Some specimens from Province of Cajatambo, were rich in metallic tin. 


\section{PERU (Continued)}

867. Larrouy, - - L'industrie minière au Pérou en 1900.

Ann. Mines, ser. 9, Vol. 20, 1901, Paris, p. 510. Extract of report by author.

Tin ore is rare in Peru and no veins that would pay for working have been found; there is however, a vein of no importance at Huancane, Puno.

868. Changed to $171 \mathrm{a}$.

869. Posth, C. Estado actual de la mineria en el Depto. de Puno.

Bol. Min. Indust. Constr., Ano 10, No. 8, 1894, Lima, p. 63.

Notes the finding of stanniferous quartz veins in the Pataoca and Accoabina Mountains. Vilque district, Puno Department.

870. Raimondi, A. Minerales del Perú.

1878, Lima, pp. 168-170.

A French translation was made by Martinet, J. B. H., "Minéraux du Pérou." 1878, Paris, pp. 187-189.

Digest: Zeitschr. Kryst. Min., Vol. 6, 1882, Leipzig, p. 632.

Amorphous cassiterite is found in small quantities in Moho district, Huancane province. Describes a new mineral plumbostannite, a sulphide of lead, tin and antimony, discovered in same district. Occurs with zinc blende and quartz.

\section{PHILIPPINE ISLANDS}

871. McCaskey, H. D. Stream tin in Negros.

Philippine Min. Ind., a separate from Min. Res. of the United States, 1905, Washington, D. C., pp. 12-13.

Reported that "large tin deposits of stream tin occur in Negros" but no details are given. [This report was later found to be erroneous.-Authors.]

\section{PORTUGAL}

872. Anonymous. Tin mines in Sandinha, Portugal.

Mg. Journ. Railw. Comm. Gaz., Vol. S0, 1906, London, p. 495.

Brief note. Mines situated near Goes. Deposits included in old Cambrian schists, near granite. Quartz veins are impregnated with cassiterite and small quantities of pyrite and mispickel.

See No. 1027.

BECK, RichaRd. See No. 1299.

873. Breidenbach, TH. Die Zinnerzlagerstätten Portugals.

Glück. Berg. hütt. Zeit. Nied. Westph., 1893, Essen, pp. 1032, 1050.

Digest: Neues Jahrb. Min., 1894, II (Ref.), Stuttgart, pp. 429-430.

Brown, A. Selwyn. See Nos. 1307 and 1308.

Calderón, D. Salvador. See No. 1029.

D'Achiardi, Antonio. See No. 1313.

874. EschweGE, W. voN. Bemerkungen über den Bergbau und Hüttenbetrieb in Portugal.

Arch. Miner. Geogn. Bergb. Hütt., Vol. 8, 1835, Berlin, pp. 221-222, 224.

Fawns, Sydney. See No. 1320.

Fuchs, E., and LaUnAT, L. DE. See No. 1323. 


\section{PORTUGAL (Continued)}

\section{Heale, Josir. Tin in Portugal.}

Mg. Journ. Railw. Comm. Gaz., Vol. 44, 1874, London, p. 343.

Report on the tin mines of São Martinho and Montesinhos in the Province of Tras os Montes.

Louis, Henry. See No. 1340.

Phillips, J. A., and Louis, Henry. See No. 1350.

\section{QUEENSLAND}

876. Anonymous. Vulcan tin mine, Irvinebank, Queensland.

Austr. Mg. Stand., Vol. 11, 1895, Sydney and Melbourne, p. 524.

Digest: Trans. Fed. Inst. Mg. Eng., Vol. 10, 1895, Newcastle-upon-Tyne and London, p. 590.

Describes the Vulcan mine and states that it is the most productive tin mine in North Queensland.

877. minerals).

The Queenslander, Vol. 51, March 27, 1897, Brisbane, p. 2.

Not available to the authors.

878. - Tin in Queensland.

Min. Ind. for 1900, Vol. 9, 1901, New York and Iondon, p. 637.

A short general review of conditions in the tin fields of Queensland during 1900.

879.

Tin in Queensland.

Min. Ind. for 1901, Vol. 10, 1902, New York and London, pp. 639-640.

Brief review of tin mining conditions during 1901.

880. - Queensland tin mining.

Austr. Mg. Stand., Vol. 30, 1903, Sydney and Melbourne, p. 801.

Particulars of a new find of rich tin ore in the neighborhood of Reid's Creek, Queensland, taken from "Wild River Times," Q.

881. - Tin mining in north Queensland. Mg. Journ. Railw. Comm. Gaz., Vol. 75, 1904, London, p. 602.

Outlook for tin in Herberton district very encouraging. The Lancelot lode, in Silver Valley, 10 miles southwest of Herberton, has an average width of 2 feet, and has been exploited to a depth of 250 feet. Average per cent of tin in the ore is from 12 to 13 per cent. Concentrates contain 60 per cent metallic tin, 5 per cent bismuth and 5 per cent copper. Outputs from 1899 to 1903 of New South Wales and Queensland given.

882. - - Tin mining in Queensland.

Mg. Journ. Railw. Comm. Gaz., Vol. 76, 1904, London, p. 113.

Gives present conditions in tin mining and the production in the Herberton district.

883. Dredging for tin at Stanthorpe.

Queensland Gov. Mg. Journ., March 15, 1904, Brisbane, p. 103.

"Shows Brisbane dredging plant."

Not available to the authors.

884. Queensland tin supply.

Austr. Mg. Stand., Vol. 31, 1004, Sydney and Melbourne, p. 80 .

"Information concerning the output, which shows a marked increase." 


\section{QUEENSLAND (Continued)}

885. - The Vulcan tin mine, North Queensland.

Eng. Mg. Journ., Vol. 82, 1906, New York, p. 155.

Vulcan mine, Herberton district, North Queensland, has recently developed into one of the most important lode tin mines of the world. It surpasses, as producer and dividend payer, even the famous Mt. Bischoff mine. During 1905, production was at the rate of 130 tons of black tin per month. Description of mine is from report by Walter E. Cameron, Asst. Geol. of the Queensland mines department.

886. Babington, Arthur. Herberton tin field.

Austr. Mg. Stand., Vol. 16, 1899, Sydney and Melbourne, pp. 88-89, 129.

"Information concerning these deposits in North Queensland, and their workings."

887. BaIN, W. H. The Tate tin mines.

Austr. Mg. Stand., May 28, 1896, Sydney and Melbourne.

"Description of the largest and most important of the stream tin mining properties now being worked in North Queensland."

Not available to the authors.

888. BaLL, Lronel C. Crow's Nest tin deposits.

Queensland Gov. Mg. Journ., Oct. 15, 1903, Brisbane.

"Report on the geology and workings of tin deposits in Queensland."

Not available to the authors.

889. - Notes on tin, copper and silver in the Stanthorpe District.

Geol. Surv. Queensland, Pub. 191, 1904, Brisbane, pp. 9-21, pls. 1-8, plan and elevation 1.

Also, Queensland Gov. Mg. Journ., July 15, 1904, 1st part. Brisbane.

Notes on tin mining in the Stanthorpe district treat of pan-washing and cradling; ground sluicing; dredgers, and lode tin mining.

890. — Progress Report, 1904.

Ann. Rep. Under-Secretary for Mines, Quecnsland, for the year 1904 (1905), Brisbane, pp. 155.

"On the 7th January, I left Brisbane to investigate a discovery of tinstone on Brovina Creek, in the Gayndah district. Small quantities of the mineral were found to occur in one branch of the creek, but the prospects were not encouraging, and it is believed that work has now ceased." (Whole reference.)

891.

Gold, platinum, tinstone and monazite in the beach sands on the South Coast (Queensland).

Geol. Surv. Rep., Queensland, Pub. No. 198, 1905, Brisbane, pp. 1-19, figs., pls. 1, 2.

"At intervals along the Currumbin-Coolangatta Beach, the sands contain payable tin, accompanied by gold. The concentrates, however, assay very much lower than was expected, and the assays show that the work thus far done for tin has been at a loss, either owing to local poverty of the ground or to the escape of tinstone with the tailings. Nevertheless, the hope is entertained that the ground may yet be proved sufficiently rich for dredging."

891a. - King of the Ranges tin mine, Watsonville, N. Q. Queensland Gov. Mg. Journ., Vol. 10, 1909, Brisbane, pp. 228-232, illus.

891b. Irvinebank Company's treatment works.

Queensland Gov. Mg. Journ., Vol. 10, 1909, Brisbane, pp. 329-330, illuśs.

Description of methods used for crushing, concentrating and smelting of tin ores at Irvinebank.

BeEr, Adolf. See No. 806.

Brown, A. Selwyn. See Nos. 1307 and 1308. 


\section{QUEENSLAND (Continued)}

892. Cameron W (alter) E. Report on the Stannary Hills tin deposits.

Queensland Gov. Mg. Journ., Vol. 1, 1900, Brisbane, pp. 190-191.

Not available to the authors.

893. - Report on the Kangaroo Hills mineral fields, Queensland.

Geol. Surv. Rep. Queensland, Pub. No. 167, 1901, Brisbane, pp. 1-11, pls. 8, geol. map 1.

894. - Report on the Cardigan (Queensland) Tin-Syndicate's Properties, Thompson's Creek, and the Coolgarra Federal Corporation Limited, Leases, Herberton Mineral District, North Queensland.

Geol. Surv. Rep. Queensland, Pub., No. 165, 1901, Brisbane, pp. 1-4.

"The above syndicate has acquired a number of abandoned tin properties formerly worked for tin by the prospectors of the Herberton field. The object of this syndicate is to develop and work these leases in a more systematic manner than was possible with the methods available to small parties of working miners."

Each piece of leased property is described.

895. - The Herberton tin field.

Geol. Surv. Rep. Queensland, Pub. No. 192, 1904, Brisbane, pp. 1-29, pl. 1 (geol. map.)

Digest: Mg. Journ. Railw. Comm. Gaz, Vol. 76, 1904, London, p. 359.

Describes the topography of the area, the geology and mining methods used. A short history of the region is given and the following districts are described: Herberton, Watsonville, Irvinebank, Eureka Creek, Koorboora, Newellton and Coolgarra. The Smith's Creek mine and the lodes on California Creek and Reid's Creek are also described.

896. - The Annan River tin field, Cooktown District.

Geol. Surv. Rep. Queensland, Pub., No. 210, 1907, Brisbane, pp. 27, map 1, pls. 14. Also, Queensland Gov. Mg. Journ., November, 1906, Brisbane.

Abstract: Mg. World, Vol. 26, 1907, Chicago, p. 7.

Tin occurs on Mt. Amos, Mt. Leswell, and at the Lion's Den in granite much altered and tourmalinised along joints. From these the alluvial deposits along the Annan River and its tributaries have been formed. Gives general description of claims.

897. Cleland, W. Lauder. Tin dressing at Stannary Hills, North Queensland.

Trans. Austr. Inst. Mg. Eng., Vol. 12, 1907, Melbourne, pp. 154-164, pl. 1, figs. 2. Description of the mills and some of the principal machinery, also methods employed in dressing of tin ore.

898. Clotten, E. Die Zinn- und Wolfram-Vorkommen von Nord-Queensland. Min. Mitth., n. f., Vol. 24, 1905, Wien, pp. 137-139.

Digest: Neues Jahrb. Min., 1906, II (Ref.), Stuttgart, pp. 26-27.

Alluvial tin was first discovered in Herberton district, North Queensland, " sometime ago," and afterwards rich deposits were found on Wild River. Older alluvial deposits were later discovered in the Herberton lowland, at Watsonville, Irvinebank, and still later, very rich and extensive tin ore deposits were found in Silver Valley near Herberton. The ores of these deposits contain on an average, 4 per cent of bismuth, 3 to 8 per cent of copper and considerable tungsten. The tin-bearing territory has now been shown to extend over an area of 12,000 square miles.

899. Cusack, W. G. Kelley. Ravenswood fields.

Ann. Rep. Under-Secretary for Mines, Queensland, for year 1904 (1905), Brisbane, p. 95 .

A short description of the tin camps on Running Creek is given, but nothing is said about the geology. 


\section{QUEENSLAND (Continued)}

D'Achiardi, Antonio. See No. 1313.

900. Daintree, R. Tin in Queensland.

Mg. Journ. Railw. Comm. Gaz., Vol. 42, 1872, London, pp. 680-690.

Also, Quart. Journ. Geol. Soc. London, Vol. 28, 1872, London, pp. 301-302.

At time of writing, discoveries were limited to drainage area of the upper part of the Severn River. These are swampy beds, intersected by numerous broad bars of granite. The alluvial beds vary in thickness from 3 to 20 feet. Outlook very encouraging; the greatest difficulty to overcome will be the swampy character of the ground, especially during the rainy season.

Davies, D. C. See No. 1317.

901. Dower, W. S. The Herberton tin field.

Austr. Mg. Stand., Nov. 17, 1898, Sydney and Melbourne. Serial.

" Information concerning these lode tin deposits in Queensland."

Not available to the authors.

902. Dunstan, B. Tin in Queensland.

Ann. Rep. Under-Secretary for Mines, Queensland, for 1904 (1905), Brisbane, p. 149.

The Lancelot Tin Mine at Silver Valley is described, and the general geology of the region is given.

903. - Monazite in Queensland.

Geol. Surv. Rep. Queensland, Pub. No. 196, 1905, Brisbane, p. 11.

Bricf mention of cassiterite, found in the beach sands at the mouth of the Tweed River, with monazite. A concentrated sample yielded 54 per cent of tin.

904. - Stanhills tin fields, Queensland.

Geol. Surv. Rep., Queensland, Pub. No. 211, 1907, Brisbane, pp. 21, maps 2, pls. 3. Country rock is altered granite, aplite and quartz-felsite. Cassiterite occurs in irregular masses of chlorite and quartz in granite; in quartz veins cutting quartzfelsite; in chlorite veins in quartz-felsite, granite and aplite; chlorite and greisen veins in granite. There are limited tin placers, and the Desert sandstone is tinbearing, though in wbat way is not explained. The total yield is small.

905. Stanhills tin fields.

Geol. Surv. Rep., Queensland, Pub. No. 211, 1907, pp. 21.

Queensland Gov. Mg. Journ., Vol. 9, 1908, Brisbane, pp. 285-288, map 1, pls. 3.

Discusses the geology, the mines, the alluvial deposits and prospects of the Stanhills district, Queensland. Cassiterite occurs in altered granite, or in close connection with granite, with much chlorite. Galena, zinc blende, chalcopyrite, and graphite occur with the tin. Alluvial deposits occur in the neighborhood around the head of Ten-mile Creek.

906. EDLINGER, W. Einige Bemerkungen über die Zinnerzlagerstätten des Herberton distrikts in Queensland.

Zeitschr. prakt. Geol., Vol. 16, 1908, Berlin, pp. 275-279 and 340-343.

I. Die primaren Lagerstätten, pp. 275-279.

A description of the lode occurrences.

II. Die Zinnseifen, pp. 340-343.

Description of elluvial, alluvial, and fossil (" deep leads") placers.

Fawns, Sydney. See No. 1320.

907. FrYar, WM. The mineral resources of the colony of Queensland.

Trans. Fed. Inst. Mg. Eng., Vol. 13, 1896-1897, Newcastle-upon-Tyne and London, pp. 358-359.

Enumerates places where tin is found, but gives little more about tin deposits. 


\section{QUEENSLAND" (Continued)}

908. Gregory, T. F. Tin in Queensland.

Journ. Soc. Arts, Vol. 20, 1872, London, pp. 853-854.

A communication from the Secretary of State for the Colonies to the Council in which he describes the stanniferous country geologically and gives its extent.

909. - A report on the tin discoveries in Queensland.

Quart. Journ. Geol. Soc. London, Vol. 29, 1873, London, pp. 1-5.

Abstract: Mg. Journ. Railw. Comm. Gaz., Vol. 42, 1872, London, p. 1105.

Abstract: Geol. Mag., 1872, London, p. 569.

Tin ore discovered in district situated about the head waters of Severn River and its tributaries, comprising area of about 550 square miles. District is described as an elevated granite tableland intersected by ranges of abrupt hills, some 3000 feet above sea. Richest deposits are found in beds of streams and in the alluvial flats along their banks.

910. HaLdane, A. C.

Ann. Rep. Under-Secretary for Mines, Queensland, for 1897 (1898), Brisbane, pp. 102-105.

Progress in mining in the Herberton tin mining district is described.

911. Herberton (Walsh and Tinnaroo) fields.

Ann. Rep. of the Under-Secretary for Mines, Queensland, for 1904 (1905), Brisbane, pp. 68-71.

912. Honsley, SyDNex. Report upon the Kangaroo Hills and Star River mineral fields.

Ann. Rep. Under-Secretary fot Mines, Queensland, 1904 (1905), Brisbane, p. 110.

913. HuMe, W. C. Report on the Queensland tin fields.

1874, pp. 31.

Not available to the authors.

914. JACK, RoBt. L. Report on the Wild River tin mines.

Geol. Surv. Rep., North Queensland, Pub. No. 9, 1881, Brisbane, pp. 8-10, map 1.

Reconnaissance report upon the tin mines in the vicinity of Wild River.

915. - On the Stanthorpe tin mining district.

Geol. Surv. Rep., Queensland, Pub. No. 12, 18s2, Brisbane, pp. 1-2.

ane "As it will be necessary for'me to return to the district and make a survey of

to berif ads the conclusions to which $\mathrm{I}$ have been led, and $\mathrm{my}$ strong faith in the probability of discovering payable deposits of ore in the rocks from which the vast stream deposits

(w) (r)

916. - On the tin mines of Herberton, Western and Thompson's Creek districts and the silver mines of the Dry River.

Geol. Surv. Rep., Queensland, Pub. No. 13, 1883, Brisbane, pp. 3-32, with geol. maps 2 and 6 plates of sections.

Abstract: Eng. Mg. Journ. Vol. 37, 1884, New York, p. 353.

The intimate connection of the tin deposits with metamorphosed igneous rocks is shown. The claims in the various districts are treated separately.

917. - On the tin mines near Cooktown.

Geol. Surv. Rep., Queensland, Pub. No. 66, 1891, Brisbane, pp. 1-9. Geol. map and 2 sheet plans.

Describes the mines of the region in detail. 


\section{QUEENSLAND (Continued)}

918. - The Kangaroo Hills silver and tin mines.

Geol. Surv. Rep., Queensland, Pub. No. 82, 1892, Brisbane, pp. 1-11, map 1.

Describes the tin mines in the central area of the Kangaroo Hills, the unnamed lodes, the Mount Brown silver and tin mines and a group of mines near Running River crossing.

LOCK, C. G. WARNFORd. See No. 1338.

Louis, Henry. See No. 1340.

919. Macdonald, A. R.

Ann. Rep. Under-Secretary for Mines, Queensland, for 1895 (1896), Brisbane, pp. 124-126.

The progress of tin mining in the Herberton District during 1895 is epitomized.

920.

Ann. Rep. Under-Secretary for Mines, Queensland, for 1899 (1900), Brisbane, pp. 13-14.

Reports on Herberton, Kangaroo Hills, Cooktown, Stanthorpe, Ravenswood, Palmer and Port Douglas distriets. Herberton yield was largest for year. The reports are devoted to economic progress more than to geology.

921.

Ann. Rep. Under-Secretary for Minus, Queensland, for 1900 (1901), Brisbane, - pp. 15-16.

The reports of the wardens of the different mining districts, showing progress in tin mining are summarized.

922.

Ann. Rep. Under-Secretary for Mines, Queensland, for 1904 (1905), Brisbane, pp. 8-10, 16-17.

General review of tin mining throughout the Province during the year with statistics. The volume contains beside, descriptions by their respective eommissioners of work done in the various districts.

923. ——. Tin mining in Queensland.

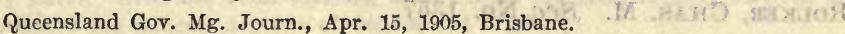

"Reviewing the condition of tin mining in Queensland."

Not available to the authors.

924. - Under Secretary for Mines, The Queensland Mining Industry,

Review of the year 1906.

2. I 1 1895 "Tueensland Gov. Mg. Journ., Vol. 8, 1907, Brisbane, pp. 111-113.

An advance copy of the Annual Report, summarizing economic conditions in the tin mining districts.

925. Maclaren, J. M. Report on Stannary Hills tin mines, Eureka Creek, Watsonville district (North Queensland).

Geol. Surv. Rep., North Queensland, Pub. No. 146, 1900, Brisbane, pp. 1-2.

Describes the geology, ores and working of the tin mines in the Stannary Hills.

926. Mattland, A. GibB. On the Coolgarra tin mines and surrrounding district.

Geol. Surv. Rep., Queensland, Pub. No. 72, 1891, pp. 1-5. With geol. map and plans. The geological features and the mines of the district are described. 


\section{QUEENSLAND (Continued)}

927. Munday, John. Notes on tin mining in and around Herberton, North Queensland.

Austr. Ass. Adv. Sci. Vol. 6, 1895, Sydney, pp. 375-381. Map 1.

Reprint: Mg. Journ. Railw. Comm. Gaz., Vol. 66, 1896, London, pp. 990-991.

Abstract: Eng. Mg. Journ., Vol. 59, 1895, New York, pp. 556-557.

Tin is found both in massive and stratified rocks. Lode mining has been extended from Herberton as a center westward to Watsonville, Irvinebank, Eureka Creek and Koorboora, southwest to Coolgarra, Glenlinedale and California Creek. Alluvial ore occurs from Herberton to the Tate River and Fossilbrook, a distance of 80 miles. In the neighborhood of Herberton, the tin bearing rock is mostly porphyry at the outcrop, but of a granitoid structure in depth; hornblende is in places a constituent. Quotes R. L. Jack in describing tin bearing veins as metamorphosed dikes, probably originally diorite, now mainly of quartzose chlorite and quartzose serpentine. In depth veins develop more quartz. Ore is cassiterite, mostly in lenticular deposits, reaching a length of 40 and 50 feet, and in depth from a few inches to several hundred feet. Yield ranges from 5 to 40 per cent oxide. Wolframite, fluorspar, galena and molybdenite occasionally accompany the tin. Alluvial tin is derived from open gullies and gravels now covered by lava. Ilmenite and gem stones sometimes accompany ore.

928. Newland, D. H. Tin in Queensland.

Min. Ind. for 1902, Vol. 11, 1903, New York and London, p. 593.

Brief summary of tin mining conditions in Queensland.

929. Newman, G. H. Kangaroo Hills mineral field.

Ann. Rep. Under-Secretary for Mines, Queensland, for 1904 (1905); Brisbane, pp. $82-84$.

The progress of tin mining in the Kangaroo Hills district during 1904 is summarized.

929a. Nicholas, C. E. Stannary Hills mines, N. Q.

Queensland Gov. Mg. Journ., Vol. 10, 1909, Brisbane, pp. 552-554. Mlus.

Reports for six months, April, 1909, to September, 1909.

PhilutPs, J. A., and Louis, H. See No. 1350.

Reyer, Eduard. See No. 1354.

Rolker, Chas. M. See No. 1357.

930. Russel, Murray. Report on the Walsh and Tinaroo mineral field and Hodgkinson gold field.

Ann. Rep. Under-Secretary for Mines, Queensland, for 1904 (1905), Brisbane, pp. 111-115.

931. Sellheim, P. F. Report of mining industry of Queensland for year 1895 . 1896, Brisbane, pp. 32-34.

Treats briefly the tin of Herberton and surrounding distriets.

932.

Ann. Rep. Under-Secretary for Mines, Queensland, for 1896 (1897), Brisbane, pp. 102-104.

Reviews tin mining during 1896 and shows that there was some reduction in the output.

933. Short, C. H. Stanthorpe and Pikedale fields.

Ann. Rep. Under-Secretary for Mines, Queensland, for 1904 (1905), Brisbane, pp. 100-101.

Notes on the mining progress of the Stanthorpe and Pikedale tin mining flelds during 1904. 


\section{QUEENSLAND (Continued)}

934. Skertchly, Sydney B. J. Report on the deep (tin) lead at Herberton. Geol. Surv. Rep., Queensland, Pub. No. 115, 1896, Brisbane, pp. 1-15, pls. 1-5. (Map, 1 inch $=40$ chains.)

Discussion of geological conditions, history, and description of tin workings.

935.

gold mines at Herberton, Chillagoe, California Creek, Tate River, etc.; also geological notes on Myola, on the recovery of the lost lodes and on the copper plant.

Geol. Surv. Rep., Queensland, Pub. No. 119, 1897, Brisbane, pp. 64, pls. 18, figs. 37. Describes various mines of the Watsonville district, with geology of the surrounding country. Gives statistics of the region. Notes tin ore that is phosphorescent when heated. Considers the tin mines of the region unsurpassed.

936. - On the geology of the country round Stanthorpe and Warwick, South Queensland, with special reference to the tin and gold fields, and the silver deposits.

Geol. Surv. Rep., Queensland, Pub. No. 120, 1898, Brisbane, pp. 98, pls. 3, maps 2 and text figs.

Gives a general article on tin showing distribution; output; percentage in ores of famous mines; table giving associated rocks, mineral, etc.; output; origin; minerals containing traces of tin. Thinks tin was deposited from solution. Detailed description of mines.

937. Staines, Arthur. Port Douglas district.

Ann. Rep. Under-Secretary for Mines, Queensland, for 1904 (1905), Brisbane, p. 87 .

Report of mining progress in the Port Douglas tin mining fields during 1904.

938. Sterling, James. Monograph on the geology and mining features of Silver Valley, Herberton, North Queensland, Australia.

Two parts, 1905, Hamburg.

Part I, pp. 41, 5 pp. geologic maps and sections, text figs.

Part II, pp. 16, 1 p. of 35 figs.

Part I deals with the geology and veins of a portion of the country adjacent to Dry River. Describes veins carrying silver, lead, tungsten, copper, bismuth and tin. Considers the mineral deposits of deep-seated origin.

Part II deals with the microscopic characters of the rocks.

939. WeEdon, Thornhill. Queensland, past and present. An epitome of its resources and development.

1898, Brisbane, pp. 252-253.

Tin is found on the Pascoe River, at Bloomfield, on Palmer River, the Barron Waters, at Herberton including Irvinebank, on the Star River and at Stanthorpe. Mineral first discovered at Stanthorpe in 1872. Production and export value for each year from 1872 to 1896 given. Queensland is third amongst the seven colonies as a tin-producing district coming after New South Wales and Tasmania.

940. William, J. Vivian. Tin production in Queensland.

Mg. Journ. Railw. Comm. Gaz., Vol. 47, 1877, London, p. 601.

Describes the mineral resources along Hopkinson and Palmer rivers, Queensland, and possible effect the tin deposits might have on the Cornwall tin trade.

940a. Williams, G. W. Tin mining and milling in North Queensland.

Eng. Mg. Journ., Vol. 87, 1909; New York, pp. 1092-1094.

Treats of mining conditions, describing operations of various companies of North Queensland. 


\section{RUSSIA}

941. ANonYmous. Russische Bergwerksverhältnisse.

Berg. Hiitt. Zeit., Vol. 52, 1893, Leipzig, p. 328.

Gives the tin production of Russia, also the amount imported for years 1888, 1889, 1890.

942. Tin in Russia.

zatiothe Mg. Journ. Railw. Comm. Gaz., Vol. 81, 1907, London, p. 219.

140 zastor f Translation from "Viestnik Frnansoff." The tin situation in Russia is serious, since the closing of the Pitkäranta tin smelter. Russia inported in 1964, 301,000 poods. Pitkäranta deposits are of little value. Recommends attention to deposits on Onon River, Transbaikal region, where the tin outlook is encouraging.

BorgströM, L. H. See No. 1594.

Cotta, Bernard von. See No. 1312.

943. FiEDLER, K. G. Ueber die alten Zinnstein-Gruben am Onon in Dauurien (Ononsky Priski Olowennoi Sawod).

Arch. Miner. Geogn. Bergb. Hütt., Vol. 12, 1839, Berlin, pp. 178-188.

Digest: Neues Jahrb. Min., 1841, Stuttgart, p. 714.

Tin deposits are located 87 "werst" from the junction of Onon and Ingoda rivers. Tin occurs in segregations in granite dikes cutting hornblende schists. Wolframite occurs with ore in some places.

Gadouin, S. A. See No. 1612.

944. Gurney, H. P. Notes on the geology of Finland.

Trans. Fed. Inst. Mg. Eng., Vol. 15, 1898, Newcastle-upon-Tyne and London, pp. $147,152$.

10 Hertigrat Mentions the deposits of tin at Pitkäranta, on the northeastern shore of Lake Ladoga. Production is small.

945. HermanN, R. Untersuchungen russischer Mineralien. Ueber das Vorkommen von gedlegenem Zinn in den Ural'schen Goldseifen.

Journ, prakt. Chenı., B. 33,1844 , Leipzig, p. 300.

946. KEPPEN, A. DE. Aperçu général sur l'industrie minérale de la Russie.

Ann. Mines, ser. 9, Vol. 5, 1894, Paris, pp. 233-234.

Treats very briefly of tin in Finland.

Koulibine, S. See Nos. 1690, 1691 and 1692.

947. Kruscr, P. Ueber sicht über die nutzbaren Lagerstätten Russlands. Zeitschr. prakt. Geol., 1897, Berlin, p. 277.

States that lode tin is found at Pitkäranta, Finland, and that stream tin is found along the Onon River, Siberia.

Louis, Henry. See No. 1340.

948. NordenskiöLd, A. E. Beitrag zu Finnlands mineralogie.

[Trans.] Ann. Physik. Chem., Vol. 101, 1857, Leipzig, pp. 625-642.

Brief digest, Neues Jahrb. Min. 1858, Stuttgart, p. 467.

Tin of Pitkäranta treated.

- See No. 1628a.

Phirlirs, J. A., and Lours, H. See No. 1350. 


\section{RUSSIA (Continued)}

949. Pusch, Geo. G. Kupfer- und Zinnerz-Bau am Ladoga-See; Geognosie Finnlands und von Petersburg.

Neues Jahrb. Min., 1836, Stuttgart, pp. 197-199.

A communication written Dec. 1835, giving an account of the tin occurrences in Finland.

950. Schoultz-Ascheraden, G. von. Die Kupfer- und Zinnerz-Lagerstätte zu Pitkäranta in Finnland.

Berg. Hütt. Zcit., Vol. 35, 1876, Leipzig, pp. 280-281. Mit. fig. 8 u. 9 auf Taf. 13.

951. STruve, H. von. Tin in Russia.

Neues Jahrb. Min., 1834, Stuttgart, p. 398.

The announcement of a discovery of tin ore at Pitkäranta, communicated in a letter by H. von Struve.

952. TörNeBonM, A. E. Om Pitkäranta malmfält och dess omgifningar.

Geol. För. Stockholm Förh., Vol. 13, 1891, Stockholm, pp. 324-325, map 1.

Description of the tin of Pitkăranta, Finland.

953. TRÜstedt, Отто. Die Erzlagerstätten von Pitkäranta am Ladoga-See.

Bull. Com. Géol. de Finland, No. 19, 1907, Helsingfors, pp. 333, with geol. map 1, pls. 19 and text figures 80. Pp. 140-151, and others.

Reviewed by Knopf, Adolph, Econ. Geol., Vol. 3, 1908, Lancaster, pp. 540-542.

“This monographic report of ore deposits of Pitkäranta, is interesting from three standpoints: As a study of contact, metamorphism; as an investigation of preCambrian ore-deposits in highly metamorphic rocks, and as an lapplication of magnetometry to the location and computation of iron-ore reserves.

"Briefly, Pitkaranta is characterized as an iron-ore district locally rich in copper and tin ores. The latter deposits are quite fully treated."

\section{SANTO DOMINGO}

954. Garston. E. M. DE. Mineral Resources of the Dominican Republic.

Mg. Journ. Railw. Comm. Gaz., Vol. 83, 1908, London, p. 682.

States that "Tin deposits are said to exist in Seybo and in the Higuei, Province of Seybo." Quoted from a British Consular Report.

\section{SCOTLAND}

Fawns, Sydney. See No. 1320.

955. Flett, J. S., and Clough, C. T. Tinstone in Scotland.

Mem. Geol. Surv., Summ. Progr. Geol. Surv. United Kingdom and Mus. Pract. Geol. for 1903 (1904), London, pp. 2, 59-60.

First recorded occurrence of tinstone in Scotland. Occurs with magnetite. No indication that it occurs in any quantity.

\section{SIAM}

956. ANonYMous. A note on mining in Siam. A reprint from the copyright publications of the Royal Commission for the Louisiana Purchase Exposition.

Published by Mining Department of Siam, 1904, pp. 3-4.

Gives a list of the districts in which alluvial tin is mined, and states that the possibilities of tin mining in Siam are large. 


\section{SIAM (Continued)}

957. - Mining in Siam.

Eng. Mg. Journ., Vol. 79, 1905, New York, p. 190. Probably taken from the Siamese Louisiana Purchase Exposition Publication. See No. 960.

Tin is the only metal, the working of which is of any importance in Siam. Deposits of importance are derived from, and lie adjacent to, the great granitic range which forms the boundary between central Siam and Tenasserim, and the backbone of the Malay Peninsula.

958. Tin mining in Siam.

Écho des Mines, April 29, 1907.

Quoted in Mg. Journ Railw. Comm. Gaz., Vol. 81, 1907, London, p. 593.

Tin mined principally in the provinces of Puket and Kedah. Annual production about 5000 tons. Vast district yet unexplored, which probably contains considerable mineral wealth.

959. Blewet, JASPer. Tin mining in the Straits Settlement.

Eng. Mg. Journ., Vol. 22, 1876, New York, p. 156.

An account of the tin mining on Junk-Seylon or Salanga, an island on the coast of Lower Siam.

960. Carter, A. Cecil. Editor. The kingdom of Siam.

Published by the Ministry of Agriculture for Louisiana Purchase Exposition, 1904, New York, pp. 211-243, 500 words.

Small amounts of tin are found in the valley of the Nam Sak River. Tin placers are worked in the following provinces: East Coast-Ratburi, Bangtaphan Langsuan, Chaija, Bandon, Lakon, Jalar, Rangeh, Rahman, Kelantan, Tringanu. West CoastKra, Renong, Takupar, Panga, Takuatung, Puket, Trang, Stul, Perlis, Kedah. Annual production about 5000 long tone, valued at $\$ 3,000,000$. Puket Island on the West Coast is the most important field. Most promising for future developments are Kedah Rahman, Jalar, Takuatung and Renong. Work mostly in hands of Chinese. One American, one English, and one Dutch firm at work. There is an enormous field for the expansion of the tin-mining industry in the Siamese possessions in the Malay Peninsula.

D'Achiard, Antonio. See No. 1313.

Fawns, Sydney. See No. 1320.

961. Fischer, H. Ueber siamesische Mineralien.

Neues Jahrb. Min., 1882, II, Stuttgart, p. 196.

Tin is the most important mineral of Siam. Alluvial tin is found in provinces of Xalang, Xaija, Xumphon, Rapri and Pak-Phrëk.

Reyer, Eduard. See No. 1354.

962. ScotT, H. G. A note on mining in Siam.

Mg. Journ. Railw. Comm. Gaz., Vol. 76, 1904, London, p. 185.

Practically the same as No. 960 from which it seems to be largely taken.

See also Laos.

\section{SIBERIA}

963. Anonymous. Tin in Siberia.

Min. Ind. for 1900, Vol. 9, 1901, New York and London, p. 640.

Notes recent discoveries of tin on the Onon River. 


\section{SIBERIA (Continued)}

964.

\section{Zinnerzlager in Ost-Sibirien.}

Zeitschr. prakt. Geol., 1901, Berlin, p. 245.

Brief digest: Eng. Mg. Journ., Vol. 71, 1901, New York, p. 240, taken from “ Engineering," London.

Notice of the deposits of tin in Province Transbaikalien, near Onon River and tributaries. Its situation is fortunate, being easy of transportation, and nearness to the forest facilitates working.

D’Achiardi, Antonio. See No. 1313.

Fawns, Sydney. See No. 1320.

965. Foniakoff, Antonin. The gold deposits of Siberia.

Trans. Fed. Inst. Mg. Eng., Vol. 7, 1894, Newcastle-upon-Tyne and London, pp. 447, 466, 479.

For more than a century and a half in the Transbaikal, silver, gold, lead, iron, copper, mercury and tin have been worked.

966. - Les richesses miniéres de la Sibèrie.

Rev. Univ. Mines Met. Trav. Publ. Sci. Arts Appl. Indust., ser. 3, Vol. 29, 1895, liége and Paris, p. 129.

967. Glasser, E. Note sur les richesses minérales de la Sibèrie et sur l'etat actuel de leur exploitation.

Ann. Mines, ser. 9, Vol. 18, 1900, Paris, p. 53, maps.

Mentions that tin is found in the valley of the Onon.

968. HermanN, R. Sur l'étain natif.

Extrait: Journ. prakt. Chem., Vol. 33, 1844, Leipzig, p. 300.

Ann. Mines, ser. 4, Vol. 8, 1845, Paris, p. 660.

M. Hermann indique la presence de l'étain natif avec l'or, dans les lavages d'or de la Sibérie. Il s'y trouve sous la forme de petits grains métalliques gris qui sont de l'étain allie d'un peu de plomb. Ces grains sont du reste peu abondants. [Whole extract.]

JEREMEJEV, P. See No. 1622.

969. Keppen, A. Mineral wealth of Siberia.

Industries of Russia, Vol. 4, 1893, St. Petersburg, pp. 30-31.

(For the World's Columbian Exposition at Chicago. Trans. by J. M. Crawford.)

Reprint: Mg. Journ. Railw. Comm. Gaz., Vol. 65, 1895, London, p. 243.

Deposits of tin are known only in Finland and Baikal province of Siberia. Production under 20 tons. Since yearly demand of Russia is over 100,000 poods, internal production is utterly insufficient for home consumption.

970. Konzoukhine, J. A. Gisements de minerais d'étain sur la Rivière Onon.

Bull. No. 4, Soc. Ing. Mines, 1899, St. Petersburg, pp. 22-35.

Digest: Trans. Inst. Mg. Eng., Vol. 17, 1900, London and Newcastle-upon-Tyne, pp. 642-646.

"With the exception of Pitkaranta, where the production of tin is insignificant, the only Russian deposits of cassiterite are in the territory of the Transbaikal, on the River Onon and its affluents."

971. RŁontovski, - Les gisements miniers dè la Sibérie.

(Bulletin) Rev. Univ. Min. Mét. Trav. Publ. Sci. Arts Appl. Indust., ser. 4, Vol. 12, 1905, Paris and Liége, p. 204.

Les gisements de cassitérite sont connus dans la vallee de la Rivière Onon, en Transbaicalie. Leur exploitation exige une preparation mecanique importante. 


\section{SOUTH AMERICA}

See under Argentine Republic, Bolivia, Chili, French Guiana, Peru.

\section{SOUTH AUSTRALIA}

972. ANonymous. Tin in South Australia.

Min. Ind. for 1900, Vol. 9, 1901, New York and London, pp. 637-638.

Discovery of tin ore near Erea Dam, in quartz vein, reported. Prospects seem encouraging.

973. Brown, H. Y. L. Report on the Koetong tin field, Wodonga district.

Reports of the Mining Surveyors and Registrars, 1873, (App. A.), Melbourne, p. 42. Quoted in Mg. Journ. Railw. Comm. Gaz,, Vol. 43, 1873, London, p. 1220.

Tin-field comprises large area between Murray and Mitta-mitta rivers. Bed rock is granite of various kinds, mostly coarse with black and white mica in large plates. Deposit varies from few inches to 2 or 3 feet thick. Wash dirt made up of boulders and angular fragments of granite and quartz. Ore is disseminated all through wash, and also in layers, but more plentiful on or near bed rock. No lodes of workable size found. Lists of principal claims given.

974. - Report on the gold discovery at Tarcoola, the Enterprise Mine, the Earea Dam tin find and the Mount Gunson copper mine.

Rec. Mines, South Australia, 1900, Adelaide, p. 6.

The tin discovery is situated $1 \frac{1}{2}$ miles south of Earea Dam, on a mud lake where the surface sand and loam have been eroded, and expose granite, diorite and other hornblendic rocks containing quartz. A dishful of the alluvial soil over the tin vein outcrop yielded 1 pound, 10 ounces of tin; on being smelted, it gave 1 pound tin or 90 per cent. Prospectors have sunk in the quartz veins, but would probably meet with more success in prospecting for alluvial tin.

Fawns, Sydney. See No. 1320.

\section{SOUTH DAKOTA}

975. ANonymous. The Black Hills of Dakota. [Tin ore.]

Eng. Mg. Journ., Vol. 36, 1883, New York, p. 111.

A communication from one who had visited the mines.

976.

Tin in the Black Hills.

Eng. Mg. Journ., Vol. 38, 1884, New York, p. 358.

Editorial: Brief review of the effect of Prot. Chas. A. Schaeffer's paper, "Note on tantalite and other minerals accompanying the tin ore in the Black Hills."

.

977. - An immense tin deposit.

Mg. Sci. Press, Vol. 4S, 1884, San Francisco, p. 34.

A very enthusiastic and exaggerated account of a recent tin discovery in the Black Hills. Statements are made that discovery will " revolutionize the trade." "Deposits are so vast as to be able to supply the whole world for centuries."

978 , The tin mines of Dakota.

Eng. Mg. Journ. Vol. 42, 1886, New York, pp. 325-326.

Editorial on the outlook of the Dakota tin mines. 


\section{SOUTH DAKOTA (Continued)}

979. - The waning probabilities of finding paying mines in Dakota. Eng. Mg Journ., Vol. 48, 1889, New York, p. 312. About 500 words.

Editorial on the effort of Harney Peak Tin-mining Co., to boom their mines. The company has induced many English, and are now endeavoring to induce the French to invest in stock.

980. - Nigger Hill tin district (South Dakota).

Eng. Mg. Journ., Vol. 50, 1890, New York, p. 555.

Short account of the finding of stream tin in the placer gold; excitement aroused; forming of companies; working of deposits.

981. The Harney Peak tin deposits.

Mg. Journ. Railw. Comm. Gaz., Vol. 62, 1892, London, pp. 1210-1215. Illus.

General description of the property, when and how tin was discovered in the Black Hills, the opinions of experts, present position of the properties and their possible future.

982. - The Harney Peak tin mines.

Mg. Journ. Railw. Comm. Gaz., Vol. 62, 1892, London, p. 1357.

Extract from "Hill City Tin Miner," of Nov. 18, 1892, detailing the working of the new mill.

983. - The tin ore concentrating plant at Harney Peak, South Dakota. Eng. Mg. Journ., Vol. 54, 1892, New York, pp. 102-104.

Reprint: Ann. Rep. Secr. Min. Wat. Supp. of Victoria for 1892 (1893), Melbourne, p. 52 .

Two pages devoted to plans of Harney Peak tin ore concentrating mill. Article describes methods used and results obtained.

984. - Tin at Nigger Hill, South Dakota.

Mg. Sci. Press, Vol. 89, 1904, San Francisco, p. 19.

The Tinton Co., on Nigger Hill, Lawrence Co., South Dakota, has the distinction of being the only concern in America at present, crushing and concentrating tin ore. Ore occurs in large dikes of coarse granite, similar to that in Harney Peak region.

985. - Tin in United States.

Mg. Sci. Press, Vol. 89, 1904, San Francisco, p. 385. Mlus.

The Nigger Hill-Bear Gulch region on the South Dakota-Wyoming line has received much encouragement in the development of the industry. The Tinton Tin Co., has been operating a small concentrating plant. Cassiterite occurs in dikes of granite of very coarse crystallization.

986. South Dakota.

Mg. World, Vol. 22, 1905, Chicago, pp. 412-413.

A stamp mill and tin concentrating plant which have been erected will treat tin and gold ore taken from a shaft 500 feet deep which has been sunk on the old Gertie property.

987. - Tin in Dakota.

Eng. Mg. Journ., Vol. 79, 1905, New York, p. 469.

Brief account of recent discovery of tin ore at Tinton, Lawrence Co., S. D.

987a. - Tin mining in South Dakota.

Eng. Mg. Journ., Vol. 88, 1909, New York, p. 828.

Short description of tin mill of Tinton Milling Co., Tinton, S. D.

988. Bailey, Gilbert E., and Riotte, E. N. Harney Peak Tin Mining, Milling and Manufacturing Company.

1886, New York, pp. 77.

Reports on the property of the company. 


\section{SOUTH DAKOTA (Continued)}

BECK, RichaRd, See No. 1299.

989. BENEDICT, WM. DE L. Prof. Vincent's estimates of possible profits of the Harney Peak tin mines (Dakota).

Eng. Mg. Journ., Vol. 48, 1889, New York, pp. 358-359.

$A$ brief review and criticism of Prof. Vincent's report on the mine.

990. - Tin in South Dakota.

Min. Ind. for 1892, Vol. 1, 1893, New York and London, pp. 453-455.

Short account of the discovery of tin and the early history of development.

991. BLAKe, W (ILLAM) P. The discovery of tinstone in the Black Hills of Dakota.

Eng. Mg. Journ., Vol. 36, 1883, New York, pp. 145, 163-164, 344; Vol. 38, August 2, 1884 , p. 69.

Summary: Amer. Journ. Sci., ser. 3, Vol. 26, 1883, New Haven, p. 235. Same material in Min. Res. U. S. for 1883-1884, U. S. Geol. Surv., Washington, D. C., pp. $592-640$.

Reviews occurrence of tin in U. S. Special description of Black Hills occurrence. Notes on foreign occurrences. A good paper.

992. - Tin ore of the Etta mine, Dakota.

Eng. Mg. Journ., Vol. 38, 1884, New York, p. 69.

An addition to author's article of September of year before. The accompanying minerals are named and briefly described.

993. - Columbite and tantalite with the tin ore of the Black Hills.

Eng. Mg. Journ., Vol. 38, 1884, New York, p. 376.

Interesting communication explaining the difficulty occasioned by Prof. Schaeffer's analysis of a sample sent to him for examination. It was not sent as tin ore, but as a specimen to be analyzed, the nature of which the superintendent wished to know. It was analyzed as tantalite and from this went abroad the report that there was no tin ore, but tantalite, in the Black Hills.

994. - Tin ore in the Black Hills, Dakota.

Min. Res. of U. S. 1883-1884, U. S. Geol. Surv., 1885, Washington, D. C., pp. 602-613. Treated under following subjects:

The discovery of tin at the Etta mine; geological horizon; development work at the Etta mine; concentric structure of the Etta vein; varieties of ore at the Etta claim; greisen rock carrying tinstone; percentage of tin in the greisen; Bob Ingersoll claim; western slope of Harney range; tin discovered at Dogtown; area of the tin region; stream tin in Dakota. An excellent account of the geology and development of the Black Hills tin district.

995. Tin ore veins in the Black Hills of Dakota.

Trans. Amer. Inst. Mg. Eng., Vol. 13, 1885, New York, pp. 691-696.

Digest: Oest. Zeitschr. Berg. Hütt., Vol. 33, 1885, Wien, p. 302.

Treated under: Structure of the Etta vein; percentage of black tin in the ore; minerals associated with the tin ore; extent of the tin region; contemporaneous origin of the ore and rock.

996. - Tantalite and columbite in the Black Hills of Dakota.

Trans. Amer. Inst. Mg. Eng., Vol. 13, 1885, New York, pp. 696-697.

"There are two localities where the mineral (tantalite or columbite) is found in the same dike or vein as the cassiterite: (1) at the Etta mine; (2) at the Bob Ingersoll claim."

Gives observations upon the occurrence of the minerals with the tin ore. States that one mass of columbite or tantalite from the Ingersoll claim weighed approximately, 2000 pounds. (Digest by Cleophas C. O'Harra.) 


\section{SOUTH DAKOTA (Continued)}

997. - Cassiterite, spodumene and beryl in the Black Hills, Dakota.

Amer. Journ. Sci., Vol. 26, 1883, New Haven, p. 235.

Brief review: Neues Jahrb. Min., 1885, II (Ref.), Stuttgart, p. 4.

$A$ short description of the manner in which tin ore occurs in the Black Hills.

998. Carpenter, Frankun R. Tin in the Black Hills.

Preliminary Report Dakota School of Mines, upon the Geology, Mineral Resources and Mills of the Black Hills of Dakota, 1888, Rapid City, pp. 133-166, figs. 2.

The paper is divided into two parts:

1. Relating to the Black Hills tin.

2. Relating to the subject of tin generally.

The occurrence of tin in the Black Hills, including its geology, extent and mode of treatment, also information compiled from the works of others that may be of benefit to the mining prospector and mining companies preparing to work deposits, A number of assays are given.

999. - Ore deposits of the Black Hills of Dakota.

Trans. Amer. Inst. Mg. Eng., Vol. 17, 1889, New York, pp. 570-598, colored map, fig. 1.

Practically same thing in Min. Res. U. S. for 1888, U. S. Geol. Surv. 1890, Wash. ington, D. C., pp. 149-156.

General statement of occurrence of tin ore. Mentions presence of mineral autunite. Says that when all three constituents of granite are present no tin is found. Any two get tin. Mentions galena, graphite, barite, ilmenite as accompanying minerals. Thinks both granite and tin are deposited by solutions. Says tin has been found near veins in the country rock. Not very reliable paper.-L. C. Graton.

1000. Tin in the Black Hills.

In Pa-Ha-Sa-Poh, or the Black Hills of South Dakota, by Rosen, Peter, 1895, St. Louis, pp. 636-645.

Gives an account of the discovery, the occurrence and character of the veins and the accompanying minerals, and likens the veins to those of Zinnwald.

1001. Tin in the Black Hills, South Dakota.

Mg. World, Vol. 25, 1906, Chicago, pp. 600-601. Sketch showing formation of the Black Hills' tin deposits.

The writer believes with increased price of tin and improvements in mining machinery, that tin mining in Black Hills will yet be an industry that will rank second to gold mining of that section.

Carpenter, F. R., and Headden, W. P. See No. 1466.

1002. Chance, H. M: Resources of the Black Hills and Big Horn Country, Wyoming.

Trans. Amer. Inst. Mg. Eng., Vol. 19, 1891, New York, pp. 49-58. Read New York meeting September, 1890.

Gives result of an examination made in 1887-1888 of the country lying between the Black Hills and Big Horn Mountains. Refers briefly to the structure, resources and scenery of the Hills. Thinks there will be a considerable output of tin from the southern hills, especially from about Custer City.

1003. Claypole, E. W. Tin islands of the northwest.

Amer. Geol., Vol. 9, 1892, Minneapolis, pp. 228-236.

Detailed account of geologic history of Black Hills with only short space devoted to tin. Thinks granite masses are segregated veins, since they conform with the schists.

1004. Day, David T. Tin.

Min. Rez. U. S. for 1887, U. S. Geol. Surv., 1888, Washington, D. C., pp. 134-137. 


\section{SOUTH DAKOTA (Continued)}

atowsci A review of work done and tin mines opened in the Black Hills, Dakota. "Cleveland" mine was selected for heaviest operations. Hoisting plant and suitable buildings have been erected. Three tons of stream tin and 250 pounds of metallic tin have been shipped.

1005 . Dakota tin mines.

14 Min. Res. U. S. for 1888, U. S. Geol. Surv., 1800, Washington, D. C., pp. 144-156. Review: Neues Jahrb. Min., 1891, II (Ref.), Stuttgart, 237-233.

Present outlook reported as very encouraging. Character of veins; analyses of cassiterite from veins; percentage of black tin in the rock; treatment of the ore; yield of metallic tin.

1006. Emmens, Stephen H. Tin in South Dakota.

Eng. News Amer. Railw. Journ., Vol. 2S, 1892, New York, pp. 208-209.

Author gives what seems to be a careful and apparently unprejudiced statement concerming the South Dakota tin.

1007. Garrison, F. Lynwood. Tin in the Black Hills.

Eng. Mg. Journ., 'Vol. 78, 1904, New York, p. 830.

Review of work done.

Geology of the district.

1008. HEADDEN, WM. P. Notes upon the history of the discovery and occurrence of tin ores in the Black Hills of South Dakota.

Proc. Colorado Sci. Soc., Vol. 3, 1890, Denver, pp. 347-350.

A good article upon the general geology of the deposits. Thinks there are two kinds of deposits: (1) original in the granites; (2) secondary in quartz veins. Says the granite (i. e. peginatite) is pre-Cambrian.

"States that the carliest identification of tin from the Black Hills was in 1876 by Mr. Richard Pearce of Denver, Colo., who detected cassiterite as stream tin in gold dust from the Northern Hills. The second discovery was made on Elk Gulch, southern section, in April, 1877. The material from the latter place was assayed by Theo. Vosburg, but the true nature of the bullion was first recognized by Mr. Fred J. Cross. Dates of various other discoveries and remarks on the general geology of the

Crit th ass. Dates of various other discoveries and remarks on
region are also given." (Digest by Cleophas C. O'Harra.)

\section{See No. 1616.}

1009. Hess, Frank L. Tin, tungsten and tantalum deposits of South Dakota. U. S. Geol. Surv. Bull., 380, 1909, Washington, D. C., pp. 131-163, text fig. 1.

(zoursero Abstract: Mg. World, Vol. 31, 1909, Chicago, pp. 457-460.

- Cassiterite occurs in the southern Black Hills in pegmatite dikes and in quartz veins. The quartz veins also carry important amounts of wolframite which sometimes forms beautiful intergrowths with light colored cassiterite. Many other minerals occur in the pegmatites with the cassiterite, including spodumene, amblygonite, lepidolite, apatite, tantalite, columbite, pyrite, arsenopyrite, chalcopyrite, tourmaline, etc., but there is little or no fluorite, topaz, or axinite. The dikes which carry most tin are the finer-grained and carry the least number of accessory minerals. The quartz veins are probably a later phase of the same intrusions which formed the pegmatites, and the two grade into each other. In the northern Black Hills, at Tinton, tin occurs in pegmatites, similar to those in the southern Hills, but with fewer accessory minerals.

Hofman, Heinrich O. See No. 1506.

1010. Irving, John DuER. Economic resources of the Northern Black Hills. U. S. Geol. Surv., Prof. Paper No. 26, 1904, Washington, D. C., pp. 95-97. 


\section{SOUTH DAKOTA (Continued)}

Gives a short history of the discovery of tin in the Black Hills and the efforts to mine it. States that cassiterite occurs at Nigger Hill in Cambrian pegmatitic granite which is an inclusion in Tertiary acid porphyry. Columbite, tantalite, tourmaline, and wolframite accompany the cassiterite. The cassiterite is irregularly distributed through the granitc, and may possibly be mined on a small scale at a profit.

Says topaz accompanies stream tin in the creeks of the area.

1011.

- The ore deposits of the Northern Black Hills.

Mg. Rep. Vol. 50, 1904, Denver, pp. 430-431.

Some tin occurs in the Algonkian schists. "The tin ore also occurs in placers as stream gravels, derived from distintegration of the country rock containing tin. The cassiterite in these gravels is but little rounded and differs in its black color from the reddish brown type of stream tin.", See No. 1010.

1012. M-, H. Tin mines in the Black Hills of Dakota.

Mg. Journ. Railw. Comm. Gaz., Vol. 61, 1891, London, p. 694.

Extracts from report of English Consul at Chicago. Speaks of tin outlook as very encouraging from various reports of experts. Describes deposits chief of which are found in Custer and Pennington counties, as veins, varying from a foot to more than 300 feet in width, and in length from a few yards to 5 miles. Outcrops are from a few feet to 150 feet above surface. Abundant fuel at hand.

1013. Morse, Arthur J. The Harney Peak tin mines.

Eng. Mg. Journ. Vol. 58, 1894, New York, p. 463. Summary of surface developments. Says surface indications are not borme out in depth. Describes and gives illustration of pinching out of " greisen " band, and says quartz veins do the same.

1014. O'Harra, Cleophas C. The mineral wealth of the Black Hills (South Dakota). Tin.

South Dakota, Geol. Surv. Bull. No. 3, Mineral Resources of South Dakota, 1902, Vermillion, pp. 62-67.

Gives a general sketch of the geology of the Black Hills and describes the occurrence of the minerals.

Rosen, Peter. See No. 1000.

1015. S(Torms?), W. H. Bear Gulch tin district, South Dakota.

Mg. Sci. Press, Vol. 86, 1903, San Francisco, pp. 198-199.

This district is of unusual interest, as in it occur both mines of gold and tin. The gold miners were greatly hampered in their sluicing, by the abundant occurrence of black sand and small pebbles of high specific gravity which filled riffles and caused loss of gold. About $\mathbf{1 8 8 0}$ it was discovered that this sand-at least part of it, was cassiterite. Other minerals of economic importance in this district are, wolframite and columbite-tantalite.

1016. Sadtuer, B. Gold and tin in Northwestern Black Hills.

Mg. World, Vol. 25, 1906, Chicago, pp. 520-522, sections 5.

Editorial on same: Ibid., p. 517.

Treats of gold and tin bearing districts in Crook Co., Wyoming, and Lawrence Co., South Dakota. "The district shows proper geologic conditions being identical with the historic Deadwood district, with addition of a large belt of tin veins. It is admirably located as regards wood, water and all necessary supplies, as well as being within the reach of railroads. It has exposed and partly developed large bodies of gold and tin ore in vein, and large and quickly available almounts of the same metals in placers, all of pay grade. Incidental to the extraction of the above metals, mica and tungsten form a prohable source of income." 


\section{SOUTH DAKOTA (Continued)}

1017. Schaefrer, Chas. A. Note on tantalite and other minerals, accompanying the tin ore in the Black Hills.

Trans. Amer. Inst. Mg. Eng., Vol. 13, 1884-1885, New York, pp. 231-233.

The analysis of some ore from Etta mine which at first seemed like tin ore, but proved to be tantalite. This report caused a great stir among mining men, thinking Prof. Schaeffer intended to show that the supposed tin ore was tantalite. Such was not the case. The specimen sent for examination was not sent as tin ore, but as an unknown ore which proved to be the above-named mineral.

1018. Simmons, Jesse. Review of South Dakota mining conditions.

Mg. Rep., Vol. 50, 1904, Denver, p. 63, photos 3, 2700 words.

"Illustrated description of the Black Hills gold and tin mines. Gives monthly tonnage, treatment and value of the different ores."

1019. - Tin mining, metallurgy and geology, Black Hills.

Mg. Rev., May 25, 1906, Los Angeles.

Not available to the authors.

1019a. Tin in the Black Hills of South Dakota.

Mg. World, Vol. 30, 1909, Chicago, pp. 925-926, sketch 1.

Extract: Mg. Journ. Railw. Comm. Gaz., Vol. 85, 1909, London, p. 703.

"A short historical review of tin mining in the Black Hills, with notes on the geology of the district and the operations of the Harney Peak Company."

1020. Struthers, Joseph, and Pratt, Joseph Hyde. Tin in South Dakota and

Wyoming.

Min. Res. for 1903, U. S. Geol. Surv., 1904, Washington, D. C., pp. 335-336.

A new district has been worked for past two years, located partly in Lawrence Co., South Dakota, and partly in Crook Co., Wyoming. Cassiterite occurs in pegmatite greisen or altered granite, and is generally in the form of coarse granules, although large msisses of fine grains of the mineral are found between the schist and porphyry. Ore has averaged 1 per cent of metallic tin, and concentrates have ranged from 62.5 to 65 per cent of metallic tin.

1021. Thomas, Josian, with notes by J. S. Chrlds. The Harney Peak tin deposits.

Eng. Mg. Journ., Vol. 54, 1892, New York, pp. 512-514, 536.

Reprint: Mg. Journ. Railw. Comm. Gaz., Vol. 62, 1892, London, pp. 1182-1183. Editorial: pp. 1190-1191.

Lodes occur in slate and schists surrounding Harney Peak, which is of granite. In almost all instances lodes or ledges are either vertical or dipping away from the granite. Lodes small but continuous, being from 1 to 3 feet wide composed principally of quartz. Gives description of various workings. No theory as to origin of deposits. Ore will yield 40 pounds of black tin per ton, giving 73 per cent metallic tin.

1022. ThurLow, Lord. The Harney Peak tin properties.

Mg. Journ. Railw. Comm. Gaz., Vol. 62, 1892, London, p. 907.

Extracts from a report made after visiting deposits, the object of which was to ascertain the amount of development done, inspect machinery, ascertain probable date at which tin production on a commercial scale might begin. Report does not give geographical or geological description.

1023. Topd, J. E. Geology of South Dakota. Tin.

South Dakota Geol. Surv. Bull No. 1, a Preliminary Report on the Geology of South Dakota, 1895, Sioux Falls, pp. 149-150, pls. 5, figs. 2, map 1.

Analyses of tin ore from veins contains 74.5 to 76.7 per cent tin which is higher than that from other prominent localities. 


\section{SOUTH DAKOTA (Continued)}

1024. Ulke, Titus. A contribution to the geology of Dakota tin mines.

Eng. Mg. Journ., Vol. 53, 1892, New York, p. 547.

Thinks granitic dikes are of igneous origin but says they show little metamorphosing action on the schists. Mentions apatite, triplite, heterosite, triphylite, almandite, wolframite, beryl, sphalerite, cuprocassiterite, graphite. Calls attention to absence of fluorine minerals, hornblende, molybdenite, etc. Tin segregated in pockets or zones with intervening barren places.-L. C. Graton.

- See No. 1646.

1025. Vincent, M. C. The tin deposits of Dakota.

Mg. Journ. Railw. Comm. Gaz., Vol. 58, 1888, London, pp. 971-972.

Extracts from a report on the Black Hills deposits. Tin occurs in granite in two distinct forms or types, "1st of the approximately circular or columnar form, where the granite mass stands almost vertical, and $2 \mathrm{~d}$, those filling a long narrow, longitudinal rent or fissure." 83 assays of black tin made by author averaged 74.31 per cent metallic tin. Absence of iron, lead, arsenic, and zinc. Description of mines. Author believes that mines will prove productive.

\section{SPAIN}

1026. Anonymous. L'industrie minérale de l'Espagne en 1893.

Rev. Univ. Mines Mét. Trav. Publ. Sci. Arts Appl. Indust., ser. 3, Vol. 26, 1894, Paris and Liége, p. 236.

The provinces of Orense, Pontevedra and Coruña are mentioned as tin producing, while that of Salamanca has ceased since 1894 on account of heavy taxation.

1027. - Tin in Spain and Portugal.

Min. Ind. for 1897, Vol. 6, 1898, New York and London, p. 641.

According to report of U. S. Consul at Corunna, tin ore has been worked considerably in Galicia during late years. There is a wide tin-bearing belt, which runs from Zamora through a corner of Portugal, through the Province of Orense and from there through Santiago up to the coast, nearly 250 miles.

Beck, Richard. See No. 1299.

1028. Borlase, William Copeland. Tin mining in Spain, past and present.

London (1898), pp. 40, illus. 10, map 1.

Gives a historical sketch and generalized account of tin mining in Spain, with a few references to Portugal. Geology is lightly skimmed. Thinks there is a large quantity of ore in Spain carrying $2 \frac{1}{2}$ per cent tin.

Brown, A. Selwyn. See Nos. 1307 and 1308.

1029. Calderón, D. Salvador. La cassiterite y los filones estanniferos de nuestra Peninsula.

Bol. Soc, esp. Hist. Nat., Vol. 1, 1901, Madrid, pp. 231-240.

Digest: Geol. Centr., Vol. 2, 1902, Leipzig, p. 357.

L'auteur donne la bibliographie concernant les filons stannifères depuis 1847 a 1900 , et examine les régions stannifères de la Péninsule, qui se groupent en une région principale située dans la Galice et passe en Portugal, et en gisements épars, de peu d'importance.-Choffat.

1030. Calvert, Albert F. Impressions of Spain.

1903 (?) London.

Reviewed: Austr. Mg. Stand., Vol. 31, 1904, Sydney and Melbourne, p. 87.

Tin is mentioned as among the resources of Spain, yet "considerably untouched."

Not available to the authors. 


\section{SPAIN (Continued)}

1031. Coquebert, Ch. Mémoire sur les mines d'Espagne.

Journ. Mines, No. 29, Vol. 5, 1796-1797, Paris, p. 407.

1031a. Connide, Josepr D. Memoria sobre las Minas de Galicia y otras producciones del reyno mineral dirigada al Sr. D. Miguel Bañuelos, su Intendente General.

The work is a folio MS. of 18 pages, in the Biblioteca de la Real Academia de la Historia, Madrid.

Noted by W. C. Borlase in Tin Mining in Spain, Past and Present (1898), page 37.

1031b. De Cortázar, Danier. Datos Geologico. Mineros de la Provincias de Zamora y Orense.

Bol. Com. Mapa Geol. España, Vol. 1, 1874, Madrid, pp. 6, 14.

D'ACHIARd, Antonio. See No. 1313.

Fawns, Sydney. See No. 1320.

Fuchs, E., and Launay, L. DE. See No. 1323.

1032. Garcia, Manuel. Nota acerca de algunos filones estanniferos de la Provincia de Salamanca.

Bol. Com. Mapa Geol. España, Vol. 3, 1876, Madrid, pp. 91-95.

1033. Gartand, Joseph. On certaih tin deposits in Galicia, Spain.

56th Ann. Rep. Roy. Cornwall Polyt. Soc. 1888, Falmouth, pp. 54-57, figs. 3.

No systematic mining or quarrying has been attempted on these tin deposits. The work has been carried on mainly by agricultural laborers and women and children. The ore occurs in a strata of soil, clay, decomposed shale, sand and pebbles. The soft character of this tin ground would admit of cheap working, the only essential dressing machinery being perhaps washing and sizing trommels and automatic jigs. There can be no doubt that these tin deposits would pay to work on a considerable scale.

1034. Gil y Maestre, Amalio. Descripción, fisica, geológica y minera de la Provincia de Salamanca.

Mem. Com. Mapa Geol. España, 1880, Madrid, pp. 255-261.

At Martinamor veins are in gneiss, at other places they are in Silurian slates, more or less dark, gray, greenish, brown, blue. Veins are principally quartz, carrying tourmaline, wolframite, some arsenopyrite and copper sulphide. Veins running in different directions are without noticeable difference in mineralization. Some greisen dikes carry up to 9 per cent tin. One vein at Terubias gave 25 kilos per cubic metre of 40 per cent tin ore. This vein is 1600 metres long. Some 60 per cent ore was obtained.

1035. Harmont, Julio. The mines of Galicia.

U. S. Consular Reports, No. 197, Vol. 53, Feb. 1897, Washington, D. C., p. 312. (House of Representatives' Document No. 164, pt. 3, 54th Congress, 2d Session.)

1035a. LA Escosura, Luis DE. Descripción de las minas de la Provincia de Zamora, 1846.

Not available to the authors.

Lock, C. G. WARNFord, See No. 1338.

Louis, Henry. See No. 1340. 


\section{SPAIN (Continued)}

1036. Lozano, R. Sanchez. Nota referente á varios yacimientos de estaña de la provincia de Pontevedra.

Bol. Com. Mapa Geol. España, Vol. 28, 1907, Madrid, pp. 14-25.

1037. Mallada, L. Explicación del mapa geológico de España.

Mem. Com. Mapa Geol. España, Vol. 1, 1895, Madrid, pp. 173-174, 545-547.

1038. Massart, Alfred. Gisements métallifères du district de Carthagène (Espagne).

Ann. Soc. géol. Belg., Vol. 2, 1875, Liége, pp. 58-107, colored plate 1.

Wood tin is found in small veins in a schist. The veins lie in the planes of schistosity at the San Isidoro, Marinera and Superior segunda mines. In the last, the vein is in lenticular spongy masses of quartz with some barytes and galena.

1039. Pacheco, Hernandez E. Los filones estanniferos de Cáceres y su comparación con los de otras regiones.

Bol. Soc. esp. Hist. Nat., Vol. 2, 1902, Madrid, pp. 72-81.

Digest: Geol. Centr. Vol. 3, 1903, Leipzig, p. 73.

L'auteur decrit quelques petits filons de cassitérite recemment découverts dans les schistes siluriens de la Montana de Caceres, a 5 kilom. de cette capitale. La cassitérite en cristaux simples ou maclès (bec d'étain) est incluse dans un quartz laité, accompagnée d'un fluorure aluminique hydraté que l'auteur rapporte a la fluéllite. Dans les bords des filons il y a une zône constituée par des lamelles de nacrite et souvent d'une bande blanche ou veodatre de lithomarge qui forme la gangue. Un filon est constituée seulement par du quartz et phosphorite.

Ces la premiére fois que la fluéllite est mentionnée en masse considérable.

Ces filons différent de tous les autres filons stannifères connus en Espagne, étant depourvus de roches éruptives dans leur voisinage. D'aprés l'auteur ces filons de Cáceres doivent être envisayés comme alumineux plutôt que comme stannifères.S. Calderon.

Phillips, J. A., and Lours, H. See No. 1350.

1040. Prlz, R. Die Erzlagerstätten von Cartagena in Spanier.

Zeitschr. prakt. Geol, Jahr. 16, 1908, Berlin, pp. 177-190, figs. 31-37.

The principal ore deposits carry argentiferous galena,-zine blende, and pyrite, with secondary cassiterite and limonite; others carry cassiterite and barite.

The cassiterite is thought to be secondary after stannite.

1041. Puig y Larraz, D. Gabriel. Descripción fisica y geológica de la Provincia de Zamora.

Mem. Com. Mapa Gecl. España, 1883, Madrid, pp. 411-437.

Tin occurs generally in quartz, sometimes in granite or granulite. Is also found in alluvial deposits. Occurs rather widely. Found in zone of contact of crystalline schists and granite rocks, and is also found in both rocks. Much tourmaline. Some chalcopyrite, cut by veins of lead-antimony sulphides Rarely found far from eruptives. Veins usually 25 to 50 centimetres wide, rarely 1 metre wide.

1042. Schubarth, E. L. Ueber das Vorkommen von Zinn in Spanien.

Ann. Physik. Chem., Vol. 86, 1852, Leipzig, p. 600.

Digest: Neues Jahrb. Min., 1853, Stuttgart, p. 460.

1043. Schulz, Guillaume, and Paillette, Adrien. Notice sur une pyrite stannifère (ballestérosite) et sur quelques gisements d'étain en Espagne.

Bull. Soc. gêol. France, ser. 2, Vol. 7, 1850, Paris, pp. 16-25.

Abstracts: Neues Jahrb. Min., 1850, Stuttgart, p. 710 and 1851, p. 350; Berg. Hütt. Zeit., Vol. 10, 1851, Leipzig, p. 352. 


\section{SPAIN (Continued)}

1043a. Schulz, Don Guillermo. Descripción geognostica de Reino de Galicia, acompañada de un mapa petrographico de esta pais.

1835, Madrid, pp. 52, pls. 2.

Abstract: Bull. Soc. géol. France, t. 4, 1835, Paris, pp. 416-418.

The original is not available to the writers. The abstract which is in the form of a letter written to the Societe Geologique de France gives a sketch of the geology of the tin-bearing part of northwestern Spain.

1044. Thomas, Charles. Some Spanish tin deposits.

Trans. Mg. Ass. Inst. Cornwall, Vol. 2, 1888-1889, Camborne, pp. 66-70.

Short description of stream tin placers near Ribadavia, Province of Orense, in Galicia.

\section{SWAZILAND}

1045. Anonymous. Tin in South Africa.

Min. Ind. for 1896, Vol. 5, 1897, New York and London, p. 528.

Extract from communication of S. Ryan. Deseribes geology of tin district of Swaziland.

1046. Tin in Swaziland.

Min. Ind. for 1897, Vol. 6, 1898, New York and London, p. 644.

According to British Consular Report No. 1996, Annual series, the Ryan Tin Company did a good deal of work in 1806, and in the first six months produced upward of 260 tons of black tin. Machinery has been erected. Great drawback to working tin and coal deposits of territory is lack of transportation facilities.

1047. - Tin in South Africa.

Austr. Mg. Stand., Vol. 29, 1903, Sydney and Melbourne, p. 699.

“' 'S. A. Mines' considers that it is not improbable that South Africa may in the near future, become one of the important tin producing countries of the world."

Description of deposits in Swaziland, near Embabaan, and new discoveries in Cape Colony, most important of which has been made on Kuil's River.

1047a. - Alluvial tin in Swaziland.

South African Mg. Journ., Vol. 7, pt. 2, 1909, Johannesburg, pp. 115-116.

Notes from Annual report of the manager of Swaziland Tin, Ltd., which, describing various creeks on which alluvial tin occurs, points out new fields for prospecting, and explains a scheme for hydraulicking or sluicing all the hill creeks.

BECK, RICHARD. See No. 1299.

1048. HahN, P. D. Presidential address.

Rep. South African Ass. Adv. Sci. 1903, Cape Town, p. 43.

"Another interesting problem for research for the student of mineral chemistry is furnished at the tin ore deposits at Embabaan in Swaziland. Together with tin ore occur at this locality extraordinarily rare and most interesting minerals, such as aeschynite, euxenite, fergusonite and monazite."

1049. HAMPTON, J. H. On the occurrence of tin.

Trans. Geol. Soc. South Africa, Vol. 4, 1899, Johannesburg, pp. 37-40.

The tin deposits of Malay Peninsula, Mt. Bischoff and Swaziland, near Embickelweni are treated in a brief manner. The author visited Swaziland in 1889-1890, and at that time received the impression from appearance of the country that tin existed in lode or alluvial form. 


\section{SWAZILAND (Continued)}

1050. Jorissen, E. Notes on some intrusive granites in the Transvaal, the Orange River colony and in Swaziland.

Trans. Geol. Soc. South Africa, Vol. 7, 1905, Johannesburg, p. 158. Read Decem. ber $12,1904$.

In East Swaziland near Embabaan, cassiterite occurs in gneiss at the contact of a narrow vein of pegmatite. Much biotite present.

Lock, C. G. WARNFoRd. See No. 1338.

1051. Lyburn, John. Mining and minerals in the Transvaal and Swaziland. Sci. Proc. Roy. Dublin Soc., n. s., Vol. 9, 1899-1902, Dublin, p. 20.

"Alluvial cassiterite occurs in the Embabaan, Swaziland. The mother lode has not yet been discovered."

1052. MolengraAfF, G. A. F. Tinstone in Swaziland. Report of the State geologist of the South African Republic for the year 1897.

Trans. Geol. Soc. South Africa; Vol. 4, pt. 6, 1898, Johannesburg, pp. 141-144.

Abstract: Zeitschr. prakt. Geol., Vol. 8, 1900, Berlin, pp. 146-147.

Digest: Neues Jahrb. Min., 1900, I (Ref.), Stuttgart, pp. 263-265.

The Ryan tin works near Embabaan in the northeast part of Swaziland, are the only important deposits of the country. $\mathrm{SnO}_{2}$ occurs in pegmatite dikes cutting granite near the contact of the latter with various schists, and in placers derived from the dikes, accompanied by corundum, monazite, magnetite, etc. Crystals of cassiterite are so distorted as to appear monoclinic. Does not think the outlook good for very large placers.

1053. Newland, D. H. Tin in South Africa.

Min. Ind. for 1903, Vol. 12, 1904, New York and London, p. 332.

Discovery of lode tin in the Transvaal was reported in August, 1903. Principal formation is granite, which is overlain in places by schistose rocks, and the tinbearing veins occur near the contact. Three lodes have been discovered.

1054. Prior, G. L. Minerals from Swaziland: niobates and titanates of the rare earths, chemically allied to euxenite and fergusonite; cassiterite, monazite, etc. The "Aeschynite from Hitterö."

Min. Mag. Journ. Min. Soc., Vol. 12, 1899, London, pp. 96-101.

Digest: Neues Jahrb. Min., 1901, I (Ref.), Stuttgart, p. 31.

\section{RYAN, - Swaziland tin fields.}

Proc. Chem. Met. Soc. South Africa, Vol. 2, 1897, Johannesburg, pp. 16-18.

Tin fields along Embabaan River on eastern slope of Drakensberg Mountains, 15 miles from Transvaal border were discovered by Mr. Ryan in 1891. Geology: "Granite boss flanked by metamorphic rocks intersected by elvan dykes, diorite and rhyolite." From January, 1894, to June, 1896, exported about 600 tons of ore. Deposits mostly alluvial, average thickness of beds $4 \frac{1}{2}$ feet, though on Lower Embabaan and Usutu rivers, beds of considerable thickness are being found.

1056. Siruts, - . Report on the trade, commerce and general condition of Swazlland.

British Consular Rep., No. 1996, 1897, London, p. 3.

The Ryan Tin Company has done a good deal of work during 1896. First 6 months, by sluicing process, upwards of 260 tons of tin were produced, valued at about $£ 45$ sterling per ton. During latter half of year, about 20,000 tons of tinbearing gravel was exposed. Tin reefs have been discovered, and further prospecting is being undertaken. 


\section{SWEDEN}

DAvIES, D. C. See No. 1317.

\section{TASMANIA}

1057. Anonymous. Report on Mount Bischoff tin mines, Tasmania, with topographical sketch map.

1874, Launceston, Svo., pp. 5.

Not available to the authors.

1058. - Tin from Tasmania.

Iron, Vol. 6, n. 8., 1875, London, p. 42.

Announcing the first shipment of tin to England. Assayed 99.96 pure tin, superior

to Australian tin. Shipment for the year probably not over 300 tons.

1059.

- Tasmanian tin.

Iron, Vol. 6, n. 8., 1875, London, p. 711.

A short review of a report by Mr. Newman, on the Mount Bischoff, Cummings and -

Henry, Stanhope and Waratah nines.

1060. Tin fields of Tasmania.

Mg. World, Eng. Rec., Vol. 14, 1878, London, p. 649.

Not available to the authors.

1061. - The greatest tin mine in the Southern Hemisphere.

Austr. Mg. Stand. September, 1896, Sydney and Melbourne.

Description, with illustration, of the Mount Bischoff Mine, Tasmania.

Not available to the authors.

1062. Tin in Tasmania.

Min. Ind. for 1898, Vol. 7, 1899, New York and London, p. 712.

Mt. Bischoff continued to be largest producer. Tin ore is also found in the Ringarooma Valley at Branxholm, Derby, Moorina, Pioneer and Mt. Cameron, where the Brothers' Home, Briseis, Brothers' Home No, 1, Arba and Armuz mines are situated. The east coast deposits have been proved to be extensive, and a discovery of tin ore on the Great Mussel Roe River has recently been reported.

1063. - Mt. Bischoff tin mine.

Mg. Sci. Press, Vol. 81, 1900, San Francisco, p. 431.

Note stating Mt. Bischoff tin mine contains perhaps most remarkable tin deposit in the world. Average grade of ore is 3 per cent. The concentrates average about 70 per cent tin, yielding an average of 68 per cent in smelting.

1064. Tin in Tasmania.

Min. Ind. for 1899, Vol. 8, 1900, New York and London, pp. 622-623.

The working expenses of Mt. Bischoff mine given. Gives a short account of the Briseis mine. A new discovery of tin at Renison Bell mine at North Dundas, on the west coast is reported. Tin was found in schist near Mt. Lyell.

\section{5. - Tin in Tasmania.}

\section{heralluswe}

Min. Ind. for 1900, Vol. 9, 1901, New York and London, pp. 638.

Tasmania is largest producer of tin in Australia, output for 1899 amounting to 3281 long tons of ore, valued at $£ 270,864$. A large part of the ore is obtained from alluvial deposits, the lodes, except at Mt. Bischoff mine, have received little attention. 


\section{TASMANIA (Continued)}

1066. - Tin mining in Tasmania.

Austr. Mg. Stand., Vol. 20, August 15, 1001, Sydney and Melbourne.

"Describes the alluvial deposits at Mt. Bischoff."

Not available to the authors.

1067. - Tin in Tasmania.

Min. Ind. for 1901, Vol. 10, 1902, New York and London, p. 640.

The output of tin ore was less in 1901 than in the preceding year. This unexpected result being due principally to the poorer quality of the ore raised from the Mt. Bischoff mines, the most productive in the State.

1068. - Heemskirk (T.), tin find.

Austr. Mg. Stand., Vol. 21, 1902, Sydney and Melbourne, p. 665.

An account of a " rich find of lode tin on the Orient farm," about nine miles from Zeehan T. Outlook is said to be good.

1069. - Tin in Tasmania.

Min. Ind. for 1902, Vol. 2, 1903, New York and London, p. 594.

Mt. Bischoff Tin Mining Company in the last six months of the fiscal year crushed 50,044 tons of stone for a yield of 636 tons of concentrates. The cost of mining, crushing and dressing was 5s. 7d. per ton. During year the company earned profits of $£ 62,612$ and distributed dividends of $£ 54,000$.

1070. The Pioneer tin mine, Tasmania.

Austr. Mg. Stand., Vol. 29, 1903, Sydney and Melbourne, pp. 13-15, 49-50. Serial. Illus.

Description of the deposits of northeast Tasmania, with some details of the history and difficulties in working (from a financial standpoint), and methods and machinery used.

1071. Northeast Dundas [Tasmania] tin.

Austr. Mg. Stand., Vol. 31, 1904, Sydney and Melbourne, pp. 810-811, 1300 words.

"Describes the deposits of this district, and work done in developing."

1072. Mining in Tasmania.

Mg. Journ. Railw. Comm. Gaz., Vol. 76, 1904, London, p. 27, 1000 words.

Digest from Mg. Mag., Vol. 10, 1904, New York, p. 154.

"Recent news of the condition of Tasmanian mines; gold, tin and copper, with estimates of reserves at Mount Lyell."

1073. Tasmania tin fields.

Min. Ind. for 1904, Vol. 13, 1905, New York and London, pp. 392-393.

"The cassiterite of Mt. Bischoff is associated with topaz, both crystalline and amorphous, in large dikes of an acidic porphyritic rock penetrating slate and sandstone. The topaz has replaced feldspar, the rock containing no alkali, and consisting practically of quartz and topaz. It is comparable to the Saxon 'sneckenstein,' a topaz quartz-porphyry."

Gives a résumé of tin mining in Tasmania during 1904.

Beck, Richard. See No. 1299.

1074. Benedict, WM. DE L. Tin in Tasmania.

Min. Ind. for 1892, Vol. 1, 1893, New York, pp. 444-445.

"Tin ore was found in Tasmania at an early date in the history of the colony, but it was not until 1872 that the great Mt. Bischoff property was discovered. . . . The tin is found in what is termed euritic porphyry and the most productive portions of the deposit are situated close to the porphyry and slate."

The next district in importance is Ringarooma. The deposits at this place appear to be the bed of an ancient river running nearly north and south and are covered by a crust of basalt. 


\section{TASMANIA (Continued)}

1075. BoNwick, JAMEs. Tasmanian tin.

Mg. Journ. Railw. Comm. Gaz., Vol. 44, 1874, London, p. 331.

Brief description of the lode and alluvial tin deposits at Mount Bischoff.

Brown, A. Selwyn. See Nos. 1307 and 1308.

1076. Clark, Donald. Tasmanian mining and metallurgy.

Austr. Mg. Stand., Vol. 29, from March 12 to April 16, 1903, Sydney and Melbourne, pp. 362-363, 398-400, 432-435, 462-463, 496-498, 528-530.

A series of articles which deal with tin mining and smelting in Tasmania.

1076a. - Australian mining and metallurgy.

1904, Melbourne, Sydney and Perth, pp. 185-228, pls. 7, figs. 13.

Describes the geology, mining methods and milling methods at the Mt. Bischoff, Anchor, Cornwall, and Maynes tin mines. All are located in Tasmania.

1077. Coghlan, T. A. Tin.

A statistical account of Australia and New Zealand, 1903-1904, p. 934.

1078. Conder, Hartwelt. Tin mining in Tasmania.

Mg. Journ. Railw. Comm. Gaz., Vol. 78, 1905, London, p. 350, 1800 words.

Reviews briefly the history, and describes present conditions of tin mining in Tasmania.

1078a. - Stanley River tin field.

Austr. Mg. Stand., Vol. 41, 1909, Sydney and Melbourne, p. 637, map 1.

The Stanley River tin field is 20 miles north of Zeehan, Tasmania, on the west coast. A road has just been finished which makes it accessible. Country rocks are quartzites and clay-stones cut by porphyritic granite. Porphyritic feldspars in many places have been replaced by green tourmaline and this, in turn; partly replaced by $\mathrm{SnO}_{2}$. One tourmaline-quartz lode 16 feet wide carries 2 per cent tin. Boulders in river are probably worth working. Wolframite and monazite form impurities in the stream tin. Notes the occurrence of pyrrhotite carrying a " small proportion of $\mathrm{Cu}$ and Ni." Map gives geology, claims and owners.

Gives some objections to the government's system of renting claims.

1079. Counser, E. A., Surveyor General. Sketch map, general geological features of Tasmania.

Government Printing Department, January, 1898, Hobart. Lithograph, hachured.

1 inch $=15$ miles.

Geological features in colors. Gold, tin, silver and lead, bismuth, antimony, copper, iron, and coal deposits shown by characters.

D’Achiardi, Antonio. See No. 1313.

1080. Daver, John. Mount Bischoff tin mines.

Rep. Proc. Min. Ass. Cornwall and Devon, for 1881 (1882), Truro, pp. 8-10.

Extract from a letter dated May, 1881. Geographical description of the tin-bearing country; manner of occurrence and working; percentage of yield; loss of ore in dressing.

Davies, D. C. See No. 1317.

1081. DiJK, P. VAN. Tinontginning in Tasmanië.

Jaarb. Mijnw. Ned. Oost-Indië, 1882, II, Amsterdam, pp. 91-101.

1082.

Tinontginning in Tasmanië.

Jaarb. Mijnw. Ned. Oost-Indië, 1883, II, Amsterdam, pp. 109-114. 


\section{TASMANIA (Continued)}

English, A. G. See No. 50.

1083. Fawns, Sydnex. Notes on the Mount Bischoff tin mine.

Trans. Inst. Mg. Met,, Vol. 14, 1905, London, pp. 221-228. Discussion, pp. 229-243. Contributed remarks, pp. 244-249.

Abstracts: Mg. Journ. Railw. Comm. Gaz., Vol. 77, 1905, London, p. 62. Eng. Mg. Journ., Vol. 79, 1905, New York, pp. 470-471.

Digest: Min. Mag., Vol. 11, 1905, New York, pp. 355-357.

Gives short history of mine; says tin occurs in veins and replacement deposits in topaz porphyry. Briefly describes the Queen and North Valley lodes, Don and Stanhope sections, the White, Brown, Slaughter-yard, and Alluvial North faces. Gives a list of minerals and rocks occurring with the deposits. Most of the paper is devoted to the working system and costs.

1084. Mount Bischoff and Dolcoath.

Mg. Journ. Railw. Comm. Gaz., Vol. 77, 1905, London, p. 297.

A letter comparing some of the modes of working.

See No. 1320.

1085. Frrcks, F. W. voN. Die Zinnerzlagerstätten des Mt. Bischoff in Tasmanien.

Zeitschr. deutsch. geol. Ges., Vol. 51, 1899, Berlin, pp. 431-434, pls. 27-28.

Digest: Neues Jahrb. Min., 1901, I (Ref.), Stuttgart, pp. 423-425.

1086. Gourd, Chas. A note upon a recent discovery of tin ore in Tasmania. Quart. Journ. Geol. Soc. London, Vol. 31, 1875, London, pp. 109-110.

Digest: Geol. Rec. for 1875, London, p. 242.

"Ore is not 'stream tin' in true sense of the word; but the disintegration of veins and strings running through the porphyritic rock, of which the mount is composed, gives rise to a shallow surface-drift from which the tin-ore is procured. Lodes in adjacent slaty rocks contain antimony and zinc blende." (Mt. Bischoff.)

1087. Grant, H. Tasmanian tin deposits.

Austr. Mg. Stand., November 17, 1898, Sydney and Melbourne.

"The history of the tin mining on the Blue Tier formations."

Not available to the authors.

1088. - The Blue Tier [Tasmania] tin dykes.

Austr. Mg. Stand., Vol. 17, 1900, Sydney, p. 151.

"Information concerning this important discovery and the working of the deposits."

1089. - Tasmanian tin fields. (I) The Blue Tier, East Coast, The Moon and Lottah claims. (II) The Echo Mine.

Austr. Mg. Stand., Vol. 18, 1900, Sydney, pp. 277-278, 551-552.

Description of Blue Tier and Echo mines on the East Coast; their possibilities, difficulties encountered and outlook.

1090. - Mining in Eastern Tasmania.

Austr. Mg. Stand. Vol. 19, 1901, Sydney and Melbourne, pp. 667-668, 3500 words. "An account of the tin mining, the deposits and their development."

1091. - Brookstead tin field.

Austr. Mg. Stand., Vol. 35, 1906, Sydney and Melbourne, 2000 words.

" A review of the development of the Brookstead lode, in northeastern Tasmania, showing the richness of the field, and the importance of thorough prospecting." 


\section{TASMANIA (Continued)}

1092. Gregory, J. W. The geological plans of some Australian mining fields. Science Progress, No. 1, 1906, London, pp. 117-136.

Describes among others the Mt. Bischoff mine, the character of the ore in the different faces, and the metamorphism of the rocks.

1093. Grodpeck, A. von. Zur Kenntniss der Zinnerzlagerstätte des Mount Bischoff in Tasmanien.

Zeitschr. deutsch. geol. Ges., Vol. 36, 1884, Berlin, pp. 642-652. Translated by Thureau, G. in Pap. Proc. Roy. Soc. Tasmania, for 1885 [1886], Hobart, pp. 358-394. Reviewed: Neues Jahrb. Min., 1885, II (Ref.), Stuttgart, pp. 91-92.

Continuation of original article, Zeitschr. deutsch. geol. Ges., Vol. 38, 1886, Berlin, pp. 370-375. Translated by Wolfhagen in Pap. Proc. Roy. Soc. Tasmania for 1886 [1887], Hobart, pp. 189-193.

Continuation of original article. Zeitschr. deutsch. geol. Ges., Vol. 39, 1887, Berlin, pp. 78-87.

Reviewed in Neues Jahrb. Min., 1888, 1 (Ref.) Stuttgart, pp. 86-87.

1094. Hampton, J. On the occurrence of tin.

Trans. Geol. Soc. South Africa, Vol. 4, 1899, Johannesburg, pp. 37-40.

The tin mine at Mt. Bischoff, discovered 1872, was visited by author in 1883. Tin bearing rock was 100 feet wide. Largest tin deposit yet discovered. It is at considerable elevation from the sea, where neither pumping nor hauling machinery are required.

1095. Harcourt-Smith, J. Report on the Shepherd and Murphy's tin mine, Bell Mount.

Rep. Secr. Min., Tasmania, for 1896-1897 (1897), Holart, pp. lv-lvi.

This property is situated 22 miles southwest from Sheffeld, at an elevation of about 2000 feet above sea level. Lodes 1 to 6 are described, and the work done, with results obtained. The company. will attempt to separate tungsten and bismuth as well as the tin contents.

See also No. 1148.

1095a. - The mineral industry of Tasmania. See Tasmania, Government Geologist, No. 1134.

1096. Hunt, JoHn. Mount Bischoff tin mines, Tasmania.

Mg. Journ. Railiv. Comm. Gaz., Vol. 44, 1874, London, p. 207.

Very general; unimportant.

1097. . On mining in Tasmania.

ad'T. Journ. Railw. Comm. Gaz., Vol. 45, 1875, London, pp. 539-540.

Thinks the deposit of tin at Mount Bischoff is not of volcanic origin. Believes the greater part of alluvial tin is derived from decomposition of granitic rocks.

1098. IrELAND, MARK. A method of timbering at the Mt. Rex tin mine, Ben Lomond, Tasmania.

Trans. Austr. Inst. Mg. Eng., Vol. 10, 1905, Melbourne, pp. 263-264.

Short article giving method of timbering which is of such a character that no blasting, however heavy, can injure it.

1099. Johnston, R. W. Geology of Tasmania.

1888, Hobart, pp. 22-2y.

Description of tin lodes, mode of occurrence, distribution, discovery and derivation. Age of superfictal gravels discussed. 


\section{TASMANIA (Continued)}

1100. KaYser, H. W. F. Tin mining in Tasmania.

Trans. Fed. Inst. Mg. Eng., Vol. 13, 1897, London and Newcastle-upon-Tyne, pp. 570-582, pl. 24, map ( 1 inch $=1125$ feet).

Abstract: Ind. and Iron, June 11, 1897, London.

A review of the mining industry of Tasmania. Discovery, difficulties and results of early tin mining. The writer was connected with Mt. Bischoff Mining Company more than 21 years, and that mine is treated at some length.

1101. - The Mount Bischoff tin mining company, registered.

Ann. Rep. School Mines Zeehan, Tasmania, for 1905, pp. 96-98, pls. 2.

Gives very briefly a history of the mine, its geology and method of working. Also description of milling plant, and the profits paid.

1102. Kayser, H. W., and Provis, Richard. Mt. Bischoff tin mine, Tasmania. Proc. Inst. Civ. Eng., Vol. 123, 1896, London, pp. 377-387, figs. 8. Abridged.

Ore in large veins averages 2 to 3 per cent cassiterite. Cost of mining and delivering ore to dressing works is $3 \mathrm{~s}$. $2 \frac{1}{2} \mathrm{~d}$. or 80 cents per ton of 2240 pounds. Cost of dressing is $18.11 / 6$ d., or say 27 cents per ton, about 6000 long tons of material being treated per month. First grade concentrates average 70.5 per cent tin. Second grade concentrates average 65 per cent tin; does not pay to dress cleaner than this.

1103. KlockmanN, F. Ueber den Antheil von Groddeck's an der Deutung der Zinnerzlagerstätte des Mt. Bischoff.

Zeitschr. deutsch geol. Ges., Vol, 52, 1900, Berlin, pp. 167-168.

Digest: Neues Jahr. Min., 1903, I (Ref.), Stuttgart, p. 91.

Digest: Geol. Centr. Vol. I, 1901, Leipzig, p. 228.

W. von Fricks asusserte in einem Aufsatze uber die Zinnerzlagerstätten des Mt. Bischoff in Tasmanien (Zeitschr. deutsch. geol. Ges., Vol. 51, 1899, Berlin, p. 431), dass v. Groddeck die Zinnführenden Gesteine dieses Berges für ursprünglich und nicht für pseudomorph erklärt habe. Verf. weist dagegen aus zwei Nachträgen v. Groddeck's, Arbeiten, die v. Fricks anscheinend tibersehen hat, nach, dass v. Gr. bereits sich mit aller Bestimmtheit für die pseudomorphe Entstehung der Erzlagerstätten des Mt. Bischoff ausgesprochen hat.

Latta, Geo. J. See No. 1517.

1104. Lewis, James B. The New Brothers' Home No. 1 Tin Mining Company, Derby.

Rep. Secr. for Mines, Tasmania, 1902-1903 (1903), Hobart, pp. XCIX-CII, pls. 2. Abstract: Eng. Mg. Journ., Vol. 75, 1903, New York, pp. 815-816.

A description of the manner in which overburden is removed.

1105. The Anchor tin mine, Tasmania.

Eng. Mg. Journ., Yol. 81, 1906, New York, p. 1249.

A communication giving a brief analysis of working cost for low grade tin ore. They are working profitably on a yield of 5 pounds black tin per ton, or 3.5 pounds metallic tin.

1106. - Tin mining in Tasmania.

Eng. Mg. Journ., Vol. 85, 1908, New York, pp, 485-489; pls. 3, map 1.

Commercial conditions at the Mount Bischoff, Heemskirk, Brookstead, Avoca, Briseis and Pioneer mines are described.

Gives a few notes upon dredging for tin in Tasmania, and refers to tin mining operations in the Gladstone District. The article has evidently been edited and abridged, not altogether to its advantage.

Lock, C. G. WARNFord. See No. 1338. 


\section{TASMANIA (Continued)}

Louis, Henry. See No. 1340.

ㄴ. See No. 1525.

1107. Meredith, C. Verbal remarks on specimens of tin ore from Mount Bischoff, Tasmania.

Pap. Proc. Roy. Soc. Tasmania [monthly notices-June], 1873 [1874], Hobart, p. 21.

Not available to the authors.

1107a. MilleN, J. D. Mount Bischoff tin mining company, Tasmania.

Austr. Mg. Stand., Vol. 41, Nos. 1061, 1062, 1900, Sydney and Melbourne, pp. 264, 293-294. Illus. (In section of Electrical Record, Vol. 19.)

aintarman "A description of the hydro-electric power plant, its equipment and opration."

- See No. 1535 .

1108. Montgomery, Alex. The Blue Tier tin field.

Geol. Surv. Rep. Tasmania, November, 1889, Hobart.

Not available to the authors.

1109. - The tin mines at the Blue Tier, county of Dorset.

Geol. Surv. Rep. Tasmania, January, 1903, Hobart.

Not available to the authors.

1110. Montgomery, Alexander. The mineral resources of Tasmania.

1894, Hobart, pp. 3-28.

Tasmania is the third largest tin producer in the world, the value of tin ore raised being greater than all the other minerals of Tasmania put together. The tin deposits may be grouped as : (1) Alluvial. (2) Lodes or veins. (3) Impregnations or stockworks. The veins occur in districts which are composed almost entirely of granite or of sedimentary rocks penetrated by quartz-porphyry dikes. Vein or lode mining has not yet been very successful in Tasmania. Stockworks or impregnations of tin ore, found in several localities are likely to be of very great importance. Mt. Bischoff mine shows a curious combination of all the different types of tin deposits.

1111. - The mineral industry of Tasmania.

Eng. Mg. Journ., Vol. 57, 1894, New York, p. 389.

Good general description of tin deposits. Principal alluvial workings in northeast part of Tasmania, along Ringarooma and George's rivers and their tributaries. Deposits of different ages, miocene to recent. Some of older drifts covered by basalt and worked by underground mining, but most is obtained from shallow workings by ground sluicing. The ore which bas been easily worked is about all taken out. Hydraulicking larger and poorer deposits. Thinks they will last for a century.

1112. - Report on the progress of the mineral fields in the neighborhood of Zeehan, viz.: Mackintosh River, Mount Black, Mount Read, Mount Dundas, Mount Zeehan, Stanley River and Mount Heemskirk.

Rep. Secr. Min. Journ. and Printed Papers of the Parliament of Tasmania. Vol. 33, 1895, Hobart, pp. VII-LI.

Not available to the authors.

1113. The useful minerais of Tasmania.

Trans. Austr. Inst. Mg. Eng., Vol. 3, 1895, Adelaide, pp. 224-229.

The tin deposits of Tasmania are classed as alluvial, fissure lodes and stockworks, and impregnations. Examples of these types may be found at different mines, while at Mt. Bischoff the deposit is unusual, presenting almost all of these known types. The ore is practically confined to the granite regions and their immediate vicinity. 


\section{TASMANIA (Continued)}

1114. Moore, T. On the occurrence of tin, zinc, silver, and traces of gold in the killas of St. Paul's Plains.

Pap. Proc. Roy. Soc. Van Diemen's Land, Vol. 2, pt. 3, 1854, Tasmania, p. 490.

1115. Mufrord, J. Tasmanian tin fields.

Mg. Journ. Railw. Comm. Gaz., Vol. 47, 1877, London, pp. 1383, 1411, 1439; Vol. 48, 1878, pp. 19, 48, 183.

A series of six articles, describing the country surrounding the tin-bearing districts, the deposits, methods of working and output. The output of Mount Bischoff from 1873-1877, giyen.

1116. - The tin mines of Tasmania.

Mg. Journ. Railw. Comm. Gaz., Vol. 48, 1878, London, p. 483.

Extract of paper read before Mining Institute of Cornwall, 1878, with discussion. Gives output of Tasmania for first half of 1878 and estimates whole output for the year. All derived from alluvial washings. Gives descriptions of the tin bearing districts. Believes Tasmanian mines have reached their highest production.

1117. NewMaN (-). Tasmanian tin.

Iron, Vol. 6, 1875, London, p. 711.

Extract of a report by author on the Mount Bischoff tin mines.

1118. Petrend, W. F. Minerals of Tasmania. Cassiterite.

Pap. Proc. Roy. Soc. Tasmania, 1893 [1894], Hobart, pp. 20-23.

Describes the different varieties of cassiterite found in Tasmania, where found and the principal tin-producing localities. Gives the production to close of 1892 .

1119 . Catalogue of the minerals of Tasmania. 1896, Launceston.

Stannite occurs in considerable quantity in the Silver Queen mine at Zeehan, associated with galena, copper, and iron pyrites. The stannite is gold and silver bearing.

1120. - The minerals of Tasmania.

Pap. Proc. Roy. Soc., Tasmania for 1900-1901 (1902), Hobart, pp. 75-84.

A short article reviewing the mineralogy of the island in a concise manner.

1121. Notes on Tasmanian minerals.

Rep. Secr. Min. for 1903, Tasmania, 1904, Hobart, pp. 74-75.

Abstract: Mg. Journ. Railw. Comm. Gaz., Vol. 76, 1904, London, p. 475.

Description of unusual tin spccimens from several Tasmanian mines.

Phillips, J. A., and Louis, H. See No. 1350.

1121a. Plummer, John. Australia's premier tin mine.

Mg. Sci. Press, Vol. 100, 1910, San Francisco, p. 820.

Brief account of the dividends paid by Mount Bischoff tin mine, and the outlook for future productiveness.

1122. RANFT, THEoD. Der Zinnbergbau am Bischoffsberge, Tasmania.

Berg. Hütt. Zeit., Vol, 48, 1889, Leipzig, pp. 351-353.

Brief digest: Neues Jahrb. Min., 1891, II [Ref.], Stuttgart, p. 295.

Short historical notices upon the growth of mining at Mt. Bischoff, the tin-ore occurrences of which have become better known through von Groddeck, also a sketch of the geological relations and technical operations. 


\section{TASMANIA (Continued)}

1123. RATH, M. J. voN. Eine topographisch-montanistische Karte des Mount Bischoff auf Tasmanien.

Verh. Nat. Ver. preuss. Rheinl. Westph. (Sitzungsberichte), Vol. 35, 1578, Bonn, p. 7 .

1124. REPoRT of the Secretary for Mines, Tasmania.

Hobart.

Contains reports of the mining industry, progress and development work.

Issued annually for the preceding fiscal year.

Reyer, Eduard. See Nos. 87 and 1354.

1125. Rickard, Edgar. The Briseis tin lead at Derby, Tasmania.

Eng. Mg. Journ., Vol. 75, 1903, New York, pp. 119-120. Sketch plan.

Describes placer cassiterite occurring in the gravel of a river 100 feet below the present streams. It is capped by basalt. Worked by a modification of the hydraulic system.

1126. Rrtchre, W. Tin in Tasmania.

Mg. Journ. Railw. Comım. Gaz., Vol. 43, 1873, London, p. 1109.

Extract frcm letter. . Description of tin deposits of Mount Bischoff. Some pieces of tin ore were of such size that a man could not lift them. Both lode and alluvial tin ore of much richness occur. Great natural facilities for the working of mine.

Rolker. Chas. M. See No. 1357.

1127. Rowe, Capt. James. Tin mining in Tasmania.

Trans. Mg. Ass. Inst. Cornwall, Vol. 1, 1887, Camborne, pp. 153-163, map.

Also, Berg. Hütt. Zeit., Vol. 47, 18\&8, Leipzig, pp. 183-185.

First discovery of importance at Mount Bischoff in 1872, by Chas. Smith in a deposit " of a highly ferruginous nature, consisting of oxide of iron, decomposed porphyry and tin ore." Cut 1000 feet wide and 100 feet deep gave 3 per cent ore. Two other districts. Mt. Bischoff is in northwest portion, the "West Coast" region is just southwest of it, and the Northeast District is in the northeast part of the island. "West Coast" not paying. Deposits in northeast in both recent and old river beds partly covered by basalt. Gravel up to 170 feet deep in places, carrying about three-fourths per cent of ore worked by hydraulicking.

1128. Sandeman, J. J. The mineral resources of Tasmania.

Trans. North of England Inst. Mg. Mech. Eng., Vol. 49, 1901, Newcastle-upon-Tyne, pp. 32-37, illus.

Reprint: Trans. Inst. Mg. Eng., Vol. 18, 1899-1900, London, pp. 32-37.

The tin production of Tasmania holds, according to writer, the first place among the Australian colonies. Up to end of 1897 , it produced 80,000 tons of tin, valued at $£ 6,500,000$; of this Mt. Bischoff contributed about $£ 2,700,000$. This mine is worked in three open faces or quarries: The Brown Face, the Slaughter Face and the White face. Descriptions of these quarries are given. The Blue Tier district is described as having intrusive dykes of stanniferous granite. The mines have suffered from poor management. There is every evidence that they should yield good paying ores, with modern appliances and good management.

1129. SHAw, A. Tin of Mount Bischoff, Blue Tier, and River Ringarooma.

Rep. Mines Dept., for 1883-1884, H. A. Paper, No. 70, 1884.

Not available to the authors.

1130. SHAw, B. Tin of Mount Bischoff, Mount Heemskirk, Blue Tier, Moorina, and Gladstone.

Rep. Mines Dept., 1884-1885, H. A. Paper, No. 58, 1885.

Not available to the authors. 


\section{TASMANIA (Continued)}

1131. Sowden, C. To the Tasmanian tin mines.

Nat. Hist. Journ. School Rep., Vol. 17, 1893, York, pp. 6-8.

Digest from Ann. Brit. Geol., 1898, London, p. 347.

"A description of the works at Mount Bischoff."

Stephens, D. See No. 59.

1132. Stokes, Ralpir (S. G.). The Tasmanian tin industry.

Mg. World, Vol. 26, 19n7, Chicago, pp. 718-719, 776-777, 806-807.

A series of illustrated articles giving a general review of the tin industry of Tasmania. Not much geology is given.

1133. - Mount Bischoff tin mine, Tasmania.

Mg. World, Vol. 27, 1907, Chicago, pp. 55-58. Illus.

General article giving account of the decreased output of Mt. Bischoff tin mine, owing to the working out of the Brown Face; also a description of the working of a new electric plant.

- See No. 729.

1134. Tasmania. Government geologist. The mineral industry of Tasmania.

Published quarterly, Compiled by: Harcourt-Smith, J., from 1897 through March, 1899. Wallace, W. H., from June, 1899-. (From June, 1899 to December 31, 1901, not available to the authors.) Twelvetrees, W. H., from December, 1901.

1135. Thureau, G. Report on the Ben Lomond tin deposits. On the St. Paul's River tin deposits.

Tasm. Parl. Pap. No. 108, 1881, Hobart, pp. 4, plans.

1136. The Blue Tier Mining District.

Geol. Surv. Rep., Tasmania, 1886, Hobart.

Not available to the authors.

Tregay, W. See No. 60 .

1137. Twemvetrees, W. H. Report on some tin mines in the St. Paul's River valley near Avoca.

Rep. Secr. for Mines, for 1899-1900, Tasmania, 1900, Hobart, pp. XIV-XXVII, pls. 3. Describes the Roy's Hill tin mine as being in Permo-carboniferous "wash and conglomerate" 20 feet thick and overlain by Jura-Trias sandstone. Beneath the deposit is a quartz-mica-tourmaline rock with some kaolin, from which the tin has been derived. Both are worked. Gives an exposition of the theory of pneumatolytic deposition, and advises further prospecting. The St. Paul's mines were at this time idle. They are in much silicified and tourmalinized granite. The cassiterite is well crystallized and often of amber or ruby color.

1138. - Report on the Arba extended tin sections at Branxholm. Rep. Secr. for Mines for 1899-1900, Tasmania, 1900, Hobart, pp. XLI-XLIII.

Prospects are that the tin mines (placer) will be small. The gravel occurs in pockets in a granite which contains considerable tourmaline and many quartz veins. Some gold is found with the tin.

1139. - Preliminary report on the deep lead or infra-basaltic stanniferous gravels of the Ringarooma valley near Derby.

Rep. Secr. for Mines, for 1899-1900, Tasmania, 1900, Hobart, pp. CVII-CXXVII, sketch maps 2.

Tries to trace the old valley of the Ringarooma River under basalt by which it is covered. The river and tributary streams are known to have flowed through stanniferous granite so that it is supposed the gravels may pay for working. Where denuded both tin and gold have been obtained from the gravel. 


\section{TASMANIA (Continued)}

1140. - Report on the mineral fields between Waratah and Corinna. Rep. Secr. for Mines for 1899-1900, Tasmania, 1900, Hobart, pp. CXL-CCVII, plans 2. Review: Austr. Mg. Stand., Vol. 18, 1900, Sydney and Melbourne, pp. 592-593.

Mt. Bischoff tin mine [pp. CL-CLVI], rises 500 feet above the Waratah plateau. The first discovery of tin ore was made by James Smith in 1871. The mine has been dividend-paying continuously since 1878 ; total dividends paid to date being $£ 1,674,000$; total tin ore to date, 57,358 tons; value $£ 3,316,528$.

The geology of the deposit is treated.

Webster's Workings [pp. CLVI-CLVII] and Ten-mile tin claim at White River Bridge [pp. CLVII-CLIX] are alluvial tin claims.

1141. - Report on the tin mines of Blue Tier, county of Dorset. Geol. Surv., Tasmania, 1901, Hobart, pp. 33, figs. 9.

Also in Rep. Secr. Mines, Tasmania, 1901-1902, Hobart, pp. 90-123.

Supposing only that the tinstone continues a very little below already proved depths, there is sufficient tin bearing rock to keep several mines going for a good many years. If it descends indefinitely, there is enough stone for generations. If the dyke theory is correct, there is no reason why it should not persist to great depth. If the floor theory is the right one, it will still descend to any required depth. The development of the mines appears to be governed by the water power available. With adequate water supply, the district would undoubtedly be a busy tin-producing center. It is a productive district as it is, but its production is intermittent, being dependent upon rainfall. Author holds high hopes of a future for the Tier. The mines of the district are described individually.

1142. - The Bell Mount Mining Field.

Journ. Print. Pap. Parl., Tasmania, Vol. 45, 1901, Hobart, pp. 57-60.

Not available to the authors.

1143. - - Report on the tin-bearing capabilities of the Gladstone district. Journ. Print. Pap. Parl., Tasmania, Vol. 45, 1901, Hobart, pp. 72-83, geol. map 1. Also in Rep. Secr. for Mines, Tasmania, 1901, Hobart, pp. 232-267, plan.

Digest: Geol. Centr., Vol. 2, 1902, Leipzig, p. 581.

The tin ore occurs principally in gravels spread far and wide over the surface of the country. The changes in level of the land since Tertiary times and their effect on the tin deposits, as also that of lava streams, is described. Topaz, sometimes very fine, and sapphires occur in the drift.-Geo. W. Card.

1144. - Report on the coal field of Llandaff, the Denison and Douglas rivers, on the deposits of tin ore on Schouten Main, and on out-crops of quartz near Buckland.

Rep. Secr. for Mines, for 1901-1902, Tasmania, 1902, Hobart, pp. 52-62, sketch maps 2.

"Schouten Main is the name used for that part of the mainland which is at the head of Freycinct's Peninsula, and consists of granite, with the exception of some Silurian metamorphic sandstone on the crest and east slope of the hill overlooking Bluestone Bay."

It is estimated that 150 tons of alluvial tin ore has been mined-it is possible that large lodes exist in the granite, that have eluded discovery, but the author would give different sources for it:

1. Small quartz veins enclosing coarse tin.

2. Greisenised bands of granite containing small quantities of ore.

1145. - Report on mineral fields between Waratah and Long Plains.

Geol. surv., Tasmania, 1903, Hobart, pp. 38.

Badger tin mines, pp. 35-37.

Situated 5 miles from Waratah. Tin occurs in kaolinized and silicifled porphyritic granite. Samples assayed 7.77 to 9.2 per cent metallic tin. Some alluvial tin. Little work done. 


\section{TASMANIA (Continued)}

\section{Report on the Renison Bell tin field.}

Geol. Surv., Tasmania, 1906, Hobart, pp. 12.

Renison Bell tin mine, the chief mine of the Dundas tin-bearing belt, is situated at the northern end of the area. At present worked by optionees, producing ore by sluicing; are driving underground to intersect a large pyrrhotite lode a hundred feet below its exposure in a railway cutting. District is undeveloped. Present price of tin is acting as a stimulus that will lead to working lodes.

1147. - Geological report on Cox's Bight tin field.

Geol. Surv., Tasmania, 1906, Hobart, pp. 18, geologic map 1.

A little known field on the south coast of Tasmania, 36 miles by water from Recherche, and three or four days walk overland. A biotite granite bass of Devonian age, $11 / 4$ miles in diameter, intruded through quartzite and schist is intersected by veins carrying cassiterite and accessory molybdenite. Tin found here in early ' 90 's, and about 120 tons taken out to 1906. Gives individual descriptions of several claims. Yield, 1 pound to $7 \frac{1}{2}$ pounds per cubic yard, generally nearer the smaller figure. Gravel 6 feet and more thick. Field restricted.

1148. - Report on the Bell Mount and Middlesex district (Tasmania). Geol. Surv., Tasmania, 1907, Hobart, Fp. 1-30.

At Shepherd \& Murphy mine, on Bismuth Creek, a tin-tungsten-bismuth vein occurs in a wollastonite-epidote rock, evidently altered limestone. Vesuvianite, diopside and garnet also occur. Granite or quartz-porphyry supposed to exist close at hand. 'l'opaz occurs in the vein with quartz. The vein cuts Middle Silurian rocks. Also mentions quartz bismuth-tungsten veins at All Nations mine; tin-bearing stockworks in granite and quartz-porphyry, at All Nations and Dolcoath mines; alluvial deposits of gold, tin and tungsten and veins carrying pyrite, galena, molybdenite, "cupriferous quartz," gold and silver occur in the same district. Spodumene is found in one of the veins.

1148a. - The mineral industry of Tasmania. See No. 1134.

1149. Tweuvetrees, W. H., and Petrern, W. F. On the topaz quartz porphyry or stanniferous eivan dykes of Mount Bischoff.

Pap. Proc. Roy. Soc., Tasmania, 1897 (1898), Hobart, pp. 119-128, pl. 1.

The dikes of Mt. Bischoff are granitic and both feldspar and quartz have been more or less replaced by topaz and to a lesser degree, cassiterite, so that the latter mineral is also secondary.

1149a. Twelvetrees, W. H., and WARD, L. KeITH. Geological examination of of the Zeehan field.

Geol. Surv., Tasmania, Bull. No. 7, 1909, Hobart, pp. 25. (Preliminary statement.) Extract: Mg. Journ. Railw. Comm. Gaz., Vol. 87, 1909, London, pp. 532-534.

Treated under heads: Introduction; nature of the examination; its scope and method; forecast of the forthcoming report; preliminary statement of the results of the geological examination.

1150. Ulrich, G. H. F. A report on Mount Bischoff tin mines, Tasmania, with topographical sketch map.

1874, Launceston, pp. 5 .

Not available to the authors.

1151. Ueber die Zinnmine am Mt. Bischoff in Tasmanien.

Neues Jahrb. Min., 1877, Stuttgart, pp. 494-497.

1152. Waddington, H. Tin; its future.

Mg. Journ. Railw. Comm. Gaz., Vol. 49, 1879, London, p. 1310.

Extracts from a report by H. W. F. Kayser on the Bischoff tin mines. 


\section{TASMANIA (Continued)}

1152a. Wallace, W. H. The mineral industry of Tasmania. See No. 1134.

1153. WALLER, G. A. Report on the mining districts of the Scamander River and St. Helens.

Rep. Secr. for Mines, 1900-1901, Tasmania, 1901, Hobart, pp. 268-301.

Alluvial deposits of tin at the Scamander River and at St. Helens.

A description of the following mines is given: The Scamander Tin and Gold Co.; the mines at St. Helens; Royal Ruby Tin Mining Co.; Fern Tree Creek; Saxelby Creek; Thureau's Deep Lead Tin Mining Co.; Fenton's Mine; the Upper Ruby; the Rose Tin Co., Ltd.

1154. Tin mining at St. Helens, Tasmania.

Austr. Mg. Stand., Vol. 20, October 17, 24, 31, 1901, Sydney and Melbourne. Serial, 3 parts, 4000 words.

"Describes the deposits and various workings."

Not available to the authors.

1155. - Report on the tin mining district of Ben Lomond.

Journ. Print. Pap. Parl. Tasmania, Vol. 45, 1901, Hobart, pp. 95-107, geol. sketch ialnaturas map 1, figs. 3.

Also in Rep. Secr. for Mines, Tasmania, 1900-1901, Hobart, pp. 302-342.

Digest: Geol. Centr., Vol. 2, 1902, Leipzig, pp. 580-581.

Tin occurs in silicified and pegmatitic portions of Devonian granite, which breaks through Silurian slates, sandstones, etc. Considers tin to be of pneumatolitic origin. Accompanied by tourmaline, beryl, fluorspar, chlorite, argentiferous-galcna, zine blende, chalcopyrite, arsenopyrite and pyrite, wolframite, and probably gold. In one occurrence, considers tin in a fine grained granitic rock to be original. Some veins in neighborhood carry considerable quantities of wolframite. Describes different mines and gives rainfall.

1156. - Tin ore deposits of Mount Heemskirk.

Geol. Surv., Tasmania, 1902, Hobart, pp. 46, pls. 4.

Review: Austr. Mg. Stand., Vol. 28, 1902, Sydney and Melbourne, pp. 441, 586. Five miles from coast between Trial and Granville harbors. Geology of the district described. Four kinds of veins carry $\mathrm{SnO}_{2}$ viz.: Quartz-tourmaline veins, pinitoid (decomposed feldspar) veins, greisen veins, and pyritic veins. Tin occurs in nodules of quartz and tourmaline, sometimes hollow, generally in aplite segregations, but sometimes in the granite. Green tournaline more apt to occur with tin than black tourmaline. Much of tin in residual gravel in gray colored nuggets with granular center covered by thin concentric layers, frequently, layers are radiating. Residual gravel 1 foot to 3 feet deep, gave 7.7 per cent cassiterite. Extent unknown. Some rich veins carry up to 39 per cent tin. Tin ore spreads out from veins into sandstone, parallel to bedding.

Treats nineteen tin localities of district. Thinks region has good future.

1157. Report on the tin-ore deposits of North Dundas.

Rep. Secr. for Mines, 1901-1902, Tasmania, 1902, Hobart, pp. 139-158, pls. 1, 2, plan and section, Renison Bell mine.

Most of the deposits of tin ore are located in the center of the northeast Dundas District. Most of the ore consists of dense jron-pyrites and pyrrhotite, with small grains of tin oxide embedded in it. Following mines are described:

1. Penzance Tin Mining Co. 2. Mount Lyell Copper Estate Co. 3. Cornwall Tin Mining Co. 4. Renison Bell Prospecting and Mining Co.

1158. - Report on the prospects of the Stanley River tin field.

Geol. Surv., Tasmania, January, 1904, Hobart, pp. 1-19, map 1.

On Stanley River, a tributary of the Pieman, West Tasmania. Field five miles long. Rocks, granite, porphyry and aplites, in southern part "older Silurian metamorphic sandstones and claystones." Tin of pneumatolitic origin. Feldspar 


\section{TASMANIA (Continued)}

replaced by tin, tourmaline and quartz. Tin lodes consist of a zone of replaced granite (quartz tourmaline), with usually a central seam or flssure filled with tourmaline and tin, which may vary from a few inches to many feet in width. Pyrites and monazite occur in some veins. The small amount of work done has not only shown the presence of rich alluvial tin, but has afforded evidence of the presence of rich lode tin.

1158a. Ward, L. KeItrir. The tin field of North Dundas.

Geol. Surv., Trasmania, Bull. No. 6, 1909, Hobart, pp. 166 . Locality map, pls. 5.

Extract: Mg. Journ. Railw. Comm. Gaz., Vol. 86, 1009, London, pp. 232-233.

Treated under hends: Introduction; previous literature on the fleld; physiography; general geology; economic geology; history of mining on the fleld; the mining properties.

1159. Wellington, WM. Notice on Mount Bischoff, Tasmania.

Trans. Roy. Geol. Soc. Cornwall, Vol. 9, 1875, Penzance, pp. 161-162.

Author thinks tin of $\mathrm{Mt}$. Bischoff is the result of volcanic eruptions, Mt. Bischoff being an extinct volcano.

First deposit, of about 6 feet, is composed of small detached pieces of porphyry, granite and tin disseminated through it.

Second eruption is more granite, in shape of large boulders and not so much tin.

Last eruption appears to have been more violent sending up large masses of granite and the greatest quantity of tin.

1160. WickHAM, F. D. The tin products of Mount Bischoff, Tasmania.

Mg. Journ. Railw. Comm. Gaz., Vol. 44, 1874, London, p. 396.

1161.

The tin mines of Tasmania.

Mg. Journ. Railw. Comm. Gaz., Vol. 48, 1878, London, p. 483.

1161a. Williams, Gerard W. Notes on the Zeehan mining field, Tasmania.

Eng. Mg. Journ., Vol. 89, 1910, New York, pp. 713-715, diagrams 2.

1162. Wilson, A. P. Minerals and mining in Tasmania.

Trans. Fed. Inst. Mg. Eng., Vol. 7, 1893-1894, Newcastle-upon-Tyne and London, 1894, pp. $277-278$.

Also, Trans. North of England Inst. Mg. Mech. Eng., Vol. 43, 1894, Newcastle-uponTyne, p. 385.

Short account of Mt. Bischoff tin mining. Other districts mentioned as important are: Ringarooma, Branxholme, George's Bay and Blue Tier.

Author thinks Tasmania is destined to occupy a more prominent place as a tin producing district. Further examination will doubtless bring to light massive lodes of tinstone which have been the source of the great alluvial deposits of the island.

1163. Wintle, S. H. Stanniferous deposits of Tasmania.

Trans. Proc. Roy. Soc. New South Wales, for 1875, Vol. 9, 1876, Sydney, pp. 87-94, fig. 1.

Extract: Mg. Journ. Railw. Comm. Gaz., Vol. 45, 1875, London, pp. 1095-1096.

Mount Bischoff tin deposits in eurite porphyry thrust through Paleozoic rocks,

" clay-slate, altered sandstone, limestone, conglomerate and quartzose rock."

Limestones carry argentiferous galena, tin- and iron-pyrites and bismuth. All covered by basalt. Mount Bischoff 3500 feet altitude. Tin ore occurs as veins and lodes in porphyry.

Description of tin ore occurrence at Mt. Ramsay.

1164. Notes on the mineral resources of Tasmania.

Eng. Mg. Journ., Vol. 28, July 19, 1897, New York, pp. 38-39.

An outline of the geological and commercial features of the island, including the tin resources. 


\section{TEXAS}

1164a. Chauvenet, Regis. Franklin mountain tin prospects.

Mines and Min., Vol. 30, 1910, Scranton, pp. 529-531, figs. 3.

Treats of the locality, extent, and geology of the deposits, also nature of ores in the Franklin Mountains, near El Paso, Texas.

1165. Comstock, Theo. B. Report on the geology and mineral resources of the central region of Texas.

1st Ann. Rep. Geol. Surv. Texas, 1889 (1890), Austin, p. 345.

Author was unable, in a critical examination of more than 8000 specimens from various parts of the districts, to detect presence of tin.

1166. Tin in Central Texas.

2d Ann. Rep. Geol. Surv. Texas, 1890 (1891), Austin, pp. 595-602, figs. 68-69.

Discussion of the situation, with cuts showing the geological conditions in the Llano region where tin ore is said to have been found, character of ore and mode of occurrence. Uncertainty of discovering the mineral in commercial quantities.

\section{7. - Tin in central Texas.}

Eng. Mg. Journ., Vol. 51, 1891, New York, pp. 117-118.

Mr. Comstock, as a member of the Geol. Surv. of Texas, tells of his discovery of tin, the manner of its occurrence, and the localities. Did not find any extensive deposits.

P. 229. An addition to above article "made by correspondent [G. A. F.], in which he says two discoveries of tin in the State have been overlooked.

P. 281. Mr. C. answers correspondent.

1168. Occurrence of tin in central Texas.

Amer. Journ. Sci., Vol. 41, 1891. New Haven, p. 251.

States that a few crystals of cassiterite have been found in Mason and Llano counties, but not in commercial quantity.

1168a. Dinsmore, Chas. A. Development of a Texas tin mine.

Mg. World, Vol. 31, 1909, Chicago, p. 1120.

The tin prospect now being developed is on Mount Franklin, 161/2 miles from El Paso. The deposit is in a ternary granite, composed of a pink or reddish orthoclase feldspar, quartz and mica; it is intersected in many places by veins of fine-grained granite and pegmatite. This is overlain by rhyolite. The tin-bearing area contains " true fissure veins of quartz carrying cassiterite," and of zones of impregnations in the neighboring granite. The cassiterite occurs disseminated through the quartz and in masses, many of which are pure enough for smelting. Associated minerals are uncommon, and so far consist of hematite, pyrite, pyrrhotite, tourmaline, topaz, fluorite, garnet and hornblende. Tungsten, gold, silver and copper have also been found in small quantities on the property. The cassiterite is often found in very beautiful twin crystals, varying in color from white to dark brown.

1169. Dumble, E. T. Tin.

2d Ann. Rep. Geol. Surv. Texas, 1890 (1891), Austin, p. LXIX.

Found in connection with lead ores in Trans-Pecos, Texas. Dr. Comstock and party found pieces of cassiterite in Burnet and Mason counties.

1169a. Lakes, Arthur. A tin mine in the United States.

Mg. Sci., Vol. 61, 1910, Denver, pp. 346-348.

Description of tin prospect in Franklin Mountains, 10 miles north of El Paso, Texas. Regis Chauvenet's article "Franklin Mountain tin prospects" in Mines and Min., Vol. 30 , No. 9, 1910, Scrarton, pp. 529-531 is quoted in full. 


\section{TEXAS (Continued)}

Pavlov, Alexander W. See No. 1216.

1170. Richardson, G. B. Tin in the Franklin Mountains, Texas.

U. S. Geol. Surv. Bull. 285, 1906, Washington, D. C., pp. 146-149, fig. 1.

Description of the El Paso tin deposits, first described by Weed in U. S. Geol. Surv. Bull. 178, 1901. Gives a general description of the topography and geology of the Franklin Mountains, and a partial analysis of the tin bearing granite. The tin deposits are close to faults. Found little new development. States that water can be obtained in the mesa east of the mountains.

1171. Streenuwitz, W. H. von. Report on the geological and mineral resources of Trans-Pecos, Texas.

2d Ann. Rep. Geol. Surv. Texas, 1890 (1891), Austin.

Mentions finding traces of tin in West Texas ores.

1172. Weed, Walter H. The El Paso tin deposits (Texas).

U. S. Geol. Surv. Bull. 178, 1901, Washington, D. C., pp. 1-15, pl. 1, figs. 1-4.

Digest: Neues Jahrb. Min., 1902, II (Ref.), Stuttgart, p. 342.

Reprinted, U. S. Geol. Surv. Bull. 213, 1903, pp. 99-102.

Describes briefly the geological structure and formation of the Franklin Mountains. Thinks the veins are similar to those of Cornwall, and that the ores are formed largely by replacement. Notes the absence of topaz and presence of wolframite.

\section{TRANSVAAL AND RHODESIA}

\section{Anonymous. Discovery of tin in the Transvaal.}

California Journ. Tech., Vol. 2, No. 3, 1903, Berkeley, p. 53.

Quotes from the "British South African Export Gazette," of September 4, 1903, that three tin-bearing lodes have been discovered in the Transvaal.

1174.

- Gold and tin in northern Rhodesia.

\section{Austr. Mg. Stand., Vol. 32, 1904, Sydney and Melbourne, p. 373.}

Taken from South African Mines, reports a deposit of stream tin on west bank of Lualaba.

\section{5. - Tin discoveries in the Bushveld.}

Journ. Soc. Arts, Vol. 52, 1904, London, pp. 736-737.

A summary of particulars respecting the discovery of tin in the Bushveld, near Pretoria, taken from the "African Review."

1176. - Tin in the Transvaal.

Mg. Sci. Press, Vol. 89, 1904, San Francisco, p. 295, 250 words. (Probably from Hall, A. L., No. 1181.)

Digest: Mg. Mag., Vol. 10, New York, p. 442.

"Notes on the occurrence of this metal in several different places in the Transvaal."

1177. - Tin in the Transvaal.

Mg. World, Vol. 24, 1906, Chicago, p. 774.

States that the first output of tin in the Transvaal has recently been declared. Tin lodes in various forms have been traced over a considerable area. Other tin areas in the neighborhood are being discovered from time to time.

1178. - Failure of tin mine at Vlaklaagte, South Africa.

Eng. Mg. Journ., Vol. 82, 1906, New York, p. 180.

It was expected that this mine would prove one of the world's greatest deposits. Unless things improve considerably, the tin mine at Vlaklaagte cannot run much longer. Up to date the total amount of material won is roughly $251 / 2$ long tons cassiterite equal to $\mathbf{1 7 . 8 5}$ tons or $\mathbf{1 . 7 5}$ per cent metallic tin, from 1020 tons treated. 


\section{TRANSVAAL AND RHODESIA (Continued)}

1178a. - Potgietersrust tin fields.

South African Mg. Journ., May 23, 1908, Johannesburg, pp. 11/2.

Not available to the authors.

1178b. - The Groenfontein tin plant.

South African Mg. Journ., July 4, 1908, Johannesburg, p. \$/4.

"Describes methods for the recovery of tin in the Potgietersrust fleld, and also a new plant which is to be built."

Not, available to the authors.

1178c. Base metals in the Transvaal.

Eng. Mg. Journ., Vol. 88, 1909, New York, p. 250.

Briefly describes tin producing districts of the Transvaal.

\section{8d. - Tin deposits of the Transvaal.}

Eng. Mg. Journ., Vol. 88, 1909, New York, p. 778.

Describes the manner of occurrence in the various fields.

1178e. Zaaiplaats tin mines.

South African Mg. Journ., Vol. 7, pt. 1 (Feb. 13), 1909, Johannesburg. Jllus.

"Describes the plant and workings, going into the geology of the deposits."

Not available to the authors.

1178f. - Notes on the tin fields.

South African Mg. Journ., Vol. 7, pt. 1, 1909, Johannesburg, p. 109, illus.

Describes some occurrences and operation on Groenvlei.

1178g. - Transvaal tin: establishment of an industry.

South African Mg. Journ., Vol. 7, pt. 1, 1909, Johannesburg, p. 145.

Gives encouraging reports from the Waterberg, also an account of activity at Rooiberg and Weynek.

1178h. Waterberg tin mines.

South African Mg. Journ., Vol. 7, pt. 1, 1909, Johannesburg, p. 407.

Very encouraging outlook for tin-mining becoming a great industry in this colony.

Describes activity at Zaaiplaats property-geological features, extension of plant, scarcity of labor, etc.

11781. - The government tin report.

South African Mg. Journ., Vol. 7, pt. 1, 1909, Johannesburg, No. 338, pp. 719-721, pl. 1.

Deals with the tin industry of the Waterberg field, which is treated under heads: General geological structure; the tin rocks; the tin limits; investigation in depth; the shale-felsite deposits; the Rooiberg quartzites.

1178j. - The Transvaal tin industry to-day.

South African Mg. Journ., Vol. 7, pt. 2, 1909, Johannesburg, pp. 253-254.

Treated under heads: Some monthly reports; the Groenfontein profits; alleged secondary enrichment at Rooiberg; prospects at Doornhoek.

1178k. - Tin in Rhodesia: the beginning of an industry.

South African Mg. Journ., Vol. 7, pt. 2, No. 350, 1909, Johannesburg, p. 279, 400 words.

Probably reference to same occurrence in Mines \& Min., Vol. 30, 1909, p. 11-quoted from U. S. Consular report.

Note on the discovery of tin at Rusapi on the Salisbury-Beira line. 


\section{TRANSVAAL AND RHODESIA (Continued)}

1179. Davey, T. G. Trans-Zambesian mining.

Mg. Journ. Railw. Comm. Gaz., Vol. 73, 1903, London, p. 158.

"In many instances the granite and porphyries, which I traversed, show promising indications of the presence of tin." Whole reference.

1180. Griffith, H. D. Largest tin producing fields in the world.

South African Mines, December 3, 1904, Johannesburg, 2000 words.

"Abstract of a report on the Bushveld tin properties; character of deposits, results of development, and estimate of costs."

1181. HALL, A. L. The geological survey of the northeastern portions of the Pretoria district, including the tin fields.

Transvaal Mines Department, Report, Geological Survey for 1904 (1905), Pretoria, pp. 37-44, pls. 15, 22, map 1.

The larger part of the article is devoted to the general geology of the district. A coarse red granite at Bushveld (Enkeldoorn), 42 miles northeast of Pretoria, is apparently the youngest of the rocks except diabase, and is intrusive in a felsite. Finer grained portions, probably a later phase, carry the cassiterite in microscopic grains: One lode is about 12 feet wide at the surface, and is said to carry 1.5 per cent tin. The Vlaklaagte deposits are 12 miles further hortheast. Here cassiterite is rather evenly distributed through a gray granite cutting the coarse red granite. Cassiterite crystals are $1 / 8$ inch and less long. Topaz and mica also occur, and the author supposes the deposit to be due to pneumatolytic action.

1182. Geological notes on the Bushveld tin fields and surrounding area.

Trans. Geol. Soc. South Africa, Vol. 8, 1905, Johannesburg, pp. 47-55, pls. 9, 10, [geol. map and section of vein].

Practically the same article as No. 1181.

1183. Johnson, J. B. The tin, molybdenum and lead occurrences near Potgietersrust.

Trans. Geol. Soc. South Africa, Vol. 10, 1908, Johannesburg, pp. 115-119.

The tin deposits occur between the Magalakwin and Sterk rivers. A quartz vein carries coarsely crystalline cassiterite, which is sparsely distributed in fine crystals through the granite for a width of 40 yards. Fluorite is an accompaniment in both vein and granite. Peculiar round pipes in the granite also carry cassiterite. Other minerals with the cassiterite are molybdenite, pyrite, chalcopyrite, arsenopyrite, galena, copper, tourmaline and a greenish mica. Attributes tin, molybdenum and lead deposits to pneumatolytic metasomatism.

1183a. KYNASTON, H. Cassiterite deposits of the Waterberg.

South African Mg. Journ., Nov. 21, Dec. 12, 1908, Johannesburg. See 1183b.

1183b. - Report on a preliminary examination of the cassiterite deposits of Zaaiplaats, and some of the neighboring farms of the Waterberg district.

Transvaal Mines Dep., Rcp. Geol. Surv. for 190 ' (19c8), Pretoria, pp. 91-102, figs. 5-7. Reprint: South African Mg. Journ., Nov. 21, and Dec. 12, 1908, Johannesburg.

Deposits at Zaaiplaats, Groenfontein and Roodepoort are described.

The cassiterite occurs in the red (Bushveld) granite in pipes and chutes. The former are cylindrical bodies of altered granite impregnated with ore and sometimes surrounded with a selvage of tourmaline, fluorspar, copper and arsenic pyrites, specular iron ore, blende, galena, stibnite, wolframite, and molybdenite. 


\section{TRANSVAAL AND RHODESIA (Continued)}

1183c. LAwn, - South African tin mines.

South African Mg. Journ., Vol. 7, pt. 2, 1910, Johannesburg, p. 660.

Extracts from report of Consulting Engineer Lawn of the Doornhoek mine of South African Tin Mines Company, Ltd., Transvaal. He reports very promising outlook.

1184. MerenskY, H. Neue Zinnerzyorkommen in Transvaal.

Zeitschr. prakt. Geol., Vol. 12, 1904, Berlin, pp. 409-411, 1000 words.

Digests: Neues Jahrb. Min., 1906, II (Ref.), Stuttgart, p. 228.

Geol, Centr., Vol. 7, 1905-1906, Leipzig, pp. 328-329.

Mg. Mag., Vol. 11, 1905, New York, p. 369.

South African Mines, Vol. 2, 1904, Johannesburg, p. 512.

The new occurrence is in Enkeldoorn district, 40 miles northeast of Pretoria. The ore could be readily concentrated and smelted where found, water and coal being close at hand. Prospecting is now under way.

1184a. - The rocks belonging to the area of the Bushveld granite complex, in which tin may be expected, with descriptions of the deposits actually found. (Read March 16, 1908.)

Trans. Geol. Soc. South Africa, Vol. 11, 1908, Johannesburg, pp. 25-42.

Discusses the general theory of tin deposition, the rocks surrounding the South African deposits, and their relative ages. He then takes up the tin deposits and discusses them and their accessory minerals and also other veins which seem to have close relations to the tin veins. Treats the Rooiberg, Warmbaths, Nylstroom and Potgietersrust districts. Believes the tin ore was deposited largely from thermal solutions.

1185. Potgietersrust tin fields.

South African Mines, May 23, 1908, Johannesburg.

"Treats of output to date, geology of district, failure of government scheme and success of private producer."

Not available to the authors.

1185a. Milis-Davies, J. E. The Transvaal tin industry.

South African Mg. Journ., Vol. 7, pt. 1, 1909, Johannesburg, pp. 463-465, 493-494, 547-548, 575-576, 605-606. Illus.

$A$ series of five articles.

I. Treats of tin mining at Nylstroom.

II. Treats of Potgietersrust district.

III. Treats of Warmbaths district, describing especially the Rooiberg mine, and ancient Rooiberg workings.

IV. Continues description of Rooiberg mines, extent of lodes, ore chutes and values. v. Describes Rooiberg dressing plant. Yield to date.

New discoveries in Rooiberg district are described in Vol. 7, pt. 2, 1910, p. 495.

1186. Prangh, L. V. The Transvaal and its mines.

London and Johannesburg (1907), pp. 631-633.

States that cassiterite occurs along the Transvaal-Swaziland border on the water. sheds of Steynsdorp Creek and Black Umbelosi and Little Usutu rivers in pegmatite accompanying gneissoid and schistose rocks. In September, 1906, the mines of this area were idle, owing to paucity of ore. Gives history of discovery of Bushveld (Vlaklaagte) deposits. Tin ore on the Enkeldoorns farm in this area is in thin quartz veins cutting a coarse red granite and in the rock between the veins. Describes the unsuccessful working of these mines. Refers to several other prospects in the Great Red Granite Laccolite.

1186a. Recknager, $R$. On some mineral deposits in the Rooiberg district.

Trans. Geol. Soc. South Africa, 1909, Johannesburg, pp. 83-106, pls. 6-16.

Read July 20, 1908.

Abstract: Mg. Journ. Railw. Comm. Gaz., Vol. 84, 1908, London, p. 778. 


\section{TRANSVAAL AND RHODESIA (Continued)}

Describes the geology of the country in the neighborhood of Rooiberg, 40 miles west of Warmbaths. Tin occurs in granite, in irregular pockets, as veins in sediments and replacement deposits in quartzite. In one group of replacement deposits cassite. rite occurs with cobaltite, scheelite, cupro-scheelite, wolframite, and tourmaline. Nickel deposits are possibly connected with the tin deposits. The tin deposits were worked long ago as shown by old pits, slag-dumps, etc., but by whom is unknown.

1187. Simmersbacr, W. Die neuen Entdeckungen von Zinnerzlagerstätten in Transvaal.

Zeitschr. Berg. Hütt. Sal. preuss. Sta., Vol. 53, 1905, Berlin, pp. 245-248.

Digest: Geol. Centr., Vol. 7, 1905-1906, Leipzig, p. 521.

"Im roten Granit 35-50 engl. Meilen nordöstlich von Prätoria setzen die Zinnerzgänge in einem $11 \mathrm{~m}$ mächtigen bisweilen sich teilenden Hauptgange und 8 kleineren parallel verlaufenden Nebengängen auf."-K. Keilhack.

1188. Stewart, D. S. S. The mineral wealth of Zoutpansberg: the Murchison Range gold-belt.

Trans. Inst. Mg. Eng., Vol. 17, 1898-1899, London and Newcastle-upon-Tyne, p. 424.

"Tin occurs as stream tin at the Great Letaba River and also in veins in the granite which contains large orthoclase crystals." Whole reference.

1189. Swinburne, U. P. Government tin prospecting in Transvaal.

Mg. Journ. Railw. Comm. Gaz., Vol. 83, 1908, London, p. 7.

Extract from Government Gazette, November 29, 1907. Deposits located af Zaaiplaats, 22 miles northwest of Potgietersrust. Ore occurs in: (a) more or less isolated ore chutes or chimneys in the red granite, (b) pegmatites and coarse granite containing large tin crystals, (c) alluvial or shed tin, probably derived from the rocks referred to in (b).

1189a. The economic aspect of Waterberg tin field.

South African Mg. Journ., Vol. 7, pt. 1, Nos. 337, 338, 1909, Johannesburg, pp. 695-699, 719-721.

Describes various mines and reviews their prospects.

\section{UNITED STATES}

1190. Anonymous. Tin in America.

Mg. Journ. Railw. Comm. Gaz., Vol. 58, 1888, London, p. 384.

An enthusiastic outlook for American tin.

1191.

- Our tin mines.

Eng. Mg. Journ., Vol. 54, 1892, New York, p. 98.

Editorial. Treats of tin mining in the United States.

1192. Wus: Tin mining in United States.

Mg. Sci. Press, Vol. 82, 1901, San Francisco, p. 143, illus. 2.

Tin deposits of Southern California and South Dakota are recorded as only deposits in United States which might be made paying. Both are described, with brief history of South Dakota tin boom, and unsatisfactory results.

- Tin in United States.

Mg. Sci. Press, Vol. 87, 1903, San Francisco, p. 117.

Brief outline of tin developments in United States. Deposits of York, Alaska, are most promising, because unproven. The stone occurs there in abundance, though the veins have not been explored. 


\section{(6in UNITED STATES (Continued)}

1194.

Mg. Sci. Press, Vol. S7, 1903, San Francisco, p. 282.

Editorial. Giving brief outline of the tin mining industry of United States.

1195. - The production of tin in 1903.

Mg. Rep., Vol. 50, 1904, Denver, p. 632,700 words.

Editorial. Short review of tin deposits in United States and their outlook.

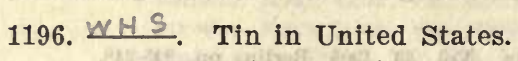

Mg. Sci. Press, Vol. 89, 1904, San Francisco, p. 385.

Rather general and brief review of tin deposits of the Carolinas; Black Hills of South Dakota; Southern California and Alaska.

1197. — Development of American tin deposits.

rrosidrenul Iron Age, December 8, 1904, New York, 1800 words.

Review of the tin industry taken from the United States Geological Survey reports.

1198. — The search for tin.

Mg. Rep., Vol. 51, 1905, Denver, pp. 624-625, 1500 words.

"Gives a summary of places in the United States where tin ore is known to have been found, with a brief description of the mode of occurrence and means for determining the mineral."

1199. - Tin mining in United States.

Eng. Mg. Journ., Vol. 81, 1906, New York, pp. 474-475.

Editorial on the prospect of profitably mining low grade tin ore in the United States.

Beck, Richard. See No. 1299.

1200. Benedict, WM. De L.

Min. Ind. for 1892, Vol. 1, 1893, New York, pp. 452-457.

Tin deposits of California, South Dakota, North Carolina, Virginia and Alabama treated.

1201. BLAKE, Wm. P. Occurrence of tin ore (wood-tin) in California, Idaho and Montana.

Mg. Sci. Press, Vol. 45, 1882, San Francisco, p. 89.

Stream tin has been found in the alluvions of the middle fork of the Feather River about 3 miles above Big Bar, in Plumas County, California.

" The many points at which the ore has been found in Montana and Idaho indicate that this important ore has a wide and general distribution in the granitic region of the northwest, particularly in the Rocky Mountains at the headwaters of the Missouri and in the western drainage, including the streams flowing from the Bitter Root range, especially in the Snake and the Salmon and their affluents."

1202. - Ores of tin.

Min. Res., U. S. Geol. Surv., 1883-1884, Washington, D. C., pp. 592-640.

Contains chapters on: Ores of tin; origin of tin ore; tin ore in the New England States; tin ore localities in the Middle and Southern States; tin ore in the Black Hills of Dakota, in Wyoming, Idaho and Montana; tin ore in California; foreign sources of tin; physical properties of tin; alloys of tin; the tin plate industry and prices, exports, etc.

D'AChIARd, Antonio. See No. 1313. 


\section{UNITED STATES (Continued)}

1203. Day, David T. Tin.

Min. Res. U. S. for 1391, U. S. Geol. Surv., 1893, Washington, D. C., pp. 164-166.

Treats of the development of the tin mines of United States during 1891.

1203a. - Tin. Mineral Industries of the United States.

Eleventh Census. Census Office, 1892, Washington, D. C., pp. 249-265.

Treats of the occurrence of tin in Massachusetts, New Hampshire, Maine, Virginia, North Carolina, Georgia, Alabama, Texas, California and South Dakota. The conditions of occurrence in the Black Hills is treated at some length, development work done, and a list of claims given. Also treats of the foreign production of tin.

1204. Douglas, JAs. Summary of American improvements and inventions in ore crushing and concentration, and in the metallurgy of copper, lead, gold, silver, nickle, aluminum, zinc, mercury, antimony and tin. Trans. Amer. Inst. Mg. Eng., Vol. 22, 1894, New York, p. 343.

"Tin is widely diffused from Maine to Alabama in Appalachian Range, exploited from Dakota to California, but the mining of it so far has nowhere been sufficiently alian remunerative to create a smelting industry."

1205. Emmens, Stephen H. American tin mines.

Eng. News Amer. Railw. Journ., Vol. 28, 1892, New York, pp. 484-486.

Abstract of reports of J. Thomas and Lord Thurlow on Harney tin mines. Also brief review and prospects of the tin deposits in North Carolina, California and Virginia.

1206. Emmons, S. F. Geological distribution of useful metais in United States.

Trans. Amer. Inst. Mg. Eng., Vol. 22, 1893, New York, pp. 71-72.

Describes the geological occurrence in different parts of the United States of iron, manganese, nickel, tin, copper, lead, zinc, quicksilver, gold and silver, and gives a summary of conclusions concerning the genesis of their minerals.

Fawns, Sydney. See No. 1320.

Fuchs, E., and Launay, L. DE. See No. 1323.

1207. Garrison, F. LYnwood. Tin in the United States.

Eng. Mg. Journ., Vol. 78, 1904, New York, pp. 830-832.

Reprint: Min. Ind. for 1904, Vol. 13, 1905, New York and London, pp. 400-405.

Brief review of history of discoveries of tin in this country. Summary of occurrence in Black Hills, at Temescal, York River, Virginia, North and South Carolina. Compares United States deposits with those in different parts of the world.

Gives average yield from some principal producers elsewhere. Short sketches of occurrence in Bolivia and Malay Archipelago.

1208. Headden, W. P. Mineralogical notes, No. III.

Proc. Colorado Sci. Soc., Vol. 8, 1906, Denver, pp. 167-173.

Pp. 167-168 give an analysis of cassiterite (credited to " Mecklenberg, N. C.," but probably from further west or south in the tin belt), which contains $\mathrm{SnO}_{2} 95.18$, $\mathrm{FeO}, 1.11$ and $\mathrm{Ta}_{2} \mathrm{O}_{5}$ 3.82. Sp. gr. 6.7671. Pp. 169-170: Cassiterite which he thinks resulted from the decomposition of stannite, from the Etta mine, South Dakota, gave $\mathrm{SnO}_{2}$ 94.36, $\mathrm{Ta}_{2} \mathrm{O}_{3} 2.42, \mathrm{Fe}_{2} \mathrm{O}_{3} 1.80, \mathrm{SiO}_{2} 1.00$.

Analyses of cassiterite from Herbert's Placer and the Sammelias claim No. 3, Pennington County, South Dakota, showed only iron and $\mathrm{SiO}_{2}$ as impurities.

1209. Hess, Frank L. Tin.

Min. Res. U. S. for 1905, U. S. Geol. Surv., 1906, Washington, D. C., pp. 445-451. 


\section{UNITED STATES (Continued)}

1210. Tin.

Min. Res. U. S. for 1906, U. S. Geol. Surv., 1907, Washington, D. C., pp. 543-549. The production of tin in the United States during the year is reviewed and estimates made of the world's production.

1211. Tin.

Min. Res. U. S. for 1907, Geol. Surv. 1908, Washington, D. C., pt. 1, pp. 725-729.

Reviews briefly the production of tin in the United States, injports, market conditions and prices. Gives an estimate of the world's production and the amount recovered in the United States from secondary sources.

Similar articles were published in the volumes for 1908 and 1909.

1212. KeMP, J. F. Zinn in den Vereinigten Staaten von Nord-Amerika.

14. Zeitschr. prakt. Geol., 1896, Berlin, p. 233.

Brief paragraph stating different localities where tin has been found in the United States.

1213. KEMP, JAs. F. The ore deposits of the United States and Canada.

3d Edition, New York, 1900, pp. 441-444, fig. 1. Bibliography.

Edition of 1893: pp. 273-274.

Edition of 1895: pp. 324-325.

General description of tin.

Short account of deposits in Black Hills, Montana, Idaho, California, Virginia, North Carolina, Alabama, Maine, New Hampshire and Texas. The tin of Mexico is also briefly treated.

1214. Leonhard, Gustav. Topographische Mineralogie der Vereinigten Staaten von Nord-Amerika.

Neues Jahrb. Min., 1849, Stuttgart, p. 836.

Tin is mentioned as occurring at Goshen, Massachusetts; Jackson, New Hampshire; and in Virginia.

Lock, C. G. WARNFond. See No. 1338.

Louis, Henry. See No. 1340.

1215. OHLY, J. Tin and its occurrence, mineralogy and metallurgy.

Mg. Rep., Vol. 48, 1903, Denver, pp. 487-488, 509-510. Serial.

1st article describes the characteristics of tin and its occurrence in the United States and Alaska.

2d article gives brief history of Temescal (Cal.), ore deposits. Notes foreign localities where mostly produced, describes the ores of tin, and treats of the metallurgy of tin.

1216. Pavlov, Alexander W. Ueber einige neue Zinnlagerstätten der Vereinigten Staaten von Amerika.

Bull. Mines Ind. or, Nos. 19 and 20, Tomsk, 1904, text figs. 2. (Russian.)

Short description of tin deposits of El Paso (Texas) and Alaska (York Region).

(Geol. Centr. Vol. 6, 1905, Leipzig, p. 200.)

Phillips, J. A., and Louis, H. See No. 1350.

1217. Pratt, J. H. Tin.

Min. Res. U. S. Geol. Surv., 1904 (1905), Washington, D. C., pp. 377-380.

Reviews briefly the production of tin in the United States and in other portions of the world. 


\section{UNITED STATES (Continued)}

1218. R-, N. Zinn in der Vereinigten Staaten.

Zeitschr. prakt. Geol., 1893, Berlin, pp. 170-171.

Brief notice of tin in South Dakota, California, Virginia. Outlook for tin production in United States not very bright.

1219. RAYMOND, R. W. Occurrence of tin in the United States.

Trans. Amer. Inst. Mg. Eng., Vol. I, 1871-1873, Philadelphia, pp. 374-375.

Remarks following a paper by T. S. Hunt on tin in Maine, in which the ore from other states is discussed.

Rolker, Chas. M. See No. 1357.

1220. Struthers, Joseph, and Pratt, J. H. Tin.

Min. Res. U. S. for 1903 (1904), Washington, D. C., pp. 335-349.

Digest: Neues Jahrb. Min., 1906, II, Stuttgart [Ref.], p. 169.

Tin of South Dakota and Wyoming briefly treated. The Carolina tin belt, its geological location, geology of district, and mineralogical and chemical character of ore, with production, treated by J. H. Pratt.

1221. See No. 1203a.

WeEks, JosepH D. See No. 1372.

See also Alabama, Alaska, California, Carolinas, Colorado, Georgia, Idaho, Maine, Massachusetts, Michigan, Missouri, Montana, Nevada, New Hampshire, New Jersey, South Dakota, Texas, Virginia, Washington, Wyoming.

\section{VICTORIA}

1222. AnNual Reports of the Secretary for Mines and Water Supply.

From 1899, Melbourne, Victoria.

Give statistics of production and aniount exported and imported annually.

1223. Anonymous. Tin in Australia.

Min. Ind. for 1898, Vol. 7, 1899, New York and London, p. 710.

Tin-bearing gravel 6 to 8 feet deep found near Beenah, Gippsland, Victoria. Plenty of water.

1224. BrachE, J. Report on gold and tin mining at Eldorado, Victoria.

1872, Melbourne,

Not available to the authors.

D'Achiakd, Antonio. See No. 1313.

Davies, D. C. See No. 1317.

1225. EDDy, Wrufam. Special report on the Victoria stream tin deposits.

Mg. Journ. Railw. Comm. Gaz., Vol. 45, 1875, London, p. 1223.

The deposits on Latrobe River, South Gippsland, are from 6 to 30 feet below the surface, and from 6 inches to 3 feet thick all over the flat valley which is from 500 to 1000 feet across. Average assay of concentrates is 65 per cent $\mathrm{SnO}_{2}$. From deepest parts of flat, sufficient gold exists to pay working expenses. River affords abundant water and power, and there is plenty of timber.

Fawns, Sydney. See No. 1320. 


\section{VICTORIA (Continued)}

1226. Gregory, J. W. The Mount Cudgewa tin field.

Geol. Surv. Victoria Bull. No. 22, 1907, Melbourne, pp. 1-4.

A preliminary report on recently discovered tin lodes of the Cudgewa district, in Benambra. Alluvial tin has unquestionably wide distribution in some parts of northeast Victoria, but attempts to work the tin-bearing lodes have hitherto failed. The tin-bearing veins of the district occur mostly in the granitic rocks, close to the contact wirh the schists, but sometimes in the schists.

1227. Herman, H. Report on mining at Mitta-Mitta, Eskdale, Tallandoon, and Mt. Elmo.

Special Report Department Mines, 1898, Melbourne, Victoria, pp. 5-6.

Brief article on the geology of the surrounding country and the tin deposits of the districts.

1228. - Report on alleged tin and gold discovery at Falls Creek, near Bruthen.

Records of Geological Survey Victoria, Vol. 1; pt. 1, 1902, Melbourne, pp. 70-71, sketch locality plan 1 .

Writer visited locality and found nothing done by way of development work since 1880, until two months before his visit, so little real information could be obtained.

Discoverers claim 10 pounds tin obtained on Foggy Creek, and good prospects of tin found in most of gullies tried, also in loam on the slopes of the hills.

1229. KITson, A. E. The economic minerals and rocks of Victoria.

(iin) Special Report Department of Mines, 1906, Melbourne, Victoria, p. 520.

Tin is the second mineral of importance in Victoria, gold occupying the first place.

It occurs as lotes:

1. Thin veins [stockworks] ramifying granitic and porphyritic rocks.

2. Dykes of coarsely crystalline rocks [pegmatite and greisen].

3. Quartz reefs traversing granitic and porphyritic rocks.

vly As alluvial or stream tin, it is found in the sands and gravels of streams, which have worn down rocks containing tin.

Principal occurrences of the lode tin are at Mt. Cudgewa, Mt. Wills, Pilot Range, and Eskdale in the northeastern district, and Mt. Singapore on Wilsons Promontory, Southern Gippsland.

Stream tin is found in the northeast district, Southern Gippsland, Eastern Gippsland, Western Gippsland, Upper Yarra and other districts.

1230. Murray, Reginald A. F. Report on the geology and mineral resources of Southwest Gippsland.

Rep. Prog. Geol. Surv. Victoria, 1876, Melbourne, p. 171.

No payable tin workings in this district have been mapped. The largest quantity yet obtained was in two small tributaries of the Franklin River. As the deposits are narrow, and do not occupy any considerable length of the creeks, remunerative tin workings are hardly to be hoped for.

1231. Murray, R. A. F. Report on the Mt. Wills tin field.

Reports and Statistics of Mines Department for Quarter ended March 31, 1890, Melbourne, Victoria, pp. 15-17, 2 sheets of underground survey of mines, Ballarat East. Digest: Neues Jahrb. Min., 1891, II, Stuttgart, p. 100.

1232. Newbery, J. Cosmo. Laboratory report of tin ore.

Rep. Prog. Geol. Surv. Victoria, No. 11, 1875, Melbourne, p. 129.

Brief examination of cassiterite from Franklin, Corner Inlet, and Upper Murray. 


\section{VICTORIA (Continued)}

1233. Nicholas, WM. Localities of minerals which occur in Victoria. Rep. Prog. Geol. Surv. Victoria, No. 3, 1876, Melbourne, p. 287.

The most important districts where tin is to be found are:

1. Lode tin, Beechworth.

2. Stream tin, Beechworth, Berwick, Bright, Burrowa Creek, Cudgewa Creek, Dry Forest Creek, La Trobe River, Mt. Fatigue, Murray River [upper].

Phillits, J. A., and Louis, H. See No. 1350.

Reyer, Eduard. See No. 1354.

Rolker, Chas. M. See No. 1357.

1234. Rosales, Hy. Report on Mt. Wills as a gold field and tin field respectively.

Special Report Department Mines, Melbourne, Victoria, 1897, p. 5.

1235. Skene, A. J., and Smytr, R. B. Report on the physical character and resources of Gippsland.

1874, Melbourne, pp. 3-65, with map and geol. sect.

"Black oxyd of tin" has been found in basin of River La Trobe, near Mt. Fatigue. Nearly all areas occupied by granite, yield some tin ore. Up to this time little has been done in Gippsland toward mining tin ore.

1236. Sмутн, R. Brovgh. The manner of occurrence of tin ore on the Upper Murray River.

Rep. Prog. Geol. Surv. Victoria, No. 1, 1874, Melbourne, pp. 5-7.

In all granitic tracts, "black oxyd of tin" is found in the beds of the creeks and gullies. Mr. H. Y. L. Brown, of Geological Survey of West Australia, examined the district and gives facts concerning the tin deposits.

1237. - Tin in Victoria.

Rep. Prog. Geol. Surv. Victoria, 1875, Melbourne, pp. 41, 42, 45.

Author predicts that rich veins of tin ore will be found in the basin of the MittaMitta and the Cudgewa.

Tin ore is found in southwestern and northwestern parts of Gippsland.

1238. Stirling, James. Report on the tin lodes at Wombat Creek.

Department of Mines, Victoria, Report of Mining Registrars for quarter ended March 31, 1889, Melbourne, pp. 65-67, hachured map 1, pls. 3, figs. 4.

Veins are on a ridge between Mt. Wills Creek [tributary of Big River], and Wombat and Nine Mile creeks, tributary to Mitta River. Tin found in creeks and bench gravels with bismuth and gold. Some lodes were found by government party. The country rock is slate and feldspathic sandstones, of Upper Silurian age, converted into nodular schists and sandstones and highly inclined. Cut by pegmatitite and aplite masses. Tin occurs in pegmatites as stockworks. "Granulitic " lodes traverse the slates. At places there is much tourmaline in the pegmatite. Some granite dikes [ternary] near by are younger than Silurian; thought probably to be Devonian. [No proof given.] Small amount of alluvial tin in Wombat valley, probably indicates that veins have not been exposed long to erosion, and will grow better in depth. Several large diorite dikes have cut the sediments and metamorphosed them. "When the lode or vein intersects certain felsitic sandstones and nodular schists, and the lode is mainly greisen, it is rich in tin, and when the small grains of white feldspar, partly converted into kaolinite are present as additional ingredients, schorl is more abundant." Cassiterite is said to be evenly distributed through some of the lodes. Lodes 1 to 5 feet wide carry 2.9 per cent to 20 per cent tin. Accompanying minerals: tourmaline, wolfram and plumose muscovite in large plates. 


\section{VIRGINIA}

1239. Benedict, WM. DE L. Tin in Virginia.

Min. Ind. for 1892, Vol. I, 1893, New York, pp. 455-456.

Tin known to exist in Virginia about ten years. Found on Irish Creek, Rockbridge County. Ore found in veins in granite. Three veins thus far discovered. Developments consist of open cut extending about 60 feet into face of hill, and a tunnel which penetrates some $\mathbf{4 0}$ feet further. Mill has been erected, and experimental tests of ore were made.

1st test: 90 tons assayed 3.44 per cent metallic tin; concentrates from which assayed 43.44 per cent tin.

2d test: 75 tons assayed 3.28 per cent tin, concentrates showing 40.40 per cent tin. 3d test: 125 tons ore, assayed 3.26 per cent tin, concentrates gave 45.07 per cent tin.

1240. Brown, W. G. On cassiterite from Irish Creek, Rockbridge Co., Virginia. Amer. Chem. Journ., Vol. 6, 1885; Baltimore, pp. 185-187.

The veins have not been prospected to more than 20 feet in depth, and are much weathered. The cassiterite is brown, from waxy to dark, and the faces are generally dull. Wolframite, arsenopyrite, quartz and mica accompany the cassiterite. Gives a description of crystals and an analysis which shows nearly 0.3 per cent $\operatorname{Ta}_{2} \mathrm{O}_{5}$.

1241. Campbetu, Harry D. Tin ore (cassiterite) in the Blue Ridge in Virginia.

The Virginias, Vol. 4, 1883, Staunton, p. 151.

Abstract: Amer. Journ. Sci. Arts, ser. 3, Vol. 27, 1884, New Haven, p. 411.

Note on the discovery of tin in eastern corner of Rockbridge County. Cassiterite occurs in quartz veins. Incomplete analysis given.

1242. Crookes and Roenrig. Tinstone, cassiterite.

The Virginias, Vol. 4, 1883, Staunton, p. 169.

Extract from Crookes \& Roehrig's Metallurgy.

Short general article.

Garrison, F. LYnwood. See No. 1207.

1243. McCreath, A. S., and Platt, Frankuin. Description of locality of tin ore, Rockbridge Co., Virginia.

The Virginias, Vol. 4, 1883, Staunton, pp. 150-151.

Not sufficient prospecting had been done to give a good idea of the veins. They occur in crystallines beneath Potsdam No. 1. The ore taken out probably averaged 31.60 per cent tin.

1244. Robertson, W. B. On Virginia tin mines.

Mg. Journ. Railw. Comm. Gaz., Vol. 54, 1884, London, pp. 1221-1222.

Deposits are in high ridges on both sides of Irish Creek, in Rockbridge County. Ore occurs in the form of a "pure and rich cassiterite" permeating quartz veins and mica slate to a width of $\mathbf{4 0}$ feet or more. Many crystals are also found. Gives description of the tin veins and outcrops of the district.

\section{Ulke, Trtus. Cash Mine, near Vesuvius, Virginia.}

Min. Res. U. S. Gẻol. Surv., 1893 (1894), Washington, D. C., pp. 178-182.

Development of property hindered by years of litigation. In writer's judgment Cash property warrants development. Mill, said to have cost $\$ 50,000$, was erected on property several years ago, and about 290 tons of rock, averaging about 3.3 per cent metallic tin were tested. Mineral association and geological occurrence of tin here more closely resembles that of Cornwall than that of any other known tin locality in United States. 


\section{VIRGINIA (Continued)}

1246. Watson, Thos. L. Mineral resources of Virginia.

The Virginia Jamestown Exposition Commission. 1907, Lynchburg, pp. 567-578.

Gives the location, a short history of the working, and a brief description of the geology of the Irish Creek tin-bearing locality. Most of the article is a transcript of a commercial report upon the region by Major Hotchkiss. Mentions that the occurrence of cassiterite has been reported at Nellys Ford, Nelson County, and at Capron Springs. Gives a bibliography.

1247. Whiteifead, EDGar. The tin ore of Virginia.

The Virginias, Vol. 5, 1884, Staunton, p. 38.

Reprinted from "The Advance" (no date), Lynchburg, Va.

A letter dated January 22, 1884, to the "American Artizan," Chicago, in which the Martha Cash tin properties are described. States that there are five known veins, which he thinks will supply the United States with tin. Gives a number of assays of both tin ore and mispickel from the same veins. The latter carried gold and silver up to $\$ 255$ per ton.

1248. Winslow, Arthur. Tin ore in Virginia.

Eng. Mg. Journ., Vol. 40, 1885, New York, p. 320, sketch maps 3.

Abstract: The Virginias, Vol. 6, 1885, Staunton, p. 168.

Location-western slope of Blue Ridge Mountains, in eastern edge of Rockbridge County.

Description of veins-fissure veins, traversing the granite in all directions. Present developments not sufficient to permit estimate of value nor a prediction as to future of deposits.

\section{WASHINGTON}

1249. ANonymous. Tin in Washington.

Mg. World, Vol. 26, 1907, Chicago, p. 784, 325 words.

Short account of discovery of tin ore, May 1906, near Spokane, Washington, close to border of Idaho, with brief notes upon the geology and development.

1250. Collier, ARThur J. Tin ore at Spokane, Wash.

U. S. Geol. Surv. Bull. 340, 1908, Washington, D. C., pp. 295-305.

Cassiterite occurs in an elevation known as Silver Hill half an hour's ride from Spokane on an electric road. Cassiterite is in peginatite accompanied by sillimanite, andalusite and tourmaline. Wolframite and scheelite occur in granite in the same hill.

\section{WESTERN AUSTRALIA}

1251. ANonymous. Tin mines in West Australia.

Mg. Sci. Press, Vol. 70, 1895, San Francisco, p. 39.

A short account of mining operations in the tin fields at Greenbushes, West Australia.

1252. Greenbushes tin field.

Austr. Mg. Stand., Vol. 17, 1900, Sydney, pp. 247-248.

"Information concerning the situation and the character of these deposits, which are known to contain certain deleterious inpurities, difficult to eliminate."

1253. - Tin of Western Australia.

Min. Ind. for 1900, Vol. 9, 1901, New York and London, pp. 638-639.

Mining operations were active during 1900, at Greenbushes. The district is described geologically. About 400 tons of ore were treated at local smelting works during 1900. Specimens of rock from the Cornwall mine assayed 1.79 per cent Sn. 


\section{WESTERN AUSTRALIA (Continued)}

1254. - Tin in Western Australia.

Min. Ind. for 1901, Vol. 10, 1902, New York and London, p. 641.

Total quantity of black tin mined during 1901 amounted to 734 tons, valued at $£ 40,000$.

1255. - Die Zinnproduction Westaustraliens.

Zeitschr. prakt. Geol., 1902, Berlin, pp. 209-210.

Taken from "The British Australasian," 1899, p. 330.

1256. - Tin in West Australia.

Eng. Mg. Journ., Vol. 80, 1905, New York, p. 1071.

Tin ore has been mined for several years on the Greenbushes and Pilbarra mining fields, West Australia. Output of these fields is about 200 tons per annum. Mentions recent discoveries of tin in the Wodgina district, and thinks it possible that within the next few years West Australia will become an important tin producer.

Wodgina district described.

1257. Krusch, P. Die Tellurerze Westaustraliens.

Zeitschr. prakt. Geol., Vol. 9, 1901, Berlin, pp. 211-217.

Digest translation in Trans. Inst. Mg. Eng., Vol. 22, 1901-1902, London and Newcastle-upon-Tyne, pp. 731-733.

"Quartz porphyry dikes, also occur bearing tinstone with tourmaline and titanite; and the weathering of these dikes has given rise to the Greenbushes stream tin workings."

1258. traliens.

Beitrag zur Kenntniss der nutzbaren Lagerstätten Westaus-

Zeitschr. prakt. Geol., Yol, 11, 1903, Berlin, pp. 378-385, figs. 2.

Digest: Neues Jahrb. Min., 1904, II [Ref.], Stuttgart, p. 242.

Author states that cassiterite occurs:

I. Sparsely in granite.

II. In greisen cutting amphibolite. Wolfram bearing minerals are rare and there

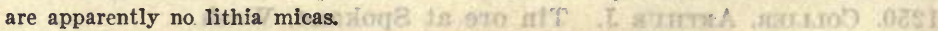

III, IV. In alluvial and disintegrated deposits along with muscovite, tourmaline, quartz, garnet, wolframite, tantalum and columbium minerals.

Thinks veins occupy cooling cracks in granite, and that the cassiterite is of pneumatolytic origin though some water is present.

1259. LAPAGE, HeRBERT. Gold and other mineral resources of Western Australia.

Trans. Fed. Inst. Mg. Eng., Vol. 7, 1894, London and Newcastle-upon-Tyne, p. 510.

"In 1888, Mr. Stinton found some stream tin near Bridgetown on the Blackwood River, which led to rich deposits, extending over about 100 square miles. The tin fields are likely to produce great wealth, if properly worked."

1260. Maitland, A. GibB. Notes on the Greenbushes tin field.

Ann. Progr. Rep. Geol. Surv. Western Australia for 1899 (1900), Perth, pp. $7-8$ and 15-20, geologic map 1.

Description of claims and geology of Dumpling Gully, Cowan Brook, Bunbury Gully, and adjoining land. The country rock is granite, sometimes gneissoid and containing much tourmaline, largely covered, up to 20 feet thick, with a residual conglomerate. Cassiterite occurs in both alluvial and residual deposits.

1261. The mineral wealth of Western Australia.

Western Australian Geol. Surv. Bull. No. 4, 1900, Perth, pp. 84-90.

Introduction treating of tin deposits in general.

Exports of tin ore from Greenbushes and Pilbarra, given. Production of tin throughout Western Australia also given. 


\section{WESTERN AUSTRALIA (Continued)}

1262. - Preliminary report on the geological features and mineral resources of the Pilbara gold field.

Western Australia Geol. Surv. Bull. No. 15, 1904, Perth.

Digest: Mg. Mag., Vol. 11, 1905, New York, p. 369.

The tin deposits so far worked are all of detrital origin and have yielded considerable quantities of ore. The ores examined seem to be free from the deleterious constituents which are known to occur in the Greenbushes tinfield.

1263. - Report on the Wodgina tin field.

Rep. Dept. Mines for 1905. Western Australia, 1906, Perth, pp. 126-140.

Digest: Eng. Mg. Journ., Vol. 80, 1905, New York, p. 1071.

Output of Greenbushes and Pilbara fields about 200 tons of tin per annum. In the; new Wodgina field, tin always occurs in granite and pegmatite dikes. In pegmatite dikes tin generally occurs along the sides, though sometimes through the mass. Veins are accompanied by mica and tourmaline.

1264. Mattrand, A. GibB, and JACkson, C. F. V. The mineral production of

Western Australia up to the end of 1903.

Western Australia Geol. Surv. Bull. No. 16, 1904, Perth, pp. 56-60.

Brief introduction treating tin deposits in general, followed by a detailed descrip. tion of the Greenbushes and Marble Bar (Pilbara) districts.

1265. Mulholland, C. A. The Greenbushes tin field, Western Australia.

Austr. Mg. Stand., Vol. 29, 1903, Sydney and Melbourne, pp. 159-160, 192. Serial.

"Begins a description of an interesting fleld from a scientific point of view, the variety of the deposits and.the metallurgical problems to be solved."

Second article treats of mineralogical details in connection with deposits at Greenbushes.

1266. Newland, D. H. Tin in Western Australia.

Min. Ind. for 1902, Vol. 11, 1903, New York and London, p. 595.

Output of tin ore in 1902 was 620 long tons valued at $£ 39,783$ as compared with. 734 tons valued at $£ 40,000$ in 1901 . Greenbushes alluvial ore carries 40 to 73 per cent tin and is associated with tantalite. Tin dressing plant has been erected in the district by the government as an aid to the mining industry.

1267. Srmpson, EDWARD S. Report of the mineralogist and assayer (gold, tin, cobalt).

Annual Progress Report, Geological Survey of Western Australia for 1899 (1900), Perth, pp. 52-54.

Gives notes upon tin ore from Greenbushes fleld; assays of dressed ore ran from 22.6 to 71.3 per cent, averaging 53.8 per cent.

The reason why some apparently well-dressed ore ran so low was found to be on account of the presence of stibiotantalite. Gives analysis. Notes presence of fine particles of native tin, also zircon, garnet, topaz, and tourmaline.

1268. - Cassiterite (tinstone). Minerals of economic value.

Western Australia Geol. Surv. Bull. No. 19, 1905, Perth, pp. 53-54.

General account of the properties and characteristics of cassiterite; its mode of occurrence and of troublesome accompanying minerals. Also a few words about stannite.

1269. Simpson, Edward S., and Gibson, Chas. G. The distribution and occurrence of the baser metals in Western Australia.

Western Australia Geol. Surv. Bull. 30, 1907, Perth, pp. 49-76 with map showing distribution.

A compilation of the information upon the various tin claims in each district of the State, with history, geologic conditions, and production. 


\section{WESTERN AUSTRALIA (Continued)}

1270. "StanNifer." The Greenbushes tin fields (Western Australia).

Austr. Mg. Stand., Vol. 18, 1000, Sydney and Melbourne, p. 811.

Describes country geologically and geographically, and gives an account of both stream and lode deposits, the prospects of which he considers are good.

1271. TaLBot, - Wodgina tin field.

Rep. Dep. Mines for 1905, Western Australia, 1906, Perth, pp. 126-128, sketch map 1.

Wodgina is at headwaters of western branch of the Turner River, and within limits of the Pilbara goldfield, about 74 miles from Port Hedland. District bids fair to rise to importance as tin and tantalite producer.

1272. Woodward, H. P. Coal and tin in West Australia.

Geol. Mag., n. s., V९l. 6, 1889, London, p. 432.

Thinks discoveries of tin at Bridgetown seems to indicate the biggest thing of the kind that has ever been found. One shaft 18 feet deep will average all the way down about 4 or 5 pounds to the pan. Tin found at surface in sand over area of about 100 square miles.

1273. Woodward, Harry P. Greenbushes tin field (with special reference to the deep leads).

Western Australia Geol. Surv. Bull. 32, 190\$, Perth, pp. 1-75, maps 3, pls. 3. nifser A general description of the district and its mineralogy with detalled descriptions of claims.

Woolvough, W. G. See No. 1649.

\section{WYOMING}

Anonymous. See No. 985.

1274. Aughey, SAmuEx. Minerals of Wyoming territory.

Annual Report of the Territorial Geologist, 1886, Laramie, p. 111.

Tin occurs near Rawhide Buttes in minute quantities, also in small quantities in Silver Crown district.

1275. BeNEDICT, WM. DE L. Tin in Wyoming.

Min. Ind. for 1892, Vol. I, 1898, New York, p. 454.

Area of tin-bearing rocks extends to granite district west and south of Custer City, South Dakota, throughout Nigger Hill district, and into Wyoming.

Chance, H. M. See No. 1002.

1276. Ricketrs, Louis D. Tin in Wyoming.

Annual Report of the Territorial Geologist Wyoming, 1890, Cheyenne, pp. 74-75.

The tin described in this report is in the Black Hills, Crook County. The cassiterite occurs in imperfect crystals [rare], granules, and grains scattered through dikes of quartz, feldspar and mica, which cut the granite country rock. Samples yielded from 2 to 6 per cent metallic tin, and those samples showing no tin minerals from 2 to 4 per cent. Stream tin in fine particles has been found in all gulches that cut the granite dikes.

SAdTler, B. See No. 1016. 


\section{GENERAL BIBLIOGRAPHY}

1277. Agricola, Geongrus (pen name of George Bauer). Bergwerck buch: darinn nicht allain alle empte' instrument gezeug und alles so zu diesem handel gehörig mit figurem vorgebildet und klärlich beschriben.

1580, Frankfort-am-Mayn.

General treatise on mining and smelting, in which the working of tin ores is mentioned in a number of places.

1278. Anonymous. Notes on tin.

Journ. Soc. Arts, Vol. 1, 1853, London, p. 550.

Briefly treats of bronze articles of Assyria; the Great Polgooth tin mine of Cornwall; metallurgy of tin and the recent discovery of tin at St. Ives, Cornwall. General article.

1279. The position of tin.

The Iron Monger, September 4, 1880, London.

Reprint: Eng. Mg. Journ., Vol. 30, 1880, New York, p. 205.

Tin of the great mining centers discussed and compared.

1280. - Tin.

Mg. Sci. Press, Vol. 45, 1882, San Francisco, p. 152.

Tin ore and how it appears. Some plain directions to enable the prospector to distinguish that ore. Character of the rocks in which tin ore is generally found.

1281. - Tin.

Eleventh census U. S. 1890, Min. Industries, 1892, Washington, D. C., pp. 249-265.

Tin of Virginia, North Carolina, Georgia, Alabama, Texas, South Dakota and- California treated. The tin deposits of the world are discussed in a general manner.

1282. Tin.

Min. Ind. for 1893., Vol. 2, 1894, New York, pp. 607-614.

A general article treating of general cenditions.

1283.

Tin.

Min. Ind. for 1894, Vol. 3, 1895, New York and London, pp. 521-528.

A general article, prices, statistics, etc.

1284.

Tin.

Min. Ind. for 1895, Vol. 4, 1896, New York and London, pp. 569-578.

General prices; the situation in Bolivia, Singkep, Malay Peninsula and Tasmania is reviewed.

1285. Tin.

Min. Ind. for 1896, Vol. 5, 1897, New York and London, pp. 523-532.

General article upon the tin production of the world and the general situation of tin mining. A full page (528) is devoted to South Africa.

1286. . Tin.

Min. Ind. for 1897, Vol. 6, 1898, New York and London, pp. 637-648.

Banka, Bolivia, England, Singkep, Spain, Portugal, Straits Settlements, Swaziland and Tasmania are treated briefly. 


\section{GENERAL BIBLIOGRAPHY (Continued)}

1287. Tin.

Min. Ind. for 1898, Vol. 7, 1899, New York and London, pp. 707-716.

General, markets, statistics.

Tin resources of Australia, Bolivia, China, Congo, Great Britain, Straits Settlements and Tasmania briefly treated.

1288. The occurrence of tin.

Mg. Sci. Press, Vol. 79, 1899, San Francisco, p. 749.

Short general review of tin, localities where found, average yearly output, percentage of output from various countries, manner of occurrence, associated rocks, and kinds of deposits.

1289. Tin.

Min. Ind. for 1899, Vol. 8, 1900, New York and London, pp. 618-628.

Short remarks on the tin-deposits and production of Australia, Banka, France (Montebras) Great Britain and Tasmania.

1290. $\longrightarrow$ Tin.

Min. Ind. for 1900, Vol. 9, 1901, New York and London, pp. 635-616.

General article; statistics, short articles on Australasian colonies (New South Wales, Queensland, South Australia and Western Australia), Bolivia, Burmah, Malay Peninsula, Russia (Siberia), and United Kingdom; tin markets; progress of technology (metallurgy, tinning, effect of tin on canned meats, chemical analysis, electrolytic deposition).

1291. - Sources of tin supply.

Engineer, Vol. 91, 1901, London, p. 6, 1700 words.

"Discusses the position of tin in the market, and the need of readjusting the balance. Reviews the principal supplies and conditions affecting the output."

1292. - Tin.

Min. Ind. for 1901, Vol. 10, 1902, New York and London, pp. 637-646.

Imports, supplies, production; Alaska, New Scuth Wales, Northern Territory, Queensland, South Australia, Tasmania, Western Australia, Bolivia, France. Malay Peninsula, United Kingdom; tin markets in 1901.

1293. - The sparse distribution of tin.

Mg. Sci. Press, Vol. 85, 1902, San Francisco, pp. 51-52.

Considered most sparingly distributed metal in common use. Workable deposits of gold cover 1,500,000 square miles, while tin deposits cover less than 125,000 square miles. Gold is, or has been obtained in nearly every country in the world, while tin comes from not more than a dozen different districts.

1294. - Tin.

New Volumes of the Encyclopædia Britannica, 10th Edition, Vol. 33, 1902, London, pp. 346-347.

"Primary deposits of tin are in or closely connected with granite or acid eruptive rocks of the same type, associated with tourmaline, fluorspar, topaz, wolfram and arsenical pyrites, and the invariable gangue being quartz." Bolivia is the only exception, "where the tin ore occurs intimately associated with silver ores, bismuth ores and various sulphides, whilst the gangue includes barytes and certain carbonates."

Over $\%$ of the world's tin is from secondary alluvial deposits. Cornwall and Bolivia deposits all in veins. Small portion of that yielded by Australia from veins. Methods of smelting.

1295. -Tin in 1902.

Eng. Mg. Journ., Vol. 75, 1903, New York, pp. 29-30.

Good general review of the year. 


\section{GENERAL BIBLIOGRAPHY (Continued)}

1296. Tin.

Mg. World, Vol. 20, 1904, Chicago, p. 21.

A page of random paragraphs on tin.

1297.

- The tin position.

Mg. Journ. Railw. Comm. Gaz., Vol. 76, 1904, London, p. 595.

"An editorial reviewing trade conditions and the probable effect of recent discoveries."

1298. - Tin.

Min. Ind. for 1904, Vol. 13, 1905, New York and London, pp. 391-400.

Tin mining in United States: Carolinas, South Dakota. Tin mining in foreign countries: Australia, Bolivia, Cornwall, Dutch Eașt Indies, Germany, Malay States. Tin Markets.

1298a. The origin of tin.

Mg. Sci., Vol. 59, 1909, Denver, p. 227, about 190 words.

$1298 \mathrm{~b}$. Tin.

Mg. Sci., Vol. 59, 1909, Denver, pp. 401-402.

Rather general, reviewing the various localities in United States in which tin has been found, closing with brief account of tin in Cornwall.

1298c. - Review of mining in foreign countries.

Eng. Mg. Journ., Vol. 87, 1909, New York, p. 125.

Brief review of tin mining at Mount Bischoff and in Derby districts, Tasmania;

New South Wales; Queensland and Northern Territory.

1298d. World's production of tin.

Mg. World, Vol. 32, 1910, Chicago, p. 140.

Statistics showing world's tin production and average prices.

1298e. - Short answers to some problems in economic geology.

Mg. Sci., Vol. 61, 1910, Denver, p. 517.

Answering the questions: How does tin ore occur; what does it look like; how may it be recognized in the field? A general article.

Bauer, George. See No. 1277.

1299. BECK, RICHARD. Lehre von den Erzlagerstätten.

1901, Berlin.

- Nature of ore deposits.

Translated and revised by Walter H. Weed, Vols. 2, 1905, New York.

Contains descriptions of the occurrence and method of mining tin ore, both in alluvial and lode deposits in various parts of the world, and discusses the origin of tin ore.

1300. BECK, R. On the relation between ore veins and pegmatites.

Trans. Geol. Soc. South Africa, Vol. 8, 1905 (1906), Johannesburg, pp. 147-150.

States that tin veins at Zinnwald, Graupen, on the island of Elba, the Etta mine (South Dakota), and Embabaan, South Africa, are pegmatite dikes.

Translated from English by G. Berg in Zeitschr. prakt. Geol., Vol. 14, 1906, Berlin, pp. 71-73.

1301. BeNedict, W. DE L. Tin.

Min. Ind. for 1892, Vol. 1, 1893, New York, pp. 439-462.

Treats of tin in Cornwall, Australia, East Indies, Malay Peninsula, Bolivia, Mexico and the United States, and the markets during 1902. 


\section{GENERAL BIBLIOGRAPHY (Continued)}

1302. Bergman [-]. Suite de la traduction d'un chapitre de la géographie physique.

Journ. Mines, Vol. 3, No. 16, 1795-1796, Paris, pp. 31-32.

Translated by Guichelin, A.

Short general article on the tin veins of Europe.

1303. Berzélius, - - Sur la présence d'étain et de cuivre dans les sources sortant d'un terrain volcanique.

C. R. Acad. Sci., Vol. 9, 1839, Paris, pp. 164-165.

1304. Bettany, G. Papers on the tin trade.

Western Morning News, 1866.

Not available to the authors.

Betrs, Anson G. See No. 1451.

1305. BoerhaAve, H. A new method of chemistry; including the history, theory, and practice of the art.

1753, London. (Two volumes.)

Translated from the Latin by Peter Shaw. Vol. 1 contains a description of tin and its characteristics; form in which found; metallurgy, and uses, among which medicinal use is mentioned, pp. $98-100$. Vol. 2 treats of the chemistry of tin in a brief way, pp. 300-301.

1306. Branner, JoHn C., and Newsom, JoHn F. Syllabus of a course of lectures on economic geology. Stanford University, 1900.

Outline of a general article on the economic geology of tin deposits, pp. 88-91 and 262.

1307. Brown, A. Selwyn. The occurrence of tin.

Austr. Mg. Stand., Vol. 16, 1899, Sydney and Melbourne, pp. 369, 385-386, 404-405. Serial.

Describes the tin deposits in various parts of the world and some of their more prominent features.

1308.

A review of the world's tin-mining industries.

Eng. Mag., Vol. 34, 1907, New York and London, pp. 325-333.

"Shows how tin deposits are now exploited only in a restricted area and analyzes the steadily growing demand for the metal. The known tin deposits of the world are then reviewed with the idea of determining where and how the increased demand for tin is to be met."

1309. Campagne, Émile Mathieu. Les mines, or, argent, fer, cuivre, plomb, étain, zinc, mercure et platine.

1883, Paris.

Not available to the authors.

1310. Charleton, Arthur G. Tin: describing the chief methods of mining, dressing and smelting it abroad. With notes upon arsenic, bismuth and wolfram.

1884, London and New York, pp. 83, pls. 14.

Briefly describes the geology of the tin deposits of Altenberg and Zinnwald, Saxony, and Abertham, Bohemia, but gives more attention to methods of mining, dressing and smelting. 


\section{GENERAL BIBLIOGRAPHY (Continued)}

1311. Clarke, Frank W. The data of geochemistry.

U. S. Geol. Surv. Bull. 330, 1908, Washington, D. C., pp. 591-595.

Treats the principal known minerals of tin; the artificial production of cassiterite; the solubility of cassiterite; rocks in which tin ores occur; and the associated minerals. Many bibliographic references.

1312. Cotta, Bernard von. A treatise on ore deposits.

Translated from 2d German Edition by F. Prime, 1870, New York, pp. 553.

Treats of tin deposits; modes of occurrence; relation of the rocks to the ore deposits; distribution of ores in deposits; tin of Germany, France, Cornwall and Finland.

1313. D'AChiard, Antonio. I metalli loro minerali e miniere.

Vol. II, 1883, Milan, pp. 522-559.

Gives a general treatment of tin as a metal and then of its minerals, cassiterite and stannite, and accompanying rninerals. Gives descriptions of deposits in Italy, Great Britain, France, Spain, Portugal, Germany, Austria, Siberia, China, Japan, India, Siam, Malay Peninsula, East Indies, Queensland, Victoria, Tasmania, Bolivia and the United States followed by generalizations upon the deposits.

1314. Daubrée, A. Mémoire sur le gisement, la constitution, et l'origine des amas de minerai d'étain.

Ann. Mines, 3d ser., Vol. 20, 1841, Paris, pp. 65-112.

Extrait par l'auteur, C. R. Acad. Sci., Vol. 12, 1841, Paris, pp. 886-890.

Extrait: Bull. Soc. Geol. France, 1st ser., Vol. 12, 1841, Paris, pp. 393-401.

Also, Edinburgh, New Philos. Journ., Vol. 32, 1842, Edinburgh, pp. 154-159.

Translation, Mg. Journ. Railw. Cornm. Gaz., Vol. 12, 1842, London, pp. 9-10.

"In the above memoir Daubrée describes the mode of occurrence of tin ore in certain stockworks in Saxony, Bohemia, Cornwall and France. He shows that, after quartz, the minerals most frequently accompanying tin ore are compounds containing fluorine, principally fluosilicates (lepidolite, topaz), sometimes fluophosphates (apatite) and fluorides (fluorspar). The element boron (tourmaline, axinite) is often abundant. The other elements most commonly met with are tungsten, molybdenum, phosphorus, arsenic and iron. Daubree draws the conclusion that the tin ore, fluorine compounds, and borosilicates owe their origin to the same set of reactions. He supposes that the tin, tungsten, molybdenum, boron, phosphorus, and some of the silicon came up through flssures from some deep seated source as fluorides. Finally, Daubrée suggests that the present condition of the stockworks, which consist of quartz, tin ore, silicates, fluosilicates and borosilicates, resulted from the reactions of these fluorides, probably in the presence of water, on the enclosing rocks."-C. Le Neve Foster.

\section{5. - Ueber Zusammensetzung und Entstehung der Zinnerzlager-} stätten.

(From Dufrenoy's report to the Paris Academy, 1841.) Institut Vol. 9, 1841, Paris, pp. 365-366.

Abstract: Neues Jahrb. Min., 1842, Stuttgart, p. 609-610.

General discussion as to the manner in which tin occurs in different deposits of the world.

1316. —_ Études synthétiques de géologie expérimentale. 1879, Paris, pp. 24, 37, 67-68, 113, 594 .

Treats of tin oxide in veins, the artificial production of tin oxide, its presence in kaolin in Allier, occurrence of tin in Central France, the occurrence of tin in an altered lead in Bourbonne, also the presence of tin in meteorites. 


\section{GENERAL BIBLIOGRAPHY (Continued)}

1317. Davies, D. C. A treatise on metalliferous minerals and mining.

Published by Crosby Lockwood \& Co., 1880, London, pp. 162-186, figs. 64-78.

Treated under heads: General description; modes of occurrence; alluvial mining in Banca, in the Malay Peninsula; tin ore deposits of Bohemia and Saxony; France and Sweden; tin in the British Isles, importance and antiquity of the industry; tin of Bolivia, Queensland, New South Wales, Victoria and Tasmania.

1318. Day, David T. Tin.

Min. Res, U. S. for 1885, U. S. Geol. Surv., 1886, Washington, D. C., pp. 370-385.

Treats of American and foreign tin resources and production in a very general way.

1319. - Tin.

Min. Res. U. S. for 1889 and 1890, U. S. Geol. Surv., 1892, Washington, D. C., pp. 119-123.

Brief review of developments made during 1890 in California, South Dakota and Virginia. Census statistics.

1320. Fawns, Sydney. Tin deposits of the world.

Published by Mg. Journ., Railw. Comm. Gaz., 1905, London, pp. 1-9 and 1-204.

Reviewed by Hess, Frank L.: Econ. Geol., Vol, 1, 1906, Lancaster, pp. 500-502.

Chap. 1. The common forms of stanniferous minerals and the early history of tin mining, p. 1-7.

Chap. 2. Description of tin deposits, pp. 7-18.

Chap. 3. Alluvial tin deposits of the Malay Peninsula, pp. 18-31.

Chap. 4. Alluvial tin deposits of Banca, Billiton, Siak, Sumatra, Siam; and British

Burma, pp. 31-45.

Chap. 5. Alluvial tin mining, pp. $45-56$.

Chap. 6. Tin lode deposits in the Malay Peninsula, pp. 56-68.

Chap. 7. Tin deposits of New South Wales, pp. 68-83.

Chap. 8. Tin deposits of Queensland, pp. 83-90.

Chap. 9. Tin deposits of Tasmania, pp. 90-105.

Chap. 10. Tin deposits of Western Australia, Northern Territory of South Australia,

New Zealand and Victoria, pp. 105-112.

Chap. 11. Tin deposits of Bolivia, pp. 112-125.

Chap. 12. Tin deposits of Cornwall, pp. 125-139.

Chap. 13. Tin deposits of Northern Nigeria, Transvaal, Swaziland and Congo Free

State, Japan, Greenland, Finland, China, Korea, Siberia, pp. 139-149.

Chap. 14. Tin deposits of Central Europe, Spain, Portugal, France, Italy, Scotland,

Ireland, Mexico, United States and Alaska, pp. 149-165.

Chap. 15. Mount Bischoff tin mine, pp. 165-175.

Chap. 16. The Dolcoath tin mine, pp. 175-186.

Chap. 17. Tin crushing and dressing machinery, pp. 186-199.

Chap. 18. Dredging for tin, pp. 199-207.

Chap. 19. Methods of tin assaying, pp. 207-224.

Chap. 20. Statistics of tin production, pp. 224-233.

Bibliography of 54 articles, pp. 233-236.

The most complete compilation on the subject to date; but contains many inaccuracies.

1321. Feuchtwanger, Lewis. Tin and its applications.

Iron, Vol. 5, n. s., 1875, London, p. 179.

General article, treating briefly; early history of tin, its properties, its manner and form of occurrence, uses, localities, where found, metallurgy and chemistry.

1322. FouxcoN, H. Ueber Zinnerze und gediegenen Wismuth.

Verh. k. k. geol. Reichs., No. 7, 1884, Wien, pp. 144-148.

An account of the occurrence of tin in Zinnwald, New South Wales, Tasmania, Chile, Bolivia and Cornwall. 


\section{GENERAL BIBLIOGRAPHY (Continued)}

1323. Fuchs, E., and de Launay, L. Traité des gîtes minéraux et métallifères.

Vol. 2, 1893, Paris, pp. 101-158.

Treats of the uses and statistics of tin, tin veins and general geology; tin of Cornwall, Germany, France, Spain and Portugal, Italy, Bolivia, Malay Peninsula, Banka and Billiton and Australia.

1323a. Goon, T. The world's tin supply.

Cassier's Magazine, Vol. 34, 1908, New York, pp. 483-487.

By arguing from wrong and insufficient data, concludes that there is no danger of the world's tin supply giving out in the near future.

1324. Graham, Walter. Tin, tin plate and tin alloys.

Brit. Mfr. Indust., Vol. 1, 1876, pp. 155-172,

Treats subject under following heads:

Early history of Cornwall tin; discovery of tin in Misina and Bohemia; properties of tin; description of tin ore and its occurrence; reduction of ore; refining; uses of tin in manufactures; tin-plate working; tin alloys; uses in the arts.

1325. Gray, John W. Some notes concerning tin.

Mg. Sci. Press, Vol. 88, 1904, San Francisco, pp. 197-198, 2000 words.

Concerning the location of the tin deposits of the world, method of extraction, the distribution and production of the metal.

1326. Guenther, Richand. Tin production of the world.

Monthly Consular Reports, State Department, March, 1905, Washington, D. C., p. 32. "Quotes "German returns" giving production of 1903 as 93,093 tons. (Kind of tons not stated.) Refers to "considerable deposits" in South Dakota; Wyoming, South Carolina and North Carolina.

1327. Henwoon, WM. J. Observations on metalliférous deposits.

Trans. Roy. Geol. Soc. Cornwall, Vol. 8, 1871, Penzance.

Treats of tin as an occasional constituent of rocks; of the derivation of stream tin, and why it is superior to lode tin in purity; extraction of tin ore by different classes of labor; the association of stream tin with gold in Wicklow and Banca, and with gold and platinum in Australia; of Roman remains in partially worked stream beds; and of the association of tin with fluorine.

1328. Hess, Frank L. Review of "Tin deposits of the worid," by Sydney Fawns.

Econ. Geol., Vol. 1, 1906, Lancaster, pp. 500-502.

1329. Hess, Frank L., and Graton, L. C. The occurrence and distribution of tin.

Contributions to Economic Geology, 1904, U. S. Geol. Surv. Bull. 260, Washington,

D. C., pp. 161-188.

Digest in Mg. Mag., Vol. 11, 1805, New York, p. 559.

A short compilation of data upon most of the known occurrences of tin, with a bibliography of ninety-two works.

1330. Horkins, Evan. On the superficial production of gold, oxide of tin, etc., or alluvial metalliferous deposits.

H. English's Min. Almanac, 1849, pp. 192-197.

Not available to the authors. 


\section{GENERAL BIBLIOGRAPHY (Continued)}

1331. Hunt, T. S. Remarks on the occurrence of tin ore at Winslow, Me.

Trans. Amer. Inst. Mg. Eng., Vol. 1, 1871-1873, New York, pp. 373-374.

Remarks by Prof. Silliman and R. W. Raymond, pp. 374-375.

Besides Winslow, Paris and Hebron are mentioned as having tin deposits.

In the discussion, a very brief and general review of tin deposits is given to afford comparison with the deposits under discussion.

1332. INGALLS, W. R. Tin.

Min. Ind. for 1905, Vol. 14, 1906, New York and London, pp. 534-556.

Treats of the tin deposits of the world.

1333. Jars, Gabrier. Voyages metallurgiques.

3 Vols., 1774-1781, Lyon.

Not available to the authors.

1334. Kalb, Courtnay DE. Relation of tin to trap dikes.

Eng. Mg. Journ., Vol. 45, 1888, New York, p. 435.

States that he has never heard of tin in greisen or granitic rocks, but always in quartz veins close to basaltic dikes. States that small amounts of cassiterite have been found in Haywood and Henderson counties, North Carolina.

1334a. Lakes, Arthur. Tin. History, use.

Mg. World, Vol. 30, 1909, Chicago, pp. 1170-1171. 1 fig.

"The geology and mineralogy, history, uses and sources of tin are treated. The object of this article is to familiarize the reader with tin mining."

1335. Lapparent, A. DE. Traité de géologie.

1883, Paris, pp. 1172-1177, fig. 1.

Treats in a general way tin deposits in Saxony, Bohemia, Cornwall, France, East Indies, Australia, China, Mexico and Italy.

1336. Leibrus, AdotPr. Remarks on tin ore and what may appear like it. Trans. Roy. Soc. New South Wales, Vol. 6, 1872 (1873), Sydney, pp. 73-74. Description of minerals that may be nistaken for tin ore, and ways of differentiating them.

1337. Lindgren, Watdemar. Metasomatic processes in fissure-veins.

Trans. Amer. Inst. Mg. Eng., Vol. 30, 1900 (1901), New York, pp. 619-626.

Topaz-cassiterite veins. Altenberg and Zinnwald, Saxony, Mt. Bischoff, Tasmania. Same paper also published with Pošepný's "Genesis of Ore Deposits," pp. 540-515

(2d Ed.). Uses these tin deposits as examples of metasomatism.

1338. Lock, C. G. WARNFord. Economic mining.

1895, New York, pp. 622-635, fig. 1.

Tin mining districts treated, rocks in which tin occurs described, yield, method of

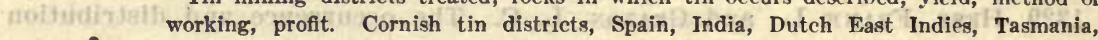
Australia, Queensland, New South Wales, Mexico, Bolivia, South Africa. Treatment of ores. Commerce.

1339. Loos, D. DE. Tin.

1888, Haarlem.

Not available to the authors.

1340. Louis, Henry. The production of tin.

Mg. Journ. Railw. Comm. Gaz., Vol. 69, 1899, London. A series of articles.

Pp. 516, 547. On tin in general; history, mode of occurrences, manner of working. Pp. 581, 611. Cornwall.

P. 643. Central Europe, Iberian Peninsula, Finland, remainder of Europe, Africa. 


\section{GENERAL BIBLIOGRAPHY (Continued)}

P. 676. Asia, Malay Peninsula.

P. 707. Shipments of tin from Straits Settlement, production of tin returned as metal in Federated Malay States.

P. 736. Malay Archipelago, remainder of Asia.

P. 771. Australia, New South Wales, Tasmania, Queensland.

P. 804. Mexico; United States, South America; world's production.

Extract: Zeitschr. prakt. Geol., 1899, Berlin, pp. 287-293.

Reprinted in pamphlet form, 1899.

A good synopsis of the mining, history, distribution, occurrence and production of tin throughout the world.

1341. MacAlister, Donadd A. Tin and tourmaline.

Quart. Journ. Geol. Soc. London, Vol. 59, 1903, London, pp. 53-54.

Abstracts: Neues Jahrb. Min., 1905, I (Ref.), Stuttgart, p. 101. .

Geol. Mag. n. s., decade 4, Vol. 10, 1903, London, p. 46. Abstract of paper read before the society.

Cassiterite rarely occurs without tourmaline, although the latter is found without the former. A discussion as to causes of deposition of the oxide of tin follows.

1342. Majende, Ashurst. Contributions towards a knowledge of the geological history of wood-tin.

Trans. Roy. Geol. Soc. Cornwall, Vol. 1, 1818, London, pp. 237-239.

Short description of wood-tin and its manner of occurrence. Ascribes it to vein formation.

1343. MASSART, ALFred. Minerales de estaño en los terrenos secundarios.

Rev. Min., ser. B, Vol. 2, 1876, Madrid, p. 87.

1344. MerriLl, Geo. P. Our sources of tin.

Sci. Amer. Suppl., No. 830, Vol. 32, 1891, New York, pp. 13257-13258.

"World's supply of tin amounts to some 50,000 and odd tons annually, of which nearly one-half comes from Malayan Peninsula and adjacent islands, $1 / 6$ from Cornwall, 1/9 from Australia and the remainder trom scattering sources, including Saxony and Bohemia, Finland, Spain, Tasmania, Bolivia and Mexico. United States has until recently produced very little."

1345. MEYers, -. Konversations-Lexikon, Vol. 17.

1897, Leipzig and Wien, pp. 1038-1040.

General article on tin.

1346. Newland, D. H. Tin.

Min. Ind. for 1902, Vol. 11, 1903, New York and London, pp. 584-597.

Review of tin deposits in general:

United States, Alaska, Bolivia (by J. B. Minchin), Malay States, New South Wales, Queensland, Tasmania, United Kingdom, Western Australia; general remarks regarding tin markets.

1347. Tin.

Min. Ind. for 1903, Vol. 12, 1904, New York and London, pp. 325-339.

Treats tin production in Alaska, Australia, Austria, Bolivia, Germany, Malay States, Mexico, South Africa, and the United Kingdom. Reviews the New York and London tin markets during 1903, and the progress of technology.

1348. Nicholls, -., DR. Some further observations towards composing a natural history of mines and metals.

Philos. Trans. Roy. Soc. London, No. 403, Vol. 35, 1728, London, p. 408.

Abridged Ed. Vol. 7, 1809, pp. 249-250.

A general article describing the crystals of cassiterite and the manner in which the ore occurs. 


\section{GENERAL BIBLIOGRAPHY (Continued)}

1349. Phillups, J. Arthur. Ore deposits:

1884, London, pp. 109, 230, 301, 310,317, 353, 375, 382, 398, 435, 443-445, 473, 481, $491,505,565,610,621$.

The tin deposits of the world are treated in a general way under the headings of the different countries.

1350. Pimllips, J. Arthur, and Louis, Henry. A treatise on ore deposits. 1896, London.

Tin deposits in the following countries treated:

Australia, Austria, England, France, Finland, Germany, Hungary, India, Italy, Malaysia, New South Wales, Portugal, Queensland, Russia, South America, Spain, Tasmania, United States and Victoria.

In this 2d Edition Phillips' original work is rewritten and enlarged by Henry Louis.

1351. Pošepnex́, Franz. The genesis of ore deposits.

Published with other papers on ore deposits by the Amer. Inst. Mg. Eng., 1902, New York (2d Ed.).

Cornwall pp. 139-140; placer deposits pp. 158-160.

Quotes tin deposits to draw general conclusions concerning the deposition of ores.

Pratt, Josepin Hyde, and Sterretr, Douglass. See No. 252.

1352. Pryce, WM. Mineralogia Cornubiensis: a treatise on minerals, mines and mining to which is added an explanation of the terms and idioms of mines.

1778, London, folio, pp. 331, pls. 7, portrait of author, tables 2.

1353. Rerhly, - Sur les gisements de l'étain, au point de vue géologique. C. R. Acad. Sci., Vol. 104, 1887, Paris, pp. 600-602.

1354. REYER, EDUARD. Zinn. Eine geologisch-montanistisch-historische Monographie.

1881, Berlin, pp. 248, bibliography.

Resume of the geological, mineralogical and metallurgical conditions in, as well as the history of different tin producing regions.

1355. - Geologie des Zinnes.

Oest. Zeitschr. Berg. Hätt. Vol. 29, 1881, Wien, pp. 9-11, 24-27, 33-34, sketches 4.

1. Die Wăschen.

2. Zinnbergbaue.

3. Die Genesis des Zinnerzes.

1356. Richter, KARL. Zink, Zinn und Blei.

1883, Wien, Pest, Leipzig.

The characteristics and working of these metals, their relations to each other and to other metals.

1357. Rolker, Charles $M$. The production of tin in various parts of the world.

16th Ann. Rep., Dir. U. S. Geol. Surv., 1894-1895, pt. 3, 1895, Washington, D. C., pp. 458-538.

Review of the tin mines of the world. Includes statistics and notes on the occurrence of tin in Maine, Virginia, North Carolina, Alabama, Texas, South Dakota, and California. 


\section{GENERAL BIBLIOGRAPHY (Continued)}

1358. SANDBERger, F. Ueber das Vorkommen des Zinn in Silicaten. Sitz. Kön. bayer. Akad. Wiss., Vol. 8, 1878, München, pp. 136-139.

Digest: Neues Jahrb. Min., 1878, Stuttgart, pp. 748-749.

1359. Schultz, F. W. Solder, its production and application with a brief history of tin and lead.

Unpaged. About 23 pages including Chapters III to VI are devotcd to tin. A brief history of the use of tin, a summary of its production, and a someivhat inaccurate description of the localities producing it, are given.

1360. Sedgwick, AdaM. Remarks on the structure of large mineral masses, . and especially on the chemical changes produced in the aggregation of stratified rocks during different periods after their deposition.

Trans. Geol. Soc. London, Vol. 3, 1829, London, p. 483.

States that besides occurring along joints tin deposits occur as segregations from . granite.

Short paragraph.

1361. Sexton, A. Humbolt. Notes on tin.

Mech. Eng., Vol. 21, 1908, London, pp. 43-46, 99-101, 175-177, 239-240, illus.

Serial. First part. "The present number considers its physical and chemical properties, uses, value; tin minerals and ores, their distribution," etc.

Second part. Mining and ore dressing. "The methods of working alluvial tin deposits are described and then the methods of concentrating tin ore are outlined. Notes regarding crushing, magnetic separation, and wet concentration given."

Third part. Smelting. "Discusses different methods of smelting tin. Reverberatory method as used in Cornwall and Singapore described; also shaft furnace smelting and Chinese methods."

Fourth part. Refining. "Discusses the refining of the metal and the process used in Cornwall."

1362. Smyti, Warington. Address of the president.

Trans. Roy. Geol. Soc. Cornwall, Vol, 10, 1887, Penzance, pp. XVII-XX. If S I

Treats of tin occurrence, mining and production of Queenstand, New South Wales, Banca, Billiton and the East Indies in a very brief way.

1363. Stevens, Chas. Tin; history and production.

Austr. Mg. Stand., Vol. 28, 1902, Sydney and Melbourne, pp. 543-544, 580, 2700 words.

" Reviews the history of this mineral, giving the sources of supply, the formation of the lodes, etc."

1364. Struthers, Joseph, and Pratt, JosepH Hybe. The production of tin in 1903.

Min. Res. U. S. for 1903, U. S. Geol. Surv., 1904, Washington, D. C., pp. 335-349.

Treats briefly of the Black Hills deposits; the Alaskan deposits (taken from $\mathbf{A}$. J. Collier's Bull, 229, U. S. Geol. Surv.); the Carolina tin belt; the market conditions, especially in the United States; and the world's production.

1365. TASSIN, WIRT. Descriptive catalogue of the collections of gems in the U. S. National Museum.

Ann. Rep. Board Reg. Smithsonian Institution, 1902, Washington, D. C., p. 494. Cassiterite is described. 


\section{GENERAL BIBLIOGRAPHY (Continued)}

1366. URE's Dictionary of Arts, manufactures and mines.

7th Ed., Vol. 3, 1878, London, pp. 998-1009, figs. 12.

General article on tin. Description of minerals, localities where found, method of treatment of ore.

1367. Van Hise, Chardes Richard. A treatise on metamorphism.

Monogr. U. S. Geol. Surv., Vol. 47, Washington, D. C., pp. 1053-1055, 1058, 1127-1128. Treats of the processes of deposition of tin ores.

1368. Vogt, J. H. L. Ueber die durch pneumatolytische Processe an Granit gebundenen Mineral-Neubildungen.

Zeitschr. prakt. Geol., 1894, Berlin, pp. 458-465.

Exposition of the author's and others' views upon the deposition of tin and other minerals connected with granite intrusions.

1369.

Zinnstein-Gang gruppe.

Zeitschr. prakt. Geol., 1895, Berlin, pp. 145-156, figs. 5.

Most of the tin deposits of the world are treated. A general, genetic discussion is given.

1370. - Problems in the geology of ore deposits.

Trans. Amer. Inst. Mg. Eng., Vol. 31, 1902, New York, pp. 134-136.

Also in Genesis of Ore Deposits, Amer. Inst. Mg. Eng., pp. 639 and 657 (2d Ed.).

Cassiterite and apatite veins. Points out that the former are always connected with acid igneous rocks, while the apatite veins are connected with gabbro.

1371. Walker, Chas. H. Hints to aid the identification of stream tin.

Mg. Sci. Press, Vol. 90, 1905, San Francisco, pp. 188-189.

"Several tests that may be used by the miner are given: most common colors are black, brown, red and yellow. A sapphire will easily scratch the smooth surface of a pebble or crystal of stream tin, but a quartz crystal will only make a scratch when a heavy pressure is applied. . . . Extremely hard, very heavy, unmetallic appearance, uninteresting, and unsuggestive of value."

1372. Weeks, Joseph D. Tin. Its history, production and statistics.

Amer. Mfr. Iron World (Tin-plate Suppl.), Vol. 50, 1892, Pittsburg, pp. 11-33. nlus.

Gives a history of tin; describes tin ores; their occurrence; deposits of Cornwall, with short notes upon other deposits of the world; methods of mining, smelting and refining; and gives statistics of production. Also treats of the tin plate industry, defines technical terms and describes machinery used.

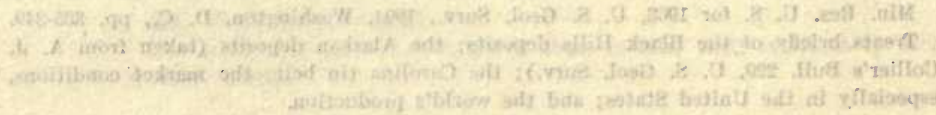




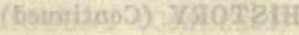 \\ III. HISTORY}

1373. Anonymous. Tin trade of the seventeenth century.

Mg. Journ. Railw. Comm. Gaz., Vol. 19, 1849, London, p. 400.

- See Nos. 310 and 611.

1374. Appleton, W. S. The earliest American coin.

American Journal of Numismatics, Vol. 5, 1870, Boston, pp. 25-27, fig. 1.

Short description and illustration of the anchor shaped piece of tin used by the

Aztecs as money.

1375. Bapst, Germain. Les métaux dans l'antiquité et au moyen âge. L'étain. 1883, Paris.

Not available to the authors.

1376. - Études sur l'étain, dans l'antiquité et au moyen âge.

1884, Paris.

Not available to the authors.

1377. Batten, John. The stannaries act, 1869 , with notes.

1873 , London.

Not available to the authors.

1378. Baudot, F. Histoire, conditions géologiques et principaux usages de l'étain.

Bull. Soc. Indust. min., ser. 3, Vol. 1, livre 1, 1887, Saint Etienne, pp. 335-343.

1379. Berthelot, P. Métaux et minéraux provenant de l'antique Chaidée. Sur les origines de l'étain dans le monde ancien.

C. R. Acad. Sci., Vol. 104, 1887, Paris, pp. 265-271.

1380. BiBLE.

Numbers 31: 22. Tin found among spoils of Midianites in days of Moses.

Ezekiel 27: 12. Tin is mentioned as abundant in Phœnicia in early ages, and as a current commodity of commerce at Tyre, although not produced there.

1381. Borlase, William Copeland. Observations on the ancient and present state of the island of Scilly, and their importance to the trade of Great Britain.

1756, Oxford, pp. $72-78$.

Discusses the question of where the Phœnicians got their tin. Historical.

1382.

Antiquities, historical and monumental of the county of Cornwall, etc.

1769, London (2d Ed.), pp. 29-30.

Treats very briefly of the early Grecian and Phœnician tin trade.

1383. - Historical sketch of the tin trade in Cornwall, from the earliest period to the present day. 1874, Plymouth, pp. 7-72. Illus. 


\section{HISTORY (Contínued)}

\section{Burnard, Robert. Antiquity of mining in Dartmoor.}

Ann. Rep. Trans. Plymouth Inst., Devon and Cornwall Nat. Hist. Soc., Vol. 11, 1890-1894 (1894), Plymouth, pp. 85-112, flgs. 5.

From an examination of evidence to be found in Cornwall, and also from early writers, the author reaches the conclusion that the "probable antiquity of the Bronze Age in Britain is from three to four thousand years, and the consequent production of tin in Devon and Cornwall must be as old."

A number of old documents dealing with the laws and customs of the Stannaries in Devon are reprinted.

Church, A. H. See No. 620.

1385. Colxins, J. H. Seven centuries of tin production in the west of England. Read March, 1891.

Trans. Mg. Ass. Inst. Cornwall, Vol. 3, 1892, Camborne, pp. 173-184, discussion, pp. 184-193.

Historically interesting. Review of English tin production from early records.

1386. D-, C. H. The "Cornwall" of France; ancient tin works.

Mg. Journ. Railw. Comm. Gaz., Vol. 36, 1866, London, p. 210.

A brief review of the writings of M. Simonin and M. Mallard on the subject of the working of the ancient tin mines at Limousin and La Marche, thought to have been worked by the Gauls.

1387. Davy, L. Sur l'ancienneté probable de l'exploitation de l'étain, en Bretagne.

C. R. Acad. Sci., Vol. 125, 1897, Paris, pp. 337-339.

1388. Dufrent, Hector. Étude sur l'histoire de la production et du commerce de l'étain.

Ann. Gên. Civ., Vol. 9, 1880, Paris, pp. 649-681, 798-826.

Not available to the authors.

1389. Edmonds, Richard. On the Phœnician tin trade in Cornwall, with remarks on the great irruption of the sea in the eleventh century, sandhillocks, " raised beaches," the causeway between Marazion and St. Michael's Mount; and the origin of the names Marazion, Market Jew, Iktin and Britain.

Ann. Rep. Trans. Plymouth Inst. Devon and Cornwall Nat. Hist. Soc., Vol. 3, 1868, Plymouth, pp. 17-37.

Historical.

1390. Flower, PHulip WM. A history of the trade in tin; a short description of tin mining and metallurgy; a history of the origin and process of the tin plate trade, and a description of the ancient and modern process of manufacturing tin plates.

Extracts from "Boston Herald," Sci. Amer. Suppl., Vol. 32, 1891, New York, pp. 13280-13281.

1391. GätzschmanN, M. F. Beiträge zur Geschichte des Freiberger Zinnbergbaues.

Berg. Hütt. Zeit., Vol. 3, 1844, Leipzig, pp. 3-8, 63-68, 125-131, 164-171, 232-243.

1392. George, R. D. Mining and use of metals by the ancient Egyptians.

Pop. Sci. Mo., Vol. 67, 1905, New York, pp. 696-697.

Mentions a bronze article found dating back to Papi, a Pharaoh of the sixth dynasty, about 2500 B. C. 


\section{HISTORY (Continued)}

1393. Greathead, Samuel. On the knowledge and commerce of tin among ancient nations.

Trans. Roy. Geol. Soc. Cornwall, Vol. 2, 1822, Penzance, pp. 359-365.

Article tracing the use of tin among the ancient nations, and also drawing conclusions as to where it was mined.

1394. HaNks, HeNRy G. Tin.

Ann. Rep. California State Min. 1880 (1881), Sacramento, pp. 31-32.

Short history of the discovery of the tin deposits of the world. Tin is mentioned as occurring in "veins of rich tin ore" in San Bernardino County, California.

1395. Hawkins, C. Observations on the tin trade of the ancients, in Cornwall and on the "Ictis" of Diodorus Siculus.

1811, London.

Historically interesting.

1396. HAwKINs, Jorn. On the state of our tin mines at different periods, until the commencement of the 18 th century.

Trans. Roy Geol. Soc. Cornwall, Vol. 4, 1838, Penzance, pp. 70-94.

A histcrical recount of the tin mines of England beginning with the period of the Romans.

1397. Hunt, RoBt. Tin mining in Cornwall and its traditions.

Good Words, 1867, London, pp. 126-131.

Historical, treating of the traditions and early history of Cornish tin mining.

Hunt, Robert. See Nos. 412 and 413.

1398. JAMES, HenRY. Note on the block of tin dredged up in Falmouth harbor.

45th Ann. Rep. Roy. Inst. Cornwall, 1863, Truro, pp. 29-33, pls. 4.

Considering the peculiar form of this block of tin, its weight and the place where it was dredged up, it appears to throw. light upon the still vexed question of the - locality of the Ictis of Diodorous. Quotations from passages of Diodorous, relative to tin trade of Britain.

1399. - On ancient Phœnician tin trade.

Mg. Journ. Railw. Comm. Gaz., Vol. 34, 1864, London, p. 65.

$\Lambda$ bstract of address delivered at Southampton Polytechnic Institution.

1400. KeNDRICK, JoHN. Phœnicia.

1855, London, pp. 212-223.

Treats of the early Phœnician tin trade with Britain and speculates as to the Cassiterides.

1401. Lewis, George Cornewall. An historical survey of the astronomy of the ancients.

1862, London, pp. 450-457.

Quotes many of the ancient writers on Phœnician trade, and comes to the conclusion that tin was supplied in early times to nations in the east of the Mediterranean by the overland route across Gaul, and that the Phonician ships got it at the mouth of the Rhone, without sailing as far as Britain. Some tin may have been obtained from Gades.

1402. Lewis, George Randall. The Stannaries: A study of the English tin miner.

1908, Boston, pp. 299, Bibl.

"The author aims to give, on the basis of the available printed and manuscript sources, an account of English tin mining and miners from the twelfth to the eighteenth centuries." 


\section{HISTORY (Continued)}

Louis, Henry. See No. 1340.

1403. Maclean, JoHn. Stannary roll 34th, Edward I (1305-1306) with introductory remarks thereon, and on other similar rolls.

Journ. Roy. Inst. Cornwall, Vol. 3, No. 12, 1871, Truro, pp. 238-241.

Remarks on same, pp. XXVI-XXVII.

Extracts from MSS. showing the magnitude of tin mining in Cornwall during the fourteenth century.

1404. - The tin trade of Cornwall in the reigns of Elizabeth and James compared with that of Edward I.

Journ. Roy. Inst. Cornwall, Vol. 4, 1874, Truro, pp. 187-190.

Brief account of tin " coined" between years 1305-1607.

1405. Napier, Chas. R. G. On the localities from whence the gold and tin of the ancients were derived.

Rep. Brit. Ass. Adv. Sci., 45th meeting 1875, Bristol, pt. 2, 1876, London, p. 177 (Abs.).

Tin was known, at least 1500 years B. C. Britain, Brazil and Sumatra mentioned as tin supplying countries for ancients.

1406. Patrison, S. R. On ancient and modern tin-works in France.

Journ. Roy. Inst. Cornwall, Vol. 2, October, 1867, Truro, pp. 343-345.

Author arrives at following conclusions, some as historical facts, the rest as probabilities:

(1) At one epoch the provinces of Limousin and Marche possessed at Montcbras and Vaulry important tin mines.

(2) Similar works were probably attempted throughout these two Provinces, which accounts for the numerous remains of open works now visible.

(3) Gold, which is found at Vaulry, and traces of gold at St. Leonard, had probably been sought for by the old miners in these works.

(4) The silence of history, and the open character of the works, justify him in attributing them to the Gauls.

1407. Pearce, Gimbert B. Blocks of tin found in Fowey Harbour.

Journ. Roy. Inst. Cornwall, Vol. 15, pt. 2, 1903, Truro, pp. 345-346.

Brief account of four blocks of tin, very rough castings. As they bore no mark or coinage stamp, the writer infers that they probably belong to a time previous to the institution of the coinage law.

\section{Plinius, Carus. Natural History.}

Bohns Classical Library.

Trans. by John Bostock \& H. T. Riley, 1887, London.

Book 4, chap. 30 , Vol. 1, p. 352 .

Timaeus, the historian said to mention that "white lead" is found on the island of Mictis 6 days' sail from Britannia.

Book 7, chap. 57 , Vol. 2, p. 225.

Midacritus was the first who brought tin from the island called Cassiteris.

Book 34, chap. 47 , Vol. 6, pp. 212-215.

Greeks brought "white lead" from Lusitania and Gallæcia.

P. 213. "White lead was held in estimation even in the days of the Trojan war,

a fact that is attested by Homer, who calls it 'cassiteros.' "'

1409. Polwhete, R. The history of Cornwall.

Vols. 7, 1816, London.

Not available to the authors. 


\section{HISTORY (Continued)}

1410. Rawlinson, George. Phœnicia.

1898, New York and London, pp. 66-67, 69-70.

Gives an account of the planting of colonies in Andalusia, Spain; led there by riches of country, among which gold, silver, quicksilver, tin, lead, copper and iron are mentioned as occurring in the mountains in which the ancient Baetis and tributaries rise. They also planted colonies on the Scilly islands, attracted by mineral wealth, and from there they exported tin and lead to Greece and Asia.

1411. REYER, - Tin, and its history.

Mg. Journ. Railw. Comm. Gaz., Vol. 49, 1879, London, p. 1299.

Historical sketch of tin beginning with 1800 B. C. down to 1873 , A. D., when Tasmanian stream tin became known.

1412. Reyer, Eduard. Allgemeine Geschichte des Zinnes.

Oest. Zeitschr. Berg. Hütt. Vol. 28, 1880, Wien, pp. 499-501, 514-516.

Translated by Symons, B. in 1881. Trans. Mg. Ass. Inst. Cornwall, Vol. 4, 1893, pp. 138-150.

Review: Eng. Mg. Journ., Vol. 31, 1881, New York, pp. 313-314.

Digest: Ann. Brit. Geol. 1893, London, p. 280.

"The name 'tin' is of Gallic origin, being derived from 'ostean,' Cornish 'stean.' It is estimated that in 1881 the production of tin in the various parts of the world was: Australia, 10,000 to 15,000 tons; England, 10,000; Straits of Malacca, etc., 10,001); Banca and Billiton, 7000 to 9000 ; Tasmania, 3000 to 5000; and China, 5000 tons."

1413. RIYs, JoHn. Early Britain, Celtic Britain.

1904, London, pp. 44, 46, 48, 204, 287.

Gives account of early tin trade, history of Cassiterides, location, etc.

1414. Saunders, C. D. The ancient Cornish tin trade. 33d Ann. Rep. Roy. Cornwall Polyt. Soc., 1865, Falmouth, pp. 42-45.

A discussion as to whether the Phoenicians carried on their tin trade as a maritime one, i. e. through the Pillars of Hercules, or as a land trade through Gaul to Mediterranean Sea.

Schmidt, Albert. See Nos. 570 and 571.

1415. Schudrman, J. A. Historische schets van de tinwinning op Banka.

Jaarb. Mijnw. Ned. Oost-Indië, 1898, II, Tech. and Admin. Amsterdam, pp. 1-112.

1416. Srmonin, L. Sur l'ancienne exploitation des mines d'étain de la Bretagne.

C. R. Acad. Sci., Vol. 62, 1866, Paris, pp. 346-347.

1417. Smirke, EDwARD. Tin trade between Britain and Alexandria in the 17 th century.

Journ. Roy. Inst. Cornwall, Vol. 2, 1867, Truro, pp. 283-291.

1418. Smith, George. The Cassiterides: an inquiry into the commercial operations of the Phœnicians in Western Europe, with particular reference to the British tin trade.

1863, London, pp. 154.

Believes that tin was obtained from Cornwall as early as the period between 1200 and 1500 B. C., and that tin did not come from Malay Peninsula during these early times.

1419. TAYLOR, JoHn. Sketch of the history of mining in Devon and Cornwall. Philos. Mag. Vol. 5, 1800, London, pp. 357-365. 


\section{HISTORY (Continued)}

1420. TyLOR, A. Is Iktis in Cornwall, and did iron and copper precede tin? Mg. Journ. Railw. Comm. Gaz., Vol. 53, 1883, London, p. 1395, sketch maps 4.

Historical. States that pure iron was used in Egypt B. C. 3124, and argues that since iron was a necessity for production of copper, and tin was of no use without copper, iron and copper must have been known first.

WAIT, F. W. See No. 482.

1421. WARNER, Richard. A tour through Cornwall (with an account of the mines).

1809, Bath and London, pp. 245-282.

Gives a sketch of the early history of tin, and in a brief way, the geology of tin deposits of Cornwall.

WeEks, Josepr D. See No. 1372.

1422. Werner, - Le plus ancien de tous les métaux.

Journ. Mines No. 18, Vol. 3, 1795 et 1796, Paris, pp. 90-96.

1423. Wheeler, H. A. Tin mining in the Ozarks. A bit of history.

Eng. Mg. Journ., Vol. 77, 1904, New York, p. 323.

Describes attempt to mine tin at Tin Mountain, some 10 miles south of Fredericktown, about 130 iniles south of St. Louis, Mo., where there was no tin. Exposes the methods used. Account of a clever fraud.

1424. Winer, - - Die Metalle und Mineralien bie den alten Egyptiern.

Berg. Hütt. Zeit., Vol. 40, 1881, Leipzig, p. 467.

Tin is mentioned among the metals used by the ancient Egyptians.

1425. WoRTH, R. N. Historical notes concerning the progress of mining skill

in Devon and Cornwall.

40th Ann. Rep. Roy. Cornwall Polyt. Soc., 1872, Falmouth, pp. 63-121.

From a historical point of view the author treats of the discovery, methods and progress of early mining, including tools, machinery and power; dressing, smelting and sale of tin and copper, with short discussion of the early miner.

1426. - The antiquity of mining in the west of England.

42d Ann. Rep. Trans. Plymouth Inst. Devon and Cornwall Nat. Hist. Soc., 1873-18it (1874), Plymiouth, pp. 120-140.

Conclusions reached are:

"First. That the historical evidence of the antiquity of western mining takes it back at least 2300 years.

" Second. That the inferential evidence carries it nearly 2000 years further, and possibly doubles the first-named period.

" Third. That the geological evidence would antedate the commencement of mining,

(ii) ai atil and consequently the use of metals, to a time when the mammoth either still existed in the west of England, or had not long disappeared; and when the general level of Devon and Cornwall was at least 30 feet higher than it is now. Taking Sir Charles Lyell's estimate of the rate of crust motion at $2 \frac{1}{2}$ feet in a century, fully 2000 years

(1) womald thus be covered by the gradual process of subsidence and whilst we cannot tell inlusiluing when it ended, nor perhaps accurately estimate the chronological value of later changes, we know from St. Michael's Mount that it must have ceased certainly 2000 years ago; whilst other reasons appear to indicate a much more remote antiquity."

1427. The ancient stannary of Ashburton.

Thans. Devonshire Ass. Adv. Sci. Lit. Art, Vol. 8, 1876, Plymouth, pp. 311-322.

Digest: Geol. Rec. for 1876, London, p. 332.

"An historical account of the stannaries of Devonshire with special reference to that of Ashburton, from the year 1197; statistics as to the produce of tin in county, and note of the minerals found." 


\section{METALLURGY AND CHEMISTRY}

1428. Aaron, C. H. Assaying of tin ores.

Assaying, pts. II and III, 1900, San Francisco, pp. 127-128.

Short account of methods used in assaying tin ore.

Agricola, Georgius. See No. 1277.

1429. Altard, - Crystallization of tin.

Ann. Indust. nat. etr., April, 1820, Paris.

Translated and abstracted by Editor Amer. Journ. Sci. Arts, 1st ser., Vol. 17, 1830, New Haven, pp. 206-208.

A method of producing "moire metallique" on tin plate by the application of acids and heat.

1430. Allen, Alfred H. On metastannic acid and the detection and estimation of tin.

Chem. News, Vol. 25, 1872, London, pp. 170-171.

Abstract of paper read before the Chemical Society, March 7, 1872.

Finds that matastannic acid is much more soluble in acids than had been supposed by Fresenius and others, and that ordinary stannic sulphate is formed by treatment with hot $\mathrm{H}_{2} \mathrm{SO}_{4}$. Uses this reaction in the estimation of tin in alloys.

1431. Alcen, J. F. On the alloys of tin, zinc, lead and other metals with manganese.

Rep. Brit. Ass. Adv. Sci. 40th meeting, September, 1870, Liverpool, pt. 2, 1871, London, pp. 50-51. [Abs.]

Makes manganese-copper alloy from the oxides, then adds tin or other metal, forming an alloy that can be rolled or cast for bearings, etc.

1432. ANONYMOUS. Improved method of estimating tin.

Mg. Journ. Railw. Comm. Gaz., Vol. 20, 1850, London, p. 489.

"Hitherto in chemical analysis tin has always been estimated in the form of stannic acid (peroxide of tin) ....... The new method depends on the facility with which protochloride of tin withdraws chlorine from bodies capable of furnishing it."

1433. - Properties of the alloys of copper and tin.

Iron Age, Vol. 24, 1879, Dec. 4, New York, p. 15; Dec. 11, pp. 9, 11; Dec. 18, p. 3. Gives results of torsional, compressive and transverse stress tests; analyses and specific gravities; and a comparion of the ductilities of various bronzes.

1434. - Disintegration of tin.

Mg. Sci. Press, Vol. 44, 1882, San Francisco, p. 275.

Short discussion of the cause of the disintegration of tin from cold. Theory advanced that it is due to crystallization, possibly to dimorphism.

1435. - Recovering tin from scrap tin.

Mg. Sci. Press, Vol. 49, 1884, San Francisco, p. 51.

Describes a process of tin recovery by oxidizing the tin on tin scrap in heated air. Copied. Original place of publication unknown to authors. 


\section{METALLURGY AND CHEMISTRY (Continued)}

1436. - Mercurialized tin.

Eng. Mg. Journ., Vol. 45, 1888, New York, p. 217.

Note from "Chemical Journal," of Nüremberg stating persons working in a smelting establishment were poisoned by tin containing 1.3 per cent $\mathrm{Hg}$.

1437.

Assais des minerais d'étain par la voie seche.

Metallurgie, Vol. 28, 1897, Paris, pp. 331-333.

1438. - Recovering tin from scrap.

Eng. Mg. Journ., Vol. 76, 1903, New York, p. 58, about 150 words.

Plants for the recovery of metallic tin are being operated in Germany [seven], Austria [one], England [one]. Germany is drawing supplies for tin recovery plants from England, France and Switzerland.

1439. - British patent, 736, 924 of 1903.

Eng. Mg. Journ., Vol. 76, 1903, New York, p. 360 .

Electrolytic method of recovering tin from scrap.

1440. - Electrolytic production of tin.

Queensland Gov. Mg. Journ., November, 1904, Brisbane.

"Description of German patent for obtaining tin from any substance containing the metal."

Not available to the authors.

1441. - Electrolytic methods of treating tin scrap.

Engineer, Vol. 98, 1904, London, pp. 5-6, 2500 words.

Details of all processes which have been tried industrially; cost of operating, and the future of industry.

1442. - Recovery of tin from old cans.

Eng. Mg. Journ., Vol. 79, 1905, New York, p. 428, 500 words.

"Tin cans are put in 2 per cent solution of $\mathrm{SnCl}_{2}$, which dissolves tin forming SnCl. Then electrolysed, tin falling in crystals .1875 in. long and solution again containing $\mathrm{SnCl}_{2}$ is pumped back. Carried on at $70^{\circ} \mathrm{F}$. Known as Bergse process and used at Copenhagen, Denmark, works.

1442a. - Wet method for the assay of tin in ores, etc.

South African Mg. Journ., May 2, 1908, Johannesburg, p. \$/4.

"Gives a simple and reliable process for the determination of tin in tin ores by the wet method."

1442b. - Detinning industry.

Iron and Coal Tr. Rev., Vol. 78, 1909, London, p. 415, fig. 2.

"A review of the detinning industry with notes on chlorine detinning and also a short note on the Goldschmidt company."

—. See No. 1294.

1443. Balling, CarL. Manuel pratique l'art de l'assayeur.

1881, Paris, pp. 488-500.

Methods of assaying tin ores.

\section{Bannister, C. O. On the assay of auriferous tinstone.}

Trans. Inst. Mg. Met., Vol. 15, 1905-1906, London, pp. 513-519. Discussion pp. 520-523.

Gives results obtained in assaying stream-tin for gold by scoriflcation, crucible assay, a wet method, concentration of the gold in a part of the tin, and by the collection of the gold in the whole of the tin. Considers the crucible method to be the best. 


\section{METALLURGY AND CHEMISTRY (Continued)}

1445. BEcifamp, A., and SaintpierRe, C. Recherches sur la séparation [par voie humide] de l'or et du platine, d'avec l'étain et l'antimoine.

C. R. Acad. Sci., Vol. 52, 1861, Paris, pp. 757-759.

1446. Bergemann, C. Mineral-Analysen. Zinnstein von Xeres in Mexico.

Neues Jahrb. Min., 1857, Stuttgart, p. 395.

1447. Berglund, Emm. Neue Methode zur qualitativen Scheidung von Zinn, Antimon und Arsen.

Berichte deutsche Chemische Gesellschaft, Vol. 17, I, 1884, Berlin, pp. 95-98.

Digest: Amer. Chem. Journ., Vol. 7, 1885-1886 (1886), Baltimore, p. 133.

1447a. Beringer, J. J. Wet assay of tin ores.

Mg. Mag., Vol. 1, 1909, London, pp. 231-232.

Discussion by Pearce, Richard, ibid., pp. 307-308.

1448. Berthelot, - Action de l'oxygène sur les chlorures acides et composés analogues: étain, silicium, bore.

C. R. Acad. Sci., Vol. 86, 187s, Paris, pp. 920-926.

1449. Bertirier, P. Analyse d'un étain allié.

Ann. Mines, 3d ser., Vol. 11, 1837, Paris, pp. 513-514.

1450.

Analyse d'un étain allié. [Extrait.]

Ann. Mines, 3d ser., Vol. 19, 1841, Paris, pp. 702-703.

1450a. BetTeL, W. Assaying tin ores.

South African Mg. Journ., September 12, 1908, Johannesburg, pp. 11/2.

"Discusses the various methods for the assay of tin and compares the merits of the Cornish wet and dry methods."

1451. Betts, Anson G. Electrolytic lead refining. [Tin in refined lead.]

Trans. Amer. Inst. Mg. Eng., Vol. 34, 1903, New York, p. 180.

Tin has been found in electrolytically refined lead at Trail, B. C., to the extent of 0.62 per cent. No difficulty is experienced in removing this from the lead by poling before casting.

1452. Billings, G. H. The properties of iron alloyed with other metals.

Trans. Amer. Inst. Mg. Eng., Vol. 5, 1877, New York, p. 450.

Reprint: Eng. Mg. Journ., Vol. 23, 1877, New York, pp. 394-395.

Results of experiments made by combining a small per cent of tin with iron. Of all metals alloyed with iron, experiments point to the fact that tin has the most hurtful effect.

1453. BoHNE, E. Vererbeitung der Schlacken vom Zinnerzschmelzen vermittelst verdünnter Schwefelsäure.

Berg. Hütt. Zeit., Vol. 57, 1898, Leipzig, pp. 203-204.

Digest: Proc. Inst. Civ. Eng., Vol. 133, 1898, London, pp. 452-453.

"The final slags produced in smelting of tin ores in the reverberatory furnace cannot, as a rule, be brought to lower content of tin than about 4 per cent, which in works smelting ten tons of ore daily, represents a loss of $3 \mathrm{cwt}$. to $4 \mathrm{cwt}$. of metallic tin. Author finds that this may be reccvered to a great extent by decomposing the slag with sulphuric acid, when the iron and tin are dissolved, giving a solution from which the latter metal may be recovered by electrolysis."

1454. Boucard, A. Dosage de l'étain dans les minerais.

Rev. Univ. Mines Met. Trav. Publ. Sci. Arts Appl. Indust., sem. 2, Vol. 8, 1860, Liége and Paris, pp. 482-483. 


\section{METALIURGY AND CHEMISTRY (Continued)}

1455. —_ Recherches sur la séparation par vole humide de l'or et du platine d'avec l'étain et l'antimoine.

Rev. Univ. Mines Mét. Trav. Publ. Sci. Arts Appl. Indust., sem. 2, Vol. 10, 1861, pp. 171-173.

1455a. Brackenbury, C. Notes on tin dressing.

Bull. Inst. Mg. Met., 52, Jan. 14, 1909, London.

"Contributed remarks in which the author gives a series of experiments showing a great variation between vanning assays and chemical assays of tin ore."

1456. Brandenburg, H., Weyland, A., and Kempen, A. R. British patent, 16,377 of 1903.

Eng. Mg. Journ., Vol. 76, 1903, New York, p. 630.

"Tin extraction from dross. The use of a mixture of sulphuric and hydrocbloric acids for extracting tin from dross and slags, the whole of the tin being thus extracted in soluble form without being thrown down as oxide."

1457. Brooks, CeCH J. Quantitative estimation of tin.

Eng. Mg. Journ., Vol. 61, 1896, New York, p. 494.

A brief record of experiments made to ascertain the cause of the low results which are often obtained in the determination of tin.

1458. Browne, Frank. Chinese tin.

Chem. News, Vol. 95, 1907, London, pp. 3, 4.

Abstract by W. S. Landis in Chem. Abs., No. 5, Vol. 1, March 5, 1907, Easton, p. 549 .

Description of a Chinese method of smelting tin.

1459. Bunsen, R. Unterscheidung und Trennung des Arseniks von Antimon und Zinn.

Ann. Chem. Pharm., Vol. 106, 1858, Heidelberg, p. 3.

1460. Cahours, A: Recherches sur les radicaux organo-métallique.

C. R. Acad. Sci., Vol. 48, 1859, Paris, pp. 833-837.

Action des alliages d'étain et de sodium sur les ethers iodhydriques des différentes séries alcooliques.

1461. Cahours, A., and Demarçay, E. Sur les stannpropyles et les isostannpropyles.

C. R. Acad. Sci., Vol. 88, 1879, Paris, pp. 1112-1117.

1462. - Sur les radicaux organométalliques de l'étain. Stannbutyles et stannamyles.

C. R. Acad. Sci., Vol. 89 , 1879, Paris, pp. 68-73.

1463. Camours, A., and Riche, A. Recherches sur le stannéthyle, nouveau radical organique renfermant de l'étain.

C. R. Acad. Sci., Vol. 35, 1852, Paris, pp. 91-95.

Abstract in Amer. Journ: Sci. Arts, 2d ser., Vol. 14, 1852, New Haven, p. 421.

Description of and mode of making an organic tin compound to whose radical the authors give the name "stannethyl."

1464. - Recherches sur un nouveau radical organique refermant de l'étain, le stanméthyle.

C. R. Acad. Sci., Vol. 36, 1853, Paris, pp. 1001-1004. 


\section{METALLURGY AND CHEMISTRY (Continued)}

1465. Capitane, H. De l'action de l'étain, de l'arsenic, de l'antimolne et du soufre sur les chlorures de mercure.

Ann. Mines, ser. 3, Vol. 17, 1840, Paris, pp. 441-445.

Extrait: Journ. Pharm., Vol. 25, 1839, Paris, p. 50.

1466. Carpenter, F. R., and Headden, W. P. Note on the influence of columbite upon the tin assay.

Trans. Amer. Inst. Mg. Eng., Vol. 17, 1889, New York, pp. 633-636.

Discussion by Blake, W. P., ibid., pp. 785-787.

The results of assays made upon tin ores from the Black Hills are given: conclude that the presence of columbite is injurious, and that the buttons owe their increase in weight to impurities derived from it.

Charleton, Arthur G. See No. 1310.

Clark, Donald. See No. 1076.

1467. Clakke, F. W. On a new method of separating tin from arsenic, ant1mony and molybdenum.

Chem. News, Vol. 21, 1870, London, p. 124.

Amer. Journ. Sci. Arts, ser. 2, Vol. 49, 1870, New Haven, pp. 48-51.

Reviewed by Koninck, L. L. de.-Rev. Univ. Mines, Met. Trav. Publ. Sci. Arts Appl. Indust., ser. 1, Vol. 29, 1871, Liége and Paris, p. 151.

(See No. 1477.)

1468. Collins, Henry F. On adobe and other cheap and makeshift furnaces. Trans. Inst. Mg. Met., Vol. 12, 1902-1903, London, p. 425.

Reference to furnaces and slags at some large old tin mines at Bundi, Federated Malay States.

1469. Coluins, J. H. On the assay of tin and on the solubility of cassiterite. Trans. Inst. Mg. Met., Vol. 13, 1905, London, pp. 485-486, remarks, p. 487.

Reprint: Austr. Mg. Stand., Vol. 32, 1904, Sydney and Melbourne, p. 174.

Abstract: Eng. Mg. Journ., Vol. 77, 1904, New York, p. 928.

Believes vanning to be the best mine test, and reduction by fusion of $\mathrm{SnO}_{2}$ with $\mathrm{KCN}$ a good assay. Finds that finely powdered $\mathrm{SnO}_{2}$ may be largely dissolved by $\mathrm{H}_{2} \mathrm{SO}_{4}$ and zinc, and with $\mathrm{HCl}$.

1470. The use of the impact screen in tin dressing.

Mg. Mag., June, 1906, New York, p. 521.

Abstract: Journ. Chem. Met. Min. Soc. South Africa, Vol. 7, 1906, Johannesburg, pp. 54-55.

1471. CoWPER, CoLes S. Electrolytic refining of tin and treatment of tin ores. Electr. Eng., Vol. 22, 1898, New York, pp. 81-82.

Digest: Min. Proc. Inst. Civ. Eng., Vol. 136, pt. II, 1898-1899 (1899), London, p. 442.

Description of various methods tried from time to time for the electrolytic refining of tin, and also for the recovery of tin from its ores. The process of Claus, which consists in using an electrolyte of stannate of sodium or sulpho-stannate of sodium, is given as one of the most successful methods.

1472. Cramer, JoHn ANdrew. Elements of the art of assaying metals. Translated from the Latin. Illustrated with copper plates. 1741, London. The titles of the chapters dealing with tin are:

1. Tin, pp. $3,19-20$. 


\section{METALLURGY AND CHEMISTRY (Continued)}

(15) 16 valion. Precipitation of silver out of tin, by scorification, pp. 228-230.

3. The reduction of tin ore in a close vessel, pp. 334-335.

4. The reduction of tin ore, extempore, pp. 335-336.

5. 'To reduce tin ore by a stratification with coals, pp. 336-337.

1473. Croockéwıt, J. H. Over de wijze van uitsmelting (herleiding) van den tinerts door de Chineezen op Banka.

1852, Batavia, pp. 37.

Not available to the authors.

1474. De Koninch, L. L., and Lecrenier, A. Séparation qualitative de l'or et du platine d'avec l'arsenic, l'antimonie et l'étain.

Rev. Univ. Mines Met. Trav. Publ. Sci. Arts Appl. Indust., ser. 3, Vol. 2, 1888, Liêge and Paris, pp. 98-99.

1475. Delachanal, B., and Mermet, A. Sur un composé de platine, d'étain et d'oxygène, analogue au pourpre de Cassius.

4hetrat $\quad$ C. R. Acad. Sci., Vol. 81,1875 , Paris, pp. 370-371.

1476. Delvaux de Fenffe, A. Purification de l'étain et emploi du tungstène pour l'amélioration de l'acier et de la fonte de fer.

Rev. Univ. Mines Mét. Trav. Publ. Sci. Arts Appl. Indust., sem. 1, Vol. 7, 1860, Liége and Paris, pp. 81-86.

1477. Dewey, Fred P. On Clarke's method for the separation of tin from arsenic and antimony.

Amer. Chem. Journ., Vol. 1, 1879-1880 (1880), Baltimore, pp. 244-251.

See No. 1467.

1478. Diest, P. H. van. Het tinsmelten op Bangka.

Jaarb. Mijnw. Ned. Oost-Indië, 1872, I, Amsterdain, pp. 217-253. Twee platen en twee bijlagen.

Abstract: Berg. Hitt. Zeit., Vol. 32, 1873, Leipzig, pp. 423-424.

Bijlage I, Bevattende het rapport der Commissie tot het uitvoeren van vergelijkende smeltproeven, ingesteld bij gouvernementsbesluit, dd. 2 Mei 1866.

Bijlage II, Beschrijving van de unrichting, den bouw en het gebruik van den nieuwen of vierkanten smeltoven voor Bangka.

1479. Dietzsch, F. The treatment of tin-wolfram-copper ores at the Clitters United Mines.

Trans. Inst. Mg. Met., Vol. 15, 1906, London, pp. 2-28, discussion, pp. 29-61, figs. 5.

A detalled account of new methods used in reopening and working the old Clitters mine, near Gunnislake in East Cornwall.

1480. DiJK, P. van. Omsmelting en zuivering van drie partijen Banka-tin aan het Koloniaal Etablissement te Amsterdam.

Jaarb. Mijnw. Ned. Oost-Indië, 1890, Amsterdam, I, Tech. en Admin. pp. III-XXIII, Verslag, waarbij twee platen.

1481. Douglas, J. C. The cry of tin.

Mg. Sci. Press, Vol. 43, 1881, San Francisco, p. 99.

The sound emitted by tin when bent, is not peculiar to tin and can be imitated with other metals of a crystalline structure. Heated rolled zinc emits a "cry" like tin, only fainter. Cast zinc, if pinched between the teeth or plier emits the sound distinctly. This cry, alone or in conjunction with a microphone, becomes an indicator of the crystalline texture of metal beams and their fitness for certain classes of work.

The original place of publication is unknown to the authors. 


\section{METALLURGY AND CHEMISTRY (Continued)}

1482. Dussauce, - Metallurgy of tin.

Amer. Journ. Mg. Mill. Oilb. Geol. Min. Met., Vol. 4, 1867, New York, pp. 354-355, 371, 386-387.

Describes the ores of tin, localities where found, preparations for smelting, and smelting and refining processes. Serial. First three articles only available to the authors.

1483. Drkes, F. J. B. Analysing of tin slag.

Perak Gov. Gaz., Vol. 17, No. 26, July 15, 1904, Supplement, Kuala Lumpur, Malay Peninsula, p. 1.

Ten analyses of slags from slag heaps at native furnaces gave from 2.32 per cent to 8.4 per cent tin.

1483a. Edwards, C. P. Assay of tin.

South African Mg. Journ., November 7, 1908, Johannesburg, p. $\%$.

"A description of the method used, with special reference to adapting the scheme to different ores."

1484. Egleston, T. The law of fatigue and refreshment of metals. Effect of vibration on tin.

Trans. Amer. Mg. Eng., Vol. 8, 1879-1880, New York, pp. 400-401.

Tín is apparently an exceptional metal in its behavior under vibration, although enough data could not be obtained to prove the law or the exception.

Eulis, Thos. F., and McKillop, John. See No. 1530.

1485. Elsner, L. Moyen de séparer l'arsenic de l'étain.

Ann. Mines, ser. 3, Vol. 19, 1841, Paris, p. 529.

Extract from Ann. Chem. Pharm., Vol. 32, Heidelberg.

1486. Arsenik.

Journ. prakt. Chem., Vol. 35, 1845, Leipzig, pp. 310-312.

1487. ENGEL, R. Sur les acides stanniques.

C. R. Acad. Sci., Vol. 125, 1897, Paris, pp. 651-654.

1488.

Sur l'action de l'étain azotique sur l'étain.

C. R. Acad. Sci., Vol. 125, 1897, Paris, pp. 7c9-711.

FLower, P. W. See No. 1390.

1489. Flower-Ellis, T. J. A brief account of the Malay tin industry.

Proc. Chem. Met. Soc. South Africa, Vol. 2, 1897, Johannesburg, pp. 5-18, fig. 1.

Reprint: Mg. Journ. Railw, Coinm. Gaz., Vol. 67, 1897, London, pp. 532, 592-593.

Peninsula is described as a " huge ridge of granite and porphyry, with occasional tracts of overlying and highly distorted sandstone, slate, schists and limestones, the lower ground being flled in with alluvial beds of clay, sand and gravel." Ore is associated with granite, both in lode and alluvial deposits. Richest pay gravel rests on the lowest clay bed, usually an impure kaolin. Methods of obtaining valuation of tin-bearing ground, Chinese method of mining, methods of smelting used by both Chinese and Europeans, tests for quantity of tin given.

1490. Foullon, H. von. Ueber Krystallisirtes Zinn.

Jahrb. k. k. geol. Reichs., Vol. 34, 1884, Wien, pp. 367-384, mit 2 Holzschn. u. 1 Taf.

Review: Neues Jahrb. Min., 1885, II (Ref.), Stuttgart, pp. 266-268. 


\section{METALLURGY AND CHEMISTRY (Continued)}

1491. Frangken, V. Determination de l'étain.

Rev. Univ. Mines Met. Trav. Publ. Sci. Arts Appl. Indust., ser. 2, Vol. 11, 1882, Liége and Paris, p. 503.

1492. Fritzche, P. Sur un phénomène de rupture produit au milieu de blocs d'étain sous l'action d'un froid intense.

C. R. Acad. Sci., Vol. 67, 1868, Paris, pp. 1106-1107.

1493. Fraenker, A., and Fasal, J. Estimation of tin in salts of tin.

Chem. News, Vol. 78, 1898, London, pp. 100-101.

Mitth. k. k. Techn. Gewerbe-Museums in Wien, Vol. 7, 1907, Wien, p. 227.

Extract: Rev. Univ. Mines Mét. Trav. Puòl. Sci. Arts Appl. Indust., ser. 3, Vol. 44, 1898, Liége and Paris, pp. 301-302.

Digest: Eng. Mg. Journ., Vol. 66, 1898, New York, p. 333.

"The authors have worked out a method for the estimation of tin which consists in precipitating this metal on aluminum dissolving the two metals in hydrochloric acid, and titrating the stannous chloride thus formed by means of iodine or bichromate of potassium."

1494. Gaultier de Claubry, H. F. Dosage de l'étain par volumes.

C. R. Acad. Sci., Vol. 22, 1846, Paris, pp. 861-862; Vol. 23, 1846, pp. 101-103.

Extrait par l'auteur.

1495. Gay-Lussac, Louis J. Sur la séparation de l'antimoine d'avec l'étain.

Ann. Chim. Phys., Vol. 46, 1831, Paris, p. 222.

Ann. Physik. Chem., Vol. 21, 1831, Leipzig, pp. 589-590.

Extrait: Ann. Mines, ser, 3, Vol. 2, 1832, Paris, pp. 329-330.

Extract. Amer. Journ. Sci. Arts, ser. 1, Vol. 27, 1835, New Haven, p. 197.

1496. Gerardin, A. (?). Note sur le bichlorure d'étain considéré comme un dissolvant.

C. R. Acad. Sci., Vol. 51, 1860, Paris, p. 1097.

1497. Gmenlivg, Andreas. Metallurgische Beiträge aus Bolivia.

Oest. Zeitschr. Berg. Hutt., Vol. 38, 1890, Wien, pp. 269-273, 281-286, .294-298, pls. $13,14$.

1497a. Goldschmid, K. Recovery of tin from tin-plate waste.

Oest. Zeitschr. Berg. Hütt., 1909, Wien, p. 103.

Digest translation in Min. Proc. Inst. Civ. Eng., Vol. 177, pt. 3, 1909, London, pp. 358-359.

Desuribes the removal of tin from tin scrap, including tin cans, by the dry chlorine process.

Estimares 75,000 tons of scrap are treated in Germany each year, and about 25,000 tons in the rest of Europe, making 1500 tons of tin and tin-salts. In America 60,000 tons, giving 3000 to 3500 tons tin or $3 \frac{1}{2}$ per cent of the world's product.

Goldschmidt handles 50,000 tons in Germany.

1498. GREgor, W. Observations on a remarkable change which metallic tin undergoes, under peculiar circumstances, and on its partial conversion into a muriate of tin.

Trans. Roy. Geol. Soc. Cornwall, Vol. 1, 1818, Penzance, pp. 51.59.

Description of metallic tin changed to chloride of tin, presumably through weathering in air near the sea.

Halse, Ed. See No. 773. 


\section{METALLURGY AND CHEMISTRY (Continued)}

1499. HaÜy, - Substances Métalliques.

Journ. Mines, Vol. 5, No. 30, 1796, Paris, pp. 457-466.

1500. Hawkins, JoHn. On a process of refining tin.

Trans. Roy. Geol. Soc. Cornwall, Vol. 1, 1818, Penzance, pp. 201-211.

A proposal to purify tin by allowing impurities to settle from liquid mass.

1501. Hayes, Augustus A. On the action of metallic tin on solutions of muriate of tin.

Amer. Journ. Sci. Arts, ser. 1, Vol. 38, 1840, New Haven, pp. $408-410$.

1502. Headden, WM. P. Formation of the alloys of tin and iron with description of some new alloys.

Proc. Colorado Sci. Soc., Vol. 4, 1891, Denver, pp. 81-122.

Abstract: Amer. Journ. Sci. Arts, ser. 2, Vol. 44, 1892, New. Haven, pp. 464-468.

1503. Henz, F. Beitrag zur Kenntniss Trennung von Antimon und Zinn mittels Oxalsäure.

Zeitschr. Anorg. Chem., Vol. 37, 1903, München and Leipzig, pp. 39-58.

Based upon Dr. Clarke's article, No. 1467.

1504. HeYcock, C. T., and NeviLIe, F. H. On the constitution of copper-tin alloys.

Proc. Roy. Soc. London, Vol. 69, 1902, London, pp. 320-329.

Conclusions reached from a number of experiments on alloys of tin and copper.

1505. Hicks, James. Treatment of slime tin.

Trans. Mg. Ass. Inst. Cornwall, Vol. 4, 1893-1895, Camborne. pp. 111-137, illus. 4. Read at Camborne, December 20, 1892.

Short review: Mg. Sci. Press, Vol. 66, 1893, San Francisco, p. 244.

Showing waste of mines under management at that time and ways of saving slime tin ore.

1505a. Hiontdahr, F. H. Sur la forme cristalline des combinaisons des stannméthyles et leurs homologues.

C. R. Acad. Sci., Vol. 88, 1879, Paris, pp. 584-586.

1506. Hofman, Heinricir O. The dry assay of tin ores.

Trans. Amer. Inst. Mg. Eng., Vol. 18, 1889-1890, New York, pp. 3-54.

Also, Techn. Quart., Vol. 3, 1890, Boston, pp. 112-143, 261-280.

Describes a series of experiments with the tin ores of the Black Hills to ascertain the best method of assay.

1506a. Hohagen, Georg. Assay of tin ores.

Eng. Mg. Journ., Vol. 85, 1908, New York, p. 422.

Short article on methods used in assaying tin ores.

1507. Hughes, T. W. H. Notes on tin smelting in the Malay Peninsula.

Rec. Geol. Surv. India, Vol. 22, pt. 4, 1889, Calcutta, pp. 235-236.

Notes on the use of the native or Tonka type of furnace, and more especially upon the English furnace at Singapore.

1507a. Hutchin, H. W. Notes on tin dressing.

Trans. Inst. Mg. Met., Vol. 18, 1908-1909, London, pp. 69-107.

Review: Eng. Mg. Journ., Vol. 87, 1909, New York, pp. 651-652.

Describes a series of investigations on tin ore dressing performed at South Crofty mine, Cornwall. The work covers in particular the preparation of concentrates for the calciner.

The paper is discussed by various members and author's reply given. 


\section{METALLURGY AND CHEMISTRY (Continued)}

$1507 \mathrm{~b}$. Tin dressing.

Mg. Mag., Vol. 2, 1910, New York, pp. 295-296.

1508. Jolyet, F., and CAhours, A. Recherches sur l'action physiologique des stannéthyles et des stanméthyles.

C. R. Acad. Sci., Vol. 68, 1860, Paris, pp. 1276-1280.

1509. Kensgotт, A. Ueber die alkalische Reaction einiger Minerale.

Neues Jahrb. Min., 1867, Stuttgart, pp. 437-438.

1510. Kerl, Bruno. The Assayer's Manual. An abridged treatise on the docimastic examination of ores, and furnace and other artificial products.

Translated from the German by W. T. Brannt, 1883, London, np. 214-224.

Treats of the deternination of tinstone by washing; and by both fire and wet assays.

1511. Kershaw, John B. C. Progress in electrochemistry and electrometallurgy in 1902.

Min. Ind. for 1902, Vol. 11, 1903, New York and London, p. 235, 300 words.

The electroyltic method of stripping tin from tin scrap and waste appears to be extending. The consumption of tin scrap in Germany alone is said to reach 30,000 tons per annum.

1511a. - Electro-Metallurgy.

D. Van Nostrand Co., 1908, New York, pp. 256-268.

Treats of the electric scparation of tin from tin scrap.

1512. Kersten, C. M. Ueber die chemische Zusammensetzung mehrerer Sorten ungereinigten, so wie gereinigten Abgangszinnes von Altenberg und zweier Zinnsorten aus Peru.

Arch. Min. geogn. Bergb. Hütt., Vol. 22, 1848, Breslau and Berlin, pp. 662-690.

1513. KLAProth, Martin H. Analytical essays toward promoting chemical knowledge of mineral substances.

[Translated from German.] 1801, London, pp. 515-531.

1. Chemical examination of the native oxyd of tin.

a. Experiments in a dry way.

I. Assays in charcoal-crucibles.

II. Habitudes of tinstone, when exposed to heat in a crucible made of clay.

b. Experiments in a humid way.

2. Chemical examination of the native sulphuret of tin.

Samples of tin ore from Cornwall and Germany were used in these analyses.

1514. KüNZEL, C. Ueber die Verarbeitung von Weissblechabfällen.

Berg. Hutt. Zeit., Vol. 33, 1874, Leipzig, pp. 57-60.

1515. Lampadius, W. A. De l'essai et de l'analyse des minerais d'étain. Ann. Mines, Vol. 3, 1818, Paris, pp. 203-208.

1516. - Versuche mit einem Quarzzuschlage bei dem Verschmelzen der Zinnerze zu Altenberg.

Arch. Bergb. Hütt., Vol. 14, 1827, Breslau and Berlin, pp. 296-298.

1517. Latta, Geo. J. The smelting of tin ore at the Mount Bischoff tin smelting works, Launceston.

Rep. Secr. Mines for 1899-1900, Tasmania, 1900, Hobart, pp. 91-92.

Gives the amount and kind of tin ores smelted during first half of 1899, the method of smelting used, proper mixtures of ores, and charges. 


\section{METALLURGY AND CHEMISTRY (Continued)}

1518. LE GRICE, C. V. Notice of an ancient smelting place for tin, generally called a Jew's House, lately discovered on the estate of Trereife, near Penzance.

Trans. Roy. Geol. Soc. Cornwall, Vol. 6, 1846, Penzance, pp. 43-46.

Early mode of smelting tin by flling a small excavation with sticks piled cross-wise, flling interstices with $\mathrm{SnO}_{2}$ and setting afire. Called "Jews" House" because Jews first worked tin in England. Tin smelted in blast furnaces until early in 19th cencury.

1519. Levol, A. Méthod de séparation quantitative de l'étain d'avec l'antimoine.

Ann. Chem. Phys., ser. 3, Vol. 13, 1845, Paris, pp. 125-127.

Extracts: Ann. Mines, ser. 4, Vol. 8, 1845, Paris, pp. 200-201.

Amer. Journ. Sci. Arts, ser. 2, Vol. 1, 1846, New Haven, p. 107.

Journ. prakt. Chem., Vol. 35, 1845, Leipzig, p. 179.

Reviewed by Elsner, L., in Journ. prakt. Chem., Vol. 35, 1845, Leipzig, pp. 313-314.

1520. De l'essai du minérai d'étain.

Ann. Chim. Phys., ser. 3, Vol. 49, 1857, Paris, pp. 87-91.

1521.

Note sur la sonorité de l'étain.

Ann. Chim. Phys., ser. 3, Vol. 56, 1859, Paris, pp. 110-111.

1521a. LEVY, D. M., and EwEN, D, Waste products of smelting-The Bessemerising of hardhead.

Bull. Inst. Mg. Met., May 13, 1909, pp. 9.

Gives results of a research to determine, (1) whether a bessemerizing process lends itself to the profitable recovery of values from hardhead and other tin smelting products, and (2) the rate of oxidation and elimination of the constituents of hardhead.

1522. LEWY, B. Sur quelques combinaisons nouvelles du perchlorure d'étain. C. R. Acad. Sci., Vol. 21, 1845, Paris, pp. 369-374.

1523. Louis, Henry. The metallurgy of tin.

Min. Ind. for 1896, Vol. 5, 1897, New York and London, pp. 533-588, figs. 30.

Review: Berg. Hütt. Zeit., Vol. 56, 1897, Leipzig, pp. 449-453.

1. Smelting in the shaft furnace: (a) old Cornish process; (b) the German process;

(c) Chinese method of tin smelting; (d) treatment of the slag.

2. Tin smelting in the reverberatory furnace.

1524. - Notes on the metallurgy of tin during 1897.

Min. Ind. for 1897, Vol. 6, 1898, New York and London, p. 648.

1525. - Tin smelting at the Mt. Bischoff works, Launceston, Tasmania. Min. Ind. for 1897, Vol. 6, 1898, New York and London, pp. 649-650.

Reprint: Berg. Hütt. Zeit., Vol. 58, 1899, Leipzig, pp. 174-175.

Short article giving plan of tin smelting furnace.

1526. - Notes on the metallurgy of tin.

Min. Ind. for 1898, Vol. 7, 1899, New York and London, pp. 716-717, fig. 1.

1527. - Notes on the metallurgy of tin.

Min. Ind. for 1899, Vol. 8, 1900, New York and London, pp. 629-631.

Gives a review of the progress of the metallurgy of tin during 1899.

1528. LöwIG, - New organic radicals, containing tin.

Journ. prakt. Chein., Vol. 57, Leipzig. p. 385.

1 ind Extract: Amer. Journ. Sci. Arts, ser. 2, Vol. 16, 1853, New Haven, pp. 116-118.

" Löwig has communicated the results of an elaborate investigation of the products resulting from the action of iodide of ethvl upon alloys of tin and sodium." 


\section{METALLURGY AND CHEMISTRY (Continued)}

1529. MACkenzIE, Geo. L. Determination of tin in tailings and slimes.

Trans. Inst. Mg. Met., Vol. 13, 1903-1904, London, pp. 87-92, discussion and remarks, pp. 92-101, fig. 1 .

Abstract: Eng. Mg. Journ., Vol. 77, 1904, New York, pp. 928-929.

Discusses: Cleaning the ore; reduction of stannic oxide to tin; solution of the reduced tin: (a) precipitation as stannic sulphide, (b) conversion of the stannic sulphide to oxide.

1530. McKrlop, John, and Ellis, Tros. F. Tin smelting at Pulo Brani, Singapore.

Proc. Inst. Civ. Eng., Vol. 125, pt. 3, 1806, London, pp. 145-162, discussion, pp. 163 174, correspondence, pp. 174-181, figs. 8.

Review: Mg. Sci. Press, Vol. 72, 1896, San Francisco, p. 484.

Review: Berg. Hüt. Zeit., Vol. 57, 1898, Leipzig, p. 164.

Treated under headings: General arrangement of the works; buying and handling ores; preparation of impure ores; system of labor in mixing charges; smelting furnaces; metallurgical processes; marketable tin; loss of tin; consumption of iron; consumption of culm; consumption of fuel; future improvements.

1531. MaluetT, J. W. Analysis of tin pyrites.

Amer. Journ. Sci. Arts, ser. 2, Vol. 17, 1854, New Haven, pp. 33-35.

1531a. Meade, Richard $K$. The valuation of engineering alloys.

Chem. Engr., Vol. 7, 1908, pp. 235-243, Vol. 8, 1908, Chicago, pp. 45-50, 110-115.

Treats of the composition and uses and methods of analysis of the babbitt metal alloys.

1532. MÈne, Crr. Mémoire sur un nouveau mode de dosage de l'étain.

C. R. Acad. Sci., Vol. 31, 1850, Paris, pp. 82-84.

Extrait: Ann. Mines, ser. 4, Vol. 19, 1851, Paris, pp. 399-400.

Brief digest: Berg. Hütt. Zeit., Vol. 10, 1851, Leipzig, p. 256.

1533. Menarn, U. Séparation et dosage de l'étain et de l'antimoine dans un alliage.

C. R. Acad. Sci., Vol. 119, 1894, Paris, pp. 224-226.

1534. Menniche, H. British patent, 17,616 of 1902.

Eng. Mg. Journ., Vol. 76, 1903, New York, p. 284.

" Tin ore treatment. A process for recovering silver, lead, bismuth, tungsten and copper from tin ores by roasting, grinding, moistening with water and then immersing in a bath of molten sodium bisulphate, all the metals but tin being transformed into sulphates, which can be removed."

1535. Mrllen, J. D. Tin smelting at Launceston, Tasmania.

Eng. Mg. Journ., Vol. 82, 1906, New York, p. 1135.

Abstract from the annual report of the Zeehan School of Mines and Metallurgy. Method of smelting Mt. Bischoff tin.

1536. Moissenet, L. Du dosage de l'étain dans les minerais de ce métal.

C. R. Acad. Sci., Vol. 51, 1860, Paris, pp. 205-207. Extrait par l'auteur.

1537. MOODY, S. E. Hydrolysis of salts of iron, chromium, tin, cobalt, nickel and zinc in the presence of iodides and iodates.

Amer. Journ. Sci. ser. 4, Vol. 22, 1906, New Haven, pp. 178-180. 


\section{METALLURGY AND CHEMISTRY (Continued)}

1538. Mulder [-]. Ueber das Banka-Zinn.

Chem. Gaz., 1849, London, No. 165.

Twenty specimens, mostly from different tin mines in Banka were examined, and found to contain only a trace of foreign metals.

One analysis was:

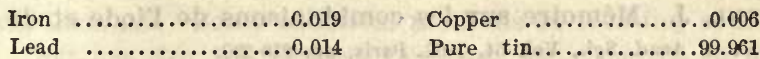

1539. Muller, J. A. The analysis of tin ores.

Chem. News, Vol. 85, 1902, London, pp. 147-148.

1540. Musculus, F. Des hydrates stanniques.

C. R. Acad. Sci., Vol. 65, 1867, Paris, pp. 961-963.

1541. MYrick, C. M. Tin concentration in Cornwall.

- Mg. Sci. Press, Vol. 86, 1963, San Francisco, p. 167, illus. 2.

Methods of tin concentration, improvements and results.

Nevius, J. Nelson, See No. 781.

1542. NoRth, Oliver. The practical assayer.

1874, London.

Assay of tin, pp. 106-116.

1543. ORDWAy, John M. On some soluble basic salts of tin.

Amer. Journ. Sci. Arts, ser. 2, Vol. 23, 1857, New Haven, pp. 220-223.

1544. Overman, Frenerick. Practical mineralogy, assaying and mining.

1882, Philadelphia.

Description of tin, pp. 68-69. Assay of tin ore, pp. 169-171.

1545. Parry, L. Assay of tin and antimony.

1906, London, pp. 3-49, $2 \mathrm{~d}$ Ed.

Describes various methods of tin assaying.

1545a. - Note on the eutectic alloy of lead and tin.

Mg. Journ. Railw. Comm. Gaz., Vol. 87, 1909, London, pp. 420-421.

1545b. - The assay of tin ore.

Mg. Journ. Railw. Comm. Gaz., Vol. 86, 1909, London, pp. 421-424.

Copied: Mg. Sci., Vol. 60, 1909, Denver, pp. 370-373.

1546. Pearce, Richard. On the application of chemistry to the dressing of tin ores.

Mech. Mag., Vol. 6, n. s., 1861, London, p. 339.

1547. - Description of the process for the separation of copper, iron and other heavy impurities from tin ore.

36th Ann. Rep. Roy. Cornwall Polyt. Soc., 1868, Falmouth, pp. 23-25.

Method proposed is to subject impure tin to the combined action of steam and air in conjunction with a little dilute acid.

1548. PeEtZ, Le. Scheidung von Zinn und Blei aus Zinn-Blel-Legierungen.

Métallurgie, August 22, 1904, Paris, pp. 9.

Brief digest: Mg. Mag., Vol. 10, 1904, p. 439.

"One chemical and one electroyltic method of separating lead and tin in lead-tin alloys are given in considerable detail." 


\section{METALLURGY AND CHEMISTRY (Continued)}

1549. Perret, Auguste. Zinc, étain, nickel, cobalt. 1903, Paris.

Petite Encyclopedie de chimie industrielle pratique. Not available to the authors.

1550. Personne, J. Mémoire sur les combinaisons de l'iode et de l'étain. C. R. Acad. Sci., Vol. 54, 1862, Paris, pp. 216-220.

PIKE, E. R. See No. 715.

1551. Platte, Gabriel. A discovery of subterranean treasure, viz., all manner of mines and minerals, etc.

1792, Philadelphia, pp. 9-10.

Operation of tin refining. "And as for refining of it, I am sure it cannot be done by any artifice."

1552. Plattner, C. A. Die Darstellung von Zinn- und Antimonblei auf den Königl. Sächs. Frelberger Hüttenwerken.

Jahrb. Berg. Hütt. Kön. Sachsen., 1883, Freiberg, pp. 1-18.

1553. Rawson, S. G. The qualitative separation of arsenic, antimony and tin. Chemical News, Vol. 75, 1897, London, p. 221.

Reprinted: Eng. Mg. Journ., Vol. 63, 1897, New York, p. 545.

Arsenic and antimony are precipitated from a mixture of oxalic and hydrochloric acids by hydrogen sulphide. Hydrides of arsenic and antimony are passed through a silver nitrate solution, and the antimonide of silver filtered out.

1554. RAY, JoHN. A collection of English words not generally used. With an account of the preparing and refining such metals and minerals as are found in England.

1768, London, 4th Ed.

The preparing and smelting or blowing of tin in Cornwall, pp. 131-134.

Reyer, Eduard. See No. 1354.

1555. Richards, Joseph. Utilization of the wastes from the use of white metal.

Journ. Franklin Inst., Vol. 151, 1901, Philadelphia, pp. 446-447.

Also, Mg. Sci. Press, Vol. 82, 1901, San Francisco, p. 293.

Methods used by writer in removing tin from tin scrap, saving both tin and iron.

1556. Richards, RoBert $H$. Block tin resulting from distillation of a tin amalgam.

Trans. Amer. Inst. Mg. Eng., Vol. 11, 1882-1883, New York, pp. 235-236.

1557. RiefFec, - Mémoire sur les combinaisons chimiques du cuivre avec l'étain, et sur leurs mélanges entre elles, constituant les alliages non chimiques de ces deux métaux.

C. R. Acad. Sci., Vol. 37, 1853, Paris, pp. 456-453.

Roscoe, H. E. See No. 1568.

1558. Rose, H. Ueber die Trennung des Zinns vom Antimon.

Ann. Physik. Chem., Vol. 71, 1847, Leipzig, pp. 301-304.

Extract: Ann. Mines, ser. 4, Vol. 15, 1819, Paris, pp. 129-130. 


\section{METALLURGY AND CHEMISTRY (Continued)}

1559. - Ueber eine neue quantitative Bestimmung des Arseniks, Antimons und Zinn.

Journ. prakt. Chem., Vol. 44, 1848, Leipzig, pp. 117-118, Ann. Physik. Chem., Vol. 73, 1848, Leipzig, pp. 582-585.

1560. Rowe, LeONARD. Some chemical methods of treating ores.

66th Ann. Rep. Roy. Cornwall, Polyt. Soc., 1898, Falmouth, pp. 102-103.

Methods and difficulties of extracting tin from its associated minerals.

1561. SalEt, G. Sur les spectres de l'étain et de ses composés.

C. R. Acar. Sci., Vol. 73, 1871, Paris, pp. 862-863.

1562. Salmon, - . Art du potier d'étain, 1788.

Not available to the authors.

1563. SANDALL, S. A. Preparation of protoxide of tin.

London and Edinburgh Philos. Mag. Journ. Sci., Vol. 12, 1838, London, p. 216.

Extract: Ann. Mines, ser. 3, Vol. 15, 1839, Paris, pp. 435-436.

Makes tin protoxide by heating the protochloride with sodium carbonate.

1564. Scheurer-Kestner, A. Sur les produits de l'oxydation du protochlorure d'étain et la dissolution de quelques oxydes dans le bichlorure.

C. R. Acad. Sci., Vol. 50, 1860, Paris, pp. 50-54.

1565. — Action l'oxygène sur le protochlorure d'étain. Dosage de

l'étain par le permanganate de potasse.

C. R. Acad. Sci., Vol. 52, 1861, Paris, pp. 531-533.

1566. Schultze, B. A new method of recovering tin from tin-plate scrap.

Polyt. Journ., Vol. 276, 1890, Stuttgart, p. 279.

Digest: Proc. Inst. Civ. Eng., Vol. 102, pt. 4, 1890, London, pp. 400-401.

Description of the process of stripping tin plate with acid ferric sulphate, acid stannic sulphate, dilute sulphuric acid or dilute hydrochloric acid.

1567. Schunck, Ed. Process for the use of tin-plate scrap in the manufacture of malleable iron.

Chem. Gaz., 1849, London; Amer. Journ. Sci. Arts, ser. 2, Vol. 9, 1850, New Haven, p. 279 .

A patent issued to Ed. Schunck covers the stripping of tin plate scrap by an alkaline persulphuret; the recovery of the tin by the evaporation of the solution and the smelting of the residue; also the treatment of the iron by washing, packing in sheet iron cylinders, heating to welding heat and hammering.

1568. Schunck, E., SMIth, R. A., and Roscoe, H. E. On the recent progress and present condition of manufacturing chemistry in the South Lancashire district.

Rep. Brit. Ass. Adv. Sci., 31st meeting, Manchester, September, 1861, pt. 1, London,

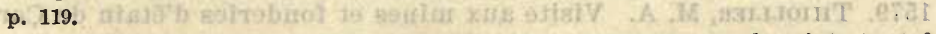

The manufacture of compounds of tin-chlorides and stannate of soda briefly treated.

Sexton, A. Humbolt. See No. 1361.

1569. Slagle, Robert L. The double halides of tin with aniline and the toluidines.

Amer. Chem. Journ., Vol. 20, 1898, Baltimore, pp. $633-646$. 


\section{METALLURGY AND CHEMISTRY (Continued)}

1570. Srater, W. Alliages de zinc, d'étain et de plomb.

Rev. Univ. Mines Mét. Trav. Publ. Sci. Arts Appl. Indust., sem. 2, Vol. 5, 1859, Liége and Paris, p. 187.

From "Chemical Gazette," 1858, London.

1571. Smith, J. Lawrence. Analysis of alloys of tin and antimony.

Amer. Journ. Sci. Arts, ser. 1, Vol. 49, 1845, New Haven, p. 206.

Translation and abstract from "Chemical Gazette," August, 1844, London, p. 347.

Giving Chevalier and Lassaigne's method.

1572. - Separation of tin from antimony.

Amer. Journ. Sci. Arts, ser. 2, Vol, 1, 1846, New Haven, p. 107.

Extract from Levol, A., Ann. Chim. Phys., January, 1845, Paris.

1573. Sмiтh, Oberis. Nails from tin scrap.

Trans. Amer. Inst. Mg. Eng., Vol. 17, 1889, New York, pp. 495498.

Method of making good quality of nails, at one operation, directly from tin scrap.

Sмith, R. A. See No. 1568.

1574. Streng, A. Ueber einige mikroskopisch-chemische Reaktion.

Neues Jahrb. Min., 1888, II, Stuttgart, pp. 142-146.

The testing of tin is treated.

1575. TAдвот, J. H. On the quantitative separation of tin and tungsten.

Amer. Journ. Sci. Arts, ser. 2, Vol. 50, 1870, New Haven, pp. 246-247.

Separation depending upon reduction of stannic oxide by potassic cyanide, while tungstic trioxide is unaffected.

1576. TAYLOR, JoHn. On the smelting of tin ores in Cornwall and Devonshire. Trans. Geol. Soc. London, Vol. 5, 1821, London, pp. 358-368.

Describes the smelting of "mine tin" in reverberatory furnaces and of "stream tin" in shaft-furnaces. The "block tin" of commerce is obtained from " mine tin" while "grain tin," a purer article, is obtained from "stream tin."

1576a. Terrell, S. L. The final stages of tin and wolfram dressing.

Mg. Journ. Railw. Comm. Gaz., Vol. 83, 1908, London, p. 714, fig. 1.

Deals with the final treatment of tin and tungsten after concentration and takes up calcining and acid treatment.

1577. Thibault, P. J. The metallurgical treatment of complex tin sulphides.

Trans. Austr. Inst. Mg. Eng., Vol. 8, pt. 2, 1902, Melbourne, pp.' 155-163.

1578.

The metallurgy of tin.

1907, London, pp. 250.

First appeared as a series of articles under the above heading in Austr. Mg. Stand., in 1907, Sydney and Melbourne.

Treats of the various branches of the metallurgy of tin, especially as practiced in Australia; methods of assaying tin ores and furnace products; the working of placer deposits by dredging and sluicing, and the reduction of ore.

1579. Thollier, M. A. Visite aux mines et fonderies d'étain de Cornwall.

Bull. Soc. Indust. min., Vol. 14, $2 \mathrm{~d}$ ser., 1885, Saint Ftienne, pp. 575-587.

Also, Berg. Hütt. Zeit., Vol. 45, 1886, Leipzig, pp. 360-363.

Treatcd under heads: Reduction of mineral, treatment of slag left after first operation, refining of metal.

1580. Thomas, V. Action du peroxyde d'azote sur les sels halogénés d'étain. C. R. Acad. Sci.. Vol. 122, 1896, Paris, pp. 32-35. 


\section{METALLURGY AND CHEMISTRY (Continued)}

1580a. VAN Osdet, EDgar B. Determination of tin and antimony.

Eng. Mg. Journ., Vol. 87, 1909, New York, p. 850 .

Gives a method which has proved satisfactory in the analysis of alloys such as type metal or of solutions containing only tin and antimony.

1581. Vignon, LẼo. Sur l'étain.

C. R. Acad. Sci., Vol. 107, 1888, Paris, pp. 734-737.

Discussion of the precipitation of tin from tin-chloride, and of the easy oxidizability of the reduced metal.

1582.

Sur l'oxydabilité et le décapage de l'étain.

C. R. Acad. Sci., Vol. 108, 1889, Paris, pp. 96-98.

1583. Welis, J. S. C. New method for the analysis of tin-ores, and for the separation of copper and cadmium.

School Mines Quart., Vol. 12, 1891, New York, pp. 295-296; Vol. 14, 1893, p. 156.

Reprint: Eng. Mg. Journ., Vol. 77, 1904, New York, p. 957.

Description of assay by reduction of cassiterite with $\mathrm{HCl}$ and metallic zinc. Note emphasizes fact that with some ores a piece of platinum must be used to effect complete reduction.

1583a. Weston, E. M. See No. 3d.

1584. WIRTz, L. British patent, 20,496 of 1902.

Eng. Mg. Journ., Vol. 76, 1903, New York, p. 362.

Recovering tin and zinc from scrap. "Dissolves the tin in hydrochloric acid and then immerses galvanized iron scrap in the solution of chloride of tin, the tin thus being precipitated and recoverable, while the zinc goes into solution as chloride."

1585. Witmer, Luther Ferree. The electrolytic determination of tin and its separation from antimony with a rotating anode.

1906, Lancaster, Pa., pp. 3-19.

1586. Worsey, JAs. W. Recovery of tin from tinplate clippings.

Mg. Sci. Press, Vol. 83, 1901, San Francisco, p. 121.

Describes processes of stripping tin scrap with hydrochloric acid and with sodium sulphate, sulphuric acid and sulphur dichloride.

1587. Wright, C. R. Apler. On certain ternary alloys.

Proc. Roy. Soc. London, Vol. 45, 1889, London, pp. 461-481.

Alloys of lead, tin, and zinc, Vol. 48, 1891, pp. 25-32.

Mixtures of lead, zinc, and tin at higher temperatures, Vol. 49, 1891, pp. 158-163.

Alloys of bismuth, zinc, and tin.

A study showing the solubility of the metals in each other, and the mixtures and variations of the alloys upon cooling. 


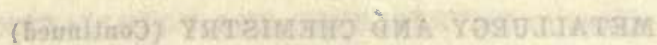

\section{MINERALOGY}

1588. ADGER, J. B. Analysis of an anomalous variety of stannite (tin pyrites) from Cornwall.

Chem. News, Vol. 25, 1872, London, p. 259.

Analysis of a specimen of stannite showing some peculiarities.

1589. Anonymous. A new tin mineral.

Trans. Fed. Inst. Mg. Eng., Vol. 21, 1900-1901, Newcastle-upon-Tyne and London, p. 590.

New tin mineral called stokesite discovered in Cornwall. Cólorless, conchoidal fracture, formula, $\mathrm{H}_{4} \mathrm{CaSnSi}_{8} \mathrm{O}_{31}$.

7. See Nos. 673 and 674 .

1590. Arzruni, A. Künstlicher Kassiterit.

Zeitschr. Kryst. Min., Vol. 25, 1896, Leipzig. pp. 467-470.

"Cassiterite has been repeatedly observed as a furnace product, formed by the direct oxidation of tin." An occurrence of this kind is described by the author.

1591. Bauer, Max. Zinnstein.

Lehrbuch der Mineralogie, 1904, Stuttgart, pp. 556-558, figs. 3.

General description of tin ore as it occurs in different localities. Composition and crystalline form.

1592. Becke, F. Ueber die Krystallform des Zinnsteins.

Min. Mitth., 1877, Wien, pp. 243-260.

Digest: Neues Jahrb. Min., 1878, Stuttgart, pp. 76-78.

1593. BERNHARDI, - Bestimmung der Krystallisation einiger mineralischen Substanzen.

Tasch. ges. Min., 1807, Vol. 3, 1809, Frankfurt-am-Main, pp. 76-86.

On the crystal form of tin.

1594. Bongström, L. H. Ueber Kassiterit von Pitkäranta.

Zeitschr. Kryst. Min., Vol. 40, 1905, Leipzig, pp. 1-12, pl. 1.

Description of cassiterite crystals from Pitkäranta, Finland.

1595. Bourgeors, Lkon. Sur la présence de la cassitérite dans les scories de la fonte du bronze et sur une nouvelle méthode de reproduction de cette espèce minérale.

Bull. Soc. franc. Min., Vol. 11, 1888, Paris, pp. 58-61.

1596. BRöGGER, W. C. Die Mineralien der Syenitpegmatitgänge der südnorwegischen Augit- und Nephelinsyenite.

Geol. För. Stockholm Förh., Vol. 9, 1887, Stockholm, p. 255.

Also, Zeitschr. Kryst. Min., Vol. 16, 1890, Leipzig, p. 61.

Nordenskiöldine, a very rare borate of calcium and tin, is described. Interesting because it directly connects tin and boron. Composition: $\mathrm{CaSnB}_{2} \mathrm{O}_{6}$. Mentioned as occurring on the island Arö. 


\section{MINERALOGY (Continued)}

1597. Chapman, E. J. Tinstone pseudomorphs.

London, Edinburgh, Dublin Philos., Mag. Journ. Sci., ser. 4, Vol. 6, 1853, London, p. 121.

A paragraph upon the composition of pseudomorphs of cassiterite after feldspar twins. They carried 43.6 and 55.46 per cent of metallic tin.

1598. Coluins, J. H. On some Cornish tinstones and tin capels.

Min. Mag. Journ. Min. Soc., 1st payer, No. 17, Vol. 4, April, 1880, London, pp. 1-20; 2d paper, No. 18, Vol. 4, September, 1880, London, pp. 103-116; 3d paper, No. 24, Vol. 5, April, 1883, London, pp. 121-130.

Vol. 4 contains 12 plates, 5 of which are colored.

A description of Cornish tin-ores, and the minerals accompanying the cassiterite.

1599. Cronstedt, Axel F. Mineralogy. Translated from Swedish with annotations, and an additional treatise on the blow-pipe by Gustar von Engestrom.

$2 d$ Ed. Vol. 2, 1788, London, pp. 618-643.

Tin is treated under heads: Its properties; native tin; calciform ores of tin; calciform tin ores crystallized; tin grains, calces of tin, mixed with metals; aurum

iii) 4 (4) musivum; observations on tin.

1600. DanA, J. D. A system of mineralogy.

1892, New York. (6th Ed.).

Mineralogical descriptions are given as follows: Cassiterite, pp. 234-236; nordenskiöldine, p. 875 ; stannite, p. 83.

An analysis is quoted from Leuchtenberg which shows the presence of tin in olivine found in a meteorite (p. 453) and a number of analyses showing the presence of tin in tantalite and columbite are given on pp. 732-733.

1601. Daubré, A. Sur la production artificielle de quelques espèces minérales cristallines particulièrement de l'oxyde d'étain, de l'oxyde de titane et du quartz. Observations sur l'origin des filons titaniféres des Alpes.

Ann. Mines, 4th ser., Vol. 16, 1849, Paris, pp. 129-141.

Extrait par auteur, C. R. Acad. Sci., Vol. 29, 1849, Paris, pp. 227-229.

Extract: Bull. Soc. Geol. France, 2d ser., Vol. 7, 1849, Paris, pp. 267-276.

Report: C. R. Acad. Sci., Vol. 30, 1850, Paris, pp. 383-387.

Extract: Neues Jahrb. Min., 1849, Stuttgart, pp. 712-715.

Abstract: Amer. Journ. Sci. Arts, 2d ser., Vol. 9, 1850, New Haven, pp. 120-121.

The first part of this memoir gives the results of experiments made by Daubree, with a view of imitating the processes by which Nature may have acted in forming minerals. Instead of using fluorides, which are not so easily. prepared, Daubrée generally employed chlorides. From the great analogy of fluorides with chlorides he considers that the results obtaired with the latter may be safely supposed to occur with the former. The first experiment consisted in passing a current of stannic chloride and a current of steam into a red-hot porcelain tube. Double decomposition took plare, and crystals of stannic oxide were deposited on the sides of the tube. The crystals were found to belong to the rhombic system, which shows that stannic oxide, like titanic oxide, is dimorphous. The temperature of the end of the tube, where the crystals were deposited did not exceed $572^{\circ} \mathrm{F}$. $\left(300^{\circ} \mathrm{C}.\right)$, or, in other words was rather less than the melting point of leai. Titanic chloride, treated in the same way, gave crystals of brookite; whilst a deposit of vitreous and in part crystallized quartz was obtained from chloride of silica and steam.-C. Le Neve Foster. 


\section{MINERALOGY (Continued)}

1602. - Recherches sur la production artificielle des minéraux de la famille des silicates et des aluminates, par la réaction des vapeurs sur les roches.

C. R. Acad. Sci, Vol. 39, 1854, Paris, pp. 135-140.

Cassiterite artificially prepared by passing the vapor of stannic chloride over heated lime.

- See No. 1314.

Davey, Richard. See No. 1603.

1603. Davey, Stephen. Notice of pseudomorphous crystals of oxide of tin, found in Huel Coates mine, in St. Agnes in the year 1828.

Trans, Roy. Geol. Soc. Cornwall, Vol. 4, 1838, Penzance, pp. 484-485.

A short description of pseudomorphs after feldspar. Crystals in many stages of replacement were found.

Boase and Courtney (Bibliotheca Cornubiensis, Vol. 1, 1874, London, p. 106), state that this paper is really by Richard Davey, which is the name given in the index of the book in which the article occurs.

1604. Devinle, H. Saint-Claire. De la reproduction de l'étain oxydé et du rutile.

C. R. Acad. Sci., Vol. 53, 1861, Paris, pp. 161-164.

The crystallized oxide of tin obtained "by heating the amorphous oxide in a slow current of hydrochloric acid gas and again by a repetition of Daubrée's first process."

1605. Deville, Saint-Claire H., and Caron, H. Sur un nouveau mode de production à l'état cristallisé d'un certain nombre d'espèces chimiques et minéralogiques.

C. R. Acad. Sci., Vol. 46, 1858, Paris, p. 768.

"The crystallized oxide of tin was obtained when stannic fluoride and boric oxide were heated together to whiteness." No details.

1606. Ditre, A. Sur quelques combinaisons du bioxyde d'étain.

C. R. Acad. Sci., Vol. 104, 1887, Paris, pp. 172-175.

Fawns, Sydney. See No. 1320.

1607. Field, Frederick. On a specimen of tin ore hitherto undescribed.

Rep. Brit. Ass. Adv. Sci., Vol. 34, Bath, 1864, London, 1865, p. 27. (Notes and abstracts.)

Description of two specimens of "slime tin," a variety of " toad's-eye wood-tin (sic)."

1608. Foster, C. LE Neve. On the place and mode of occurrence of the mineral Andrewsite.

Trans. Roy. Geol. Soc. Cornwall, Vol. 9, 1875, Penzance, pp. 163-164.

A hydrous iron-copper-phosphate occurring with tin ore at the West Phoenix Mine, Liskeard, Cornwall.

1609. FouluoN, H. Ueber krystallisirtes Zinn.

Jahrb. k. k. geol. Reichs., Vol, 34, 1884, Wien, pp. 367-384, wood cuts 2, pl. of figs. 1.

Abstract: Min. Mag. Journ. Min. Soc., Vol. 6, 1885, London, p. 148.

Found that erystals of tin obtained from the molten metal were of rhombic form, generally twinned. Such crystals may also be obtained by electrolytic deposition. 


\section{MINERALOGY (Continued)}

1610. Fouque, F., and LEvY, MICHEL. Synthèse des minéraux et des roches. G. Masson, Ed., 1882, Paris, pp. 389-391.

Treats of the making of artificial cassiterite.

1611. Frenzer, A. Ueber den Kylindrit.

Neues Jahrb. Min., 1893, II, Stuttgart, pp. 125-128.

Description of a rare tin mineral, occurring in Bolivia. Composition, $\mathrm{Pb}_{3} \mathrm{FeSn}_{4} \mathrm{Sb}_{2} \mathrm{~S}_{14}$. (Cylindrite.)

1612. Gadolin, S. A. Beobachtungen über einige mineralien aus Pitkaeranta in Finnland.

Verh. Russ. Kais. min. Ges., 1855-1856 (1856), St. Petersburg, pp. 184-196.

Descriptions of cassiterite crystals.

GeNTH, F. A. See No. 820 .

1613. Granger, A. Sur un sulfophosphure d'étain cristallisé.

C. R. Acad. Sci., Vol. 122, 1896, Paris, pp. 322-323.

1614. Greg, R. P., and Letrsom, W. G. Mineralogy of Great Britain and Ireland.

1858, London, pp. 355-361.

Also, Neues Jahrb. Min., 1859, Stuttgart, pp. 186-189.

1. Oxide. Cassiterite: a. Forms of crystals. b. Analyses. c. Localities. d. Description of varieties, i. e. wood-tin, etc.

2. Sulphide in combination. Stannine.

1615. HAÜY, - "Suite de l'extrait du "Traité de Mineralogie."

Journ. Mines, Vol. 6, 1797, Paris, pp. 575-582.

1616. HeAdDEN, WM. P. Stannite and some of its alteration products from the Black Hills.

Amer. Journ. Sci., ser. 3, Vol. 45, 1893, New Haven, pp. 105-110.

Discusses analyses of his own and of Titus Ulke's of stannite alterations from the Peerless and Etta mines. He thinks tbat some of these alteration products may be soluble in water and this may explain the origin of the tin in various pseudomorphs.

1617. Some products found in the hearth of an old furnace upon the dismantling of the Trethellen tin works, Truro, Cornwall.

Proc. Colorado Sci. Soc., Vol. 6, 1897, Denver, pp. 74-85.

Abstract: Amer. Journ. Sci., ser. 4, Vol. 5, 1898, New Haven, pp. 93-96.

Author describes "wood-tin" (cassiterite) and compounds of arsenic, sulphur, iron, etc., formed in an old Cornwall furnace. He believes them sublimation products but Pearce believes them to be from slow cooling of magma.

- See No. 1208.

Herman, R. See No. 968.

1618. Changed to 1505 a.

1619. HUNT, RoBERT. Researches on the influence of magnetism and voltaic electricity, on crystallization, and other conciticins of matter.

Mem. Geel. Surv. Great Britain, Vol. 1, 1846, Lond.on, p!p. 443.

Muriate of tin and iodide of tin briefly treated. 


\section{MINERALOGY (Continued)}

1620. Hutchinson, A. Ueber Stokesite ein neues Zinnmineral von Cornwall.

Zeitschr. Kryst. Min., Vol. 34, 1901, Leipzig, pp. 345-352, text fig.

Digest: Trans. Fed. Inst. Mg. Eng., Vol. 21, 1903, Newcastle-upon-Tyne and London, p. 590 .

New tin mineral called stokesite, discovered in Cornwall. Colorless, conchoidal fracture. $\mathrm{H}_{4} \mathrm{CaSuSi}_{3} \mathrm{O}_{11}$. The mineral may be regarded as a tetrasilicate of tin and calcium.

1621. Jameson, Robert. Mineralogy.

3d Ed. Vol. 3, 1820, Edinburgh, pp. 155-169.

Tin ore is treated under: External characters; chemical characters; constituent parts; geognostic situation; geographic situation; uses; observations.

1622. Jeremejev, P. Krystalle des Zinnsteins aus Transbaikalien.

Verh. russ. kais. min. Ges., 2d ser., Vol. 11, St. Petersburg, pp. 273-280. [Russian.]

1623. - Krystalle von Zinnstein aus einigen goldführenden Sanden der

Region des Jenissel.

Verh. russ. kais. min. Ges., 2d ser., Vol. 23, 1887, St. Petersburg, pp. 269-284.

Digests: Neucs Jahrb. Min., 1890, I (Ref.), Stuttgart, p. 16; Bibl. géol de la Russie, brie irlatiluar Nikitin, St. Petersburg, 1887 (1888), p. 79.

1624. Kohlmann, W. Beobachtungen am Zinnstein.

Zeitschr. Kryst. Min., 1895, Vol. 24, Leipzig, pp. 350-365.

Compares many measurements of cassiterite crystals.

LACroIx, A. See No. 516.

1625. LAUNAY, Louis DE. Formation des gîtes métallifères ou métallogénie. 1905, Paris, pp. 129-130.

Brief summary in which he gives the ages of the tin deposits of the world.

LetTsom, W. G., and Greg, R. P. See No. 1614.

1626. Mather, W. W. Contributions to chemical science.

Amer. Journ. Sci. Arts, 1st ser., Vol. 27, 1835, New Haven, pp. 254-255.

Describes crystals of metallic tin formed from a saturated solution of tin chloride.

1627. MrLLER, W. H. On the forms of the crystals of tin.

(1007) IIf 263-265.

Measurements of metallic tin crystals formed by electrolytic action.

1628. Nöggerath, J. J. Gegenden von Zinnwald und Altenberg.

Jenaische Lit. Zeit., 1823, p. 370.

Review: Zeitschr. Min. flir 1825, Bd. I, Frankfurt-am-Main, pp. 558-563.

1628a. NornenskiöLd, A. E. Beskrifning öfver de i Finland funna mineraller.

1855, Helsingfors, p. 162, 2d kd., 1863, p. 26.

Quoted in Dana's "System of Mineralogy" (6th Ed. 19c9), p. 236.

Describes ainalite, a cassiterite containing $\mathrm{SnO}_{2} 88.95, \mathrm{Ta}_{2} \mathrm{O}_{3} 8.78, \mathrm{Fe}_{2} \mathrm{O}_{3} 2.04 \mathrm{CuO}$

$0.78=100.55$ from Pennikoja in Somero, Finland, with tantalite and beryl in albite.

1629. Pearce, Richard. Siliceous oxide of tin after quartz and allophane found in Cornwall.

44th Ann. Rup. Roy. Inst. Cornwall, 1862, pt. 1, Truro, pp. 19-20.

- Not available to the authors. 


\section{MINERALOGY (Continued)}

1630. - Notes on the occurrence of pseudomorphs of oxide of tin after some unknown mineral from Bolivia.

'Trans. Roy. Geol. Soc. Cornwall, Vol. 13, 1906, pt. 2, Penzance, pp. 150-152.

Notice of cassiterite crystals that are apparently pseumomorphs, possibly after sulpho-stannites, as they are accompanied by what seem to be alteration products.

1631. Penfield, S. L. On canfieldite, a new sulphostannate of silver from Bolivia.

Amer. Journ. Sci., Vol. 47, 1894, New Haven, pp. 451-454.

Gives description and analysis of a sulphostannate of silver, containing germanium. Formula: $4 \mathrm{Ag}_{2} \mathrm{~S}(\mathrm{Sn}, \mathrm{Ge}) \mathrm{S}_{2}$.

1632. Pinllips, J. Artirur. On the structure and composition of certain pseudomorphic crystals having the form of orthoclase.

Journ. Chem. Soc., Vol. 28, II, 1875, London, pp. 684-687.

Abstracts: Jahr. Chem. für 1875, Vol. 28, 1877, Giessen, p. 1249; Ann. Mines, ser.

7, Vol. 13, 1878, Paris, p. 516.

Results of the examination of some cassiterite crystals from St. Agnes mine.

1633. Phillips, W. A description of the oxyde of tin, the production of Cornwall; of the primitive crystal and its modifications, including an attempt to ascertain with precision, the admeasurement of the angles, by means of the reflecting goniometer of Dr. Wollaston: to which is added, a series of crystalline forms and varieties.

Trans. Geol. Soc. London, Vol. 2, 1814, London, pp. 336-376, figures.

Review Tasch. ges. Min., Vol. 12, II, 1818, Frankfurt-am-Main, pp. 543-544.

The title is a fair digest of the article, which is a classic upon the subject.

1634. Phillips, William. On the measurements, by the reflecting goniometer, of certain primitive crystals; with observations on the methods of obtaining them by mechanical division along the natural joints of crystals.

Trans. Geol. Soc. London, Vol. 4, 1817, London, pp. 241-263; oxide of tin, pp. 81 244-246; about 500 words.

Gives method of cleaving cassiterite crystals by first heating them, so that faces parallel to all the sides of the common prism, its diagonals and faces of the primitive octohedron may be measured.

1635. Pirsson, L. V. Mineralogical notes.

Amer. Journ. Sci., ser. 3, Vol. 42, 1891, New Haven, p. 407.

Description of crystals of hematite inclosing cassiterite, from Mina del Diablo, Durango, Mexico.

1636. Prior, G. T. On teallite, a new sulphostannite of lead from Bolivia; and its relations to franckeite and cylindrite.

Min. Mag. Journ. Min. Soc., Vol. 14, 1907, London, pp. 21-27.

"The new mineral occurs in thin graphite-like folia embedded in glistening kaolin, upon a dark grey matrix impregnated with iron-pyrites; on one specimen it is associated with a little wurtzite in thin plates, and on the other with a little galena." It is much like the other two minerals in physical character, but differs chemically, containing no antimony, only lead, tin and sulphur. Composition- $\mathrm{PbSnS}_{2}$.

RAIMondi, A. See No. 870.

Describes plumbostannite, a sulphide of lead, tin and antimony. 


\section{MINERALOGX (Continued)}

1637. Rammelsberg, C. Ueber die chemische Zusammensetzung des Zinnkieses.

Ann. Physik. Chenı., Vol. 88, 18j33, Leipzig, pp. 603-608.

Digest: Neues Jahrb. Min., 1855, Stuttgart, pp. 72-73.

Gives a number of analyses of stannite from Zinnwald and Cornwall.

1638. Reid, Clement, and Scrivenor, J. B. The geology of the country near Newquay.

Mem. Geol. Surv. Great Britain, 1906, London, p. 39.

The so-called pseudomorphs of cassiterite after feldspar are really a replacement of that mineral by an aggregation of cassiterite, quartz and muscovite.

1639. Rosenbusch, H. Microscopical physiography of the rock-making minerals.

Translation and abridgement by Jos. P. Iddings, 1889, New York, pp. 151-152.

Microscopical-optical properties. Only one unquestioned occurrence noted of cassiterite occurring as a microscopical rock-making mineral, where it occurs with rutile as inclusions in the lithia-mica of the granite of Greifenstein.

Schertel, A., and Stelzner, A. W. See No. 1643.

Scrivenor, J. B., and Reid, Clement. See No. 1638.

1640. Solly, R. H. Cassiterite, “sparable tin,” from Cornwall.

Mg. Mag., Vol. 9, No. 43, 1891, New York, pp. 199-208, figs. 3.

Brief digest: Neues Jahrb. Min., 1892, II (Min.), Stuttgart, p. 15.

Descriptions of the tin crystals of various mines of Cornwall.

1641. Spencer, L. J. Crystallized stannite from Bolivia.

Min. Mag. Journ. Min. Soc., Vol. 13, 1901, London, pp. 54-65, pl. 1. Read November 14, 1899.

Reprint: Zeitschr. Kryst. Min., Vol. 35, 1902, Leipzig, pp. 468-469, pl. 12, figs. 3-7. Reviews the literature upon the crystallization of stannite, and shows from measurement of specimens from Bolivia that the mineral crystallizes in the scalenohedraltetragonal system. Crystals 1-1.5 mm. across and had the composition $\mathrm{Cu}_{2} \mathrm{FeSnS}_{4}$. Reviews specimens from Oruro, Potosi, and Tatasi, Bolivia, and from Cornwall.

1642. Stelzner, A. W. Ueber Franckeit, ein neues Erz aus Bolivia.

Neues Jahrb. Min., 1893, II, Stuttgart, pp. 114-124.

Composition, $\mathrm{Pb}_{6} \mathrm{FeSn}_{3} \mathrm{Sb}_{2} \mathrm{~S}_{14}$.

1643. Stelzner, A. W., and Schertel, A. Ueber den Zinngehalt und über die chemische Zusammensetzung der schwarzen Zinkblende von Freiberg.

Jahrb. Berg. Hütt. Kön. Sachsen, 1886, Freiberg, pp. 52-70, pl. of figs. 1.

1644. Thibault, P. J. Conradite. A new mineral compound of tin.

Austr. Mg. Stand., Vol. 33, 1905, Sydney and Melbourne, pp. 124-125.

Discovered by author at the Conrad Mines, Howell, New South Wales, in 1902. Composition, $7 \mathrm{SnO}_{2}+\mathrm{Fe}_{2} \mathrm{O}_{3}$, being a compound of stannic and ferric oxides containing: Tin, 68.44 per cent, iron 9.2 per cent, oxygen 22.32 per cent. Absolutely insoluble in nitric, hydrochloric, sulphuric and hydrofluoric acids and aqua regia. Specific gravity about 6.2 ; not attracted by the magnet.

1645. Trechmann, C. O. On a probably dimorphous form of tin; and on some crystals found associated with it.

Min. Mag. Journ. Min. Soc., Vol. 3, 1879, London, pp. 186-192.

Two forms of crystals apparently obtained by electrolytic and dir methods of manufacture of metallic tin crystals. 


\section{MINERALOGY (Continued)}

TWEeDY, W. M. See No. 478.

Pseudomorphs after feldspar.

1646. Ulke, Titus. A new tin mineral in the Black Hills.

Trans. Amer. Inst. Mg. Eng., Vol. 21, 1893, New York, pp. 240-241.

Mr. Ulke has named this new tin mineral "Cuprocassiterite." "Cuprocassiterite is a light-yellowish to malachite-green mineral of an earthy fracture, dull glance, and, in the Etta mine, found with cassiterite filling cavities in a compact quartz gangue. Hardness, 3, specific gravity, nearly 5, streak, white."

Analysis: 62 per cent $\mathrm{Sn}, 13$ per cent $\mathrm{Cu}$, and 6 per cent $\mathrm{H}_{2} \mathrm{O}$, with traces of iron and silica.

1647. VtaAnderen, C. L. Bepaling van de hoeveelheid tinoxyde in tinerts aanwezig.

Jaarb. Mijnw. Ned. Oost-Indië, 1872, I, Amsterdam, pp. 269-273.

1648. Vogt, J. H. L. Künstliche Bildung von Kassiterit durch einen einfachen Oxydationsprocess ohne Gegenwart von sogenannten "agents minéralisateurs."

Zeitschr. Kryst. Min., Vol. 31, 1899, Berlin, pp. 279-280.

1649. Woolnough, W. G. Symmetrically distorted crystals from Western Australia.

Journ. Proc. Roy. Soc. New South Wales, Vol. 35, 1901, Sydney, pp. 332-335, pl. 1.

Crystals of cassiterite from Pilbarra, West Australia, are so distorted as to appear monoclinic. Intergrown with monazite which the author thinks may have caused the distortion.

See Molengraaff, G. A. F. (No. 1052) for similar crystals from Swaziland, also, Lacroix, A. (No. 516) for like distorted crystals from France. 


\section{MINING AND MILLING}

1650. Anonymous. The losses in dressing Cornish tin ores.

Eng. Mg. Journ., Vol. 55, 1893, New York, p. 295.

Brief description of improved methods and results gained.

45. See No. 312.

1651. Carcanagues, - Mémoire sur la préparation mécanique du minerai d'étain dans le Cornwall.

Ann. Mines, ser. 7, Vol. 14, 1878, Paris, pp. 209-239.

Charleton, Arthur G. See No. 1310.

1652. Colurns, J. H. On the use of the impact screen in tin dressing.

Trans. Inst. Mg. Met., Vol. 15, 1905-1906, London, pp. 524-525.

Mg. Journ. Railw. Comm. Gaz., Vol. 79, 1906, London, p. 511.

The author reports that the impact screen is for the first time, as far as is known, being used for tin dressing at Wheal Kitty mine, and with very satisfactory results.

-1653. Commans, RoBert E. The concentration and sizing of crushed minerals.

Proc. Inst. Civ. Eng., Vol. 116, 1894, London, pp. 3-66. Discussion and correspondence pp. $67-113$, figs. 50 .

An account of methods and apparatus used in treatment of ores including tin ores, to render them marketable.

FAwns, SYDNEY. See No. 1320.

1654. Ferguson, Henry T. On the mechanical appliances used for dressing tin and copper ores in Cornwall.

Proc. Inst. Mech. Eng., 1873, London, pp. 119-137.

Discussion, pp. 137-152.

Treated under the heads: Tin dressing, stamping, buddling, calcining, treatment of slimes, pulverizing.

1655. Frechevilue, R. J. The results obtained by the Cornish system of dressing tin ore, with observations thereon.

Trans. Mg. Ass. Inst. Cornwall, Vol. 1, 1887, Camborne, pp. 93-104.

Reprint: Eng. Mg. Journ., Vol. 40, 1885, New York, pp. 416-417.

A paper discussing the amount of tin saved at the mines, the amount caught by the stream works, and amount finally lost.

1656. Henwood, W. J. On the manipulation to which the ores of tin and copper are subjected in the central mining district of Cornwall.

Trans. Roy. Geol. Soc. Cornwall, Vol. 4, 1838, Penzance, pp. 145-165.

Description of stamps, buddles, kieves, etc., used. Also roasting furnace and jigs.

1657. Hicks, James. Treatment of slime tin.

Trans. Mg. Ass. Inst. Cornwall, Vol. 4, 1893-1895, Camborne, pp. 111-123.

Discussion, pp. 123-137, figs. 4. Read December 20, 1892.

"The increasing importance of the careful treatment of slime tin arises from the fact that as our mines increase in depth the tin in the stone becomes finer in grain."

Mentions the fact that ore is being crushed finer than formerly, and discusses the loss of slimes in the Red River and the recovery by streamers. 


\section{MINING AND MILLING (Continued)}

1658. Kunhardt, Wheaton B. The practice of ore dressing in Europe.

School Mines Quart., 1884, New York, pp. 103-104.

Describes calcining, to fissure tough rock, as practiced in tin districts of Saxon Erzgebirge; and roasting, to decompose arsenopyrite in tin ore.

1659. MacAlister, Donald A. Notes on ore dressing in Cornwall.

Summ. Progr. Geol. Surv. United Kingdom for 1904 (1905), London, pp. 153-163, fig. 1.

Present high price of tin makes it probable that some abandoned mines could be profitably worked by modern methods. In early days lodes were worked for only one of the metalliferous minerals, rest thrown to waste. Can be made to cover cost of nining and dressing if it carries only a little under 1 per cent (22.4 pounds per ton) of "black tin" which generally contains over 90 per cent cassiterite and yields on smelting about 65 per cent of metallic tin.

1660. Pearce, Richard. Losses in vanning tin ores.

Mg. Journ. Railw. Comm. Gaz., Vol. 77, 1904, London, pp. 116-117.

Gives results of experiments in vanning material containing a known amount of cassiterite.

- See Nos. 1546 and 1547.

1661. Phillips, JoHn. Improvements in dressing of tin.

Mg. Journ. Railw. Comm. Gaz., Vol. 15, 1845, London, p. 184, fig. 1.

Explanation of diagram of improved furnace for calcining tin ore.

Sexton, A. Humbolt. See No. 1361.

1662. SkEWEs, EDWARD. Magnetic separation of tin and wolfram at Gunnislake Clitters.

Eng. Mg. Journ., Vol. 76, 1903, New York, pp. 424-425, 700 words.

After crushing and separating the concentrates are calcined and then run through the magnetic separator. One magnet picks up the iron oxide made from pyrites, and a second picks out the wolframite. Tin ore sold ranks as best in Cornwall. Yield of tin 0.378 per cent, wolframite 0.72 per cent.

1663. TAYLOR, J. On the economy of the mines of Cornwall and Devon.

Trans. Geol. Soc. London, Vol. 2, 1814, London, pp. 309-327.

A general treatise upon the business methods of mines in Cornwall and Devon, including operations of the tin mines.

1664. Terrent, S. L. The final stages of tin and wolfram dressing.

Mg. Journ. Railw. Comm. Gaz., Vol. 83, 1908, London, pp. 714-715, figs. 2.

"Deals with tin and wolfram after concentration, considering fine and rough concentrates."

1665. Thomas, Chas. Tin dressing.

50th Ann. Rep. Roy. Cornwall Polyt. Soc., 1882, Falmouth, pp. 182-186. Discussion pp. 186-193.

Treats of methods and improvements that will reduce the waste of tin resulting from dressing.

1666. Thomas, R. Arthur. On crushing and concentrating at Dolcoath mine, Cornwall.

Trans. Inst. Mg. Met., Vol. 7, 1899, London, pp. 175-180. Discussion, pp. 180-190.

A general description of the treatment of tin ore at the mine; crushing and concentration, roasting and reconcentration, with accounts of experinents, 


\section{MINING AND MILLING (Continued)}

1667. Treany, W. All about tin; an enquiry.

Mg. Journ. Railw. Comm. Gaz., Vol. 50, 1880, London, pp. 49, 76, 105, 190, 221. Treats of tin dressing.

1668. Williams, R. H. Tin dressing and Williams's buddle.

Mg. Journ. Railw. Comm. Gaz., Vol. 47, 1877, London, pp. 487-488, 684-685, 796. Description of, and results obtained with Williams's buddle.

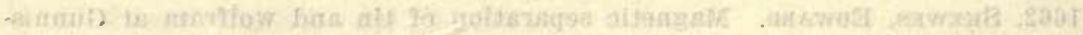

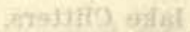

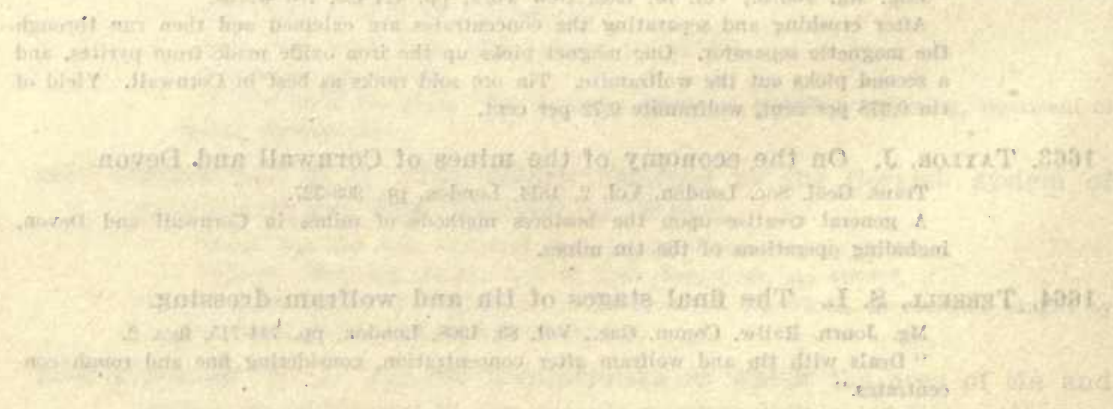


1669. Anonymous. Statistics on tin in Cornwall; etc.

Trans. Roy. Geol. Soc. Cornwall, Penzance, Vol. 1, 1818, pp. 250-251. Vol. 2, 1822, pp. 424-427. Vol. 3, 1827, pp. 339-341. Vol. 4, 1838, p. 491. Vol. 6, 1846, p. 358. Vol. 7, 1865 , p. 112 . Vol. 8,1871 , pp. $442,443,444,446,447,448,452-453,472$, and table 14, Vol. 10, 1887, pp. 153-155.

1670. La situation de l'étain.

Métallurgie, Vol. 32, 1901, Paris, pp. 1013, 1015.

Gives statistics of important tin producing countries from 1885 through 1899.

1671. Supplement to government gazette of Western Australia, No. 66 . M. S. No. 61, Perth, November 25, 1904, pp. 2963-2969.

General return of ore and minerals, other than gold, showing the quantity produced and the value thereof during 1904 and previous years.

The statistics of tin production are published annually in this form.

1672. Japan in the beginning of the 20th century.

Published by Imperial Japanese Commission to Louisiana Purchase Exposition, 1904, pp. $293,321$.

Gives the output of tin by years from 1892 to 1902, inclusive.

1673.

Return showing the quantity and value of tin exported from Tasmania from 1880 through 1904, compiled from customs returns only, and tin ore produced during 1905.

Rep. Secr. Mines, Tasmania, for 1905 (1906), Hobart, p. XVII.

1674 .

Billiton and Banca tin.

Mg. World, Vol. 24, 1906, Chicago, p. 778.

Giving the Banca tin production from 1881 to 1906 (25 years) as 184,349 long tons.

During last ten years from 1896 to 1906 Billiton produced 46,938 long tons.

1675 .

\section{Tin from the Malay Peninsula.}

Mo. Bull. Int. Bur. Amer. Repub., Vol. 23, November, 1906, Washington, D. C., pp. $1179-1180$.

As the sliding scale of prices for Bolivian tin is regulated by the quotations for the Straits Settlements product, a report on the subject by United States Consul General, D. F. Wilber is given.

1676. Annual Report, Department of Mines, New South Wales, from 1875.

Sydney.

Gives statistical and other inforivation about the tin output of New South Wales.

1677. Coghlan, T. A. A statistical account of the seven colonies of Australasia.

1892, Sydney, pp. 142-145.

Tin of New South Wales, Tasmania, Queensland and Victoria described briefly. Production for $\mathbf{1 8 9 0}$ given. Fluctuations in the price of tin. 


\section{STATISTICS (Continued)}

1678. - A statistical account of the seven colonies of Australasia. 1899-1900.

1900, Sydney, pp. 1-836, map 1.

Includes tin production in Australia.

1679. - Tin. A statistical account of Australasia and New Zealand, 1903-1904.

Sydney, pp. 933-936.

New South Wales, p. 934; Western Australia, p. 935; Victoria, p. 935; South Australia, p. 935; Queensland, p. 935; Tasmania, p. 934.

1680. Coluns, J. H. Seven centuries of tin production in the west of England.

Trans. Mg. Ass. Inst. Cornwall, Vol. 3, 1892, Camborne, pp. 173-193.

"Estimates the total produce of metallic tin in the West country between 1201 and $1900 \mathrm{~A}$. D. to be 875,900 tons, from which it may be reckoned that 711,990 tons were yielded between 1201 and 1750 A. D., from both Cornwall and Devon. Of 283,000 tons of tin yielded between 1201 and $1600 \mathrm{~A}$. D., 75,000 were derived from tin stream gravels; and of 573,800 tons yielded between 1601 and 1800 A. D., 473,000 tons were derived from tin stream gravels."

1681. Earl of Mount Edgcumbe. Production of tin in Cornwall.

Journ. Roy. Inst. Cornwall, Vol. 8, 1886, Truro, pp. 8-9.

The tin produced in Cornwall from 1873-1883 given.

1682. Ehrenwertir, J. voN. Production an Zinn in den Jahren 1881 bis 1890 . Oest. Zeitschr. Berg. Hütt. Vol. 41, 1893, Wien, p. 220.

Statistics showing the tin production of the world for the years 1881 to 1890 .

1683. Engineering and Mining Journal.

Since Vol. 17, 1874, New York.

Annually collects statistics of the world's tin production.

1684. Estadística Minera España.

Annual, Madrid.

Tables showing production of tin producing provinces of Spain. .

1685. Great Britain. Home Office.

London.

Title varies: 1882, Mineral statistics of the United Kingdom of Great Britain and Ireland.

1883, Mines and minerals. Summaries of the reports of the inspectors of mines. . . and mineral statistics of the United Kingdom of Great Britain and Ireland.

1884-1887, Mines and minerals. Mining and mineral statistics of the United Kingdom of Great Britain and Ireland.

1888-1894, Mines and minerals. Mineral statistics of the United Kingdom of Great

Britain and Ireland with the Isle of Man. . . .

1895-1896, Mines and quarries. Mineral statistics of the United Kingdom of Great Britain and Ireland with the Isle of Man.

1897, Mines and quarries: General report and statistics. . . . . Issued in four parts:: Pt. I. District statistics. Pt. II. Labor. Pt. III. Output. Pt. IV. Colonial and foreign statistics. Iff Yo Jumanon favilallat General statistics of tin.

1686. There is no reference bearing this number.

1687. Hunt, Robert. On the present state of tin production and the tin trade. Rep. Proc. Min. Ass. Cornwall and Devon, for 1874 (1875), Truro, pp. 35-40. 


\section{STATISTICS (Continued)}

Gives number of productive tin mines, quantity of ore produced, and average price per ton, of the Cornwall mines from 1864-1873; also production and price of foreign tin for same years.

1688. - Mineral statistics of the United Kingdom from 1853 through 1880.

London.

1689. JAARBoEK van het Mijnwezen in Nederlandsch Oost-Indië, from 1872 , Amsterdam to 1899. Batavia since 1900.

Publishes statistics of tin produced in East Indies.

1690. Koulibine, S. La production minière et métallurgique de la Russie en 1885 (Bulletin).

Rev. Univ. Mines, Mét. Trav. Publ. Sci. Arts Appl. Indust., ser. 3, Vol. 4, 1888, Paris and Liege, p. 88.

(Extrait d'un rapport de M. Koulibine.)

Etain-Une seule usine, situee dans le gouvernement de Wyborg, s'est occupée du traitement de l'étain. Elle n'a produit que $14,087 \mathrm{~kg}$. de métal raffiné. (Whole reference.)

1691. - La production minerale et metallurgique de la Russie en 1887. Rev. Univ. Mines Mét. Trav. Publ. Sci. Arts Appl. Indust., ser. 3, Vol. 11, 1890, Paris and Liége, p. 314.

(Extrait du rapport de M. Koulibine.) $10^{t} 351$ d'étain ont été retirées du traitement de 1738t, de minerais a l'usine de Pitkäranta (Finland). (Whole reference.)

1692.

Tableau de l'industrie minérale de la Russie en 1888-1889.

Rev. Univ. Mines Met. Trav. Publ. Sci. Arts Appl. Indust., ser. 3, Vol. 16, 1891, Liége and Paris, p. 214.

Tin production in Pitkäranta (Finland); 1888, 1.186 poods; 1889, .721 pood.

1693. MacAlister, Donatd A. Total quantity of tin, copper and other minerals produced in Cornwall, particularly with regard to the quantities raised from each parish.

Summ. Progr. Geol. Surv. Great Britain for 1906 (1907), London, pp. 132-139.

1694. Metallgesellschaft. Comparative statistics of lead, copper, tin, silver, nickel, aluminum and quicksilver, from 7th year, 1890-1899.

Frankfort-on-the-Main.

Publishes estimates of the world's production and consumption of tin.

1695. REPoRT on Mineral Industries in the United States at the eleventh census, 1890.

1892, Washington, D. C., p. 249.

For 1889, California, South Dakota, Virginia.

1696. MINeral Industry.

Vol. I, 1892, New York; New York and London since Vol. 3, 1895.

Publishes annual articles on the production of tin throughout the world.

1697. Mineral Statistics of Victoria, $1873-1877$ to $1885-1888$, also Reports and Statistics since 1890-1891.

Melbourne. 


\section{STATISTICS (Continued)}

1698. Plummer, John. Australian mineral production and export. Mg. World, Vol. 25, 1906, Chicago, p. 430.

Statistics of tin production during 1904 and 1905.

Rolker, Chas. M. See No. 1357.

1699. Spargo, T. Statistics and observations on the mines of Cornwall and Devon.

1864, London.

Not available to the authors.

See Tasmania, Government geologist No. 1134.

1700. Trasenster, Paul. Revue economique et statistique.

Rev. Univ. Mines Met. Trav. Publ. Sci. Arts Appl. Indust., ser. 2, Vol. 13, 18s3, Paris and Liége, p. 480.

Estimates the tin production of the world during 1879, 1880 and 1881.

Victoria. See No. 1222.

Watson, J. Y. See No. 483.

WEEKS, JOSEPH D. See No. 1372.

1701. Whitney, J. D. The metallic wealth of the United States.

1854, Philadelphia, p. 510.

Abstract: Zeitschr. Berg. Hütt. Sal. preuss. Sta., Vol. 2, 1854, Berlin, p. CXXXII. Table giving the mineral production of the world for the year 1854 . 


\section{INDEX}

[Prepared by Lancaster D. Burling.]

Reference

Number

$\mathrm{A} \longrightarrow$, R. D................................. 796

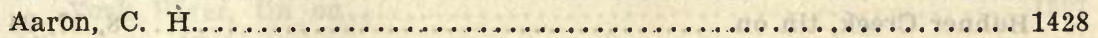

Abbaretz, see France, Lower Loire.

Abbott, George, Jr............................... 309

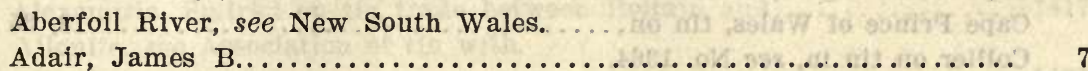

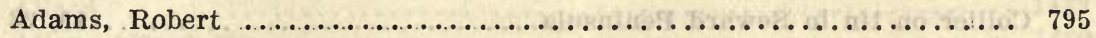

Acamistla, see Mexico, Guerrero.

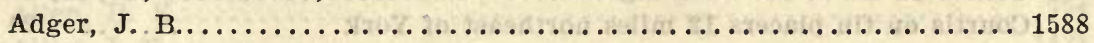

Aeschynite, see Association of tin with.

Africa:

Beck on tin deposits in southern Africa.................. 1

Gibson on tin in metamorphic areas of southern Africa......... 2

Louis on tin in ............................... 1340

Recknagel on the origin of the South African tin deposits........ $3 a$

Voit on the economically valuable mineral deposits of South Africa. 3c

See also Cape Colony, French Kongo, Kamerun, Kongo, Madagascar,

Nigeria, Pretoria, Swaziland, Transvaal, South Africa.

Agricola, Georgius .............................. 1277

Aguas Calientes, see Mexico.

Aguilera, José G...........................751, 752, 753

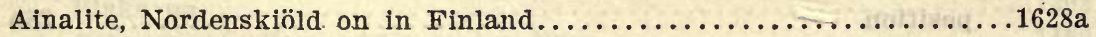

Akkeringa, J. E................................... 121

Akwa-Ibama district, see Nigeria.

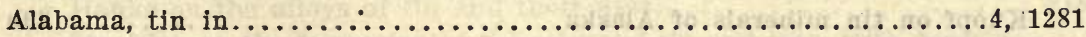

Benedict on tin in...........................1200, 1301

Benedict on the Broad Arrow Mine near Ashland, Clay County.... 5

Broad .Arrow Mine............................ 5

Coosa County, tin in.$\ldots \ldots \ldots \ldots \ldots \ldots \ldots \ldots \ldots \ldots \ldots \ldots \ldots \ldots$

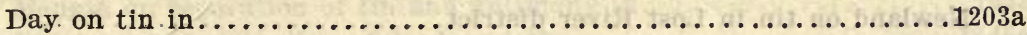

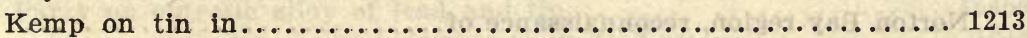

Phillips on tin in. Coosa County........................ 6

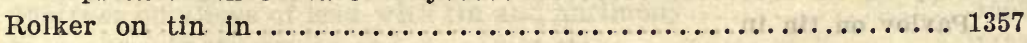

See aiso United States.

Alaska, tin in ........................... 12a, 12b, 1196, 1292

Adair on tin deposits of the York region................. 7

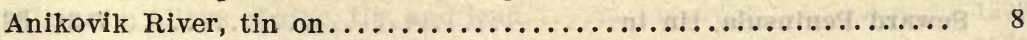

Beales on tin in Seward Peninsula..................... 13 
Alaska-Continued.

Bell on tin on Cassiterite Creek, a branch of Lost River.......... 16

Bell on tin near Port Clarence.......................... 14

Bell on tin in Seward Peninsula and on Lost River............. 15

Brooks on reconnaissances in the Cape Nome and Norton Bay

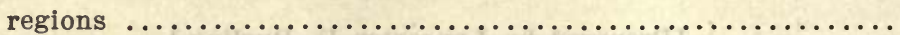

Brooks on tin on Buhner Creek......................... 17

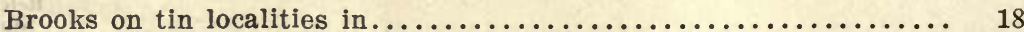

Buck Creek, occurrence of tin on .............12c, 13, 22, 28b, 30

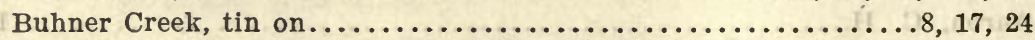

Cape Mountain, occurrence of tin in ................ 12, 22

Cape Nome region, reconnaissance of .................... 17

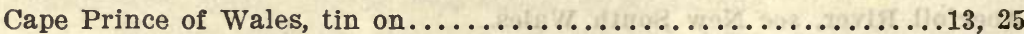

Collier on tin in, see No. 1364.

Collier on tin in Seward Peninsula........................ 23

Collier on tin in the York region...................... 21, 22

Courtis on tin placers 12 miles northeast of York............ 24

Ears Mountain, occurrence of tin in.................12c, 18, 29b

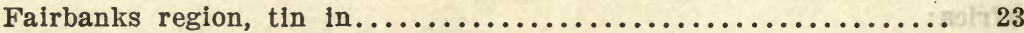

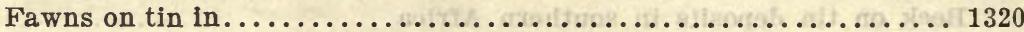

Fay on area, climate, vegetation, geology, tin deposits, mining,

economic conditions, and prices of provisions in........... 25

Fay on tin deposits of Cape Prince of Wales................ 25

Fillery Creek, tin on .............................. 30

Garrison on tin on York River........................ 1207

Hess on tin deposits of York region, Seward Peninsula...........26, 27

Hill on history of the York tin mines, Seward Peninsula......... 28a

Hill on tin deposits of the York region.................... 28

Jacobs on the mineral exhibit at the Alaska-Yukon-Pacific Ex-

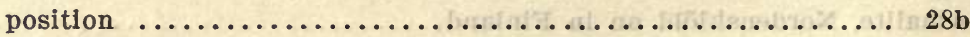

Knopf on production of tin in Seward Peninsula through 1908.... 28b

Knopf on tin deposits of Seward Peninsula................29, 29a

Knopf on tin minerals of Alaska.......................

Lost River, occurrence of tin on.................... 29 b

Lost River region, tin in .................. 13, 15, 16, 18, 22, 31

Newland on tin in.................................... 1347

Newland on tin on Buck and Fillery Creeks................ 30

Newland on tin in Lost River district................... 31

Norton Bay region, reconnaissance of................... 17

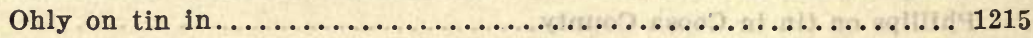

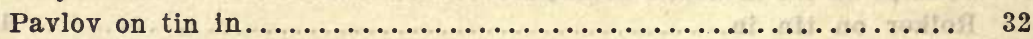

Pavlov on tin in York region...................... 1216

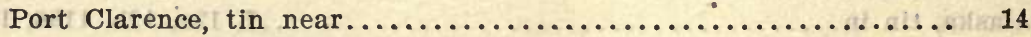

Rickard on tin deposits of the York region................. 33

Seward Peninsula, tin in..................... $7-31,33,35$

Seward Peninsula, York tin mines, history of............. 28a 
Alaska-Continued.

Seward Peninsula, see also York, Cape Nome, Norton Bay, Cape

Prince of Wales, Port Clarence, and Lost River regions.

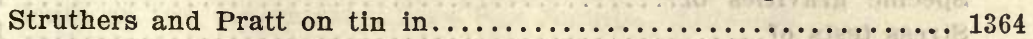

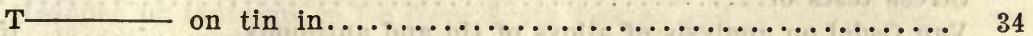

Walcott on discovery of tin near York.................. 35

York, tin 12 miles northeast of........................ 24

York region, tin in....7, 8, 17, 18, 20, 21, 22, 24, 26, 27, 28, 33, 35,

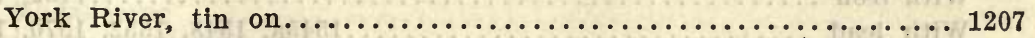
Albany, see Victoria.

Albite, see Association of tin with.

Alexandria, Smirke on tin trade between Britain and............ 1417 Allanite, see Association of tin with.

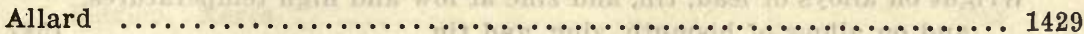

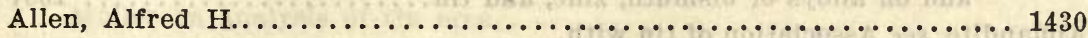

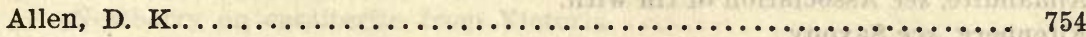

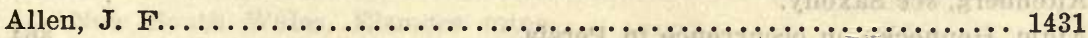

Allen, Tho. ....................................... 579

Allier, see France.

Allophane: tin oxide after quartz and allophane in Cornwall......... 1629

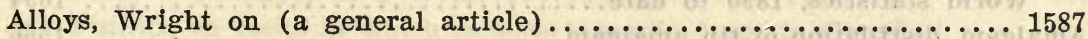

Alloys of tin:

Allen on alloy with copper and manganese................ 1431

Allen on estimation of tin in ........................... 1430

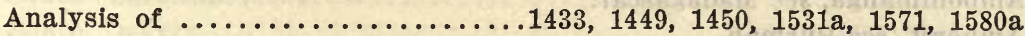

Babbitt metal, composition, uses, and analyses...............1531a

Berthier on analysis of.................................... 1450

Billings on properties of iron alloyed with tin and other metals... 1452

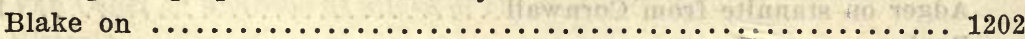

Cahours on alloys of tin and sodium.................... 1460

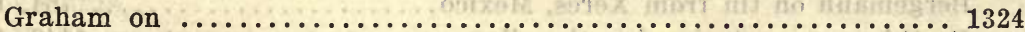

Hanks on the alloys of tin and their uses.................... 218

Headden on the formation of the alloys of tin and iron, with descrip-

tion of some new alloys........................... 1502

Heycock and Neville on the constitution of copper-tin alloys....... 1504

Meade on composition, uses, and analysis of babbitt metal alloys. ..1531a

Mengin on separation of tin and antimony in. ................ 1533

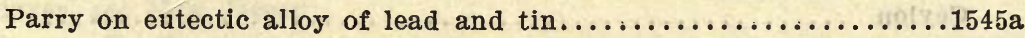

Peetz on separation of tin and lead in tin-lead alloys........... 1548

Plattner on alloys of lead with tin'and antimony............. 1552

Properties of the alloys of copper and tin................. 1433

Rieffel on the alloys of copper and tin.................... 1557

Schultz on production and application of solder............. 1359

Slater on alloys of zinc, tin, and lead.................. 1570

Smith (J. L.), on analysis of....................... 1571 
Alloys of tin-Continued.

Reference Number

Solder, its production and application.................. 1359

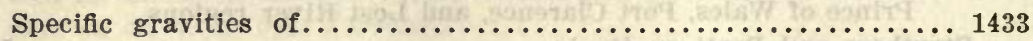

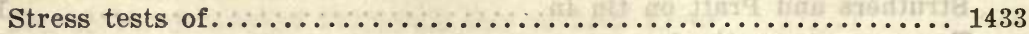

Van Osdel on analysis of alloys of tin and antimony............1580a

With antimony $\ldots \ldots \ldots \ldots \ldots \ldots \ldots \ldots \ldots \ldots \ldots \ldots \ldots . \ldots \ldots 33,1552,1580$ a

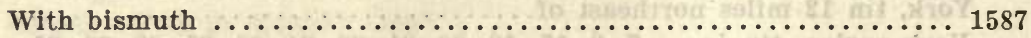

With copper $. \ldots \ldots \ldots \ldots \ldots \ldots \ldots \ldots \ldots \ldots \ldots \ldots . \ldots 1431,1433,1504,1557$

With Iron . . . . . . . . . . . . . . . . . . . 1502

With lead $\ldots \ldots \ldots \ldots \ldots \ldots \ldots \ldots \ldots \ldots \ldots \ldots . .1545 \mathrm{a}, 1548,1552,1570,1587$

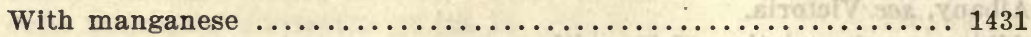

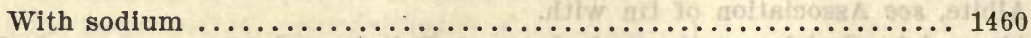

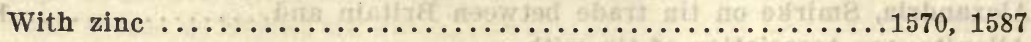

Wright on alloys of lead, tin, and zinc at low and high temperatures,

and on alloys of bismuth, zinc, and tin ................ 1587

Almandite, see Association of tin with.

Altenberg, see Saxony.

Alum, Hennecke on occurrence in Persia..................... 864

Aluminum, Douglas on metallurgy of....................... 1204

Precipitation of tin on, in estimation of tin in salts of tin....... 1493

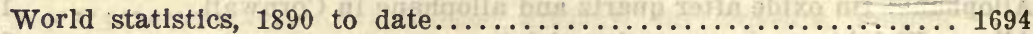

Amalgam, distillation of tin amalgam ...................... 1556

Ambatofangehana, see Madagascar.

Amblygonite, see Association of tin with.

Ambohimanga, see Madagascar.

Amherst, see Burmah.

Anaberg Revieren, see Saxony.

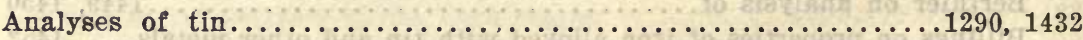

Adger on stannite from Cornwall..................... 1588

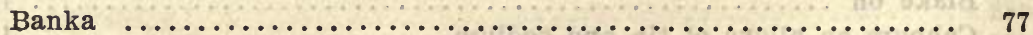

Bergemann on tin from Xeres, Mexico............... 1446

Berthier on analysis of a tin alloy ...................... 1450

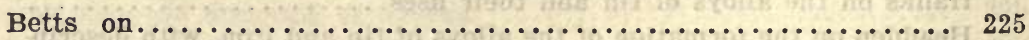

Brown on cassiterite from Rockbridge County, Virginia......... 1240

Caillaux on tin from Tuscany ..................... 618

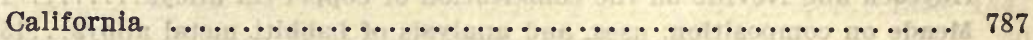

Campbell on cassiterite from Rockbridge County, Virginia....... 1241

Ceylon .................................. 258

Collins on the crust of a block of "Jews" tin ".............. 362

Cornwall .................................442, 1588

Dana on tin in tantalite, columbite, and in meteoric olivine...... 1600

Day on cassiterite in Black Hills, South Dakota............ 1005

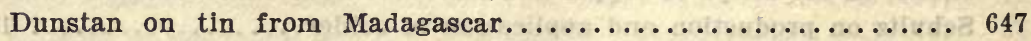

Dunstan on tin from northern Nigeria................ 857,858

Dunstan on stream tin from Ceylon................... 258 
Analyses of tin-Continued.

Reference

Dykes on analyzing tin slags....................... 1483

Genth on cassiterite near Kings Mountain, North Carolina...... 244

Genth on two concentrates from San Jacinto, California........ 787

Headden on tantalum in tin from South Dakota and the Carolinas.. 1208

Headden on tapiolite from South Dakota................ 1208

Ingalls on ten analyses of Mexican tin ore............. 776

Lampadius on analyzing the minerals of tin ............. 1515

Liversidge on tin from Elsmore mine, Inverell, New South Wales.. 830

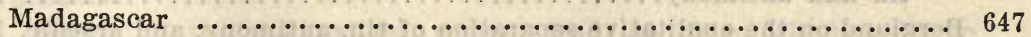

Malay Peninsula, Pahang....................... 674

Mallett on analysis of tin pyrites.................... 1531

Meade on analysis of babbitt metal alloys...................

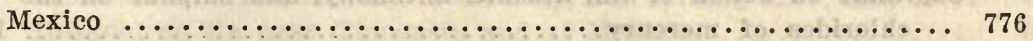

Mexico, Xeres............................ 1464,146

Muller on analysis of tin ores.................... 1539

Newberry on cassiterite from Victoria................. 1232

New South Wales, Elsmore mine................... 830

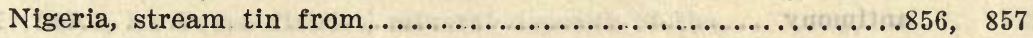

North Carolina.............................244, 1208

Peru, Cajatambo, ores from..................... 866

Phillips on rocks in which mineral deposits occur in Cornwall.... 442

Schaeffer on tantalite from the Black Hills, South Dakota....... 1017

Simpson on tin in Western Australia................. 1267

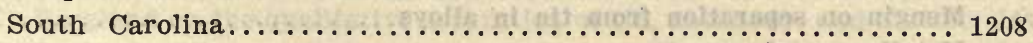

South Dakota......................1005, 1017, 1023, 1208

Todd on tin ore from South Dakota................... 1023

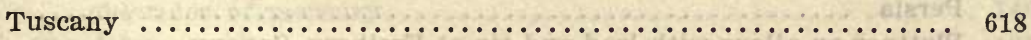

Van Osdel on analysis of alloys of tin and antimony $\ldots \ldots \ldots \ldots \ldots .1580 \mathrm{a}$

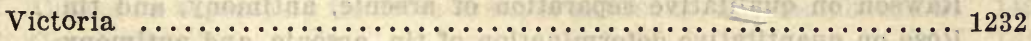

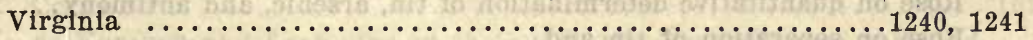

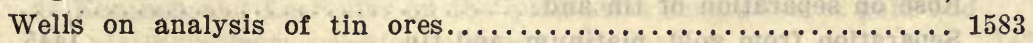

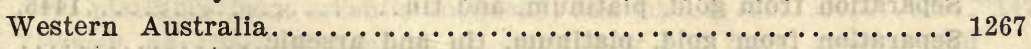

See also Chemistry of tin, and assays of tin.

See references Nos. $1428-1587$.

Anchor mine, see Tasmania.

Andalusite, see Association of tin with.

Andover, see New Jersey.

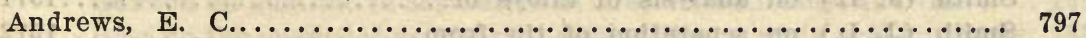

Andrewsite, Foster on place and mode of occurrence of .......... 1608 Anikovik River, see Alaska.

Anjou, see France.

Annan River, see Queensland.

Antananarivo, see Madagascar.

Antequera mine, see Bolivia. 
Antimony:

Reference

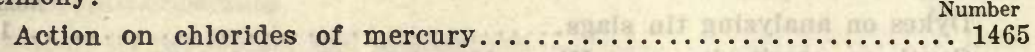

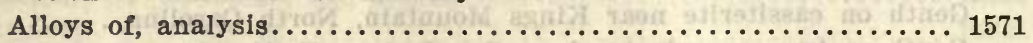

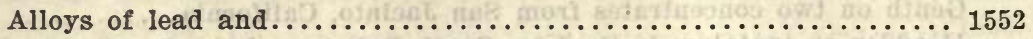

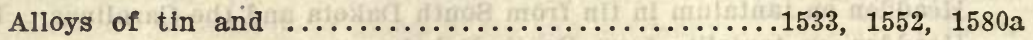

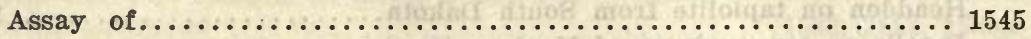

Association of tin with..............166, 172, 180a, 225, 496, 1086

Bechamp and Saintplerre on separation of gold and platinum from

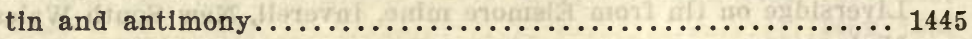

Berglund on the qualitative separation of tin, antimony, and arsenic. 1447

Boucard on separation of gold and platinum from tin and antimony. 1455

Bunsen on the separation of arsenic from antimony and tin...... 1459

Capitaine on action of tin, arsenic, antimony, and sulphur on the

chlorides of mercury............................. 1465

Clarke on separating tin from arsenic, antimony, and molybdenum. 1467

de Koninch and Lecrenier on the qualitative separation of gold and

platinum from arsenic, antimony, and tin............. 1474

Dewey on Clarke's method of separating tin from arsenic and

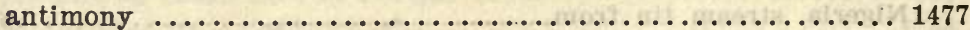

Douglas on metallurgy of.......................... 1204

Gay-Lussac on the separation of tin from................ 1495

Hennecke on occurrence in Persia.................... 864

Henz on separation of antimony and tin................ 1503

Levol on quantitative separation of tin and................ 1519

Mengin on separation from tin in alloys.................. 1533

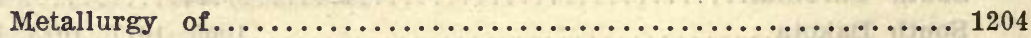

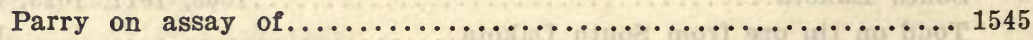

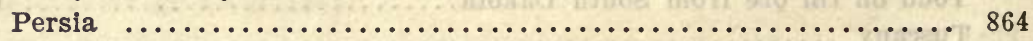

Plattner on alloys with lead and tin at Freiberg, Saxony......... 1552

Rawson on qualitative separation of arsenic, antimony, and tin... 1553

Rose on quantitative determination of tin, arsenic, and antimony... 1559

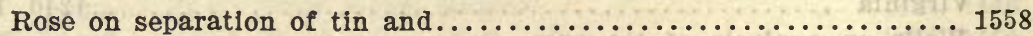

Separation from gold, platinum, and tin..................... 1455

Separation from gold, platinum, tin and arsenic............. 1474

Separation from tin..................1495, 1503, 1519, 1558, 1572

Separation from tin in alloys............................... 1552

Separation from tin and arsenic..........1447, 1459, 1477, 1553, 1559

Separation from tin, arsenic, and molybdenum............ 1467

Smith (J. L.) on analysis of alloys of............................

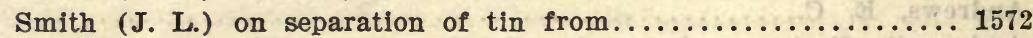

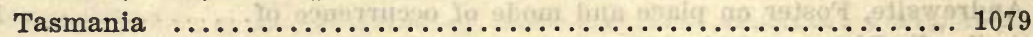

Van Osdel on analysis of alloys of tin and.................1580a

Witmer on the separation of tin from.................... 1585 Apacheta mine, see Bolivia.

Apatite, association of tin with $\ldots \ldots \ldots \ldots \ldots \ldots \ldots \ldots \ldots \ldots 227,1009,1314$

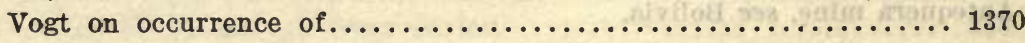




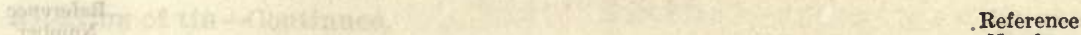
Appleton, w. S.................................. 1374 Approuague River, see French Guiana.

Araca, see Bolivia.

Arba mine, see Tasmania.

Arecayo mine, see Bolivia.

Argall, Wm.

Argentiferous galena, see Association of tin with.

Argentina:

Castro on tin, gold, silver, copper, lead, and bismuth deposits in

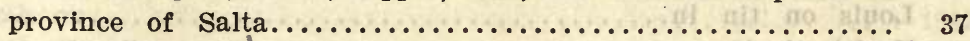

Catamarca, Tinogasta, tin near...................... 38

Hoskold on mines, mining, metallurgy, and mining laws, etc., of... 38

Hoskold on tin near Tinogasta and at Mazan.................. 38

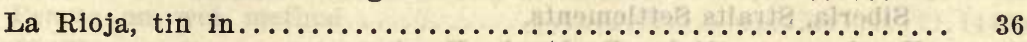

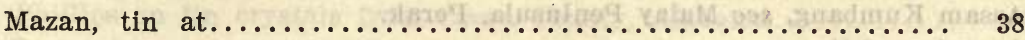

Mines, mining, metallurgy, and mining laws of.............. 38

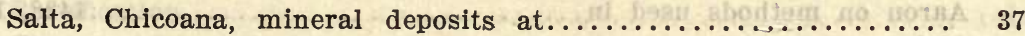

Salta, La Poma district, mineral deposits of the............. 37

See also South America.

Arksut, see Greenland: Evigtok.

Arsenic:

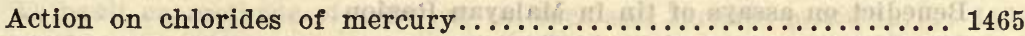

Association of tin with.........172, 180a, 225, 227, 573a, 1025(?), 1314

Berglund on the qualitative separation of tin, antimony, and arsenic. 1447

Bunsen on the separation of arsenic from antimony and tin...... 1459

Capitaine on action of tin, arsenic, antimony, and sulphur on the

chlorides of mercury ............................. 1465

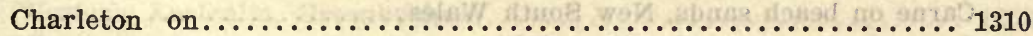

Clarke on separating tin from arsenic, antimony, and molybdenum.. 1467

Cornwall ...................................... 1617

de Koninch and Lecrenier on the qualitative separation of gold and

platinum from arsenic, antimony, and tin.............. 1474

Dewey on Clarke's method of separating tin from arsenic and

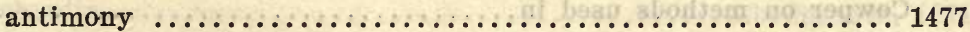

Elsner on separation from tin ....................... 1485

Elsner on the separation of gold and platinum from tin and arsenic. 1486

Headden on compounds of, in an old Cornwall furnace........... 1617

Rawson on qualitative separation of arsenic, antimony, and tin...... 1553

Rose on the quantitative determination of tin, arsenic, and antimony. 1559

Separation from gold, platinum, and tin................ 1486

Separation from gold, platinum, tin, and antimony............. 1474

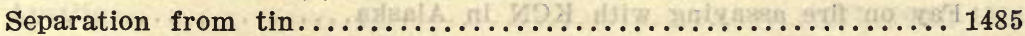

Separation from tin and antimony..........1447, 1459, 1477, 1553, 1559

Separation from tin, antimony, and molybdenum............ 1467

Arsenical pyrites, see Association of tin with. 
2015014.

Arsenopyrite, decomposed by roasting.

See Association of tin with.

Arsuk (Arsut) Fjord, see Greenland.

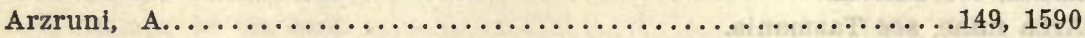

Asbestos, Voit on deposits of, in South Africa............... 3c

Ashburton, see Devon.

Asia:

Fischer on tin, Venturine glass, and Venturine quartz in....... 39

Herman on tin in Uralsk, Central Asia................ 40

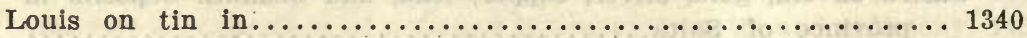

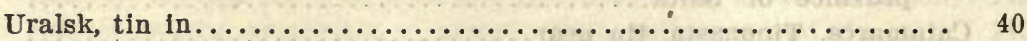

See also Burma, Ceylon, China, East Indies, India, Japan, Korea, Malay Peninsula, Manchuria, Persia, Philippine Islands, Siam, Siberia, Straits Settlements.

Assam Kumbang, see Malay Peninsula, Perak.

Assaying of tin:

Aaron on methods used in ....................... 1428

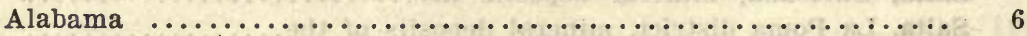

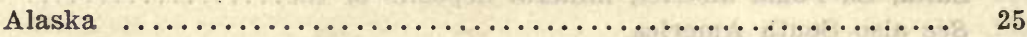

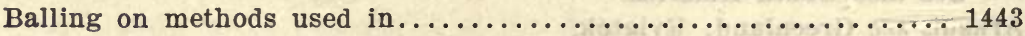

Bannister on assaying stream tin for gold................ 1444

Benedict on assays of tin in Malayan Region............... 679

Benedict on assays of tin in Sumatra................. 281

Benedict on tin in Virginia......................... 1239

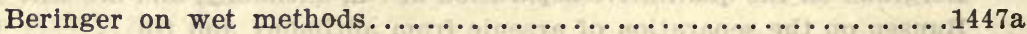

Bettel on methods used in, comparing Cornish wet and dry methods. .1450a

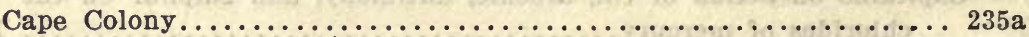

Carne on beach sands, New South Wales................ 809

Carpenter on tin in the Black Hills................... 998

Carpenter and Headden on the influence of columbite on the...... 1466

Chandler on crucible assay of tin from Durango, Mexico........ 767

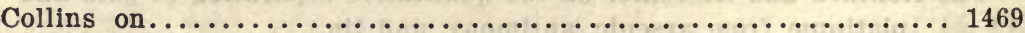

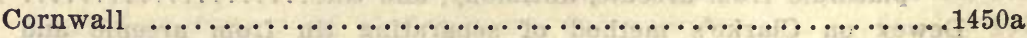

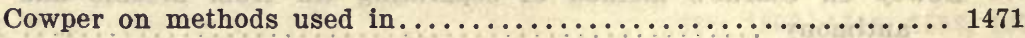

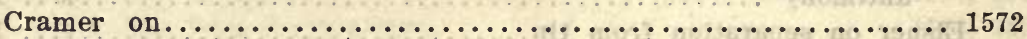

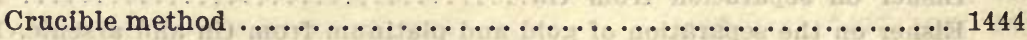

Dabney on assays of cassiterite from Kings Mountain, North

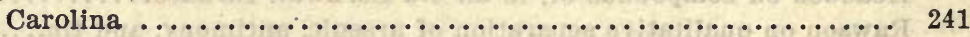

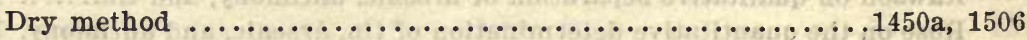

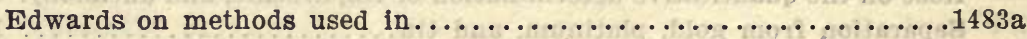

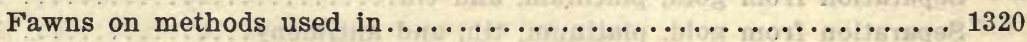

Fay on fire assaying with $\mathrm{KCN}$ in Alaska............... 25

Hofman on dry assay of tin ores in the Black Hills.......... 1506

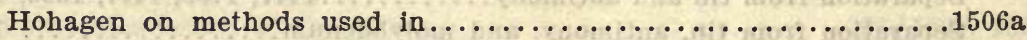

Kerl on fire and wet assays of tin .................... 1510 
Assaying of tin-Continued.

Reference Number

Klaproth on assays of tin in charcoal and clay crucibles........ 1513

Lampadius on assaying the minerals of tin................ 1515

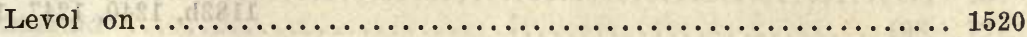

Malayan region $\ldots \ldots \ldots \ldots \ldots \ldots \ldots \ldots \ldots \ldots \ldots \ldots \ldots \ldots \ldots \ldots \ldots . .679$

Methods used in...1320,1428,1437, 1443, 1444, 1471, 1483a, 1506a,

See Dry and wet methods.

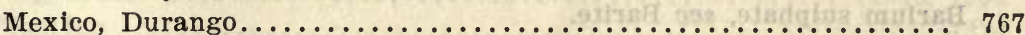

New South Wales................................. 809

North on ................................ 1542

North Carolina................................ 241

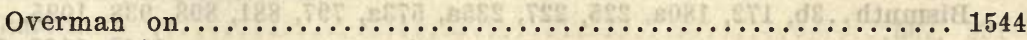

Parry on......................................... 1545b

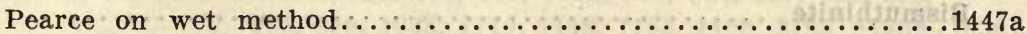

Phillips on tin crystals from Coosa County, Alabama........... 6

Pryce on ......................................... 444

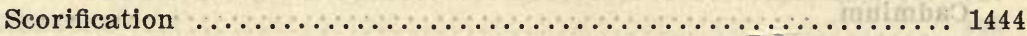

Simpson on ore from Greenbushes field, Western Australia........ 1267

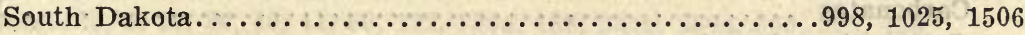

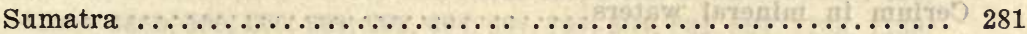

Tasmania .......................................1058, 1145

Thibault on methods of assaying tin ores and furnace products.... 1578

Twelvetrees on tin from Tasmania................... 1145

Vincent on 83 assays from South Dakota................. 1025

Virginia .....................................1239, 1247

Wagner on tin ore from Papkuilsfontein, Cape Colony ........... 235a

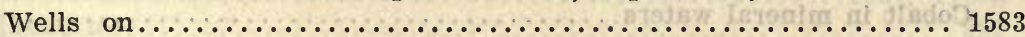

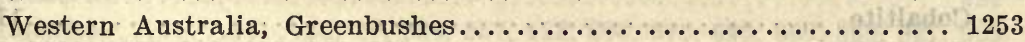

Wet method of....................1442a, 1444, 1447a, 1450a, 1510

Whitehead on assays of tin and mispickel from Virginia.......... 1247

See also Analyses of tin, chemistry of tin, metallurgy of tin.

See references Nos. $1428-1587$.

Association of tin with:

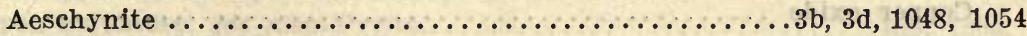

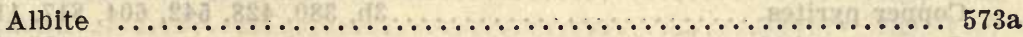

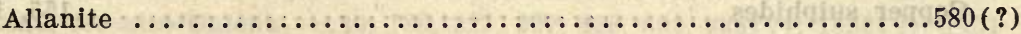

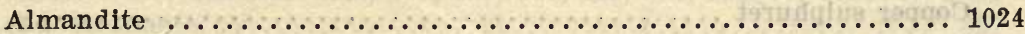

Amblygonite .................................227, 496, 1009

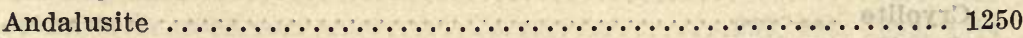

Antimony $\ldots \ldots \ldots \ldots \ldots \ldots \ldots \ldots \ldots \ldots \ldots \ldots \ldots 166,172,180 \mathrm{a}, 225,496,1086$

See also Stibnite and stibiotantalite.

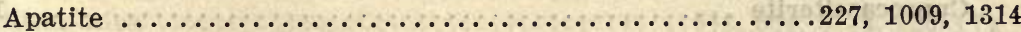

Argentiferous galena ....................816, 1040, 1155, 1163

Arsenic, see also Arsenopyrite. .172, 180a, 225, 227, 235a, 573a, 1025(?), 1314

Arsenical pyrites, see Arsenopyrite. 
Association of tin with-Continued.

Arsenopyrite, see also Arsenic....180a, 235a, 498, 523, 542, 573a, 586, $651,726 \mathrm{~b}, 792,797,816,817,872,1009,1034,1155,1183$,

$1183 \mathrm{~b}, 1240,1247,1294$

Augite 230

Autunite 999

Axinite $726 \mathrm{~b}, 1009,1024,1314$

Barite

Barium sulphate, see Barite.

Beryl . $227,797,817,997,1024,1155$

Beryllium in mineral waters. 524

Blotite 1050

Bismuth..3b, 172, 180a, 225, 227, 235a, 573a, 797, 881, 898, 938, 1095,

Bismuthinite $1148,1163,1294$

Blende 816

Boron $.586,1183 \mathrm{~b}$

Cadmium $726 \mathrm{~b}, 1314$

Calcium phosphate

Carbonates 523

Chalcedony 524

Chalcocite 797

Chalcopyrite. $573 a$

Chlorine $180 \mathrm{a}, 573 \mathrm{a}, 797,816,905,1009,1041,1155,1183$

Chlorite. 1327

Cinnabar $180 a, 380,904,905,1155$

Cobaltite $1186 \mathrm{~b}$

Columbite $227,523,859,996,1009,1010,1015$

Columbium minerals 1258

Copper...... 172, 188, 225, 227, 235a, 259a, 388, 410, 523, 586, 726a, $792,881,898,938,1119,1168 \mathrm{a}, 1183,1183 \mathrm{~b}$

Copper carbonate. 792

Copper oxide 523

Copper pyrites. $3 b, 380,428,542,604,817,1183 b$

Copper sulphides 155,1034

Copper sulphuret 792

Corundum 3d, 1052

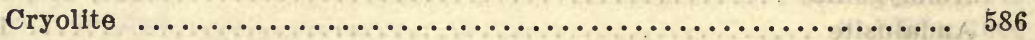

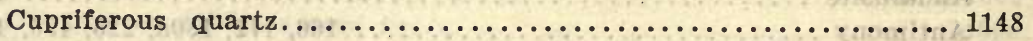

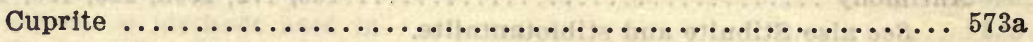

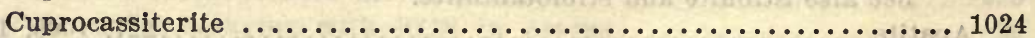

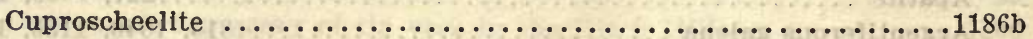

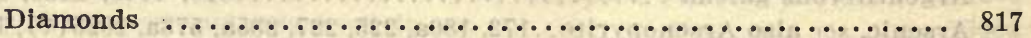

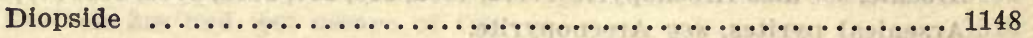


Association of tin with-Continued. Durangite ........................ 227, 751, 753, 774

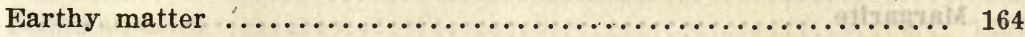

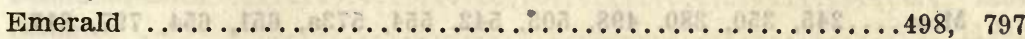

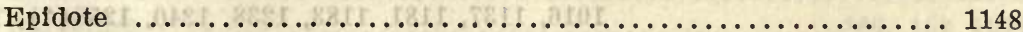

Euxenite .............................3b, 3d, 1048, 1054

Feldspar ............................498, 586, 681

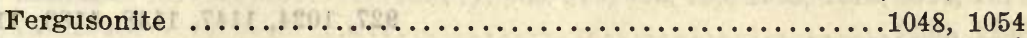

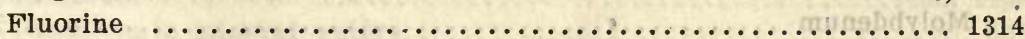

Fluorite. . .8, 17, 227, 235a, 380, 523, 542, 573a, 586, 651, 654, 681, 726a, $726 \mathrm{~b}, 797,817,927,1009,1155,1168 \mathrm{a}, 1183,1183 \mathrm{~b}, 1294,1314$

Fluorspar, see Fluorite.

Gadolinite ................................ 597

Galena, see also Lead....428, 498, 542, 573a, 586, 604, 629, 797, 816, $905,999,1038,1119,1148,1155,1163,1183,1183 \mathrm{~b}, 1636$

Garnet.........3b, 8, 17, 34, 207, 580(?), 859, 1148, 1168a, 1258, 1267

Gem minerals (in general) $\ldots \ldots \ldots \ldots \ldots \ldots \ldots \ldots \ldots 256,259,817,927$

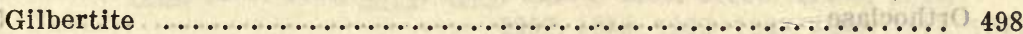

Glycium (beryllium) in mineral waters................... 524

Gold..3b, 8, 17, 34, 40, 41, 50, 172, 180a, 188, 235a, 259a, 369, 395, 428, $586 \mathrm{~b}, 599,600,601,602,604,607,797,804,831,891,1138,1139$, $1148,1155,1168 \mathrm{a}, 1327,1444$

Graphite............................905, 999, 1024

Hemątite, see also Specularite....428, 604, 613, 627, 628, 681, 751,

$753,1168 \mathrm{a}, 1635$

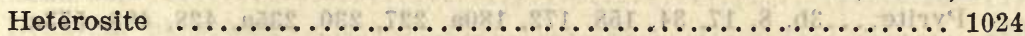

Hornblende ........................................ 1168a

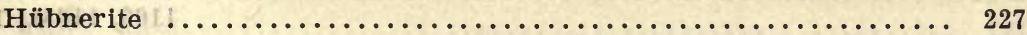

Ilmenite..........

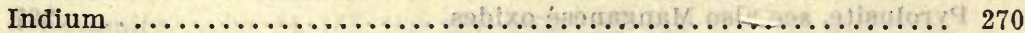

Iron. ......................5, 225, 573a, 586, 682, 1025(?), 1314

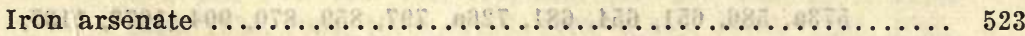

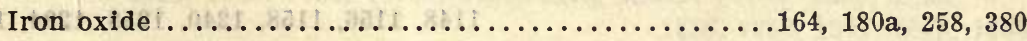

Iron pyrites, see Pyrite and pyrrhotite.

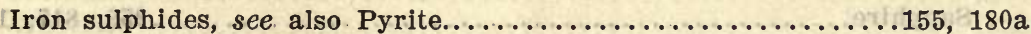

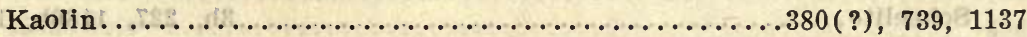

Lead, see also Galena....40,180, 227, 229, 428, 602, 938(?), $1025(?), 1451$

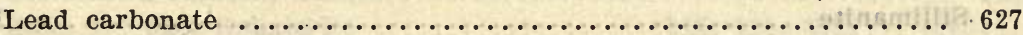

Lead sulphides ................................. 155

Lepidolite..........................227, 593, 1009, 1314

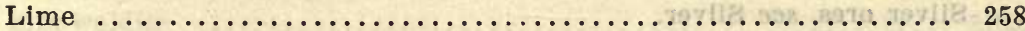

Limonite ............8, 17, 34, 227, 610,613, 615, 621, 627, 643, 1040

Lithla mica ........................542, 554, 573a, 1258(?)

Magnetite..............8, 17, 34, 180a, 227, 428, 604, 859, 955, 1052

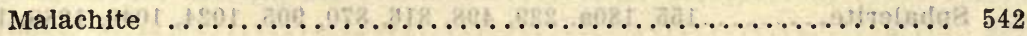

Manganese oxides, see Pyrolusite ...............258, 428, 604 
Association of tin with-Continued.

Reference Number

Manganite 227

Margarite

Mica...245, 350, 380, 498, 505, 542, 554, 573a, 651, 654, 797, 817,

Mispickel, see Arsenopyrite. $1016,1137,1181,1183,1238,1240,1258(?), 1263$

Molybdenite...227, 235a, 428, 523, 530, 573a, 580(?), 586, 604, 797, $927,1024,1147,1148,1183,1183 b$

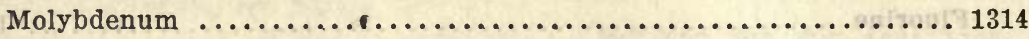

Molybdenum in mineral waters....................... 524

Monazite....3b, 3d, 227, 673, 699, 797, 804, 856, 861a, 891, 903, 1048, $1052,1054,1078 \mathrm{a}, 1158$

Montebrasite 496

Muscovite..................245, 498, 505, 1238 (plumose), 1258

Nickel in mineral waters.......................... 524

Niobic oxide, see Columbium.

Niobium, see Columbium.

Orthoclase

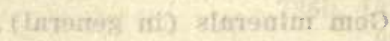

Other minerals...29b, 252, 255, 305, 405, 433, 452, 509, 538, 642, 714, $791,792,797,820,936,976,992,995,996,1000,1017,1083$,

$1184 \mathrm{a}, 1245,1268,1311,1313,1598$

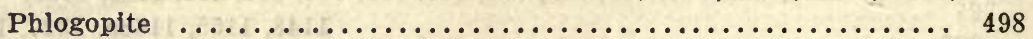

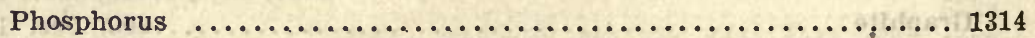

Plagioclase feldspar............................. 245

Platinum.......................... 804, 831, 891, 1327

Pyrite....3b, 8, 17, 34, 158, 172, 180a, 227, 230, 235a, 428, 498, 573a, $604,629,681,797,816,872,1009,1040,1119,1148,1155,1157,1158$,

$1163,1168 \mathrm{a}, 1183$

See also Iron sulphides.

Pyrolusite, see also Manganese oxides..................227, 511

Quartz....3b, 3d, 180a, 207, 227, 230, 234a, 350, 380, 498, 505, 542, $573 \mathrm{a}, 586,651,654,681,726 \mathrm{a}, 797,859,870,904,1073,1137$,

$1148,1156,1158,1240,1258,1294,1314$

Rutile.............................230, 257, 554, 1639

Sapphire............................... 859, 817, 1143

Scheelite.................................. 227, 1186b, 1250

Siderite ..........................180a, 227, 259a, 586

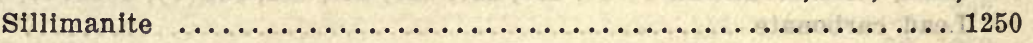

Silver...144, 145, 152, 155, 164, 166, 171, 172, 180a, 184, 225, 235a, 938 (?), 1148, 1168a, 1294

Silver ores, see Silver.

Silver sulphides, see Silver.

" Sparry iron," see Siderite.

setureintia

Specularite, see also Hematite.....................530, 1183b

Sphalerite.......155, 180a, 229, 498, 816, 870, 905, 1024, 1040, 1086, 1155

Spodumene...........................997, 1009, 1148 
Association of tin with-Continued.

Reference Number

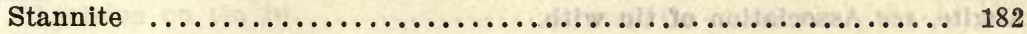

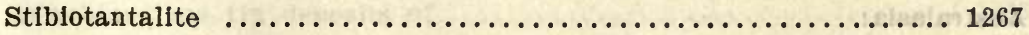

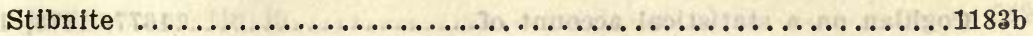

Sulphides..................................166, 1821294

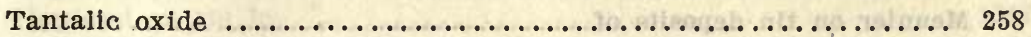

Tantalite ............580( ?), 586, 976, 993, 996, 1009, 1010, 1015, 1017

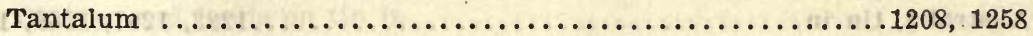

Tantalum in mineral waters........................ 524

Titanite................................ 234, 230, 1257

Titanium, see also Rutile and titanite................... 682

Titanium in mineral waters.......................... 524

Topaz...235a, 259, 498, 542, 573a, 751, 753, 767, 797, 817, 1009, 1010, $1073,1143,1148,1149,1168 \mathrm{a}, 1172,1181,1267,1294,1337$

Tourmaline...:3b, 172, 180a, 207, 227, 235a, 350, 380, 385, 498, 505, $587,591,649,681,726 \mathrm{~b}, 750,792,797,811,817,859,1010,1034$, $1041,1137,1155,1156,1158,1168 \mathrm{a}, 1183,1183 \mathrm{~b}, 1186 \mathrm{~b}, 1238$, $1257,1258,1263,1267,1294,1314,1341$

Tremolite..$\ldots \ldots \ldots \ldots \ldots \ldots \ldots \ldots \ldots \ldots \ldots \ldots \ldots \ldots \ldots \ldots \ldots \ldots$

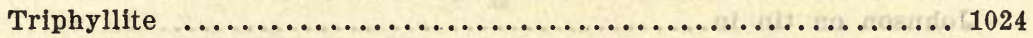

Tripolite ................................... 1024

Tungsten ...............797, 898, 938, 1016, 1095, 1148, 1168a, 1314

See also Hübnerite, scheelite, and wolframite.

Tungsten in mineral waters........................ 524

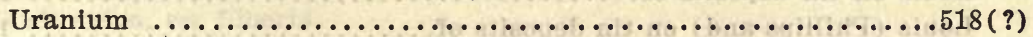

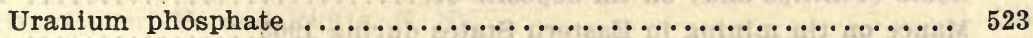

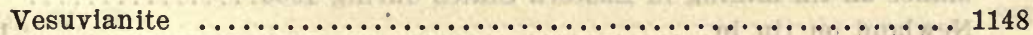

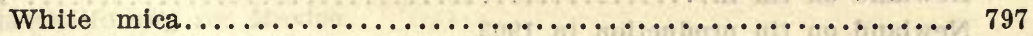

Wolfram, see Wolframite.

Wolframite....3b, 64, 158, 188, 227, 235a, 333, 428, 511, 523, 542, 573a, $604,682,753,792,797,811,816,817,927,943,1009,1010$, $1015,1024,1034,1078 \mathrm{a}, 1155,1172,1183 \mathrm{~b}, 1186 \mathrm{~b}, 1238,1240$, $1250,1258,1294,1662,1664$

Wollastonite ...................................... 1148

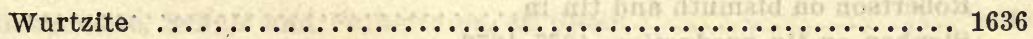

Xenotime $. \ldots \ldots \ldots \ldots \ldots \ldots \ldots \ldots \ldots \ldots \ldots \ldots \ldots \ldots \ldots \ldots \ldots . \ldots \ldots 9 . \ldots \ldots$

Yttrium in mineral waters.......................... 524

Zinc, see also Sphalerite ..............225, 227, 602(?), 1025(?)

Zinc blende, see Sphalerite.

Zinc sulphides, see Sphalerite.

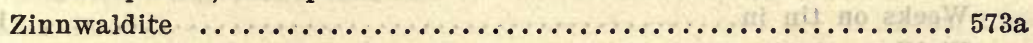

Zircon.....................257, 259, 586, 699, 817, 856, 1267

Zircon in mineral waters......................... 524

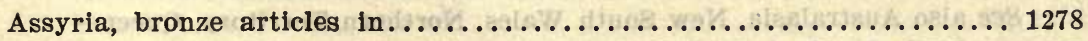

Audibert, $\mathbf{E} . \ldots \ldots \ldots \ldots \ldots \ldots \ldots \ldots \ldots \ldots \ldots \ldots \ldots \ldots \ldots \ldots \ldots \ldots \ldots$

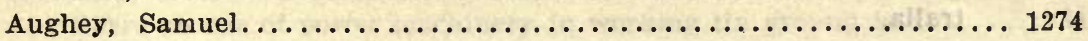


Augite, see Association of tin with.

Australasia:

Coghlan on a statistical account of...............1677, 1678, 1679

Coghlan on tin in the seven colonies of ................. 48

Meunler on tin deposits of.......................... 53

See also Australia.

Australia, tin in ............................ 1223, 1287, 1289, 1298

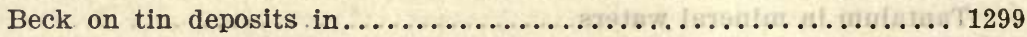

Benedict on correspondence of tin bearing granite in, to that of

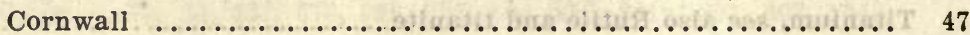

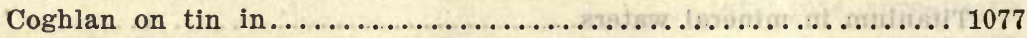

$\mathrm{E}-$ on tin production, $1874-1875 \ldots \ldots \ldots \ldots \ldots \ldots \ldots \ldots . \ldots . \ldots . \ldots$

Earl of Mount Edgcumbe on tin produced in $1883 \ldots \ldots \ldots \ldots \ldots \ldots 1681$

English on Australian and Tasmanian tin................. 50

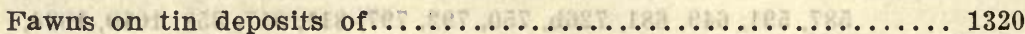

Fuchs and de Launay on tin deposits of .................... 1323

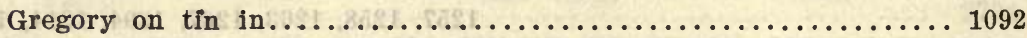

Henwood on association of tin with gold and platinum in........ 1327

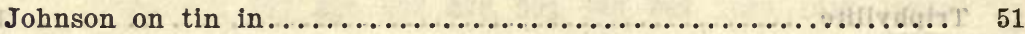

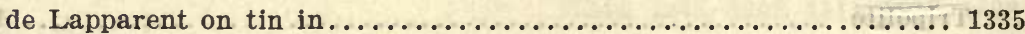

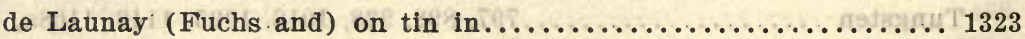

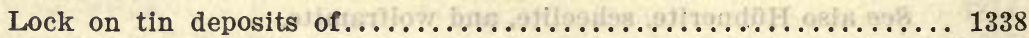

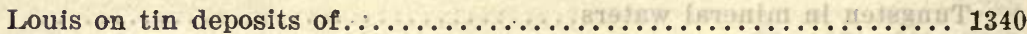

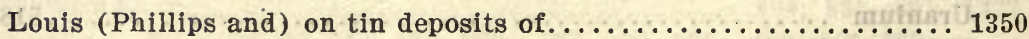

Mance on tin mining in Eastern States during $1905 \ldots \ldots \ldots \ldots \ldots \ldots . \ldots 2$

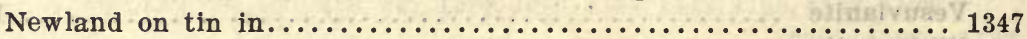

Newland on tin production in $1903 . \ldots \ldots \ldots \ldots \ldots \ldots \ldots \ldots \ldots . . . \ldots 4$

Newton on the metalliferous minerals of, including tin........ 55

Phillips and Louis on tin deposits of.................... 1350

Plummer on tin deposits of......................... 56

Plummer on tin production in 1904 and $1905 \ldots \ldots \ldots \ldots \ldots \ldots \ldots . \ldots . \ldots . \ldots 169$

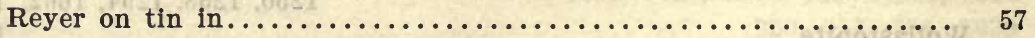

Robertson on bismuth and tin in ...................... 58

Stephen on tin production, $1877-1878 \ldots \ldots \ldots \ldots \ldots \ldots \ldots \ldots \ldots \ldots . \ldots \ldots$

Thibault on metallurgy of tin in...................... 1578

Trasenster on statistics of tin in, $1879-1881 \ldots \ldots \ldots \ldots \ldots \ldots \ldots \ldots \ldots$

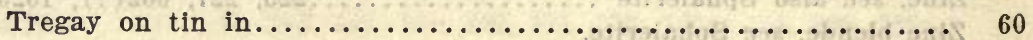

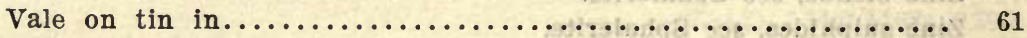

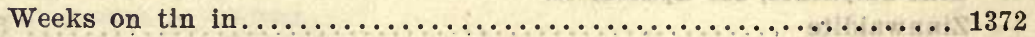

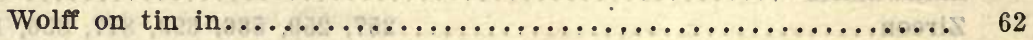

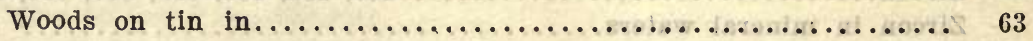

See also Australasia, New South Wales, Northern Territory, Queensland, South Australia, Tasmania, Victoria, and Western Australia. 
Austria:

Charleton on tin in ................................ 1310

D'Achiardi on tin deposits of . . . . . . . . . . . . . . . . . 1313

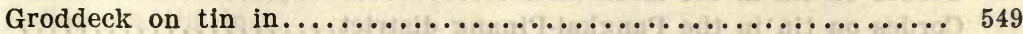

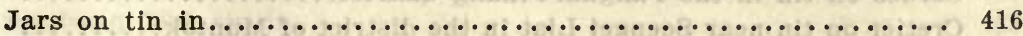

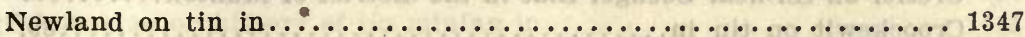

Newland on tin production of . . . . . . . . . . . . . . 70

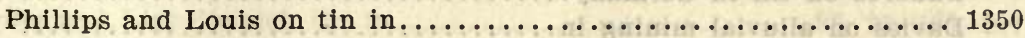

Plants for recovery of scrap tin in ..................... 1438

Schultz on tin in ................................ 573

See also Bohemia.

Autunite, see Association of tin with.

Avicaya mine, see Bolivia.

Axinite, see Association of tin with.

Ayer Dangsang, see Malay Peninsuia.

Ayer Panas, see Malay Peninsula.

Aztecs, tin used for coins by

Babbitt metal, Meade on composition, uses, and analysis of alloys of....1531a

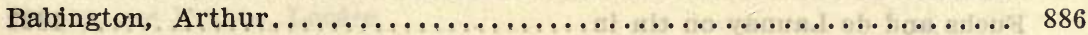
Badger mines, see Tasmania.

Badjerican mine, see New South Wales.

Baikal region, see Siberia.

Bailey, Gilbert E., and Riotte, E. N................... 988

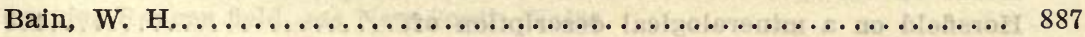

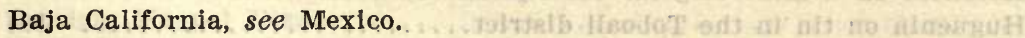

Baldauf, Martin............................... 331

Bald Nob, see New South Wales.

Balfour, John F.............................. 677

Ball, Lionel C..............331a, 331b, 331c, 888, 889, 890, 891, 891a, 891b

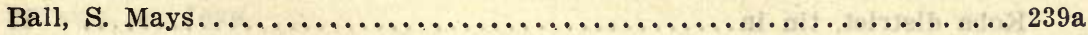

Ball, V............................................ 590

Ballesterosite, Schulz and Paillette on, in Spain.............. 1043

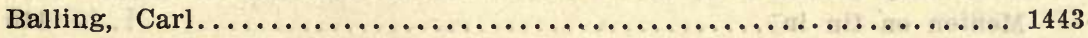

Ballivián, M. V., and Saavedra, Bautista................ 150

Bandon, see Siam.

Banghi, see French Congo, Ubanghi.

Bangtaphan, Langsuan, see Siam.

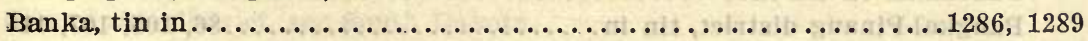

Akkeringa on tin in the Blinjoe district................ 73

Beck on tin deposits of $. \ldots \ldots \ldots \ldots \ldots \ldots \ldots \ldots \ldots \ldots \ldots \ldots \ldots . \ldots \ldots$

Benedict on tin deposits of ......................... 1301

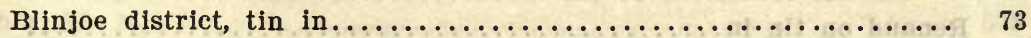

Boers on use of power machinery in working tin ground in..... 84 
Banka-Continued.

Reference Number

Bredemeyer on tin mining in ........................ 85

Cordes on tin in the Koba district..................... 87

Cordes on tin in the Pangkal-Pinang district.............. 86

Cretier on tin near Soengel Liat in the district of Muntok........ 88

Crookkewit on tin in........................... 1473

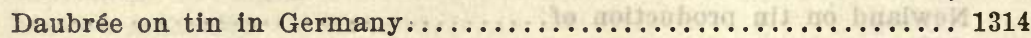

Davies on alluvial mining in ...................... 1317

Diest on tin in ..............................90, 94, 1478

Diest on tin in the Merawang district.................. 92

Diest on tin in the Sambong-Giri...................... 93

Diest on tin in the Soengei Liat district................. 91

Dijk on tin in ................................... 96

Dijk on tin smeiting in ........................... 1480

Djeboes district, tin in ........................... 98

Doorman on tin in the Dutch East Indies................ 286a

Doren on tin in .................................... 97

Earl of Mount Edgcumbe on tin produced in $1883 \ldots \ldots \ldots \ldots \ldots \ldots 1681$

Everwijn on tin in the Djeboes district................. 98

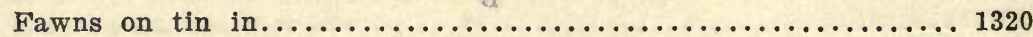

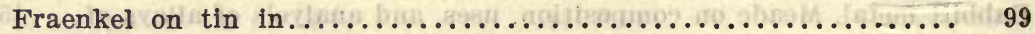

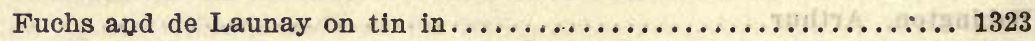

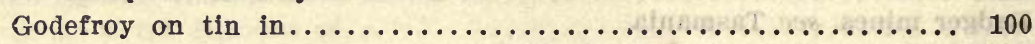

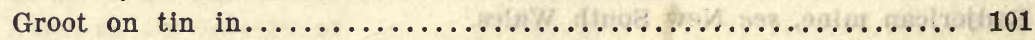

Henwood on association of tin with gold in ............... 1327

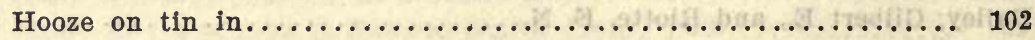

Horsfield on a mineralogical description of . . . . . . . . . . . . . 103

Huguenin on tin in the Toboali district.................. 104

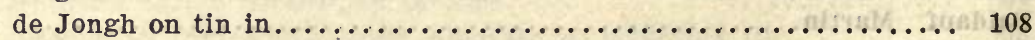

de Jongh on tin in the Merawang district................ 106

de Jongh on tin in the Soengei Liat, Pangkal-Pinang, and Merawang

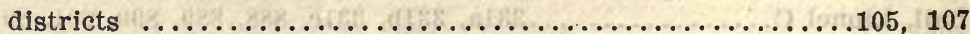

Koba district, $\operatorname{tin}$ in $\ldots \ldots \ldots \ldots \ldots \ldots \ldots \ldots \ldots \ldots \ldots \ldots \ldots \ldots . \ldots . \ldots 7$

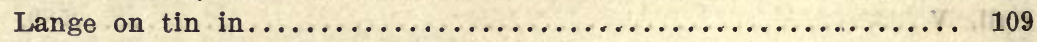

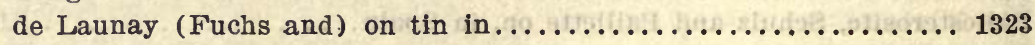

Menten on tin in ................................ 110

Merawang district, tin in ...................... 105, 106, 107

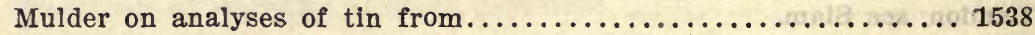

Muntok district, tin near Soengei Liat.................... 88

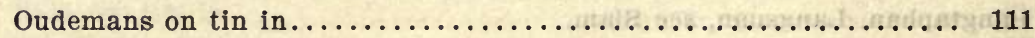

Pangkal-Pinang district, tin in ................. 105, 107, 115

Posewitz on tin in ............................ 112

Raffles on history of production, prices, placers, distribution, and

market conditions of tin in ..................... 113

Renaud on tin in ................................ 116

Renaud on tin in the Pangkal-Pinang district.............. 115

Renaud on tin in the Soengeiselan district.................. 114 
Banka-Continued.

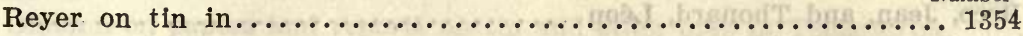

Reyer on tin mining in, writers on, and structure of the island..... 117

Rolker on tin in.............................. 719

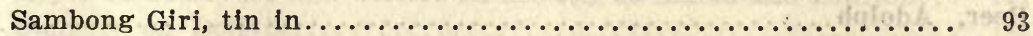

Schuurman on history of tin mining in ................. 1415

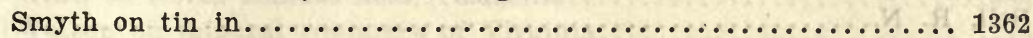

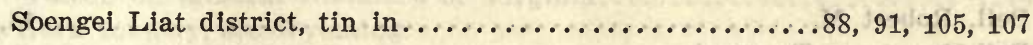

Soengeiselan district, tin in ........................ 114

Toboali district, tin in ............................ 104

Trasenster on statistics of tin in, 1879-1891................. 1700

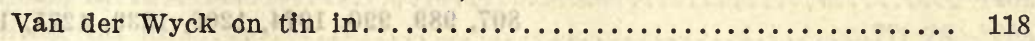

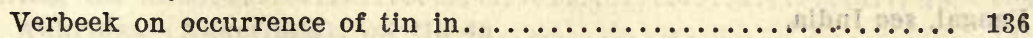

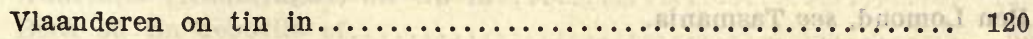

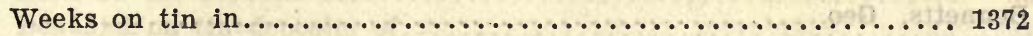

See also East Indies.

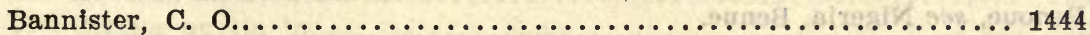

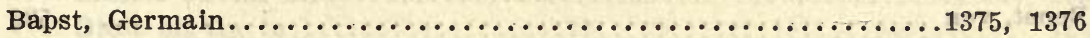

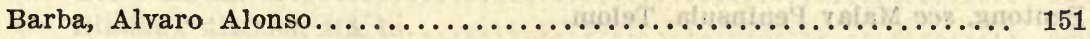

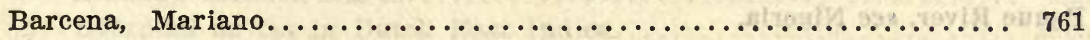

Barite, see Association of tin with. Barjac, see France, Lozére.

Barnett, A. K.................................. 332

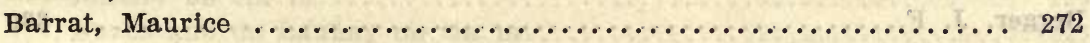

Barren Waters, see Queensland.

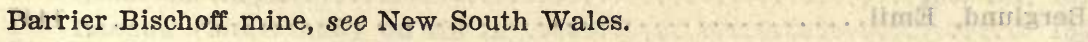

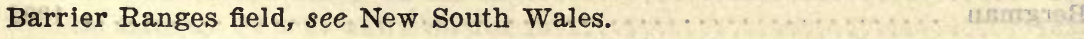

Barriga, Manuel Diaz.............................. 762

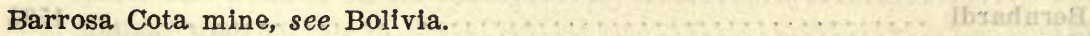

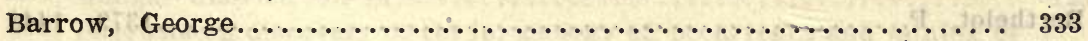

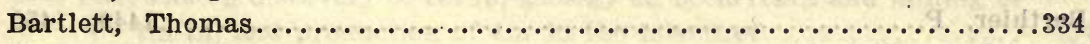

Bastar, see India.

Batavia, see Java.

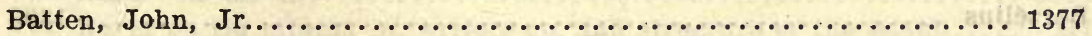

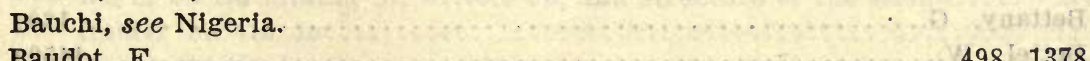

Baudot, F................................ 498,1378

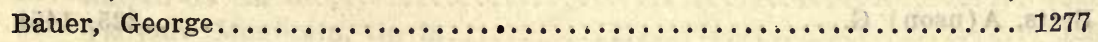

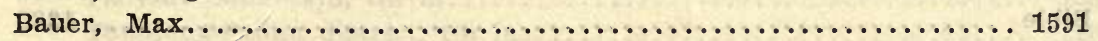

Bautshi tin fields, see Nigeria.

Bawden, S........................................ 335

Bear Gulch district, see South Dakota.

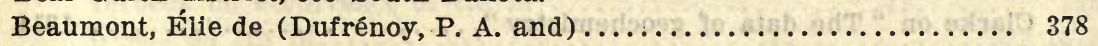

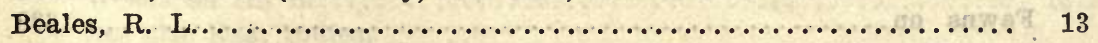

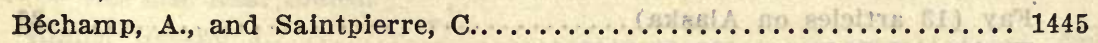

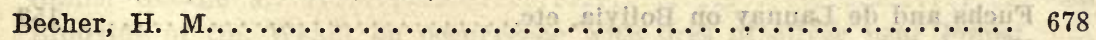

Beck, Richard. ......................1, 82, 529, 530, 531, 1299, 1300

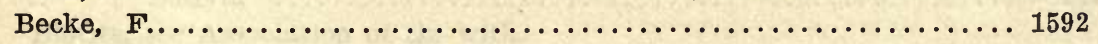




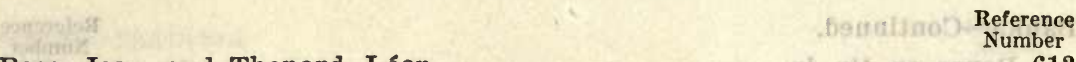

Beco, Jean, and Thonard, Léon.

Beechworth, see Victoria.

Beenah, see Victoria: Gippsland.

Beer, Adolph.................................... 806

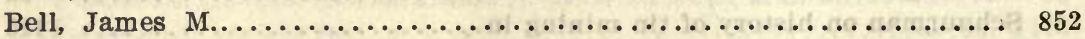

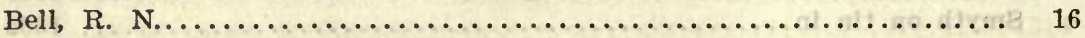

Bell, Robert M................................. 15

Bell Mount, see Tasmania.

Bendemeer, see New South Wales.

Benedict, William de L.....5, 47, 83, 152, 212, 213, 240, 281, 336, 679, 763,

$807,989,990,1074,1200,1239,1275,1301$

Bengal, see India.

Ben Lomond, see Tasmania.

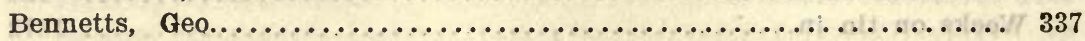

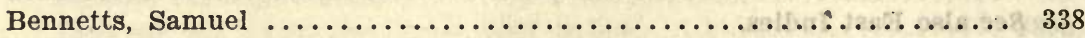

Benoue, see Nigeria, Benue.

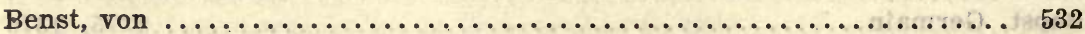

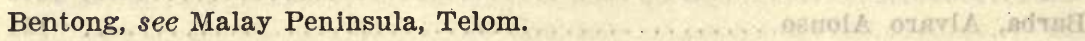

Benue River, see Nigeria.

Berenguela, see Bolivia.

Bergeat, Alfred................................ 613

Bergemann, C................................... 1446

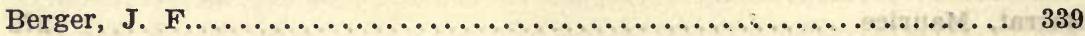

Berggiesshübel, see Saxony.

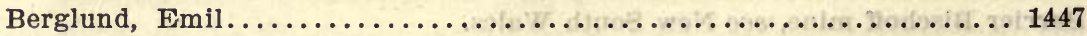

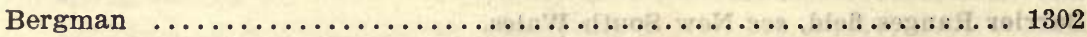

Bergse process for recovering tin from scrap................ 1442

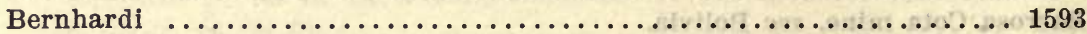

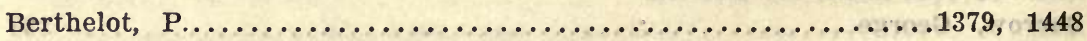

Berthier, P..................................... 14450

Berwick, see Victoria.

Beryl, see Association of tin with.

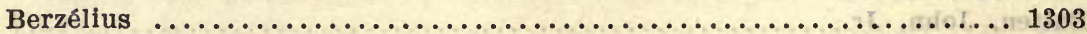

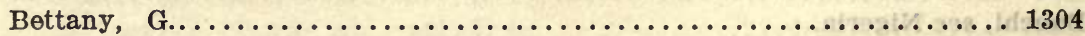

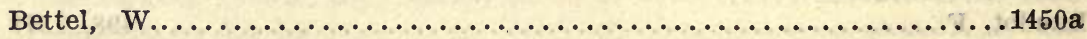

Betts, A (nson) G................................... 1451

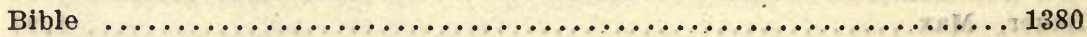

Bibliographies:

Benedict on an epitome of the reports upon the San Jacinto, Cali-

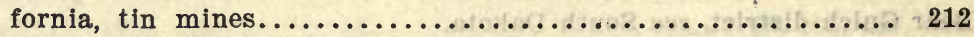

Clarke on "The data of geochemistry" .................. 1311

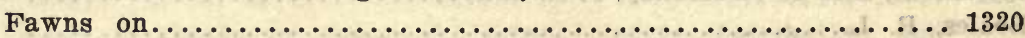

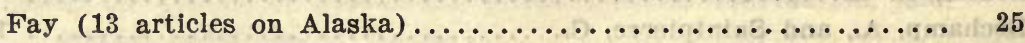

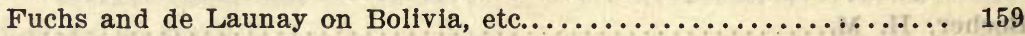

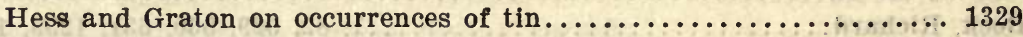


Bibliographies-Continued.

Oldham on papers and reports on tin and other ores in Tenasserim,

Burmah ................................. 198

Reyer on observers and writers on geology of Banka and Billiton... 117

Stelzner on Bolivia................................. 183

Ward on North Dundas field, Tasmania...................1158a

Watson on mineral resources of Virginia.................. 1246

Big Horn country, see Wyoming.

Big Prickly Pear Creek, see Montana.

Bilin, see Bohemia.

Billings, G. H........................................ 1452

Billiton, tin in $\ldots \ldots \ldots \ldots \ldots \ldots \ldots \ldots \ldots \ldots \ldots \ldots \ldots \ldots \ldots \ldots \ldots \ldots \ldots \ldots \ldots \ldots \ldots \ldots \ldots \ldots, 79,126 \mathrm{a}$

Akkringa (Akkeringa), on tin in .................... 121

Beck on tin deposits of ............................ 82

Benedict on tin deposits of ...........................83, 1301

Boeding district, tin in ............................. 123

Cretier on tin in ...................................... 283

Diest on tin in .................................. 128

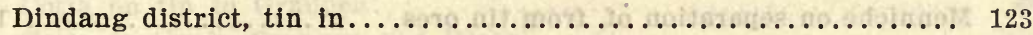

Doorman on tin in Dutch East Indies.................. 286a

Earl of Mount Edgcumbe on tin produced in $1883 \ldots \ldots \ldots \ldots \ldots \ldots . \ldots 161$

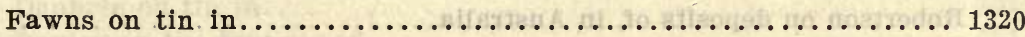

Ferrier on tin in ................................. 129

Fuchs and de Launay on tin in ....................... 1323

Groot on tin in .................................. 131, 132

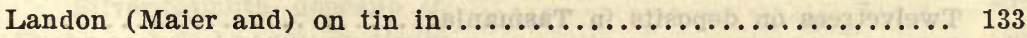

de Launay (Fuchs and) on tin in....................... 1323

Maier and Landon on tin in.......................... 133

Mangar district, tin in ........................... 123

Posewitz on discovery of tin in, geology of, occurrence and mining of

tin in, and production of tin in the island of............ 134

Rant on tin in Tadjouw Mountain....................... 135

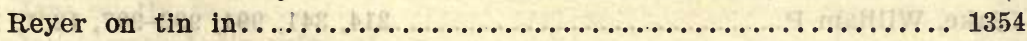

Reyer on tin mining in, writers on, and structure of the island.... 117

Rolker on tin in .............................. 719

Smyth on tin in ................................... 1362

Tadjouw Mountain, th in........................... 135

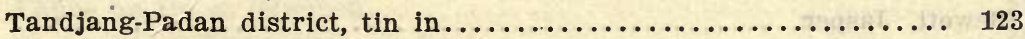

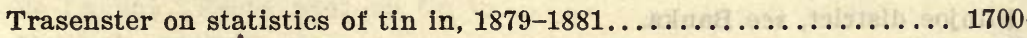

Van der Wyck on tin in ............................. 118

Verbeek on occurrence of tin in ........................ 136

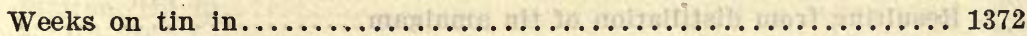

See also East Indles.

Binns, George J................................ 853

Binoxide of tin, Wendt on occurrence with ores of silver near Potosi,

Bolivia .................................... 184

Biotite, see Association of tin with. 
Bischoff (Mount) tin mines, see Tasmania.

Reference

Bishop Creek, see California, Inyo County.

Number

Bitter Root Mountains, see Montana.

Bitter Root Range, see Idaho.

Bismuth:

Alloys with zinc and tin......................... 1587

Andrews on deposits at Kingsgate, New South Wales........... 797

Argentina, Salta............................. 37

Association of tin with....3b, 172, 180a, 225, 227, 573a, 797, 881, 898,

$938,1095,1148,1163 ; 1294$

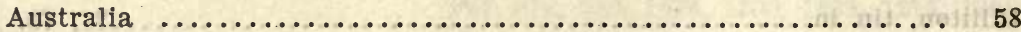

Benedict on occurrence at Chorolque, Bolivia............... 152

Bohemia, Erzgebirge.............................. 578

Bolivia, Chorolque............................... 152

Castro on working of, in Salta, Argentina................ 37

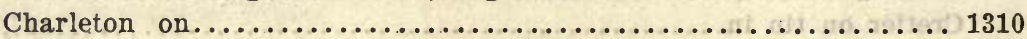

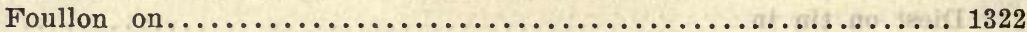

Menniche on separation of, from tin ores................... 1534

New South Wales................................ 797

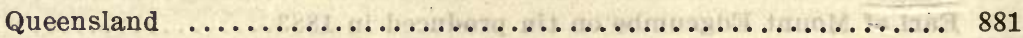

Robertson on deposits of, in Australia................... 58

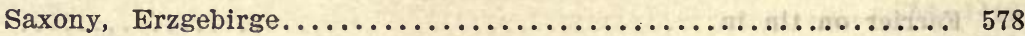

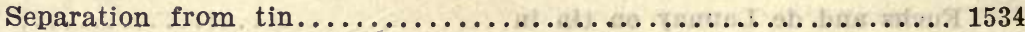

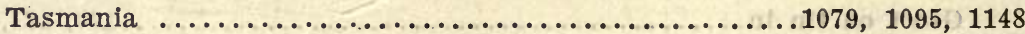

Twelvetrees on deposits in Tasmania.................... 1148

Viebig on deposits of, in the Erzgebirge of Germany........... 578

Bismuthinite, see Association of tin. with.

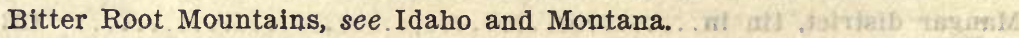

Black, A........................................ 340

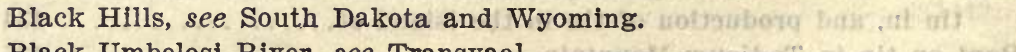

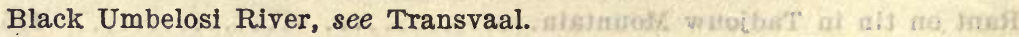

Blake, William P...................214, 341, 991, 992-997, 1201, 1202

Blanchard, Fréd.............................614, 615, 616

Blanford, W. T. (Medlicott, H. B. and) .................... 595

Blavier, Ed., and Lorieux, T........................... 499

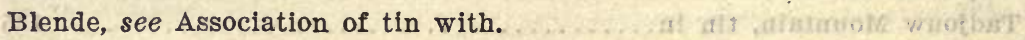

Blewett, Jasper................................. 959

Blinjoe district, see Banka. . 1

Block tin:

Preparation of, in Cornwall and Devon................ 1576

Resulting from distíllation of tin amalgam................ 1556

Blöde, Gottlob von............................... 533

Bloomfield, see Queensland.

Blue Ridge, see Virginla.

Blue Tier, see Tasmania.

Boase, G. C., and Courtney, W. P..................... 342 
Boase, Henry S....................................... 3434

Bob Ingersoll claim, see South Dakota.

Boceheggiano, see Italy, Tuscany.

Bodenmais, see New South Wales, Silberberg.

Bodmin Moor, see Cornwall.

Boeding district, see Billiton.

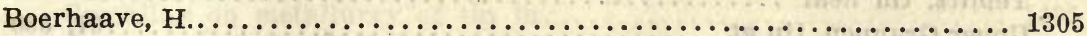

Boers, R. J.................................... 84

Bog, see Cornwall.

Boggild, 0. B.................................. 581

Bohemia:

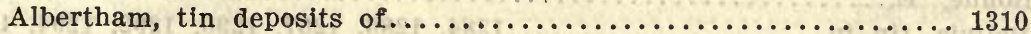

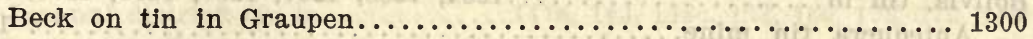

Benst on tin in Schlaggenwald........................ 532

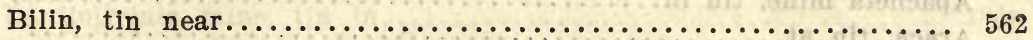

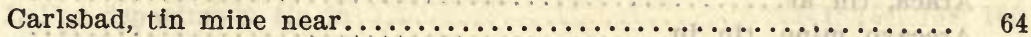

Charleton on tin deposits of Abertham.................. 1310

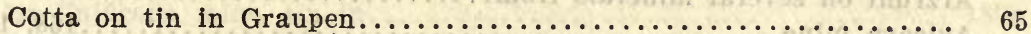

Cotta on tin in Graupen and Poebel.................. 540

Dalmer on the Altenberg-Graupen tin district............. 542

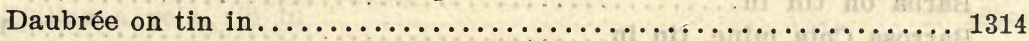

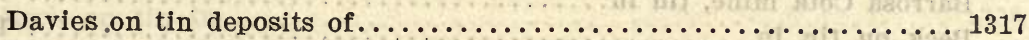

Erzgebirge, discrimination of granites in ............... 564

Origin of tin deposits of . . . . . . . . . . . . . . . .

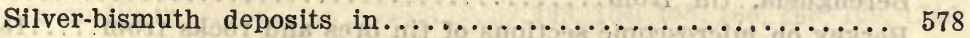

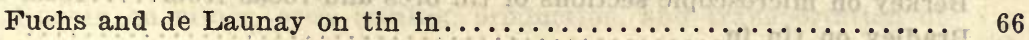

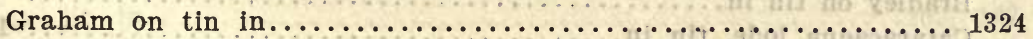

Groddeck on tin in Graupen and Schlaggenwald............ 549

Graupen, tin at. $\ldots \ldots \ldots \ldots .65,67,69,540,542,549,550,562,567,1300$

Graupen, Luxer vein at........................... $573 \mathrm{a}$

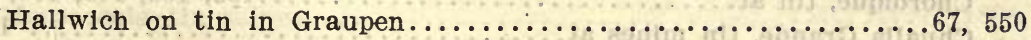

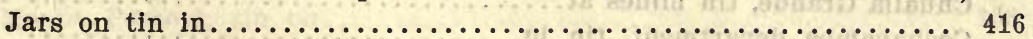

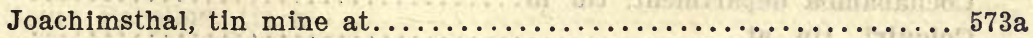

Jokèley on tin "im Leitmeritzer Kreise"................ 68

Karlsbad, geology of ................................ 564

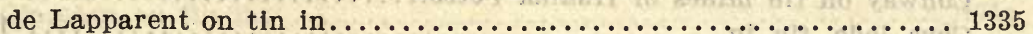

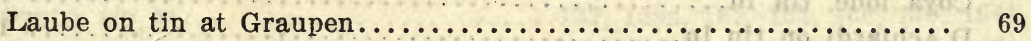

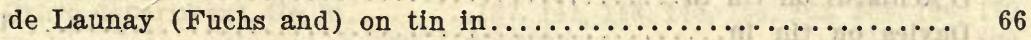

Neudeck, geology of $\ldots \ldots \ldots \ldots \ldots \ldots \ldots \ldots \ldots \ldots \ldots \ldots \ldots \ldots \ldots \ldots$

Nowicki on tin at Schlaggenwald and Schönefeld............ 71

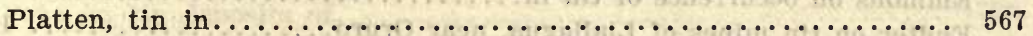

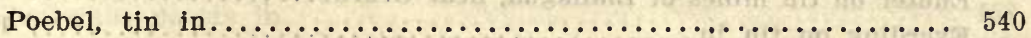

Reuss on tin near Teplitz, Bilin, and Graupen.............. 562

Reyer on discrimination of granites in the Erzgebirge........ 564

Reyer on geology of Neudeck and Karlsbad............... 564

Reyer on tin in Graupen, Platten, and Schlaggenwald......... 567 
Bohemia-Continued.

Reference Number

Reyer on tin mining in ......................565, 566, 567

Rücker on tin in Schlaggenwald..................... 568

Schlaggenwald, tin at................71, 72, 532, 549, 567, 568

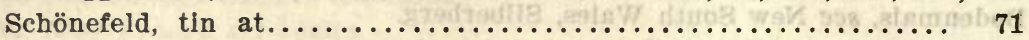

Singewald on tin deposits in the Erzgebirge............... 573a

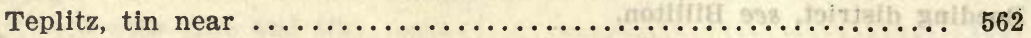

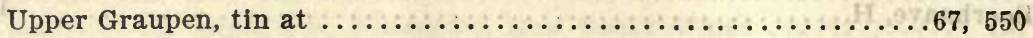

Vogelsang on mining and smelting of tin at Schlaggenwald ....... 72

Woodward on tin ore specimens from................... 489a

See also Austria and Europe.

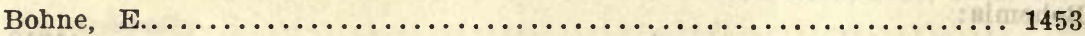

Bolivia, tin in ...............1284, 1286, 1287, 1290, 1292, 1294, 1298

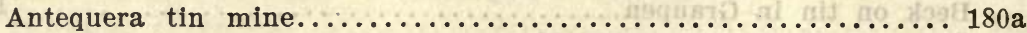

Apacheta mine, tin in................................. 158

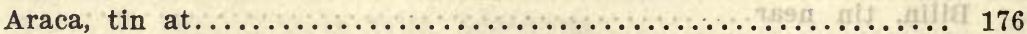

Arecayo mine, tin in ............................... 143

Arzrunt on several minerals from................... 149

Avicaya mine .................................. 180, 18 a

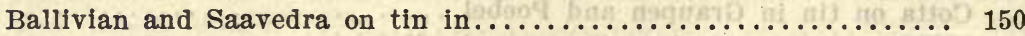

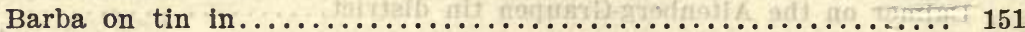

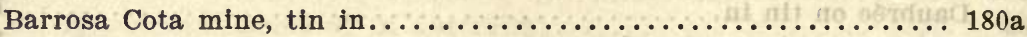

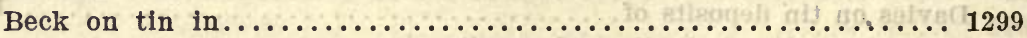

Benedict on tin at Potosi and Chorolque.................. 152

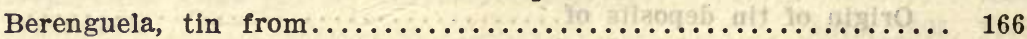

Berkey on microscopic sections of tin ores and rocks from....152a, 180a

Bradley on tin in................................ 153

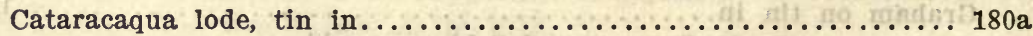

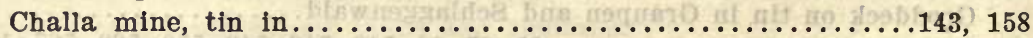

Chocaltaya mine, tin in .............................. 160

Chorolque, tin at. $\ldots \ldots \ldots \ldots \ldots \ldots \ldots \ldots \ldots \ldots \ldots . .152,166,173,178,179$

Chualla Grande, tin mines at......................... 180a

Cochabamba department, tin in ...................... 141

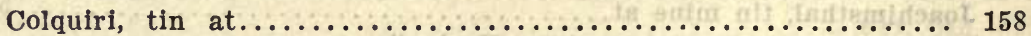

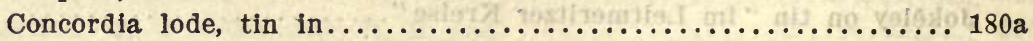

Conway on tin mines of Huaina Potosi.................. 154

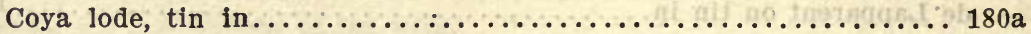

D'Achiardi on tin in ............................. 1313

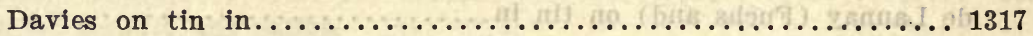

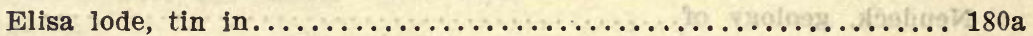

Emmons on occurrence of tin in....................... 155

Endter on tin mines of Llallagua, near Oruro...............155a

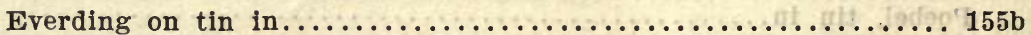

Exportation of tin to United States discussed................ 139

Fawns on tin in....................................... 1320

Forbes on occurrence and kinds of tin ores in.............. 157

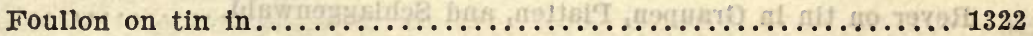


Bolivia-Continued.

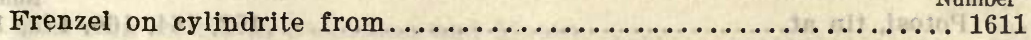

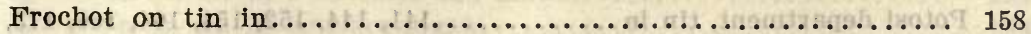

Fuchs and de Launay on tin in............................. 1323

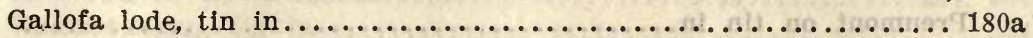

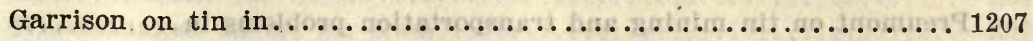

Gautier on deposition of tin near Chorolque............... 160

Gmehling on metallurgy of tin in ...................... 1497

Harrison on tin in .................................... 161

Huaina Potosi, see Juaina Potosi.

Huanuni, see. Juanuni.

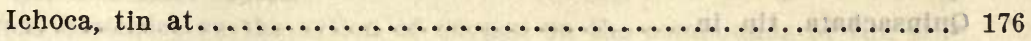

Juaina Potosi, tin mines. of ...................... 158, 176

Juanuni district, tin in...........141a, 143, 148c, 158, 166, 172, 173, 180

La Blanca, tin deposits of .......................... 146

La Bolivinia mine, tin in .................................

LaPaz department, tin in .................... 141, 158, 166

de Launay (Fuchs and) on tin in .......................... 1323

La Unificada mine, tin in .......................... 180a

Light on tin deposits of .......................... 161a

Llallagua, near Oruro, tin mines of ...................... 155a

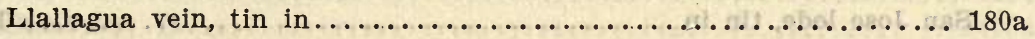

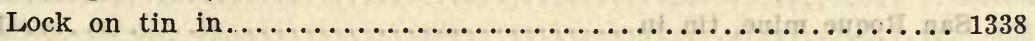

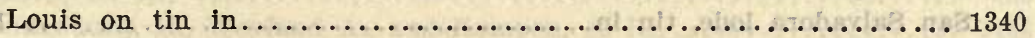

Louis (Phillips and) on tin in ...................... 1350

Minchin on tin in...................163, 164, 165, 166, 168, 169, 1346

Minchin on mines, ores, mining, production, and transportation of

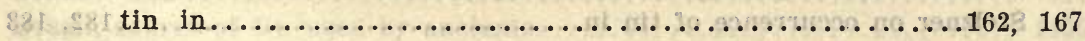

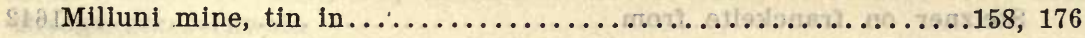

121 Mining and railway development in .................... 147

1.5 Monte Blanco mine............................... 180a

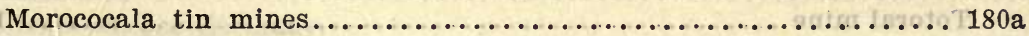

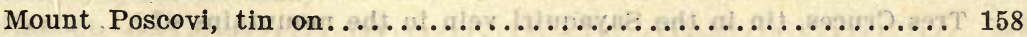

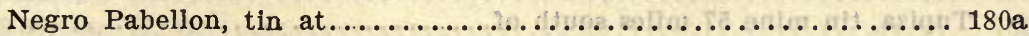

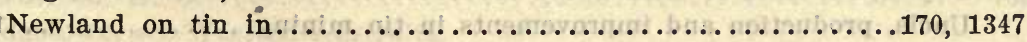

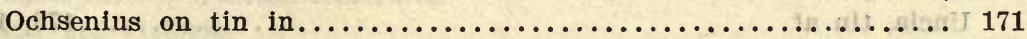

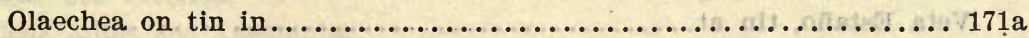

Oruro, tin at.................137, 155a, 162, 164, 166, 170, 1641

Oruro department, tin in.......137, 141, 143, 145, 158, 162, 164, 166, 170

Pasley on tin mines in the East Cordilleras................. 172

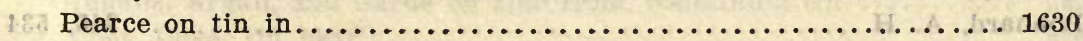

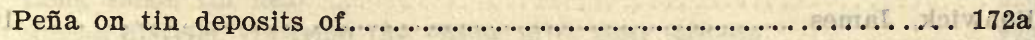

Penberthy on tin in..............................174, 467

Penberthy on tin mines and transportation problems in......... 173

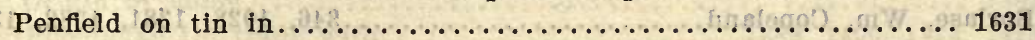

11 Phillips and Louis on tin in............................ 1350

Poopo Lake, tin near.......................... 162 
Bolivia-Continued.

Reference Number

Potosi, tin at..........................152, 164, 166, 173, 1641

Potosi department, tin in..........141, 144, 152, 154, 164, 166, 173, 184

Pozoconi mountain, tin on .......................... 143

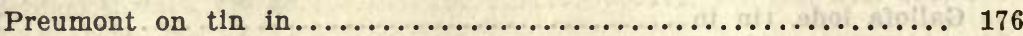

Preumont on tin mining and transportation problems in........ 175

Prices of tin in, affected by quotations on product of Straits

Settlements ............................... 1675

Prior on teallite in ............................. 1636

Punnett on tin deposits of............................ 177

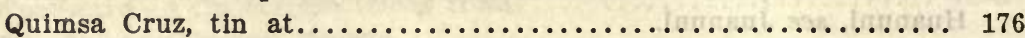

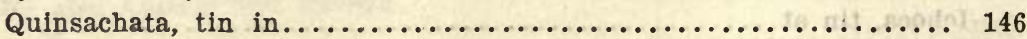

Railway and mining development in..................... 147

Roberts on geology of country near Chorolque, and on the tin mines and alluvial deposits........................... 179

Roberts on tin in the Chorolque district.................. 178

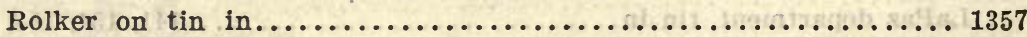

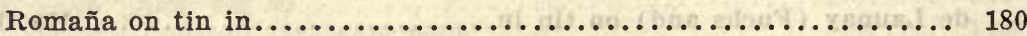

Rumbold on origin of tin deposits in.................. 180a

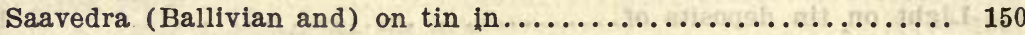

San Jose, tin deposits of.......................... 146

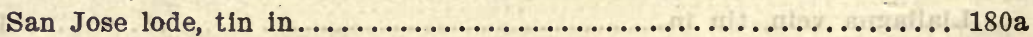

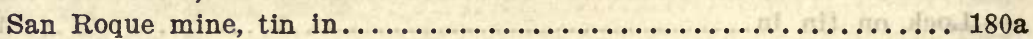

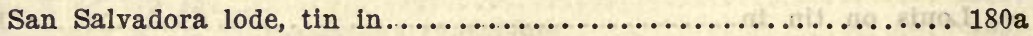

Santa Vela Cruz, tin at............................. 176

Spencer on stannite from Oruro, Potosi, and Tatasi............. 1641

Steinman on the geology of the tin deposits of.............. 181

Stelzner on occurrence of tin in............................ 183

Stelzner on franckeite from ........................ 1642

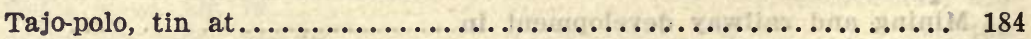

Tatasi, stannite from............................. 1641

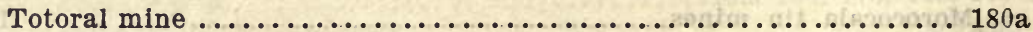

Tres Cruces, tin in the Sayaquiri vein in the mountains of....... 158

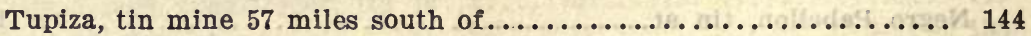

Uncia, production and improvements in tin mining.......... 148c

Uncla, tin at....................................... 180a

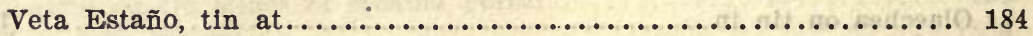

Wendt on tin in Potosi district........................ 184

See also South America.

Bombay, see India.

Bonnard, A. H.................................. 545,54

Bonwick, James ................................... 1075

Borax, Hennecke on occurrence in Persia.................. 864

Borgström, L. H................................ 1594

Borlase, Wm. Copeland..................346, 1028, 1381, 1382, 1383

Borlase, Wm. Copeland, and Rosewarne, H................ 347 
Borneo:

Everwijn on tin in Sukadana and Matan................. 291

Everwyn on tin in Kandawangan....................., 288

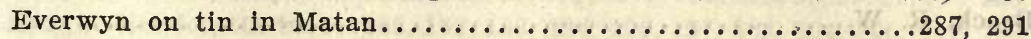

Kandawangan, $\operatorname{tin}$ in $\ldots \ldots \ldots \ldots \ldots \ldots \ldots \ldots \ldots \ldots \ldots \ldots \ldots \ldots \ldots$

Kinebetungen River, tin from ....................... 307

Matam (Matan), tin in ...................................... 291

Posewitz on tin in .................................. 302

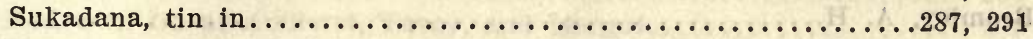

Tenison-Woods on tin from the Kinebetungen River.......... 307 See also East Indies.

Boron, Berthelot on the action of oxygen on the compounds of tin, sili-

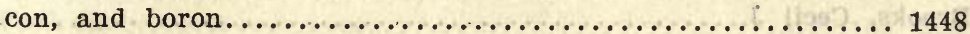

See Association of tin with.

Botallack, see England.

Boucard, A.......................................... 1455

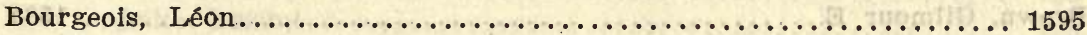

Bourke County, see New South Wales.

Bouse, Johno...................................... 646

Boven Banjoe field, see Sumatra, Palembang.

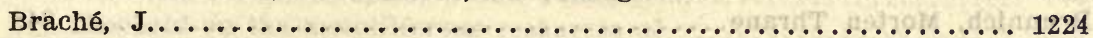

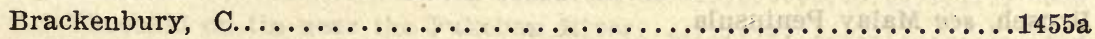

Bradley, D. H., Jr............................. 153

Brandenburg, H., Weyland A., and Kempen, A. R............... 1456

Branner, John C., and Newsom, John F................... 1306

Branxhoim, see Tasmania.

Braun, $\operatorname{Max} . \ldots \ldots \ldots \ldots \ldots \ldots \ldots \ldots \ldots \ldots \ldots \ldots \ldots \ldots \ldots \ldots \ldots \ldots$

Brazil, source of tin used by ancients.............................

Breage, see Cornwall.

Bredemeyer, W................................... 85

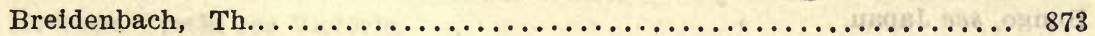

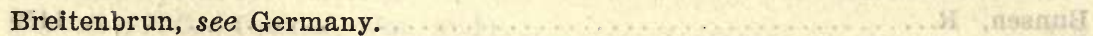

Breithaupt, A................................. 535

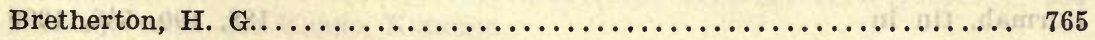

Bridgetown, see. Western Australia.

Bright, see Victoria.

Briseis mine, see Tasmania.

British Columbia, Brock on tin near Long Lake............... 226

Ingalis on tin from the Payne mill, near Sandon, Slocan district.... 229

Ingalis, Argall, and Gardé on zinc from, contalning tin......... 229

Long Lake, $\operatorname{tin}$ near............................... 226

Siocan district, tin from the Payne mill, near Sandon.......... 229

Britain:

Origin of name................................. 1389

Phœnician tin trade with..................1389, 1400, 1414, 1418

Smirke on tin trade between Alexandria and............... 1417

Source of tin used by ancients........................ 1405 
Brittany, see France.

Reference

Reference
Number

Broad Arrow mine, see Alabama.

.

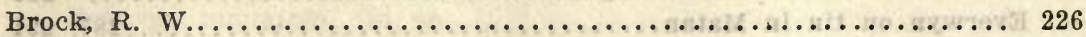

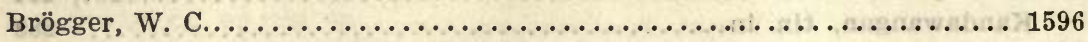

Brögger, W. C. (Kjerulf, Th., and) $\ldots \ldots \ldots \ldots \ldots \ldots \ldots \ldots \ldots \ldots \ldots \ldots$

Broken Head, see New South Wales.

Broken Hill lode, see New South Wales.

Bromley, A. H................................. 766

Bronzes, ductilities of the various bronzes compared............ 1433

Brookite, Daubrée on artificial production of ................. 1601

Brooks, A. H.................................... 18

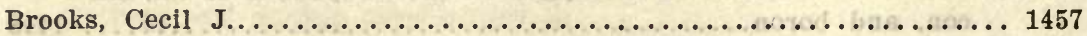

Brookstead tin field, see Tasmania.

Brothers' Home mine, see Tasmania.

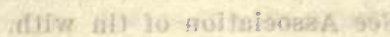

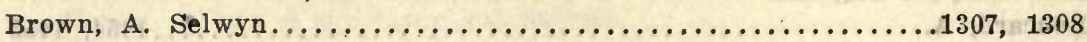

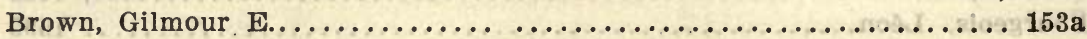

Brown, H. Y. L.................................... 974

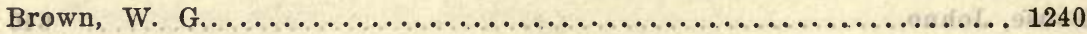

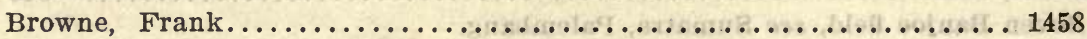

Brunnich, Morten Thrane............................. 348

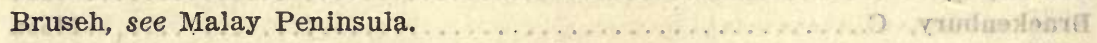

Bruthen, see Victoria.

Buck Creek, see Alaska.

Buddle (Williams) described, etc........................ 1668

Buddling of tin ore in Cornwall........................ 1654, 1656

Buhner Creek, see Alaska.

Bukit, see Malay Peninsula, Telom.

Buller, John....................................... 349

Bunde, see Malay Peninsula.

Bungo, see Japan.

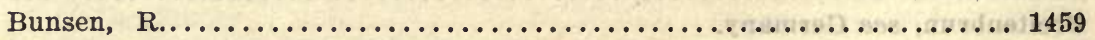

Bunter pebble bed, cassiterite in, in west of England............. 468

Burmah, tin in $\ldots \ldots \ldots \ldots \ldots \ldots \ldots \ldots \ldots \ldots \ldots \ldots \ldots \ldots \ldots .188,190,588,1290$

Amherst, tin at................................ 597

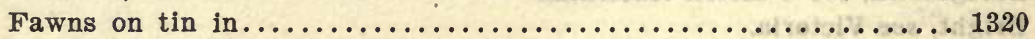

Foss on tin and gold in Lower Burmah................. 188

Fryar on tin in ................................... 189

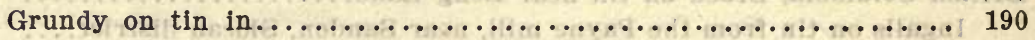

Helfer on tin and iron in Tenasserim district.............. 191

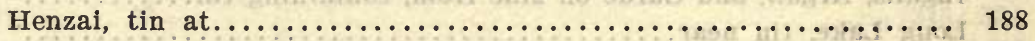

Holland on tin in Tenasserim district................. 192

Hughes on tin in the Mergui district..................193, 194

King on tin in the Tenasserim district................. 195 .

Lemon and Tremenheere on tin in Mergui and Tenasserim....... 196

Lock on tin in Mergui and Tenasserim................. 197

Maliwan, tin in .............185, 187, 197, 201, 202, 205, 207, 590 
Burmah-Continued.

Reference Number

Medlicott on tin in Tenasserim ....................... 595

Mergui district, mines in listed....................... 193

Mergui district, tin in....185, 188, 193, 194, 196, 197, 203, 204, 206, 597, 739

Oldham on coal fields and tinstone deposits in Tenasserim....... 199

Oldham on tin in the Tenasserim district...............198, 199

Reyer on tin in ................................... 1354

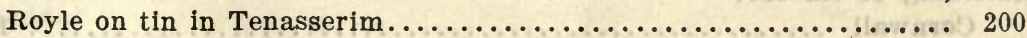

Rudra on tin at Amherst, Tavoy, and Mergui.............. 597

Snow on tin at Maliwun.......................... 201

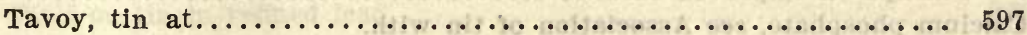

Tenasserim district:

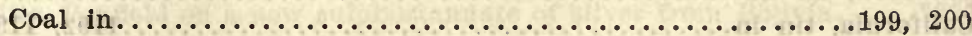

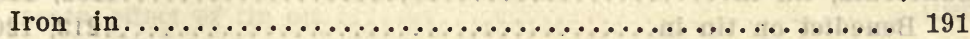

Tin in $. . .191,192,195,196,197,198,199,200,205,589,590,595,744$

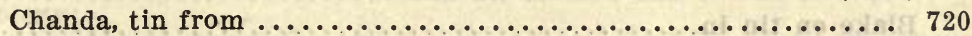

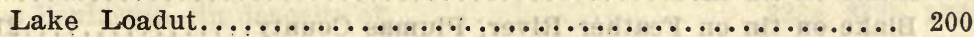

Pakchan River ................................ 202, 205

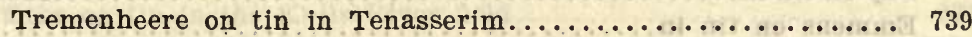

Wray on tin in Malacca and Tenasserim............... 744

Theobald on the metalliferous resources of ............... 202

Theobald on tin near the Pakchan River.................. 202

Tremenheere on tin in the Mergui district............203, 204, 206

Tremenheere on tin in the Tenasserim provinces............. 205

Tremenheere (Lemon and) on tin in Mergui and Tenasserim...... 196

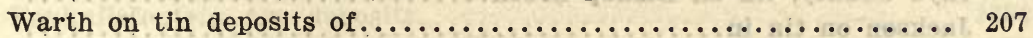

See also Malay Peninsula and Asia.

Burnard, Robert ................................. 1384

Burnet County, see Texas.

Burra Burra district, sce New South Wales.

Burrowa Creek, see Victoria.

Burrows, J. C. (Thomas, Wm., and) ................... 475

Burthe, M. P. L............................... 500

Busanga mine, see Kongo, Katanga.

Bushveld, see Transvaal.

Business methods, Taylor on, in mines of Cornwall and Devon........ 1663

Buttgenbach, H..........................273, 274, 275

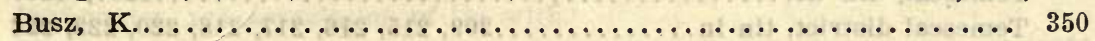

Cacária, see Mexico, Durango.

Cáceres, see Spain.

Cadiz, see Spain. (Gades In Latin.)

Cadmium, Wells on separation of copper from ................ 1583

See Association of tin with.

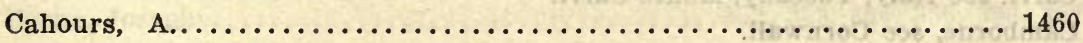

Cahours, A. (Jolyet, F., and) ...................... 1508 


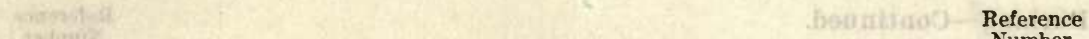
Cahours, A., and Demarçay, E............................... 1461, 1462

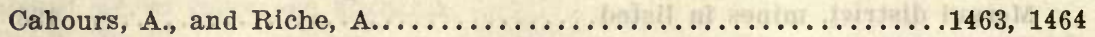

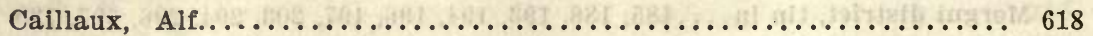
Cajatambo, see Peru.

Calcifer, see Queensland.

Calcining of tin ore:

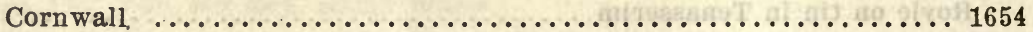

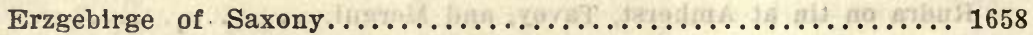

Phillips on improved furnace for ..................... 1661

Calcium phosphate, see Association of tin with.

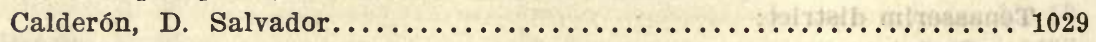

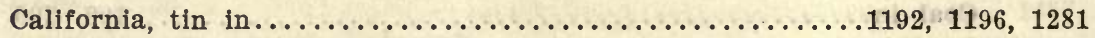

Benedict on tin in ..........................213, 1200, 1301

Benedict on the San Jacinto tin mines.................... 212

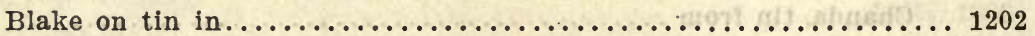

Blake on tin on Feather River, Plumas County............214, 1201

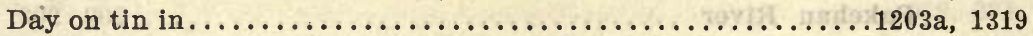

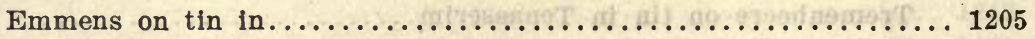

Fairbanks on geology of Temescal district, and the occurrence of the system of tin veins........................215, 216

Garrison on the Temescal tin mine...................217, 1207

Hanks on tin in San Bernardino County.................. 1394

Hanks on the Temescal mines........................ 218

Inyo County, tin on Bishop Creek.................... 211

Jackson on tin in ............................... 219

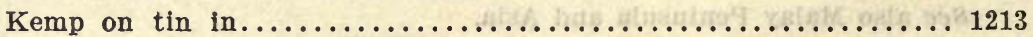

Knight on the Temescal mines (San Jacinto) ............... 220

Los Angeles, tin, gold, and silver near................. 208

Ohly on tin at Temescal........................... 1215

Plumas County, tin on middle fork of Feather River........214, 1201

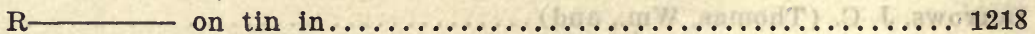

Roessler on tin near San Jacinto...................... 221

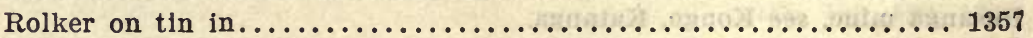

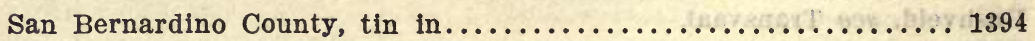

San Jacinto mines, tin in ................... 210, 212, 220, 221

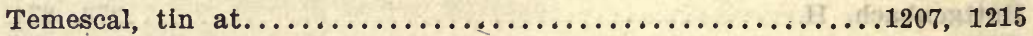

Temescal district, tin in ..........209, 215, 216, 217, 218, 220, 222, 223

West on the Temescal tin mines....................... 222

Whitney on tin in the Temescal district................. 223

See also United States.

California Creek, see Queensland.

Calorla mine, see New South Wales.

Calvert, Albert F................................ 1030

Calvi, see Italy, Tuscany, Monte Calvi.

Camborne, see Cornwall.

Cambrian pegmatitic granite, cassiterite in ................. 1010 
Cameron, Walter E................................ $892-896$

Campagne, Emile Mathieu............................. 1309

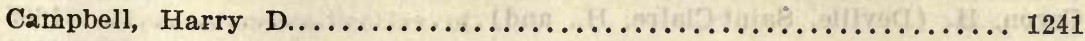

Campiglia, see Italy, Tuscany.

Campiglia Marittima, see Italy, Tuscany.

Campo Alle Buche, see Italy, Tuscany.

Canada:

Betts on tin in refined lead......................... 225

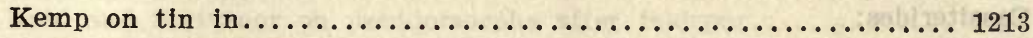

Wolf on tin in refined lead......................... 231

See also British Columbia, Greenland, Nova Scotia, Quebec, Yukon.

Canfieldite, Penfield on a new sulphostannate of silver from Bolivia.... 1631

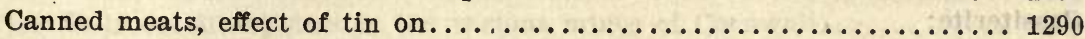

Cao-Bang, see China, Yunnan.

Cape Colony:

Cape Peninsula, tin deposits of.................233a, 233b, 233c

Griffiths on new method of concentrating alluvial tin at Kuils River, 234a

Griffiths on tin in the Kulls River field................... 234

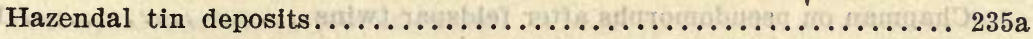

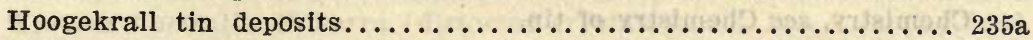

Johnson on tin at Welbeloond and Langerwacht.............. 2 a

Keyzer on tin between the Kulls River and Stellenbosch......... 235

Kuils River tin field.......3b, 233, 233a, 233c, 234, 234a, 235, 235a, 1047

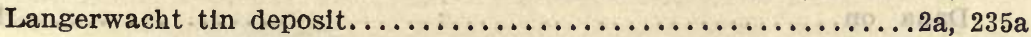

Papkuilsfontein tin deposits....................... 235a

Rumbold on Kuils River tin deposits.................... $3 \mathrm{~b}$

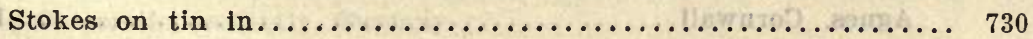

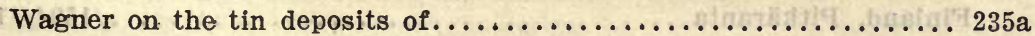

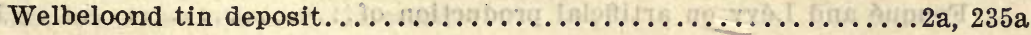

See also Africa and South Africa.

Cape Mountain, see Alaska.

Cape Nome, see Alaska.

Cape Prince of Wales, see Alaska.

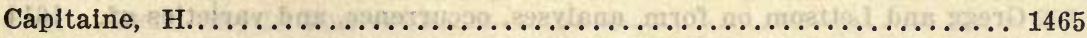

Capron Springs, see Virginla.

Caradon, see Cornwall.

Carbonates, see Association of tin with.

Carcanagues

Carclaze mine, see Cornwall.

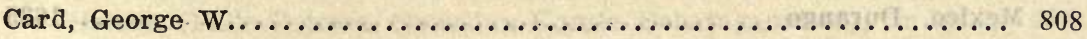

Carew, Richard.................................. 351

Carlsbad, see Bohemia.

Carn Brea mine, see Cornwall.

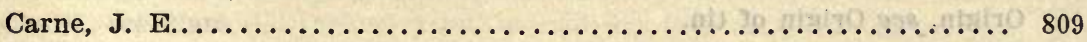

Carne, Joseph ................................. 353, 354, 355, 356, 357

Carnon, see Cornwall. 
Reference Number

Carollnas, Struthers and Pratt on tin in.................... 1220

See North and South Carolina, and United States.

Caron, H. (Deville, Saint-Claire, H., and) ................ 1605

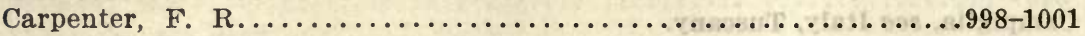

Carpenter, F. R., and Headden, W. P.................... 1466

Cartagena, see Spain.

Carter, A. Cecil. 960

Carthagene, see Spain.

Cassiterides:

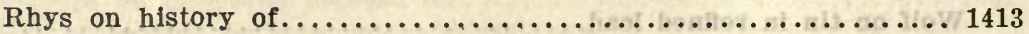

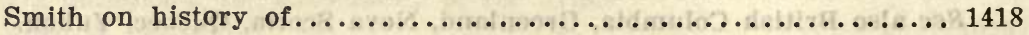

Cassiteris, Plinius on tin from island called................ 1408 Cassiterite:

Artificial production of $\ldots \ldots \ldots \ldots \ldots \ldots \ldots \ldots \ldots 1311,1602,1610,1648$

Arzruni on cassiterite as a furnace product............... 1590

Borgström on cassiterite from Pitkäranta, Finland............ 1594

Bourgeois on occurrence and formation of ................ 1595

Carne on pseudomorphs after feldspar and quartz............ 357

Chapman on pseudomorphs after feldspar twins.............. 1597

Chemistry, see Chemistry of tin.

Clarke on artificial production of.$\ldots \ldots \ldots \ldots \ldots \ldots \ldots \ldots \ldots \ldots \ldots \ldots \ldots 131$

Crystallization, see Crystallization of tin.

Cornwall .................................. 1617,1640

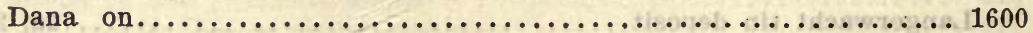

Daubrée on artificial production of ..................... 1602

Davey on pseudomorphs after feldspar in Huel Coates mine, St.

Agnes, Cornwall.............................1603

Finland, Pitkäranta................................ 1612

Fouqué and Lévy on artificial production of .............. 1610

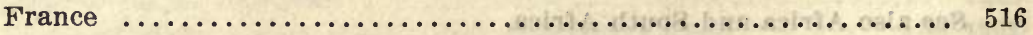

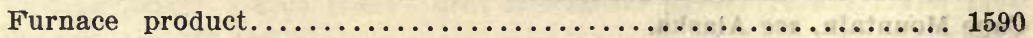

Gadolin on cassiterite crystals from Pitkäranta, Finland........ 1612

Genth on pseudomorphs after hematite................ 771

Gregg and Lettsom on form, analyses, occurrence, and varieties of.. 1614

Headden on, in an old Cornwall furnace................. 1617

Irving on occurrence and association at Nigger Hill, Black Hills,

South Dakota ............................. 1010

Kohlman on measurements of crystals of ................ 1624

Lacroix on distorted crystals from France................ 516

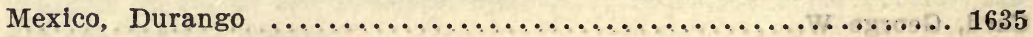

Mineralogy, see Mineralogy of tin.

Molengraaff on distorted crystals from Swaziland............. 1052

Occurrence, see Occurrence of tin.

Origin, see Origin of tin.

Pearce on pseudomorphs of, after sulpho-stannites.............1630

Petterd on varieties in Tasmania......................118, 1121 
Cassiterite-Continued.

Phillips on cleaving cassiterite crystals so that the angles may be

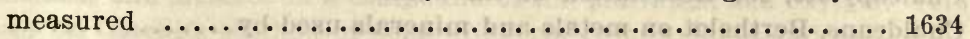

Phillips on crystallization of ...................... 1633

Phillips on pseudomorphs after orthoclase................ 1632

Pilz on cassiterite secondary after stannite.

Pirsson on hematite enclosing cassiterite at Durango, Mexico..... 1635

Pseudomorphs...357, 478, 479, 771, 1078a, 1149, 1597, 1603, 1616, $1630,1632,1638$

Reid and Scrivenor on pseudomorphs after feldspar..........1638

Replacing tourmaline which had replaced feldspar in Tasmania....1078a

Rosenbusch on association with rutile as rock making mineral in the

granite of Greifenstein........................ 1639

Solly on tin crystals in the various mines of Cornwall......... 1640

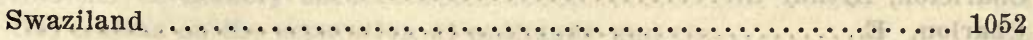

Tasmania ......................... 1078a, 1118, 1121, 1149

Tweedy on pseudomorphs after feldspar...............478, 479

Twelvetrees and Petterd on feldspar and quartz replaced by, at Mt.

Bischoff, Tasmania ........................... 1149

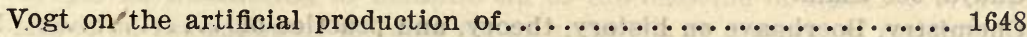

Western Australia, Pilbarra (distorted crystals) .............. 1649

Woolnough on distorted crystals from Pilbarra, Western Australia.. 1649

Castro, Mariano Salas................................ 37

Cataracagua lode, see Bolivia.

Celebes:

Koperberg on tin in Menado.

See also East Indies.

Cento Camerelle, see Italy, Tuscany.

Central Asia, see Asia.

Cerium, see Association of tin with.

Cerro de Iglesia de los Remedios, see Mexico, Durango.

Ceylon:

Coomaraswamy on tin from Niriella, near Ratnapura........255, 256

Coomaraswamy and Parsons on tin at Niriella, Induwehena, near

Dela, and in Kuruwita........................ 257

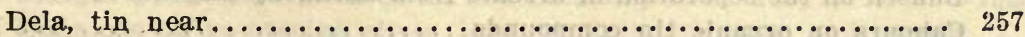

Dunstan on tin at Niriella......................... 258

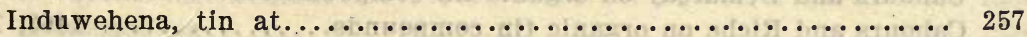

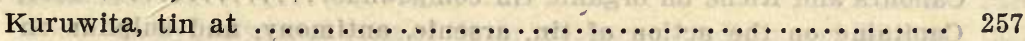

Niriella, near Ratnapura, tin from............... 255, 257, 258

Niriella (Palle Patuwa, Nowadun Korale, Sabaragamuwa), tin at... 256

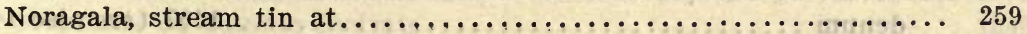

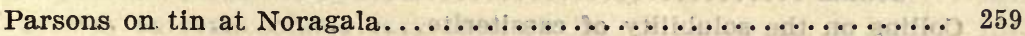

Parsons (Coomaraswamy and) on tin in ................ 257

Chaija, see Siam.

Chalcedony, see Association of tin with.

Chalcocite, see Association of tin with. 
Chalcopyrite, see Association of tin with.

Chaldeans, Berthelot on metals and minerals used by ............. 1379

Challa mine, see Bolivia.

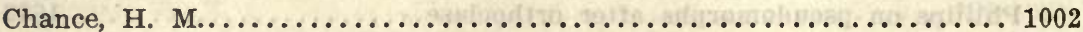

Chanda, see Burmah, Tennaserim.

Chandler, C. F................................... 767

\section{Changkat Pari, see Malay Peninsula.}

Chanteloube, see France.

Chaplin, G. P.................................... 358

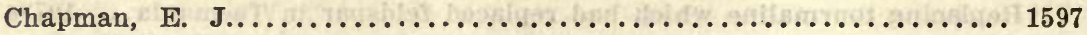

Charcoal crucibles, assays of tin in........................ 1513

Charente, see France.

Charleton, Arthur G.............................. 1310

Charlon, E.................................... 619

Charpentier, J. F. W............................. 536

Chasewater, see Cornwall.

Chauvenet, Regis.................................1164a

Chaya, see Siam.

Chemistry, Boerhaave on history, theory, and practice of.......... 1305

Chemistry of tin:

Allen on metastannic acid and stannic sulphate............. 1430

Analysis...................1446, 1515, 1531, 1538, 1539, 1583, 1616 See also Analyses of tin.

Béchamp and Saintpierre on separation of gold and platinum from

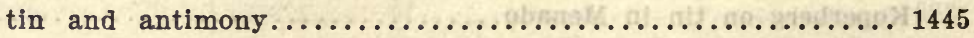

Bergemann on analysis of tin from Xeres, Mexico............ 1446

Berglund on the qualitative separation of tin, antimony, and arsenic, 1447 Berthelot on the action of oxygen on the compounds of tin, silicon,

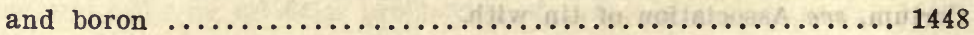

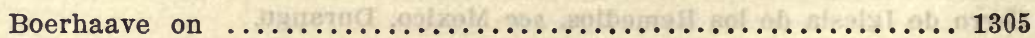

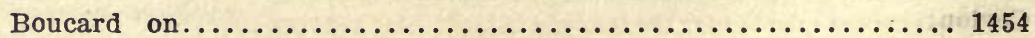

Boucard on separation of gold and platinum from tin and antimony, 1455 Brooks on the quantitative estimation of tin.............. 1457 Bunsen on the separation of arsenic from antimony and tin...... 1459

Cahours on organic tin compounds.................... 1460

Cahours and Demarçay on organic tin compounds..........1461, 1462

Cahours and Riche on organic tin compounds........... 1463, 1464

Capitaine on the action of tin, arsenic, antimony, and sulphur on the chlorides of mercury......................... 1465

Clarke on the separation of tin from arsenic, antimony, and molyb-

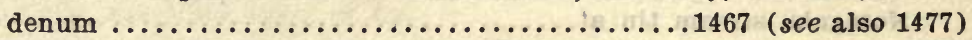

Collins on the solubility of cassiterite...................... 1469

Cramer on precipitation of silver out of tin................ 1472

de Koninch and Lecrenier on the qualitative separation of gold and platinum from arsenic, antimony, and tin............ 1474 
Chemistry of tin-Continued.

Delachanal and Mermet on a compound of tin, platinum, and oxygen. 1475

Dewey on Clarke's method of separating tin from arsenic and ant1-

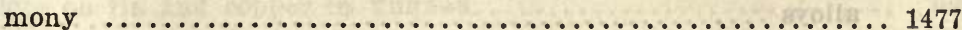

Dykes on analyses of slags......................... 1483

Elsner on separation of arsenic and tin................. 1485

Elsner on separation of gold and platinum from tin and arsenic... 1486

Engel on the action of tin nitrate upon tin................. 1488

Engel on stannic acid........................... 1487

Estimation.......................1457, 1491, 1493, 1574, 1585

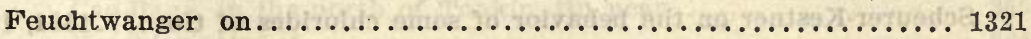

Fraenkel and Fasal on estimation of tin in salts of tin.......... 1493

Frangken on the determination of tin................... 1491

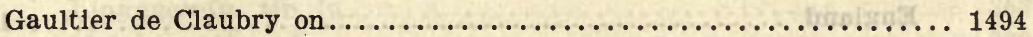

Gay-Lussac on the separation of antimony and tin............ 1495

Gerardin on the blchloride of tin as a solvent.............. 1496

Granger on a crystallized sulphophosphide of tin............. 1613

Greg and Lettsom on analyses of cassiterite.............. 1614

Gregor on weathering of metallic tin to the chloride of tin...... 1498

Hayes on the action of metallic tin on solutions of muriate of tin... 1501

Headden on analyses of stannite and its alteration products...... 1616

Henz on separation of antimony and $\operatorname{tin} \ldots \ldots \ldots \ldots \ldots \ldots \ldots \ldots \ldots . \ldots \ldots$

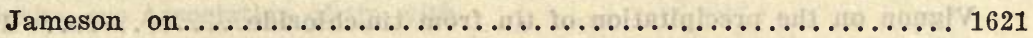

Jolyet and Cahours on the physiologic action of stannethyl and

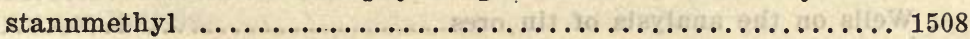

Kenngott on the alkaline reactions of several minerals.......... 1509

Kersten on tin at Altenberg and in Peru................... 1512

Klaproth on chemical examination of oxide and sulphuret of tin... 1513

Lampadius on analyzing the minerals of tin............... 1515

Levol on the quantitative separation of tin and antimony........ 1519

Lewy on some new combinations of the perchloride of tin....... 1522

Lowig on new organic radicals containing tin.............. 1528

Mallett on analysis of tin pyrites....................... 1531

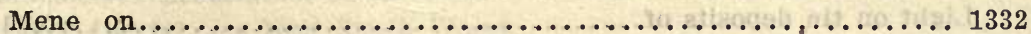

Mengin on the separation of tin and antimony in an alloy........ 1533

Menniche on recovering silver, lead, bismuth, tungsten, and copper

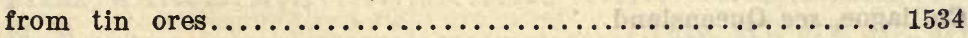

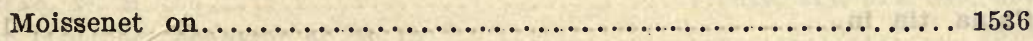

Moody on hydrolysis of salts of tin in presence of iodides and iodates. 1537

Mulder on analyses of Banka tin....................... 1538

Muller on the analysis of tin ores.................... 1539

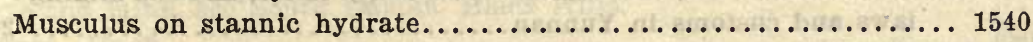

Ordway on some soluble basic salts of tin................. 1543

Pearce on application of chemistry to dressing of tin ores....... 1546

Personne on the combinations of iodine and tin............. 1550

Plattner on alloys of lead with tin and antimony............. 1552 
Chemistry of tin-Continued.

Reference Number

Rawson on the qualitative separation of arsenic, antimony, and tin.. 1553 Rieffel on chemical combinations of copper and tin, and on their

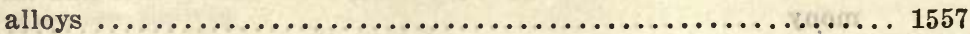

Rose on the quantitative separation of tin, arsenic, and antimony... 1559 Rose on the separation of tin and antimony............... 1558

Salet on the spectrum of tin....................... 1561

Sandall on preparing the protoxide of tin................ 1563

Scheurer-Kestner on the action of oxygen on the protochloride of tin and on the combination of tin with permanganate of potassium .. 1565

Scheurer-Kestner on the behavior of some chlorides of tin.....1564, 1565 Schunck, Smith, and Roscoe on manufacture of tin chloride com. pounds and stannate of soda in the South Lancashire district,

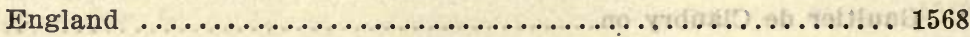
Separation....1445, 1447, 1455, 1459, 1467, 1472, 1474, 1477, 1485, 1486, $1495,1503,1519,1533,1534,1553,1558,1559,1572,1575,1581,1585$

Slagle on the double halldes of tin with aniline and the toluidines.. 1569 Smith (J. L.) on the separation of tin and antimony............ 1572 Streng on a microscopical-chemical reaction for the testing of tin... 1574 Talbott on the quantitative separation of tin and tungsten....... 1575 Thomas on the action of the peroxide of nitrogen on the halogen

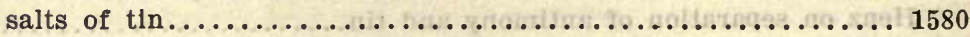

Vignon on the precipitation of tin from tin-chloride........... 1581 Vignon on the easy oxidation of the reduced metal...........1581, 1582

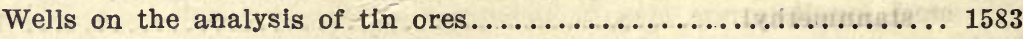
Witmer on the electrolytic determination of tin and its separation

from antimony............................. 1585

See also Anaiyses of tin, metallurgy of tin, assays of tin, origin of tin.

See references Nos. 1428-1587.

Chesterfield, see Massachusetts.

Chicoana, see Argentina, Salta.

Chili, Foullon on tin in ................................ 1322

Götting on tin at Punitaqui......................... 259a

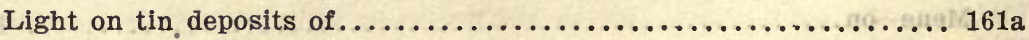

Möricke on tin at Punitaqui......................... 260

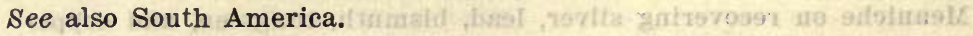

Chillagoe, see Queensland.

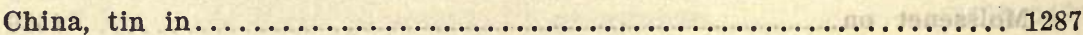

Beck on tin in .................................. 1299

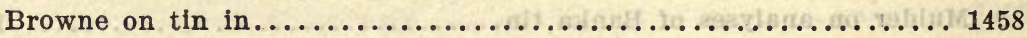

Collins on occurrence, mining, and metaliurgy of tin, and the mining

laws and customs in Yunnan.................... 266a

D'Achiardi on tin in ............................... 1313

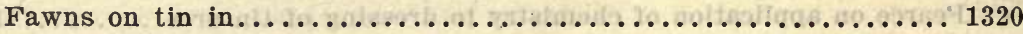

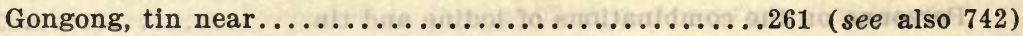

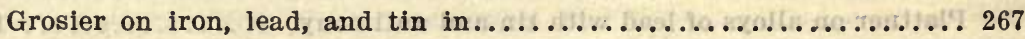


China-Continued.

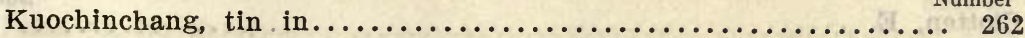

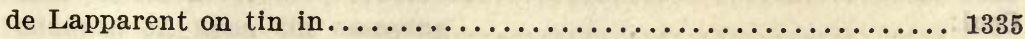

Leclère on tin and copper in Yunnan..................... 268

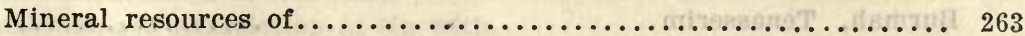

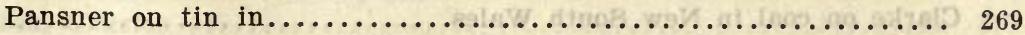

Willis on tin deposits in Yün-nan................... 269a

Yunnan:

Tin deposits, mining laws, and customs in............. 266a

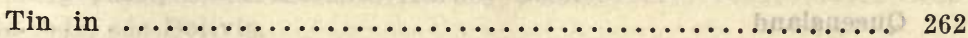

Cao-Bang, in the north of Tonkin, tin near............. 265

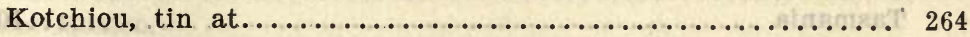

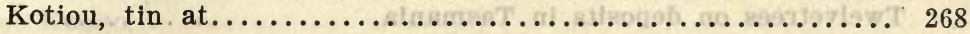

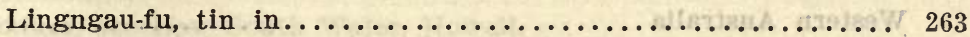

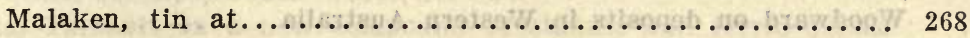

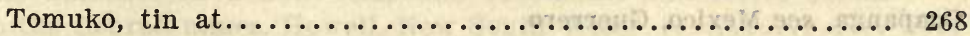

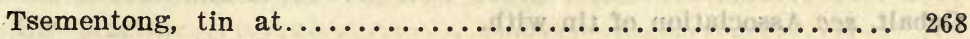

See also Indo-China and Asia.

China clay, Symons on production at Carclaze, Cornwall............ 463

Chin chin, see Malay Peninsula, Malacca.

Chinese method of smelting tin, see Smelting of tin.

Chlorine, see Association of tin with.

Chlorite, see Association of tin with.

Chocaltaya mine, see Bolivia.

Chorolque, see Bolivia.

Chota Nagpur, see India.

Christianshaabs, see Greenland.

Chromium, Moody on hydrolysis of salts of, in presence of iodides and

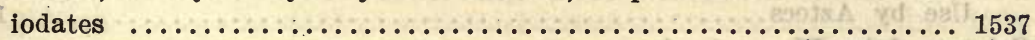

Chualla Grande, see Bolivia.

Church, A. H.

Cieux, see France.

Cinnabar, see Association of tin with.

Clarence district, see New South Wales.

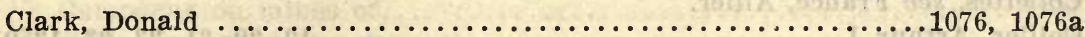

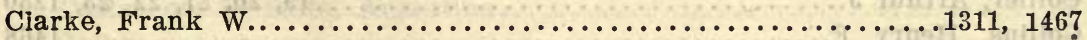

Clarke, w. B............................. 810, 812, 813, 814

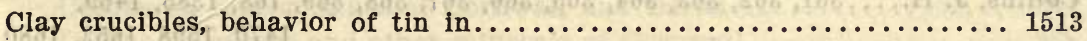

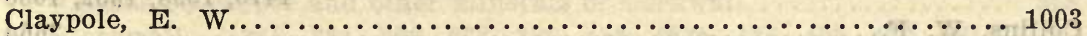

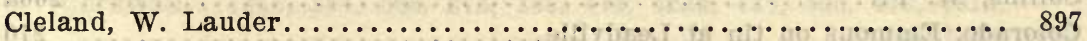

Cleveland mine, see South Dakota, Black Hills.

Clifford, Hugh.................................. 680

Cligga Head, see Cornwall.

Clitters tin mine, see Cornwall.

Clough, C. T. (Flett, J. S., and) ...................... 955 


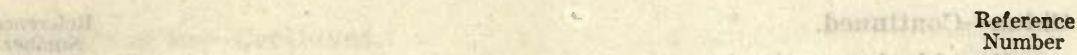

Clotten, E. .................................... 898

Coal:

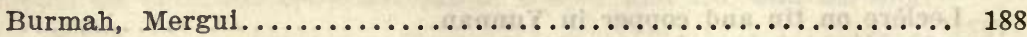

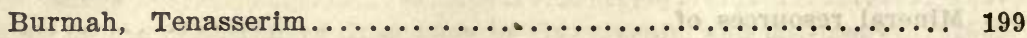

Clarke on coal in New South Wales................... 813

Foss on presence of, 28 miles from Mergui, Burmah............. 188

New South Wales.............................. 813

Oldham on coal and tin deposits of Tenasserim, Burmah......... 199

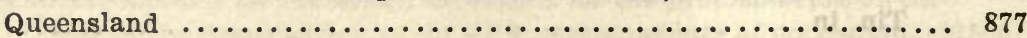

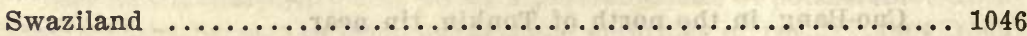

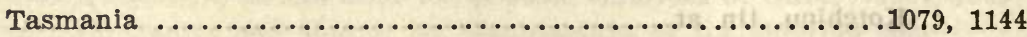

Twelvetrees on deposits in Tasmania.................... 1144

Western Australia ................................. 1272

Woodward on deposits in Western Australia................ 1272

Coapanga, see Mexico, Guerrero.

Cobalt, see Association of tin with.

Cobaltite, see Association of tin with.

Cochabamba, see Boliva.

Codrington, T.................................... 359

Coghlan, T. A....................48, 815, 1077, 1677, 1678, 1679

Coinage (tribute) of tin:

Carew on, in England .............................. 351

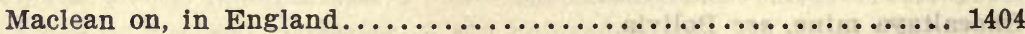

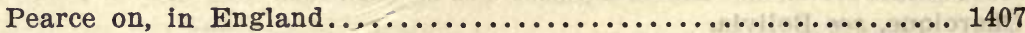

Colns, tin:

Malay Peninsula, Pahang, ancient coin discovered in.......... 736

Mexico, chisel-shaped money used in................... 769

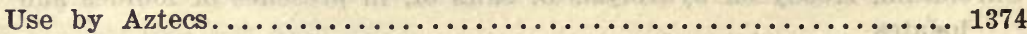

Colenso, John W................................ 360

Cooks Kitchen, see Cornwall.

Cooktown, see Queensland.

Coolangatta (Currumbin-) Beach, see Queensland.

Collett, Octave J. A............................... 681

Collettes, see France, Allier.

Collier, Arthur J.......................... 20, 21, 22, 23, 1250

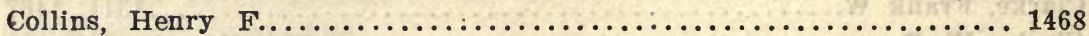

Collins, J. H.....361, 362, 363, 364, 365, 366, 367, 368, 369, 768, 1385, 1469 ,

$1470,1598,1652,1680$

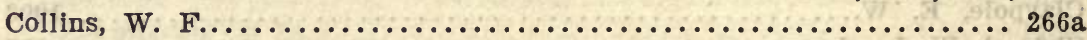

Colorado, Emmons on tin at Leadville...................... 270

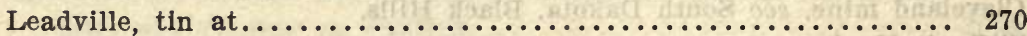

San Juan Mountains, tin in .......................... 271

Stevens on tin in the San Juan Mountains................. 271 See also United States.

Colquiri, see Bolivia. 
Columbite:

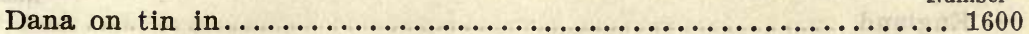

Influence of, upon tin assaying..................... 1466

See Association of tin with.

Columbium, see Association of tin with.

Combes, Charies .................................... 370

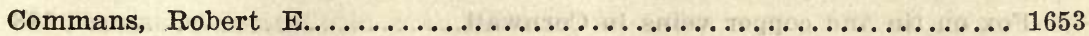

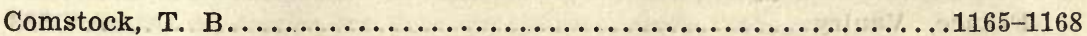

Concentrating plant, South Dakota, Harney Peak.............. 983

Concordia lode, see Bolivia.

Conder, Hartweli.

$.816,1078,1078 \mathrm{a}$

Coneto, see Mexico.

Congo, see Kongo.

Conrad mines, see New South Wales, Howell.

Conradite, Thibault on a new compound of stannic and ferric oxides

from the Conrad mines, Howell, New South Wales.............. 1644

Conway, Sir Martin............................. 154

Coolbawn, see Ireland.

Coolgara district, see Queensland.

Coomaraswamy, Ananda K..............255, 256. See also 258 and 259

Coomaraswamy, A. K., and Parsons, James................ 257

Copper:

Alloys of, with tin.......................1433, 1504, 1557

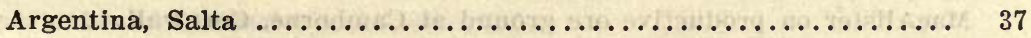

Associated with tin, see Association of tin with.

Ball on in Stanthorpe district, Queensland............... 889

Beck on occurrence at Schwarzenberg, Germany............ 530

Berzelius on occurrence of ............................ 1303

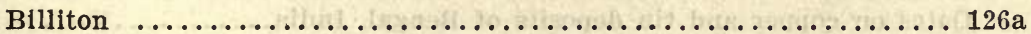

Boase on separation of copper and tin from ores in Cornwall...... 343

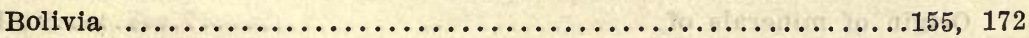

Bouse on ores in Madagascar....................... 646

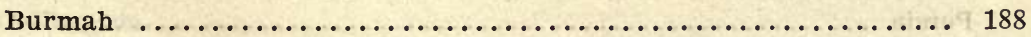

Buttgenbach on presence in Katanga................... 275

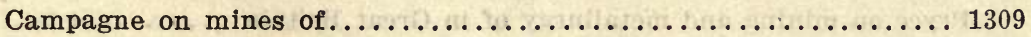

Castro on, in Salta, Argentina...................... 37

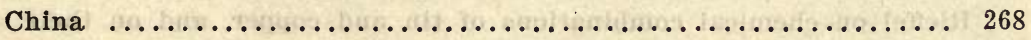

Collins on copper mines of Cornwall and Devon.............. 364

Collins on copper and other minerals of Cornwall.............. 368

Cornwall...343, 364, 368, 378, 388, 412, 422a, 426, 455, 473, 481a,

$1425,1479,1656$

Devon ............................................ 1425

Dietzsch on treatment of tin-wolfram-copper ores in Cornwall..... 1479

Doùglas on metallurgy of . ........................ 1204

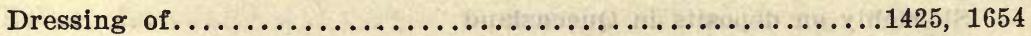

Dufrénoy and Beaumont on copper in Cornwall............. 378

Emmons on occurrence in United States and genesis of minerals of . 1206 
Copper-Continued.

England ................................. 457

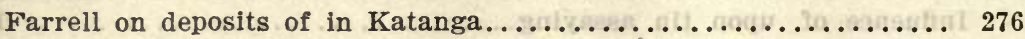

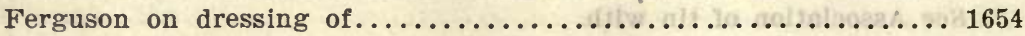

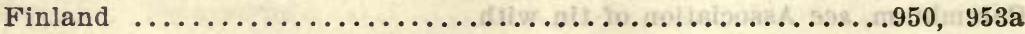

Foniakoff on deposits in Siberia........................ 965

Fox on tin and copper veins in Cornwall................. 388

France, Vaulry................................. 523

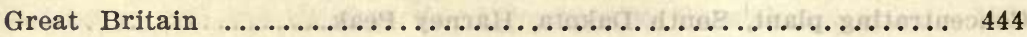

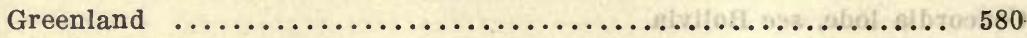

Germany, Schwartzenberg......................... 530

Hennecke on occurrence in Persia....................... 864

Henwood on manipulation of, in central mining district of Cornwall. 1656

Hunt on copper production of Cornwall.................... 412

India, Bengal ................................ 596

Ireland, Wicklow................................ 603

Jackson on the copper mines of the Lake Superior region......... 653

Kinahan on tin in copper bearing veins in Wicklow, Ireland....... 603

Kongo..................................... 3

Kongo, Katanga........................... 276

Lake Superior region.......................... 653

de Launay on occurrence in the French Kongo................. 3

Lington on the Dolcoath copper and tin mine...............422a

MacAlister on productive ore ground at Camborne, Cornwall...... 426

Madagasear ................................. 646

Menniche on separation of, from tin ores................ 1534

Metallurgy........................343, 444, 1204, 1425, 1479

Mining of .......................................... 1656

Oates on copper and tin deposits of Bengal, India............ 596

Occurrence of .................................. 1303

Origin of minerals of ............................ 1206

Pearce on separation from tin ore..................... 1547

Persia .......................................... 864

Pilz on deposits in Cartagena, Spain..................... 1040

Pryce on mining and metallurgy of in Great Britain............. 444

Queensland........................877, 881, 889, 932, 935

Rieffel on chemical combinations of tin and copper, and on their

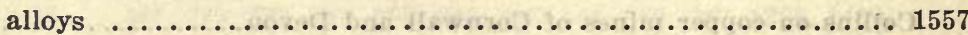

Schoultz-Ascheraden on deposits in Finland............... 950

Sellheim on Herberton district, Queensland............... 932

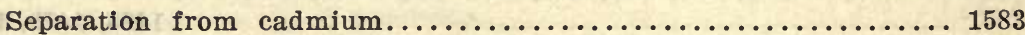

Separation from tin ores.............................. 1547

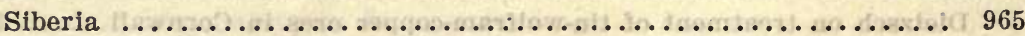

Simmons on occurrence of ores in Cornwall ............... 455

Skertchly on deposits in Queensland.................... 935

Smelting of ................................... 1425

Smyth on occurrence in England.................... 457 
Copper-Continued.

South Africa ............................... 3 3c

ste Spain, Cartagena............................... 1040

Sulphides of, associated wịth tin in Bohemla................ 155

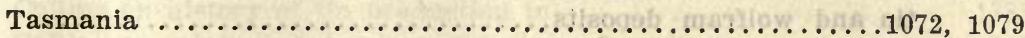

Tasmania, condition of mines, $1904 \ldots \ldots \ldots \ldots \ldots \ldots \ldots \ldots \ldots \ldots \ldots \ldots$

Thomas on copper ores near Redruth, Cornwall.............. 473

Trüstedt on copper ore deposits at Pitkäranta, Finland......... 953a

Tylor on earliest production of iron, copper, and tin........... 1420

United States................................ 1206

Vivian on history of copper mining in Cornwall..............481a

Voit on deposits of, in South Africa...................... $3 c$

Wells on separation of cadmium from .................. 1583

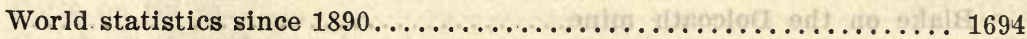

Worth on mining, dressing, smelting, and sale of, in Devon and Corn-

wall (historical) ............................. 1425

Copper alloys:

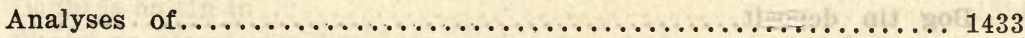

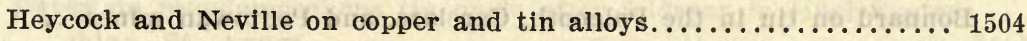

Properties of the alloys of copper and tin................ 1433

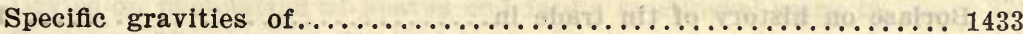

Stress tests of ................................. 1433

Copper carbonate, see Association of tin with.

Copper oxide, see Association of tin with.

Copper pyrite, see Association of tin with.

Copper sulphides, see Association of tin with.

Copper sulphuret, see Association of tin with.

Coquebert, Ch..................................... 1031

Cordes, J. H...................................... 87

Cork, see. Ireland.

Corner Inlet, see Victoria.

Cornish miners (tin):

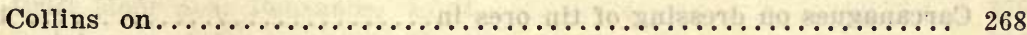

Henwood on character of, etc...................... 402

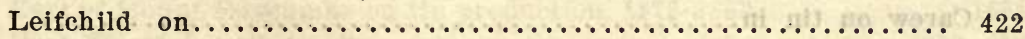

Walt on habits, characteristics, and mining methods.......... 482

Cornubian ...................................681a

Cornwall, tin in................................. 1298, 1298b

Adger on analysis of an anomalous specimen of stannite from..... 1588

Anonymous, see also W. K.

Argall on tin at Wheal Vor in Breage............................... 330

Baldauf on Redruth, Dolcoath, and East Pool mines........... 331

Ball on comparison of mining and milling methods with those of

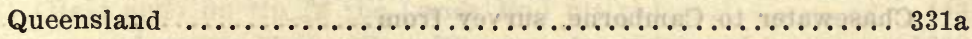

Ball on tin mining and milling at Botallack, Wheal Bassett, South

Crofty, and Porth Ledden.................................

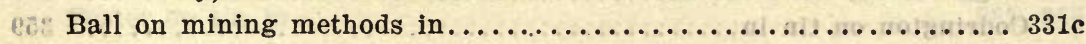


Cornwall-Continued.

Barnett on elvan courses, greenstones, and sandstones of Cornwall, and their associated minerals.................. 332

Barrow on high-level terraces of Bodmin Moor, and their relation to tin and wolfram deposits......................... 333

Beaumont (Dufrénoy and) on tin in................... 378

Benedict on correspondence of tin bearing granite in Australia to

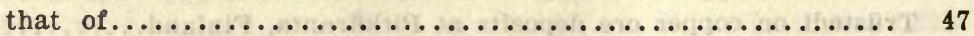

Benedict on tin in ................................. 1301

Bennetts on tin in St. Agnes district.................... 338

Berger on the physical structure and mines of.............. 339

Bettel on wet and dry methods of assaying in ...............1450a

Black on Carclaze tin mine......................... 340

Blake on the Dolcoath mine......................... 341

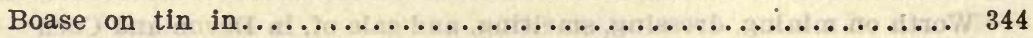

Boase on tin of Botallack and Levant................... 343

Boase and Courtney on tin mining in ................... 342

Bog tin deposit............................... 402

Bonnard on tin in the Polgooth, Carclaze, and Pentowan mines.... 345

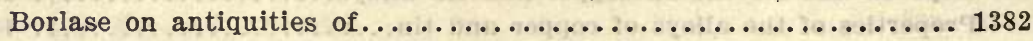

Borlase on history of tin trade in $\ldots \ldots \ldots \ldots \ldots \ldots \ldots \ldots \ldots \ldots \ldots$

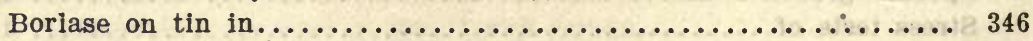

Borlase and Rosewarne on tin in ..................... 347

Botallack, geology and tin of............................... 343

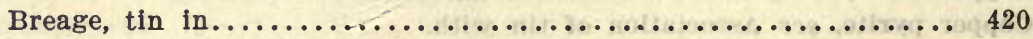

Brunnich on tin in $\ldots \ldots \ldots \ldots \ldots \ldots \ldots \ldots \ldots \ldots \ldots \ldots \ldots \ldots . \ldots \ldots$

Buller on tin at St. Just........................ 349

Burnard on the antiquity of mining in .................. 1384

Burrows (Thomas and) on the Dolcoath mine.............. 475

Camborne, tin at $\ldots \ldots \ldots \ldots \ldots \ldots \ldots \ldots \ldots \ldots . . .329 \mathrm{~g}, 385,411,425,426$

Camborne to Chasewater, survey from ................. 471

Caradon and Liskeard district, mining in ............... 484

Carcanagues on dressing of tin ores in .................. 1651

Carclaze tin mine...................... 340, 345, 418, 463, 474

Carew on tin in .................................. 351

Carn Brea tin mine.............................. 329g, 380, 389, 474

Carn Brea Hill, section through.................... 431

Carne on the relative age of the metailiferous veins of........ 353

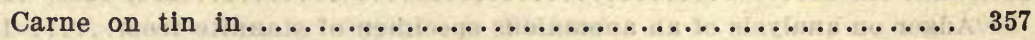

Carne on tin at Drift Moor near Penzance................. 355

Carne on tin at St. Just........................... 353

Carnon tin deposit.............................. 402

Chaplin on mine timbering, especially in the Dolcoath mine...... 358

Chasewater to Camborne, survey from.................. 471

'Clitters mine, treatment of tin-woifram-copper ores at......... 1479

Cligga Head, tin lodes at........................... 449

Codrington on tin in ............................. 359 
Cornwall-Continued.

Colenso on Happy Union mine at Pentuan................. 360

Collins on Cornish tinstones and tin capels................ 1598

Collins on Goonbarrow mine near St. Austell.............. 363

Collins on history of tin production in ................ 1385

Collins on origin and development of ore deposits in ........... 367

Collins on stanniferous deer horns in................... 365 See also on this subject 372 and $726 \mathrm{~b}$.

Collins on tin in.............................. $364,366,368$

Collins on tin production, $1201-1800 \ldots \ldots \ldots \ldots \ldots \ldots \ldots \ldots \ldots . \ldots \ldots$

Collins on use of impact screen at Wheal Kitty.............. 1652

Combes on $\operatorname{tin}$ in .............................. 370

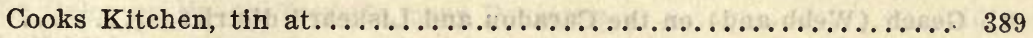

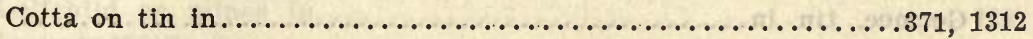

Couch on stanniferous deer horns in.................. 372

Courtney (Boase and) on tin mining in ................... 342

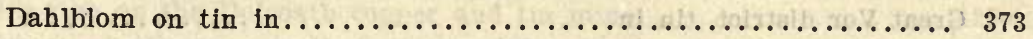

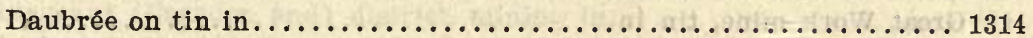

Davey on pseudomorphous tin oxide after feldspar in Huel Coates

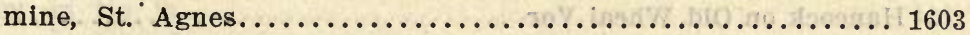

Davies on phenomena of heaves and faults in mineral veins in .... 374

Davies on tin veins at St. Agnes........................ 1603

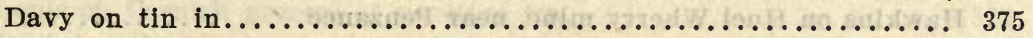

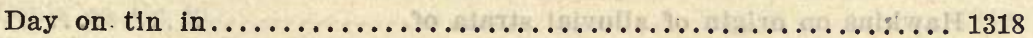

Deer horns (stanniferous) ........................... 372, 726b

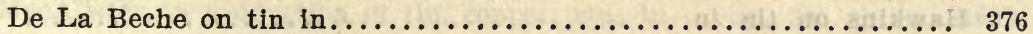

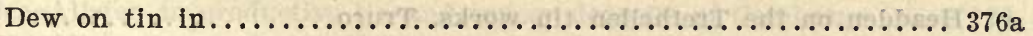

Dietzsch on treatment of tin-wolfram-copper ores at the Clitters

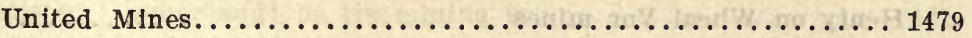

Dolcoath mine, tin in....322, 323, 324, 326, 327, 329g, 331, 341, $358,380,389,422 \mathrm{a}, 440,469,470,475,1084,1320,1666$

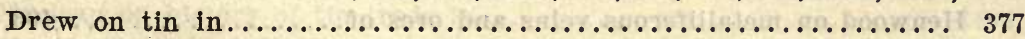

Drift Moor near Penzance, tin at...................... 355

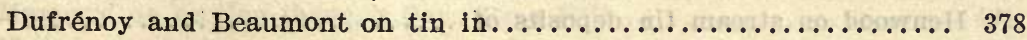

Eari of Mount Edgcumbe on tin production, $1873-1883 \ldots \ldots \ldots \ldots \ldots 1681$

East. Wheal Lovell, tin in ................................. 458

Edmonds on Phœnician tin trade with.................... 1389

Falmouth, tin near..........................411, 459, 1398

Fawns on the Dolcoath mine................................... 1320

Ferguson on dressing of tin and copper ores in .............. 1654

Fiett on brecciated stanniferous vein stones in............... 380

Flett on Dolcoath, Wheal Basset, South Crofty, Carn Brea, Wheal

Kitty, and West Kitty mines...................... 380

Flett (Reid and) on tin in the Lands End district............ 448

Foster on andrewsite at the West Phœnix mine, Liskeard......... 1608

Foster on the Great Flat Lode at Redruth and Camborne......... 385

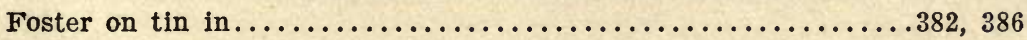


Cornwall-Continued.

Reference Number

Foster on tin at East Wheal Lovell................... 383

Foster on tin at Park of Mines....................... 384

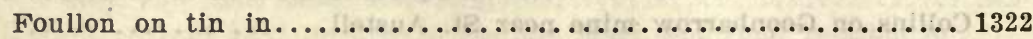

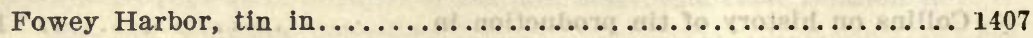

Fox on tin and copper veins in ...................... 388

Frecheville on results obtained by Cornish system of dressing tin ores ......................................... 1655

Frecheville on tin at Dolcoath, Cooks Kitchen, Tincroft, and Carn

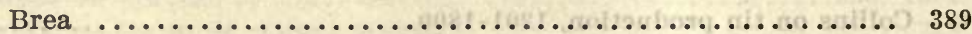

Fuchs and de Launay on tin in ........................ 391

Garby on a catalog of the minerals found in .............. 392

Geach (Webb and) on the Caradon and Liskeard district........ 484

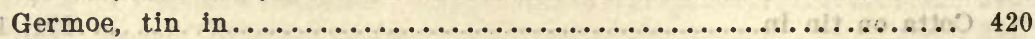

Goonbarrow mine near St. Austell..................... 363

Graham on early history of tin in.................... 1324

Great Vor district, tin in ........................... 317

Great Work mine, tin in ........................ 420

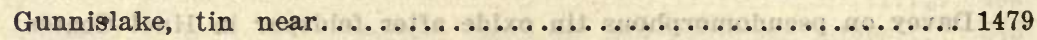

Hancock on Old Wheal Vor.......................... 394

Hawkins on ancient tin trade in ...................... 1395

Hawkins on gold in stream tin in Ladock................. 395

Hawkins on Huel Wherry mine, near Penzance.............. 396

Hawkins on origin of alluvial strata of ............... 399

Hawkins on Polgooth mine....................... 397

Hawkins on tin in .............................. 398

Headden on the Trethellen tin works, Truro.............. 1617

Helmhacker on tin in ........................... 400

Henty on Wheal Vor mines......................... 401

Henwood on Carnon, Nancothan, and Bog deposits............. 402

Henwood on manipulation of tin and copper ores in .......... 1656

Henwood on metalliferous veins and ores of .............403, 405

Henwood on Providence mines near St. Ives................ 406

Henwood on stream tin deposits of .................... 402

Henwood on tin in.........................404,407, 408

Hicks on treatment of slime tin in ................... 1657

Hill on tin in ................................409, 410

Hill and MacAlister on tin in Falmouth, Truro, Redruth, and Cam-

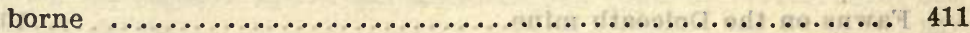

Huel Peever mine, tin in........................ 488

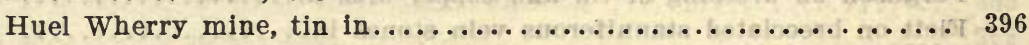

Hunt on history of tin mining in .................... 1397

Hunt on production of tin and copper in ................. 412

Hunt on tin mines, ore produced, and prices, $1864-1873 \ldots \ldots \ldots \ldots \ldots 1687$

Hutchin on tin dressing at South Crofty mine................. 1507a

Hutchinson on stokesite, a new mineral from .............. 1620 
Cornwall-Continued.

Reference

Number

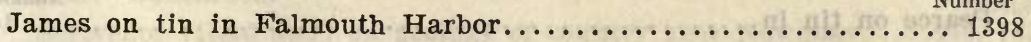

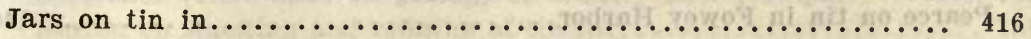

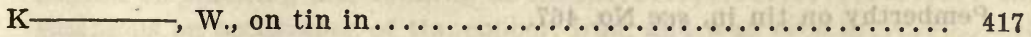

Kerl on $\operatorname{tin}$ in...................................... 419

Kerl on tin in Carclaze near St. Austell................... 418

Kitto on Great Work mine, in Breage and Germoe.............. 420

Klaproth on chemical examination of tin ore from........... 1513

Ladock, gold in stream tin in........................ 395

Lands End district, tin in .......................... 448

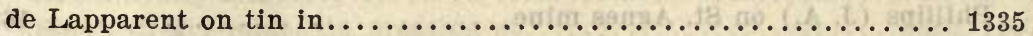

de Launay (Fuchs and) on tin in...................... 391

Le Grice on tin on Trereife, near Penzance................ 1518

Leifchild on mines in .......................... 422

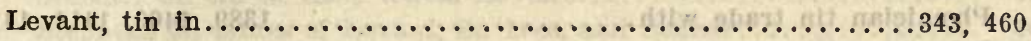

Levant (St. Ives and) district, tin in ....................... 460

Lington on the Dolcoath copper and tin mine...............422a

Liskeard (Caradon and) district, mining in................ 484

Liskeard, West Phœnix mine, andrewsite at............... 1608

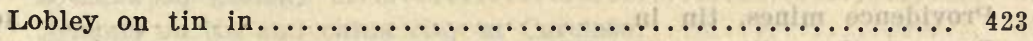

Lobley on tin and copper mining in east.................. 423

Lock on tin in............................424, 1338

Louis on Cornish process of smelting tin................. 1523

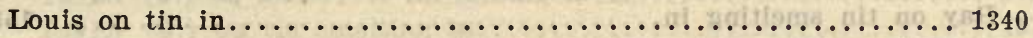

MacAlister on tin in ..........................427, 1659

MacAlister on production of tin, copper, etc., in............ 1693

MacAlister on productive tin and copper deposits of Camborne.... 426

MacAlister on vertical distribution of ores in Camborne lodes...... 425

MacAlister (Ussher and) on tin mining in................ 481

Maciaren on gold and tin in ....................... 428

Maclean on tin mining during 14 th century $\ldots \ldots \ldots \ldots \ldots \ldots \ldots \ldots 1403$

Maclean on history of tin trade in ........................ 1404

Martin on tin mining in........................... 430

Maynard on section through Carn Brea Hill............... 431

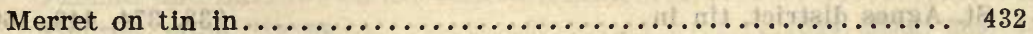

Moissenet on $\operatorname{tin}$ in...........................433,434, 435

Myrick on tin concentration in ....................... 1541

Nancothan $\operatorname{tin}$ deposit............................ 402

Newland on tin industry in....................... 436,437

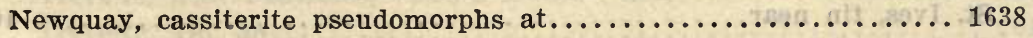

Newquay, geology of country near...................449, 1638

Oxland on possibility of reviving mining industries of .......... 438

Paris on tin in ............................... 439

Park of Mines, near St. Columb, tin at the..................... 384

Pearce on cobalt. with tin in Dolcoath mine............... 440

Pearce on oxide of tin after quartz and allophane in.......... 1629 
Cornwall-Continued.

Reference Number

Pearce on tin in ............................... 441

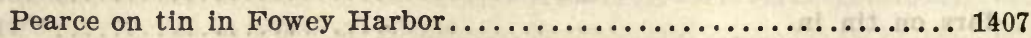

Pemberthy on tin in, see No. 467.

Pennance mine, near Falmouth...................... 459

Pentowan mine, tin in ............................ 345

Pentuan, alluvial strata at......................... 399

Pentuan, Happy Union mine, tin in .................... 360

Penzance, "Jew's House" at Trereife near................. 1518

Penzance, tin near.............................. 355, 1518

Phillips (J. A.) on St. Agnes mine.................... 1632

Phillips (J. A.) on tin in .......................... 442

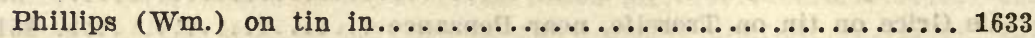

Phillips (Wm.) on the Tincroft mine................... 443

Phœnician tin trade with................1389, 1400, 1414, 1418

Polgooth mine, tin in........................... 345, 397, 1278

Polwhele on history of $\ldots \ldots \ldots \ldots \ldots \ldots \ldots \ldots \ldots \ldots \ldots \ldots \ldots \ldots . \ldots \ldots$

Porth Ledden Mills, treatment of tin ores at.............. 331b

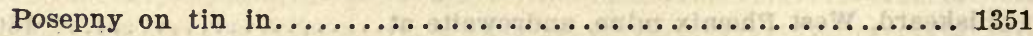

Providence mines, tin in ......................... 406

Pryce on the milling and metallurgy of tin, copper, and lead in.... 444

Rammelsberg on analyses of stannite from $\ldots \ldots \ldots \ldots \ldots \ldots \ldots \ldots 1637$

Rashleigh on alluvial deposits of ...................... 447

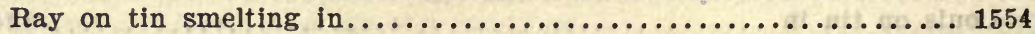

Red River, effect of tin tailings on ................... $482 a$

Red River, loss of slime tin in...................... 1657

Redruth, tin in $. \ldots \ldots \ldots \ldots \ldots \ldots \ldots \ldots \ldots \ldots \ldots \ldots . . .313,331,385,411,473$

Reid and Flett on tin in the Lands End district.............. 448

Reid and Scrivenor on geology of country near Newquay.....449, 1638

Restronguet, alluvial tin at....................... 329c

Restronguet Creek, tin on ........................ 464

Reyer on tin in $\ldots \ldots \ldots \ldots \ldots \ldots \ldots \ldots \ldots \ldots \ldots \ldots \ldots \ldots \ldots \ldots+\ldots \ldots \ldots$

Rickard on improvement in mining methods in . . . . . . . . . $450 \mathrm{a}$

Rosewarne (Borlase and) on tin in ................... 347

St. Agnes district, tin in $\ldots \ldots \ldots \ldots \ldots \ldots \ldots \ldots \ldots \ldots . \ldots \ldots, 334,449,1603$

St. Agnes district, Huel Coates mine, pseudomorphous tin oxide after

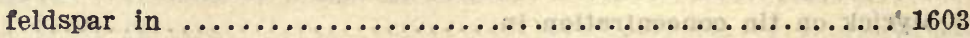

St. Austell, tin mines near........................ 418

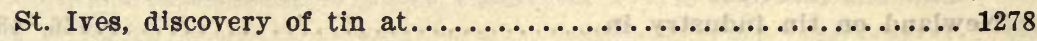

St. Ives, tin near............................ 406

St. Ives and Levant district, tin in .................

St. Just, tin at. .......................... $349,353,354$

Salmon (?) on the St. Ives and Levant district............. 315

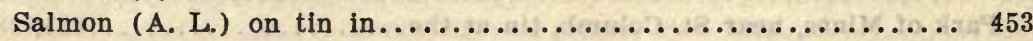

Salmon (H. C.) on tin in ........................... 454

Saunders on ancient tin trade with Phœnicians............... 1414 
Cornwall-Continued.

Scrivenor (Reld and) on geology of country near Newquay....449, 1638

Sexton on smelting and refining of tin in................. 1361

Simmons on occurrence of tin, copper, iron, and lead ores in...... 455

Skewes on magnetic separation of tin and wolfram at Gunnislake

Clitters .................................. 1662

Skewes on tin mining in.......................... 456

Smith on Phœnician trade with, and on antiquity of tin mining in.. 1418

Solly on tin crystals of various mines of ................. 1640

South Crofty mine....................................... 380

South Crofty mine, tin dressing at...................... 1507a

South Wheal Breage mine, tin in..................... 420

Spargo on statistics of tin in ......................... 1699

Stelzner on tin in East Wheal Lovell..................... 458

Stephens on mines of Levant, St. Ives, and Zennor............ 460

Stephens on the Pennance mine near Falmouth.............. 459

Spencer on stannite from ......................... 1641

Symons on Carclaze tin mine........................ 463

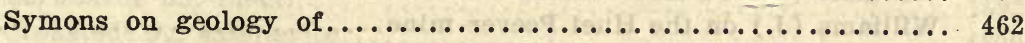

Symons on tin and china clay at Carclaze................. 463

Taylor (C. D.) on tin on Restronguet Creek near Truro......... 464

Taylor (J.) on business methods in tin mines of.............. 1663

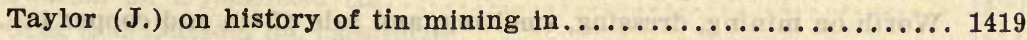

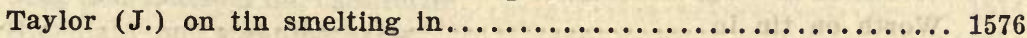

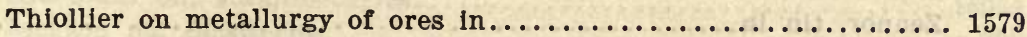

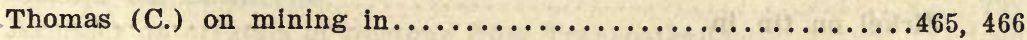

Thomas (H.) on tin in ............................. 467

Thomas (J.) on Dolcoath mine.....................469, 470

Thomas (R.) on survey from Chasewater to Camborne.......... 471

Thomas (R. A.) on tin output of .................... 472

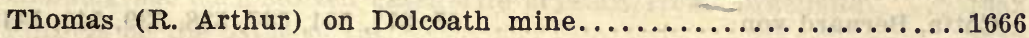

Thomas (Richard A.) on Wheal Uny, near Redruth........... 473

Thomas (Wm.) on Carclaze and Carn Brea mines............. 474

Thomas and Burrows on the Dolcoath mine............... 475

Tincroft mine, tin at...................... 314, 329g, 389, 443

Trasenster on statistics of tin in, $1879-1881 \ldots \ldots \ldots \ldots \ldots \ldots \ldots \ldots 1700$

Tredinnick on tin $1 n \ldots \ldots \ldots \ldots \ldots \ldots \ldots \ldots \ldots \ldots \ldots \ldots \ldots \ldots \ldots$

Tregaskis on tin in ............................. 477

Trerelfe, near Penzance, "Jew's House" at.................. 1518

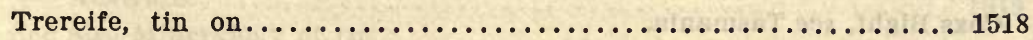

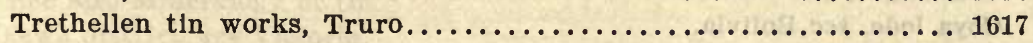

Truro, tin near.........................411, 464, 1617

Tweedy on minerals in.......................... 478

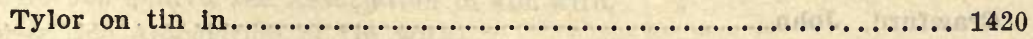

Unwin on exportation of $\operatorname{tin}$ from .................... 480

Ussher and MacAlister on tin mining in................ 481

Vivian on history of copper and tin mining in .............. 481a 
Cornwall-Continued.

Reference

Wait on tin mines of . . . . . . . . . . . . . . . . . . . . . . . 482

Walker on effect of tin tailings on Red River...............482a

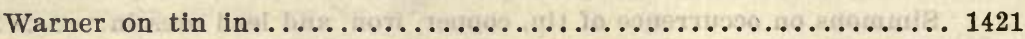

Watson on system of mining and statistics of tin in............ 483

Webb and Geach on the Caradon and Liskeard district.......... 484

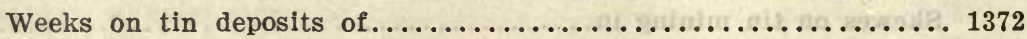

West on tin mining in ............................. 485

West Kitty mine................................... 380

Wheal Bassett, geology of ............................. 331b

Wheal Bassett, tin in .............................. 380

Wheal Breage, tin in............................. 420

Wheal Kitty, use of impact screen at................... 1652

Wheal Kitty, tin in............................... 380

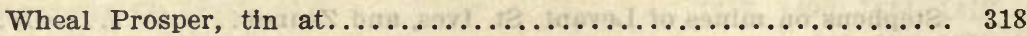

Wheal Uny, near Redruth, Great Flat Lode in.............. 473

Wheal Vor, tin in ............................... 330, 394, 401

Williams (A.) on tin mines of ...................... 487

Williams (J.) on the Huel Peever mine................... 488

Williams (R. H.) on tin in St. Austell district............... 489

Woodward on tin ore specimens from................... 489a

Worth on antiquity of tin mining in .................... 1421

Worth on mining, dressing, smelting, and sale of tin and copper in.. 1425

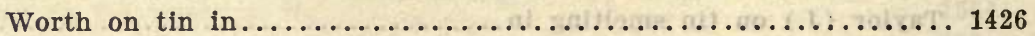

Zennor, tin in ................................... 460

Zirkel on tin in ................................ 490

See also England.

Correze (Meymac), see France.

Coruña, see Spain.

Corundum, see Association of tin with.

Cotta, Bernard von.............65, 371, 501, 537, 538, 539, 540, 541, 1312

Cotton, Leo A................................. $816 \mathrm{a}$

Couch, R. Q.................................. 372

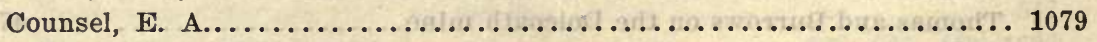

Country Harbor, see Nova Scotia, Lunenberg County.

Courtis, W. M.................................. 24

Courtney, W. P. (Boase, G. C., and) ..................... 342

Cowper, Coles S.................................. 1471

Cox, Herbert s.................................... 817

Coxs Bight, see Tasmania.

Coya lode, see Bolivia.

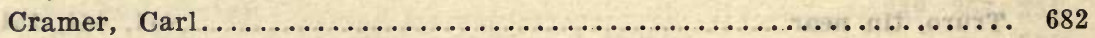

Cramer, John Andrew................................ 1472

Crawfurd, John.................................. 282

de Cressac, C....................................... 502

Cretaceous, tin ore in ............................... 182

Crettier, H................................88, 127, 283 
Creuse, see France.

Cristal Mountains, see French Kongo, Crystal Mountains.

Croaghan Mountains, see Ireland, Wicklow.

Croghan Kinshelagh, see Ireland, Wicklow.

Cronstedt, Axel F................................ 1599

Croockewit, H.................................. 683

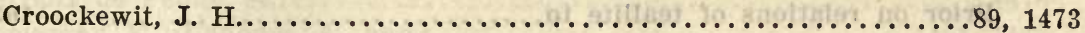

Crook County, see Wyoming.

Crookes and Roehrig.

Crows Nest deposits, see Queensland.

Cryolite, see Association of tin with.

Crystal Mountains, see French Kongo.

Crystallization of tin and tin compounds:

Allard on, metal............................... 1429

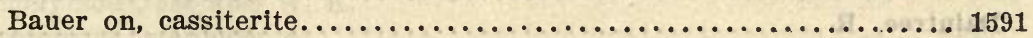

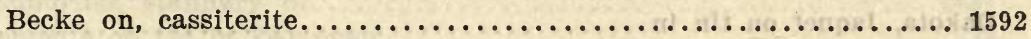

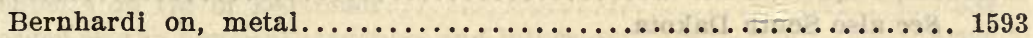

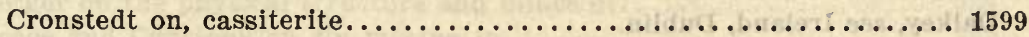

Disintegration of tin upon crystallization................. 1434

Foullon on, metal............................. 1609

Foullon on crystallized tin......................... 1490

Greg and Lettsom on, cassiterite.................... 1614

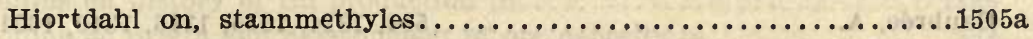

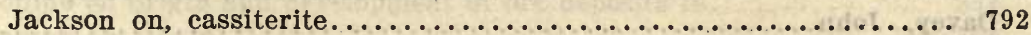

Jermejev on crystals of tinstone from Transbaikalia........... 1622

Kohlman on measurements of cassiterite crystals ............. 1624

Lacroix on distorted cassiterite crystals from France........... 516

Miller on measurements of crystals of metallic tin............. 1627

Mohlengraaf on distorted cassiterite crystals from Swaziland..... 1052

Phillips on the oxide of tin........................ 1633

Phillips on the cleaving of cassiterite crystals so that the angles may be measured............................ 1634

Pirsson on crystals of hematite enclosing cassiterite........... 1635

Spencer on crystallized stannite from Bolivia.............. 1641

Trechmann on two forms of crystals obtained in manufacture of metallic tin crystais............................ 1645

Woolnough on distorted cassiterite crystals from Pilbarra, Western Australia

See also Mineralogy of tin.

Cudgewa district, see Victoria.

Cummings mine, see Tasmania.

Cupriferous quartz, see Association of tin with.

Cuprite, see Association of tin with.

Cuprocassiterite:

Ulke on a new tin mineral in the Black Hills.............. 1646

See Association of tin with. 
Reference

Cuproscheelite, see Association of tin with.

Number

Currumbin-Coolangatta, see Queensland.

Cussack, W. G. Kelley.

Custer City, see South Dakota.

Cylindrite:

Frenzel on a rare tin ore from Bolivia.

Prior on relations of teallite to. 1636

\section{D}

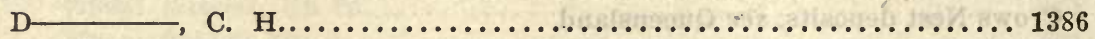

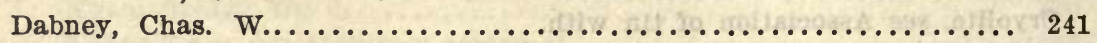

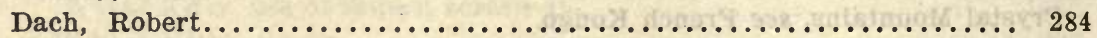

D'Achiardi, Antonio.............................621, 1313

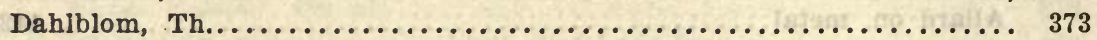

Daintree, R.................................... 900

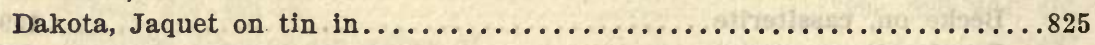
See also South Dakota.

Dalkey, see Ireland, Dublin.

Dalmer, Karl...........................542, 543, 544, 622

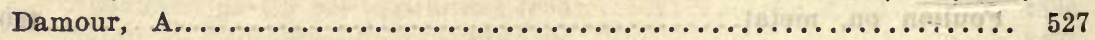

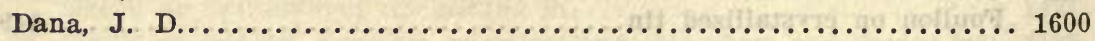

Dartmoor, see Devon.

Daubrée, A....................504, 1314, 1315, 1316, 1340, 1601, 1602

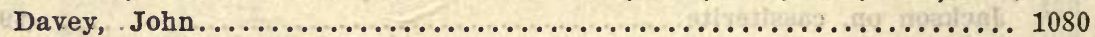

Davey, Sir Humphrey............................. 375

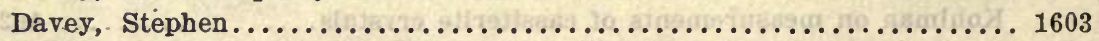

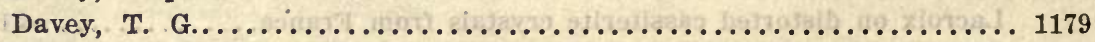

David, T. W. Edgeworth............................ 818

Davies, Alfred T.................................... 374

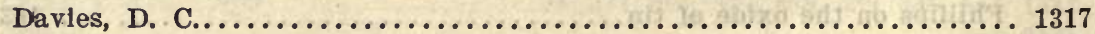

Davy, L....................................505, 1387

Dawson. region, see Yukon.

Day, David T.....................1004, 1005, 1203, 1203a, 1318, 1319

Dechen, H. von................................. 545

Deepwater, see New South Wales.

Deer horns, replaced by oxide of tin in Cornwall............... 365, 372 Deer horns, Scrivenor on absence of tin in those stated to have been re-

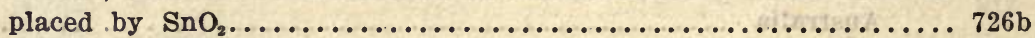

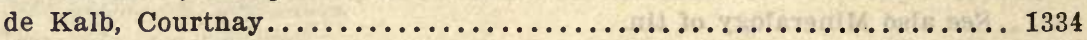

de Koninch, L. L., and Lecrenier, A...................... 1474 Dela, see Ceylon.

De La Beche, Henry T............................. 376

Delachanal, B., and Mermet, A................................. 1475

De La Croix, J. Errington .......................... 684, 685, 686

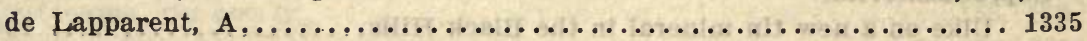

de Launay, L............................ 518, 854, 1625 
de Launay, L. (Fuchs, E., and) . .................66, 159, 509, 1323 Delime River, see Nigeria.

de Limur (ie Comte) ................................ 519

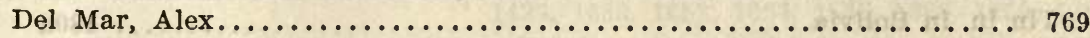

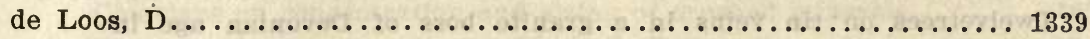

Delume (Kogin-) River, see Nigeria.

Delvaux de Fenffe, A................................ 1476

Demarçay, E. (Cahours, A, and)............................. 1462

Denmark, Bergse process used at Copenhagen for recovery of scrap tin, 1442 Derby, see Tasmania.

Derrick, W. H.................................. 687

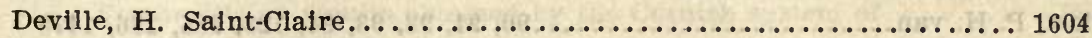

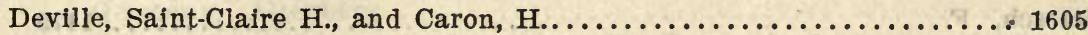

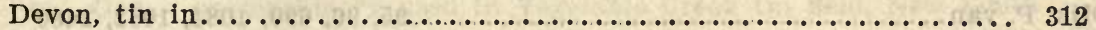

Anonymous, see also W. K.

Ashburton, stannary of ............................. 1427

Bennetts on tin in Dartmoor........................ 337

Berger on the physical structure and mines of ............... 339

Boase and Courtney, on tin mining. in................... 342

Burnard on Stannaries in, and on the antiquity of mining in....... 1384

Busz on hornfels, garnet-datolite hornfels, and hedenbergite hornfels

in Dartmoor............................... 350

Collins on history of tin production in................. 1385

Collins on origin and development of ore deposits in . . . . . . . 367

Collins on tin in..................................... 364

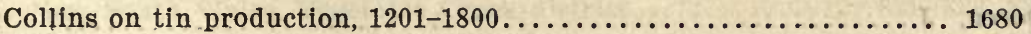

Combes on tin in ................................. 370

Courtney (Boase and) on tin mining in.................. 342

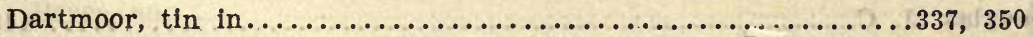

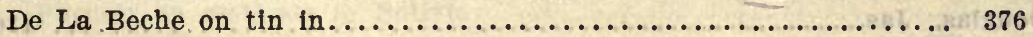

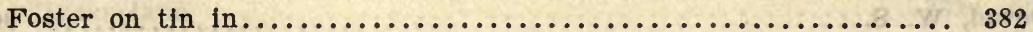

Henwood on the metalliferous veins and ores of ..............403, 405

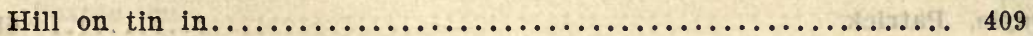

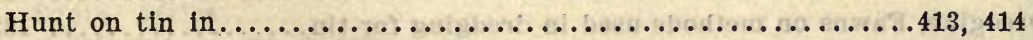

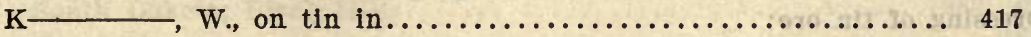

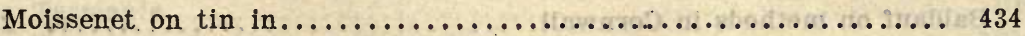

Oxland on possibility of reviving mining industries of ......... 438

Spargo on statistics of tin in .......................... 1699

Stannaries, laws and customs of the................... 1384

Taylor on business methods in tin mines of................. 1663

Taylor on history of tin mining in .................... 1419

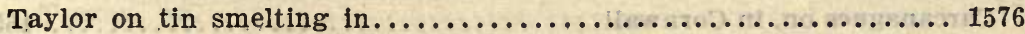

Thomas (C.) on mining in ....................... 465,466

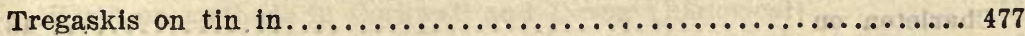

Worth on antiquity of tin mining in ................... 1426

Worth on mining, dressing, smelting, and sale of tin and copper in.. 1425 
Devon, tin in-Continued.

Reference Number

Worth on stannary of Ashburton

1427

See also England.

Devonian, tin mines of New South Wales and Queensland occur in the.. 814

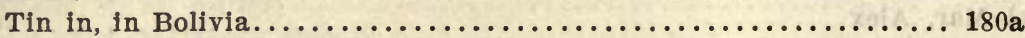

Twelvetrees on tin veins in a granite boss of Devonian age in

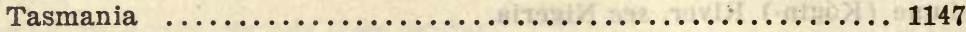

Waller on tin in granite of Devonian age cutting Silurian sediments, 1155

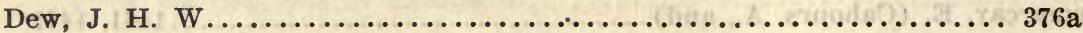

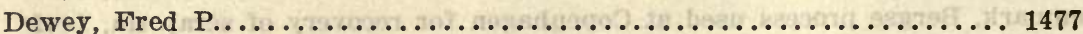

Diamonds, Voit on deposits of in South Africa................. 3c

See Association of tin with.

Diest, P. H. $\operatorname{van} \ldots \ldots \ldots \ldots \ldots \ldots \ldots \ldots \ldots 90,91,92,93,94,128,285,286,1478$

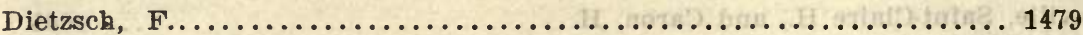

Dijk, P. van........................... 95, 690, 1081, 1082, 1480

Dindang district, see Billiton.

Dindings, see Malay Peninsula, Perak.

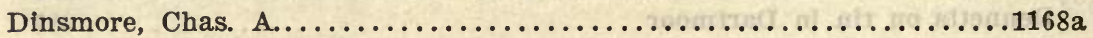

Diopside, see Association of tin with.

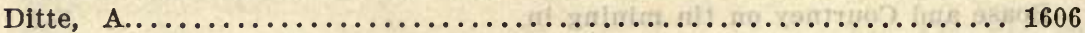

Djeboes district, see Banka.

Dogtown, see South Dakota.

Dolcoath mine, see Cornwall.

Dominican Republic, see Santo Domingo.

Doormann, w. H. C.............................. $286 a$

Doornhoek, see Transvaal.

Doren, J........................................ 97

Dorfhain, see Germany.

Dorset County, see Tasmania.

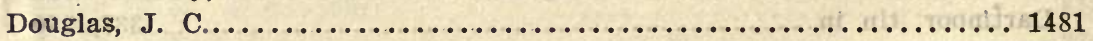

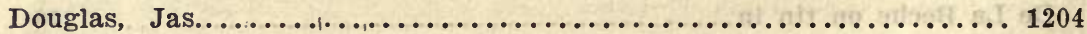

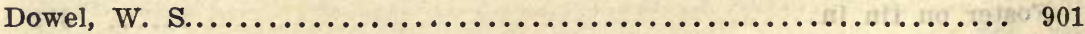

Doyle, P........................................ 689

Doyle, Patrick .................................... 688

Dredging, Fawns on methods used in dredging for tin............ 1320

Dressing of tin ore:

Baldauf on methods in Cornwall............................. 331

Ball, comparison of Cornish methods with those of Queensland..... 331a

On Cornish methods........................ 331b

Boase on method in Cornwall........................ 343

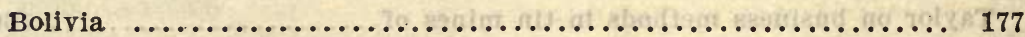

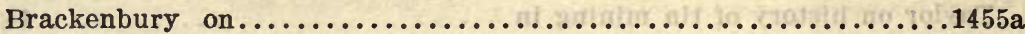

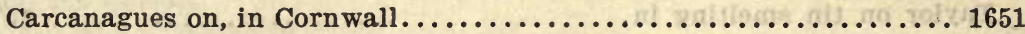

Carew on methods in Cornwali........................ 351

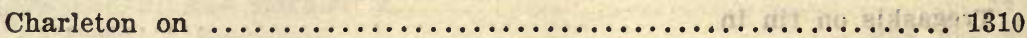

Cleland on methods at Stannary Hills, Queensland............ 897

Collins on methods in Cornwall........................ 368 
Dressing of tin ore-Continued.

Collins on use of impact screen in. ................... 1470

Cornwall...312, 331, 331a, 331b, 343, 351, 368, 390, 403, 419,490,

$1425,1650,1651,1654,1655,1656,1659,1666$

Commans on concentration and sizing of crushed minerals........ 1653

Davey on losses in at Mount Bischoff, Tasmanla...............1080

Devon .................................... 412, 403, 1425

Fawns on tin crushing and dressing machinery.............. 1320

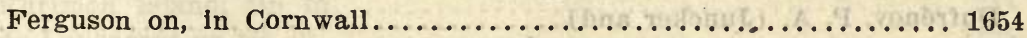

France, Montebras, ore dressing plants in................. 496

Frecheville on losses of black tin in Cornish system of .......... 390

Frecheville on results obtained by the Cornish system of........ 1655

Germany, Altenberg........................... 528

Gower on machinery used in Vegetable Creek tin field, New South

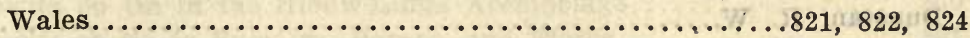

Henwood on, in central mining district of Cornwall........... 1656

Henwood on methods in Cornwall and Devon................ 403

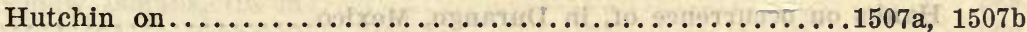

Kerl on methods in Cornwall.......................... 419

Losses in dressing Cornish ores........................... 1655

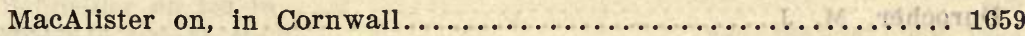

Malay Peninsula................................. 704a

Menniche on separation of silver, lead, bismuth, tungsten, and copper

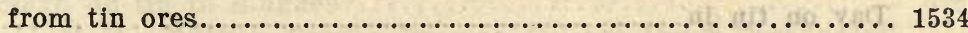

Mills-Davies on plant at Kooiberg, Transvaal................1185a

New South Wales, Vegetable Creek district............821, 822, 824

Pearce on application of chemistry to................... 1546

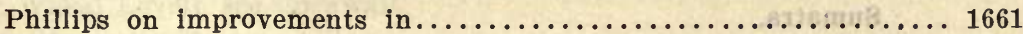

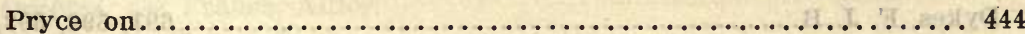

Purnett on methods in Bolivia........................ 177

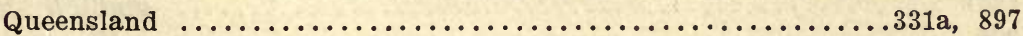

Rowe on chemical methods of treating ores............... 1560

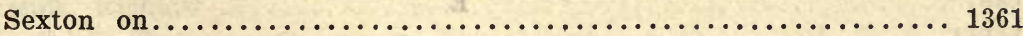

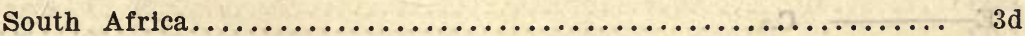

South Dakota, Black Hills.......................983, 986

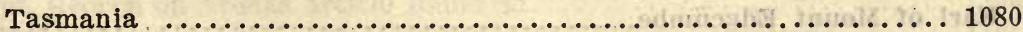

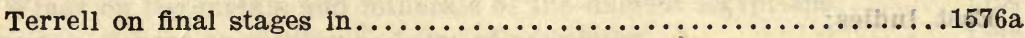

Terrell on the final stages of tin and. wolfram dressing......... 1664

Thomas (Chas.) on reducing waste resulting from............. 1665

Thomas (R. A.) on treatment of tin ore at Dolcoath mine, Cornwall, 1666

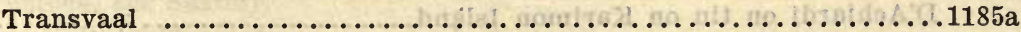

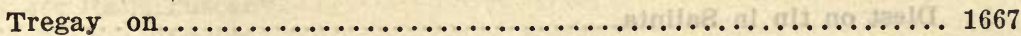

Weston on methods in South Africa.................... 3d

Worth on methods in Cornwall and Devon (historical) ......... 1425

Zirkel on methods in Cornwall........................... 490

See also Metallurgy of tin, milling of tin, refining of tin, and smelt-

ing of tin. See references Nos. 1428-1587 and 1650-1668. 


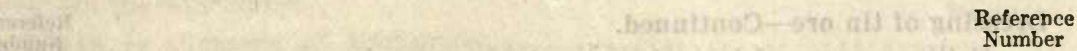

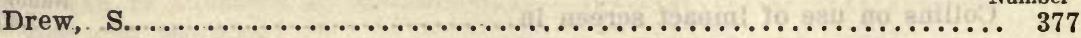

Drift Moor, see Cornwall.

Dry Forest Creek, see Victoria.

Dry River, see Queensland.

Dublin, see Ireland.

Dufrené, Hector.

1388

Dufrénoy, P. A............................... 506

Dufrénoy, P. A. (Juncker and) ......................... 513

Dufrénoy, P. A., and Beaumont, Élie de................... 378

Dufrénoy, P. A., and Juncker......................... 507

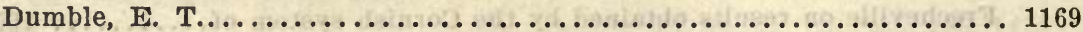

Dundee, see New South Wales.

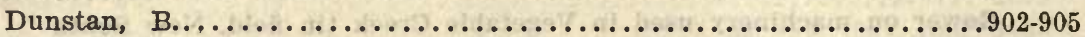

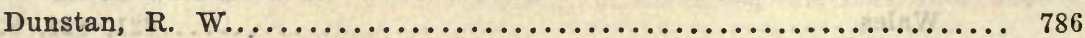

Dunstan, Wyndham R..................... 54 , 647, 857, 858, 859

Durangite:

Hanks on occurrence of, in Durango, Mexico................ 774

See Association of tin with.

Durango, see Mexico.

Durocher, M. J................................. 508

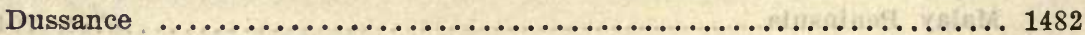

Dutch East Indies, tin in ..........................675, 1298

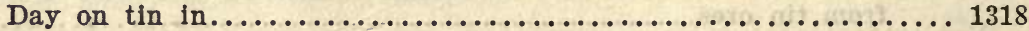

Doorman on tin in.............................. 286a

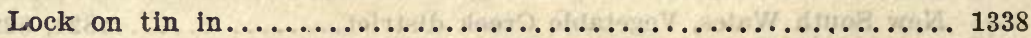

See also Banka, Billiton, Borneo, Celebes, East Indies, Java, and Sumatra.

Dykes, F. J. B...........................691, 692, 693, 1483

Dykes, F. J. B. (Hume, W. J. P., and) .................... 698

\section{$\mathbf{E}$}

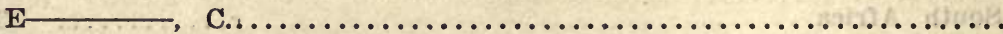

Ears Mountain, see Alaska.

Earl of Mount Edgcumbe

East Indies:

Crawfurd on tin in............................. 282

Cretier on tin in Java, Billiton, and the Dutch East Indies........ 283

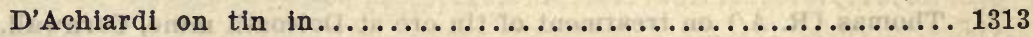

D'Achiardi on tin on Karimon Island.................... 284

Diest on tin in Salinta............................. 286

Diest on tin in Singkep Island....................... 285

Doorman on tin in the Dutch East Indies................. 286a

Everwijn on tin at Sukadana, Simpang, Matan, and Palo......... 291

Everwyn on tin in the Riouw Islands.................... 289 
East Indies-Continued.

Everwyn on tin in Sukadana, Simpang, Matan (Borneo), and

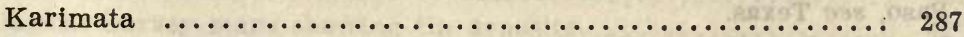

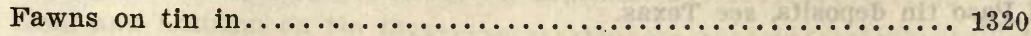

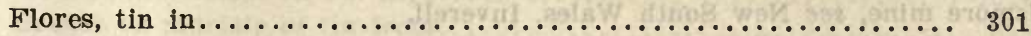

Fuchs and de Launay on tin in ........................ 1323

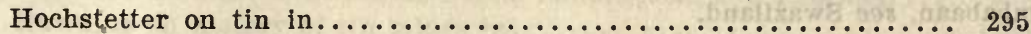

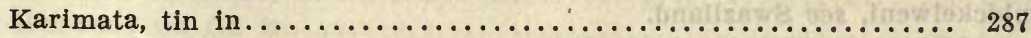

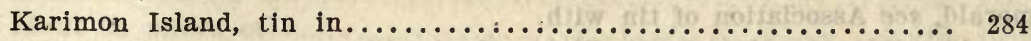

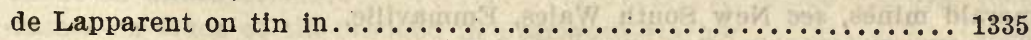

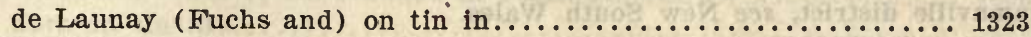

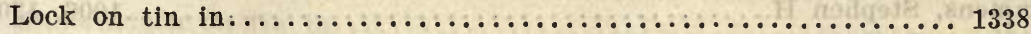

Menten on $\operatorname{tin}$ in Singkep.......................... 297

Palo, tin in $\ldots \ldots \ldots \ldots \ldots \ldots \ldots \ldots \ldots \ldots \ldots \ldots \ldots \ldots \ldots \ldots \ldots . \ldots \ldots$

Posewitz on tin in the Rlouw-Linga Archipelago.............. 300

Posewitz on tin in Sumatra, Borneo, and Flores............. 301

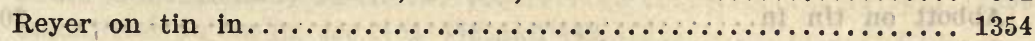

Riouw Islands, tin in ........................... 289

Riouw-Linga Archipelago, tin in ..................... 300

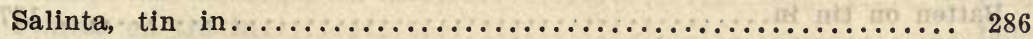

Schneider on tin in $\ldots \ldots \ldots \ldots \ldots \ldots \ldots \ldots \ldots \ldots \ldots \ldots \ldots \ldots \ldots \ldots$

Singkep Island, tin in . . . . . . . . . . . . . . . 280, 285, 297, 308, 1284

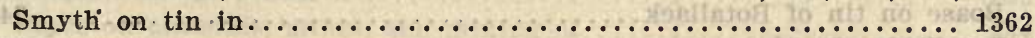

Wildman on tin in Singkep......................... 308

See also Banka, Billiton, Borneo, Burmah, Celebes, Dutch East Indies,

Java, Siam, Straits Settlements, and Sumatra.

East Pool mine, see England.

East Wheal Lovell, see Cornwall:

Échassières, see France, Allier.

Echo mine, see Tasmania.

Eddy, william .................................. 1225

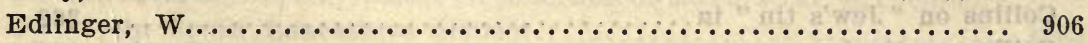

Edmonds, Richard $. \ldots \ldots \ldots \ldots \ldots \ldots \ldots \ldots \ldots \ldots \ldots \ldots \ldots \ldots \ldots \ldots \ldots \ldots . \ldots \ldots$

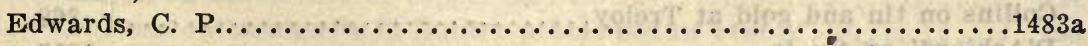

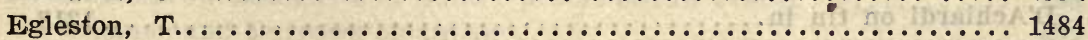

Egypt, George on bronze article found in ................... 1392

Winer on the metals and minerals of the ancient Egyptians....... 1424

Egyptians, George on mining and use of metals by ............... 1392

Ehrenfriedersdorf, see Saxony.

Ehrenwerth, J. von ...................................... 1682

Eibenstock, see Saxony.

Elba, see Italy, Tuscany.

Eldorado, see Victoria.

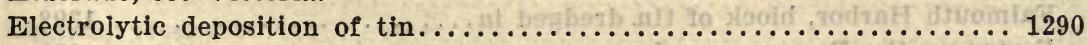

Elisa lode, see Bolivia.

Elk Gulch, see South Dakota, Black Hills. 
Reference
Sumber

Ellis, Thos. F. (McKillop, John, and)

Number

El Paso, see Texas.

El Paso tin deposits, see Texas.

Elsmore mine, see New South Wales, Inverell.

Elsner, L................................... 1485, 1486

Embabaan, see Swazlland.

Embickelweni, see Swaziland.

Emerald, see Association of tin with.

Emerald mines, see New South Wales, Emmaville.

Emmaville district, see New South Wales.

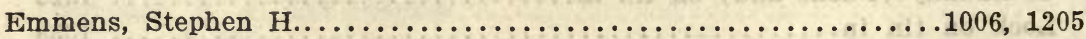

Emmons, S. F.................................... 270, 1206

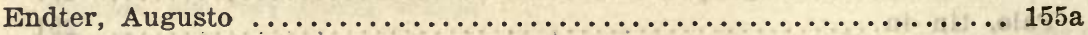

Engel, R...................................... 1488

England:

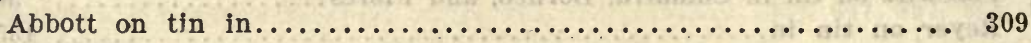

Baldauf on Redruth, Dolcoath, and East Pool mines.......... 331

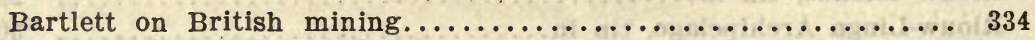

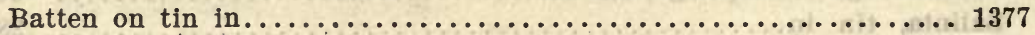

Bawden on dislocation of lodes and strata in $\ldots \ldots \ldots \ldots \ldots \ldots \ldots \ldots 335$

Beck on tin in .................................. 1299

Boase on tin of Botallack............................. 343

Botallack, tin of ................................... 343

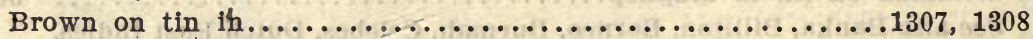

Bunter pebble bed, cassiterite in.$\ldots \ldots \ldots \ldots \ldots \ldots \ldots \ldots \ldots \ldots .468$

Burrows (Thomas and) on tin in....................... 475

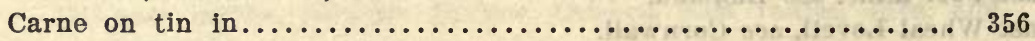

Carne on the Relistian mine........................ 352

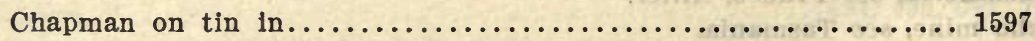

Collins on history of tin production in ................. 1385

Collins on "Jew's tin" in ......................... 362

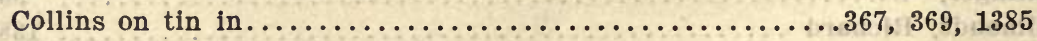

Collins on tin and gold at Treloy $\ldots \ldots \ldots \ldots \ldots \ldots \ldots \ldots \ldots \ldots \ldots . \ldots . \ldots$

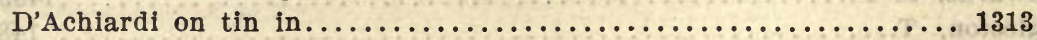

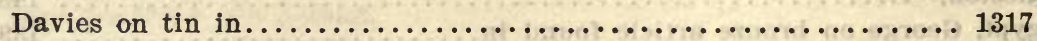

Dechen on tin in .................................. 545

De La Beche on tin in Cornwall, Devon, and Somerset......... 376

Dixon on tin in, see No. 448.

East Pool mine, tin in........................... 331

Edmons on causeway between Marazion and St. Michael's Mount, etc., 1389

English on British mining companies................. 379

English on tin mines of . . . . . . . . . . . . . . . . . . . 379

Falmouth Harbor, block of tin dredged in ............... 1398

Foster on the Rosewarne mine...................... 381

Foster on tin in Cornwall, Devon, and Somerset............ 382

Fowey Harbor, blocks of tin dredged from $\ldots \ldots \ldots \ldots \ldots \ldots \ldots . \ldots 1407$ 
England-Continued.

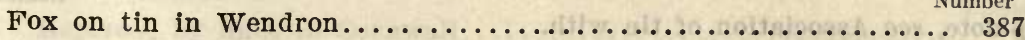

Geological Survey maps showing tin deposits................ 429

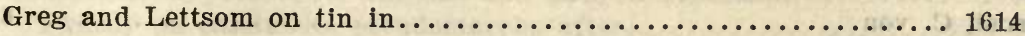

Gregor on muriate of tin from...................... 393

Hawkins on aliuviai strata at Porth, Sandrycock, and Pentuan.... 399

Hawkins on history of tin mines in................... 1396

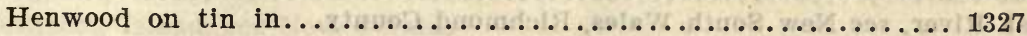

Hunt on mines of.............................. 1688

James on block of tin dredged in Falmouth Harbor............ 1398

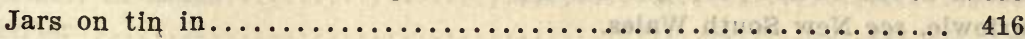

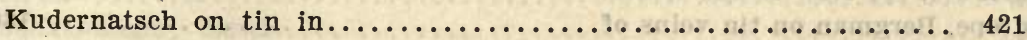

Lancashire, condition of manufacturing chemistry in .......... 1568

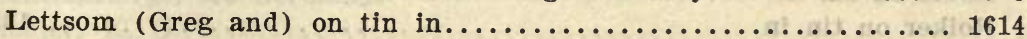

Lewis on history of tin mining in ...................... 1402

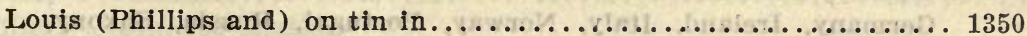

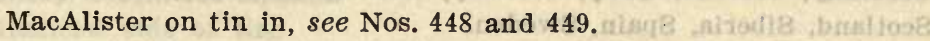

Pearce on blocks of tin dredged in Fowey Harbor............. 1407

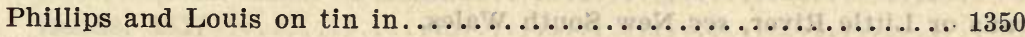

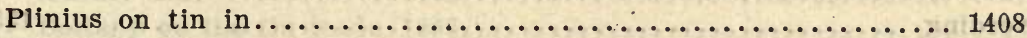

Pollard on tin in, see No. 448.

Porth, alluvial strata at.......................... 399

Pryce on minerals, mines, and mining of ................. 444

de Rance on stream tin in ......................... 446

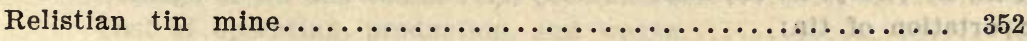

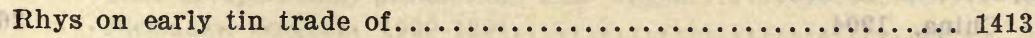

Rosewarne mine................................ 381

Rudler on minerals in British Isles................... 452

Sandrycock, alluvial strata at....................... 399

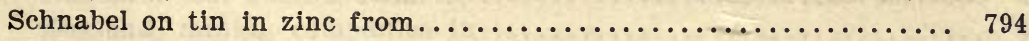

Schunck, Smith, and Roscoe on condition of manufacturing chemistry

in South Lancashire district........................ 1568

Smyth on occurrence of copper and tin in................ 457

Thomas on cassiterite in Bunter pebble bed in west of ......... 468

Thomas and Burrows on tin in....................... 475

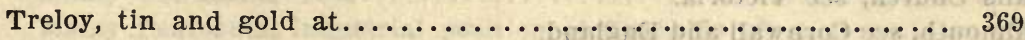

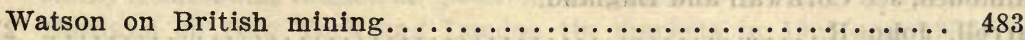

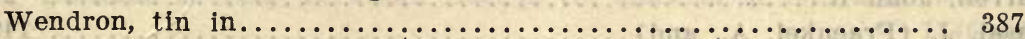

Wilkinson on tin in, see No. 448.

Woodward on a catalogue of fossils from ............... 489a

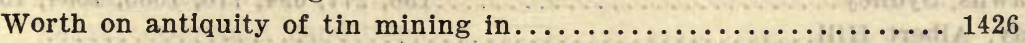

See also Cornwall, Devon, Europe, Great Britain, and Somerset.

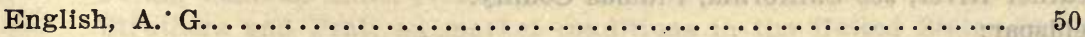

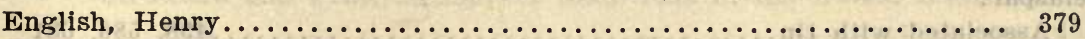

Enkeldoorn, see Transvaal.

Enterprise mine, see South Australia. 
Epidote, see Association of tin with.

Erea Dam, see South Australia.

Ernst, C. von.................................... 62

Erzgebirge, see Saxony.

Eschwege, W. von...

Eskdale, see Victoria, northeastern district.

Esk River, see New South Wales, Richmond County.

Etta mine, see South Dakota.

Eureka Creek district, see Queensland.

Eurlowie, see New South Wales.

Europe, Bergman on tin velns of ...................... 1302

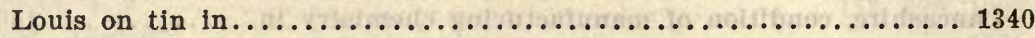

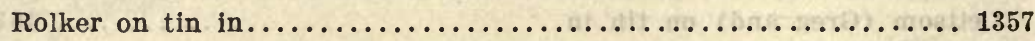

See Austria, Bohemia, Cornwall, Devon, England, Finland, France,

Germany, Ireland, Italy, Norway, Portugal, Russia, Saxony,

Scotland, Siberia, Spain, Sweden.

Euxinite, see Association of tin with.

Evans or Little River, see New South Wales.

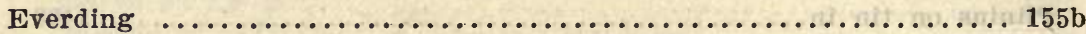

Everwijn, R.............................98, 289, 290, 291

Everwyn, R....................................... 288

Evigtok, see Greenland.

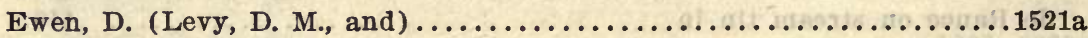

Exportation of tin:

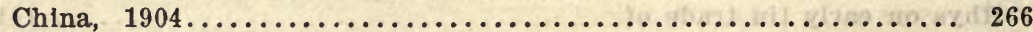

Indian Archipelago.............................. 282

Sumatra, Siak district......................... 305

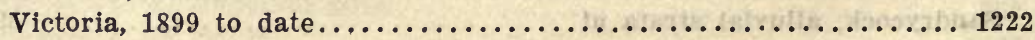

$\mathbf{F}$

Fairbanks, Harold W...................................... 216

Fairbanks region, sce Alaska.

Fairibault, E. Rodolphe.......................... 227

Falls Church, see Victoria.

Falmouth, see Cornwall and England.

Farrell, John R................................. 276

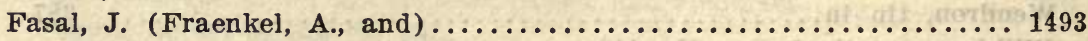

Fatigue of metals, Egleston on fatigue and refreshment of tin......... 1484

Fawns, Sydney ....................156, 277, 694, 770, 1083, 1084, 1320

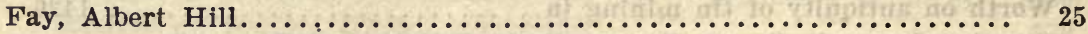

Feather River, see California, Plumas County.

Feldspar:

Associated with tin.

Cassiterite pseudomorphs after.............357,478, 479, 1603, 1638

Reid and Scrivenor on cassiterite pseudomorphs after.......... 1638 
Feldspar-Continued.

Replaced by $\mathrm{SnO}_{2}$ in Cornwall .... Number

Replaced in turn by tourmaline and $\mathrm{SnO}_{2}$ in Tasmania............1078a Tweedy on cassiterite pseudomorphs after.............478, 479 See also Association of tin with.

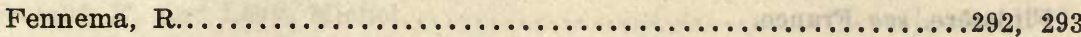

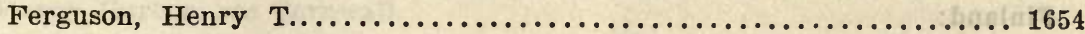

Ferguson Island, see New Guinea.

Fergusonite, see Association of tin with.

Fermor, L. Leigh................................ 590a

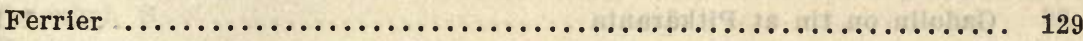

Feuchtwanger, Lewis............................... 1321

Fichtelgebirge, see Germany.

Fiedler, K. G.................................... 943

Field, Frederick.................................. 1607

Fillery Creek, see Alaska.

Financial side of tin:

Abbott on the mines of England....................... 309

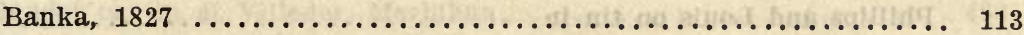

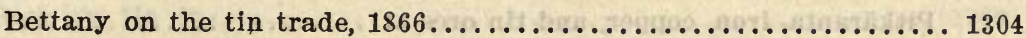

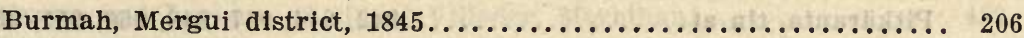

Burmah, Mergui district, $1889 \ldots \ldots \ldots \ldots \ldots \ldots \ldots \ldots \ldots \ldots \ldots . \ldots . \ldots . \ldots$

Cornwall:

Coinage of tin and commercial practices of .............. 351

Cost of operating, production, and wages............... 422

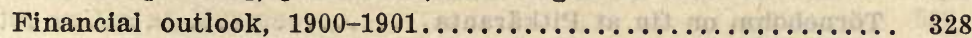

Profits derived from mines in ..................... 476

System of selling ore $\ln \ldots \ldots \ldots \ldots \ldots \ldots \ldots \ldots \ldots \ldots \ldots \ldots \ldots \ldots$

England, cost book system in ........................ 334

England, mining companies in ...................... 379

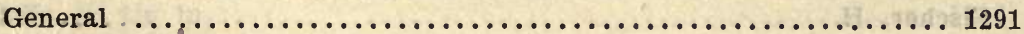

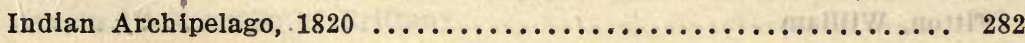

London tin market in 1902 and $1903 \ldots \ldots \ldots \ldots \ldots \ldots \ldots \ldots \ldots$ 1346, 1347

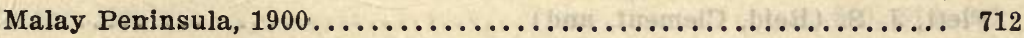

Malay Peninsula, $1903 \ldots \ldots \ldots \ldots \ldots \ldots \ldots \ldots \ldots \ldots \ldots \ldots \ldots \ldots$

Malay Peninsula, industrial position of tin fields of.......... 729

Newland on New York and London tin markets in 1902 and 1903 ,

New. York tin markets in 1902 and $1903 \ldots \ldots \ldots \ldots \ldots \ldots \ldots \ldots, 1346 \ldots \ldots \ldots \ldots \ldots \ldots$

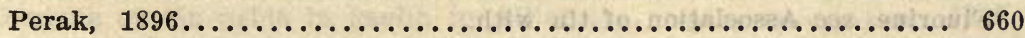

Perak, economic conditions.......................... 686

Perak, Tambun mine, profits, $1904 \ldots \ldots \ldots \ldots \ldots \ldots \ldots \ldots \ldots \ldots \ldots 670$

Struthers and Pratt on market conditions in the United States in

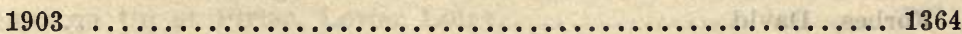

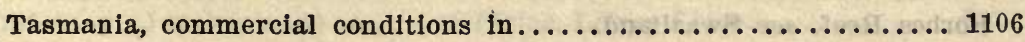

Tasmania, Mt. Bischoff, costs of mining in.........1083, 1102, 1105 
Financial side of tin-Continued.

Reference Number

Tasmania, Mt. Bischoff, dividends........................1121a

United States, imports, market conditions, and prices of tin in 1907.. 1211

United States, market condition in $1903 . \ldots \ldots \ldots \ldots \ldots \ldots \ldots \ldots . \ldots \ldots . \ldots \ldots$

United States, tin plate industry, prices, exports, etc.......... 1202

Finistère, see France.

Finland:

Borgström on tin at Pitkäranta...................... 1594

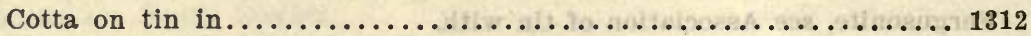

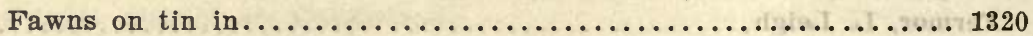

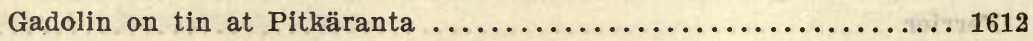

Gurney on tin at Pitkäranta, near Lake Ladoga................ 944

Keppen on tin in................................... 969

Koulibine on tin production of Pitkäranta, $1887-1889 \ldots \ldots \ldots .1691,1692$

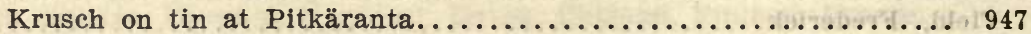

Ladoga (Lake) tin near........................... 949

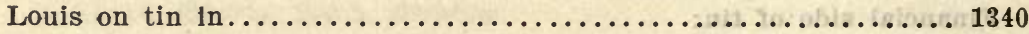

Nordenskiöld on tin in ........................... 1628a

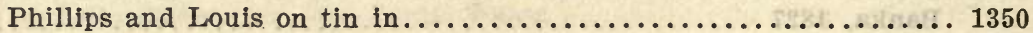

Pitkäranta, iron, copper, and tin ores at................ 953

Pitkäranta, tin at.............942, 944, 947, 948, 950, 951, 952, 953

Pusch on tin near Lake Ladoga and elsewhere in Finland........ 949

Schoultz-Ascheraden on tin at Pitkäranta............... 950

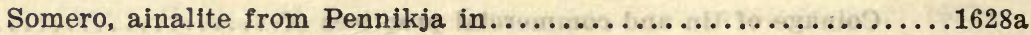

Struve on tin at Pitkäranta.......................... 951

Törnebohm on tin at Pitkäranta....................... 952

Trüstedt on iron, copper, and tin ores at Pitkäranta........... 953

Trüstedt on tin at Pitkäranta....................... 953

See Russia and Europe.

Fircks, F. W. von.................................... 1085

Fischer, H......................................... 961

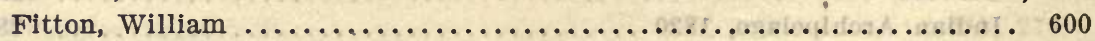

Flett, J. S.................................. 380

Flett, J. S. (Reid, Clement, and) ..................... 448

Flett, J. S., and Clough, C. T......................... 955

Flink, Gust..................................... 582

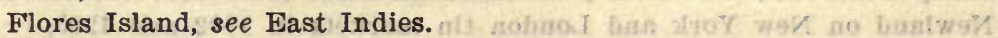

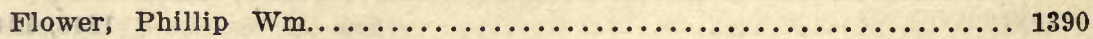

Flower-Ellis, T. J............................ 1489

Fluorine, see Association of tin with.

Fluorite, see Association of tin with.

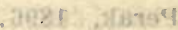

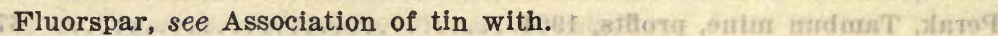

Foniakoff, Antonin . .............................965, 966

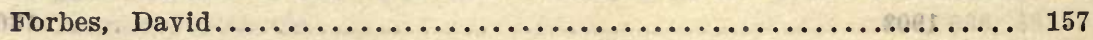

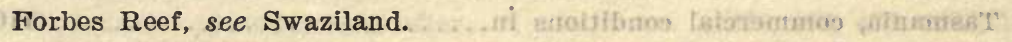

Foss, K. Mackenzie................................ 188

Fossilbrook, see Queensland. 
1.7ky

Foster, C. Le Neve .................... 381, 382, 383, 384, 385, 386, 1608

Foster, C. Le Neve (Rowe, T. P., and) ................... 451

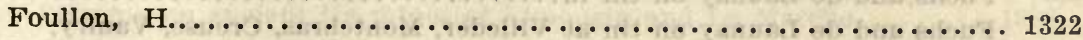

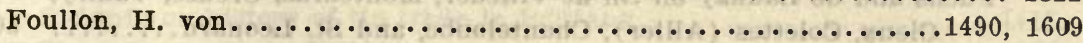

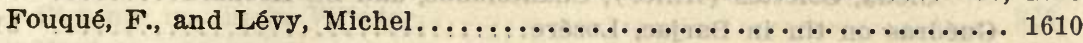

Fowey Harbor, see Cornwall.

Fox, Charles.................................... 387

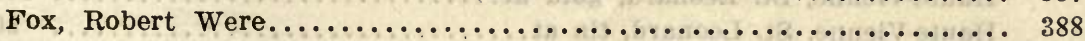

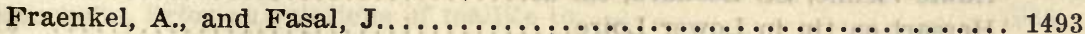

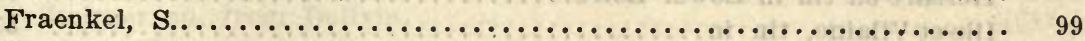

France:

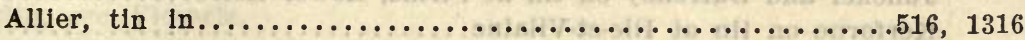

Allier, Colettes, tin at............................ 510

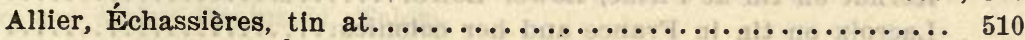

Allier, Lizolle and Échassières, tin with kaolin at............ 504

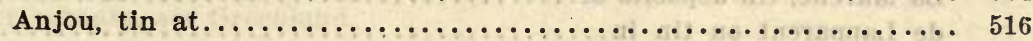

Audibert on tin veins of Maupas, Morbihan.............. 497

Baudot on tin at Villeder, Morblhan.................... 498

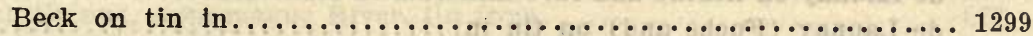

Blavier and Lorieux on tin at Villeder, Morbihan ............ 499

Bourbonne, tin in an altered lead at..................... 1316

Brittany:

History of tin trade in ....................... 1416

Tin deposits of . ....................... 501, 508, 516

Burthe on tin at Meymac......................... 500

Chanteloube, tin at.............................. 509

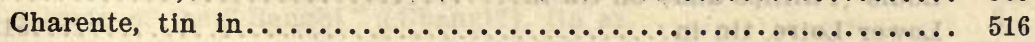

Cieux, tin at................................. 509

Corrèze $($ Meymac), tin in . .,........................ 516

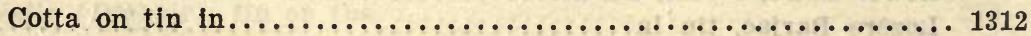

Cotta on tin deposits of Brittany..................... 501

Cressac on tin in ................................... 503

Creuse, tin in ............................... 509, 516, 522

$D$, C. H., on ancient tin mines of Limousin and La

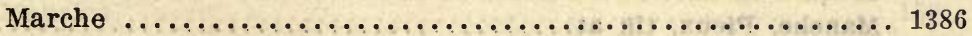

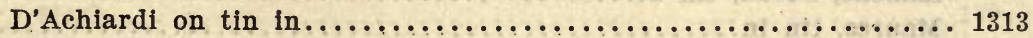

Daubrée on occurrence of tin ore in.................... 1314

Daubrée on tin in an altered lead at Bourbonne.............. 1316

Daubrée on tin oxide in kaolin in Allier................. 1316

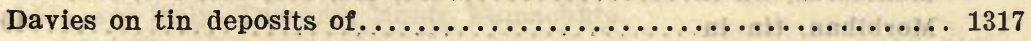

Davy on tin between Abbaretz and Vay in Lower Loire.......... 505

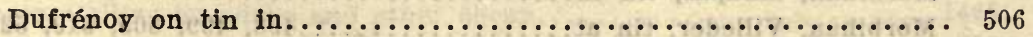

Dufrénoy on tin at Piriac, Lower Loire................ 507

Dufrénoy (Juncker and) on tin at Pirlac, Lower Loire......... 513

Durocher on tin in Brittany........................ 508

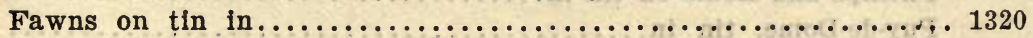


France-Continued.

Reference Number

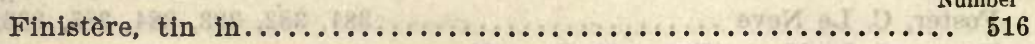

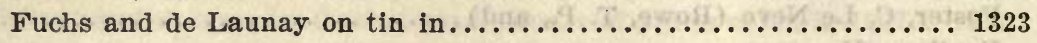

Fuchs and de Launay on tin at Villeder, Montebras, Creuse, Vaulry,

Cieux, Colettes (Allier), Chanteloube, and St. Leonard...... 509

Guédras on tín in Barjac, Lozére.................... 511

Haute-Vienne, tin in .............................. 516

Haute-Vienne, St. Leonard, gold at.................... 1406

Haute-Vienne, St. Leonard, tin at..................... 509

Hersart on tin in Lower Loire....................... 512

Ille-et-Vilaine, $\operatorname{tin}$ in ........................... 514

Juncker and Dufrénoy on tin at Piriac, Lower Loire......... 513

Kerforne on tin at Ille-et-Vilaine...................... 514

Kerndt on tin at Piriac, Lower Loire.................... 515

Lacrolx on tin in France and her colonies................ 516

La Marche, tin deposits of...................523, 1386, 1406

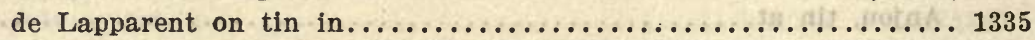

Lassalle on tin in Montebras........................ 517

de Launay on lithine and rare minerals in Montebras............ 518

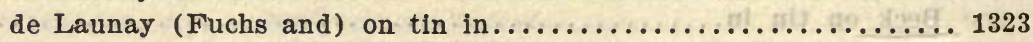

Limousin, tin in .............................. 523

Limousin, working of ancient tin mines in...............1386, 1406

de Limur on tin in Villeder.......................... 519

Lodin on tin in Pontgibaud, Puy-de-Dome................. 521

Lodin on tin in Villeder.......................... 520

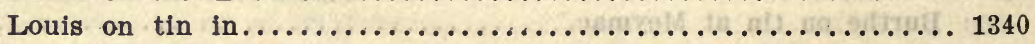

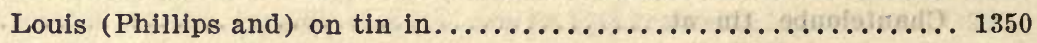

Lower Loire, $\operatorname{tin}$ in................................ 516

Lower Loire, Abbaretz and Vay, tin between............... 505

Lower Loire, Piriac, tin at.................... 507, 513, 515

Lozère Barjac, tin in ............................ 511

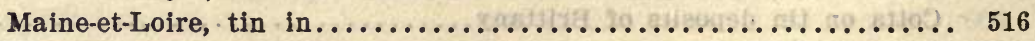

Mallard on tin at Montebras........................ 522

Mallard on tin deposits of Limousin, La Marche, and Vaulry....... 523

Mallard on ancient tin mines of Limousin and La Marche........ 1386

Manche, Pleux, tin at.............................. 491

Maures, tin in ................................ 516

Mazade on the minerals in the mineral waters of Neyrac......... 524

Meymac, tin at................................500, 516

Montebras, tin in ............494,496, 509, 517, 518, 522, 1289, 1406

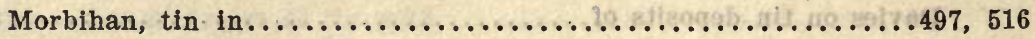

Morbihan, Maupas, tin in.......................... 497

Morbihan, Villeder, tin at............498, 499, 509, 519, 520, 526

Neyrac, tin at................................ 524

Pattison on ancient tin mines of Limousin and La Marche......... 1406

Phillips and Louis on tin in ......................... 1350

Puy-de-Dome, tin in ........................... 516 
France-Continued.

Puy-de-Dome, Pontgibaud, tin at.......................... 521

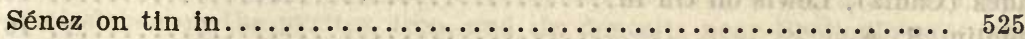

Simonin on ancient tin mines of Limousin and La Marche....... 1386

Simonin on history of tin trade in Brittany................ 1416

Simonin on tin in Villeder.......................... 526

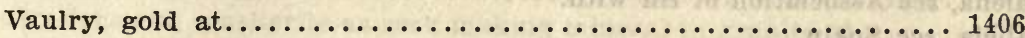

Vaulry, tin near.....................495, 509, 523, 1406

See also Europe.

Franckeite, Prior on relations of teallite to.................. 1636

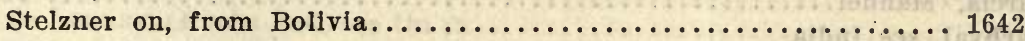

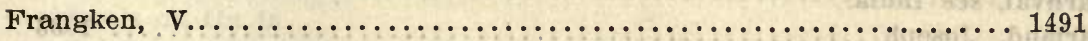

Franklin, see Victoria.

Franklin Mountains, see Texas.

Fraser, see Malay Peninsula, Telom.

Frecheville, R. J............................. 399, 1655

Frederikshaabs, see Greenland.

Freiberg, see Germany.

Freiesleben, J. C................................. 547

French Guiana, Approuague River, tin from................ 527

Damour on tin on the Approuague River.............. 527

See also South America.

French Kongo:

Barrat on tin in the Crystal Mountains................. 272

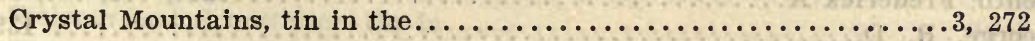

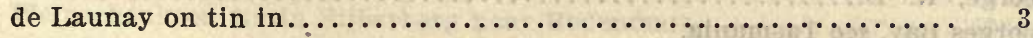

"Massinga or Massinda" (Masinde?) north of "Agapota" in the

basin of the "Banghi" (Ubangi?), tin at................ 3

Stanier on tin on the Ubangi and Welle (Djabbir) .......... 279

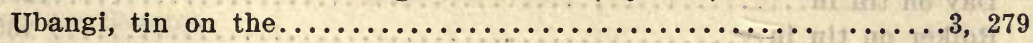

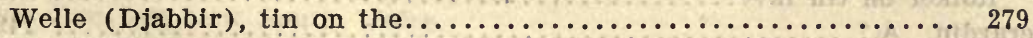

Welle Makwa, tin on the........................... 3

See also Kongo and Africa.

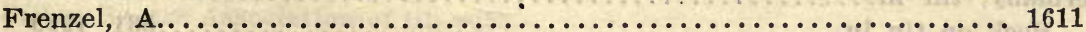

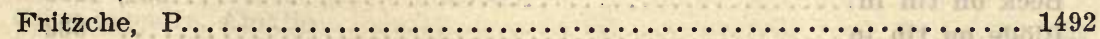

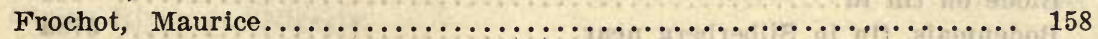

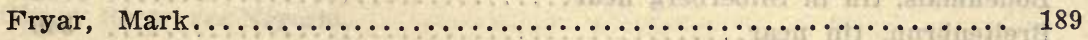

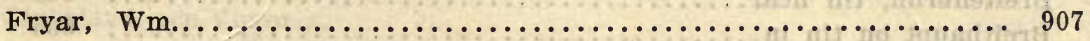

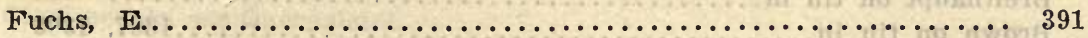

Fuchs, E., and de Launay, L...................... 159, 509, 1323

Fumachhio, see Italy, Tuscany, Monte Fumachhio.

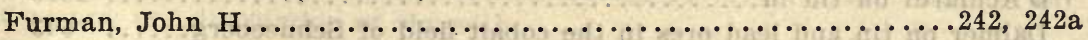

Furnaces, Collins on adobe and other cheap.................... 1468

Lesley on furnaces, forges, and rolling mills of the United States... 793

Used in roasting tin and copper ores in Cornwall.............. 1656

See also Metallurgy of tin. 


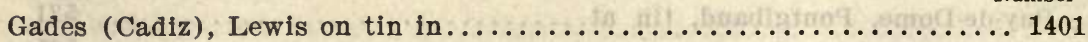

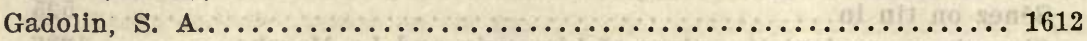

Gadolinite, see Association of tin with.

Galæcia, see Spain.

Galena, see Association of tin with.

Galicia, see Spain.

Gallofa lode, see Bolivia.

Garby, John.

Garcia, Manuel.................................. 1032

Garhval, see India.

Garland, Joseph

Garnet, see Association of tin with.

Garrison, F. Lynwood......................217, 243, 1007, 1207

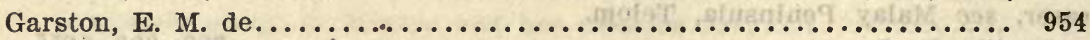

Gascuel, L.................................... 643

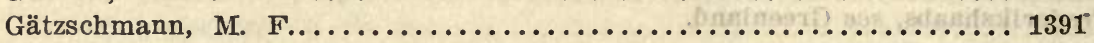

Gauls, ancient mines believed to have been worked by ..........1386, 1406

Gaultier de Claubry, H. F............................ 1494

Gautier, Ferdinand............................. 160

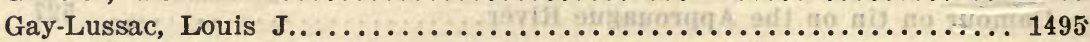

Gayndah district, see Queensland.

Gem minerals, see Association of tin with.

Genth, Frederick A..........................244, 771, 787, 820

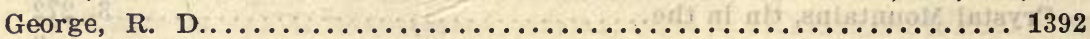

Georges Bay, see Tasmania.

Georges River, see Tasmania.

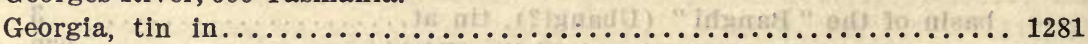

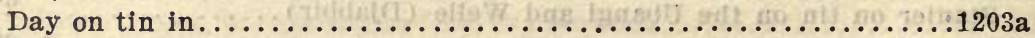

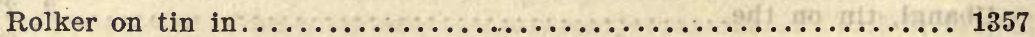

Gerardin, A.?................................. 1496

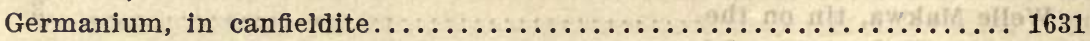

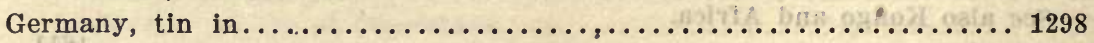

Beck on tin in................................. 1299

Blöde on tin in ................................. 533

Bodenmais, tin in Silberberg near................... $578 \mathrm{a}$

Breitenbrun, tin near........................... 546

Breithaupt on tin in ............................ 535

Brown on tin in.......................................... 1308

Cotta on tin deposits of.............................. 1312

D'Achiardi on tin in .............................. 1313

Dalmer on tin and lead ores in the cobalt field of Schneeberg..... 543

Davies on tin in ................................... 1317

Dechen on tin deposits of $. \ldots \ldots \ldots \ldots \ldots \ldots \ldots \ldots \ldots \ldots \ldots \ldots \ldots . \ldots \ldots \ldots$

Dorfhain, tin near............................... 559

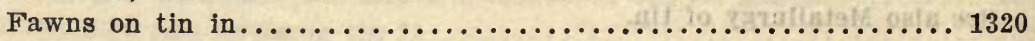


Germany-Continued.

Fichtelgebirge, tin in the................................ 571

Frelesleben on the pyrites, iron, and tin deposits near Breitenbrunn 546

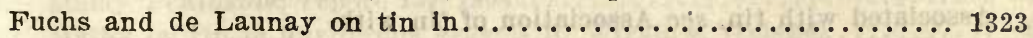

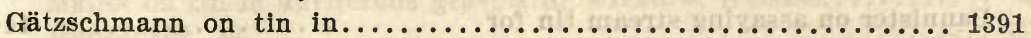

Gmelin on geology of............................ 548

Greifensteln, cassiterite as rock making mineral in granite of...... 1639

Jars on tin in................................ 416

Klaproth on chemical examination of tin ore from ............ 1513

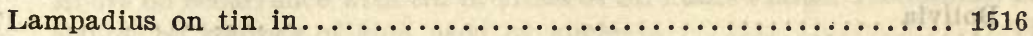

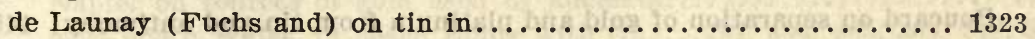

Louis on tin in ................................ 1340

Louis on German process of smelting tin................ 1523

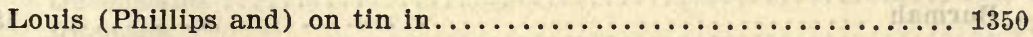

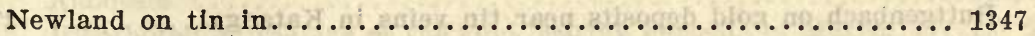

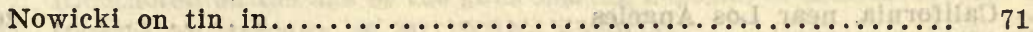

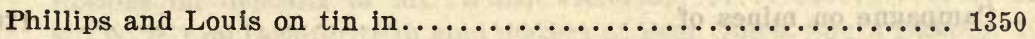

Sandberger on the origin of tin deposits of . ............... 569

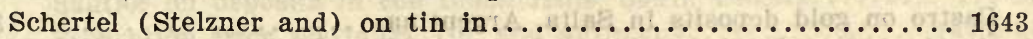

Schmidt on tin in the Fichtelgebirge.................. 570,571

Scrap tin recovered and used in .................1438, 1497a, 1511

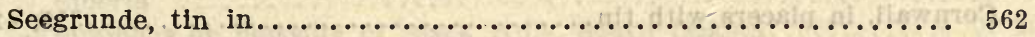

Selffen, tin near............................... 559

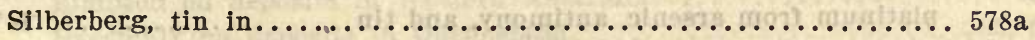

Stelzner and Schertel on tin in ........................ 1643

Weinschenk on tin in Silberberg near Bodenmais............ 578a

See also Saxony and Europe.

Germo, see Cornwall.

Gertie property, see South Dakota.

Geyer, see Saxøny.

Giants Den, see New South Wales.

Gibson, Walcott................................... 2

Giesecke, K. L.................................... 583

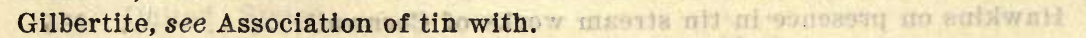

Gil y Maestre, Amalio............................... 1034

Gimpu River, see Nigeria.

Gimpy River, see Nigeria.

Gippsland, see Victoria.

Glenlinedale, see Queensland.

Gladstone district, see Tasmania.

Glasser, E.................................... 967

Glycium, see Association of tin with.

Gmehlin, J. F.................................. 548

Gmehling, Andreas................................ 1497

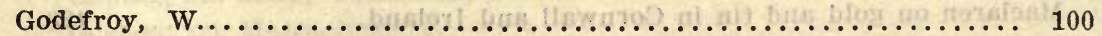

Godfrey, J. G. H............................... 631

Godhavn district, see Greenland. 
Gold:

Reference Number

Andrews on deposits at Table Top, Timbarra, New South Wales.... 797

Argentina, Salta............................ 37

Associated with tin, see Association of tin with.

Bannister on assaying stream tin for.................... 1444

Bechamp and Saintpierre on separation of gold and platinum from

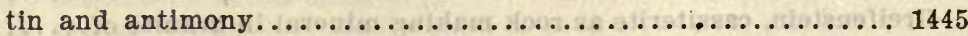

Becher on gold bearing formations of the Malay Peninsula...... 678

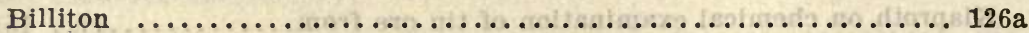

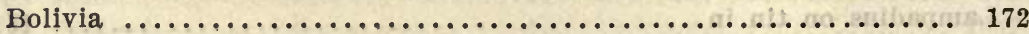

Boucard on separation of gold and platinum from tin and antimony. 1455

Brache on mining at Eldorado, Victoria.................. 1224

Brown on discovery of, in South Australia............... 974

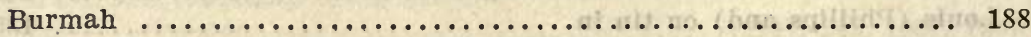

Buttgenbach on gold deposits near tin veins in Katanga......... 275

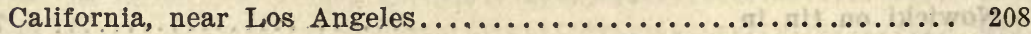

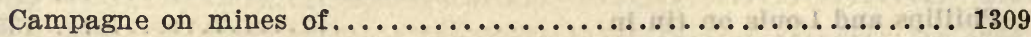

Carne on source of gold and tin in beach sands of New South Wales.. 809

Castro on gold deposits in Salta, Argentina............... 37

Clarke on researches in gold fields of New South Wales.......... 812

Collins on occurrence with tin in west of England............ 369

Cornwall, in placers with tin.................................. 428

de Koninch and Lecrenier on the qualltative separation of gold and

platinum from arsenic, antimony, and tin............. 1474

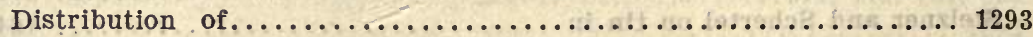

Douglas on metallurgy of ......................... 1204

Eddy on placer deposits in South Gippsland, Victoria, carrying both

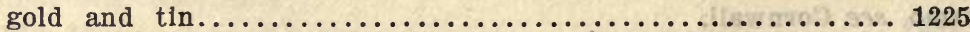

Elsner on the separation of gold and platinum from tin and arsenic. 1486

Emmions on occurrence in United States and genesis of minerals of. 1206

England, with stream tin.......................... 369

English on deposits of tin and gold near Ovens, Victoria......... 50

Foniakoff on deposits in Siberia...................... 965

Hawkins on presence in tin stream works of Cornwall.......... 395

Hawkins on superficial production of .................... 1330

Herman on occurrence near Bruthen, Victoria............... 1228

Hermann on tin in gold washings of the Ural (Central Asia) ...... 40

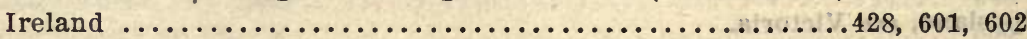

Ireland, Wicklow .........................599, 600, 605, 607

Johnson on "getting gold"............................ 51

Kinahan on occurrence and mining of, in Ireland............601, 602

Kitson on deposits in Victoria......................... 1229

Kongo, Katanga, gold and tin deposits close together........... 275

Lapage on deposits in Western Australia.................. 1259

Maclaren on gold and tin in Cornwall and Ireland............ 428

Malay Peninsula........................659, 678, 693, 728 
Gold-Continued.

Malay Peninsula, auriferous gravels in ................. 659

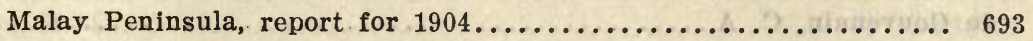

Mallet on tin in auriferous gravels in Wicklow, Ireland........ 605

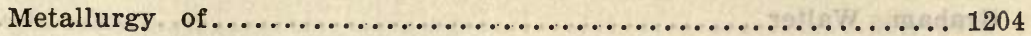

Mexico, age of deposits.......................... 783

Mingaye on occurrence in beach sands in New South Wales....... 831

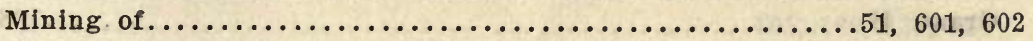

Moore on occurrence with tin in killas of St. Pauls Plains, Tasmania. 1114

Napler on sources of gold used by ancients................ 1405

New South Wales, in beach sands with tin...797, 804, 805, 809, 812, 831

Origin of minerals of ........................... 1206

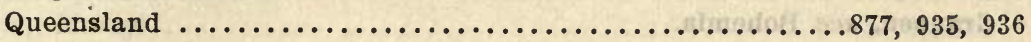

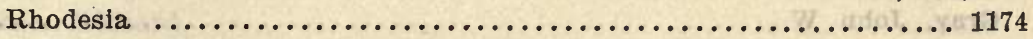

Richthofen on the age of the gold bearing deposits of Mexico...... 783

Rosales on deposits of Mt. Wills, Victoria................ 1234

S. (W. H.) on cassiterite in gold placers of Bear Gulch, South Dakota. 1015

Sadtler on deposits in the Black Hills, South Dakota.......... 1016

Separation from platinum, tin, and antimony............1445, 1455

Separation from platinum, tin, arsenic, and antimony $\ldots . . .1474,1486$

Siberia ..................................... 965

Simmons on deposits in Black Hills, South Dakota............. 1018

Simpson on deposits in Western Australla................. 1267

Skertchly on deposits in Queensland ....................... 936

Smith on tin in gold works in Wicklow County, Ireland........ 607

South Africa ................................ 3c

South Australia................................ 974

South Dakota.......................980, 1015, 1016, 1018

South Dakota, Nigger Hill district, cassiterite in gold placers..... 980

Stephens on tin and gold ores of Pahang, Malay Peninsula....... 728

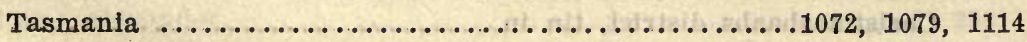

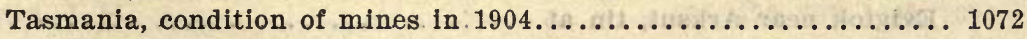

United States................................... 1206

Ural (Central Asia), tin said to occur in gold placers........... 40

Victoria, cassiterite in gold placers.......50, 1224, 1225, 1228, 1229, 1234

Voit on deposits of, in South Africa................. 3c

Western Australla................................. 1267

Goldmine River, see.Ireland.

Goldschmidt, . K...................................1497a

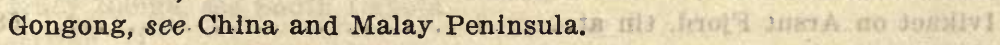

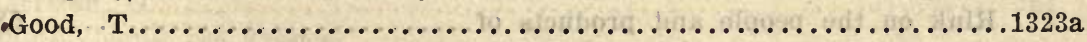

Goonbarrow mine, see Cornwall.

Goping, see Malay Peninsula, Perak.

Goshen, see Massachusetts.

Götting, A. 


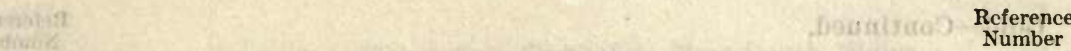

Gould, Chas......................................... 1086

de Gouvenain, C. A............................. 510

Gower, George H............................ 821, 822, 823, 824

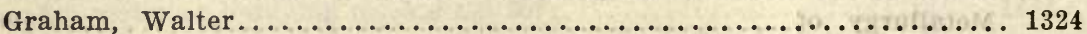

Grain tin, preparation of in Cornwall and Devon.............. 1576

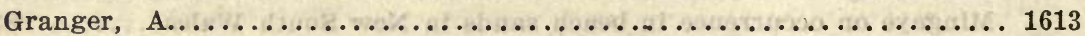

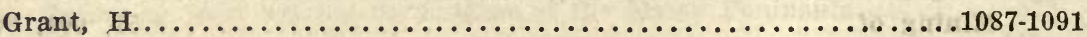

Graphite, Voit on deposits of, in South Africa............... 3c

See Association of tin with.

Graphite City, see Quebec.

Graton, L. C.......................................... 246

Graupen, see Bohemia.

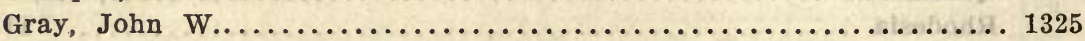

Great Britain, tin in....................1287, 1289, 1290, 1292

Hunt on mineral statistics, $1853-1906 \ldots \ldots \ldots \ldots \ldots \ldots \ldots \ldots \ldots . \ldots \ldots 8$

Newland on tin in ................................... 1347

See also England, Ireland, Scotland, and Europe.

Greathead, Samuel................................ 1393

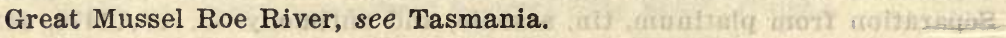

Great Vor district, see Cornwall.

Great Work mine, see Cornwall.

Greece, Borlese on early tin trade of...................... 1382

Greece, Fischer on crocidolite quartz in.................... 39

Greenbushes, see Western Australia.

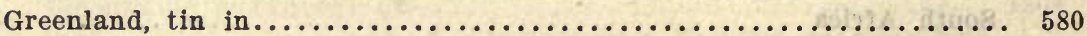

Tin in Laurentian rocks of .......................... 224

Allen on minerals in ............................... 579

Arsuk (Arsut) Fjord, tin on ............................. 584

Boggild on tin in $\ldots \ldots \ldots \ldots \ldots \ldots \ldots \ldots \ldots \ldots \ldots \ldots \ldots \ldots \ldots \ldots . \ldots \ldots 1$

Christianshaabs district, tin in...................... 583

Evigtok near Arksut, tin at....................... 586

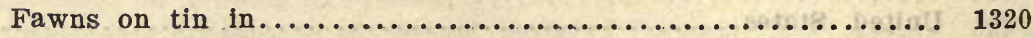

Flink on tin in southern part..................... 582

Frederikshaabs, minerals near.....................580, 583

Giesecke on tin in the Christianshaabs, Frederickshaabs, and God-

havn districts.............................. 583

Godhavn district, tin at Itivdliarsuk ................. 583

Hoff on tin at Ivikaet on Arsut Fjord.................. 584

Ivikaet on Arsut Fjord, tin at...................... 584

Rink on the people and products of .................. 585

Tayler on tin at Evigtok near Arksut................... 586

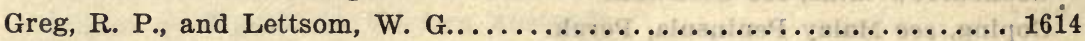

Gregor, William.................................. 1498

Gregory, J. W....................................... 1226 


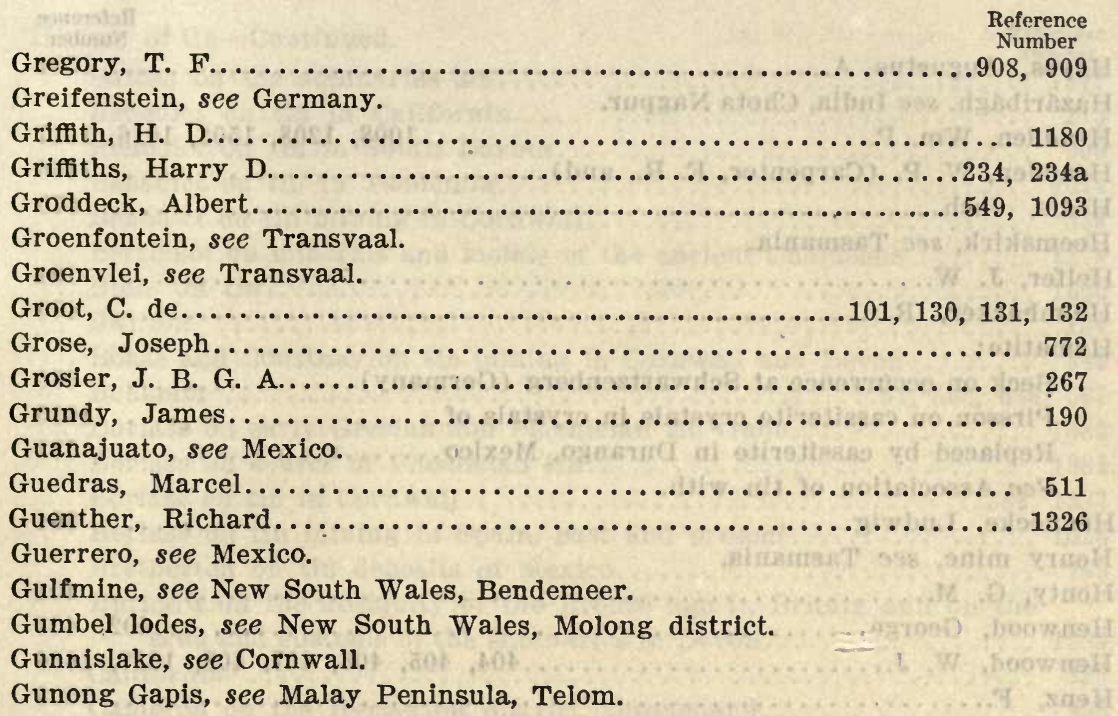

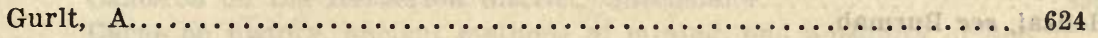

Gurney, H. P........................................ 944

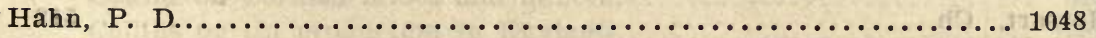

Haldane, A. C.................................... 911 Half Moon Bay, see New Zealand, Stewart Island.

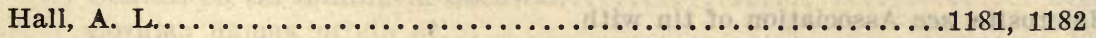

Hallwich, H....................................... 550

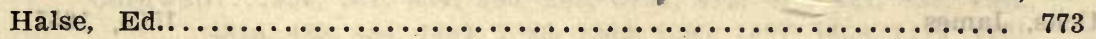

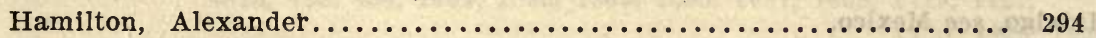

Hampton, J. H......................695, 696, 697, 1049, 1094

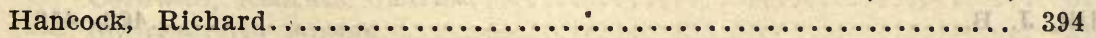

Hanks, H. G................................. 774, 1394

Happy Union mine, see Cornwall, Pentuan.

Harcourt-Smith, J.............................1095, 1095a Hardhead, Levy and Ewen on the bessemerizing of.....................

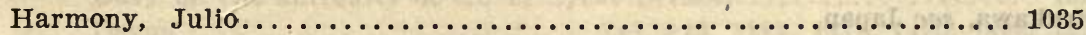
Harney Peak mine, see South Dakota.

Harney Range, see South Dakota.

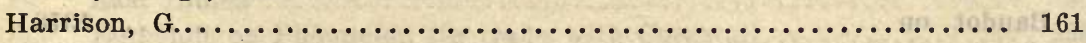

Haute-Vienne, see France.

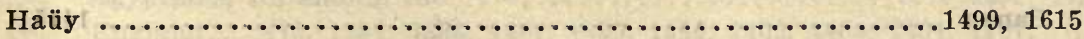

Hawkins, C......................................... 1395

Hawkins, John....................396, 397, 398, 399, 1396, 1500 


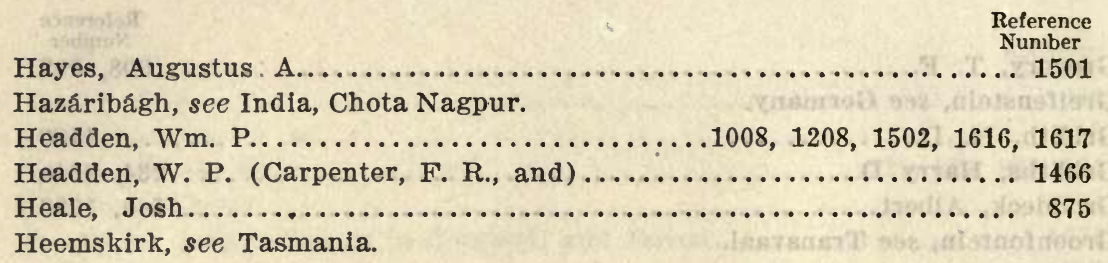

Helfer, J. W................................. 191

Helmhacker, R................................. 400

Hematite:

Beck on occurrence at Schwartzenberg (Germany) ........... 530

Pirsson on cassiterite crystals in crystals of ................ 1635

Replaced by cassiterite in Durango, Mexico................ 771

See Association of tin with.

Hennecke, Ludwig............................. 864

Henry mine, see Tasmania.

Henty, G. M................................... 401

Henwood, George...............................402, 403

Henwood, W. J.................404, 405, 406, 407, 408, 1327, 1656

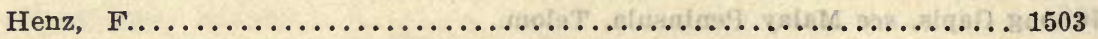

Henzal, see Burmah.

Herberton district, see Queensiand.

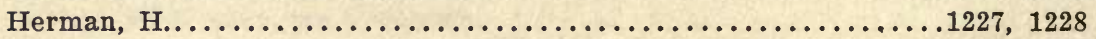

Herman, R.......................................... 968

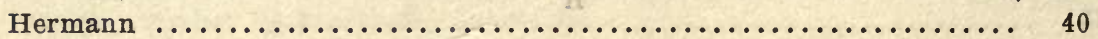

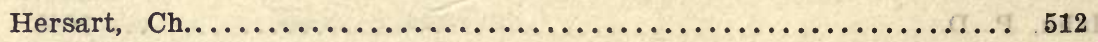

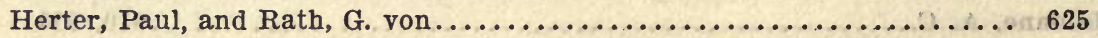

Hess, Frank L...............26, 27, 247, 1009, 1209-1211, 1328, 1329

Heterosite, see Association of tin with.

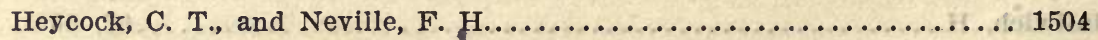

Hicks, James........................................ 1657

Hidalgo, see Mexico.

Higuei, see Santo Domingo.

Hill, J. B...................................4 409, 410

Hill, J. B., and MacAlister, D. A....................... 411

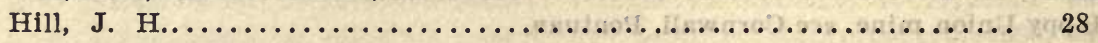

Hin-boun, see Siam, Laos.

Hiortdahl, F. H...............................................

Hirukawa, see Japan.

History of tin:

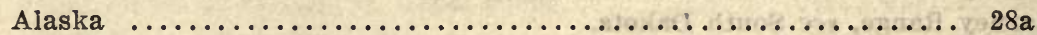

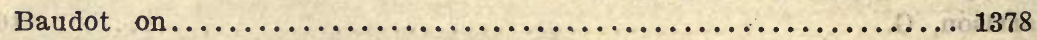

Baudot on mines of Villeder, Morbihan, France.............. 498

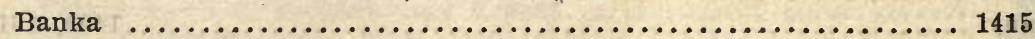

Banka, history of mining methods..................... 74

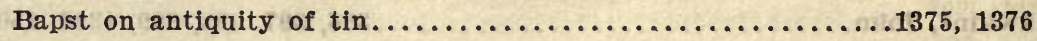


History of tin-Continued.

Batten on the stannaries act...................... 1377

Benedict on tin in California......................... 213

Benedict on tin in . South Dakota.................... 990

Benedict on tin in Tasmania........................... 1074

Benedict on tin mining in Cornwall.................... 336

Berthelot on minerals and metals of the ancient Chaldeans....... 1379

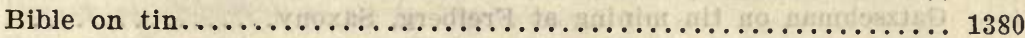

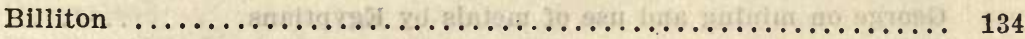

Boase and Courtney on tin mining in Cornwall and Devon........ 342

Bohemia ...........................67, 565, 566, 567

Borlase on early Grecian and Phœnician tin trade............. 1382

Boriase on source of Phœnician tin.................... 1381

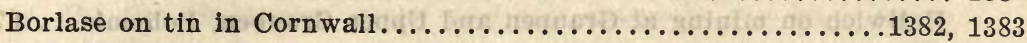

Borlase on tin mining in Spain, past and present............. 1028

Bretherton on tin deposits of Mexico.................... 765

Burnard on the antiquity of the Bronze age in Britain and on the

laws and customs of the stannaries in Devon.............. 1384

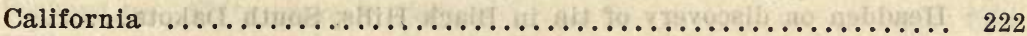

Cameron on the Herberton district, Queensland.............. 895

Carne on history, ancient methods of mining, and antiquity of dig-

gings in Cornwall................................. 355

Chaldeans, tin among the........................... 1379

Collett on tin in Malay Peninsula...................... 681

Collins on Cornish mines and miners.................... 368

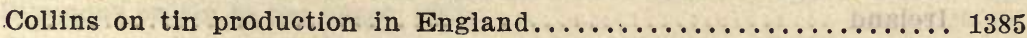

Conder on tin mining in Tasmania.................... 1078

Conran on tin mining in Cornwall..................... 370a

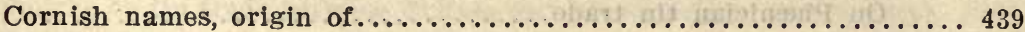

Cornwall...336, 342, 354, 355, 368, 370a, 412, 413, 427, 439, 450a, $481 \mathrm{a}, 482,484,1382,1383,1389,1395,1397,1409,1419,1421$,

Cornwall, Redruth district....................... 313

Cornwall tin mining............................. 310

Crawfurd on the Indian Archipelago.................... 282

$\mathrm{D}$

Davies on antiquity of tin mining.................... 1317

Davy on the antiquity of tin in Great Britain............... 1387

Devon......................342, 413, 1384, 1419, 1425, 1426, 1427

Dufrené on the production and commerce of tin............. 1388

East Indies .................................... 305

Edmonds on Phœenician tin trade with Cornwall............... 1389

Egyptians, tin among the.......................1392, 1424

England....415, 1384, 1385, 1387, 1395, 1396, 1402, 1403, 1404, 1407,

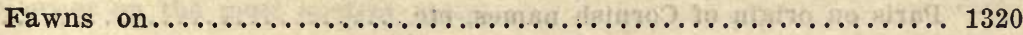


History of tin-Continued.

Reference

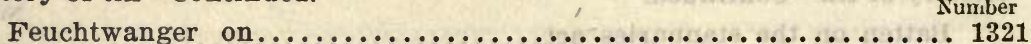

Fiower on the tin plate trađe....................... 1390

France $\ldots \ldots \ldots \ldots \ldots \ldots \ldots \ldots \ldots \ldots \ldots \ldots \ldots . \ldots . \ldots . \ldots . \ldots \ldots, 1386,1406,1416$

Freiesleben on the mines of Germany................. 547

Furman on discovery of tin in North Carolina............242, 242a

Garrison on tin in the United States.................... 1207

Gatzschman on tin mining at Freiberg, Saxony.............. 1391

George on mining and use of metais by Egyptians............ 1392

Germany .......................... $547,550,564,570,571$

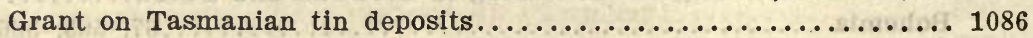

Greathead on sources and uses of tin among ancients........... 1393

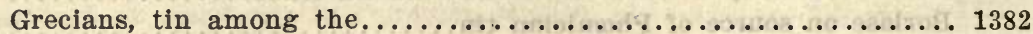

Hallwich on mining at Graupen and Upper Graupen, Bohemia...67, 550

Hamilton on discovery of tin in Sumatra................. 294

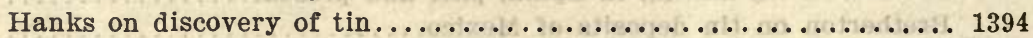

Hawkins on ancient tin trade in Cornwall................ 1395

On tin mines of England......................... 1396

Headden on discovery of tin in Black Hills, South Dakota........ 1008

Hill on York tin mines, Seward Peninsula, Alaska............ 28a

Hunt on British mining......................... 415

On tin trade in Cornwail and Devon.................. 413

On tin and copper production in Cornwall.............. 412

On traditions and history of Cornish tin mining......... 1397

Indian Archipelago .............................. 282

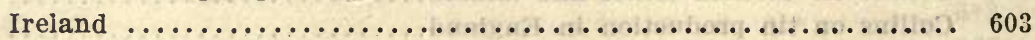

Italy, discovery of tin, and antiquity of bronze in ........... 611

James on the Ictis of Diodorus...................... 1398

On Phœuician tin trade......................... 1399

Kayser on tin mining in Tasmania..................... 1100

Kenrick on Phœnician tin trade....................... 1400

Kinahan on antiquity of tin in Ireland................ 603

Lakes on history, uses, and sources of tin................. 1334a

Lew is on the English tin miner..................... 1402

Lewis on sources of Phœnician tin ..................... 1401

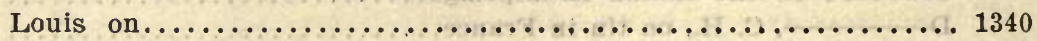

MacAlister on Cornish mines.......................... 427

Maclean on the stannary roli......................... 1403

Maclean on tin coined in England between 1305 and $1607 \ldots \ldots \ldots .1404$

Malay Peninsula .............................681, 747

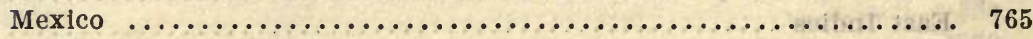

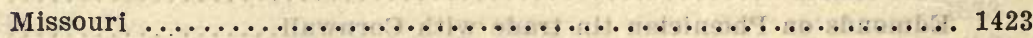

New South Wales, discovery of tin in ..................798, 802

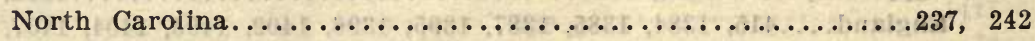

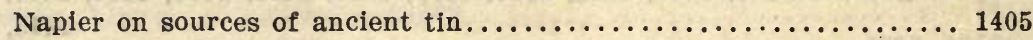

Paris on origin of Cornish names, etc................. 439 
History of tin-Continued.

Reference Pattison on antiquity of tin in France................ 1406

Pearce on ancient tin blocks found in Fowey Harbor............. 1407 Phœnicians.......744, 1381, 1382, 1389, 1399, 1400, 1401, 1410, 1414, 1418

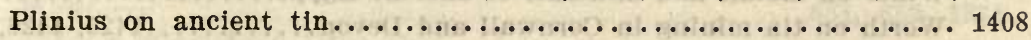

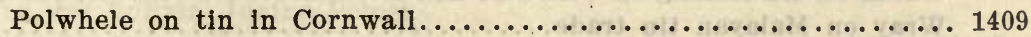
Posewitz on discovery of tin in Billiton.................... 134 Praagh on discovery of tin in Transvaal................. 1186 Queensland .................................... 934 Ranft on Mt. Bischoff mine, Tasmania................... 1122 Rawlinson on Phœnician tin trade..................... 1410

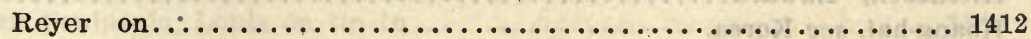

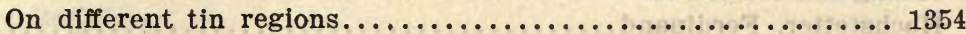

On the tin-bearing rocks and tin works in the Erzgebirge,

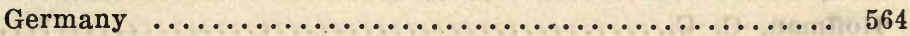

On tin between 1800 B. C. and A. D. $1873 \ldots \ldots \ldots \ldots \ldots \ldots \ldots 1411$

On tin mining in Bohemia and Saxony.............. 565,56

Rhys on early Britain, Celtic Britain.................... 1413

Rickard on "Fifty years in Cornwall".................. 450a

Rolker on tin mining in the East Indies.................. 305

Saunders on sources of Phœnician tin.................. 1414

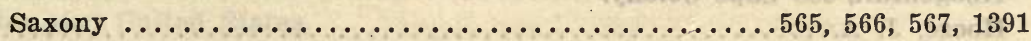

Schmidt on tin in the Fichtelgebirge................ 570,571

Schultz on history of the use of tin.................... 1359

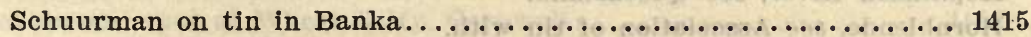

Simmons on tin in the Black Hills.................. 1019a

Simonin on tin mines in Brittany.................... 1416

Skertchly on the Herberton district, Queensland............. 934

Smirke on tin trade between Britain and Alexandria in 17th century, 1417

Smith on source of early Phœnician tin.................. 1418

South Dakota........................990, 1008, 1019a, 1192

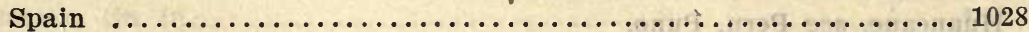

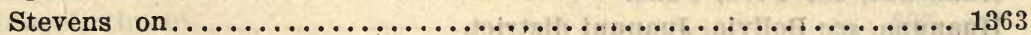

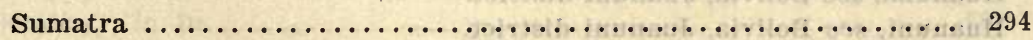

Tasmania..................1074, 1078, 1086, 1100, 1122, 1158a

Taylor on "Iktis" and on copper, iron, and tin . . . . . . . . 1420

Taylor on mining in Cornwall and Devon................ 1419

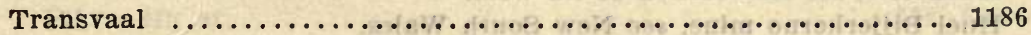

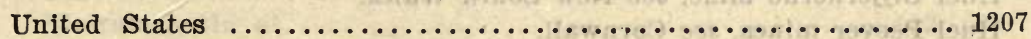

Vivian on tin and copper mining in Cornwall...............481a

Wait on history of tin in Cornwall.................... 482

Ward on tin field of North Dundas, Tasmania............. 1158a

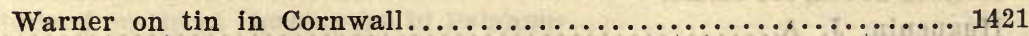

Webb and Geach on Caradon and Liskeard district of Cornwall.... 484

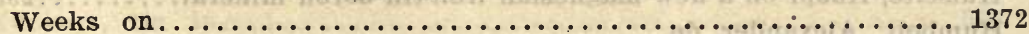

Werner on the most ancient metal..................... 1422 
History of tin-Continued.

Reference Number

West on Temescal mines, California..................... 222

Wheeler on tin mining fraud in Missouri................. 1423

Winer on metals and minerals of ancient Egypt.............. 1424

Worth on tin mining in Cornwall and Devon..........1425, 1426, 1427

Wray on Malayan tin trade....................... 747

On source of early Phœnician $\operatorname{tin} \ldots \ldots \ldots \ldots \ldots \ldots \ldots \ldots \ldots .744$

See references Nos. 1373-1427.

Hitachi, see Japan.

Hitchcock, C. H................................649, 650

Hitcheock, Edward ............................ 749

Hoang-hai, see Korea.

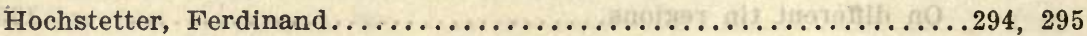

Hoff, Th.................................... 584

Hoffman, G. C................................. 228

Hoffman, w. J................................ 788

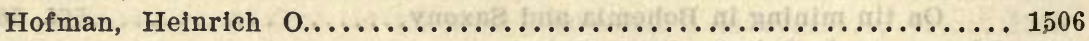

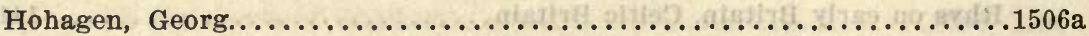

Holland, T. H........................................ 591

Honduras, Montis on tin in.......................... 586a

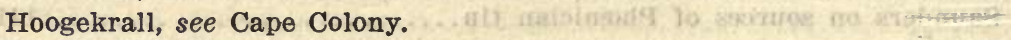

Hooze, J. A.................................. 102

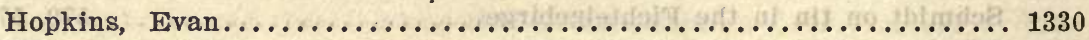

Hopkinson River, see Queensland.

Hornblende, see Association of tin with.

Horsfield, Thomas................................. 103

Horsley, Sydney................................. 912

Hosainpura, see India, Palanpur.

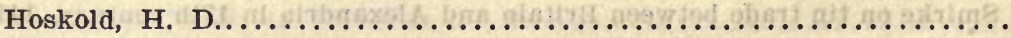

Howell, see New South Wales.

Huaina, see Bolivia, Juaina Potosi. .

Huancane, see Peru, Puno.

Huanuna, see Bolivia, Juanuni district.

Huanuni, see Bolivia, Juanuni district.

Huaina, see Bolivia, Juaina Potosi.

Huayna, see Bolivia, Juaina Potosi.

Hübnerite, see Association of tin with.

Huel Bijjerkerno mine, see New South Wales.

Huel Peever mines, see Cornwall.

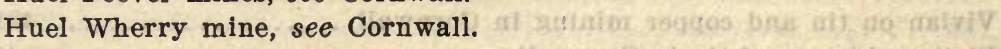

Hughes, T. W. H............................193, 194, 1507

Hughes Creek, see Idaho.

Hulseite, Knopf on a new magnesian iron-tin boron mineral.......29a, 29b

Humbolt, Alexander de............................. 775

Hume, w. C.................................. 913

Hume, W. J. P., and Dykes, F. J. B..................... 698 


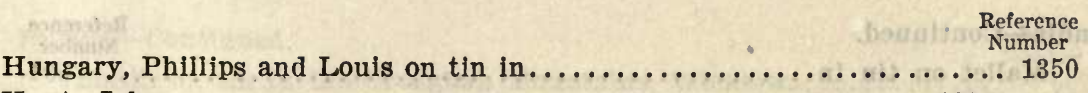
Hunt, John......................................... 1097 Hunt, Robert .............412, 413, 414, 415, 1397, 1619, 1687, 1688 Hunt, T. Sterry...........................651, 652, 1331 Huoyna, see Bolivia, Juaina Potosi.

Hutchin, H. W....................................... 1507b

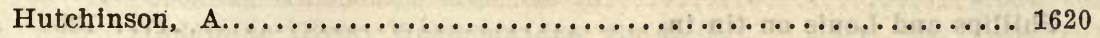
Hyūga, see Japan.

Iberian Peninsula, Louis on tin in........................ 1340 Ichoca, see Bolivia.

Ictis of Diodorus Siculus, Hawkins on the................... 1395

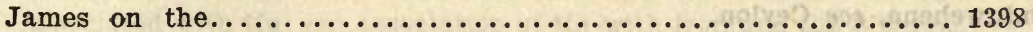

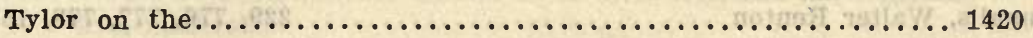

Idaho, Bitter Root Mountains, tin in drainage from............214, 1201 Blake on tin in streams flowing from Bitter Root Range.......214, 1201

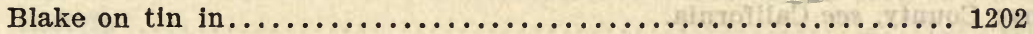

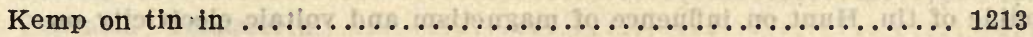

Lindgren on wood tin on Hughes Creek................. 586b See aiso United States.

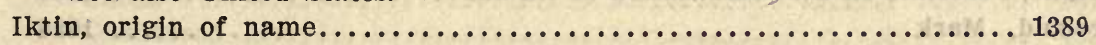

Ilmenite, see Association of tin with.

Impact screen, used at Wheal Kitty, Cornwall................ 1652 Importation of tin:

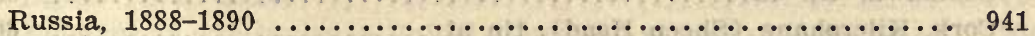

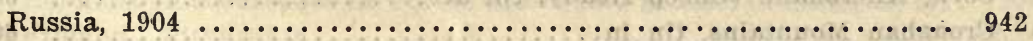

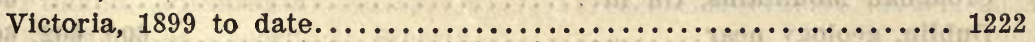

India:

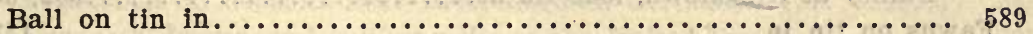

Bastar, tin in ...................................... 597

Bengal, tin in ..................................... 597

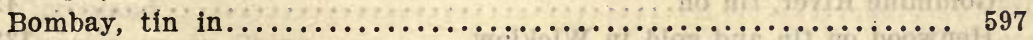

Chota Nagpur, tin in................... 588, 592, 593, 595, 596, 597

Hazáribagh district, tin in...................... 588, 593, 595

Nurgo or Nurunga (Narungo), tin at................... 596

Pihra, tin at.................................... 593

Simratari, tin at................................... 593

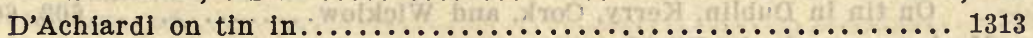

Fermor on the manganese ore deposits of ............... 590a

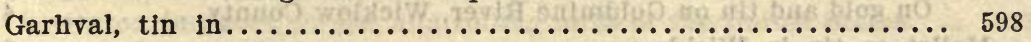

Holland on tin at Hosainpura in Palanpur................ 591

King on tin from several places in Chota Nagpur............. 592

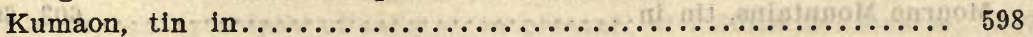

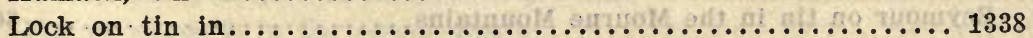

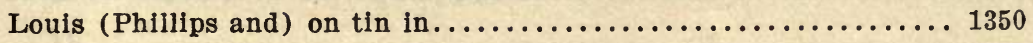


India-Continued.

Reference Mallet on $\operatorname{tin}$ in $\ldots \ldots \ldots \ldots \ldots \ldots \ldots \ldots \ldots \ldots \ldots \ldots \ldots \ldots \ldots \ldots \ldots . \ldots \ldots{ }^{594}$

Mallet on tin in Hazáribágh, Pihra, and Simratari............ 593

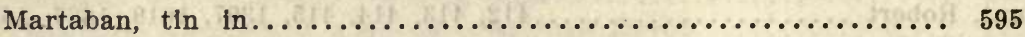

Medlicott on tin in Hazaribagh and Martaban.............. 595

Oates on tin at Narungo, near Baragunda, Bengal............ 596

Palanpur, Hosainpura, tin at.................... 587 , 591

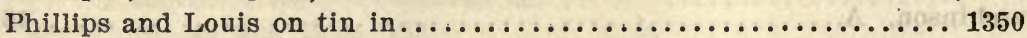

Rudra on tin in Bengal, Chota Nagpur, Bombay, and Bastar...... 597

Stephens on tin in Kumaon and Garhval................. 598

See also Burmah and Asia.

Indium, see Association of tin with.

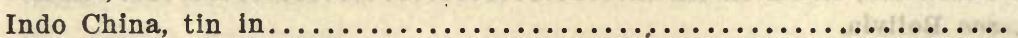

Indo China, see also Malay Peninsula, Siam, and Laos.

Induwehena, see Ceylon.

Ingalls, Walter Renton.................229, 776, 777, 778, 1332

Ingoda River, see Siberia.

Inverell district, see New South Wales.

Inyo County, see California.

Iodide of tin, Hunt on influence of magnetism and voltaic electricity on

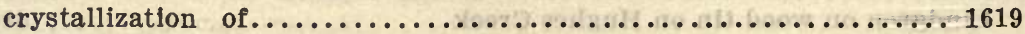

Iodine, Personne on the combination of tin and.............. 1550

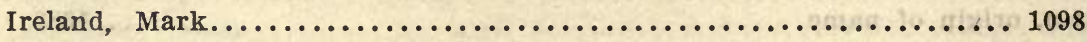

Ireland:

Ballinvally, tin at............................... 601

Coolbawn, tin in ............................... 601

Cork, Kilcrohane (Sheep Head), tin at................. 602

Croaghan Mountains, $\operatorname{tin}$ in ........................... 607

Dublin, geology near.........................600, 602, 609

Dalkey at Kingstown, lode tin at..................602, 603

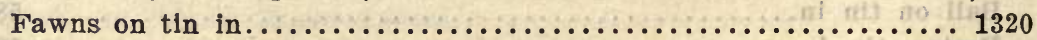

Fitton on geology near Dublin and on tin at Wicklow........... 600

Goldmine River, tin on.............................. 428

Henwood on tin and gold in Wicklow..................... 1327

Hunt on mineral statistics, $1853-1906 \ldots \ldots \ldots \ldots \ldots \ldots \ldots \ldots \ldots \ldots . \ldots \ldots$

Kerry, Killarney, tin at.................................. 603

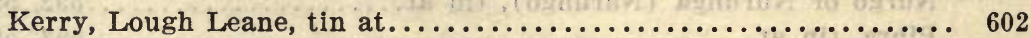

Kinahan on tin at Ballinvally, Monaglogh, and Coolbawn........ 601

On tin in Dublin, Kerry, Cork, and Wicklow...........602, 603

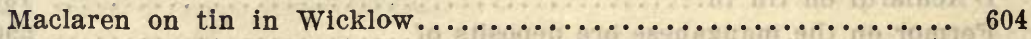

On gold and tin on Goldmine River, Wicklow County........ 428

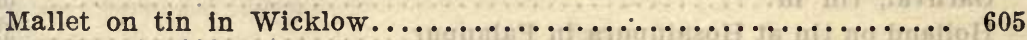

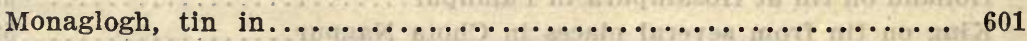

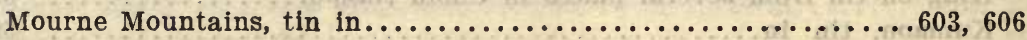

Seymour on tin in the Mourne Mountains................ 606 
Ireland-Continued.

Smith on tin in the Croaghan Mountains, Wicklow............ 607

Weaver on tin at Croghan Kinshela, Wicklow............... 608

On tin in Dublin and Wicklow..................... 609

Wicklow, tin in ...........599, 600,602, 603, 604, 605, 607, 608, 609, 1327

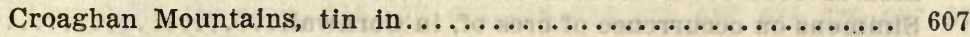

Croghan Kinshelagh area, tín in .................604, 608

Goldmine River, Woodenbridge, tin in.............602, 603

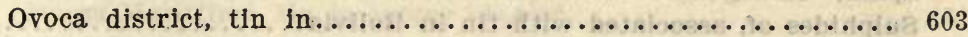

See also Great Britain and Europe.

Irish Creek, see Virginia, Rockbridge County.

Iron:

Alloys. with tin and other metals...................1452, 1502

As an element, an ore, in manufacture, in commerce, and in history. 793

Associated with tin, see Association of tin with iron and the different

iron minerals.

Billings on alloys with tin and other metals............... 1452

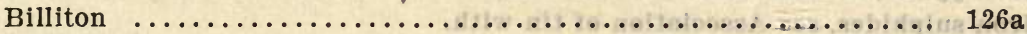

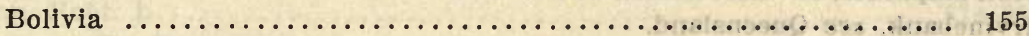

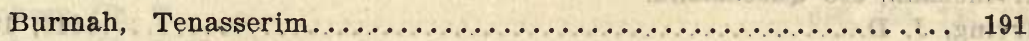

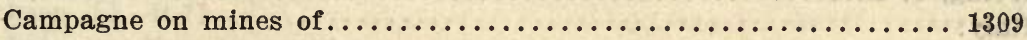

China ................................... 267

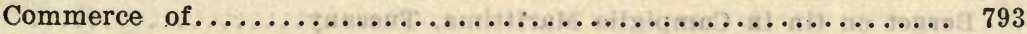

Cornwall $\ldots \ldots \ldots \ldots \ldots \ldots \ldots \ldots \ldots \ldots \ldots \ldots \ldots \ldots \ldots \ldots \ldots \ldots \ldots \ldots, 1617$

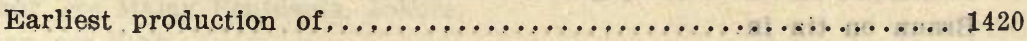

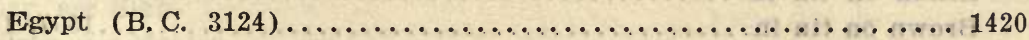

Emmons on occurrence in United States and genesis of minerals of. 1206

Finland, Pitkäranta...........................953a

Foniakoff on deposits in Siberia....................... 965

Friesleben on deposits near Breitenbrunn, Germany .......... 546

Furnaces, forges, and rolling mills of the United States......... 793

Germany, Breitenbrunn......................... 546

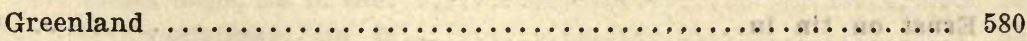

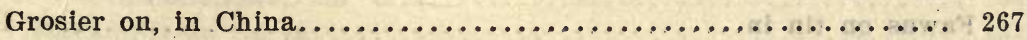

Headden on alloys of tin and iron, etc.................. 1502

Headden on iron compounds in an old Cornwall furnace......... 1617

Helfer on iron in Tenasserim district of Burmah............. 191

Hennecke on occurrence in Persia..................... 864

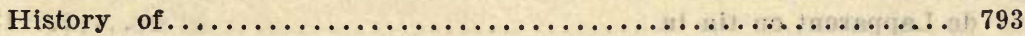

Hydrolysis of salts of, in presence of iodides and iodates........ 1537

Lesley on furnaces, forges, and rolling mills of the United States.... 793

Manufacture of ................................ 793

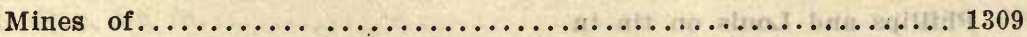

Moody on hydrolysis of salts of, in presence of lodides and iodates. 1537

Pilz on deposits in Cartagena, Spain................... 1040 
Iron-Continued.

Reference

Pearce on separation from tin ore..................... 1547

Persia ....................................... 864

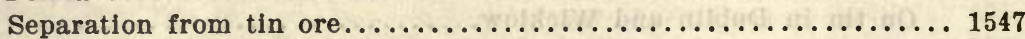

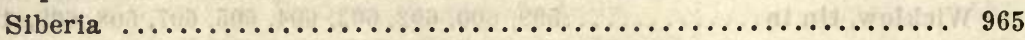

Simmons on occurrence of ores of, in Cornwall.............. 455

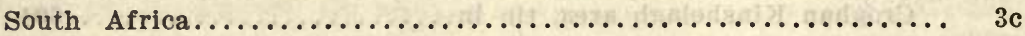

Spain, Cartagena................................ 1040

Sulphides of, associated with tin in Bolivia............... 155

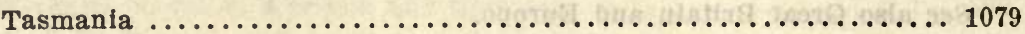

Tylor on earliest production of iron, copper, and tin........... 1420

Trüstedt on iron ore deposits at Pitkäranta, Finland.......... 953a

United States................................. 793

Voit on deposits of in South Africa.................... 3c

Iron arsenate, see Association of tin with.

Iron oxide, see Association of tin with.

Iron pyrite, see Association of tin with.

Iron sulphides, see Association of tin with.

Irvinebank, see Queensland.

Irving, J. D..................................1010, 1011 Italy :

Beco and Thonard on tin in Tuscany.................. 612

Berget on tin in Campiglia Marittima, Tuscany............ 613

Blanchard on tin in Campiglia Marittima, Tuscany........614, 615, 616

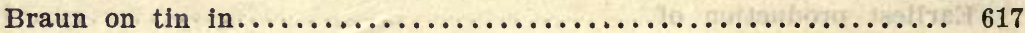

Brown on tin in ..................................... 1308

Caillaux on tin in Tuscany........................ 618

Charion on tin in Tuscany......................... 619

Church on tin in ................................. 620

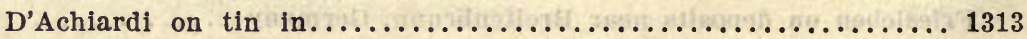

On tin in Campiglia Marittima, Tuscany............. 621

Dalmer on tin in Campiglia, Tuscany .................. 622

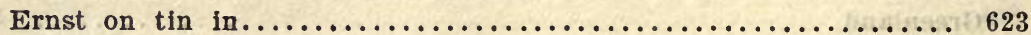

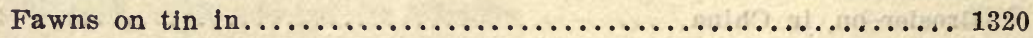

Fuchs and de Launay on tin in..................... 1323

Gurlt on tin on Monte Fumachhio near Campiglia, Tuscany........ 624

Herter and Rath on tin in Campiglia.................... 625

Langer on tin in Tuscany ......................... 626

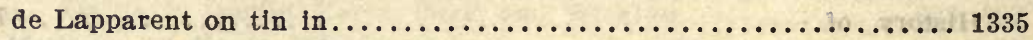

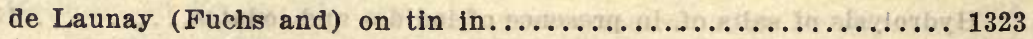

Lotti on tin in Campiglia, Tuscany.................... 627

Phillips on tin in Campiglia Marittima, Tuscany............. 628

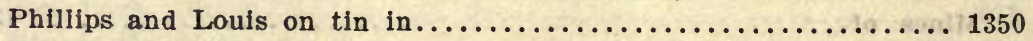

Rath (Herter and) on tin in Campiglia, Tuscany............ 625

Thonard (Beco and) on tin in Tuscany................... 612 
Italy-Continued.

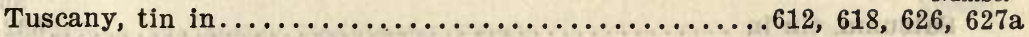

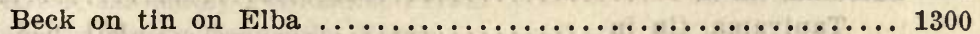

Boceheggiano, tin in copper ores of ................ 613

Campo Alle Buche, tin at...................... 627

Campiglia, tin near. $610,613,614,615,616,621,622,624,625,627,628$

Cento Camerelle, tin in the.................615, 621, 627

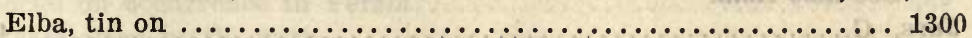

Massa Marittima, tin in copper ores of .............. 613

Monte Calvi, tin near ....................... 613

Monte Fumachhio, tin on ..................613, 615, 624

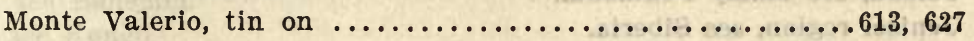

See also Europe.

Itivdliarsuk, see Greenland, Godhavn district.

Ivikaet, see Greenland.

\section{J}

Jack, Robt. L.........................................

Jackson, Ch. T............................653, 654, 791, 792

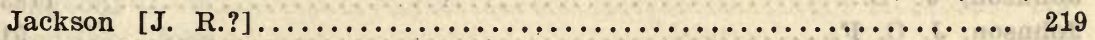

Jackson, see New Hampshire.

Jacobs, E. ....................................... $28 b$

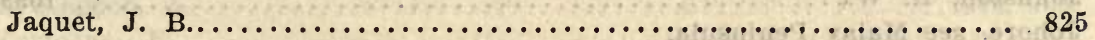

Jahor, see Malay Peninsula, Johore.

Jalar, see Siam.

Jalisco, see Mexico.

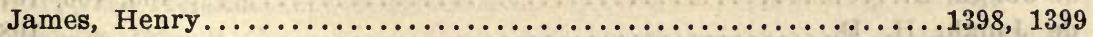

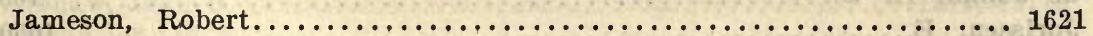

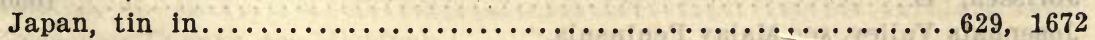

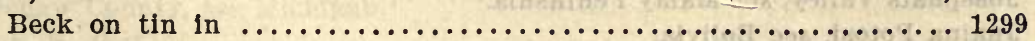

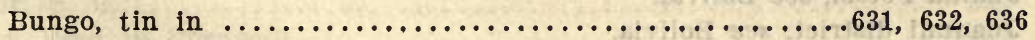

Kiura mine, tin in the......................... 630

Ohira-tetsu-san, tin in ............................ 634

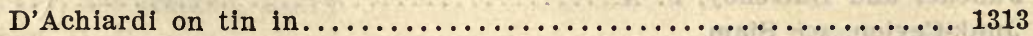

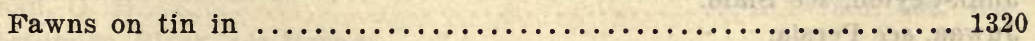

Godfrey on tin in Bungo and Taniyama, Satsuma........... 631

Hirukawa, stream tin near......................... 630

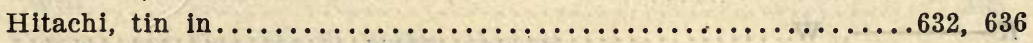

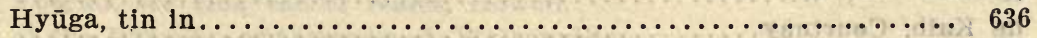

Jimbo on tin in Mino, Satsuma, Bungo, and Hitachi.......... 632

Kinshin Island, tin on......................... 634

Munroe on tin in, especially Tanlyama mine............. 633

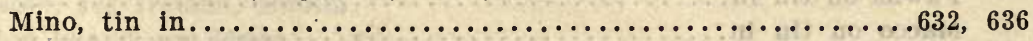

Rein on tin in Satsuma and Bungo.................. 634

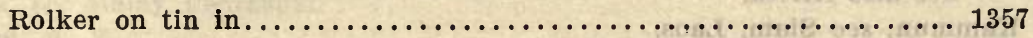


Japan-Continued.

Reference Number

Satsuma, tin in $.632,636$

Taniyama, tin in ....................631, 633, 634, 635

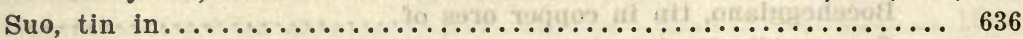

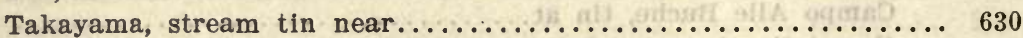

Wada on tin industry, $1867-1892 \ldots \ldots \ldots \ldots \ldots \ldots \ldots \ldots \ldots \ldots . \ldots . \ldots . \ldots 65$ See also Asia.

Jars, G....................................416, 1333

Java, Cretier on tin at Batavia.......................... 283

See also East Indies.

Jelebu, see Malay Peninsula.

Jenisei region, see Siberia.

Jeremejev, P...............................1622, 1623

Jerusalem Creek, see New South Wales, Richmond County.

"Jew's House," Le Grice on at Trereife, near Penzance, Cornwall...... 1518

Jigs used in manipulation of tin and copper ores in Cornwall....... 1656

Jimbo, Kotora................................. 632

Joachimsthal, see Bohemia.

Johanngeorgenstadt, see Saxony.

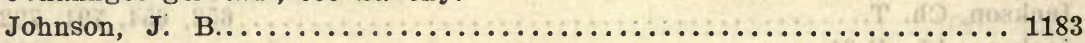

Johnson, J. C. F............................... 51

Johnson, J. P................................ 2 a

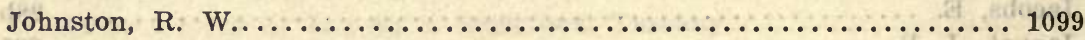

Johore, see Malay Peninsula.

Jokèly, Joh.................................... 68

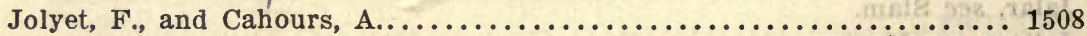

de Jongh, D......................................... 106, 107

de Jongh, H. D................................ 108

Jorissen; E.................................. 1050

Josephats Valley, see Malay Peninsula.

Juaina Potosi, see Bolivia.

Juanuni district, see Bolivia.

Juncker (Dufrénoy, P. A., and) ....................... 507

Juncker and Dufrénoy, P. A......................... 513

Junk-Ceylon, see Siam.

Juwaa, see Persia.

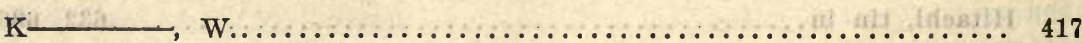

de Kalb, Courtnay................................ 1334

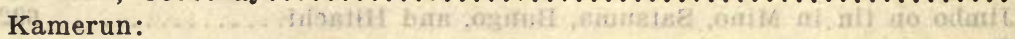

Tin in .....................................637, 638

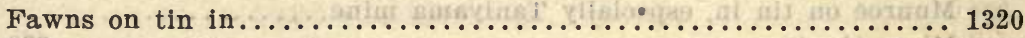

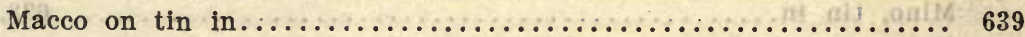

See also Africa. . . w.............

Kammun, see Siam, Laos: 
Kampar River, see Malay Peninsula, Perak. $\ldots . .$.
Kamunting, see Malay Peninsula, Perak.
Kandawangan, see Borneo.
Kangaroo Hills, see Queensland.
Kaolin:

Hennecke on occurrence in Persia..................... 864

See Association of tin with.

Karimata, see East Indies.

Karimon Island, see East Indies.

Karlsbad, see Bohemia.

Katanga, see Kongo.

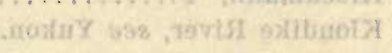

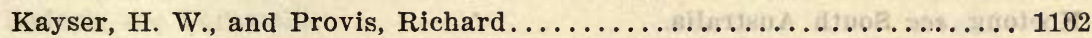

Kayser, H. W. F.............................1100, 1101

Kedah, see.Siam.

Kelantan, see Siam.

Kemaman, see Malay Peninsula.

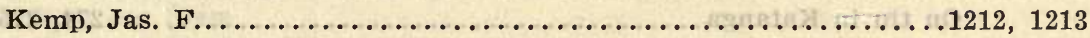

Kempen, A. R. (Brandenburg, H., Weyland, A., and) ............. 1456

Kempton, C. W.................................... 779

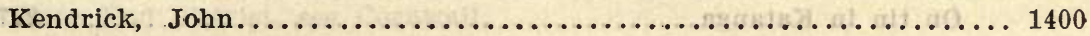

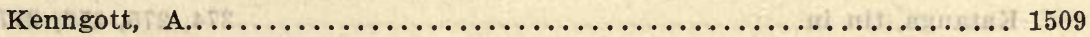

de Keppen, A....................................... 949

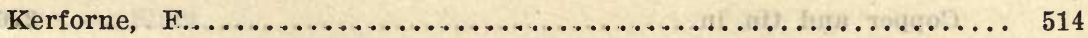

Kerl, Bruno.............................418, 419, 1510

Kerndt, C. H. Thdr............................... 515

Kerry, see Ireland.

Kershaw, John B. C................................... 1511a

Kersten, C. M................................... 1512

Keweenaw County, see Michigan.

Keyzer, S. S.................................... 235

Kieves, used in Cornwall............................ 1656

Kilcrohane (Sheep Head), see Ireland, Cork.

Killarney, see Ireland, Kerry.

Kinahan, G. H.............................601, 602, 603

Kinebetungen River, see Borneo.

King, $W \ldots \ldots \ldots \ldots \ldots \ldots \ldots \ldots \ldots \ldots \ldots \ldots \ldots \ldots \ldots \ldots \ldots \ldots \ldots \ldots, \quad 592$

King, will................................... 195

King Conrad, see New South Wales, Howell.

King of the Ranges, see Queensland, Watsonville.

Kingsgate, see New South Wales.

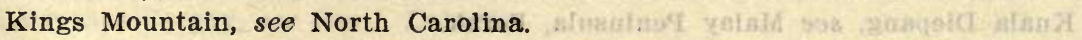
Kingston, see Ireland, Dublin.

Kinshin Island, see Japan.

Kinta, see Malay Peninsula.

Kitson, A. E................................. 1229 


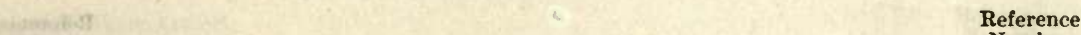

Kitto, Benedict....................................4 420

Klura mine, see Japan, Bungo.

Kjerulf, Th., and Brögger, W. C........................ 826

Klaproth. Martin H................................. 1513

Kledang Range, see Malay Peninsula.

Klipstein, A................................... 551

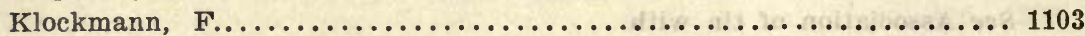

Klondike River, see Yukon.

Knight, Enoch.................................. 220

Knopf, Adolph................................. 29a, 29b

Koba district, see Banka.

Koetong, see South Australia.

Kogin-Delume River, see Nigeria, Gimpy River.

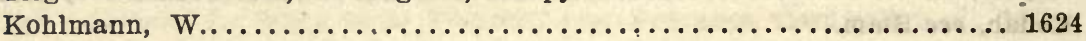

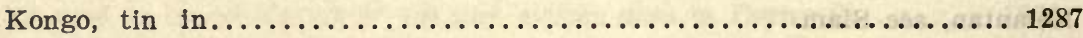

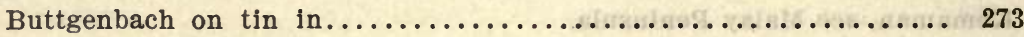

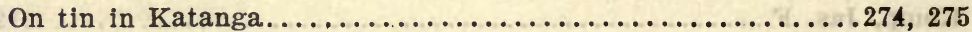

Farrell on copper and tin in Katanga................... 276

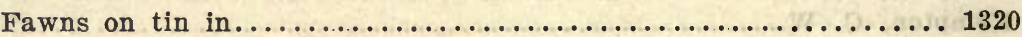

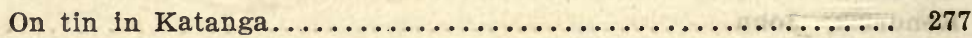

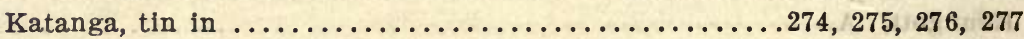

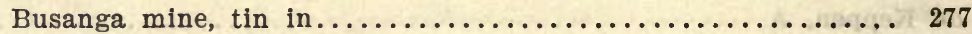

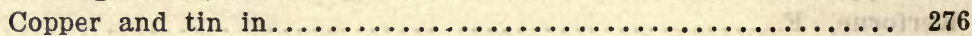

Lualaba River, tín near...................274, 276, 277

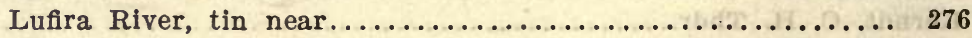

Lacroix on tin in ............................ 516

See also French Kongo and Africa.

de Koninch, L. L., and Lecrenier, A......................... 1474

Koorboora district, see Queensland.

Koperberg, M....................................... 296

Korea:

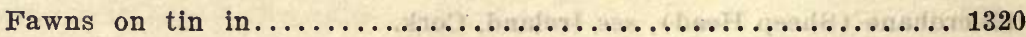

Oppert on tin in Hoang-hai........................ 640

See also Asia.

Korzoukhine, J. A................................. 970

Kotchiou, see China, Yunnan.

Kotiou see China, Yunnan.

Koulibine, S..............................1690, 1691, 1692

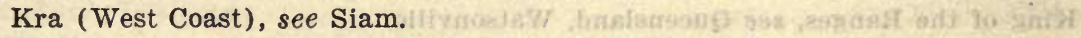

Krusch, P...............................947, 1257, 1258

Kuala Diepang, see Malay Peninsula, Perak.

Kuala Lumpur, see Malay Peninsula.

Kuantan, see Malay Peninsula, Pahang.

Kuchai, see Malay Peninsula, Selangor.

Kuils River, see Cape Colony.

Kumaon, see India. 


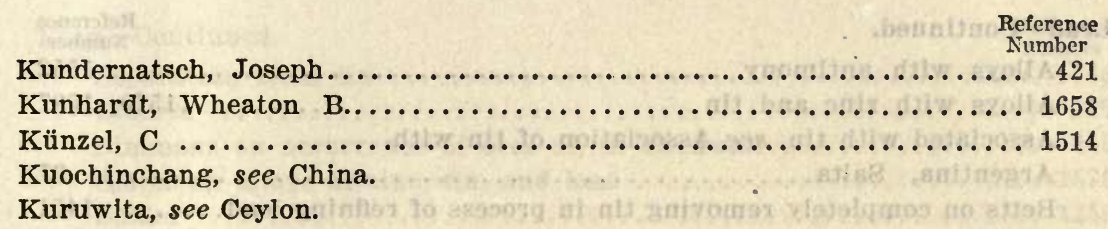
Kynaston, $\mathrm{H}$.................................... 1183b

La Blanca, see. Bolivia.

La Bolivinia mine, see Bolivia.

Lacroix, A................................ 516, 644

Ladock, see Cornwall.

Lagos, see Mexico.

Lahat, see Malay Peninsula, Perak.

Lake Loadut, see Burmah, Tenasserim.

Lakes, Arthur...............................1169a, 1334a Lakon, see Siam.

Lampadius, W. A.......................................... 1516

Landon, J. (Maier, P. J., and) ....................... 133

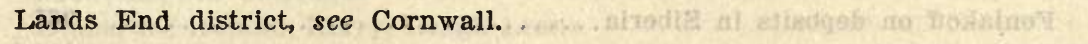

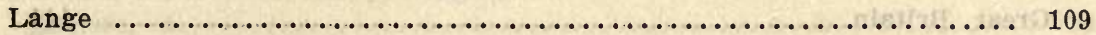

Langer, J. H.................................. 626

Laos, see Siam.

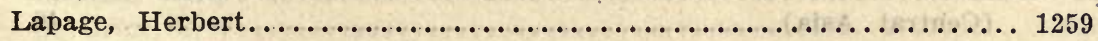

LaPaz, see Bolivia.

La Poma district, see Argentina, Salta.

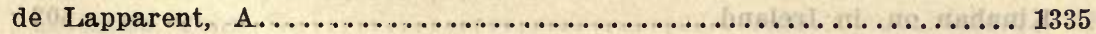

Laroot, see Malay Peninsula, Larut.

Larrouy ...................................... 867

Larut, see Malay Peninsula.

Las Cuevas, see Mexico.

Lassalle, Th..................................... 517

Latrobe River, see. Victoria, Gippsland.

Latta, Geo. J.................................... 1517

Laube, Gustav C.................................. 69

de Launay, L............................. 518, 854, 1625

de Launay, L. (Fuchs, E., and) . ................66, 159, 509, 1323

Launceston, see Tasmania.

La Unificada mine, see Bolivia.

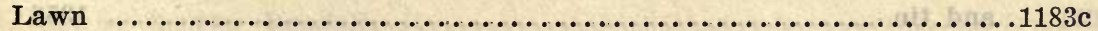

Lawrence.County, see South Dakota.

Lead:

Allen on alloy with copper and manganese............... 1431

Alloys with copper and manganese .................... 1431

Alloys with tin $\ldots \ldots \ldots \ldots \ldots \ldots \ldots \ldots \ldots \ldots \ldots \ldots \ldots$ 1545a, 1548, 1552 
Lead-Continued.

Reference Number

Alloys with antimony

1552

Alloys with zinc and tin............................ 1587

Associated with tin, see Association of tin with.

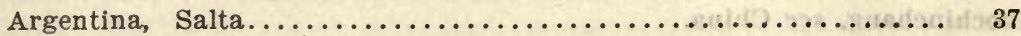

Betts on completely removing tin in process of refining lead...... 1451

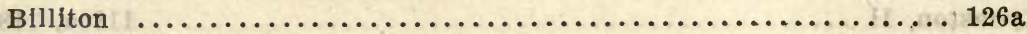

Bohemia, Graupen............................... 542

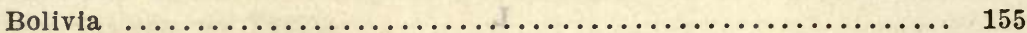

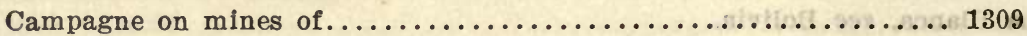

Castro on, in Salta, Argentina........................... 37

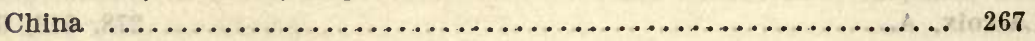

Composition of refined lead........................ 231

Cornwall ..................................... 455

Dalmer on origin of ores in Altenberg-Graupen district of Saxony and Bohemia .................................. 542

Dalmer on presence in cobalt district of Schneeberg, Saxony...... 543

Douglas on metallurgy of ......................... 1204

Dumble on tin in lead ores in Texas..................... 1169

Emmons on occurrence in United. States and genesis of minerals of. 1206

Foniakoff on deposits in Siberia....................... 965

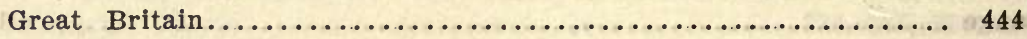

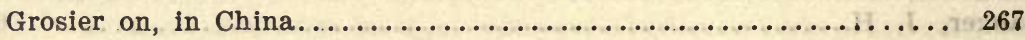

Hermann on lead in metallic tin in gold washings of the Ural

(Central Asia) .................................. 40

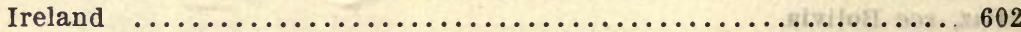

Johnson on origin of deposits in South Africa.............. 1183

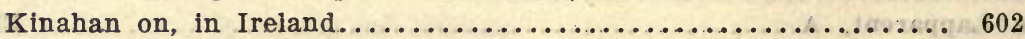

Korea, Hoang-hai ............................... 640

Menniche on separation of from tin ores................... 1534

Metallurgy ..................................444, 1204

Oppert on, in Hoang-hai, Korea....................... 640

Origin of minerals of .................................. 1206

Origin of ores...........................542, 575, 1183

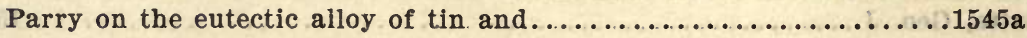

Peetz on separation of tin and lead in tin-lead alloys........... 1548

Pilz on deposits in Cartagena, Spain...................... 1040

Plattner on alloys of tin and antimony with lead at Freiberg, Saxony. 1552

Pryce on mining and metallurgy of in Great Britain............ 444

Richter on characteristics and working, and on relations with zinc

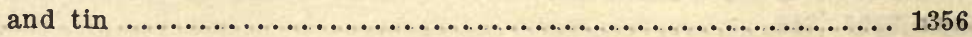

Saxony:

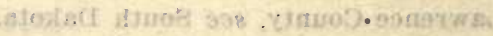

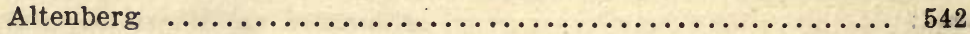

Freiberg ..................................575, 1552

Schneeberg .................................. 543

Schultz on production and application of solder.............. 1359 
Lead-Continued.

Separation from tin................................ 1548

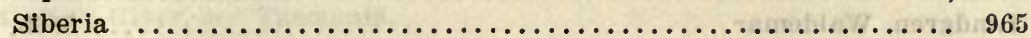

Simmons on occurrence of ores of, in Cornwall............ 455

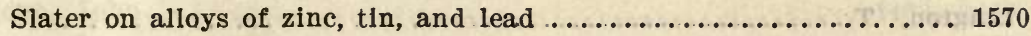

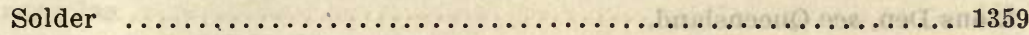

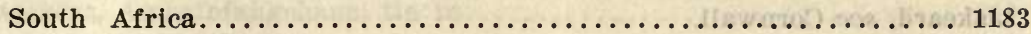

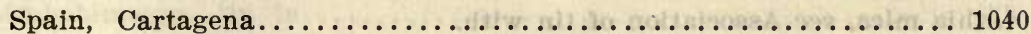

Stelzner on origin of ores at Freiberg, Saxony............. 575

Sulphides of, associated with tin in Bolivia ................ 155

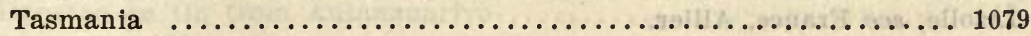

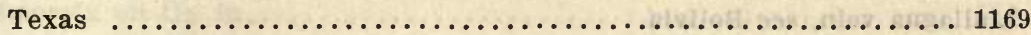

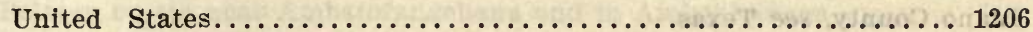

Ural (Central Asia), with metallic tin ..................... 40

Wolf on composition of refined lead....................... 231

World statistics since $1890 \ldots \ldots \ldots \ldots \ldots \ldots \ldots \ldots \ldots \ldots \ldots \ldots \ldots \ldots . \ldots \ldots 4$

Wright on alloys of zinc, lead, and tin at low and high temepratures. 1587 Lead carbonate, see Association of tin with.

Lead sulphide, see Assaciation of tin with.

Leadville, see Colorado.

Leane, see Ireland, Kerry, Lough Leane.

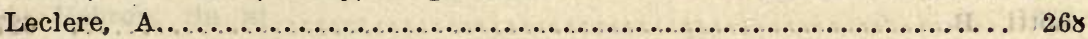

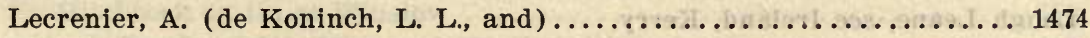

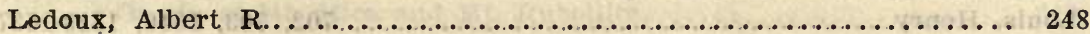

Le Grice, . C. V................................... 1518

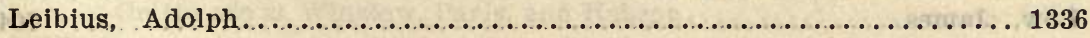

Leier mine, see Saxony.

Leifchild, John R................................ 422

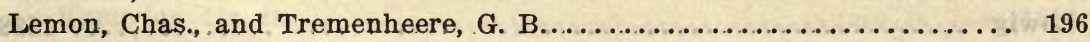

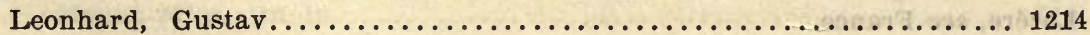

Lepidolite, see Association of tin with.

Lepsius, Richard............................... 551 .

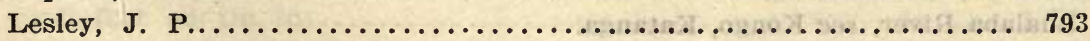

Lettsom, W. G. (Greg, R. P., and) ..................... 1614

Levant, see Cornwall.

Levol, A. .........................................1519-1521

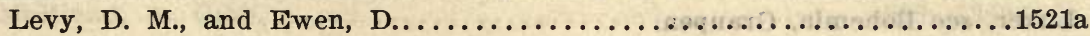

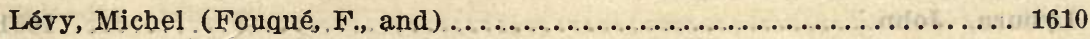

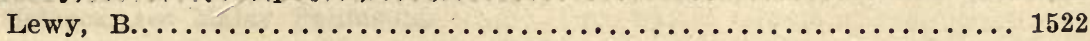

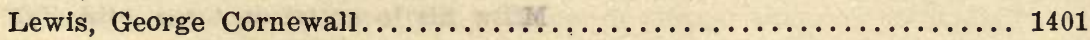

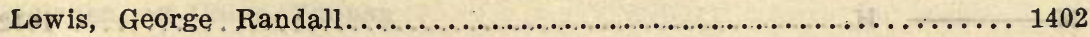

Lewis, James B................................. 1105, 1106

Lias, tin at contact between tourmaline granite and linestones of Lias

age in Tuscany ........................610,613, 615, 627, 628

Limonite, see Association of tin. with.

Limousin, see France. 


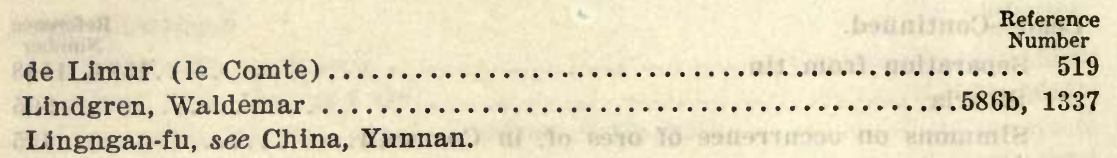

Lington, T................................. 422a

Lions Den, see Queensland.

Liskeard, see Cornwall.

Lithia mica, see Association of tin with.

Little Usutu River, see Transvaal.

Liversidge, Archibald ..................... 827, 828, 829, 830

Lizolle, see France, Allier.

Llallagua vein, see Bolivia.

Llano County, see Texas.

Loadut (Lake), see Burmah, Tenasserim district.

Lobley, J. Logan.............................. 423

Lock, C. G. Warnford..................197, 424, 699, 700, 701, 1338

Lodin ....................................... 521

Loire Inferieure, see France, Lower Loire.

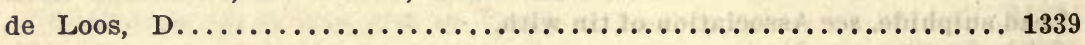

Los Angeles, see California.

Lost River, see Alaska.

Lotti, B.................................... 627

Lough Leane, see Ireland, Kerry.

Louis, Henry........................702, 703, 1340, 1523-1527

Louis, H. (Phillips, J. A., and) ....................... 628, 1350

Low, James.................................... 704

Lower, T., see No. 489a.

Lower Loire, see France.

Lowig ......................................... 1528

Lozére, see France.

Lozano, R. Sanchez................................ 1036

Lualaba, see Rhodesia.

Lualaba River, see Kongo, Katanga.

Lufira River, see Kongo, Katanga.

Lunenberg County, see Nova Scotia.

Lusitania, Plinius on "white lead" from................... 1408

Luxer, see Bohemia, Graupen.

Lyburn, John................................. 1051

M

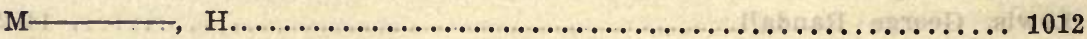

MacAlister, Donald A................426, 427, 449, 1341, 1659, 1693

MacAlister, D. A. (Hill, J. B., and) ..................... 411

MacAllster, D. A. (Ussher, W. A. E., and) .................. 481

Macco, A.................................... 639

Macdonald, A. R.............................. 919-923, 924

Machi, see Malay Peninsula. 
Mackenzie, Geo. L................................. 1529 Mackintosh River, see Tasmania.

Maclaren, J. Malcoim................................428, 604, 925

Maclean, John.....................................1403, 1404

Mactear, Jas....................................... 865

Madagascar, Ambatofangehana, tin in.................... 648

Ambohimanga, $\operatorname{tin}$ in $\ldots \ldots \ldots \ldots \ldots \ldots \ldots \ldots \ldots \ldots \ldots \ldots \ldots$

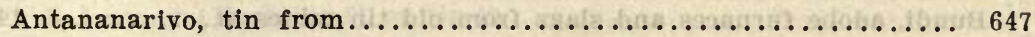

Bouse on the mineral and other resources of ............... 646

Dunstan on tin from Antananarivo.................... 647

Lacroix on tin in .............................. 516

Pelatan on tin near Ambatofangehana and in Ambohimanga....... 648 Madison County, see Missouri.

Magnesite, Voit on deposits of in South Africa.................. 3 c Magnetite:

Beck on occurrence at Schwartzenberg, Germany............ 530

See Association of tin with.

Maier, P. J., and Laudon, J......................... 133 Maine:

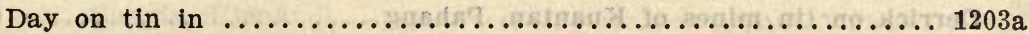

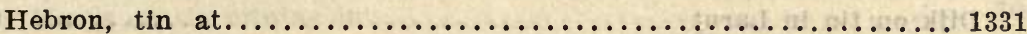

Hitchcock on tin at Winslow...................... 650

On tin at Mt. Mica and Mt. Rubellite............... 649

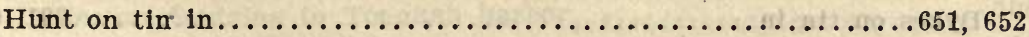

On tin ore at Winslow, Paris, and Hebron.............. 1331

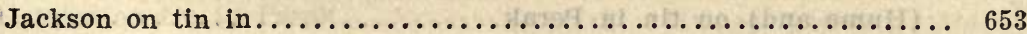

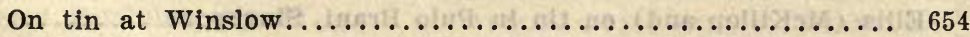

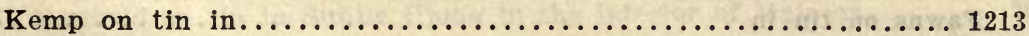

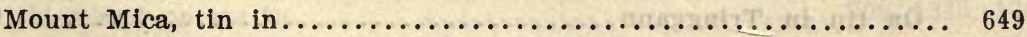

Mount Rubellite, tin in ............................ 649

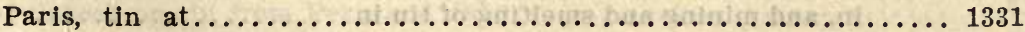

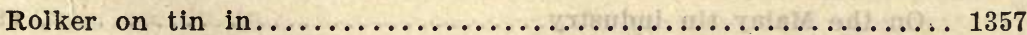

Winslow, tin at...................650, 651, 652, 654, 1331

See also United States.

Maine-et-Loire, see France.

Maitland, A. Gibb..........................926, 1260-1264

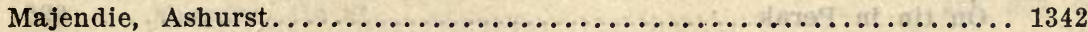

Malacca, see Malay Peninsula.

Malachite, see Association of tin with.

Malaken, see China, Yunnan.

Malay Archipelago, Garrison on tin in................... 1207

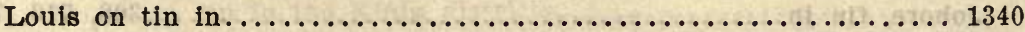

Malay Peninsula, tin in................676a, 1284, 1290, 1292, 1298

Ayer Dangsang, tin and other minerals at............... 726 , 26 a

Ayer Panas, tin in siliceous sinter from................. $726 \mathrm{~b}$ 
Malay Peninsula-Continued.

Reference Number

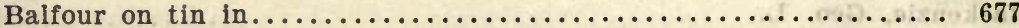

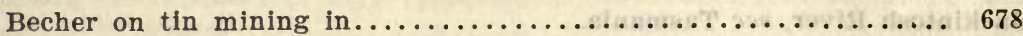

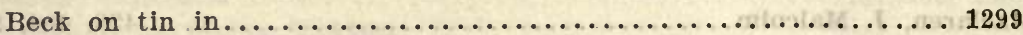

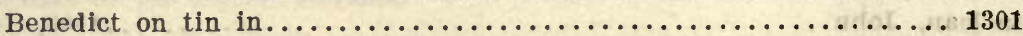

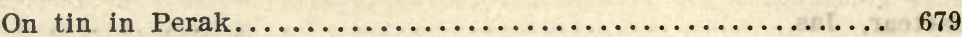

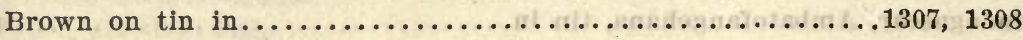

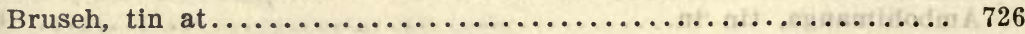

Bundi, adobe furnaces and slags from old tin mines at........ 1468

Tin in ...........................659, 726, $726 \mathrm{~b}$

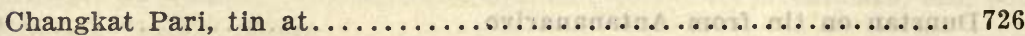

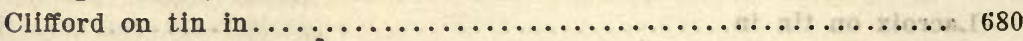

Collett on tin in.............................. 681

Collins on adobe furnaces and siags from old tin mines at Bundi... 1468

Cornubian on lode mines of Pahang................. 681a

Cramer on tin in Malacca.......................... 682

Croockewit on tin in Malacca........................ 683

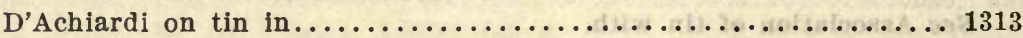

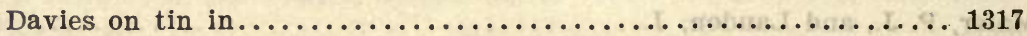

De La Croix on tin in Perak..................... 684, 686

Derrick on tin mines of Kuantan, Pahang.............. 687

Dijk on tin in Larut............................ 690

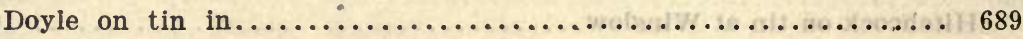

On tin mining in Larut........................ 688

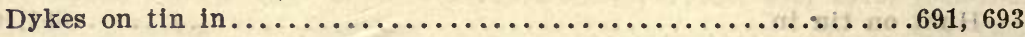

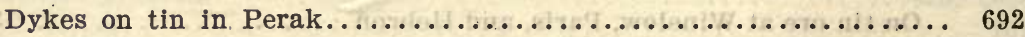

(Hume and) on tin in Peraik......................... 698

Ellis (McKillop and) on tin in Pulo Brani, Singapore......... 1530

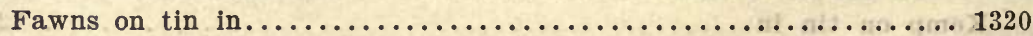

On tin in Tringganu............................ 694

Flower-Eliis on geology of, occurrence of tin ore in, valuation of tin

in, and mining and smelting of tin in .............. 1489

On the Malay tin industry.......................694a

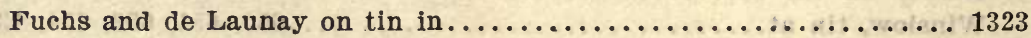

Gongong, tin at.............................. see also No. 261

Hamilton on tin in Perak, Selangor, and Parcelore........... 294

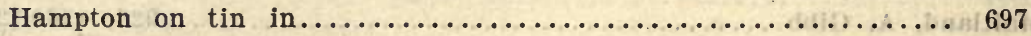

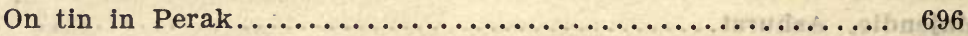

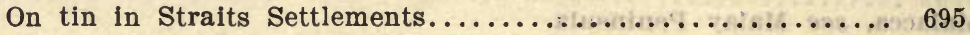

Hughes on tin smeiting and furnaces in Singapore........... 1507

Hume and Dykes on tin in Perak.................... 698

Jelebu, Sungel Riu, tin at ...................... 659

Johore, tin in ........................... 710, 742

Muntaha, tin deposits of ....................... 741

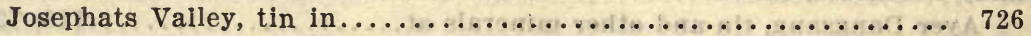

Kledang Range, mineral veins in the................. 726 a 
Malay Peninsula-Continued.

Kemaman tin in

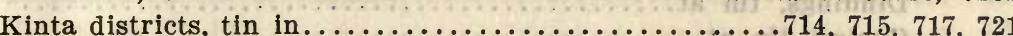

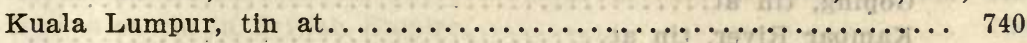

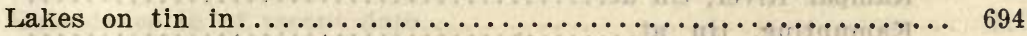

Laroot, see Larut.

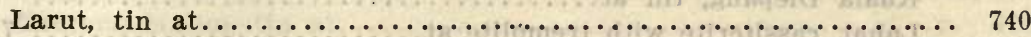

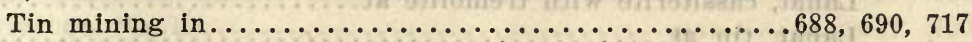

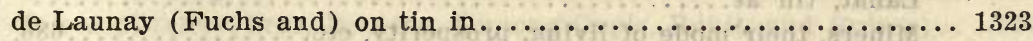

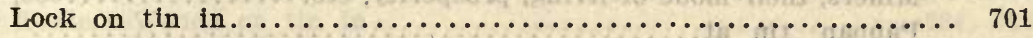

On tin in Tringganu................................ 700

Louis on tin in ....................................... 1340

On tin in Malacca............................... 703

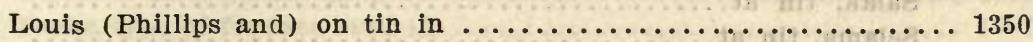

Low on tin in countries lying between Malay Peninsula and $18^{\circ}$

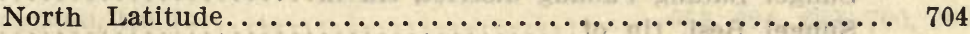

Machi tin field................................ 726

Malacca, tin in...............299, 303, 304, 682, 683, 703, 740, 744

(Chin Chin and Tanjong Serai), tin in ................. 726

Earl of Mount Edgcumbe on tin produced in $1883 \ldots \ldots \ldots \ldots \ldots 1681$

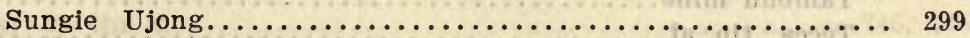

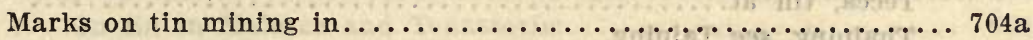

McKillop and Ellis on tin smelting in Pulo Brani, Singapore...... 1530

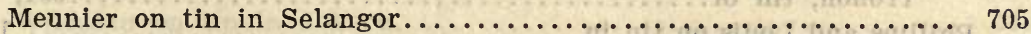

Miles on dredging in Tongkah harbor.................. $705 \mathrm{a}$

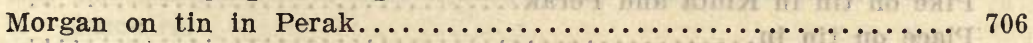

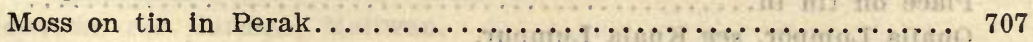

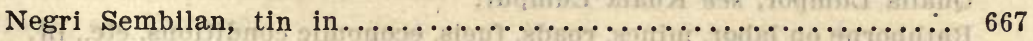

Newbold on tin in Sunjie Ujong in the interior of Malacca...... 299

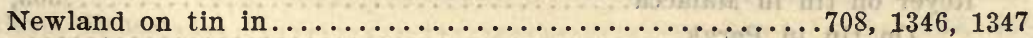

Noyes on tin in Serendah Valley, Selangor............... 709

Osbeck on tin from Pegu and Jahor................... 710

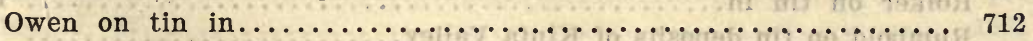

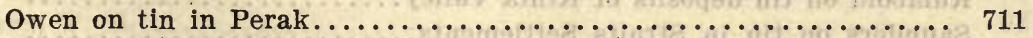

Pahang, lode mines of . . . . . . . . . . . . . . . . . . . . . .

Scheelite in tin deposits at....................... $726 \mathrm{a}$

Pahang, tin in ............659, 663, 667, 673, 674, 687, 697, 728, 736

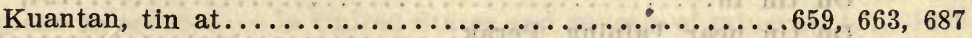

Kuantan (Sungei Lembing), tin of.................... 726

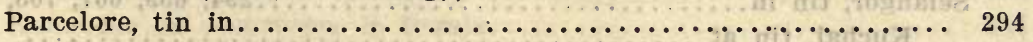

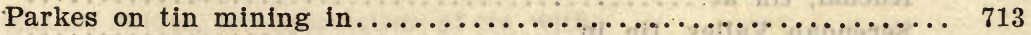

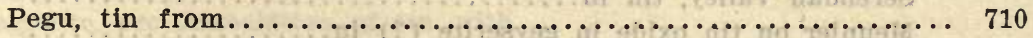

Penrose on tin in the Kinta districts................... 714

Perak, tin in...294, 304, 658, 660, 667, 670,679, 684, 685, 686, 691, $692,696,698,706,707,711,715,731,732,735,737,747$

Assam Kumbang, tin at. ............................. 737 
Malay Peninsula: Perak-Continued.

Reference

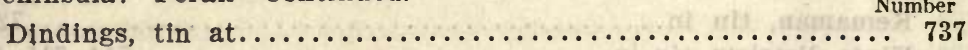

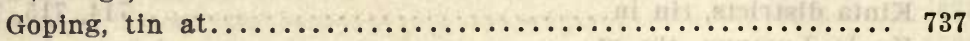

Kampar River, tin at...................... 737

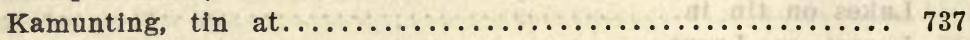

Kuala Diepang, tin at...................... 737

Lahat, cassiterite with tremolite at............... 726a

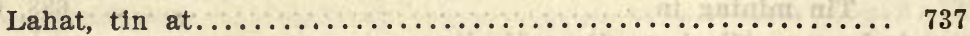

Miners, their mode of living, prosperity, etc..........6. 686

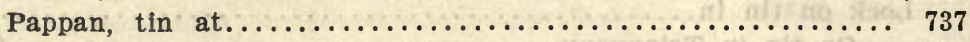

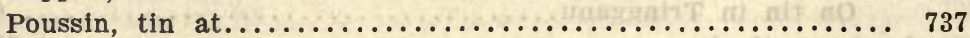

Salak, scheelite deposits at.................... 726a

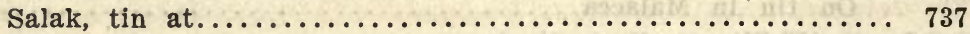

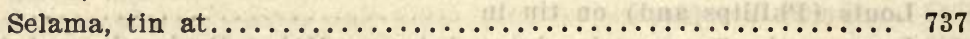

Sungel Bâtang Pâdang district, tin in .............. 684

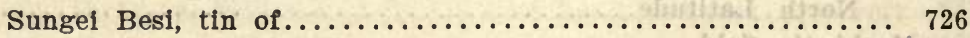

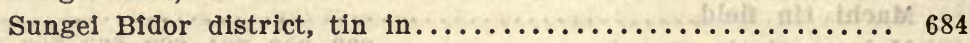

Sungei Kinta district, tin in .................... 684

Taiping, tin near................................. 737

Tambun mine.............................670, 691

Tecca, tin at.................................. 737

Thaiping, see Taiping.

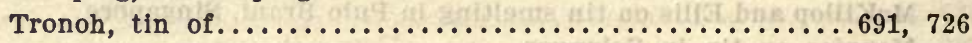

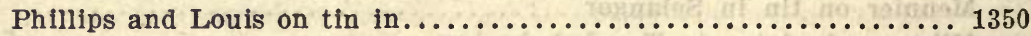

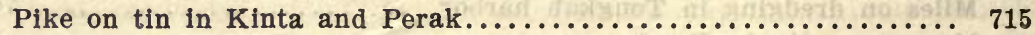

Place on tin in............................... 716

Qualla Lumpor, see Kuala Lumpur.

Rathborne on labor, mines, roads, fuels, economic conditions, etc., in. 717

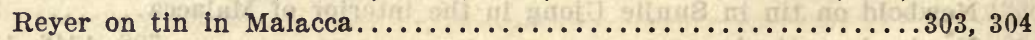

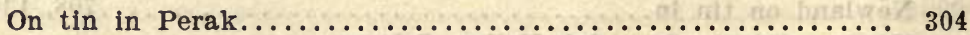

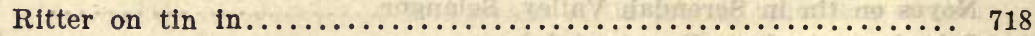

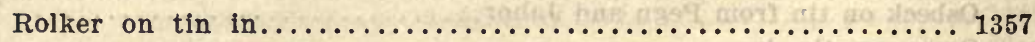

Rumbold on tin deposits of Kinta Valley................. 721

Saunders on tin in Straits Settlements................. 722

Scrivenor on origin of tin deposits, with special reference to those of Malay Peninsula........................... $726 \mathrm{~b}$

On tin in.................................... 724,726

On tín near Talping, Perak...................... 723

Selangor, tin in $. \ldots \ldots \ldots \ldots \ldots \ldots \ldots \ldots \ldots \ldots \ldots 294,659,667,705,709$

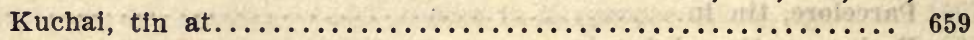

Serendah Valley, $\operatorname{tin}$ in........................ 709

Meunier on tin oxide in geyserite (?) in.............. 705

Sexton on smelting methods at Singapore............1361, 1507, 1530

Singapore, McKillop and Ellis on tin smelting at Pulo Brani...... 1530

Sexton on smelting methods at..............1361, 1507, 1530

Slack on a handbook of the mining companies in............ 727

Slack on $\operatorname{tin}$ in $\ldots \ldots \ldots \ldots \ldots \ldots \ldots \ldots \ldots \ldots \ldots \ldots \ldots \ldots \ldots \ldots \ldots$ 
Malay Peninsula-Continued.

Stephens on tin at Pahang........................... 728

Stokes on tin in ................................ 729

Stokes on tin in British Empire...................... 730

Subsidence in of recent date........................ 717

Swettenham on tin in Perak......................... 732

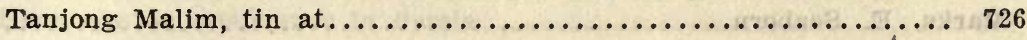

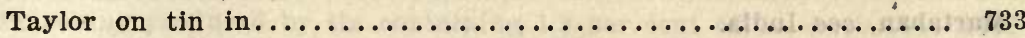

Telom district (Tras, Bentong, Gunong Gapis, Bukit, and Fraser).. 726

Tenison-Woods on tin in.......................... 734 , 735

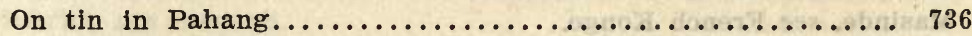

On tin in Perak................................ 737

Tonghah Harbor, dredging for tin in ...........6.6.6.6. $676 \mathrm{a}, 70 \mathrm{a}$

Tonka type of furnace used in ...................... 1507

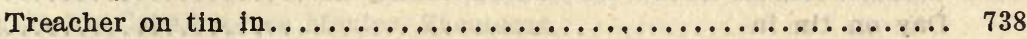

Tringganu, tin in $\ldots \ldots \ldots \ldots \ldots \ldots \ldots \ldots \ldots \ldots 6 . \ldots \ldots, 694,699,700,960$

Vercoe on tin near Malacca, at Kuala Lumpur, and Larut........ 740

On tin at Muntaha, Johore..................... 741

Viator on tin at Gongong, Johore River................ 742

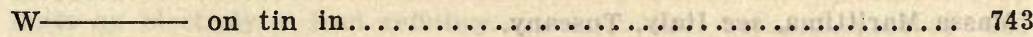

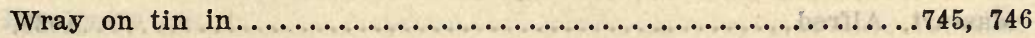

On tin in Malacca and Tenasserim................. 744

On tin in Perak............................. 747

Wildman on tin in Johore......................... 308

See also Asia, Burmah, East Indies, Siam, Straits Settlements, and Sumatra.

Maleewoon, see Burmah, Maliwan.

Maliwan, see Burmah.

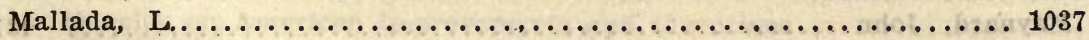

Mallard, Ernest............................... 522,523

Mallet, F. R................................... 593, 594

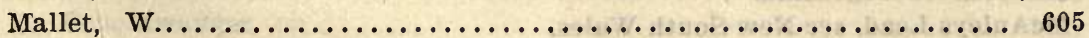

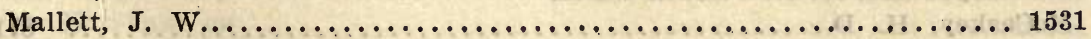

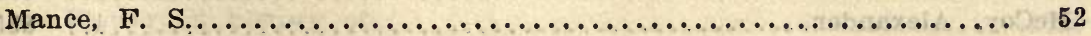

Manche, see France.

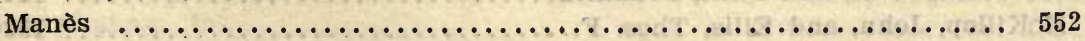

Manganese, Allen on alloys of tin and..................... 1431

Emmons on occurrence in United States and genesis of minerals of. . 1206

Fermor on the ores of in India...................... 590a

Hennecke on occurrence in Persia..................... 864

Manganese oxides, see Association of tin with.

Manganite, see. Association of tin with.

Mangar district, see Billiton.

Mann, O........................................ 553

Mantebras, see France, Montebras.

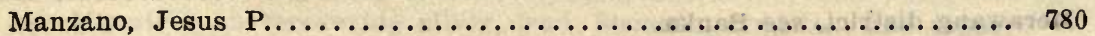


Marble Bar, see Western Australia.

Marche, see France, La Marche.

Margarite, see Association of tin with.

Marienberg, see.Saxony.

Marinera mine, see Spain, Carthagene.

Marks, .E. Seaborn............................... 704a

Martaban, see India.

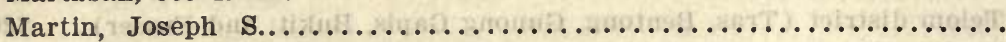

Martinamor, see Spain, Salamanca.

Masinde, see. French Kongo.

Mason County, see. Texas.

Massachusetts:

Chesterfield, tin at the tourmaline locality at.............. 750

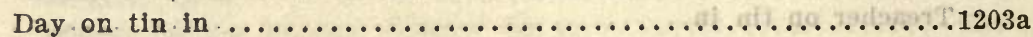

Goshen, tin from........................748, 749, 1214

Hitcheock on tin from Goshen....................748, 749

Leonhard on tin at Goshen......................... 1214

Teschemacher on tin at Chesterfield................... 750

Massa Marittima, see. Italy, Tuscany.

Massart, Alfred.................................1038, 1343

Massinda, see French Kongo.

Massinga, see French Kongo.

Matam, see Borneo, Matan.

Matan, see Borneo.

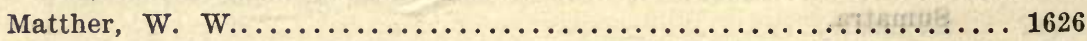

Maupas, see France, Morbihan.

Maures, see France.

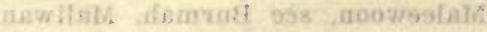

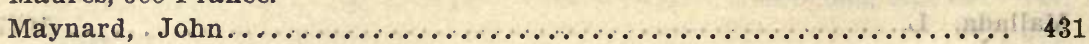

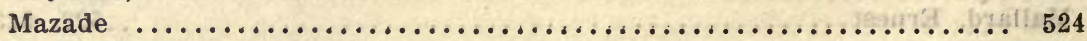

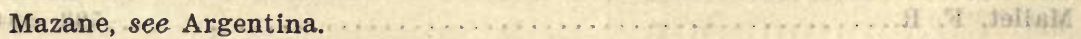

McAuleys Lead, see. New South Wales. ..................

McCaskey, H. D................................. 871

McCoy, Alexander ................................. 855

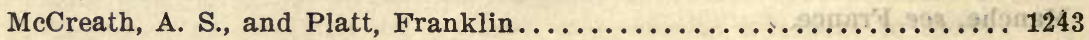

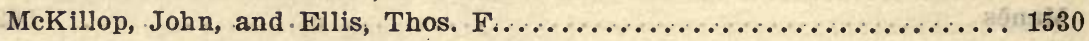

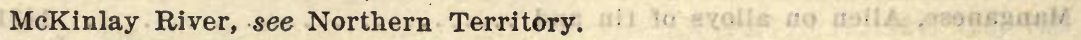

Mecklenburg County, see South Carolina. Ints ni

Medicine, Boerhaave on medicinal use of tin.................. 1305

Medlicott, H. B., and Blanford, W. T..................... 595

Menado, see Celebes.

Mene, Ch..................................... 1532

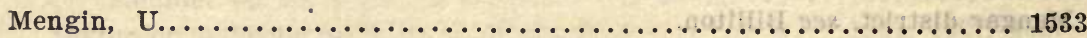

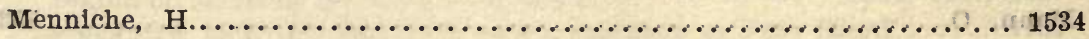

Menten, J. H.................................110, 297

Merawang district, see Banka. 
Mercury:

Reference Number

Campagne on mines of ............................. 1309 Capitaine on action of tin, arsenic, antimony, and sulphur on the

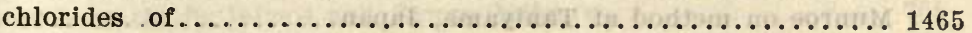

Douglas on metallurgy of ........................... 1204

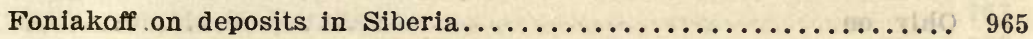

Hennecke on occurrence in Persia...................... 864

Poisoning. produced by tin containing 1.3 per cent of .......... 1436

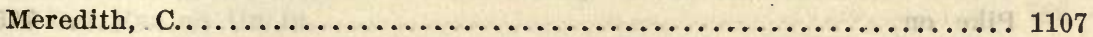

Merensky, H..................................... 1185

Mergui district, see Burmah.

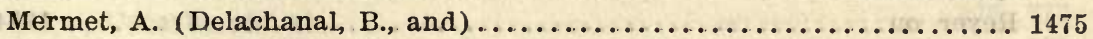

Merret, C...................................... 432

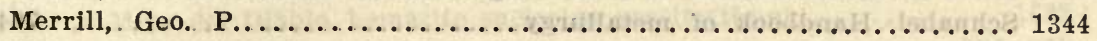

Mesa de los. Caballos, see Mexico, Zacatecas.

Metallurgy of tin ............................1278, 1290

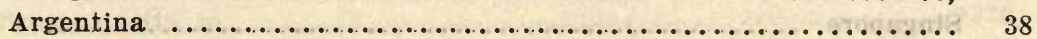

Australia ............................................ 1578

Ball on treatment of tin ores at Irvinebank, Queensland........ 891b

Betts on electrolytic lead refining....................... 225

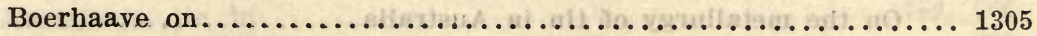

British Columbia, Trail............................... 231

California ............................................... 222

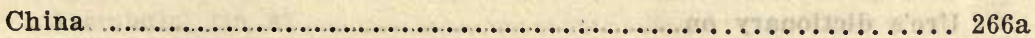

Clark on methods in Tasmanla........................ 1076

Collins on methods in Yunnan, China..................... 266a

Cornwall. ............................419,422, 490, 1579

Dietzsch on treatment of tin-wolfram-copper ores............. 1479

Douglas on American improvements and inventions............ 1204

Douglas on ore crushing, concentration, and metallurgy of tin, etc.. 1204

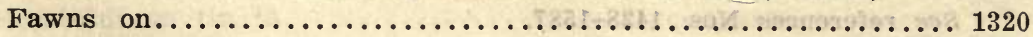

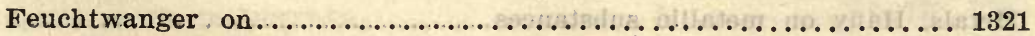

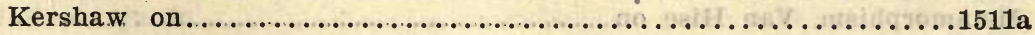

Flower on history of........................... 1390

Gmehling on in Bolivia............................. 1497

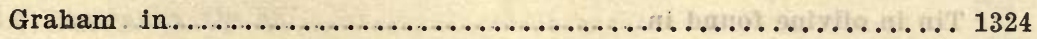

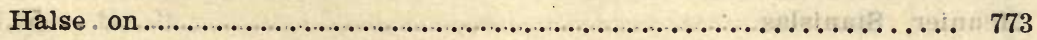

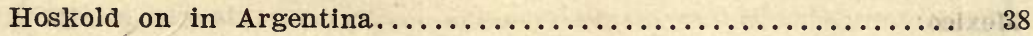

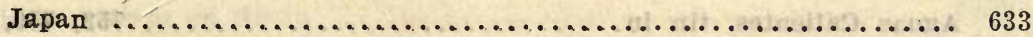

Kerl on methods in Cornwall.......................... 419

Leifchild on methods in Cornwall..................... 422

Louis on .........................1523, 1524, 1526, 1527

Low on practices in Malay Peninsula and vicinity ........... 704

Malay. Peninsula.........................676c, 704, 706

McKillop and Ellis on at Pulo Brani, Singapore............. 1530

Menniche on recovering silver, lead, bismuth, tungsten, and copper

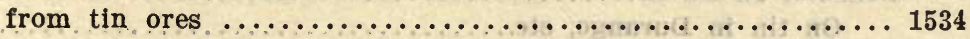


Metallurgy of tin-Continued.

Reference Number

Morgan on methods in Malay Peninsula................. 706 Mulholland on the Greenbushes tin field, Western Australia....... 1265 Munroe on method at Taniyama, Japan................... 633

Nevius on .................................... 781

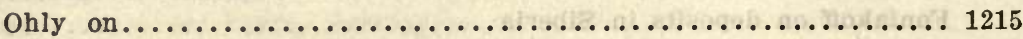

Pearce on separation of copper, iron, etc., from tin ore......... 1547

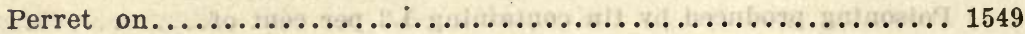

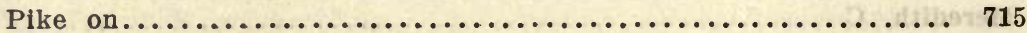

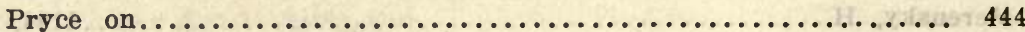

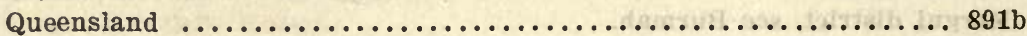

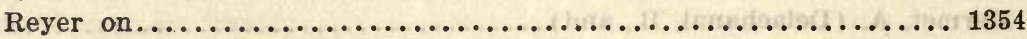

Rowe on chemical methods of treating ores................ 1560

Schnabel, Handbook of metallurgy..................... 794

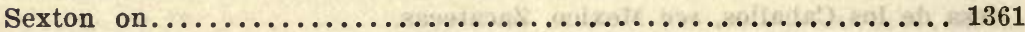

Simmons on methods in Black Hills..................... 1019

Singapore ......................................... 1530

South Dakota..................................... 1019

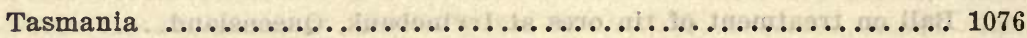

Thibault on the metallurgy of complex tin sulphides........... 1577

On the metallurgy of tin in Australia................ 1578

Thiollier on methods in Cornwall........................ 1579

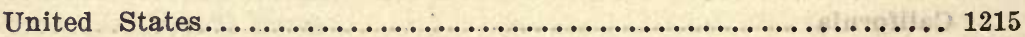

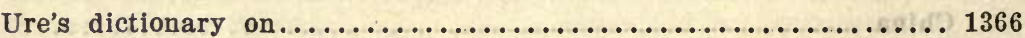

West on Temescal mines, California...................... 222

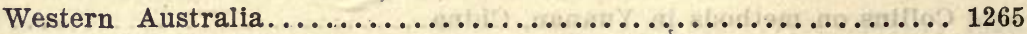

Wolf on the Betts process at Trail, British Columbia........... 231

Zirkel on methods in Cornwall.......................... 490

See also Assaying of tin, chemistry of tin, dressing of tin, milling of tin, refining of tin, and smelting of tin.

See references Nos. 1428-1587.

Metals, Haüy on metallic substances...................... 1499

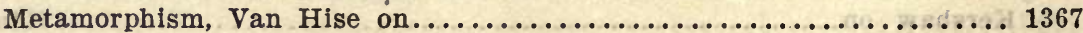

Metasomatism in tin veins, Lindgren on .................... 1337

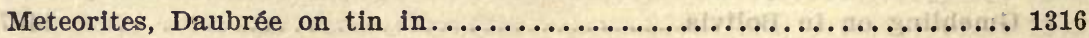

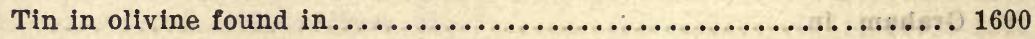

Meunier, Stanislas.................................... 705 Mexico:

Aguas Calientes, tin in $\ldots \ldots \ldots \ldots \ldots \ldots \ldots \ldots \ldots \ldots \ldots \ldots . \ldots \ldots 2,759,765$

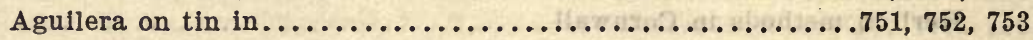

Allen on tin in Baja California...................... 754

Baja California, tin in............................ 754

Barcena on tin in Zacatecas and Lagos................... 761

Barriga on tin at Coneto in Durango..................... 762

Beck on tin in ..............................1299, 1300

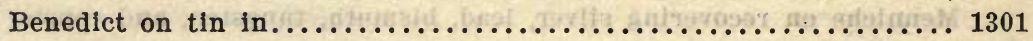

On tin in Durango, etc....................... 763 
Mexico-Continued.

Number

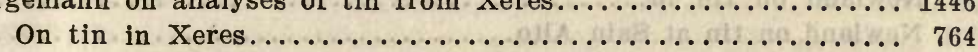

Bretherton on tin in Jalisco and Aguas Callentes............. 765

Bromly on tin at Santa Barbara, Guanajuato.............. 766

Chandler on tin in Durango........................ 767

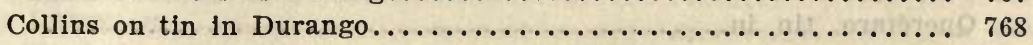

Coneto, tin at.......................... 755, 756, 762, 774

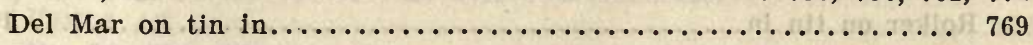

Durango, tin in...752, 755, 756, 762, 763, 767, 768, 770, 771, 773,

$774,776,779,783,1635$

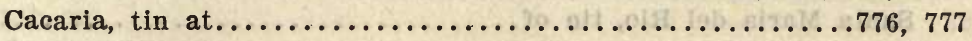

Cerro de Iglesia de los Remedios, tin at.............. 777

Mina del Diablo, hematite enclosing cassiterite at......... 1635

Potrillos, tin at................................ 777

Sierra de Catalan, tin from.................... 771

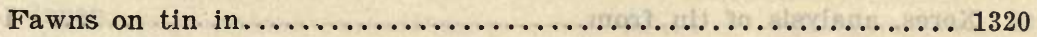

Fawns on tin in Durango and Sain Alto................. 770

Genth on tin from Sierra de Catalan, Durango.............. 771

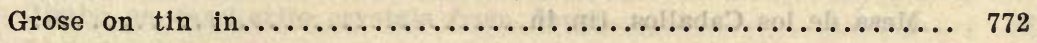

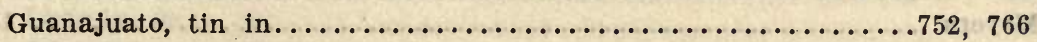

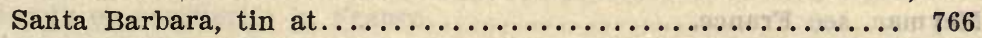

Guerrero, $\operatorname{tin}$ in $\ldots \ldots \ldots \ldots \ldots \ldots \ldots \ldots \ldots \ldots \ldots \ldots \ldots \ldots \ldots \ldots \ldots \ldots$

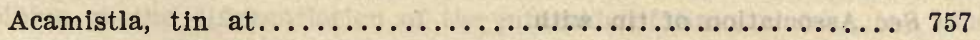

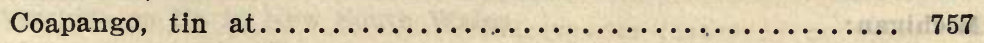

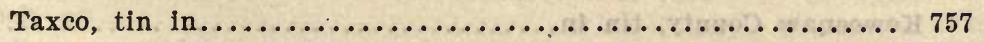

Halse on tin in San Luis Potosi, Durango, Sain Alto, and Zacatecas.. 773

Halse on tin smelting at Las Cuevas................... 773

Hanks on tin near Coneto, Durango................... 774

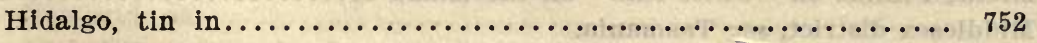

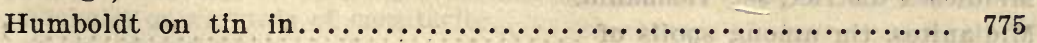

Ingalls on tin in Durango................. 776,778

Jalisco, tin in ..................................... 765

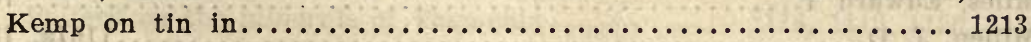

Kempton on tin in Durango and Zacatecas............... 779

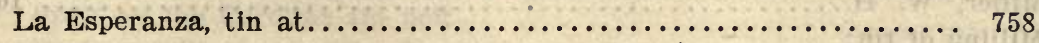

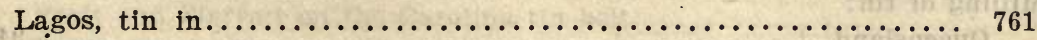

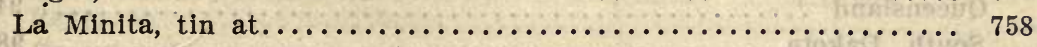

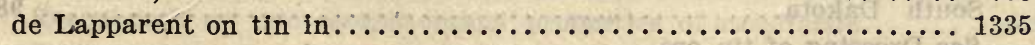

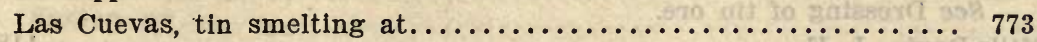

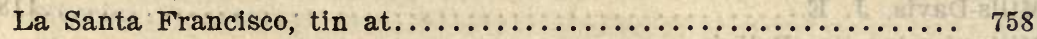

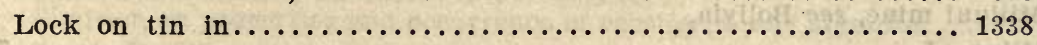

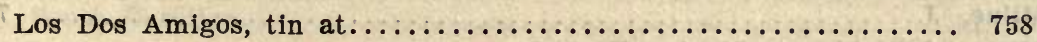

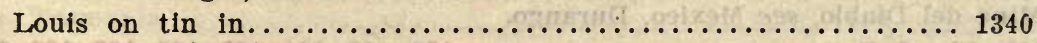

Manzano on tin in San Luis Potosi................... 780

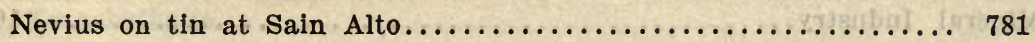


Mexico-Continued.

Reference Number

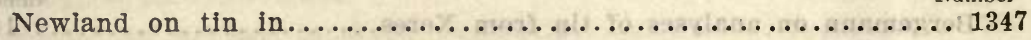

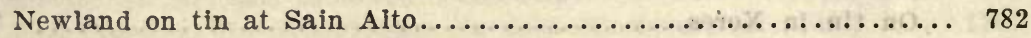

Pirsson on hematite enclosing cassiterite at Durango.......... 1635

Pratt and Sterrett on tin in ......................... 252

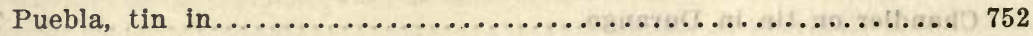

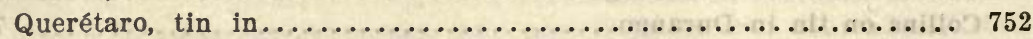

Richthofen on the age of the gold bearing deposits at Durango.... 783

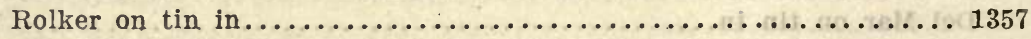

Sain Alto, tin in ......................770, 773, 779, 781, 782

San Luis Potosi, tin in ....................... 752, 773, 780

Santa Maria del Rio, tin of....................... 780

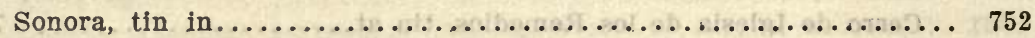

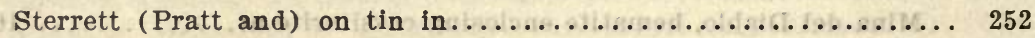

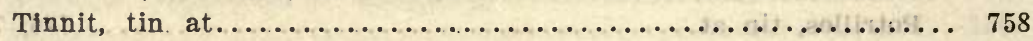

Wilson on tin and petroleum in ...................... 784

Xeres, analysis of tin from ....................... 1446

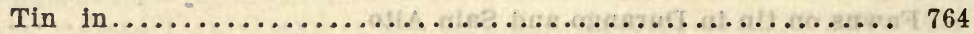

Zacatecas, tin in ........................ 752, 761, 773, 779

Mesa de los Caballos, tin in ......................... 761

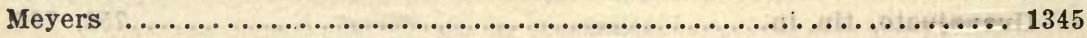

Meymac, see France.

Mica, Sadtler on deposits in the Black Hills, South Dakota......... 1016

See Association of tin with.

Michigan:

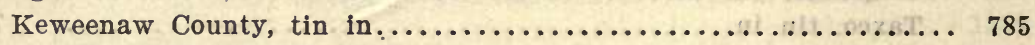

Stevens on tin in Keweenaw County..................... 785

See also United States.

Mictis, Plinius on "white lead" on the island of ............... 1408 Middlesex district, see Tasmania.

Midianites, tin among spoils of $\ldots \ldots \ldots \ldots \ldots \ldots \ldots \ldots \ldots \ldots \ldots \ldots \ldots \ldots \ldots \ldots$

Miklucho, Maclay M. von............................ 554

MHles, Edward T.................................... $705 a$

Millen, J. D.............................................. 1535

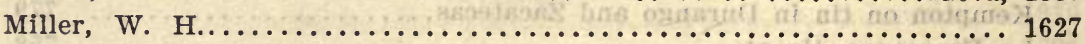

Milling of tin:

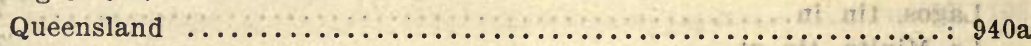

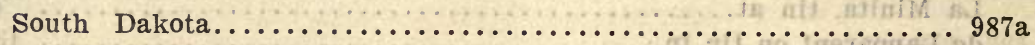

See Dressing of tin ore.

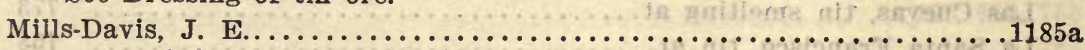

Milluni mine, see Bolivia.

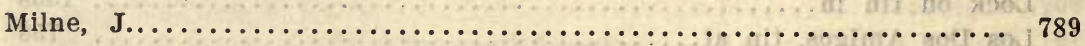

Mina del Diablo, see Mexico, Durango.

Minchin, J. B. $\ldots \ldots \ldots \ldots \ldots \ldots \ldots \ldots \ldots$ 162, 163, 164, 165, 166, 167, 168, 169

Mineral Industry $\ldots \ldots \ldots \ldots \ldots \ldots \ldots \ldots \ldots \ldots \ldots \ldots \ldots \ldots \ldots \ldots \ldots$ 
.

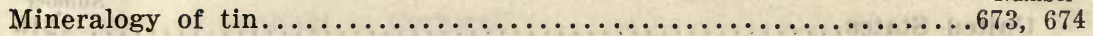

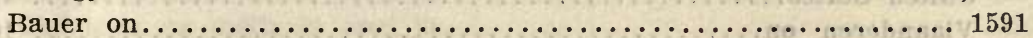

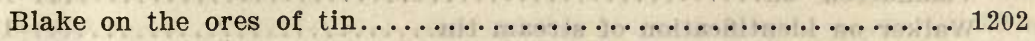

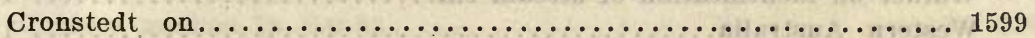

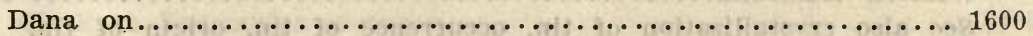

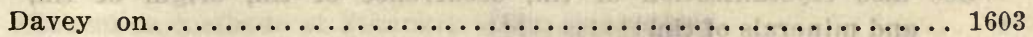

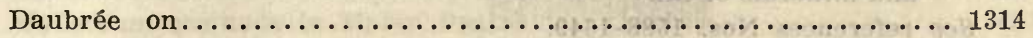

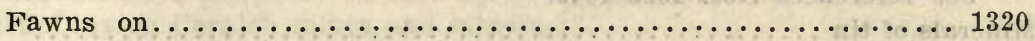

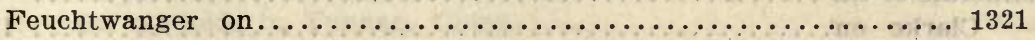

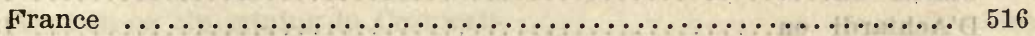

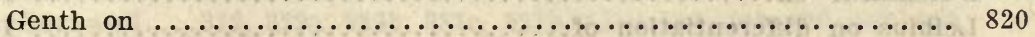

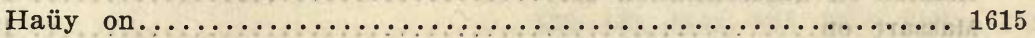

Headden on . . . . . . . . . . . . . . . 1208

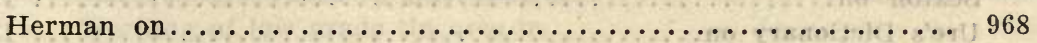

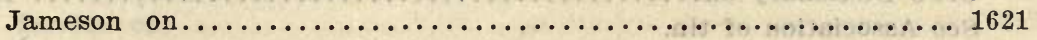

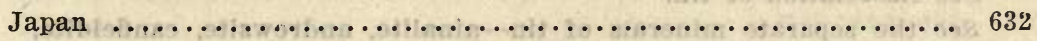

Jermejev on crystals of tinstone from the Jenisei Region......... 1623

On crystals of tinstone from Transbaikalia............. 1622

Jimbo on cassiterite crystals from Japan................ 632

Lacroix on ................................ 516

Lacroix on cassiterite in France.................... 516

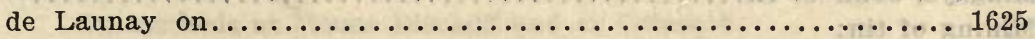

Leibius on the differentiation of the minerals of tin .......... 1336

Liversidge on tin in New South Wales................. 828

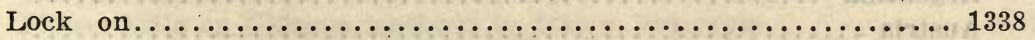

Mather on artificial production of crystals of metallic tin....... 1626

Mulholland on the Greenbushes tin field, Western Australia...... 1265

New South Wales............................. 828

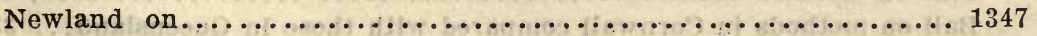

Nicholls on crystals of cassiterite...................... 1348

North Carolina.................................. 252

Ohly on ores of tin in the United States................ 1215

Petterd on the minerals of Tasmania...........1118, 1119, 1120, 1121

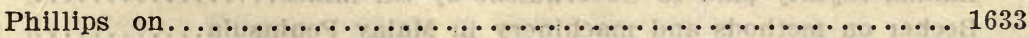

Pratt on the Carolina tin belt........................ 251

Pratt and Sterrett on the Carolina tin belt................ 252

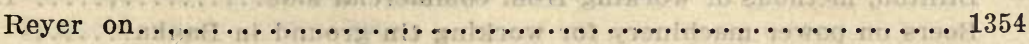

Rosenbusch on microscopic-optical properties of cassiterite...... 1639

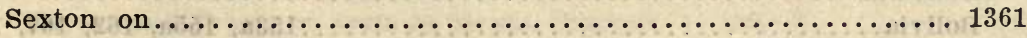

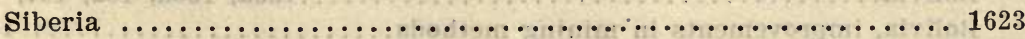

Simpson on properties and occurrence of cassiterite and stannite... 1268

South Carolina............................ 252

Tasmania $\ldots \ldots \ldots \ldots \ldots \ldots \ldots \ldots \ldots \ldots \ldots \ldots \ldots \ldots$ 1118, 1119, 1120, 1121

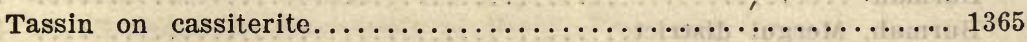

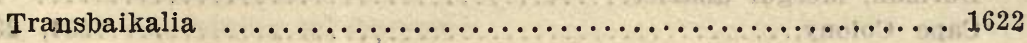


Mineralogy of tin-Continued.

Reference

United States................................. 1215

Vlaanderen on ................................ 1647

Walker on identification of stream tin................. 1371

Western Australla............................... 1265

See also crystallization of tin, occurrence of tin, origin of tin, and minerals of tin.

See references Nos. 1588-1649.

Minerals of tin .................................... 755

Clarke on .................................. 1311

D'Achiardi on ................................ 1313

Leibius on differentiation of ...................... 1336

Massart on .................................. 1343

Sexton on ................................... 1361

Ure's Dictionary on .............................. 1366

See Association of tin.

See the separate minerals of tin-ainalite, andrewsite, canfieldite, cassiterite, conradite, cuprocassiterite, cylindrite, franckeite, hulseite, native tin, nordenskiöldine, paigeite, plumbostannite, stannite, stokesite, teallite.

See also Slime tin, sparable tin, toad's-eye tin, and wood-tin.

Mingaye, John C. H.............................. 831 Mining of tin:

Agricola on ................................ 1277

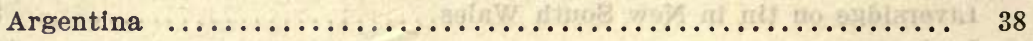

Austria .................................... 67

Baldauf on methods in Cornwall....................... 331

Balfour on methods in Malay Peninsula................. 677

Ball on Cornish methods............................. 331b,

Ball on methods in Cornwall compared with those in Queensland... 331a

Ball on methods in Stanthorpe district, Queensland............ 889

Baudot on methods in Morbihan, France................. 498

Banka...................... 74, 76, 77, 78, 84, 116, 117, 118

Banka, royalty paid to Government by tin mines............ 77

Becher on methods and machinery in Malay Peninsula.......... 678

Billiton................................117, 118, 134

Billiton, methods of working from commercial side........... 126a

Boers on power machinery for working tin ground in Banka...... 84

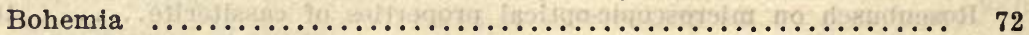

Bolivia.........................153a, 155a, 162, 167, 177

Bolivia, improvements in mining methods............... 148c

Bolivia, machinery used.......................... 148b

Brown on costs in Bolivia........................... 153a

Burmah ...................................... 204

Burmah, Mergui district........................... 185

Cape Colony,...............................234, 234a 
Mining of tin-Continued.

Carew on methods in Cornwall........................ 351

Charleton on methods used in ....................... 1310

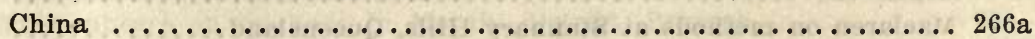

Chinese method in Banka.......................... 116

Clark on Tasmanian methods......................... 1076

Cleland on methods at Stannary Hills, Queensland............. 897

Collett on methods in Malay Peninsula................... 681

Collins on Cornish mines and miners................... 368

On methods in Yunnan, China.................... 266a

Conran on tin mining in Cornwall...................... 370a

Cornwall....312, 329a, 329b, 331a, 331b, 331.c, 351, 368, 370, 403, 413,

$422,433,450 \mathrm{a}, 456,1084,1425,1479$

Methods illustrated by photographs................. 320

Working of low grade tin ores in .................. 318

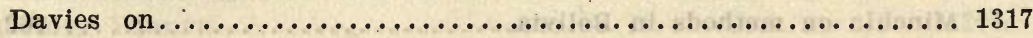

Devon...............................312, 403, 413, 1425

Dietzsch on reopening and working of Clitters mine, Cornwall..... 1479

Doyle on methods in Larut, Perak.................... 688

East Indies, mining of tin and labor troubles in ........... 675

Endter on methods in Bolivia........................ 155a

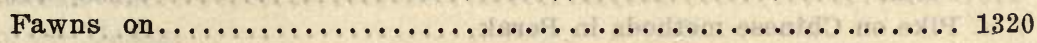

On methods at Mount Blschoff and at Dolcoath............ 1084

On methods and costs at Mount Bischoff, Tasmania.......... 1083

Flower on history of . . . . . . . . . . . . . . . . . . . 1390

Flower-Ellis on Chinese methods in Malay Peninsula.......... 1489

On methods in Malay Peninsula..................6.694a

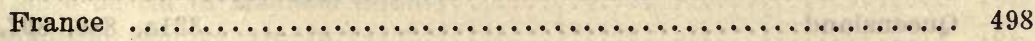

Germany, Altenberg deposits....................... 528

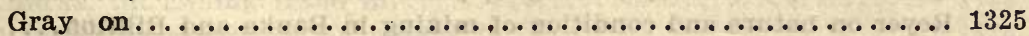

Great Britain.................................. 444

Griffiths on methods and costs in Cape Colony............... 234

Griffiths on mining in Cape Colony.................... 234a

Hallwich on ancient and modern methods in Austria........... 67

Hampton on Chinese methods in Malay Peninsula............ 695

Henwood on methods used in ........................ 1327

Henwood on methods in Cornwall and Devon.............. 403

Hoskold on in Argentina........................... 38

Hunt on methods in Cornwall and Devon in $1868 \ldots \ldots \ldots \ldots \ldots \ldots .413$

Kayser and Provis on costs at Mount Bischoff, Tasmania........ 1102

Laos ...................................... 642

Ledoux on methods and future of tin mining in North Carolina.... 248

Leifchild on methods in Cornwall..................... 422

Lewis on costs at Anchor mine, Tasmania................ 1105

On removing overburden at Derby, Tasmania............ 1104

On tin mining in Tasmania...................... 1106 
Mining of tin-Continued.

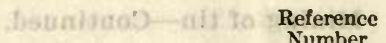

Lock on yield, methods used, and profits................ 1338

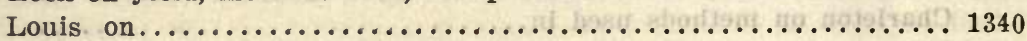

Maclaren on methods at Stannary Hills, Queensland............ 925

Malacca ..................................... 299

Malay Peninsula....665, 676, 676b, 676c, 677, 678, 681, 694a, 695, 704a,

$706,713,728,730,740,1489$

Chinese methods........657, 658, 668, 678, 688, 695, 706, 715, 740

Labor troubles in............................. 675

Marks on methods in Malay Peninsula.................. 704a

Miller on new hydro-electric power plant at Mt. Bischoff, Tasmania..1107a

Mining terms explained.........................1352, 1372

Moissenet on methods in Cornwall.................... 433

Morgan on methods in Malay Peninsula.................. 706

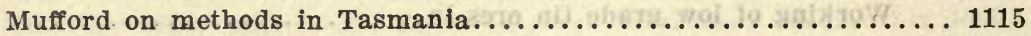

Minchin on methods in Bolivia........................... 167

Newbold on Malay and Chinese methods in Malacea............ 299

New South Wales..........................834, 844, 844a

North Carolina................................ 248

Parkes on methods in Malay Archipelago................. 713

Perak .................................688, 715, 738

Pike on Chinese methods in Perak ..................... 715

Pittman on mines and mining methods in New South Wales....... 834

Posewitz on methods in Billiton....................... 134

Pryce on methods in Great Britain....................... 444

Pryce on minerals, mines, mining, and mining terms and idloms.... 1352

Punnett on methods in Bolivia....................... 177

Queensland...........................331a, 889, 897, 925

Queensland, Stanthorpe, dredging. plant at............... 883

Reyer on nature and condition of mining in Banka and Billiton.... 117

Richter on ................................ 1356

Rickard on improvements in methods in Cornwall............. 450a

Rolker on costs, labor, and tools in Siak district, Sumatra........ 305

Sexton on ...................................... 1361

Siam, dredging operations in Tongkah Harbor................ 676

Simmons on tin mining in the Black Hills, South Dakota........ 1019

Skewes on, in Cornwall............................. 456

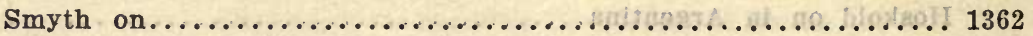

South Dakota.................................... 1019

Sowden on works at Mount Bischoff, Tasmania................ 1131

Stephens on tin mining at Pahang, Malay Peninsula........... 728

Stokes on methods in Malay Peninsula..................... 730

Stokes on new electric plant at Mount Bischoff, Tasmania......... 1133

Sumatra....................................... 305

Tasmania....1076, 1083, 1084, 1102, 1104, 1105, 1106, 1107a, 1115, 1131, 1133

Methods of working, expenses, and profits.........1064, 1069, 1070 
Mining of tin-Continued.

Thibault on dredging methods and results in New South Wales.... 844

Treacher on labor, wages, contracts, and mining methods in Perak, 738

Tremenheere on methods in Mergui district, Burmah.......... 204

Trenchard on sluicing plants at Tingha, New South Wales........844a

Van der. Wyck on methods in. Banka and Billiton.............. 118

Vercae on Chinese methods in Malay Peninsula.............. 740

Vogelsang on methods in Schlaggenwald, Bohemia............. 72

Weeks on methods, machinery, and technical terms........... 1372

Worth on tools and methods in Devon and Cornwall (historical) ... 1425

See references Nos. 1650-1658.

Mining laws:

Bartlett on British mining laws...................... 334

Boase and Courtney on British mining laws................ 342

Carew on court practices in Cornwall..................... 351

China, Yunnan.................................266a

Legislation regarding tin in Malay Peninsula.............681, 706

Mining terms explained............................. 444

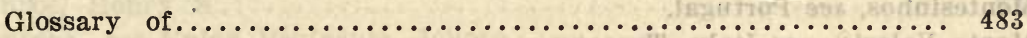

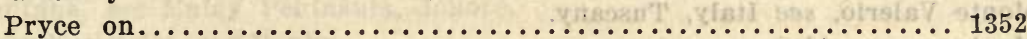

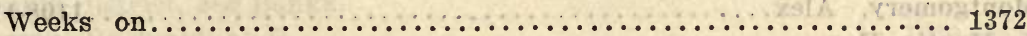

Mino, see Japan.

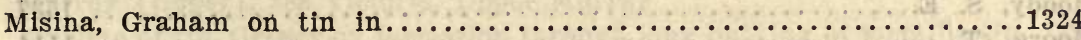

Mispickel, Whitehead on assays of, from Virginia............... 1247

See Association of tin with.

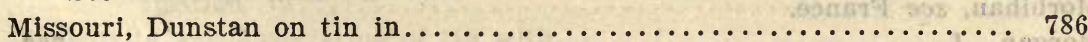

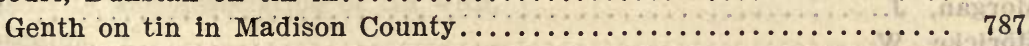

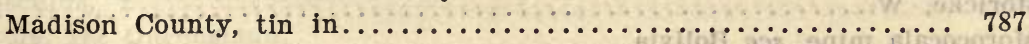

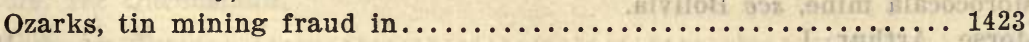

Wheeler on attempted tin mining in..................... 1423

See also United States.

Missouri River, see Montana.

Mitta Mitta, see Victoria.

Mitta River Valley, see Victoria.

Mohlengraaff, G. A. F.

Moho district, see Peru, Puno.

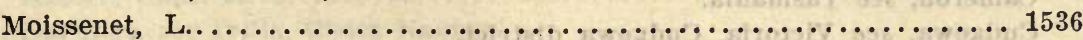

Moissenet, Leon...............................433, 434

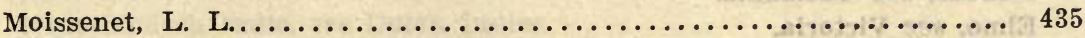

Molong district, see New South Wales.

Molybdenite, Andrews on deposits at Kingsgate, New South Wales..... 797

See Association of tin with.

Molybdenum, Clarke on separating tin from arsenic, antimony, and molybdenum

Monaglogh, see Ireland. 
$\ldots$.

Monazite, distortion of cassiterite crystals caused by............ 1649

Voit on deposits of in South Africa.................... $3 c$

See Association of tin with.

Montalbion, see Queensland.

Montana, Bitter Root Mountains, tin in.................... 214

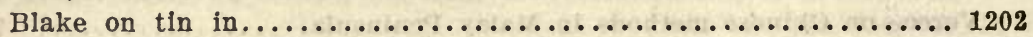

Blake on tin in the headwaters of the Missouri............. 1201

Blake on tin in the Bitter Root Mountains............... 214

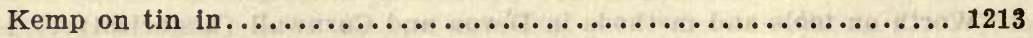

Missouri River, tin in headwaters of ................... 1201

Raymond on stream tin on Big Prickly Pear Creek............ 787a

See also United States.

Monte Blanco mine, see Bolivia.

Montebras, see France.

Montebrasite, see Association of tin with.

Monte Calvi, see Italy, Tuscany.

Monte Fumachhlo, see Italy, Tuscany.

Montesinhos, see Portugal.

Monte Valerio, see Italy, Tuscany.

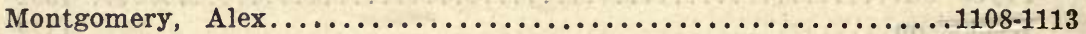

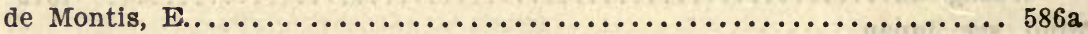

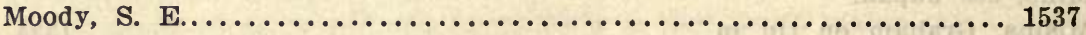

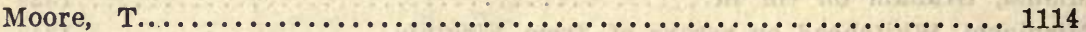

Moorina, see Tasmania.

Morblhan, see France.

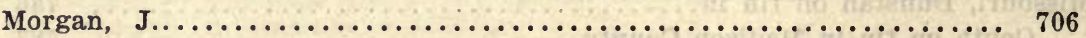

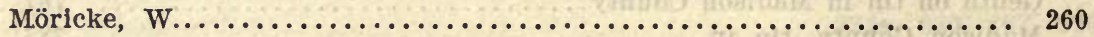

Morococala mine, see Bolivia.

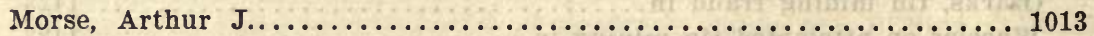

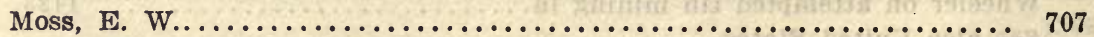

Mount Amos, see Queensland.

Bischoff, see Tasmania.

Black, see Tasmania.

Brown, see Queensland.

Calvario, see Peru.

Cameron, see Tasmania.

Cudgewa, see Victoria, Cudgewa district.

Dundas, see Tasmania.

Elmo, see Victoria.

Euriowie, see New South Wales.

Fatique, see Victoria.

Gunson mine, see South Australia.

Leswell, see Queensland.

Lyell, see Tasmania.

Mica, see Maine.

Pllot, see New South Wales. 
Mount Amos-Continued.

Poscovi, see Bolivia.

Ramsay, see Tasmanla.

Read, see Tasmania.

Rex, see Tasmania, Ben Lomond.

Rubellite, see Maine.

Singapore, see Victoria.

Wells, see Northern Territory.

Wills Creek, see Victoria.

Mourne Mountalns, see Ireland.

Mufford, J......................................1115, 1116

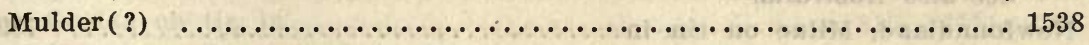

Muldiva, see Queensland.

Mulholland, C. A.................................... 1265

Muller, H., and Richter............................. 560

Müller, Hermann $\ldots \ldots \ldots \ldots \ldots \ldots \ldots \ldots \ldots \ldots \ldots \ldots . \ldots \ldots 5,556,557,558,559$

Muller, J. A................................... 1539

Munday, John ....................................... 927

Munroe, Henry S................................. 633

Muntaha, see Malay Peninsula, Johore.

Muntok district, see Banka.

Murray, Reginald A. F...........................1230, 1231

Murray (Upper), see Victoria, Upper Murray.

Muriate of tin, Gregor on formation through long burying of metallic tin, 393

Hunt on influence of magnetism and voltaic electricity on crystal-

lization of .................................. 1619

Muscovite, see Association of th with.

Musculus, F...................................... 1540

Myola, see Queensland.

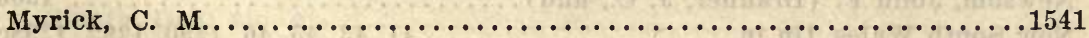

N

Nails, made from tin scrap.

Nam-Patene, see Siam, Laos.

Nam Sak River, see Siam.

Nancothan, see Cornwall.

Napier, Chas. R. G.................................. 1405

Narungo, see India, Chota Nagpur.

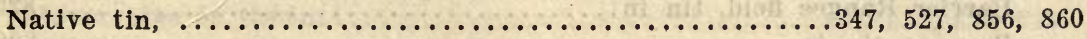

Nederlandsch Indie, see Dutch Indies.

-Neeb, E. A......................................... 298

Negri Sembilan, see Malay Peninsula.

Negro Pabellon, see Bolivia.

Nellys Ford, see Virginia, Nelson County.

Nelson County, see Virginia.

Neudeck, see Bohemla. 


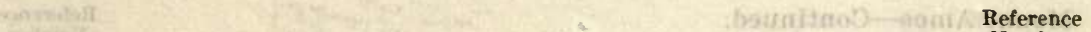
Nevada, Hoffman on tin in Tuscarora placer mines............ 788 See also United States.

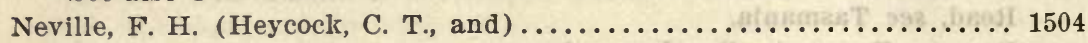

Nevius, J. Nelson............................... 781

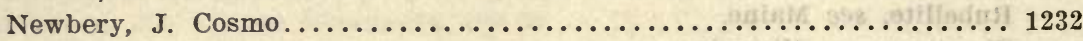

Newbold, T. J............................... 299

Newellton district, see Queensland.

New England plateau, see New South Wales.

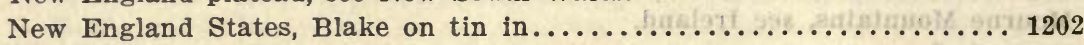
See also Australia.

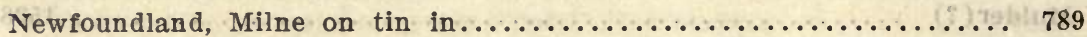

New Guinea, Ferguson Island, tin on..................... 790

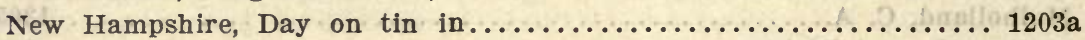

Jackson, tin at............................791, 792, 1214

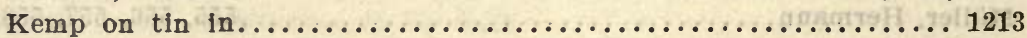

Leonhard on tin at Jackson....................... 1214

See also United States.

New Jersey, Andover, tin near......................... 793

Lesley on tin near Andover......................... 793

Schnabel on tin in zinc from........................ 794

See also United States.

Newland, D. H.....30, 31, 54, 70, 170, 436, 437, 708, 782, 832, 833, 928,

the cath

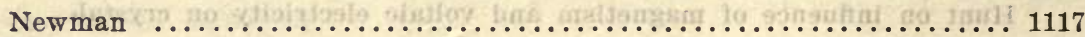

Newman, G. H................................ 929

Newquay, see Cornwall.

New Ross, see Nova Scotia, Lunenberg County.

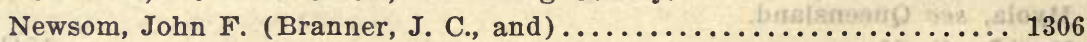

New South Wales, tin in................41, 43, 45, 46, 1290, 1292, $1298 \mathrm{c}$

A-, R. D., on tin mining in Vegetable Creek district...... 796

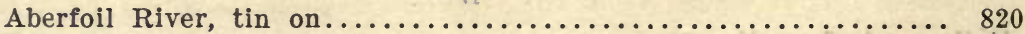

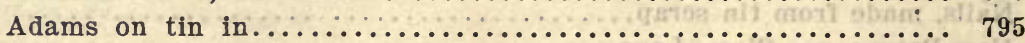

Andrews on tin in the New England plateau............... 797

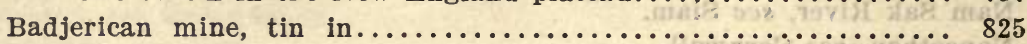

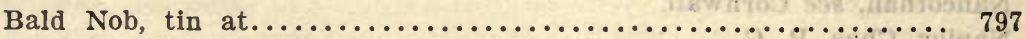

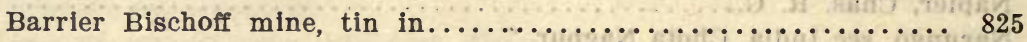

Barrier Ranges field, tin in ............................ 825

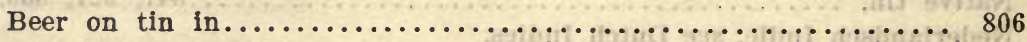

Bendemeer, Gulf mine, $\operatorname{tin}$ in ...................... 817

Benedict on tin deposits of......................., 1301

Benedict on Oetery mine in Emmaville district............ 807

Bourke County, tin in .......................... 841

Brögger (Kjerulf and) on tin in ..................... 826

Broken Head, beach mining at..................... 805 
New South Wales-Continued.

Reference Number

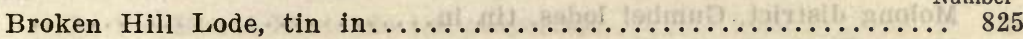

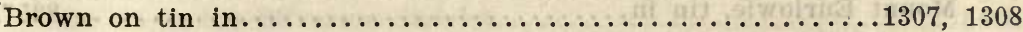

Burra Burra district, tin in..................... 847a

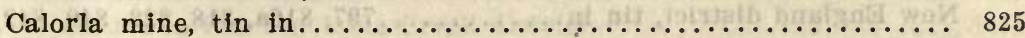

Card on minerals of economic value in .................. 808

Carne on beach sand of the Esk River and Jerusalem Creek, Rich-

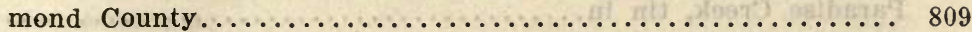

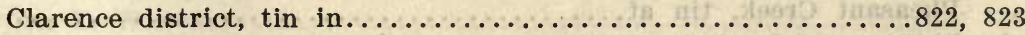

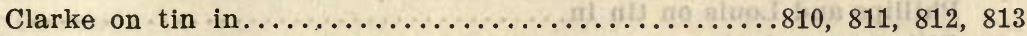

Clark on tin mines in the Devonian of ................... 814

Coglan on tin in .......................... 815, 1677, 1679

Conder on the Conrad tin mines...................... 816

Cotton on the tin deposits of New England................ 816a

Cox on tin near Bendemeer, in Inverell district, and at Silverton.... 817

David on the Vegetable Creek field, New England district......... 818

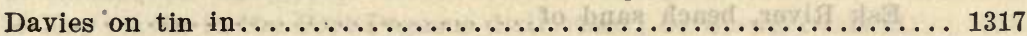

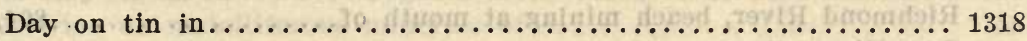

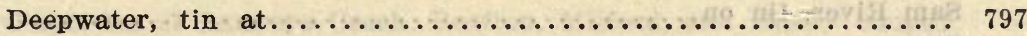

Department of mines on tin in ...................... 819

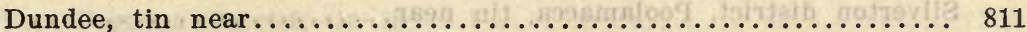

Emmaville district...................... 797, 800, 807

Emmaville district, Emerald mines, tin in ................. 797

English on tin in the Invereli district................... 50

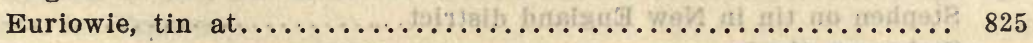

Evans on Little River to McAuley's Lead, beach mining from..... 804

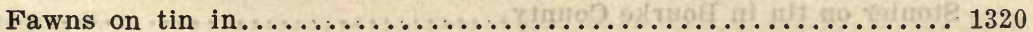

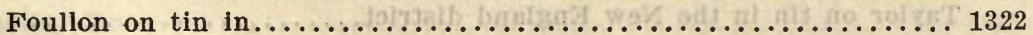

Genth on tin from Aberfoil and Sam Rivers............... 820

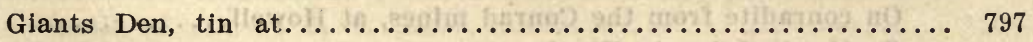

Gower on the Vegetable Creek field.............821, 822, 823, 824

Howell, Conrad mines, conradite from................. 1644

Conrad mines, tin in .......................... 816

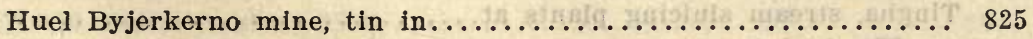

Inverell district, tin in .............50, 797, $803,817,844,847 \mathrm{c}$

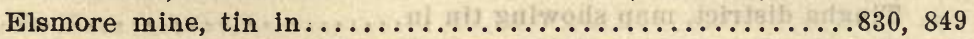

Jaquet on tin in Euriowie and Waukeroo................ 825

Kjerulf and Brögger on tin in ........................ 826

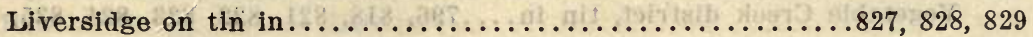

Liversidge on Elsmore mine, Inverell................ 830

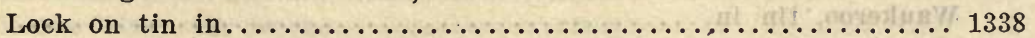

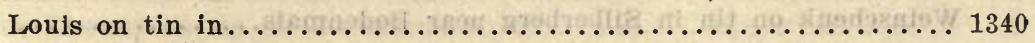

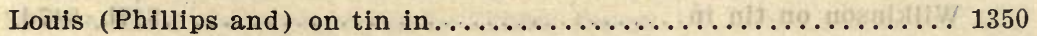

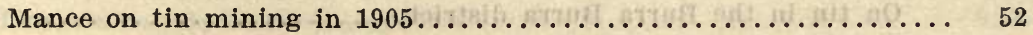

McAuleys Lead to Evans or Little River, beach mining from....... 804

Mingaye on tin in the Richmond River district............. 831 
New South Wales-Continued.

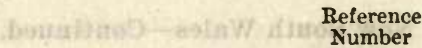

Molong district, Gumbel lodes, tin in.

Mount Euriowie, $\operatorname{tin}$ in............................... 848

Mount Pilot, tin at foot of........................ 799

New England district, tin in.........797, 816a, 818, 822, 840, 842, 845

Newland on tin in .............................. 832, 1346

Newton on metalliferous minerals of .................. 55

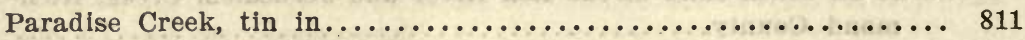

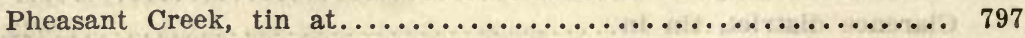

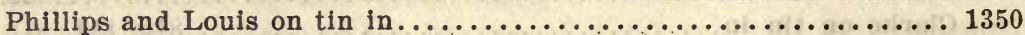

Pittman on tin in ................................. 835

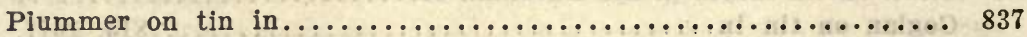

On tin in Vegetable Creek fleld.................... 836

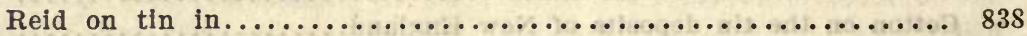

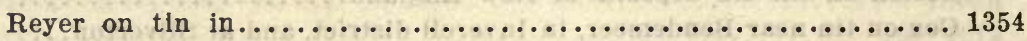

Richmond County, Jerusalem Creek, beach sand of............ 809

Esk River, beach sand of....................... 809

Richmond River, beach mining at mouth of ............. 804,831

Sam River, tin on ............................. 820

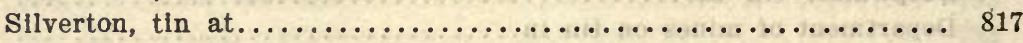

Silverton district, Poolamacca, tin near............... 847h

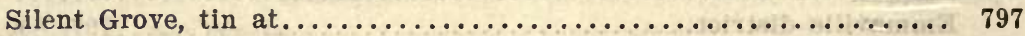

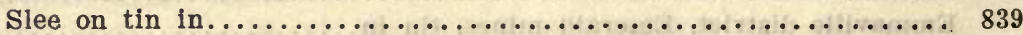

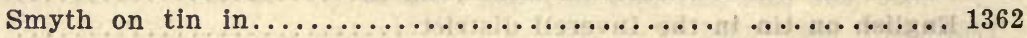

Stephen on tin in New England district................. 840

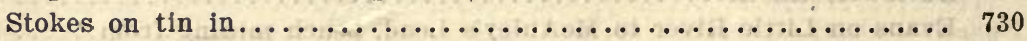

Stonier on tin in Bourke County..................... 841

Taylor on tin in the New England district............... 842

Thibault on $\operatorname{tin}$ in $\ldots \ldots \ldots \ldots \ldots \ldots \ldots \ldots \ldots \ldots \ldots \ldots \ldots \ldots . \ldots \ldots . \ldots \ldots$

On conradite from the Conrad mines, at Howell........... 1644

On tin dredging in Tingha...................... 844

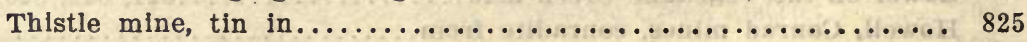

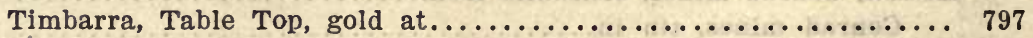

Tingha, stream sluicing plants at.................. 844a

Tin dredging at. $\ldots \ldots \ldots \ldots \ldots \ldots \ldots \ldots \ldots \ldots \ldots \ldots \ldots \ldots, 803,844$

Tingha district, map showing tin in................... 849

Trenchard on stream sluicing plants at Tingha............. 844a

Ulrich on tin in New England district.................. 845

Vegetable Creek district, tin in...796, 818, 821, 822, 823, 824, 835,

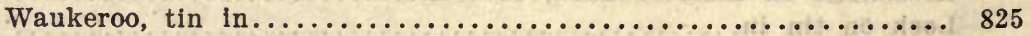

Weinschenk on tin in Silberberg near Bodenmais............ 846

Wilkinson on tin in ...................... $847 \mathrm{~b}, 847 \mathrm{~d}$, 847e

On tin in the Burra Burra district................ 847a

On tin in the Inverell district................. 847c

On tin in the Molong district................... $847 \mathrm{~g}$ 
New South Wales: Wilkinson-Continued. Reference On the Mount Euriowie tin properties.

On tin in the Silverton district................... $847 \mathrm{~h}$

On tin in the Tingha and Elsmore districts............ 849

On tin in the Vegetable Creek district................ $847 f$

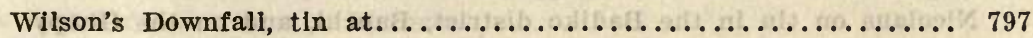

Wood on $\operatorname{tin}$ in $\ldots \ldots \ldots \ldots \ldots \ldots \ldots \ldots \ldots \ldots \ldots \ldots \ldots \ldots \ldots \ldots$

See also Australia.

Newton, E. Wilton................................ 55

New Zealand:

Bell on tin on Stewart Island....................... 852

Binns on tin on west coast of Otago and South Island.......... 853

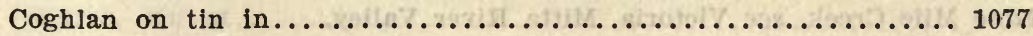

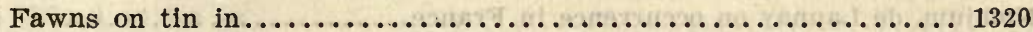

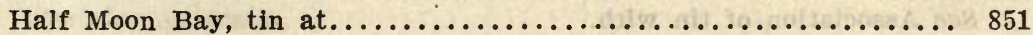

de Launay on tin in ............................. 854

McKay on tin in the Port Pegasus district and on Stewart Island... 855

Newton on metalliferous minerals of .................. 55

Otago, tin at Laukeys Creek, Reefton, Milford, and Dusky Sounds

on west coast of............................... 853

Port Pegasus district, tin in........................ 855

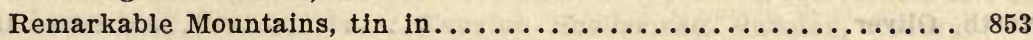

South Island, tin at Humphreys Gulley near Hokitika.......... 853

Stewart Island, tin on................... 851, 852, 853, 855 Neyrac, see France.

Nicholas, C. E..................................... 929a

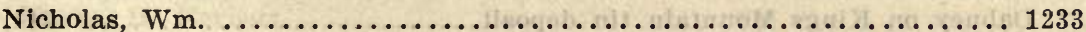

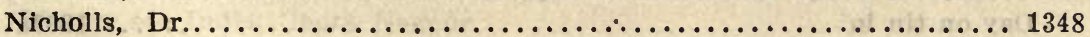

Nickel, Emmons on occurrence in United States and genesis of min-

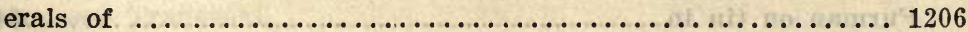

Douglas on metallurgy of ......................... 1204

Moody on hydrolysis of salts of, in presence of iodides and iodates. . 1537

Perret on metallurgy of ........................... 1549

World statistics since $1890 \ldots \ldots \ldots \ldots \ldots \ldots \ldots \ldots \ldots \ldots \ldots \ldots \ldots . \ldots \ldots$

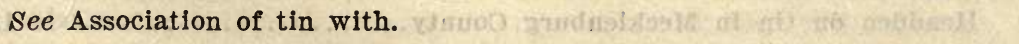

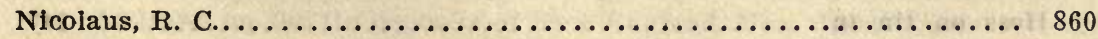

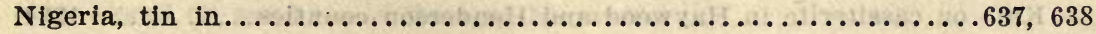

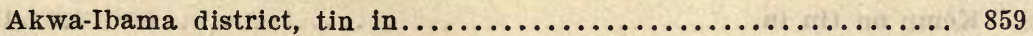

Bauchi, $t$ in in Badiko district....................... 860

Bautshi tin fields............................... 857

Benue River, tin on the............................ 3

de Launay on tin on the Benue River................... 3

Delime River, tributary to Lake Tchad, tin on............ 856

Dunstan on the Bautshi tin fields...................... 857

On tin from the Tilde area and the River Gimpu......... 858

On tin in the Uwet and Akwa-Ibama districts........... 859 
Nigeria-Continued.

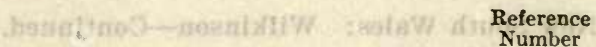

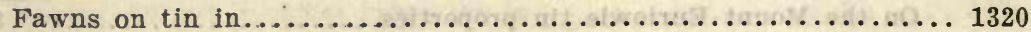

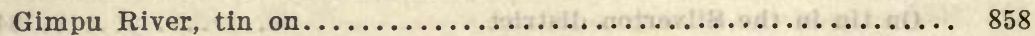

Gimpy or Kogin-Delume River, tin on the.............. 860

Kogin-Delume River, see Gimpy River.

Nicolaus on tin in the Badiko district, Bauchi, and on the Gimpy

or Kogin-Delume . River....................... 860

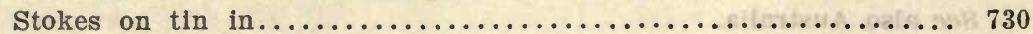

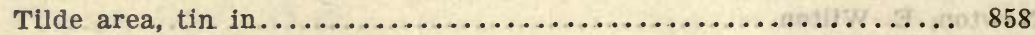

Uwet district, tin in ............................. 859

See also Africa.

Nigger Hill district, see South Dakota.

Nine Mile Creek, see Victoria, Mitta River Valley.

Niobium, de Launay on occurrence in France.................. 518

See Association of tin with.

Niriella, see Ceylon.

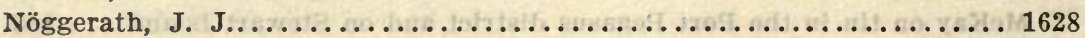

Noragala, see Ceylon.

Nordenskiöld, A. E.............................948, 1628a

Nordenskiöldine, Brögger on à rare borate of calcium and tin....... 1596

Dan on ..................................... 1600

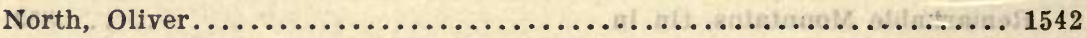

North America, see Alaska, Canada, Greenland, Mexico, Newfoundland, Santo Domingo, United States, etc.

North Carolina, tin in.......................... 1196, 1281, 1298

Benedict on tin in .........................240, 1200, 1301

Dabney on Kings Mountain tin deposit.................. 241

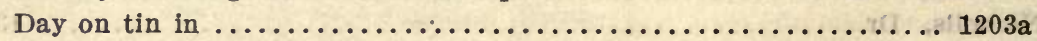

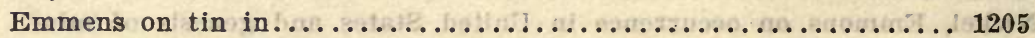

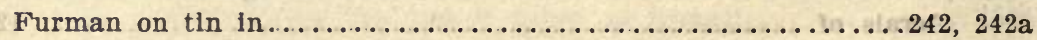

Garrison on tin in ...........................243, 1207

Genth on tin at Kings Mountain and on other minerals in........ 244

Graton on tin in .................................... 246

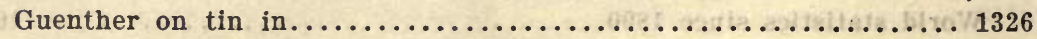

Headden on tin in Mecklenburg County.................. 1208

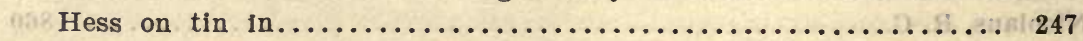

Kalb on cassiterite in. Haywood and Henderson counties.......... 1334

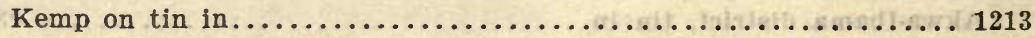

Kings Mountain tin deposit........240, 241, 242a, 244, 247, 248, 254, 254a

Ledoux on tin at Kings Mountain.................... 248

Mecklenburg County, analysis of cassiterite. supposed to be from.... 1208

Phillips on tin in ............................. 250

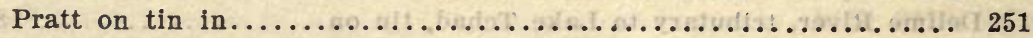

Pratt and Sterrett on tin in ........................ 252

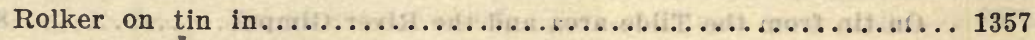

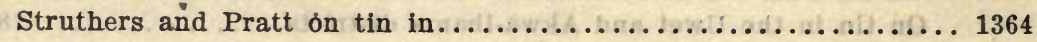


North Carolina-Continued.

Ulke on tin at Kings Mountain...................... 254

Van Ness on tin at Kings Mountain..................... 254a

See also Carolinas and United States.

North Dundas, see Tasmania.

Northeastern district, see Victoria.

Northern Hills, see South Dakota, Black Hills.

Northern Territory, tin in..................... 1292, 1298c

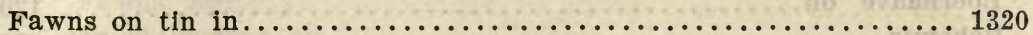

Playford on tin at Warra.............................. 861 a

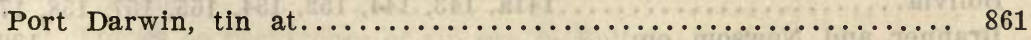

Tate on tin near Mt. Wells and on a tributary of McKinlay River... 862

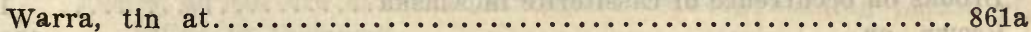

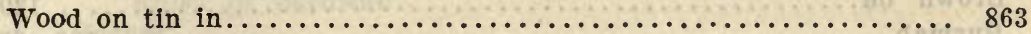

See also Australia.

Norton Bay, see Alaska.

Norway, Brögger on the minerals of the syenite pegmatite......... 1596

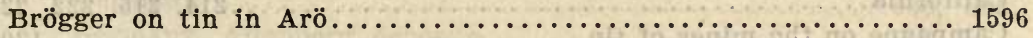

See also Europe.

Nova Scotia, Fairibault on tin in Lunenberg County............. 227

Lunenberg County, tin at New Ross..................224, 227, 232

Lunenberg County, tin at Tangier, Shelbourne, Rawdon, Country

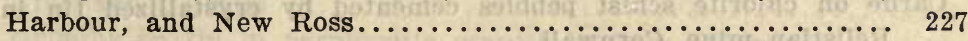

Young on geology of country near New Ross............... 232

See also Canada.

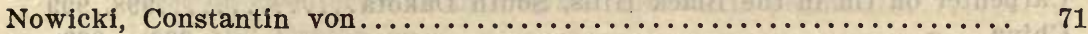

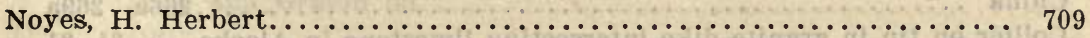

Nurgo, see India, Chota Nagpur.

Nurunga, see Narungo.

Nylstroom, see Transvaal.

0

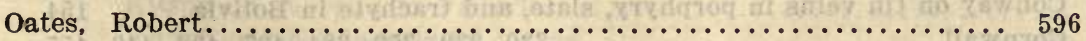

Occurrence of tin........................ 1280, 1288, 1293, 1294

Alaska.......................... 12c, 17, 21, 29a, 29b, 31

Andrews on the tin deposits of New England, New South Wales.... 797

Argall on wood tin in Breage, Cornwall................. 330

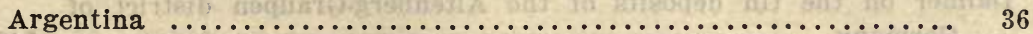

Argentina, Tinogasta, in granulite..................... 36

Balfour on tin in Malay Peninsula.................... 677

Banka ............................................. 136

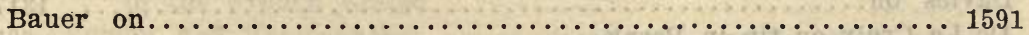

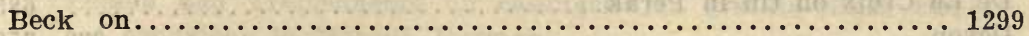

Beck on the mineral deposits of Schwartzenberg............. 530

Benedict on tin and bismuth in closely associated but distinct veins

at Chorolque, Bolivia........................ 152 
Occurrence of tin-Continued.

Reference Number

Bergeat on the tin deposits of Tuscany 613

Berger on matrices accompanying mineral deposits of Cornwall and

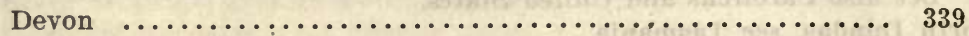

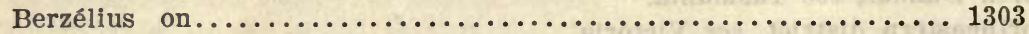

Billiton................................ 134, 136

Blake on tin ore in the Black Hills, South Dakota............ 994

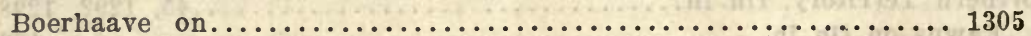

Bohemia ................................. 573a

Bolivia.................141a, 143, 144, 152, 154, 155, 157, 158, 172

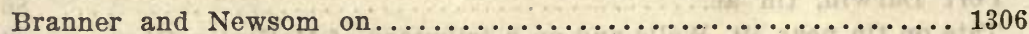

Brooks on occurrence of cassiterite in Alaska............... 17

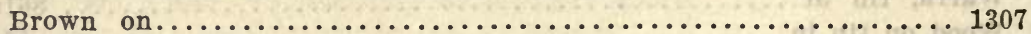

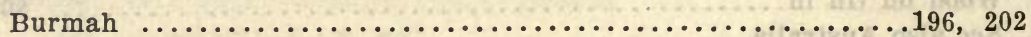

Busz on cassiterite in hornfels in Devon................ 350

Buttgenbach on cassiterite-bearing lodes in Katanga........... 275

California............................... 214, 222, 223

Campagne on the mines of tin......................... 1309

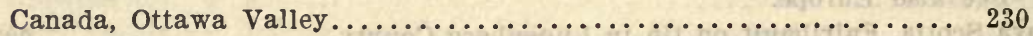

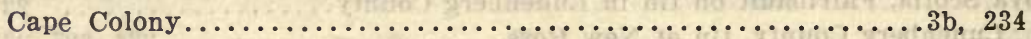

Card on occurrence of tin ore....................... 808

Carne on chlorite schist pebbles cemented by crystallized tin in

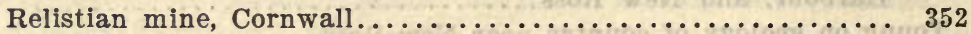

Carolinas, pegmatite dikes with cassiterite as original constituent.. 239

Carpenter on tin in the Black Hills, South Dakota............998, 999

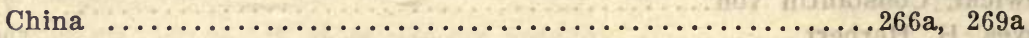

Collier on tin in granite dike intersecting limestone in Alaska....21, 31

Collins on tin in west of England..................... 367

On tin in Yunnan, China................................

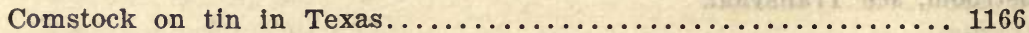

Conder on the Stanley River tin field, Tasmania............. 1078a

Conway on tin veins in porphyry, slate, and trachyte in Bolivia.... 154

Cornwall...................330, 339, 352, 384, 427, 433, 442, 455

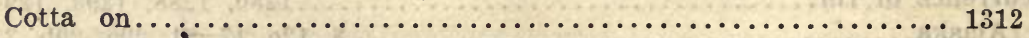

Cotton on the tin deposits of New England, New South Wales.... 816a

Cox on lode and alluvial deposits in New South Wales.......... 817

Dalmer on the tin deposits of the Altenberg-Graupen district of

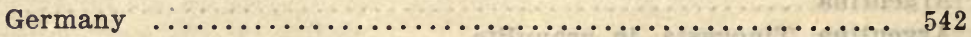

Daubrée on .................................. 1314, 1315, 1316

David on tin deposits of the Vegetable Creek field, New South Wales, 818

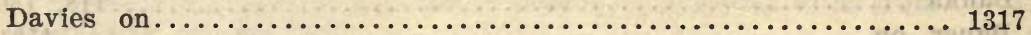

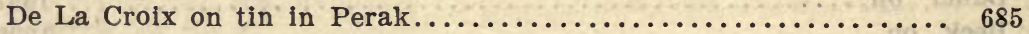

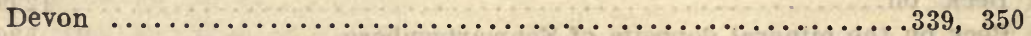

Dinsmore on tin in Franklin Mountains, Texas............. 1168a

Dunstan on tin deposits of Stannary Hills, Queensland......... 904

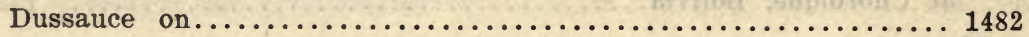


Occurrence of tin-Continued.

Reference

Number

Emmons on occurrence in the United States................ 1206

Emmons on tin ore in andesitic or trachytic rocks of Cretaceous or

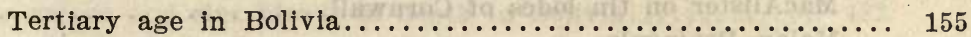

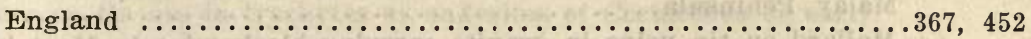

English on tin in decayed granite, porphyry, and quartzose rock at

M.t. Bischoff, Tasmania........................ 50

Fairbanks on system of tin veins in Temescal district, California, 215, 216

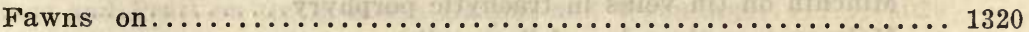

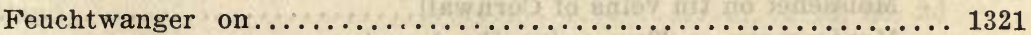

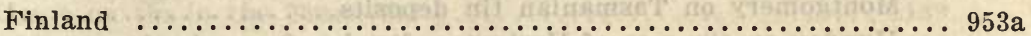

Forbes on occurrence of tin ore in Bolivia............... 157

Foster on tin ore as lenticular layers between bedding planes of

killas in Cornwall............................. 384

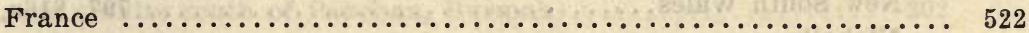

France, Montebras, at contact of granite and feldspathic porphyry, 494, 517

Frochot on the grading of $\mathrm{SnO}_{2}$ into tin pyrites at depth in Bolivia, 158

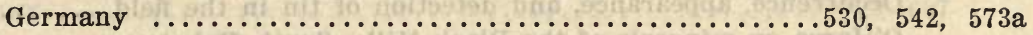

Germany, Altenberg deposits........................ 528

Grading of $\mathrm{SnO}_{2}$ into tin pyrites at depth in Bolivia............ 143

Graton on cassiterite as a primary constituent of pegmatite dikes

in Carolina tin belt.............................. 246

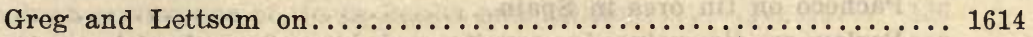

Griffiths on tin in porphyritic granite in Cape Colony.......... 234

Hanks on ..................................... 218

Hess on cassiterite as an original mineral in pegmatite......... 247

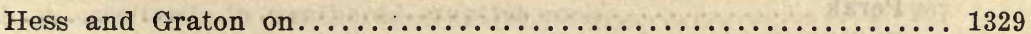

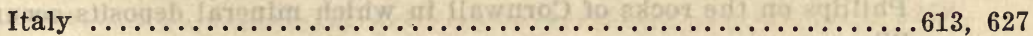

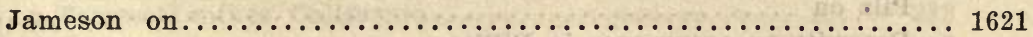

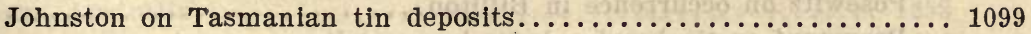

Jokèly on tin in gneiss, felsite, porphyry, and greisen.......... 68

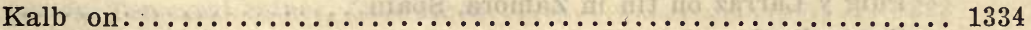

Kitson on deposits in Victoria........................ 1229

Knopf on tin minerals in Alaska........................... 29b

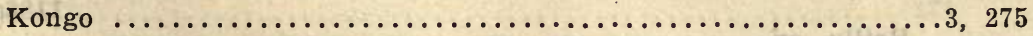

Krusch on tin deposits of Western Australia................ 1258

Lacroix on cassiterite at Hin-boun, Laos.................... 644

Laos ........................................ 644

de Launay on cassiterite in pegmatite cutting mica, talc, chlorite, and amphibolite schists at Embabaan, Swazland............

de Launay on tin with copper in region of Archæan rocks and granite

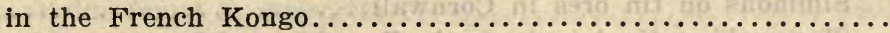

Lemon and Tremenheere on cassiterite in granite dikes cutting sandstone in Mergui, Burmah..................... 196

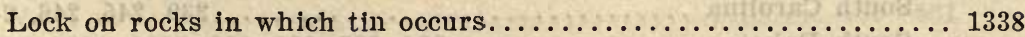

Lott1 on the tin deposits of Tuscany................... 627 
Occurrence of tin-Continued.

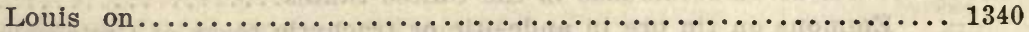

MacAlister on tin lodes of Cornwall................... 427

Malay Peninsula.............................. 714

Mallard on tin veins in granite carrying black mica in Montebras,

France ................................ 522

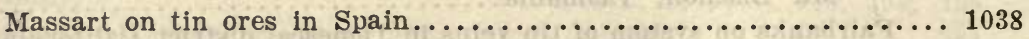

Minchin on tin veins in trachytic porphyry................... 164

Moissenet on tin veins of Cornwall..................... 433

Montgomery on Tasmanian tin deposits...............1110, 1113

Munday on tin ores of Herberton district, Queensland......... 927

Newland on tin in granite dike intersecting limestone near Lost

River, Alaska............................ 31

New South Wales.....................

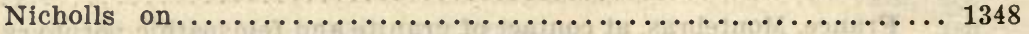

North Carolina.....................239, 245, 246, 247, 1220

Occurrence, appearance, and detection of tin in the field.........1298e

O'Harra on minerals of the Black Hills, South Dakota........... 1014

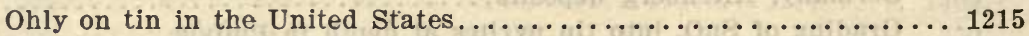

Osann on cassiterite in graphitic gneiss derived from limestone in

the Ottawa Valley, Canada...................... 230

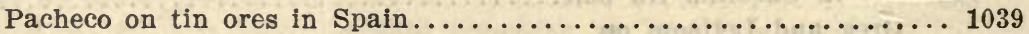

Pasley on tin veins in granite and later "porphyritic rocks"-

trachytic in the south - of Bolivia.................. 172

Penrose on tin deposits of Malay Peninsula ............... 714

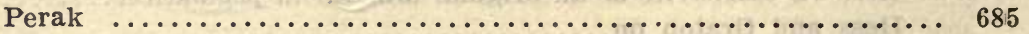

Phillips on the rocks of Cornwall in which mineral deposits occur.. 442

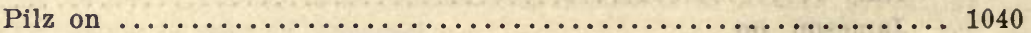

Posewitz on occurrence in Billiton..................... 134

Preumont on tin bearing lodes in quartzite.............. 176

Puig y Larraz on tin in Zamora, Spain...................... 1041

Queensland ................................... 927

Recknagel on the tin deposits in the Rooiberg district, Transvaal,

$1186 \mathrm{a}, 1186 \mathrm{~b}$

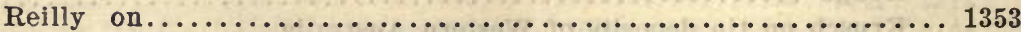

Rudler on occurrence of cassiterite and stannite in Great Britain... 452

Rumbold on tin deposits of Cape Colony, Transvaal, and Swaziland.. 3b

Sandberger on occurrence in silicates................... 1358

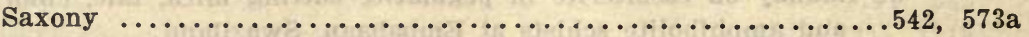

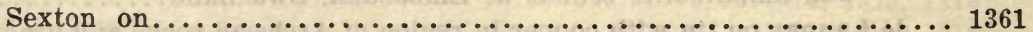

Simmons on tin ores in Cornwall..................... 455

Singewald on tin deposits in the Erzgebirge of Saxony and Bohemia. 573a

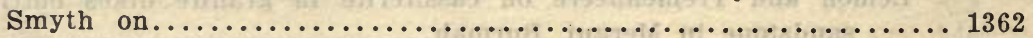
South Carolina $\ldots \ldots \ldots \ldots \ldots \ldots \ldots \ldots \ldots \ldots \ldots . \ldots \ldots, 245,246,247,1220$

South Dakota.............994, 997, 998, 999, 1009, 1014, 1020, 1221

Spain ..................................... 1039, 1041 
Occurrence of tin-Continued.

Stelzner on tin grading into argentiferous fahlerz, pyrites, and locally galena and zinc blende at depth in Bolivia........... Stelzner on tin ore in trachytes or andesites of Cretaceous or early Tertiary age in Bolivia.......................... 182 Stirling on tin deposits of Victoria.................... 1238 Struthers and Pratt on tin In North and South Carolina.......... 1220 Struthers and Pratt on tin in South Dakota and Wyoming........ 1020 Swaziland ...................................... 3d Swinburne on tin in the Transvaal.................... 1189 Tasmania................50, 1078a, 1099, 1110, 1113, 1155, 1156, 1158

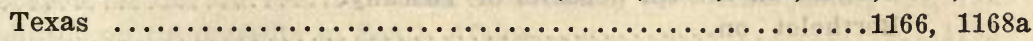
Theobald on tinstone as one of the integral constituents of a stanniferous granite south of Pakchan, Burmah.............. 202 Transvaal.......................3d, 1178d, 1186a, 1186b, 1189 Trustedt on iron, copper, and tin deposits at Pitkäranta, Finland... 953a

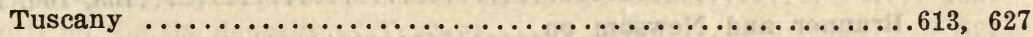
Ulke on deposits at Kings Mountain, North Carolina, and Vesuvius, Virginia

United States.............................1206, 1215

Van der Wyck on occurrence in Banka and Billiton............ 118

Verbeek on occurrence of tin in Banka and Billiton............. 136

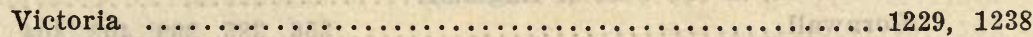

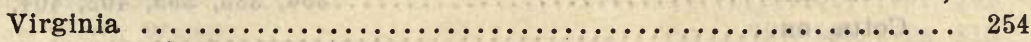

Waller on tin in Tasmania....................1155, 1156, 1158

Warth on cassiterite in weathered eruptive rock............. 207

Weeks on ...................................... 1372

West on Temescal mines, California ..................... 222

Western Australia.................................... 1258

Weston on tin deposits of Swaziland and Transvaal............. 3d

Whitney on Temescal mines, California.................. 223

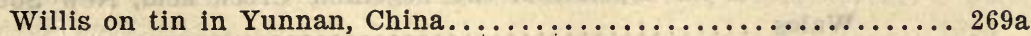

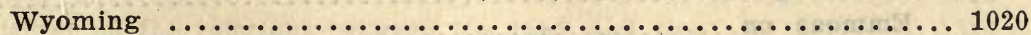

Ochsenius, C....................................... 171

Oetery mine, see New South Wales, Emmaville district.

O'Harra, Cleophus C................................... 1014 Ohira-tetsu-san, see Japan, Bungo.

Ohly, J........................................... 1215

Olaechea, T......................................... 171a

Oldham, T.......................................... 199

Olivine, tin in olivine found in meteorite.................... 1600

Onon River, see Siberia.

Oonah mine, see Tasmania.

Oppe, H. V........................................ 561

Oppert, Ernest .................................. 640

Orange River Colony, Jorissen on intrusive granites in.............1050 
Reference

Number

Ordway, John M.

1543

Orense, see Spain.

Orient farm, see Tasmania.

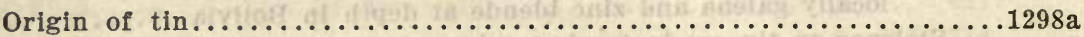

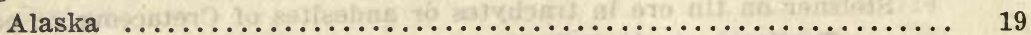

Andrews on the tin and wolfram deposits of New England, New

South Wales............................ 797

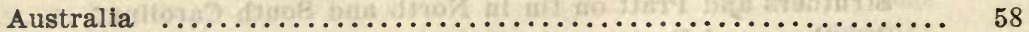

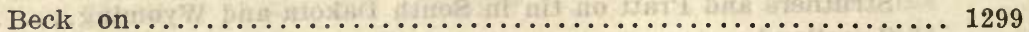

Beck on the mineral deposits of Schwartzenberg............ 530

Beck on relation between ore veins and pegmatites............ 1300

Bergeat on the tin deposits of Tuscany .................. 613

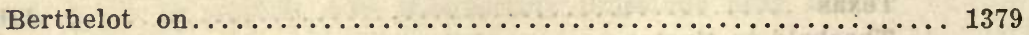

Blake on tin ores of the Black Hills, South Dakota............ 995

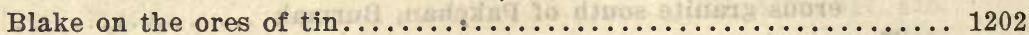

Bohemia .................................... 542

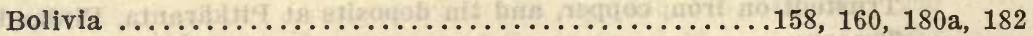

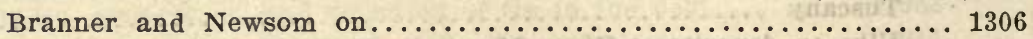

Breithaupt on the paragenesis of minerals................... 535

Carne on the source of the tin in beach sands of New South Wales. 809

Carne on stream tin in Cornwall....................... 356

Collier on stream tin in Alaska....................... 19

Collins on, in the west of England................... 367

Cornwall.....................356, 385, 399, 402, 404, 410, 427

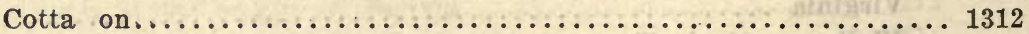

Cotta on gradual passage from granite to stanniferous zwittergestein in Germany............................ 539

Cotton on the tin deposits of New England, New South Wales..... 816a

Dalmer on the tin deposits of the Altenberg-Graupen district, Germany .................................. 542

Daubrée on .....................................1314, 1315, 1316

David on the tin deposits of the Vegetable Creek field, New South

Wales ........................................ 818

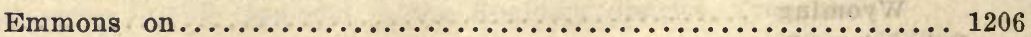

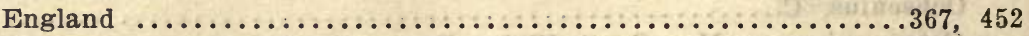

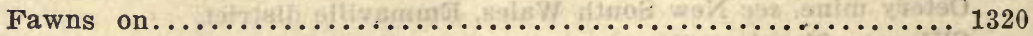

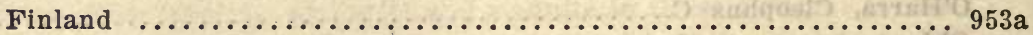

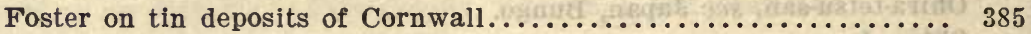

Frochot on tin deposits of Bolivia...................... 158

Gautier on tin deposits near Chorolque, Bolivia.............. 160

Germany ........................... 530, 539, 542, 575

Graton on tin deposits of the Carolina tin belt.............245, 246

Hall on tin deposits of Pretoria............................ 1182

Hawkins on origin of alluvial strata in Cornwall............ 399

Headden on tin in the Black Hills, South Dakota............. 1008 
Origin of tin-Continued.

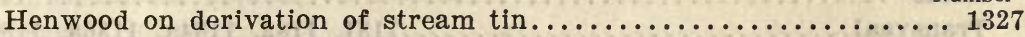

On the stream tin deposits of Cornwall...............402, 404

Hess on the Carolina tin deposits..................... 247

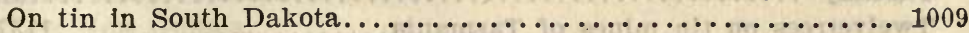

Hill on tin deposits of Cornwall...................... 410

Hopkins on alluvial tin deposits.......................... 1330

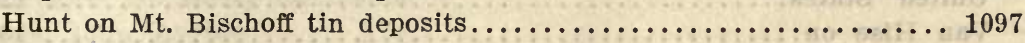

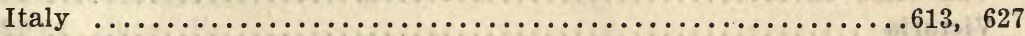

Jackson on the tin bearing veins of Jackson, New Hampshire, 791, 792

Johnson on tin deposits in South Africa.................. 1183

Krusch on tin deposits of Western Australia.............. 1258

Lacroix on cassiterite at Hin-boun, Laos................ 644

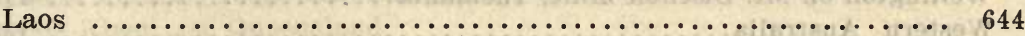

Lindgren on metasomatic processes in fissure veins.......... 1337

Lotti on the tin deposits of Tuscany ................... 627

MacAlister on tin and tourmaline $\ldots \ldots \ldots \ldots \ldots \ldots, \ldots \ldots \ldots, 1341$

On tin lodes of Cornwall $\ldots \ldots \ldots \ldots \ldots \ldots \ldots \ldots \ldots \ldots \ldots . \ldots \ldots \ldots$

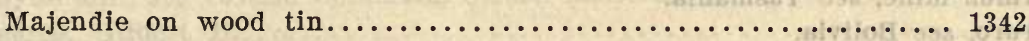

Malay Peninsula..................... 714, 721, 725, 726b

Merensky on tin deposits of Transval.................... 1184a

New Hampshire................................. 792

New South Wales......................

North Carolina............................. 245, 246, 247

Penrose on alluvial and lode tin in Malay Peninsula ........... 714

Pošepny on the genesis of ore deposits................. 1351

Pretoria................................ 1182

Recknagel on the tin deposits of the Rooiberg district, Transvaal,

$1186 \mathrm{a}, 1186 \mathrm{~b}$

Recknagel on the tin deposits of South Africa............. $3 a$

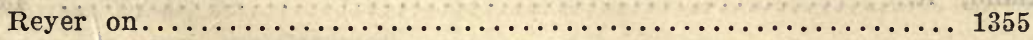

Richter on the relations between tin, lead, and zinc.......... 1356

Robertson on stream tin in Australia.................. 58

Rudler on tin deposits of Great Britain................. 452

Rumbold on origin of Bolivian tin deposits.............. 180a

On tin deposits of Malay Peninsula................ 721

Saxony.............................. 530, 575

Scrivenor on tin deposits of Malay Peninsula...........

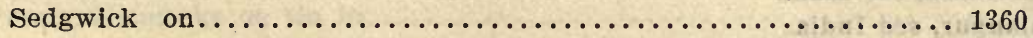

South Africa................................. 1183

South Carolina..........................245, 246, 247

South Dakota............................. 1008, 1009, 1024

Stelzner on tin deposits of Bolivia.................... 182

Stelzner on tin deposits of the Erzgebirge of Germany ......... 575

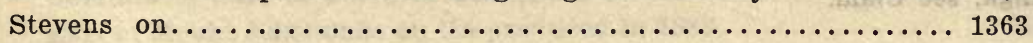

Stirling on tin deposits of Victoria..................... 1238 
Origin of tin-Continued.

Reference Number

Tasmania................1097, 1137, 1141, 1155, 1156, 1158, 1159

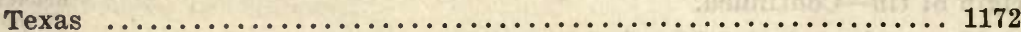

Transvaal......................1181, 1182, 1184a, 1186a, 1186b

Trüstedt on the iron, copper, and tin deposits at Pitkäranta, Finland, 953a

Tuscany ............................................ 627

Twelvetrees on tin mines of Tasmania................1137, 1141

Ulke on tin ores of South Dakota..................... 1024

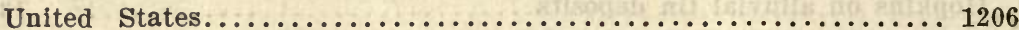

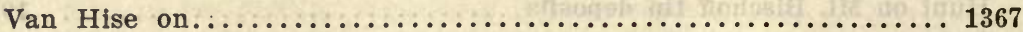

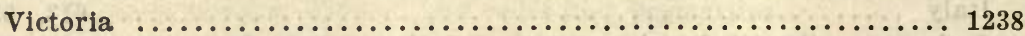

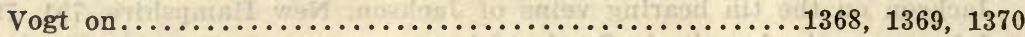

Waller on tin in Tasmania................................. 1156, 1158

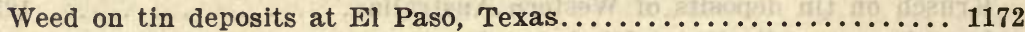

Wellington on Mt. Bischoff mine, Tasmania................. 1159

Western Australia................................. 1258

See also Association of tin and Minerals of tin.

Orthoclase, Phillips on pseudomorphs of cassiterite after.......... 1632 See Association of tin with.

Ormuz mine, see Tasmania.

Oruro, see Bolivia.

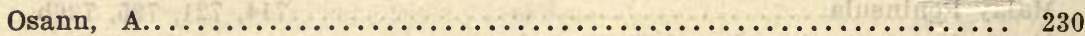

Osbeck, Peter.................................... 710

Oshoek, see Swaziland.

Otago, see New Zealand.

Oubanghi, see French Kongo, Ubangi.

Oudemans, Jr., A. C................................ 111

Ouelle Makua, see French Kongo, Welle Makwa.

Overman, Frederick................................. 1544

Ovoca district, see Ireland, Wicklow.

Owen, Frank......................................... 712

Oxland, R....................................... 438

\section{$\mathbf{P}$}

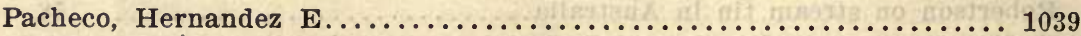

Pahang, see Malay Peninsula.

Paigeite, Knopf on a new magnesian iron-tin boron mineral.......29a, 29b

Paillette, Adrien (Schulz, Guillaume, and) ..................... 1043

Pakchan River, see Burmah, Tenasserim district.

Pak-Phrëk, see Siam.

Palanpur, see India.

Palmer district, see Queensland.

Palmer River, see Queensland.

Palo, see Eảst Indies.

Palembang, see Sumatra.

Panga, see Siam. 
Pangkal-Pinang district, see Banka.

Pansner, Hofrath..................

Pappan, see Malay Peninsula, Perak.

Papua, see New Guinea.

Paradise Creek, see New South Wales.

Parcelore, see Malay Peninsula.

Paris, John Ayrton................................. 439

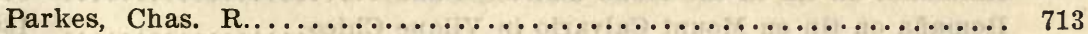

Park of Mines, see Cornwall.

Parry, L................................... 1545a, 1545b

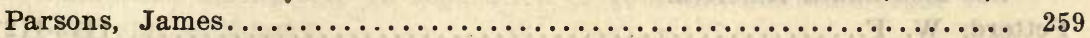

Parsons, James (Coomaraswamy, A. K., and) ................ 257

Pascoe River, see Queensland.

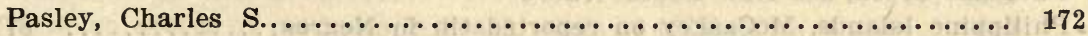

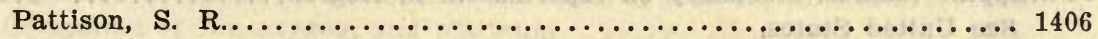

Pavlov, A. W......................................... 1216

Payne Mill, see British Columbia, Slocan district.

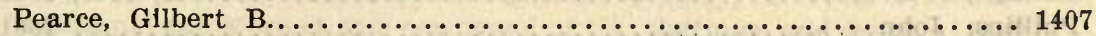

Pearce, Richard............440,441, 1447a, 1546, 1547, 1629, 1630, 1660

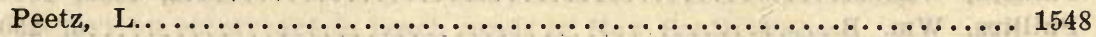

Pegu, see Malay Peninsula.

Pelatan, L..................................645, 648

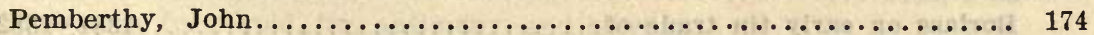

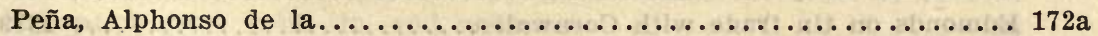

Penberthy, John.................................. 467

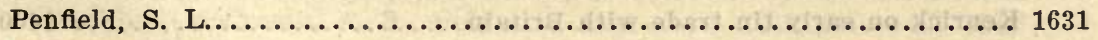

Pennance mine, see Cornwall.

Pennington County, see South Dakota, Black Hills.

Penrose, R. A., Jr..

Pentowan mine, see Cornwall.

Pentuan, see Cornwall.

Penzance, see Cornwall.

Perak, see Malay Peninsula.

Perlis, see Siam.

Permo-carboniferous, Twelvetrees on tin in, in Tasmania........... 1137

Perrett, Auguste................................ 1549

Persia, Hennecke on tin in ............................. 864

Mactear on tin near Juwaa, 60 miles northeast of Tabriz........ 865 See also Asia.

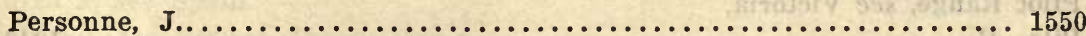

Peru:

Cajatambo, west of Cerro de Pasco, tin at................ 866

Earl of Mount Edgcumbe on tin produced in $1883 \ldots \ldots \ldots \ldots \ldots \ldots . \ldots 168$ 
Peru-Continued.

Reference Number

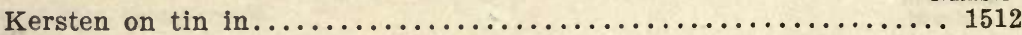

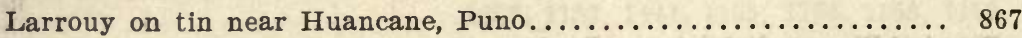

Mount Calvario, tin on.......................... 180

Olaechea on tin in Puno........................... 171a

Posth on tin in the Vilque district, Puno................ 869

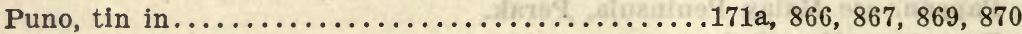

Huancane, tin near.................................................. 860

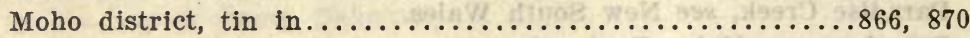

Vilque district, tin in .............................. 869

Raimondi on tin In the Moho district, Puno................ 870

Romaña on tin on Mount Calvario in Vilque Chico............. 180

Vilque Chico, tin in ............................ 180

See also South America.

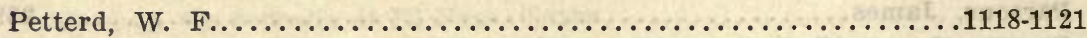

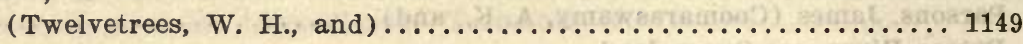

Pheasant Creek, see New South Wales.

Philippine Islands, McCaskey on reported tin in Negros........... 871

See United States.

Phillips, J. A., and Louis, H.......................628, 1350

Phillips, J. Arthur...........................442, 1349, 1632

Phillips, John................................ 1661

Phillips, Wm..............................443, 1633, 1634

Phillips, $\mathrm{Wm}$. B.................................. 250

Phlogopite, see Association of tin with.

Phœnicia:

Borlase on early tin trade of . . . . . . . . . . . . . . . 1381, 1382

Edmonds on tin trade with Cornwall.................... 1389

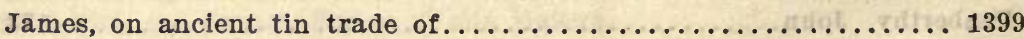

Kenrick on early tin trade with Britain.................... 1400

Lewis on sources of tin used in.......................... 1401

Rawlinson on Phœnician colonies in Andalusia, Spain, and in the

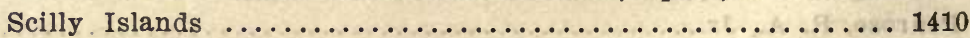

Saunders on route traversed in tin trade with Britain........... 1414

Sources of tin used in .......................... 144,1401

Tin trade of...........1380, 1382, 1389, 1399, 1400, 1401, 1414, 1418

Wray on source of $\operatorname{tin}$ used $\ln \ldots \ldots \ldots \ldots \ldots \ldots \ldots \ldots \ldots \ldots \ldots \ldots \ldots$

Phosphorus, see Association of tin with.

Pieux, see France, Manche.

Pihra, see India, Chota Nagpur.

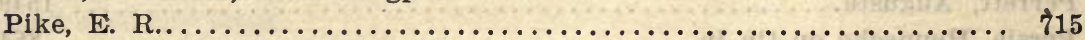

Ptkedale field, see Queensland.

Pilbarra, see Western Australia.

Pilot Range, see Victoria.

Pilz, R.......................................... 1040

Pioneer, see Tasmania. 
Piriac, see France, Lower Loire.

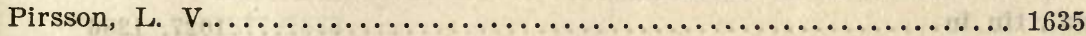

Pitkäranta, see Finland.

Pittman, Edward F...................................... 835

Place, John.................................... 716

Placer deposits, dredging and sluicing of ................... 1578

Plagioclase, see Association of tin with.

Platinum:

Associated with tin, see Association of tin with.

Bechamp and Saintpierre on separation of gold and platinum from

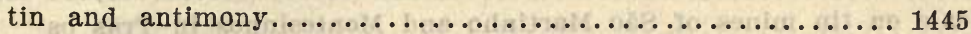

Boucard on separation of gold and platinum from tin and antimony, 1455

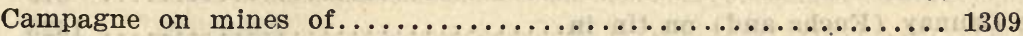

Carne on source of platinum in beach sands of New South Wales... 809

Compound of tin, oxygen, and platinum.................. 1475

de Koninch and Lecrenier on the qualitative separation of gold and

platinum from arsenic, antimony, and tin.............. 1474

Delachanal and Mermet on a compound of tin, platinum, and oxygen. 1475

Elsner on the separation of gold and platinum from tin and arsenic.. 1486

Mingaye on occurrence in beach sands of New South Wales....... 831

New South Wales.............................. 809

Separation from gold, tin, and antimony...................... 1455

Separation from gold, tin, antimony, and arsenic............. 1474

Separation from gold, tin, and arsenic.................. 1486

Used to effect complete reduction of tin................... 1583

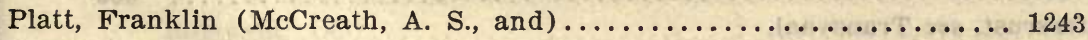

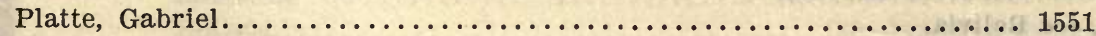

Platten, see Bohemia.

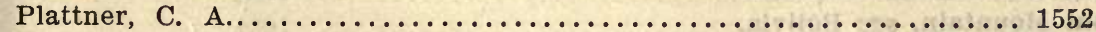

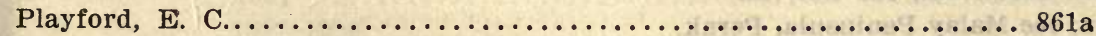

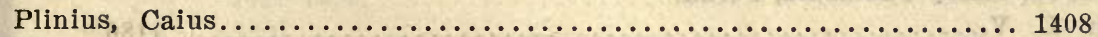

Pliocene terraces in Cornwall containing deposits of tin and wolfram... 333 Plumas County, see California.

Plumbostannite, Raimondi on the new mineral............... 870

Plummer, John..................... 56, 836, 837, 1121a, 1698

Plumose muscovite, see Assoclation of tin with.

Poebel, see Bohemia.

Polgooth mine, see Cornwall.

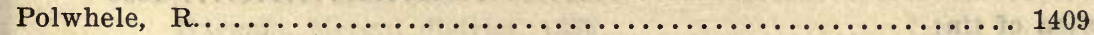

Pontevedra, see Spain.

Pontgibaud, see France, Puy-de-Dome.

Poolamacca, see New South Wales, Silverton district.

Poopo Lake, see Bolivia.

Port Clarence, see Alaska.

Port Darwin, see Northern Territory.

Port Douglas district, see Queensland. 
Porth, see England.

Porth Ledden Mills, see Cornwall.

Port Pegasus district, see New Zealand.

Portugal, tin in ..................................... 1286

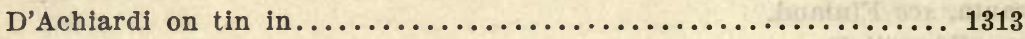

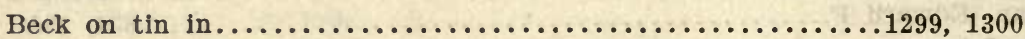

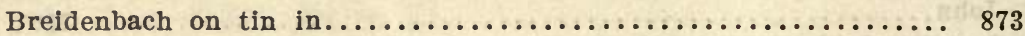

Brown on tin in .................................... 1308

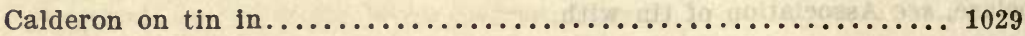

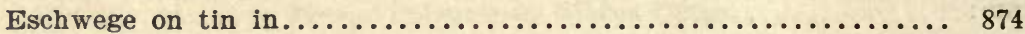

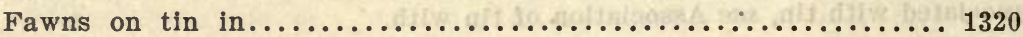

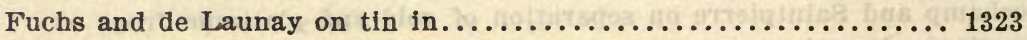

Heale on tin mines of São Martinho and Montesinhos in Tras os

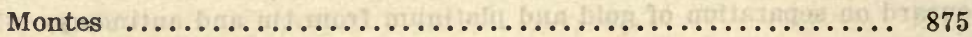

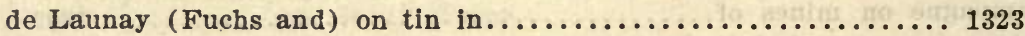

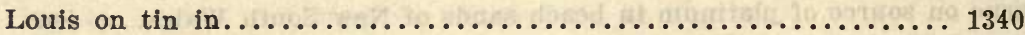

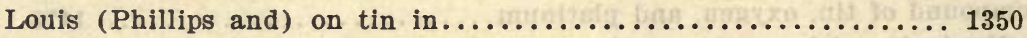

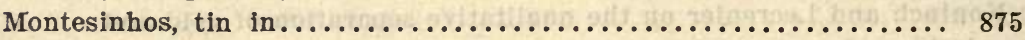

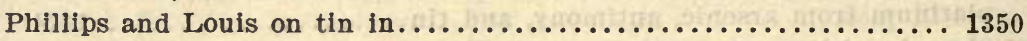

Sandinha, tin near Goes in...................... 872

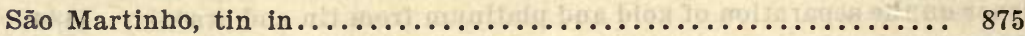

Tras os Montes, tin in............................. 875

See also Europe.

Poscovi, see Bolivia.

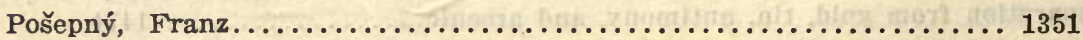

Posewitz, Th..........................112, 134, 300, 301, 302

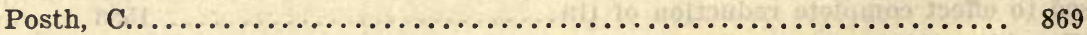

Potgietersrust, see Transvaal.

Potosi, see Bolivia.

Potrillos, see Mexico, Durango.

Pozoconi Mountain, see Bolivia.

Poussin, see Malay Peninsula, Perak.

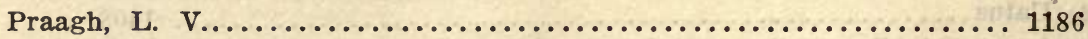

Pratt, Joseph Hyde...........................251, 1217

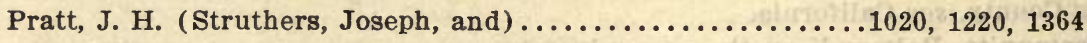

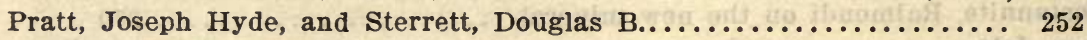
Pretoria, see Transvaal.

Preumont, G......................................... 176

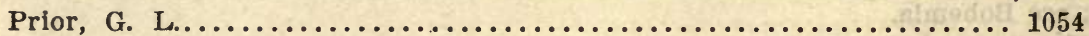

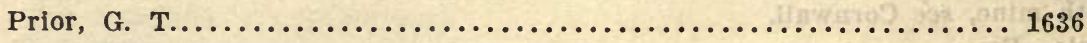

Production of tin:

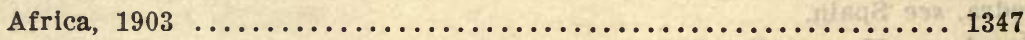

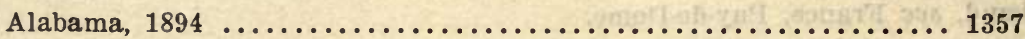

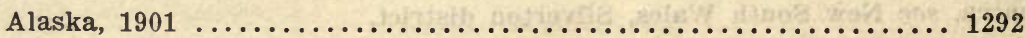

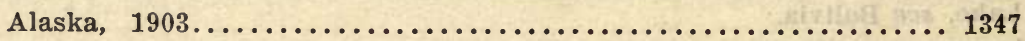

Alaska, Seward Peninsula, through $1908 \ldots \ldots \ldots \ldots \ldots \ldots \ldots \ldots$ 28b 
Production of tin-Continued.

Australasia, 1890.

1899-1900

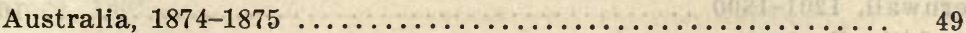

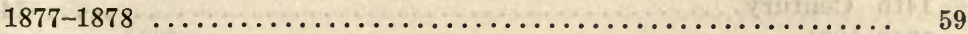

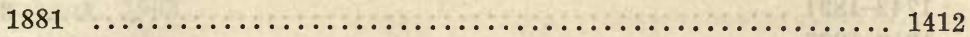

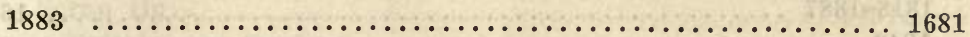

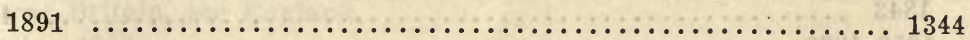

$1903 \ldots \ldots \ldots \ldots \ldots \ldots \ldots \ldots \ldots \ldots \ldots \ldots \ldots \ldots \ldots \ldots \ldots \ldots . . \ldots 4,1347$

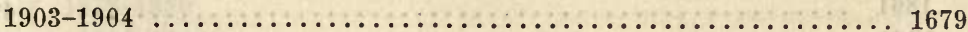

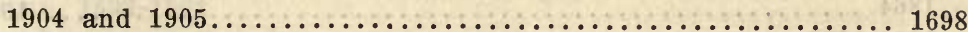

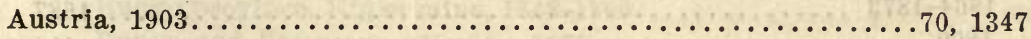

Banka, history, prices, etc.......................... 113

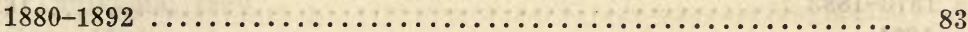

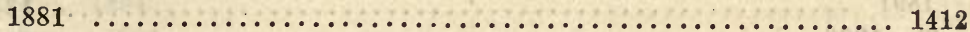

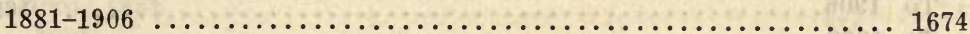

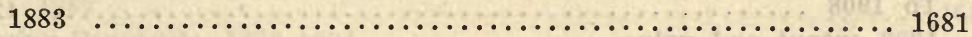

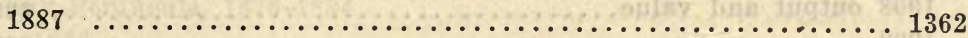

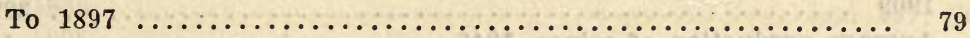

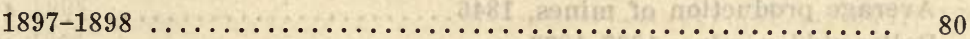

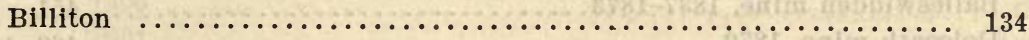

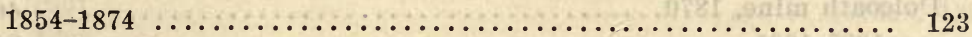

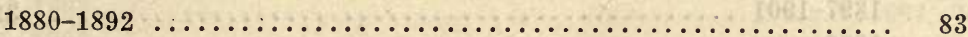

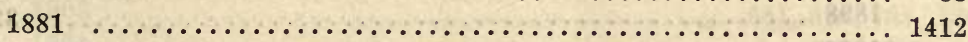

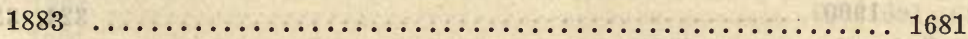

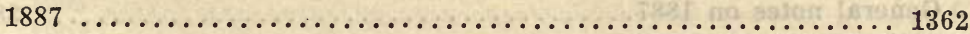

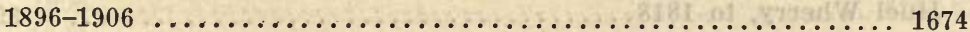

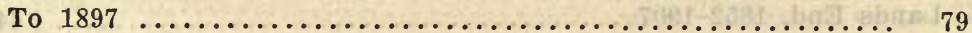

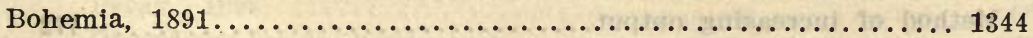

Bolivia,..................... 138, 142, 146, 167, 168, 180

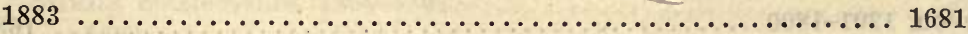

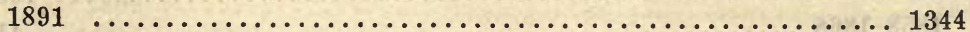

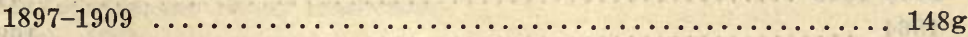

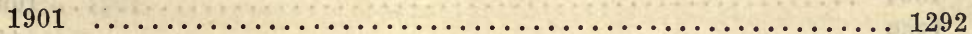

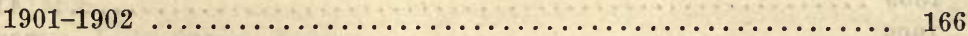

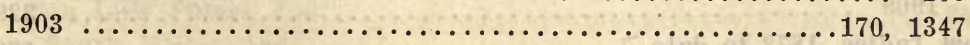

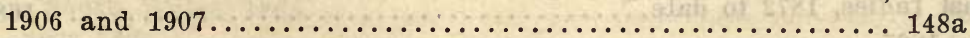

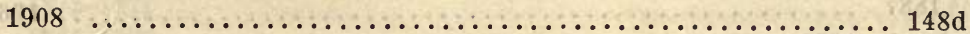

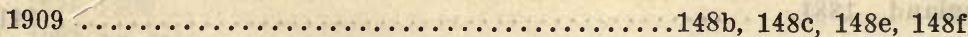

Near Tupiza ............................... 144

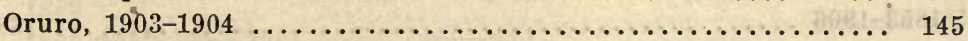

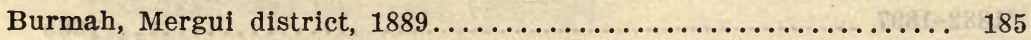

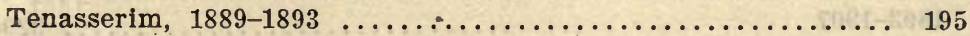

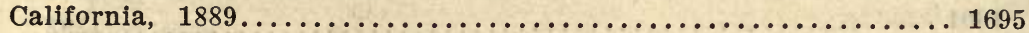

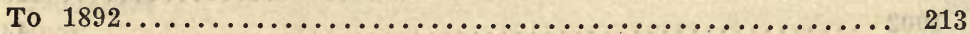

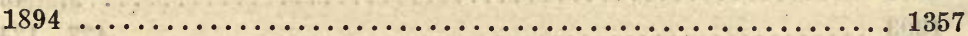

San Jacinto mine, 1891, giving gross value............ 210 
Production of tin-Continued.

China, 1881.

Reference

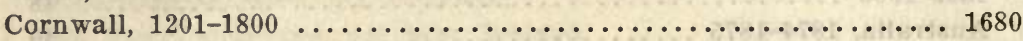

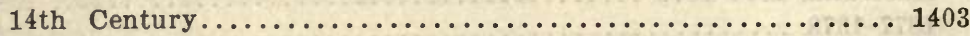

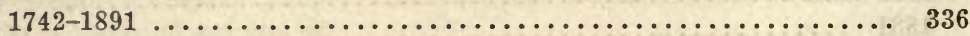

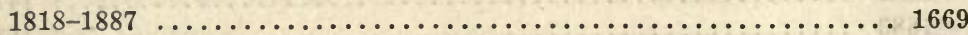

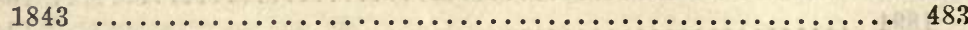

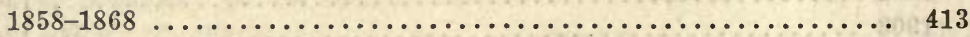

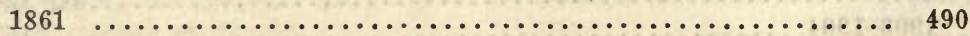

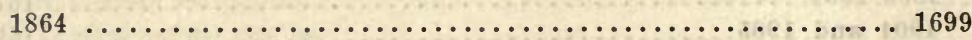

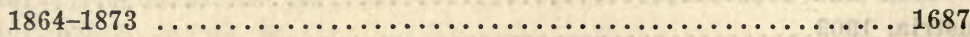

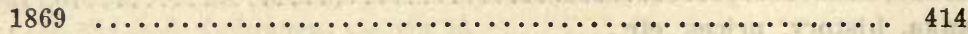

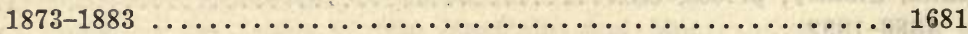

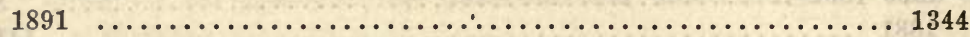

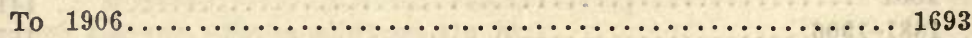

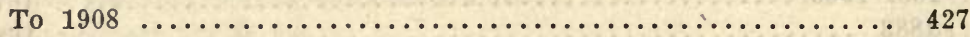

1908 output and value................................

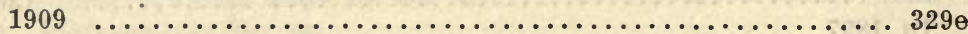

Average production of mines, $1846 \ldots \ldots \ldots \ldots \ldots \ldots \ldots \ldots \ldots 412$

Balleswidden mine, $1837-1873 \ldots \ldots \ldots \ldots \ldots \ldots \ldots \ldots \ldots \ldots \ldots . \ldots \ldots \ldots$

Dolcoath mine, $1870 \ldots \ldots \ldots \ldots \ldots \ldots \ldots \ldots \ldots \ldots \ldots \ldots \ldots . \ldots \ldots$

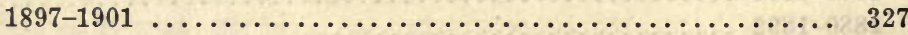

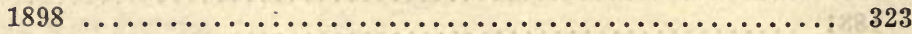

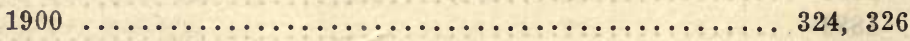

General notes on $1887 \ldots \ldots \ldots \ldots \ldots \ldots \ldots \ldots \ldots \ldots \ldots \ldots \ldots \ldots$

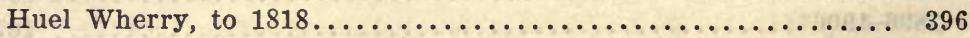

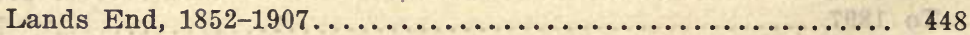

Method of increasing output.................. 472

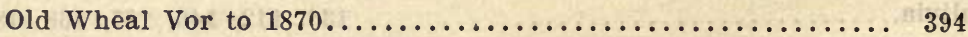

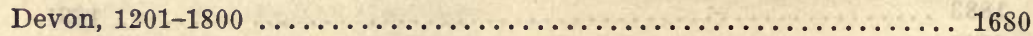

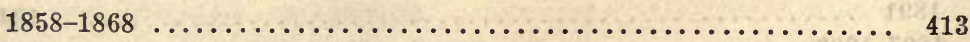

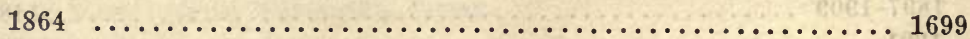

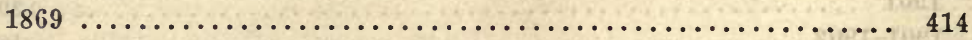

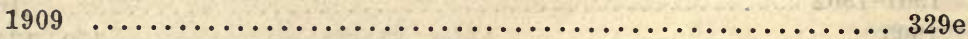

East Indies, 1872 to date............................... 1689

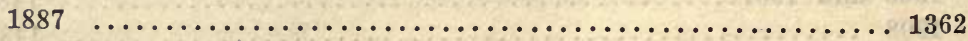

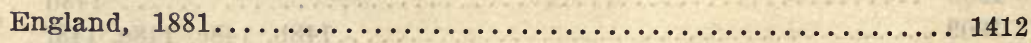

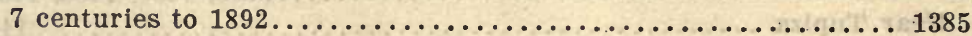

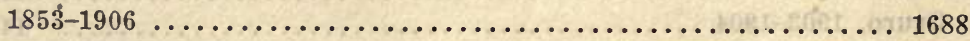

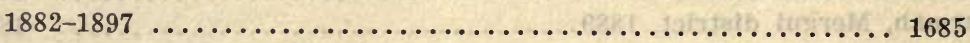

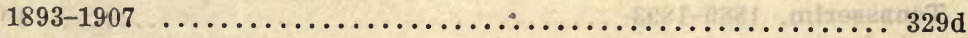

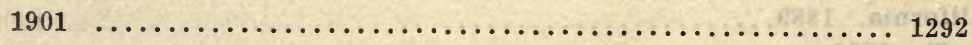

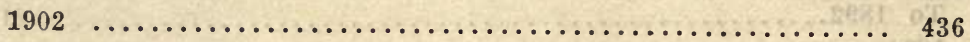

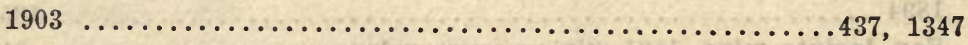


Production of tin-Continued. Reference

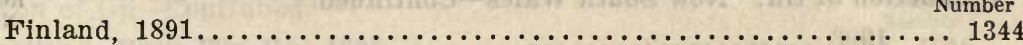

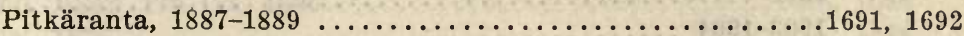

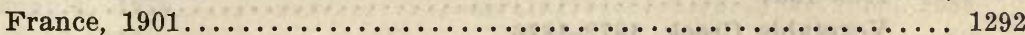

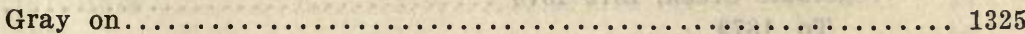

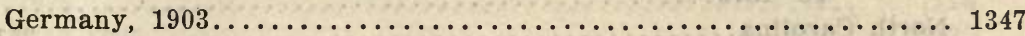

Scrap tin................................. 1511

Great Britain, see England.

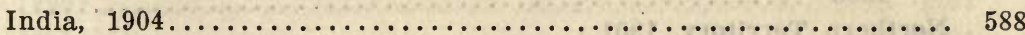

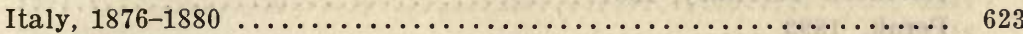

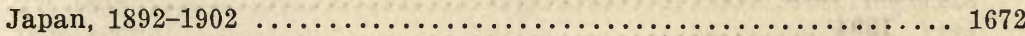

Bungo province, Klura mine, $1848-1860 \ldots \ldots \ldots \ldots \ldots \ldots \ldots 630$

Bungo and Satsuma, estimate, $1878 \ldots \ldots \ldots \ldots \ldots \ldots \ldots \ldots 6 . \ldots \ldots$

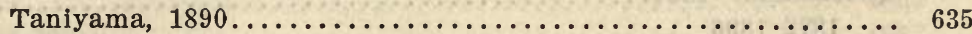

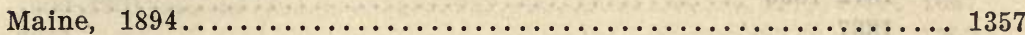

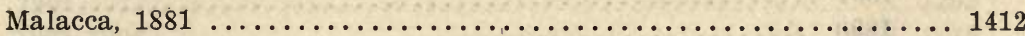

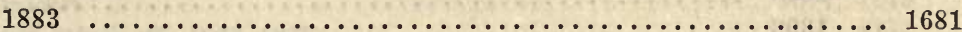

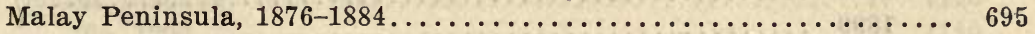

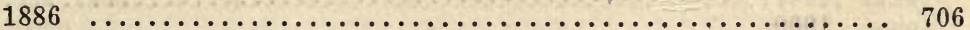

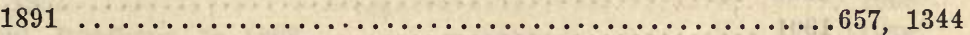

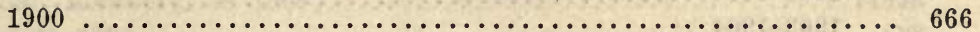

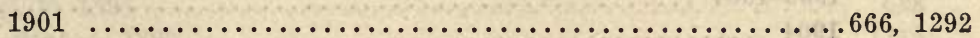

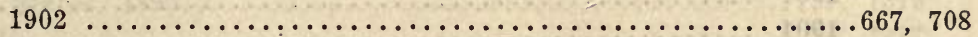

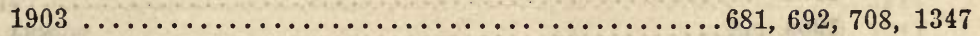

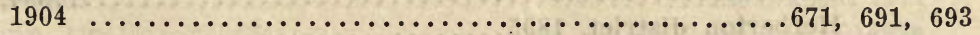

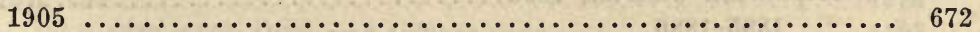

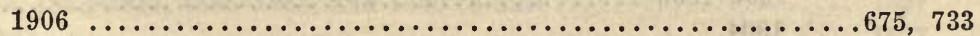

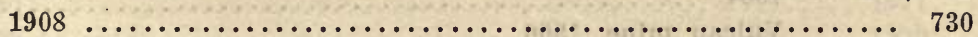

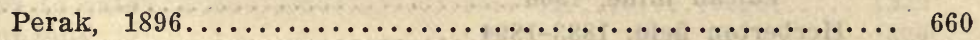

Quotations for tin product of ...................... 1675

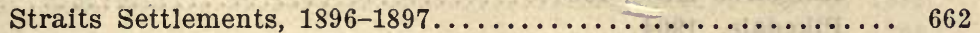

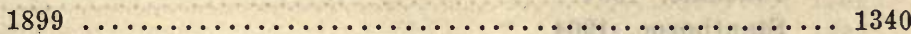

Malay states, see Malay Peninsula.

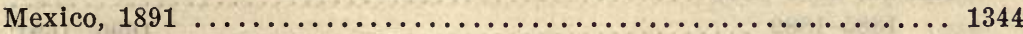

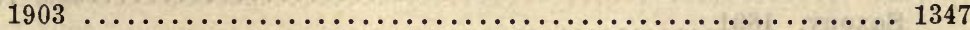

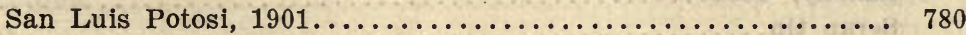

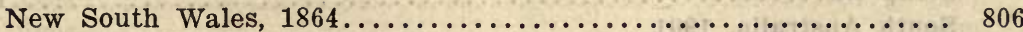

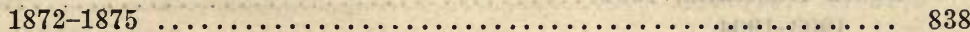

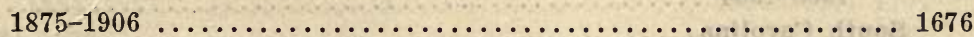

1875 to date......................................... 819

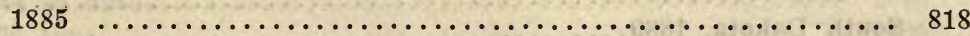

$1886-1887,1890-1891,1894,1895-1896 \ldots \ldots \ldots \ldots \ldots \ldots \ldots \ldots .815$

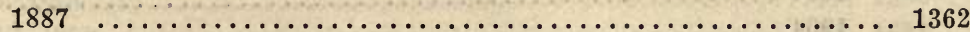

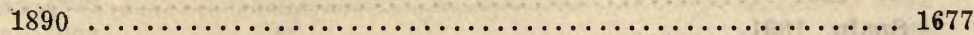

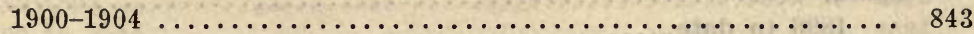

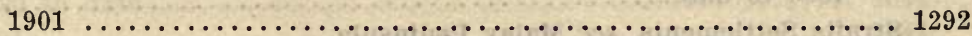


Production of tin: New South Wales-Continued.

1902

Reference Number

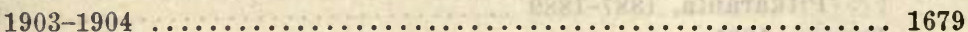

Vegetable Creek, $1872-1876 \ldots \ldots \ldots \ldots \ldots \ldots \ldots \ldots \ldots \ldots \ldots . \ldots 22$

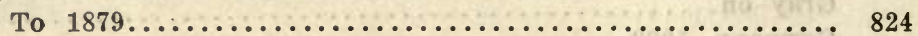

North Carolina...................................... 252

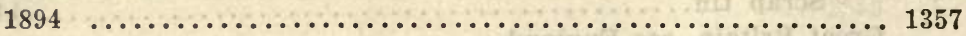

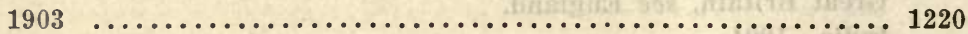

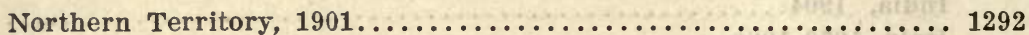

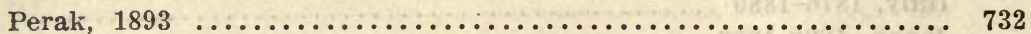

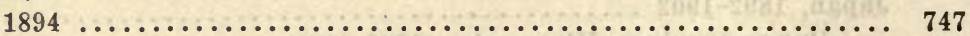

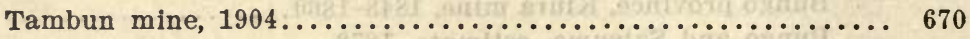

Queensland, $1864 \ldots \ldots \ldots \ldots \ldots \ldots \ldots \ldots \ldots \ldots \ldots \ldots \ldots \ldots \ldots$

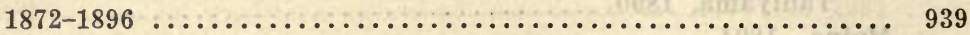

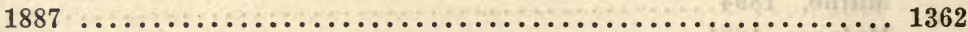

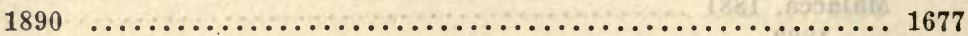

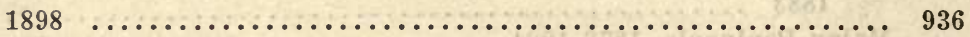

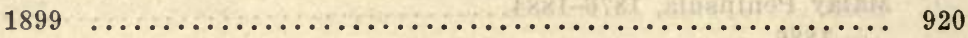

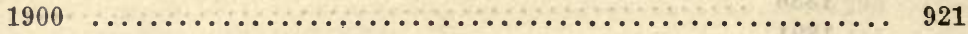

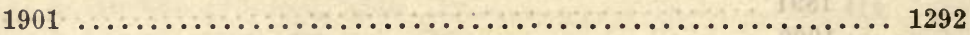

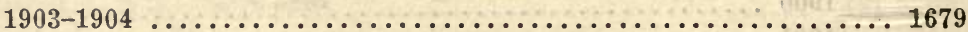

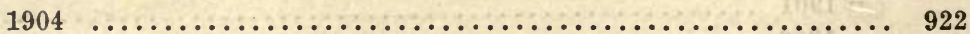

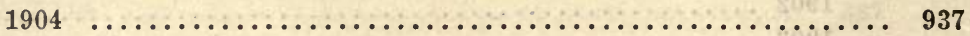

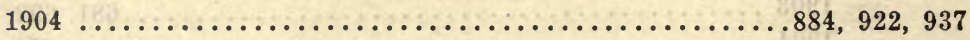

Herberton district, $1895 \ldots \ldots \ldots \ldots \ldots \ldots \ldots \ldots \ldots \ldots \ldots \ldots .919$

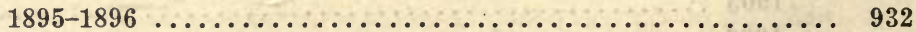

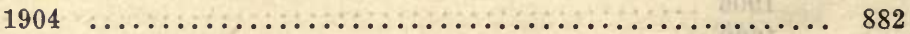

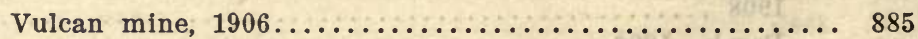

Herberton field, $1883-1894 \ldots \ldots \ldots \ldots \ldots \ldots \ldots \ldots \ldots \ldots . \ldots \ldots . \ldots \ldots$

Kangaroo Hills, $1904 \ldots \ldots \ldots \ldots \ldots \ldots \ldots \ldots \ldots \ldots \ldots \ldots \ldots . . \ldots 29$

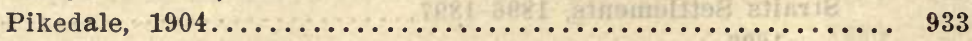

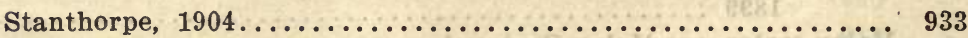

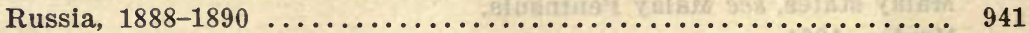

$1885-1889 \ldots \ldots \ldots \ldots \ldots \ldots \ldots \ldots \ldots \ldots \ldots \ldots \ldots \ldots . \ldots \ldots, 1691,1692$

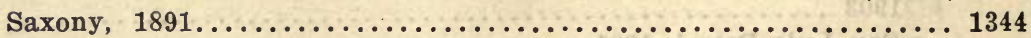

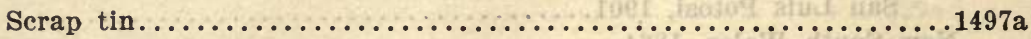

South Australia, 1901........................... 1292

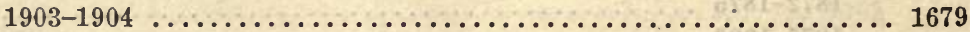

South Carolina................................251, 252

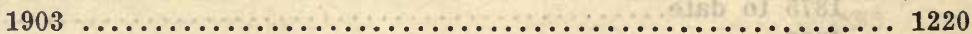

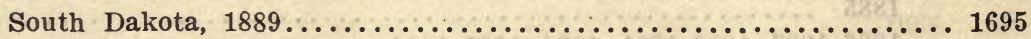

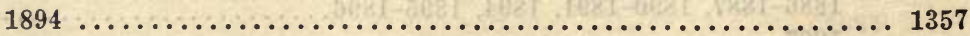

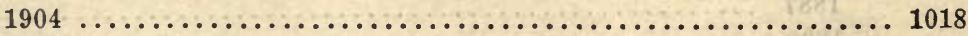

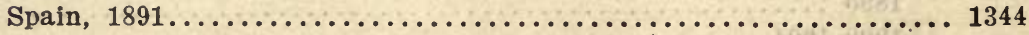

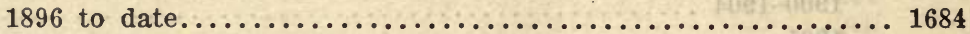

Straits Settlements, see Malay Peninsula. 
Production of tin-Continued.

Reference

Number

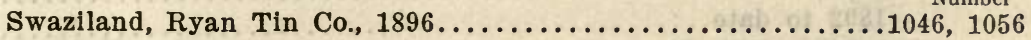

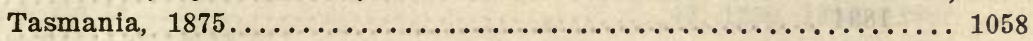

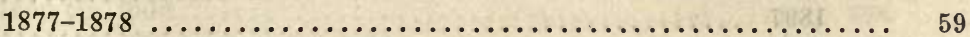

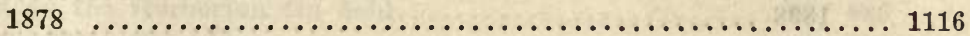

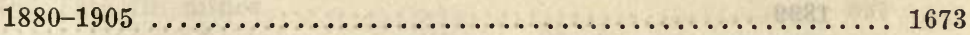

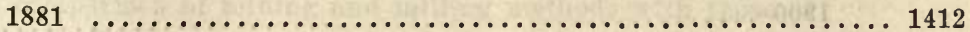

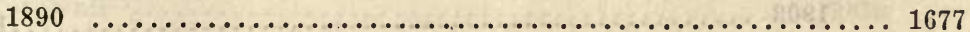

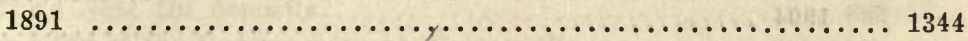

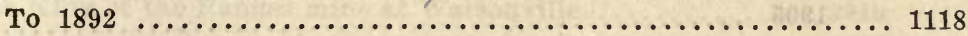

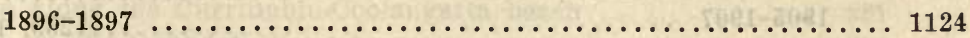

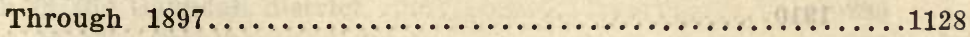

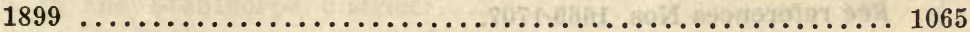

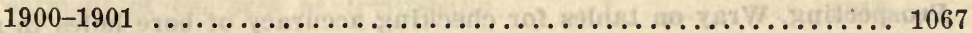

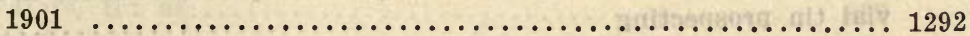

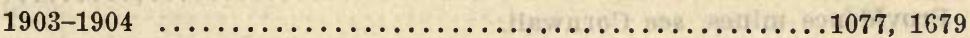

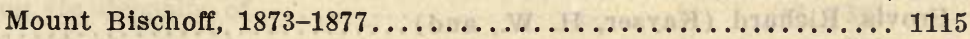

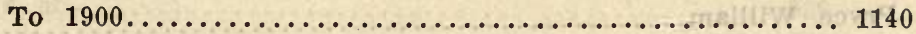

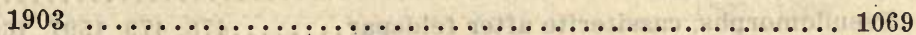

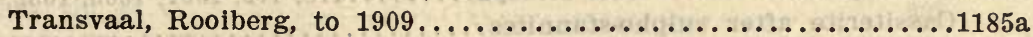

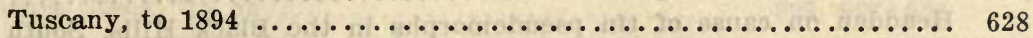

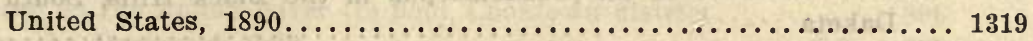

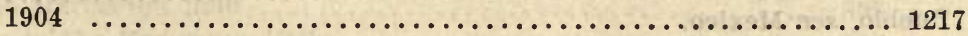

1905-1907 ...........................1209, 1210, 1211

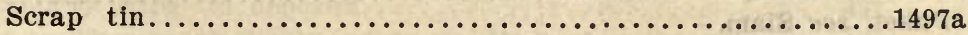

Victoria, $1873-1877,1885-1888$, and 1890 to date............. 1697

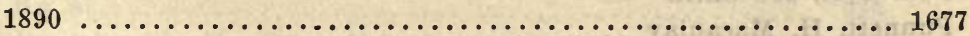

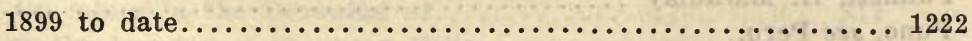

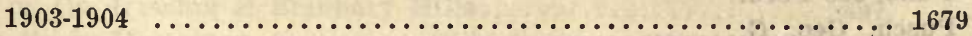

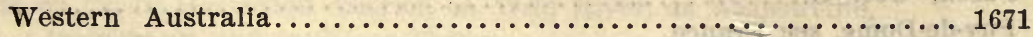

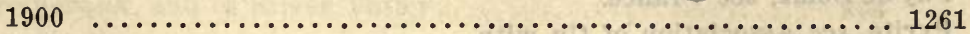

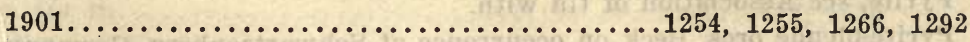

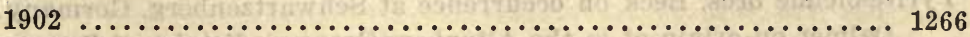

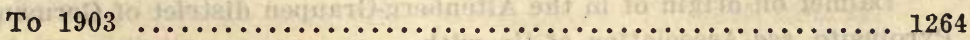

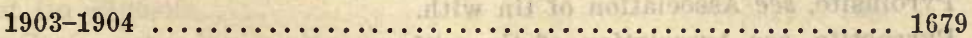

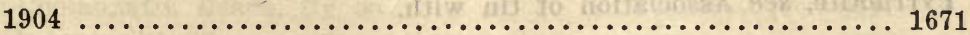

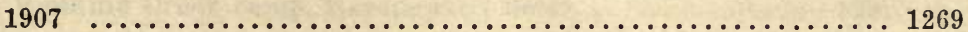

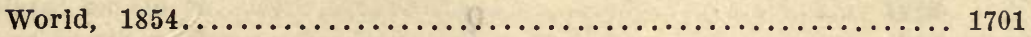

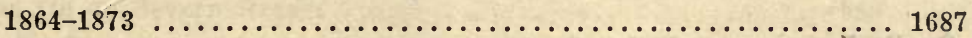

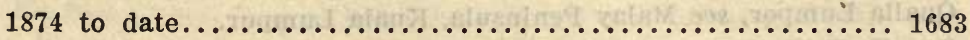

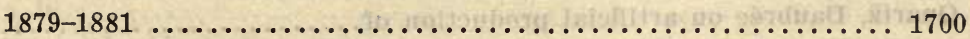

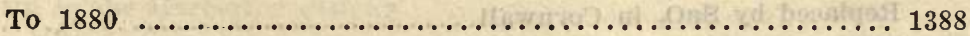

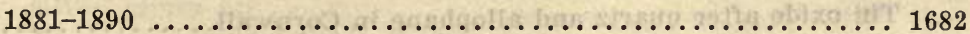

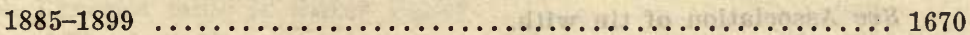

1890 to date.................................... 1694

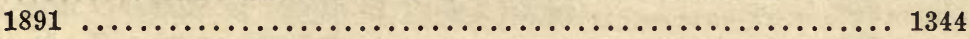


Production of tin: World-Continued.

Reference 1892

Number

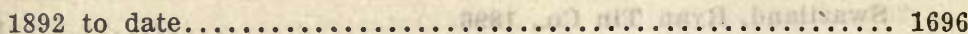

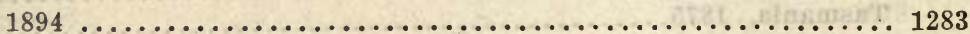

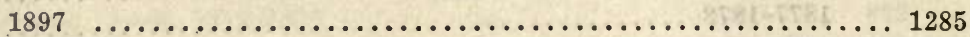

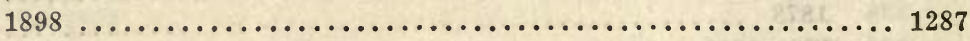

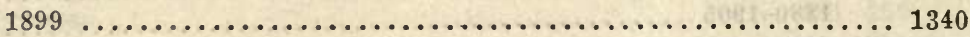

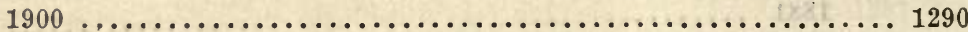

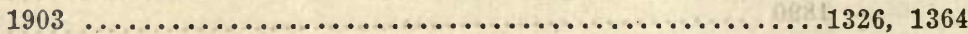

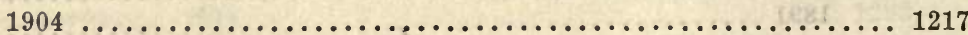

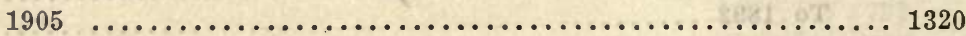

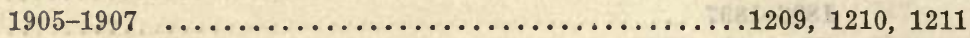

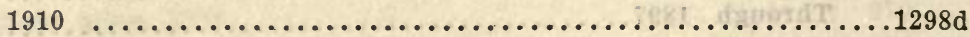

See references Nos. $1669-1707$.

Prospecting, Wray on tables for checking accuracy of bore holes in allu-

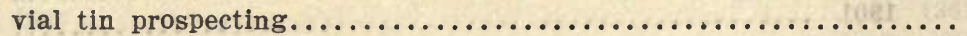

Providence mines, see Cornwall.

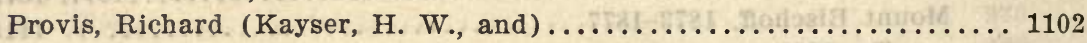

Pryce, william.................................444, 1352

Pseudomorphs, cassiterite after feldspar......478, 479, 1597, 1603, 1632, 1638

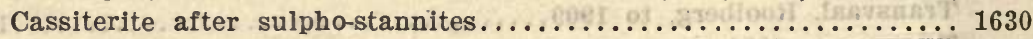

Headden on cause of tin pseudomorphs in the Black Hills, South

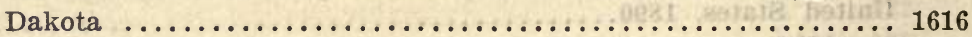

Pueblo, see Mexico.

Puig y Larraz, D. Gabriel................................ 1041

Puket, see Siam.

Punitaqui, see Chili.

Punnett, H. Macaulay

Puno, see Peru.

Pusch, Geo. G...................................... 949

Puy-de-Dome, see France.

Pyrite, see Association of tin with.

Pyrite-blende ores, Beck on occurrence at Schwartzenberg, Germany.... 530

Dalmer on origin of in the Altenberg-Graupen district of Germany. . 542 Pyrolusite, see Association of tin with.

Pyrrhotite, see Association of tin with.

Qualla Lumpor, see Malay Peninsula, Kuala Lumpur.

Quartz, Daubrée on artificial production of ................... 1601

Replaced by $\mathrm{SnO}_{2}$ in Cornwall.......................... 357

Tin oxide after quartz and allophane in Cornwall............. 1629

See Association of tin with.

Quebec, Osann on tin at Graphite City in the Ottawa Valley........... 
Queensland tin in ..............................

$\ldots \ldots 45,1290,1292,1298 \mathrm{c}$

Annan River tin field............................ 896

Babington on the Herberton tin field.................. 886

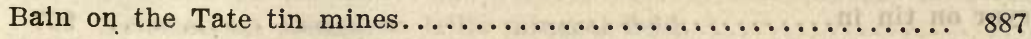

Ball on a comparison of mining and milling methods with those of

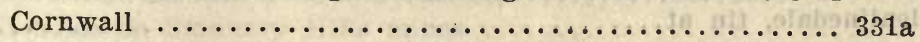

On Crows Nest tin deposits..................... 888

On the King of the Ranges mine at Watsonville........... 891a

On tin along the Currumbin-Coolangatta beach............. 891

On tin in the Gayndah district..................... 890

On tin in the Stanthorpe district................. 889

On treatment of tin ores at Irvinebank............. 891b

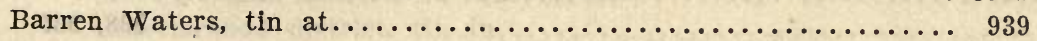

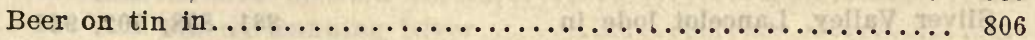

Benedict on tin deposits of . . . . . . . . . . . . . . . . . 1301

Bloomfield, tin at $\ldots \ldots \ldots \ldots \ldots \ldots \ldots \ldots \ldots \ldots \ldots \ldots \ldots \ldots . \ldots \ldots$

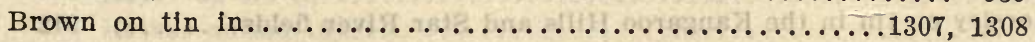

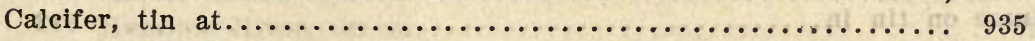

Californla Creek, tin on .......................... 927, 935

Cameron on the Annan River tin field, Cooktown district........ 896

On the Herberton field.......................... 895

On tin in the Kangaroo Hills..................... 893

On Stannary Hills tin deposits..................... 892

On tin on Thompsons Creek and in the Herberton district.... 894

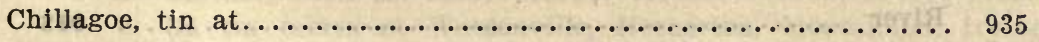

Clarke on tin mines in the Devonian of ................. 814

Cleveland on tin dressing at Stannary Hills................. 897

Clotten on tin in Herberton district, on Wild River, at Watsonville,

Irvinebank, and in Silver Valley............... 898

Coghlan on tin in .......................................... 1679

Cooktown district, tin in $\ldots \ldots \ldots \ldots \ldots \ldots \ldots \ldots \ldots \ldots \ldots \ldots, 917,920$

Coolgarra district, tin in $\ldots \ldots \ldots \ldots \ldots \ldots \ldots \ldots \ldots \ldots \ldots . \ldots \ldots, 926,927$

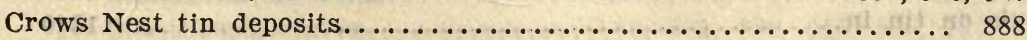

Currumbin-Coolangatta Beach, tin on................... 891

Cusack on Running Creek camp, Ravenswood fields............. 899

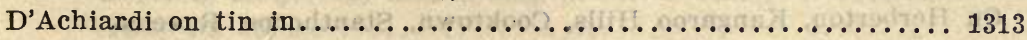

Daintree on tin on Severn River...................... 900

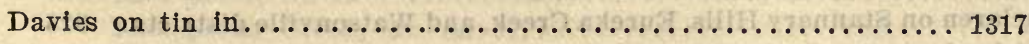

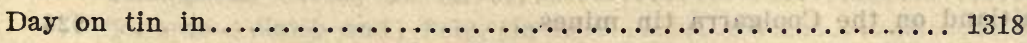

Dowel on tin in the Herberton district.................... 901

Dry River, silver mines on ........................ 916

Dunstan on Lancelot mine in Silver Valley................ 902

On Stannhills tin fields........................... 905

On tin with monazite at mouth of Tweed River........... 903

Edlinger on the Herberton district................... 906 
Queensiand-Continued.

Reference Number

English on tin at Stanthorpe...................... 50

Eureka Creek district, tin 1 ...................... 895, 925, 927

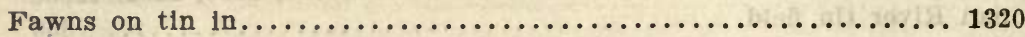

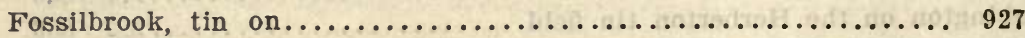

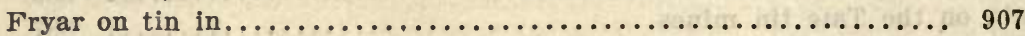

Gayndah district, $\operatorname{tin}$ in ........................... 890

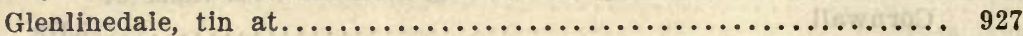

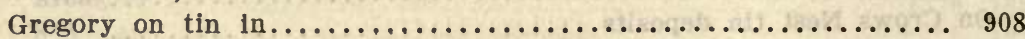

On tin on Severn River........................ 909

Haldane on the Herberton district..................... 910,9

On the Walsh and Tinaroo field................... 911

Herberton district, tin in....43, 876, 878, 881, 882, 885, 886, 894, 895, $898,901,906,910,911,916,919,920,927,931,932,934,935$,

938,939

Silver Valley, Lancelot lode in............881, 898, 902, 938

Vuican mine.................................... 885

Hopkinson River, tin on ....................... 940

Horsley on tin in the Kangaroo Hills and Star River fields....... 912

Hume on $\operatorname{tin}$ in ................................. 913

Irvinebank district, tin in $\ldots \ldots \ldots \ldots \ldots \ldots . . .676,895,898,927,935,939$

Treatment of tin ores in ...................... 891b

Jack on silver mines on Dry River.................. 916

On tin near Cooktown.......................... 917

On tin in Herberton, Western, and Thompsons Creek districts.. 916

On tin in the Kangaroo Hills, at Mount Brown, and on Running

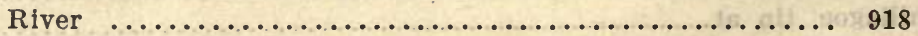

On tin in Stanthorpe district.................... 915

On Wild River tin mines...................... 914

Kangaroo Hilis, tin in the................893, 912, 918, 920, 929

King of the Ranges mine ........................... 891a

Koorboora district, tin in................................. 927

Lions Den, tin in ............................... 896

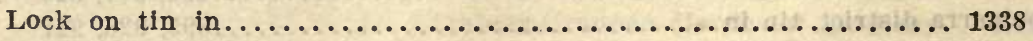

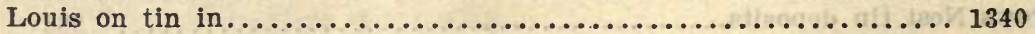

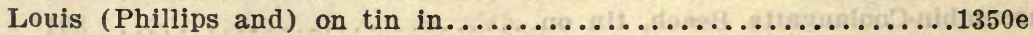

Macdonald on tin in......................... 921, 922, 923, 924

On Herberton, Kangaroo Hills, Cooktown, Stanthorpe, Ravens-

wood, Paimer, and Port Douglas tin districts......... 920

Maclaren on Stannary Hilis, Eureka Creek, and Watsonville districts. 925

Maitland on the Coolgarra tin mines................... 926

Mance on tin mining during $1905 \ldots \ldots \ldots \ldots \ldots \ldots \ldots \ldots \ldots \ldots \ldots . \ldots \ldots$

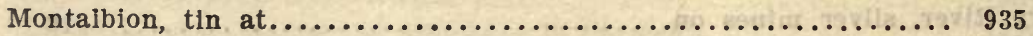

Mount Amos, tin on............................. 896

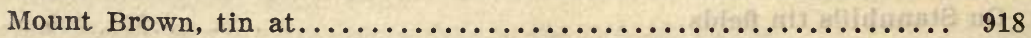

Mount Leswell, tin on ........................... 896

Muldiva, tin at............................... 935 
Queensland-Continued.

Reference

Munday on tin mining in and around Herberton............. 927

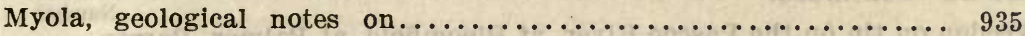

Newellton district, tin in........................... 895

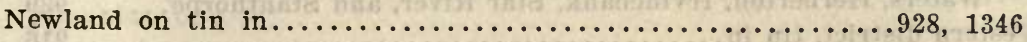

Newman on Kangaroo Hills mineral fleld................ 929

Newton on metalliferous minerals of . . . . . . . . . . . . 55

Nicholas on Stannary Hills mines................... 929a

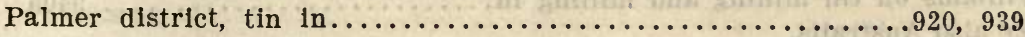

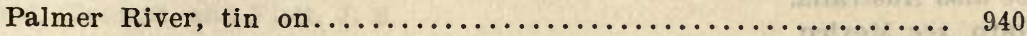

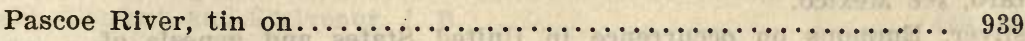

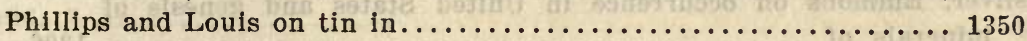

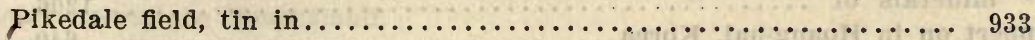

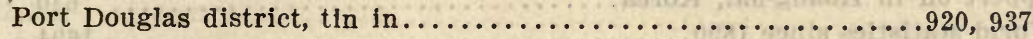

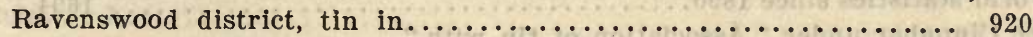

Tin on Running River ........................ 899

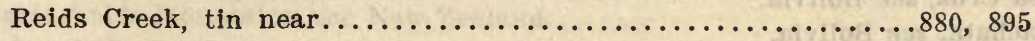

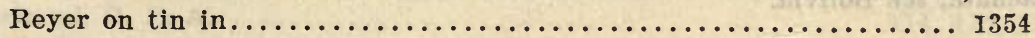

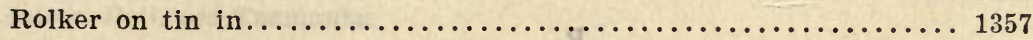

Running River, tin on .................................... 918

Russell on Walsh and Tinaroo mineral field............... 930

Sellheim on tin of Herberton and other districts............931, 932

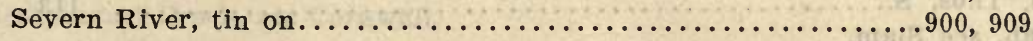

Short on Stanthorpe and Pikedale fields................. 933

Skertchly on geology near Stanthorpe and Warwick........... 936

On Herberton tin lead.......................... 934

On tin mines at Watsonville, Herberton, Montalbion, Irvine-

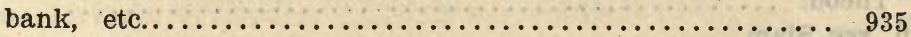

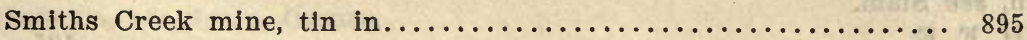

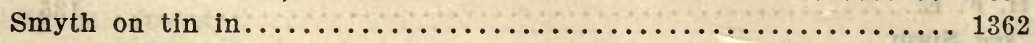

Staines on Port Douglas district.................... 937

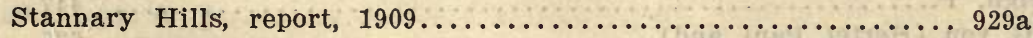

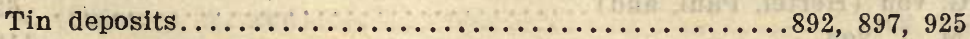

Stannhills tin fields..................................... 905

Stanthorpe, tin at............50, 883, 889, 915, 920,933, 936, 939

Star River field, tin in.................................. 939

Sterling on geology and mining in Silver Valley, Herberton...... 938

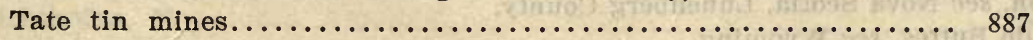

Tate River, tin on ..................................... 935

Thompsons Creek, tín on ........................... 916

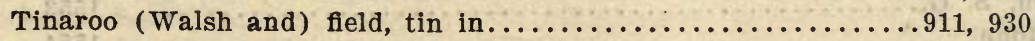

Tweed River, tin at mouth of....................... 903

Walsh and Tinaroo field, tin in ............................ 930

Warwick, geology near............................ 936

Watsonville district, tin in ................. $895,898,925,927,935$

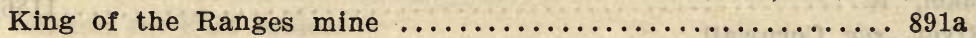


Queensland-Continued.

Weedon on tin on the Pascoe River, at Bloomfield, at Palmer, Barren

Waters, Herberton, Irvinebank, Star River, and Stanthorpe.... 939

Western district, $\operatorname{tin}$ in .......................... 916

Wild River, tin on ................................ 914

William on tin along Hopkinson and Palmer rivers........... 940

Williams on tin mining and milling in................... 940a

See also Australia.

Queretaro, see Mexico.

Quicksilver, Emmons on occurrence in United States and genesis of

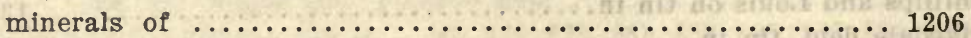

Oppert on in Hoang-ha1, Korea..................... 640

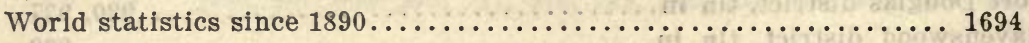

See Cinnabar under "Association of tin with."

Quimsa Cruz, see Bolivia.

Quinsachata, see Bollvia.

\section{$\mathbf{R}$}

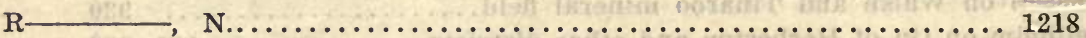

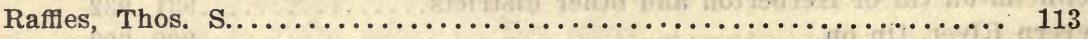

Rahman, see Siam.

Raimondi, A........................................... 1636a

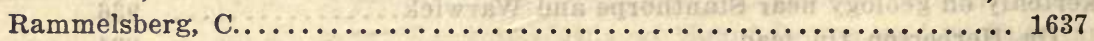

de Rance, Charles E................................ 446

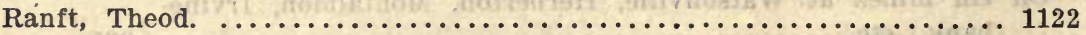

Rangeh, see Siam.

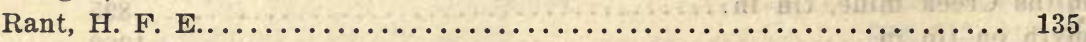

Rapri, see Siam.

Rashleigh, P................................ 447

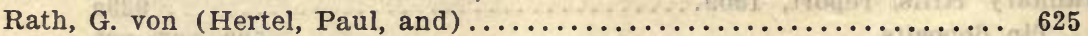

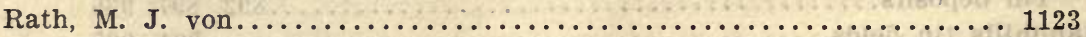

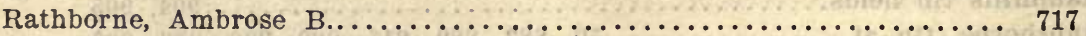

Ratburi (East Coast), see Siam.

Ravenswood fields, see Queensland.

Rawdon, see Nova Scotia, Lunenberg County.

Rawhide Buttes, see Wyoming.

Rawlinson, George................................ 1410

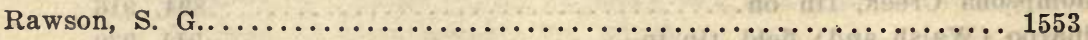

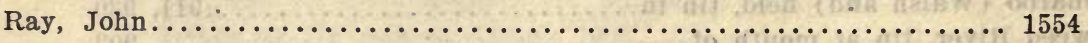

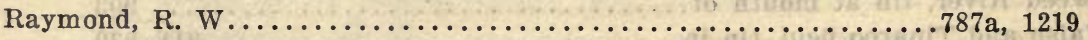

Realgar, Hennecke on occurrence in Persia.................... 864

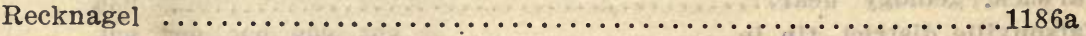

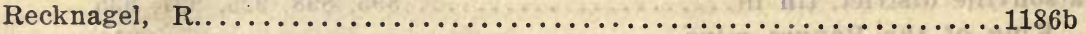

Red River, see Cornwall.

Redruth, see Cornwall. 
Refining of tin:

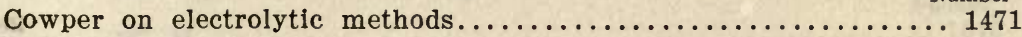

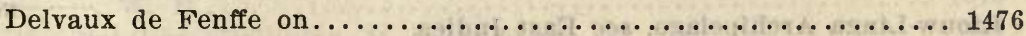

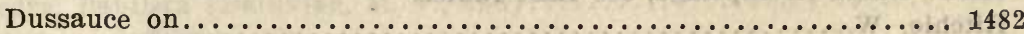

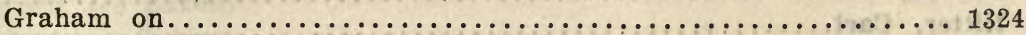

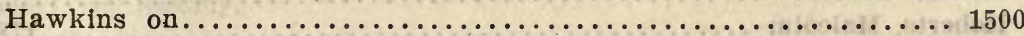

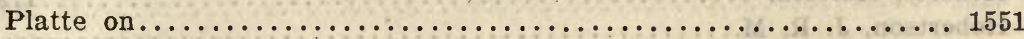

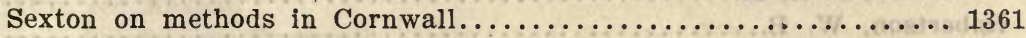

Thiollier on refining of tin in Cornwall.................. 1579

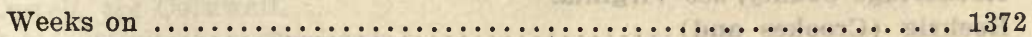

Reid, Clement, and Flett, J. S........................ 448

Reid, Clement, and Scrivenor, J. B.................... 1638

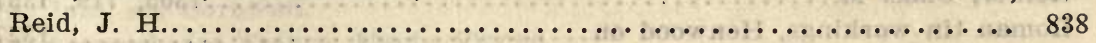

Reids Creek, see Queensland.

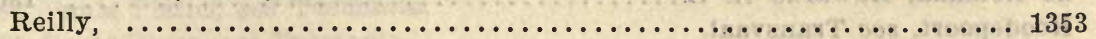

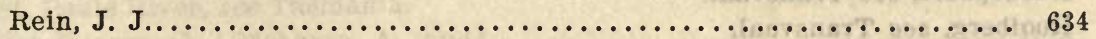

Relistian mine, see England.

Remarkable Mountains, see New Zealand.

Renaud, G. P. A.......................... 114, 116

Renison Bell, see Tasmania.

Renong, see Siam.

Réontovski

Resources of tin, see Supply of tin.

Restronguet Creek, see Cornwall.

Reuss, A. E............................... 562

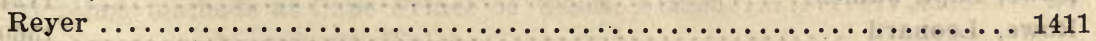

Reyer, E......57, 117, 303, 304, 450, 563, 564, 565, 566, 567, 1354, 1355, 1412 Rhodesia, see Transvaal.

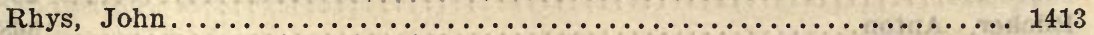

Ribadavia, see Spain, Orense.

Richards, Joseph............................ 1555

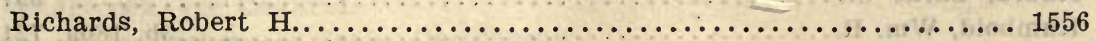

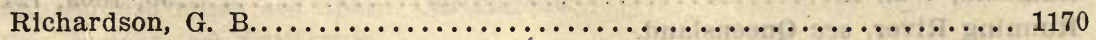

Riche, A. (Cahours, A., and) ......................... 1464

Richmond County, see New South Wales.

Richmond River, see New South Wales.

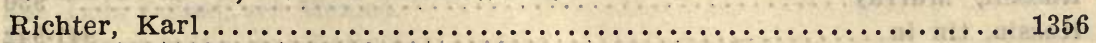

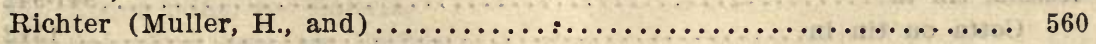

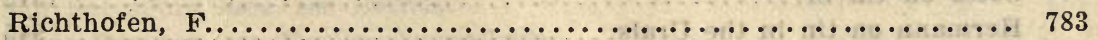

Rickard, Edgar...................................... 1125

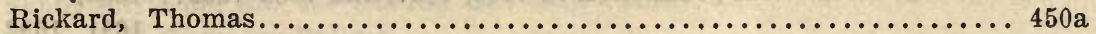

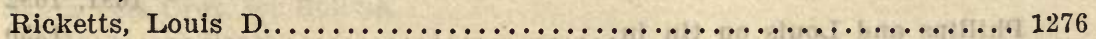

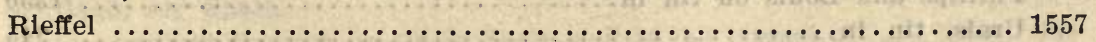

Ringarooma Valley, see Tasmaniạ.

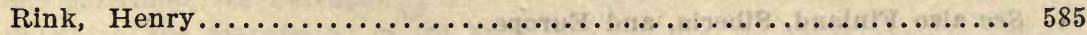

Riotte, E. N. (Bailey, Gilbert E., and) .................. 988

Riouw Islands, see East Indies. 
Riouw-Linga Archipelago, see East Indies.

Reference Number

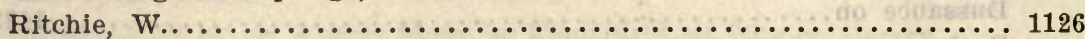

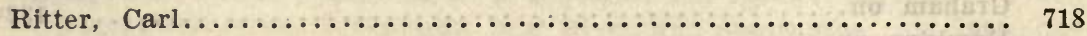

Roberts, Malcolm .................................. 179

Robertson, J. R. M.............................. 58

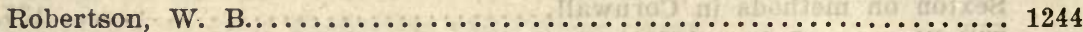

Rockbridge County, see Virginia.

Roehrig (Crookes and) ................................ 1242

Roessler ........................................ 221

Rolker, Chas. M................................ 719, 1357

Roman tin workings, Henwood on ....................... 1327

de Romana, Edwardo A. L........................... 180

Roodepoort, see Transvaal.

Rooiberg, see Transvaal.

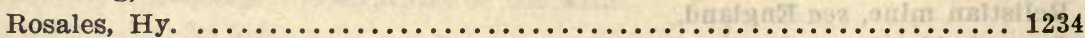

Roscoe, H. E. (Schenck, E., Smith, R. A., and) .................. 1568

Rose, H...................................1558, 1559

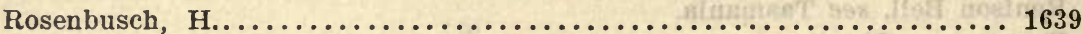

Rosewarne, H. (Borlase, Wm. Copeland, and) ............... 347

Rosewarne mine, see England.

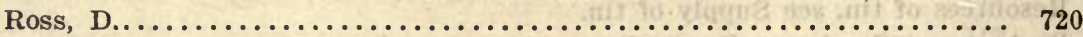

Ross mine, see South Carolina.

Rowe, Capt. James.................................... 1127

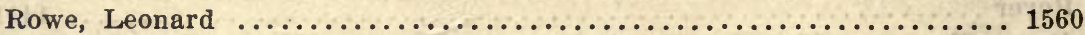

Rowe, T. P., and Foster, C. LeNeve..................... 451

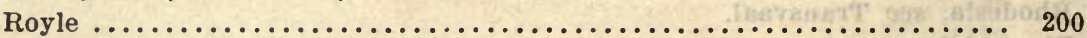

Rücker, Anton................................. 568

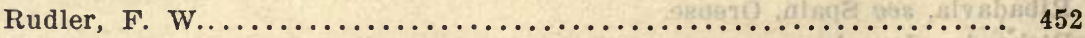

Rudra, Sarat C....................................... 597

Rumbold, Wm. R.................................. 180a, 721

Running River, see Queensland.

Rupert's drops, crystals behaving like.................... $3 \mathrm{~b}$

Rusapi, see Transvaal, Rhodesia.

Russell, Murray................................. 930

Russia, tin in .............................................

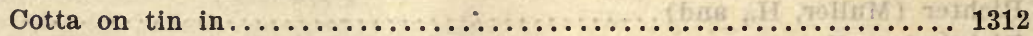

Hermann on tin in the Urals......................... 945

Koulibine on mineral production in 1885,1887 , and $1888-1889.1690$,

Phillips and Louis on $\operatorname{tln}$ in............................. 1350

Urals, $\operatorname{tin}$ in ................................... 945

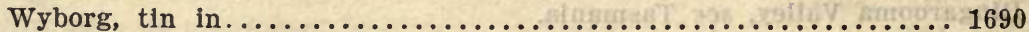

See also Finland, Siberia, and Europe.

Rutile, Deville on the artificial production of.................. 1604 See Association of tin with.

Ryan tin works, see Swaziland, Embabaan. 


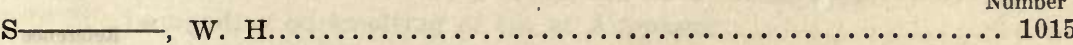

Saavedra, Bautista (Ballivian, M. V., and) ................ 150

Sadisberg, see Saxony.

Sadisdorf, see Saxony.

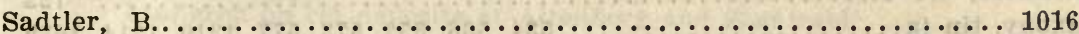

Sain Alto, see Mexico.

St. Agnes district, see Cornwall.

St. Austell, see Cornwall.

St. Helens district, see Tasmania.

St. Ives, see Cornwall.

St. Just, see Cornwall.

St. Leonard, see France, Haute Vienne.

St. Pauls Plains, see Tasmania.

St. Pauls River, see Tasmania.

Saintpierre, C. (Béchamp, A., and)

Salak, see Malay Penlnsula, Perak.

Salamanca, see Spain.

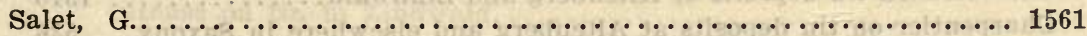

Salinta, see East Indies.

Salmon . . . . . . . . . . . 1562

Salmon, Arthur L................................ 453

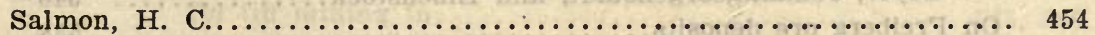

Sambong Giri, see Banka.

Sampling, methods at Cape Prince of Wales, Alaska............ 25

Sam River, see New South Wales.

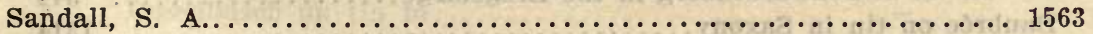

Sandberger, F...................................... 1358

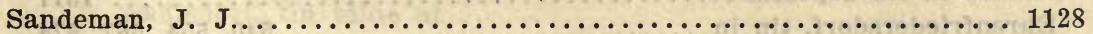

Sandinha, see Portugal.

Sandrycock, see England.

San Isidoro mine, see Spain, Carthagene.

San Jacinto, see California.

San Jose, see Bolivia.

San Juan Mountains, see Colorado.

San Luis Potosi, see Mexico.

San Roque mine, see Bolivia.

San Salvadora lode, see Bolivia.

Santa Barbara, see Mexico, Guanajuato.

Santa Maria del Rio, see Mexico, San Luis Potosi.

Santa Vela Cruz, see Bolivia.

Santiago, see Spain.

Santo Domingo, Garston on tin in Seybo and in the Higuei.......... 954

São Martinho, see Portugal.

Sapphire, see Association of tin with.

Satsuma, see Japan. 
Sauberg, see Saxony.

Reference

Saunders, C. D.

Number

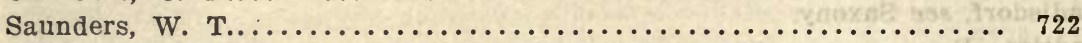

Saxony, tin in...................534, 536, 552, 573, 577, 1310, 1314, 1639

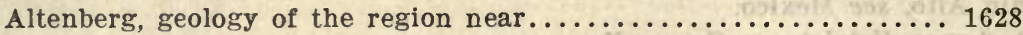

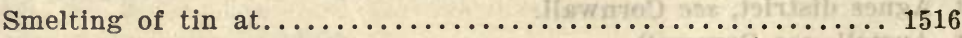

Tin at...512, 528, 529, 536, 537, 539, 540, 542, 549, 551, 563, 567,

$573 a, 1310,1337$

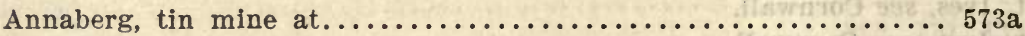

Anaberg Revieren, tin deposits of ..................... 558

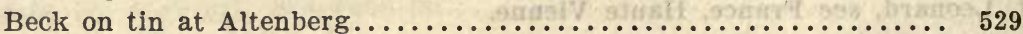

On tin near Schwarzenberg....................... 530

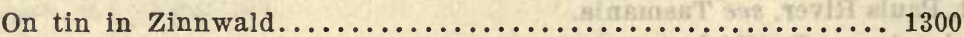

Berggiesshübel, tin near......................... 557

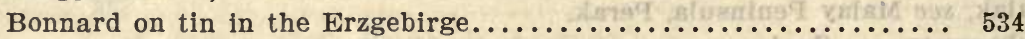

Charleton on tin deposits of Altenberg and Zinnwald............ 1310

Charpentier on tin deposits at Altenberg and elsewhere in Saxony.. $\mathbf{5 3 6}$

Cotta on tin at Altenberg......................... 5379

On tin at Altenberg, Zinnwald, Marienberg, Ehrenfriedersdorf,

Geyer, Johanngeorgenstadt, and Eibenstock...........540

On Freiberg ore deposits. .......................... 538

Dalmer on tin in Aitenberg-Graupen district.............. 542

On tin in Schneeberg.......................... 543

On tin at Schwarzenberg in the Erzgebirge.............. 544

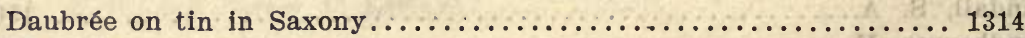

Davies on tin deposits of . . ............................ 1317

Ehrenfriedersdorf, $\operatorname{tin}$ in $\ldots \ldots \ldots \ldots \ldots \ldots \ldots \ldots \ldots \ldots . \ldots \ldots, 554,567,574$

Eibenstock, tin in........................ 540,561, 564, 572

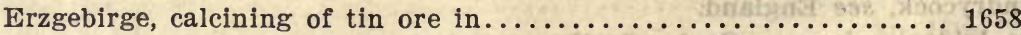

Discrimination of granites in..................... 564

Origin of tin deposits of ....................... 575

Silver-bismuth deposits in...................... 578

Tin in...528, 529, 530, 534, 544, 547, 551a, 553, 555, 556, 564, $574,575,576,577,578$

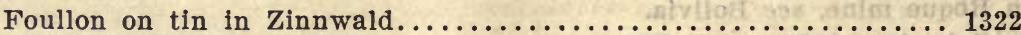

Freiberg, ore deposits of .......................... 538, 560, 575

Friesleben on the Erzgebirge...................... 547

Fuchs and de Launay on tin in.......................66 66

Gätzschmann on the history of tin mining in Freiberg........... 1391

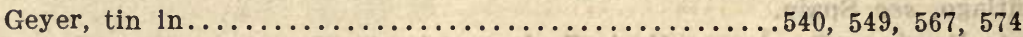

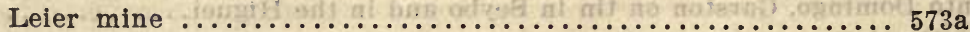

Groddeck on tin at Altenberg, Geyer, and Zinnwald........... 549

Johanngeorgenstadt, tin in ......................... 540. 578

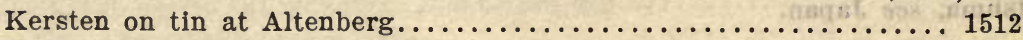

Klipstein on tin at Altenberg........................ 551 
Saxony-Continued.

Kunhardt on the calcining of tin ore in the Erzgebirge.......... 1658

Lampadius on smelting of tin at Altenberg............... 1516

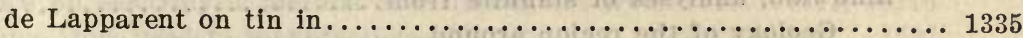

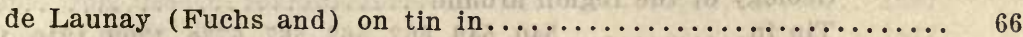

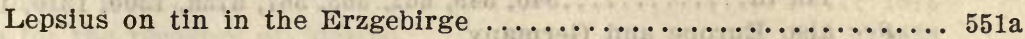

Lindgren on tin deposits at Altenberg and Zinnwald............ 1337

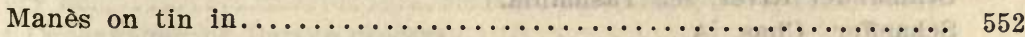

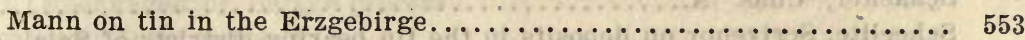

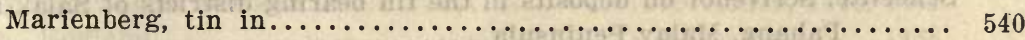

Miklucho-Maclay on tin at Ehrenfriedersdorf............... 554

Müller on tin deposits of the Anaberg Revieren............. 558

On tin near Berggiesshübel.................... 557

On tin in the Erzgebirge.......................... 556

On tin deposits of the Freiberg Revieren.............. 559

Müller and Richter on tin in the zinc-blende deposits of Freiberg.... 560

Nöggerath on the regions of Zinnwald and Altenberg.......... 1628

Oppe on tin in Eibenstock, Johanngeorgenstadt, and Schneeberg.... 561

Rammelsberg on analyses of stannite from Zinnwald.......... 1637

Reuss on tin in Zinnwald.......................... 562

Reyer on the discrimination of the granites in the Erzgebirge..... 564

On the geology of Eibenstock, Schwarzenberg, and the Erzge-

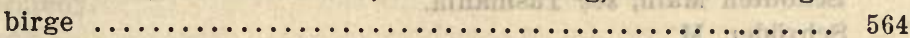

On tin mining in ............................. $565,566,567$

On tin in Zinnwald and Altenberg.................. 563

On tin in Zinnwald, Altenberg, Ehrenfriedersdorf, and Geyer.. 567

Richter (Müller and) on tin in Freiberg................ 560

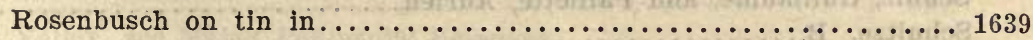

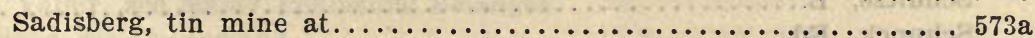

Sadisdorf, tin mine at............................... $573 a$

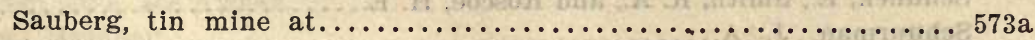

Schneeberg, tin in ......................... 543, 561, 573a

Schröder on tin in Eibenstock..................... 572

Schultz on tin deposits of .............................. 573

Schwarzenberg, tin at........................... 544, 564

Singewald on tin deposits in the Erzgebirge............... 573a

Stelzner on the origin of the lead deposits of Freiberg and the tin

deposits of the Erzgebirge.................... 575

On tin in Ehrenfriedersdorf, Geyer, and the Erzgebirge...... 574

On tin in Freiberg and the Erzgebirge.............. 575

Stelzner and Schertel on zinc-blende from Freiberg........... 1643

Sternberger on tin in the Erzgebirge................. 576

Telkin on tin mining in the Erzgebirge................. 577

Viebig on the silver-bismuth deposits in Johanngeorgenstadt, in the

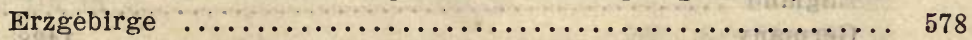

Woodward on tin ore specimens from $\ldots \ldots \ldots \ldots \ldots \ldots \ldots \ldots \ldots . \ldots . \ldots$ 
Saxony-Continued.

Reference

Zinnwald, analyses of stannite from

Number

Geology of the region around . . . . . .

Tin in..........540,549,562, 563, 567, 573a, 1300, 1310, 1322, 1337 See also Europe and Germany.

Scamander River, see Tasmania.

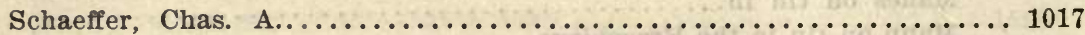

Scheelite, Scrivenor on deposits in the tin bearing districts of Salak and

Pahang, Malay Peninsula.

See Association of tin with.

Schertel, A. (Stelzner, A. W., and) ........................ 1643

Scheurer-Kestner, A.................................... 1565

Schlackenwald, see Bohemia, Schlaggenwald.

Schlaggenwaid, see Bohemia.

Schmidt, Albert..................................... 571

Schnabel, Carl....................................... 794

Schneeberg, see Saxony.

Schneider, C. F. A............................... 306

Schönefeld, see Bohemia.

Schouitz-Ascheraden, G. von............................ 950

Schouten Main, see Tasmania.

Schröder, M........................................ 572

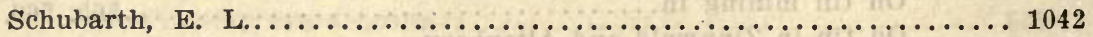

Schultz ........................................ 573

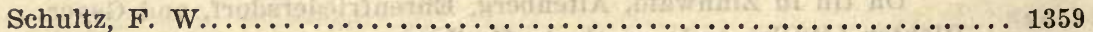

Schulz, Guillaume, and Paillette, Adrien.................... 1043

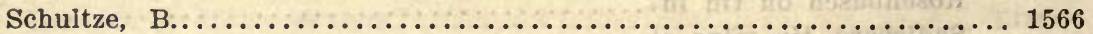

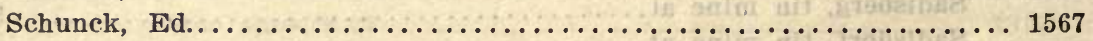

Schunck, E., Smith, R. A., and Roscoe, H. E.................... 1568

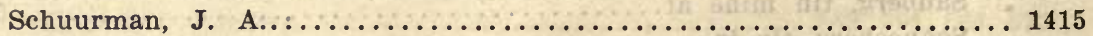

Schwarzenberg, see Saxony.

Scilly Islands, tin and lead exported to Greece and Asia............ 1410

Borlase on ancient and present state of................... 1381

Plinius on tin from ................................. 1408

Rawlinson on Phœnician colonies in..................... 1410

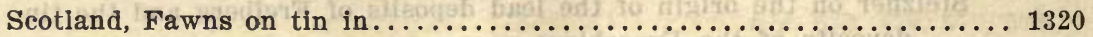

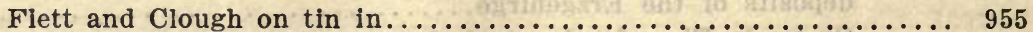

See also Great Britain and Europe.

Scott, H. G................................... 962

Scrap tin:

Bergse process for recovery of......................... 1442

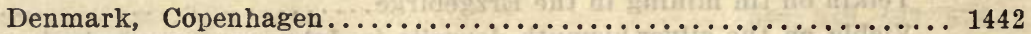

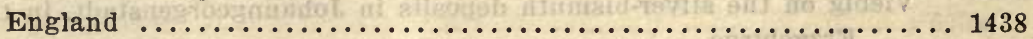

Germany .......................................... 1497a, 1511

Goldschmidt on recovery of tin from .........................

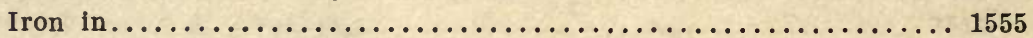


Scrap tin-Continued.

Kershaw on electrolytic method of stripping tin from.......1511, 1511a Malleable iron, used in manufacture of ................. 1567

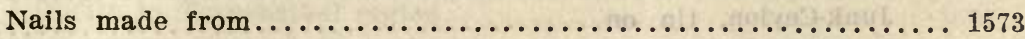

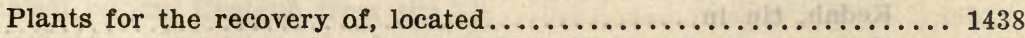

Recovery of.................1435, 1438, 1439, 1440, 1441, 1442b

At Copenhagen by Bergse process.................. 1442

By electrolytic methods...................1439, 1440, 1441

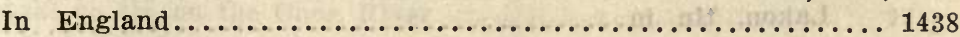

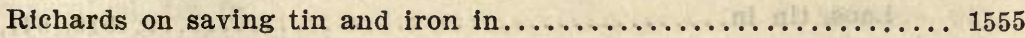

Schultze on recovering tin from tin plate scrap................... 1566

Schunck on recovering tin from tin plate scrap............... 1567

Smith (0.) on making nails from....................... 1573

Wirtz on recovery of tin and zinc from ................... 1584

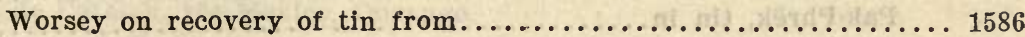

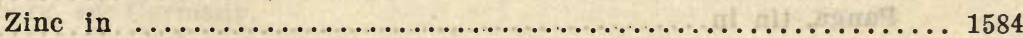

Scrivenor, J. B...................... 723, 724, 725, 726, 726a, 726b

Scrivenor, J. B. (Reid, Clement, and) .................449, 1638

Sebastopol, see Victoria.

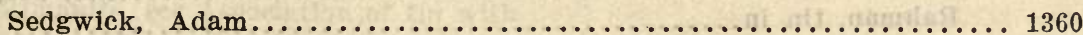

Seegrunde, see Germany.

Seiffen, see Germany.

Selama, see Malay Peninsula, Perak.

Selangor, see Malay Peninsula.

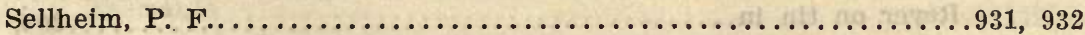

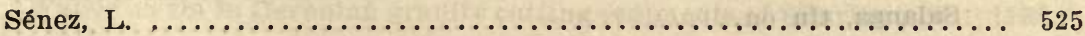

Serendah Valley, see Malay Peninsula, Selangor.

Severn River, see Queensland.

Seward Peninsula, see Alaska.

Sexton, A. Humbolt............................... 1361

Seybo, see Santo Domingo.

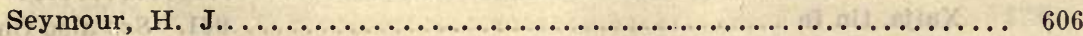

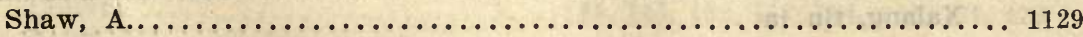

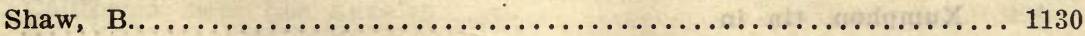

Shelbourne, see Nova Scotia, Lunenberg County.

Shepherd and Murphy's mine, see Tasmania, Bell Mount.

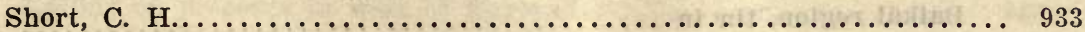

Siak, see Sumatra.

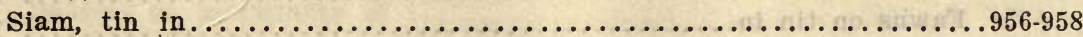

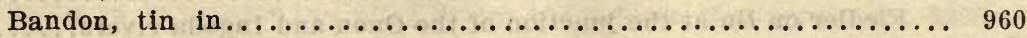

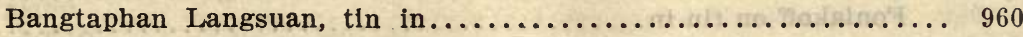

Blewett on tin on Junk-Ceylon or Salanga Island .............. 959

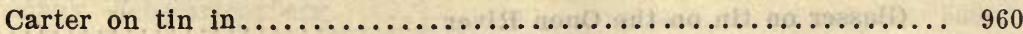

Chaija, tin in ............................. See also Xaija

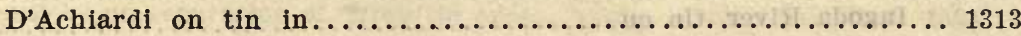

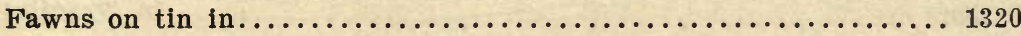


Siam-Continued.

Fischer on tin in.

Reference

Number

Gascuel on tín in Nam-Patène, Laos.................... 643

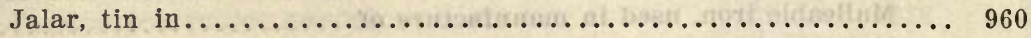

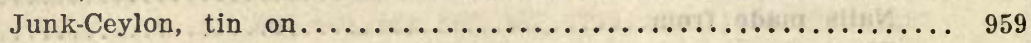

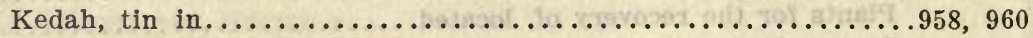

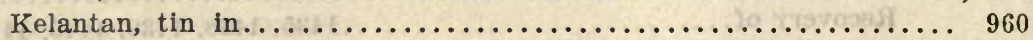

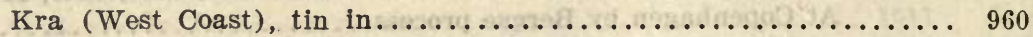

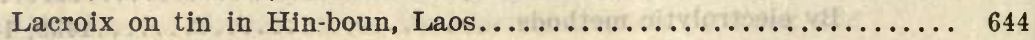

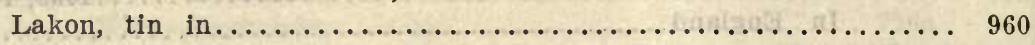

Laos, tin in............................ $516,641,642,645$

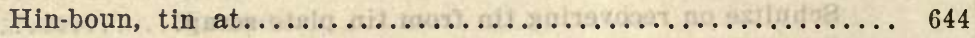

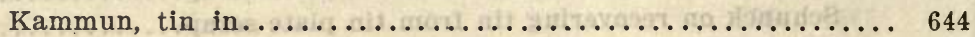

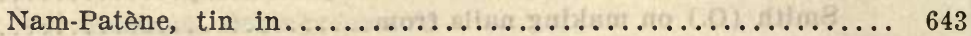

Nam Sak River, tin in ........................... 960

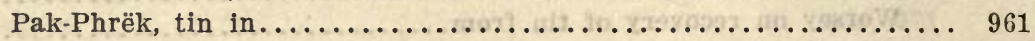

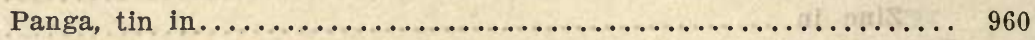

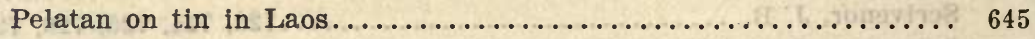

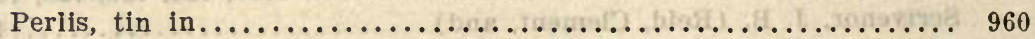

Puket, tin in .................................. 960,962

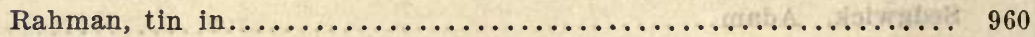

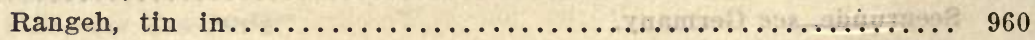

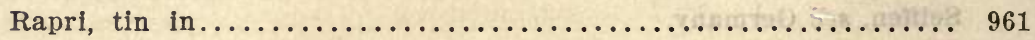

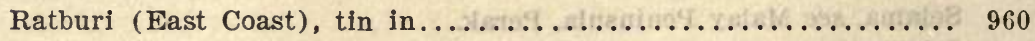

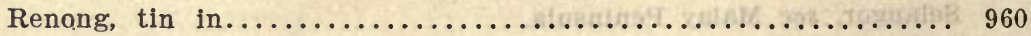

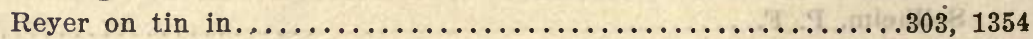

Salanga, tin on ...................................... 959

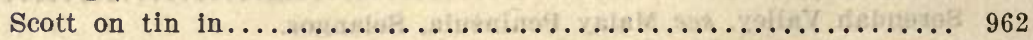

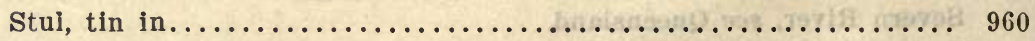

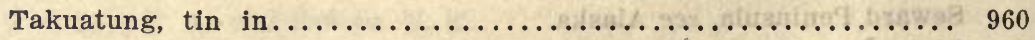

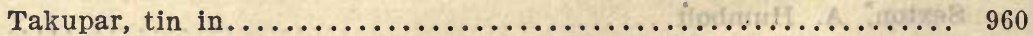

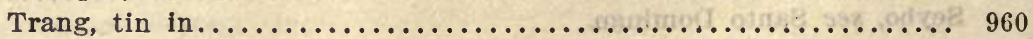

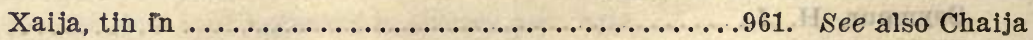

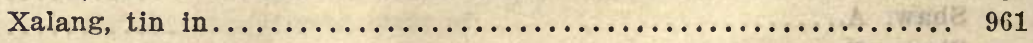

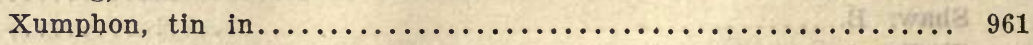

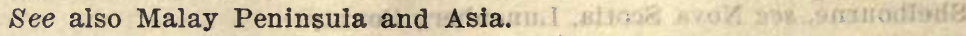

Siberia, tin in .................................... 1290

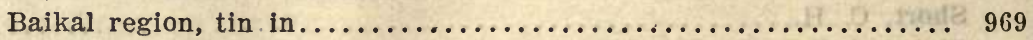

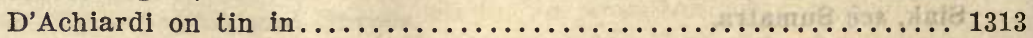

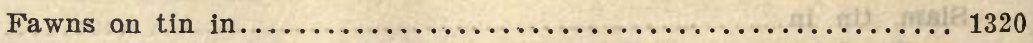

Fiedier on tin at the junction of the Onon and Ingoda rivers....... 943

Foniakoff on tin in ............................... 966

On tin in the Transbaikal. ........................ 965

Giasser on tin on the Onon River.................... 967

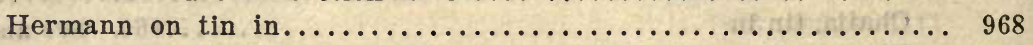

Ingoda River, tin on $\ldots \ldots \ldots \ldots \ldots \ldots \ldots \ldots \ldots \ldots \ldots \ldots \ldots . \ldots . \ldots . \ldots \ldots$ 
Siberia-Continued.

Jeremejev on crystals of tinstone from the Jenisei region........ 1623

On tin in Transbaikal region...................... 1622

Jenisei region, tinstone from the..................... 1623

Korzoukhine on tin on the Onon River................. 976

Krusch on tin on the Onon River.................. 947

Onon River, tin on $\ldots \ldots \ldots \ldots \ldots \ldots \ldots \ldots \ldots \ldots . . \ldots 63,964,967,970,971$

Réontovski on tin on the Onon River........................ 971

Transbaikal, tin in ........................... 970,971

Transbaikal region, tin in ......................... 942

Yenisei, see Jenisei.

See also Russia and Asia.

Siderite, see Association of tin with.

Sierra de Catalan, see Mexico, Durango.

Silberberg, see Germany.

Silent Grove, see New South Wales.

Silicon, Berthelot on the action of oxygen on the compounds of tin,

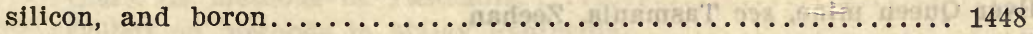

Sillimanite, see Association of tin with.

Silurian, tin in slate of Silurian age in Spain..............1034, 1039

Tin ore in dikes cutting Silurian strata ...................... 172

Stirling on tin in pegmatites cutting rocks of Upper Silurian age. . 1238

Twelvetrees on tin veins cutting rocks of Middle Silurian age in

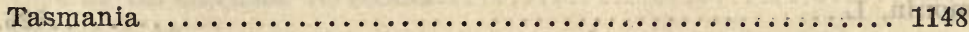

Waller on tin in Devonian granite cutting sediments of Silurian age.. 1155 Silver:

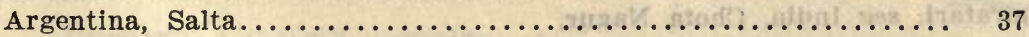

Associated with tin, see Association of tin with.

Ball on in Stanthorpe district, Queensland................ 889

Beck on occurrence at Schwartzenberg, Germany............. 530

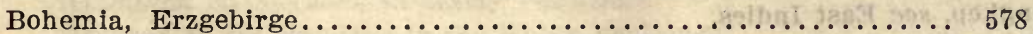

Bolivia .....................144, 145, 152, 155, 164, 166, 171, 172

California, near Los Angeles........................ 208

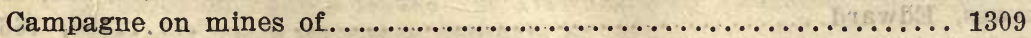

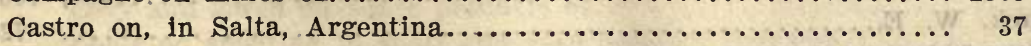

Collins on presence in west of England.................. 369

Cramer on precipitation of, out of tin................... 1472

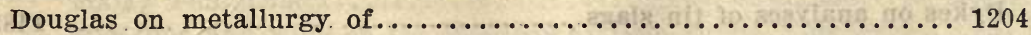

Emmons on occurrence in United States and genesis of minerals of. 1206

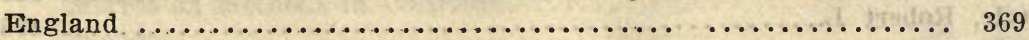

Foniakoff on deposits in Siberia..................... 965

Germany, Schwartzenberg........................ 530

Jack on Kangaroo Hills mines, Queensland................. 918

Menniche on separation of, from tin ores................. 1534

Metaliurgy of ..................................... 1204

Moore on occurrence with tin in killas of St. Pauls Plains, Tasmania. 1114 
Silver-Continued.

Reference Number

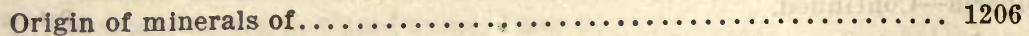

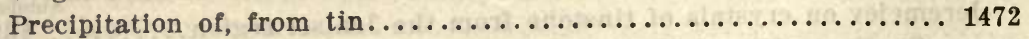

Queensland $\ldots \ldots \ldots \ldots \ldots \ldots \ldots \ldots \ldots \ldots \ldots$. $477,889,918,932,935,936$

Saxony, Erzgebirge........................... 578

Sellheim on Herberton district, Queensland ............... 932

Separation from tin................................ 1534

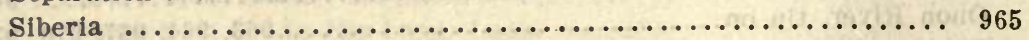

Skertchly on deposits in Queensland....................... 939

Sulphides of associated with tin in Bolivia............... 155

Tasmania .......................................... 1114

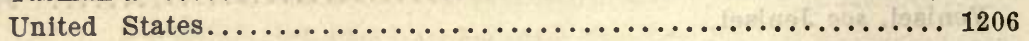

Viebig on deposits of, in the Erzgebirge, Saxony............ 578

World statistics since $1890 \ldots \ldots \ldots \ldots \ldots \ldots \ldots \ldots \ldots \ldots \ldots \ldots . \ldots \ldots$

Silver ores, see Association of tin with.

Silver sulphides, see Association of tin with.

Silver Crown district, see Wyoming.

Silver Hill, see Washington.

Silver Queen mine, see Tasmania, Zeehan.

Silverton district, see New South Wales.

Silver Valley, see Queensland, Herberton district.

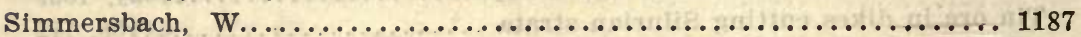

Simmons, Jesse...........................1018, 1019, 1019a

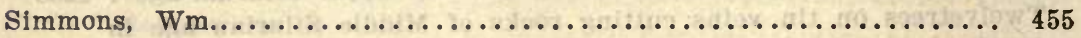

Simonin, L........................................ 1416

Simpang, see Sumatra.

Simpson, Edward S..............................1267-1269

Simratari, see India, Chota Nagur.

Singapore, see Malay Peninsula.

Singewald, J. T., Jr............................. $573 a$

Singkap Island, see East Indies, Singkep.

Singkep, see East Indies.

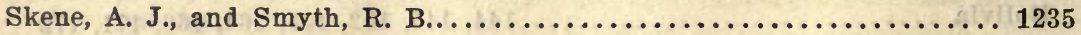

Skertchly, Sydney B. J................................ 935, 936

Skewes, Edward................................. 1662

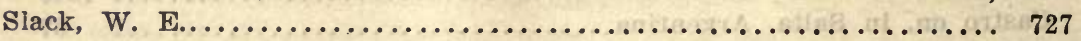

Slags, Bohne on recovery of tin from...................... 1453

Brandenburg, Weyland, and Kempen on recovery of tin from...... 1456

Dykes on analyses of tin slags........................ 1483

Thiollier on treatment of tin slags in Cornwall.............. 1579

Slagle, Robert. L.................................... 1569

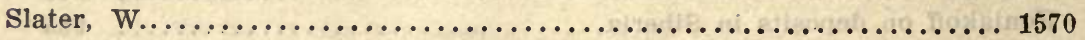

Slee, W. H. J.................................. 839

Slimes (tin), Mackenzie on determination of tin in.............. 1529

Hicks on methods of saving......................... 1505

Treatment of, in Cornwall..................................... 1657

Slime tin (a variety of wood tin), Field on two specimens of ........ 1607 
Sloan, Earl

(4)

Slocan district, see British Columbia.

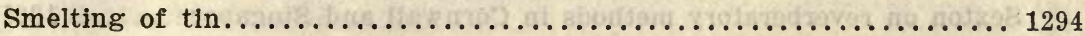

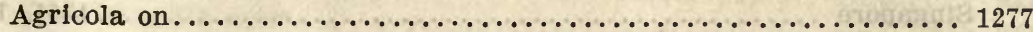

Banka ............................... 1473, 1478, 1480

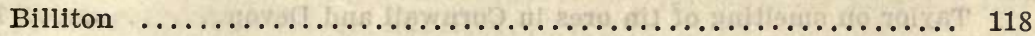

Boase on methods in Cornwall........................ 343

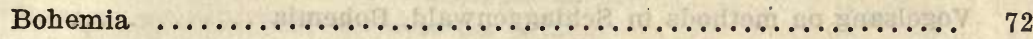

Bohne on recovery of tin from slags produced in ............. 1453

Bolivia ..................................... 153a

Bromley on methods and results with various tin ores at Santa Bar-

bara, Mexico ............................. 766

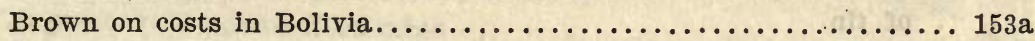

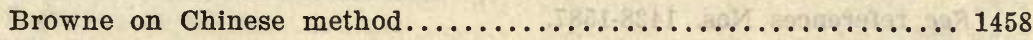

Charleton on methods used in ........................ 1310

Chinese methods...............299, 694a, 711, 1458, 1473, 1489, 1523

Clark on methods in Tasmania...................... 1076

Collett on methods in Malay Peninsula.................. 681

Cornwall.................312, 343, 432, 1361, 1425, 1518, 1554, 1576

Croockewit on Chinese methods in Banka................. 1473

Devon .................................. 1425, 1576

Diest on methods in Banka.......................... 1478

Dijk on tin smelting in Banka....................... 1480

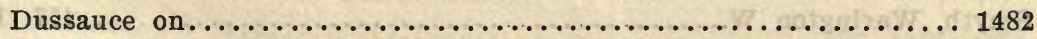

Flower-Ellis on Chinese and European methods in Malay Peninsula,

Germany, Altenberg deposits...................... 528

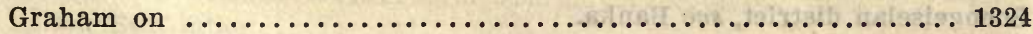

Halse on methods at Los Cuevas, Mexico................. 773

Hampton on methods in Malay Peninsula............... 695

Hughes on tin smelting in the Malay Peninsula............. 1507

Latta on tin smelting at Mt. Bischoff, Tasmania............. 1517

Le Grice on "Jew"s House" at Trereife, near Penzance, Cornwall.. 1518

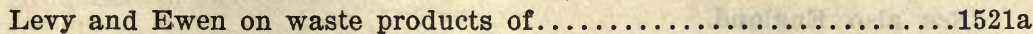

Louis on smelting in shaft and reverberatory furnaces......... 1523

Malacca ...................................... 299

Malay Peninsula................681, 694a, 695, 716, 1489, 1507

McKillop and Ellis on tin smelting at Pulo Brani, Singapore..... 1530

Merret on methods in Cornwall........................ 432

Mexico..............................766, 773, 781

Nevius on methods at Sain Alto, Mexico................ 781

Newbold on Malay and Chinese methods in Malacca.......... 299

Owen on Chinese methods in Perak...................... 711

Perak ..................................... 711 ,

Pike on methods in Perak......................... 715

Place on methods in Malay Peninsula .................. 716 
Smelting of tin-Continued.

Reference Number

Pryce on ....................................... 444

Ray on tin smelting in Cornwall...................... 1554

Sexton on reverberatory methods in Cornwall and Singapore...... 1361 Singapore ................................... 1530

Tasmania .......................................... 1517

Taylor on smelting of tin ores in Cornwall and Devon......... 1576

Van der Wyck on methods in Banka and Billiton............. 118

Vogelsang on methods in Schlaggenwald, Bohemia............. 72

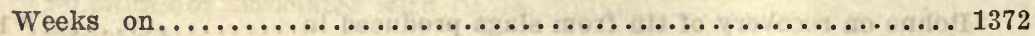

Worth on smelting and sale of tin and copper in Devon and Corn-

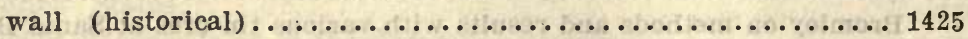

See also Assays of tin, dressing of tin, metallurgy of tin, refining of tin.

See references Nos. 1428-1587.

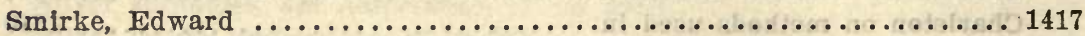

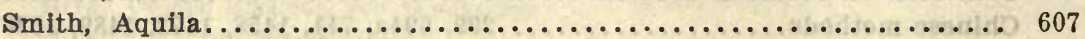

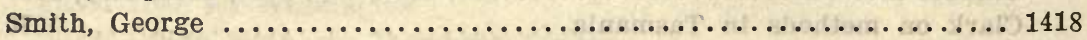

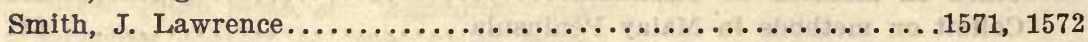

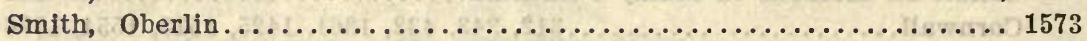

Smith, R. A., and Roscoe, H. E. (Schenck, E., and) ............ 1568

Smiths Creek mine, see Queensland.

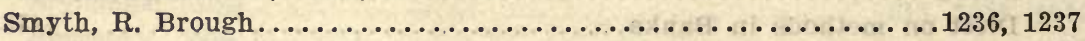

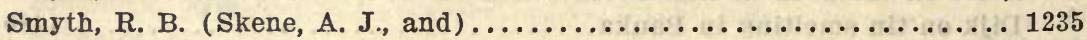

Smyth, Warington W................................. 1362

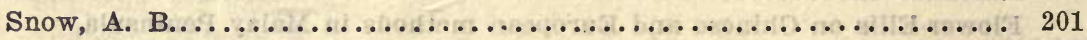

Soekadana, see Borneo, Sukadana.

Soengei Liat district, see Banka.

Soengeiselan district, see Banka.

Solder, Schultz on production and application of $\ldots \ldots \ldots \ldots \ldots \ldots \ldots \ldots$

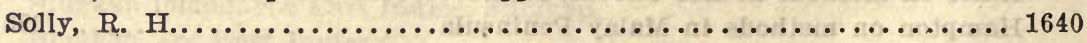

Somero, see. Finland.

Somerset, De La Beche on tin in....................... 376

Foster on tin in .................................. 382

See also England.

Sonora, see Mexico.

South Africa, tin in ........................... 1045, 1047, 1285

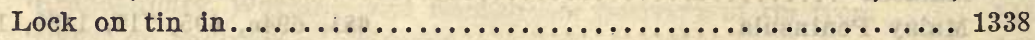

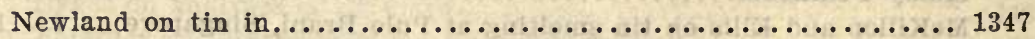

See also Africa, Cape Colony, Rhodesia, Swaziland, Transvaal, etc.

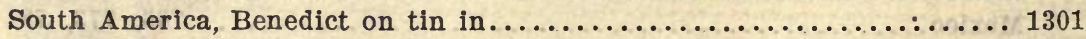

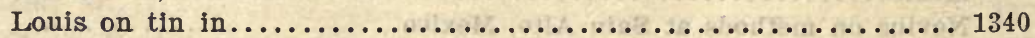

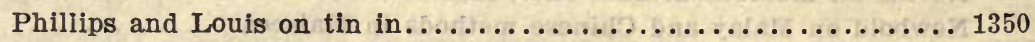

See also Argentina, Bolivia, Chili, French Guiana, and Peru.

South Australia, tin in.......................45, 1290, 1292

Brown on gold at Tarcoola, Enterprise mine, and the Earea Dam

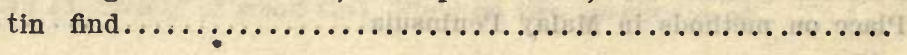


South Australia-Continued.

Brown on the Koetong tin field, Wodonga district............. Number

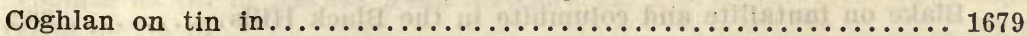

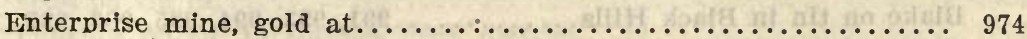

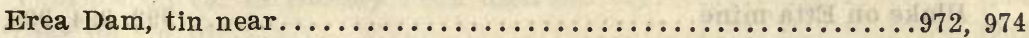

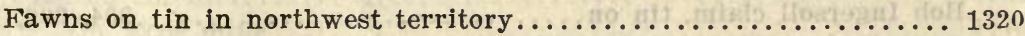

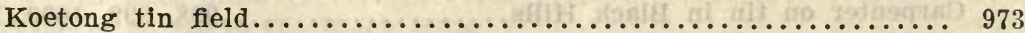

Mount Gunson mine, gold and copper at.................. 974

Newton on metalliferous minerals of .................... 55

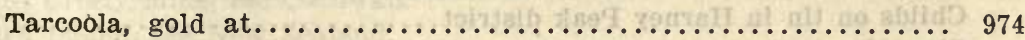

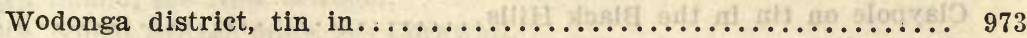

See also Australia.

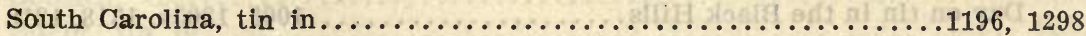

Ball (S. M.) on the Ross mine ........................ 239a

Garrison on tin in .................................. 1207

Graton on tin in .................................... 246

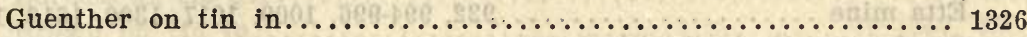

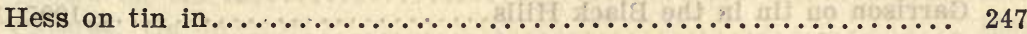

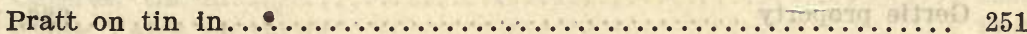

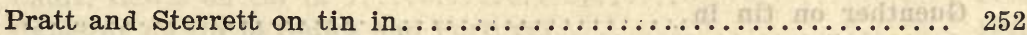

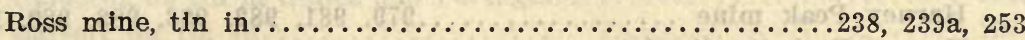

Sloan on the Ross mine $\ldots \ldots \ldots \ldots \ldots \ldots \ldots \ldots \ldots \ldots \ldots \ldots \ldots . \ldots \ldots . \ldots \ldots$

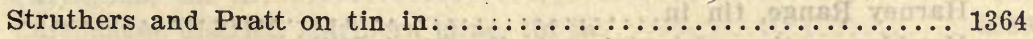

See also Carolinas and United States.

South Dakota, tin in...........................1192, 1196, 1281

Bailey and Riotte on Harney Peak Tin Company.............. 988

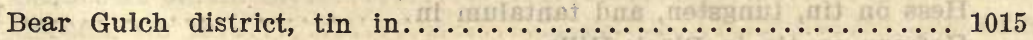

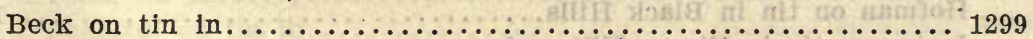

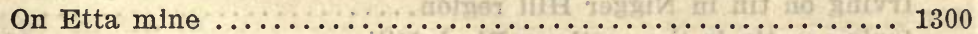

Benedict on tin in ................................ 1200, 1301

Benedict on tin near Custer City and in the Nigger Hill district... 1275

Benedict on Harney Peak tin mines..................... 989

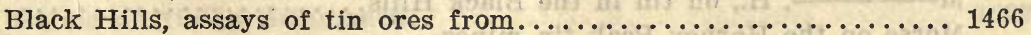

Tantalite and tin in ................976, 993, 996, 1009, 1017

Tin in...975, 976, 977, 979,981,982, 983, 991, 992, 1004, 1007, $1008,1012,1013,1014,1025,1196,1202,1203 \mathrm{a}, 1207,1208,1213$, $1318,1364,1466,1506,1616,1646$

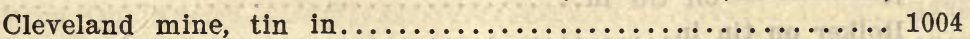

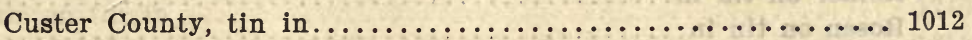

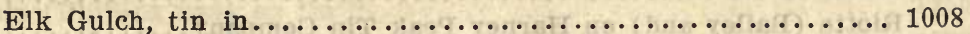

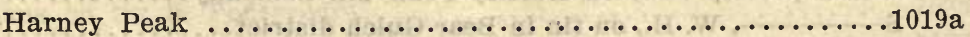

Northern Hills, tin in......................1008, 1011

Peerless mine ............................. 1616

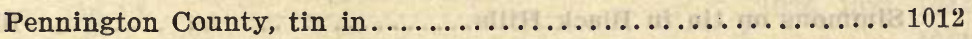

Tinton, tin at.......................... 985, 987a, 1009 
South Dakota-Continued.

Reference

Blake on the Geology of the Black Hills tin district............ 994

Blake on tantallite and columbite in the Black Hills.........993, 996 Blake on tin in Black Hills.........991, 993, 994, 995, 996, 997, 1202

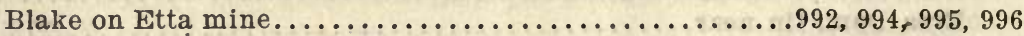
Bob Ingersoll claim, tin on ....................994, 996, 1009 Carpenter on tin in Black Hills..............998, 999, 1000, 1001 Carpenter and Headden on assays of tin ore from the Black Hills... 1466 Chance on tin in the Black Hills....................... 1002 Childs on tin in Harney Peak district.................... 1021 Claypole on tin in the Black Hills...................... 1003

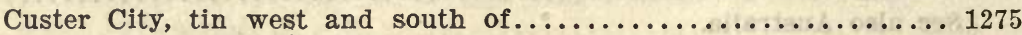
Day on tin in the Black Hills................1005, 1203a, 1318, 1319

On tin in Cleveland mine, Black Hills .................. 1004

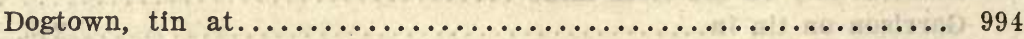

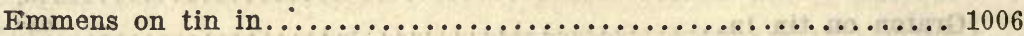
Etta mine ...............922, 994-996, 1009, 1017, 1300, 1616, 1646 Garrison on tin in the Black Hills............................ 1207

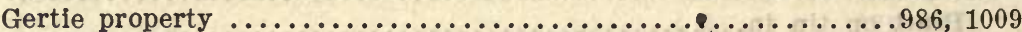

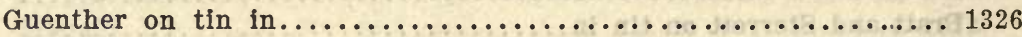
Harney Peak mine ............979, 981, 982, 983, 988, 989, 1205 Harney Peak tin district..................... 1013, 1021, 1022

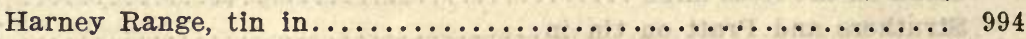
Headden on tin and tantalum in the Black Hills.............. 1208 Headden on the Peerless and Etta tin mines, Black Hills......... 1616 Headden (Carpenter and) on tin in Black Hills.............. 1466 Hess on tin, tungsten, and tantalum in.................. 1009 Hofman on tin in Black Hills......................... 1506 Irving on tin in Nigger Hill region.................... 1010 Irving on tin in the northern Black Hills..............1010, 1011

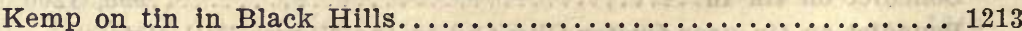

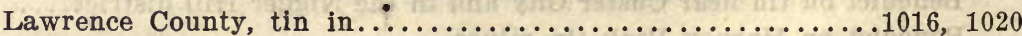
$\mathrm{M}-$, H., on tin in the Black Hills................ 1012

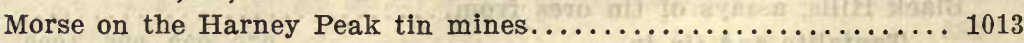
Nigger Hill district, tin in ..............980,984, 985, 1010, 1275 O'Harra on tin in the Black Hills....................... 1014 Pratt (Struthers and) on tin in northwestern Black Hills......... 1020

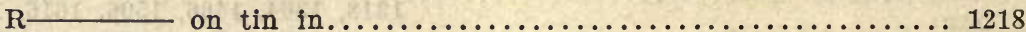
Rolker on tin in............................... 1357

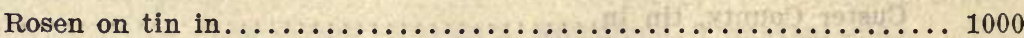
Riotte (Bailey and) on Harney Peak Tin Company.............. 988 $\mathrm{S}-$ W. H., on tin in Bear Gulch district................ 1015 Sadtler on tin in the northwestern Black Hills. . . . . . . . . . . . . . 1016 Schaeffer on tin in Etta mine, Black Hills.................. 1017 Simmons on tin in Black Hills.....................1018, 1019 Struthers and Pratt on tin in Black Hills................1020, 1364 
South Dakota-Continued.

Thomas on tin in Harney Peak district.................. 1021

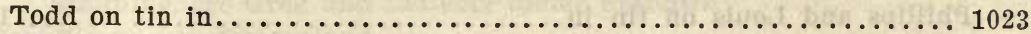

Thurlow on tin in Harney Peak district................. 1022

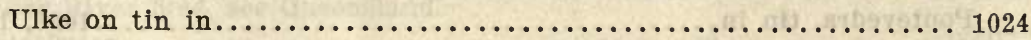

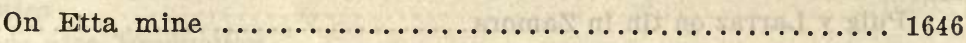

Vincent on tin in the Black Hills...................... 1025

See also Dakota, Wyoming, and United States.

South Crofty mine, see Cornwall.

South Island, see New Zealand.

South Wheal Breage mine, see Cornwall.

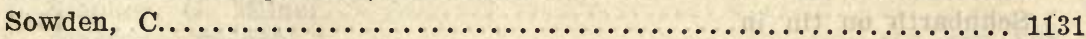

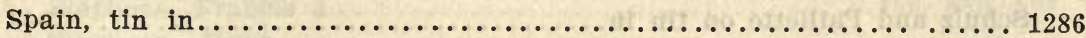

Andalusia, gold, silver, quicksilver, tin, lead, copper, and iron in... 1410

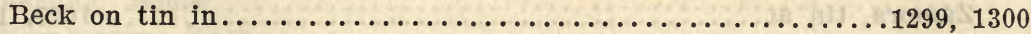

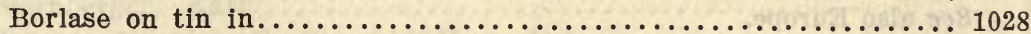

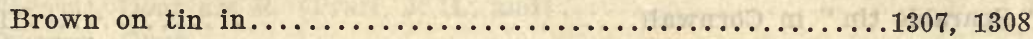

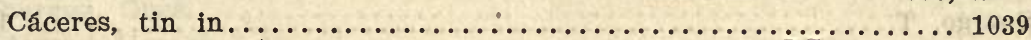

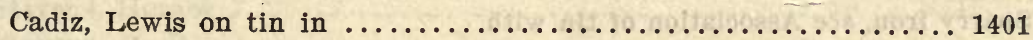

Calderón on tin in Galice and Portugal................... 1029

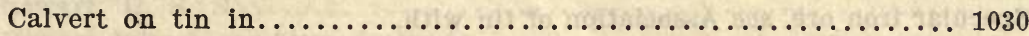

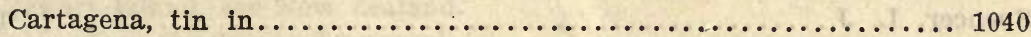

Carthagene district, Marinera mine, tin in ................ 1038

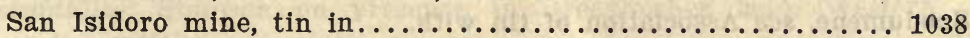

Superior Segunda mine, tin in .................... 1038

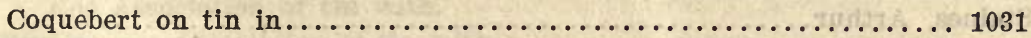

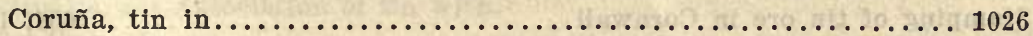

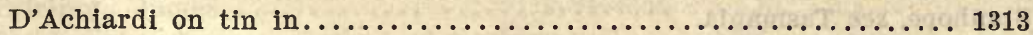

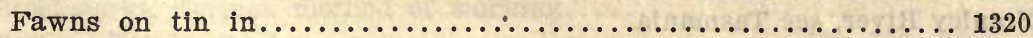

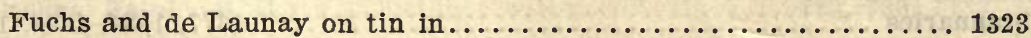

Galæcia, Plinius on "white lead" from................... 1408

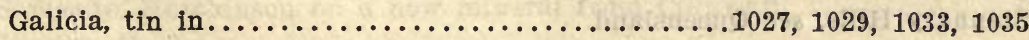

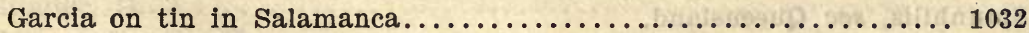

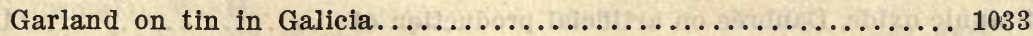

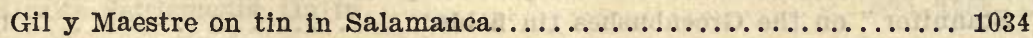

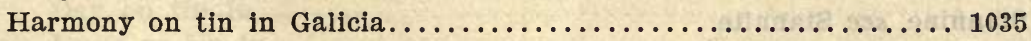

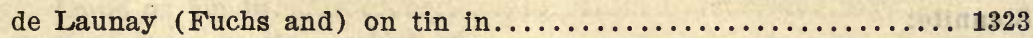

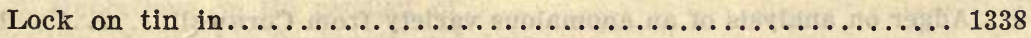

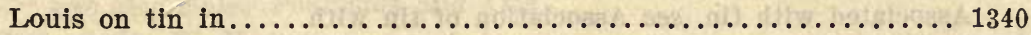

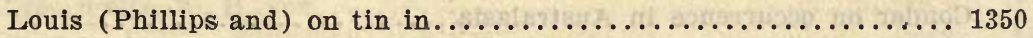

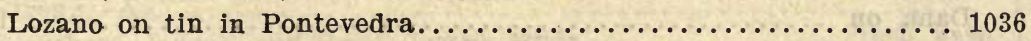

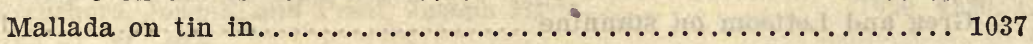

Massart on tin in the "district de Carthagene".............. 1038

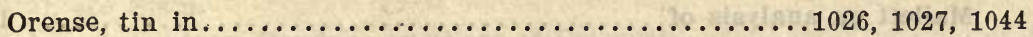

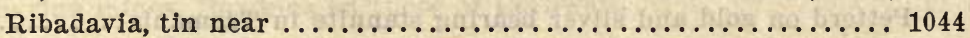

Pacheco on tin in Cáceres.......................... 1039 
Spain-Continued.

Reference Nuniber

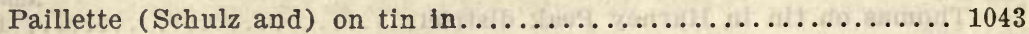

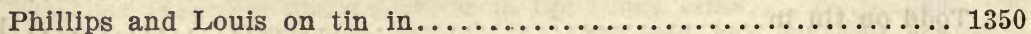

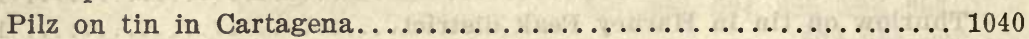

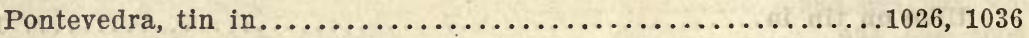

Puig y Larraz on tin in Zamora....................... 1041

Rawlinson on Phœnician colonies in Andalusia............. 1410

Salamanca, tin in.................................... 1032

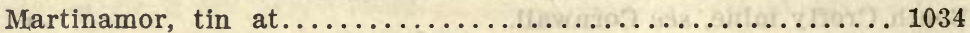

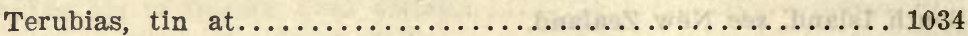

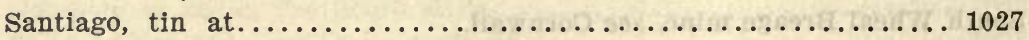

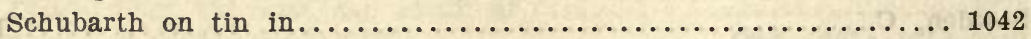

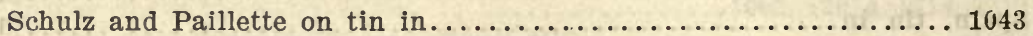

Thomas on tin near Ribadavia, Orense................... 1044

Zamora, tin at................................ 1041

See also Europe.

"Sparable tin" in Cornwall............................. 1640

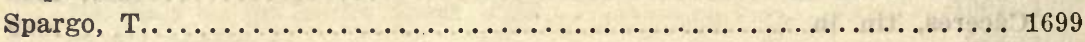

Sparry iron, see Association of tin with.

Spectrum of tin, Salet on ............................. 1561

Specular iron ore, see Association of tin with.

Spencer, L. J................................... 1641

Sphalerite, see Association of tin with.

Spodumene, see Association of tin with.

Spokane, see Washington.

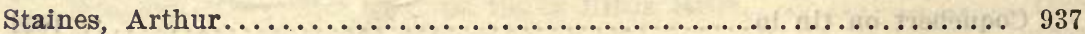

Stamping of tin ore in Cornwall.......................... 1656

Stanhope, see Tasmania.

Stanley River, see Tasmania.

Stannaries ...........................1377, 1384, 1402, 1403

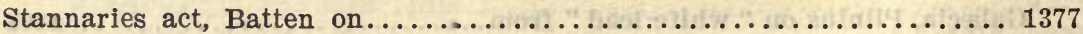

Stannary Hills, see Queensland.

Stannhills, see Queensland.

Stannic oxide, Daubrée on artificial production of ............... 1601

"Stannifer" on the Greenbushes tin fields.................... 1270

Stannine, see Stannite.

Stannite:

Adger on analysis of an anomalous variety from Cornwall........ 1588

Associated with tin, see Association of tin with.

Conder on occurrence in Australasia.................... 816

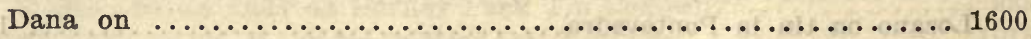

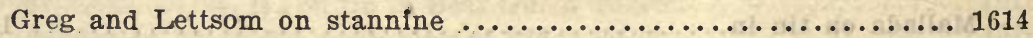

Headden on alteration products of in the Black Hills, South Dakota. . 1616

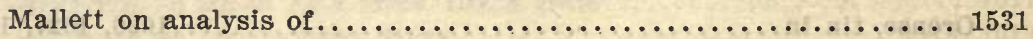

Petterd on gold and silver bearing stannite in Tasmania......... 1119

Rammelsberg on analyses of from Zinnwald and Cornwall....... 1637

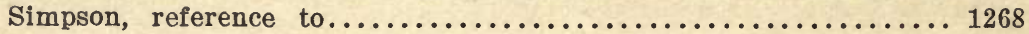


Stannite-Continued.

Spencer on crystals from Bolivia...................... 1641

Stannine, see Greg and Lettsom under Stannite.

Stanthorpe, see Queensland.

Star River field, see Queensland.

Statistics

See also Production.

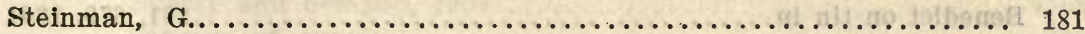

Stelzner, A. W......................182, 183, 458, 574, 575, 1642

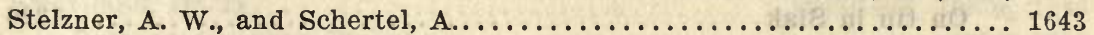

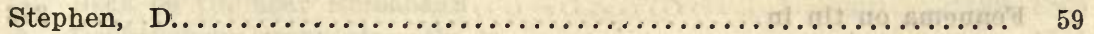

Stephen, G. Milner.............................. 840

Stephens, Francis J......................459, 460, 598, 728

Stephens, Hugh.............................. 461

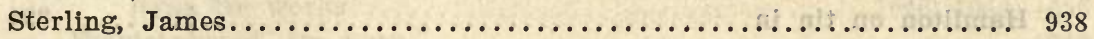

Sternberger, Karl............................... 576

Sterrett, Douglass B. (Pratt, J. H., and) ....................... 252

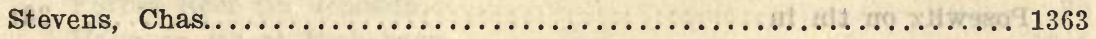

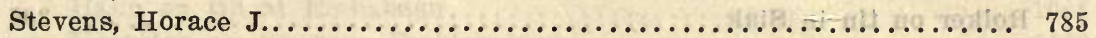

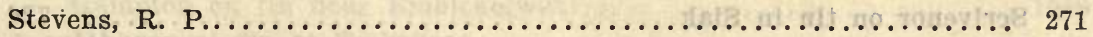

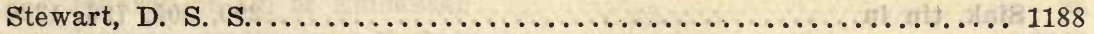

Stewart Island, see New Zealand.

Steynsdorp Creek, see Transvaal.

Stibiotantalite, Simpson on presence in Greenbushes field, Western

Australia .................................. 1267

See Association of tin with.

Stibnite, see Association of tin with.

Stirling, James.................................... 1238

Stockworks, German method of working................... 398

Stokes, Ralph (S. G.) .......................729, 730, 1132, 1133

Stokesite, described................................. 1589

Stokesite, Hutchinson on a new mineral from Cornwall............ 1620

Stonier, G. A.................................... 841

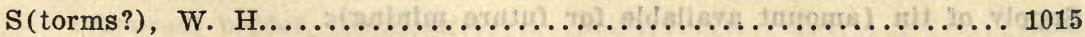

Straits Settlements, tin in ....................695, 1286, 1287

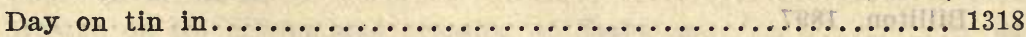

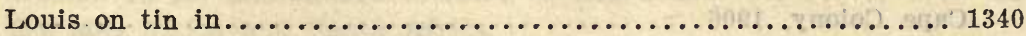

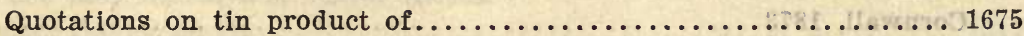

See also Malay Peninsula and Asia.

Streeruwitz, W. H. von................................... 1171

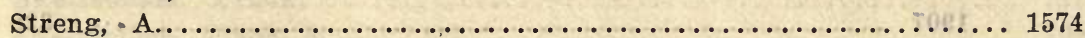

Struthers, Joseph, and Pratt, Joseph Hyde.............1020, 1220, 1364

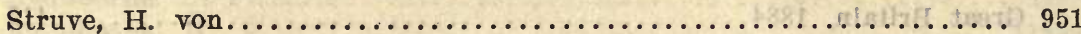

Stul, see siam.

Submarine mines, Hawkins on those of Cornwall................. 396

Sukadana, see Borneo.

Sukandana, see Borneo, Sukadana. 


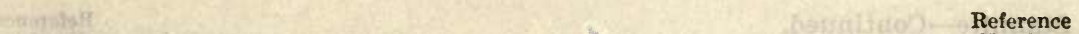

Sulphides, see Association of tin with.

Sulphur, Capitaine on action of tin, arsenic, antimony, and sulphur on

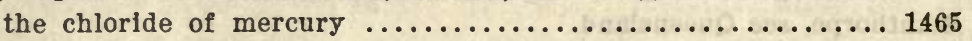

Headden on compounds of, in an old Cornwall tin furnace....... 1617

Hennecke on occurrence in Persia .................... 864 Sumatra:

Benedict on tin in ................................. 679,1301

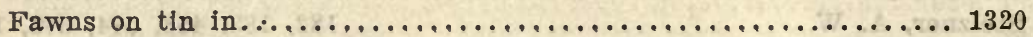

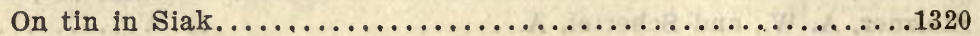

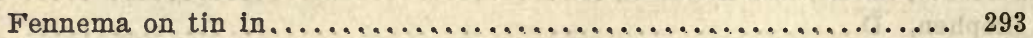

On tin in the Boven Banjoe field of Palembang............ 292

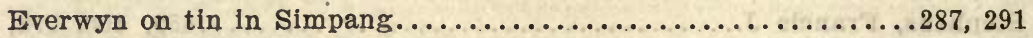

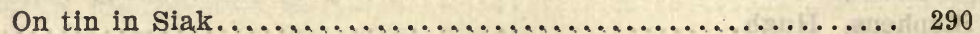

Hamilton on tin in .............................. 294

Neeb on tin in ................................. 298

Palembang, Boven Banjoe tin field................... 292

Posewitz on $\operatorname{tin}$ in $\ldots \ldots \ldots \ldots \ldots \ldots \ldots \ldots \ldots \ldots \ldots \ldots \ldots \ldots \ldots \ldots \ldots \ldots . \ldots 1$

Rolker on tin in Siak.............................. 305

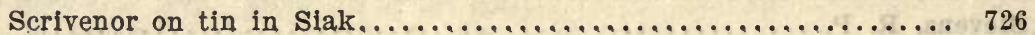

Siak, tin in ............................... 305, 726, 1320

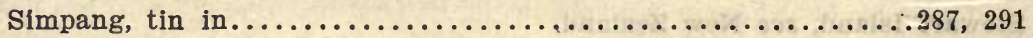

Source of tin used by ancients...................... 1405

See also East Indles.

Sungel Bâtang Pâdang, see Malay Peninsula, Perak.

Sungei Besi, see Malay Peninsula, Perak.

Sungel Bidor, see Malay Peninsula, Perak.

Sungei Kinta, see Malay Peninsula, Perak.

Sungei Lembing, see Malay Peninsula, Kuantan.

Sungei Riu, see Malay Peninsula, Jelebu.

Sungei Ujong, see Malay Peninsula, Malacca.

Suo, see Japan.

Superior segunda mine, see Spain, Carthagene.

Supply of tin (amount available for future mining):

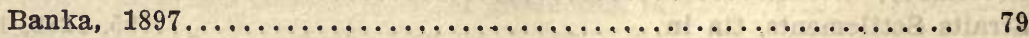

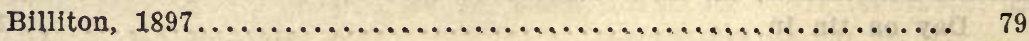

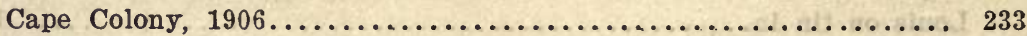

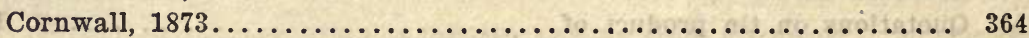

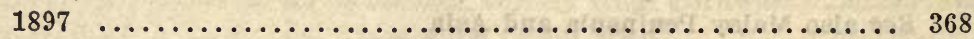

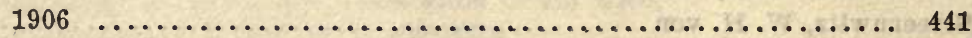

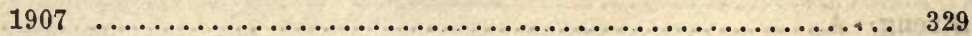

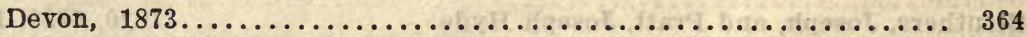

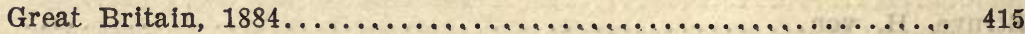

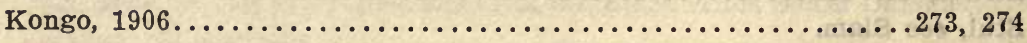

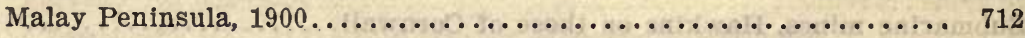

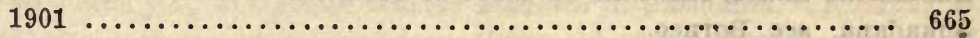


Supply of tin-Continued.

New South Wales, Inverell district, Tingja, $1906 \ldots \ldots \ldots \ldots \ldots \ldots . . \ldots 03$

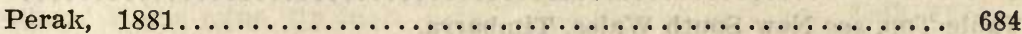

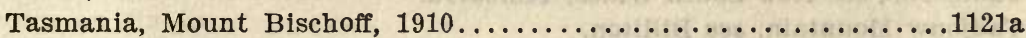

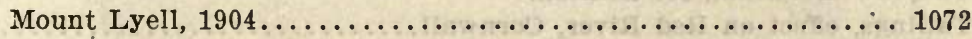

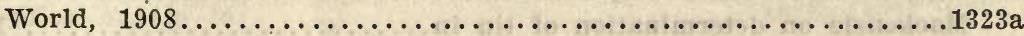

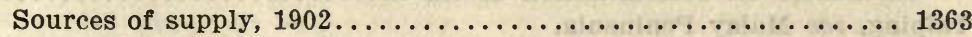

Supply and demand, $1907 \ldots \ldots \ldots \ldots \ldots \ldots \ldots \ldots \ldots \ldots \ldots . \ldots \ldots$

Sources of supply.......................... 730

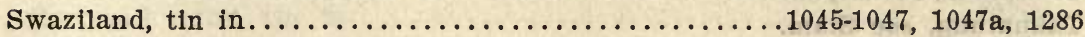

Beck on tin near Embabaan...................... 1299, 1300

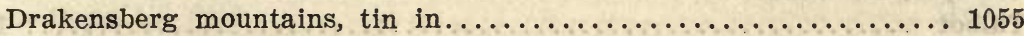

Embabaan, geology of region around.................... 3

Tin near........2a, 3, 3d, 1047, 1048, 1050, 1051, 1052, 1055, 1300

Ryan tin works.......................1046, 1052, 1056

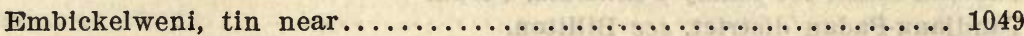

Flower-Ellis on tin fields in ....................... 694a

Forbes Reef tin deposits.......................... $3 \mathrm{~b}$

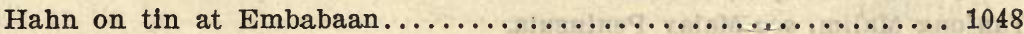

Hampton on tin near Embickelweni.................... 1049

Johnson on tin at Embabaan ......................... 2 a

Jorissen on tin near Embabaan..................... 1050

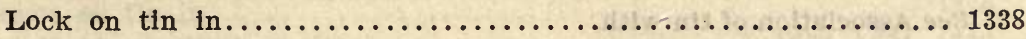

de Launay on tin at Embabaan....................... 3

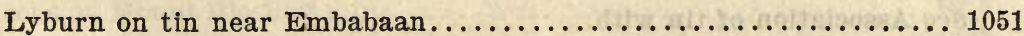

Molengraaff on distorted cassiterite crystals from Embabaan...... 1052

On geology of region around Embabaan.............. 1052

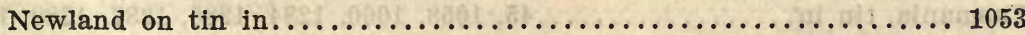

Oshoek tin deposits................................ 3 b

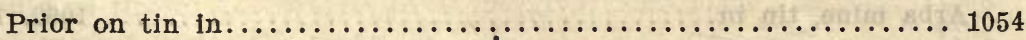

Rumbold on Oshoek and Forbes Reef tin deposits............ 3b

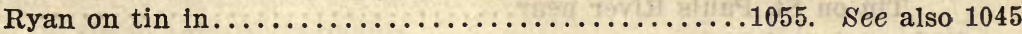

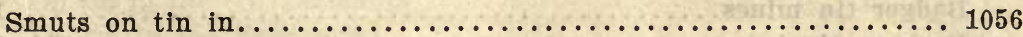

Transvaal border, tin along...................... 1186

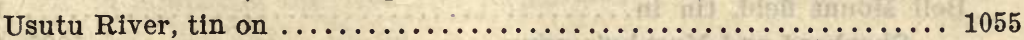

Weston on tin mining and dressing at Embabaan............ 3d

See also Africa and South Africa.

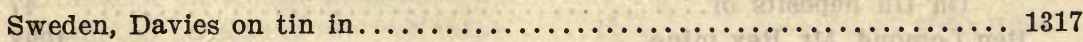

See also Europe.

Swettenham, Frank.............................. 731

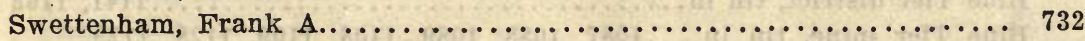

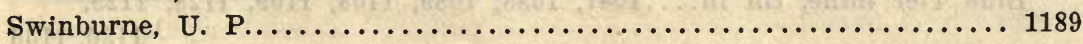

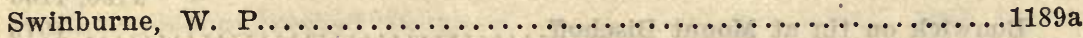

Symons, Brenton................................ 462

Symons, R.................................... 463 
Table Top, see New South Wales, Timbarra.

Tadjouw Mountain, see Billiton.

Tallings, effect on Red River, Cornwall................... 482a

Mackenzie on determination of tin in .................. 1529

Taiping, see Malay Peninsula.

Tajo-polo, see Bolivia.

Takayama, see Japan.

Takuatung, see Siam.

Takupar, see Siam.

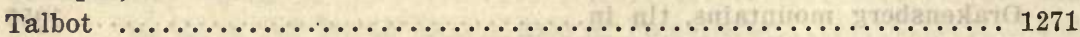

Talbott, J. H................................ 1575

Tallandoon, see Victoria.

Tambun mine, see Malay Peninsula, Perak.

Tandjang-Padan district, see Billiton.

Tangier, see Nova Scotia, Lunenberg County.

Taniyama, see Japan, Satsuma.

Tanjong Malim, see Malay Peninsula.

Tanjong Serai, see Malay Peninsula, Malacca.

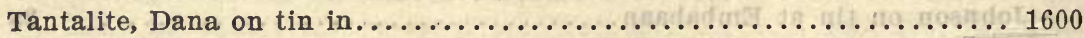

Schaeffer on analysis of, from the Black Hills, South Dakota...... 1017 See Association of tin with.

Tantalum, Hess on deposits in South Dakota.................. 1009

See Association of tin with.

Tapiolite, Headden on analysis of from Black Hills, South Dakota..... 1208 Tarcoola, see South Australia.

Tasmanta, tin in ............45, 1058, 1060, 1284, 1286, 1287, 1289, 1292

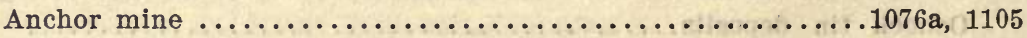

Arba mine, tin in ................................ 1138

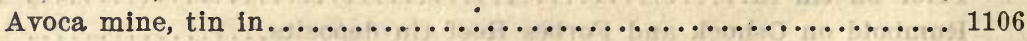

Tin on St. Pauls River near.................... 1137

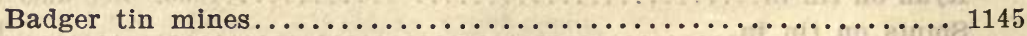

Beck on tin in ....................................... 1300

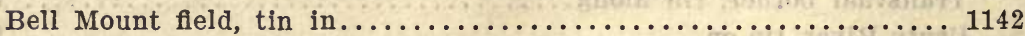

Shepherd and Murphy's mine ........................... 1148

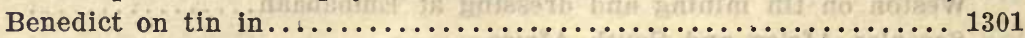

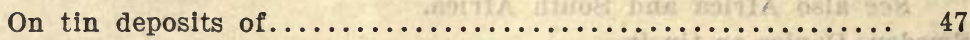

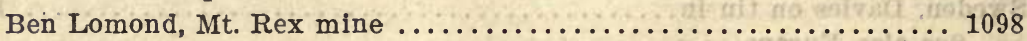

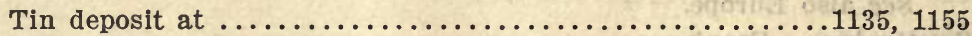

Blue Tler district, tin in.........................1141, 1162

Blue Tier mine, tin in....1087, 1088, 1089, 1108, 1109, 1128, 1129,

1130,1136

Bonwick on tin at Mount Bischoff........................ 1075

Branxholm, tin at........................1062, 1138, 1162

Briseis mine, tin in..................1062, 1064, 1106, 1125 
Tasmania-Continued.

Brookstead tin field.......................... 1091, 1106

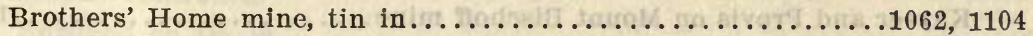

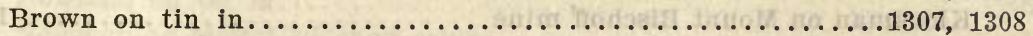

Clark on tin in .............................. 1076a

Coghlan on tin in .....................1077, 1677, 1679

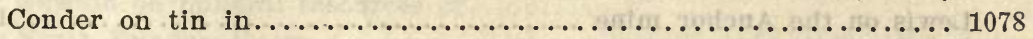

On Stanley River tin field.............................

On tin in the Oonah mine (Zeehan) and at Heemskirk...... 816

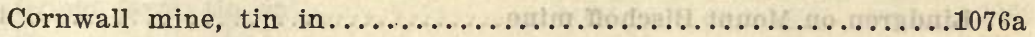

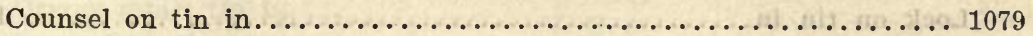

Coxs Bight tin field .............................. 1147

Cummings mine ................................. 1059

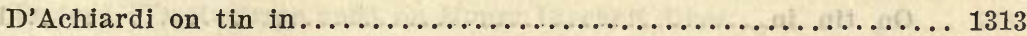

Davey on Mount Bischoff tin mines........................ 1080

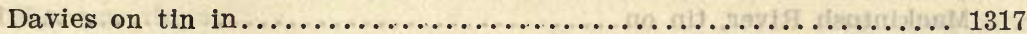

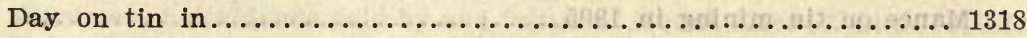

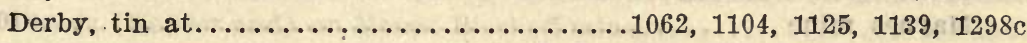

Dijk on tin in.................................. 1082

Dorset County, tin in ............................... 1141

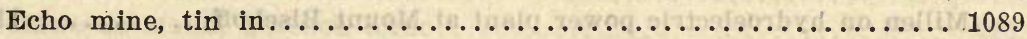

English on tin at Mount Bischoff...................... 50

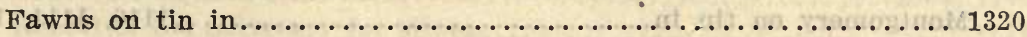

On Mount Bischoff mine...................1083, 1084, 1320

Fircks on Mount Bischoff mine....................... 1085

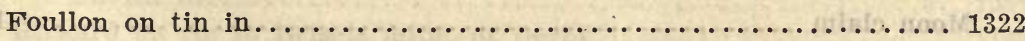

Georges Bay tin field............................. 1162

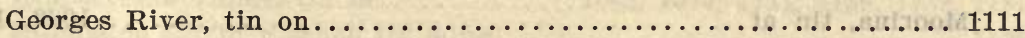

Gladstone district, tin in ....................1106, 1130, 1143

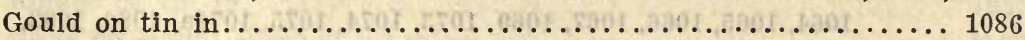

Government geologist's report on ...................... 1134

Grant on the Brookstead tin field...................... 1091

On tin in eastern Tasmania ....................... 1090

On tin in the Echo mine........................ 1089

On tin mining in the Blue Tier formations........1087, 1088, 1089

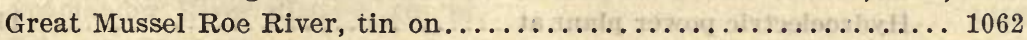

Gregory on the Mount Bischoff and other mines............... 1092

Groddeck on Mount Bischoff mine......................... 1093

Hampton on Mount Bischoff mine...................1049, 1094

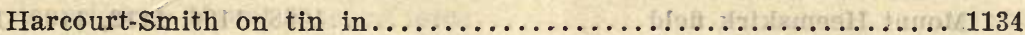

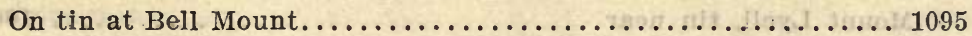

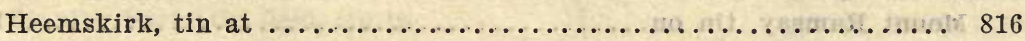

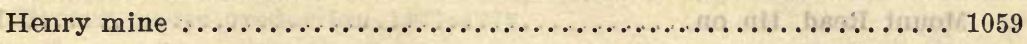

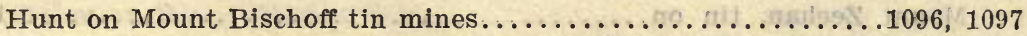

Ireland on timbering at Ben Lomond..................... 1098

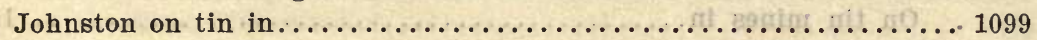


Tasmania-Continued.

Reference Number

Kayser on the Mount Bischoff mine..............1100, 1101, 1152

Kayser and Provis on Mount Bischoff mine............... 1102

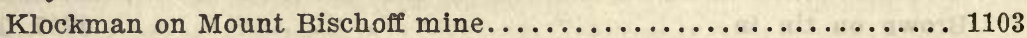

Latta on smelting of tin ore at Mount Bischoff, Launceston........ 1517

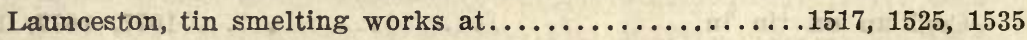

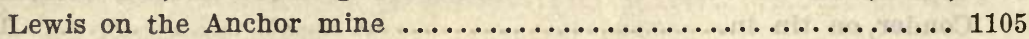

On Brothers' Home Mining Company at Derby............ 1104

On the Gladstone district and other mines............. 1106

Lindgren on Mount Bischoff mine...................... 1337

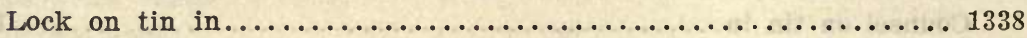

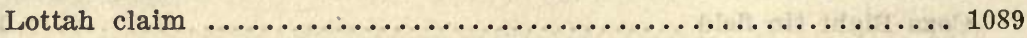

Louis on smelting of tin at Mount Bischoff, Launceston.......... 1525

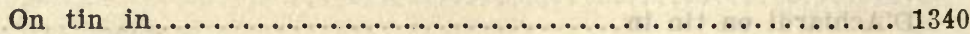

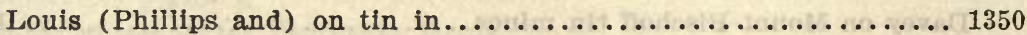

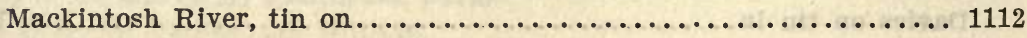

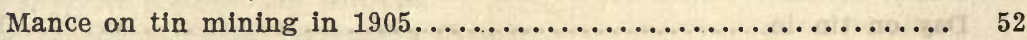

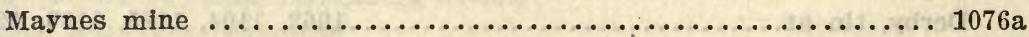

Meredith on tin from Mount Bischoff................... 1107

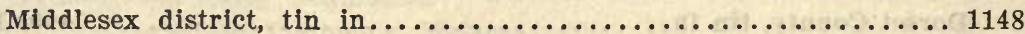

Millen on hydroelectric power plant at Mount Bischoff...........1107a

On smelting of tin at Mount Bischoff, Launceston.......... 1535

Montgomery on tin in.....................1110, 1111, 1113

On Blue Tier tin fleld.......................... 1109

On mineral flelds near Zeehan................... 1112

Moon claim ................................... 1089

Moore on tin in killas of St. Pauls Plains.................. 1114

Moorina, tin at............................... 1130

Mount Bischoff mine..50, 63, 730, 1049, 1057, 1059, 1061, 1062, 1063, $1064,1065,1066,1067,1069,1073,1074,1075,1076 \mathrm{a}, 1080,1083$, $1084,1085,1092,1093,1094,1096,1097,1100,1101,1102,1103$, $1106,1107,1110,1113,1115,1117,1122,1123,1126,1127,1128$, $1129,1130,1131,1133,1140,1149,1150,1151,1152,1159$,

$1160,1162,1163,1298 \mathrm{c}, 1320,1337,1517,1525,1535$

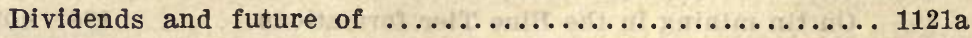

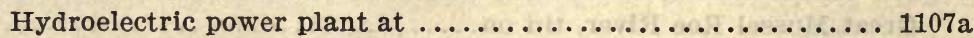

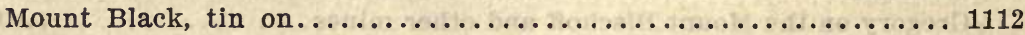

Mount Cameron, tin at.......................... 1062

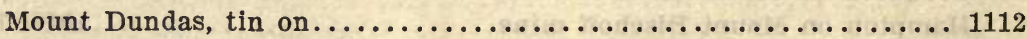

Mount Heemskirk field..............1068, 1106, 1112, 1130, 1156

Mount Lyell, tin near ............................. 1072

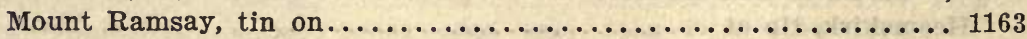

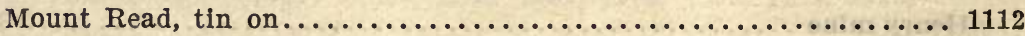

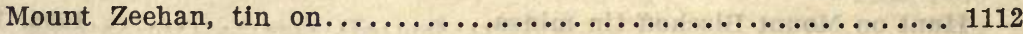

Mufford on Mount Bischoff mine...................... 1115

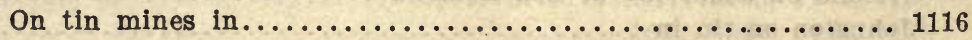


Tasmania-Continued.

Newland on tin in ................................ 1346

Newman on Mount Bischoff mine....................... 1117

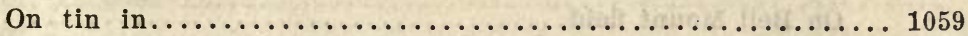

Newton on mineral resources of ..................... 55

North Dundas, tin in..................1064, 1071, 1157, 1158a

Oonah mine $($ Zeehan), tin in........................... 816

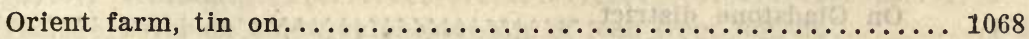

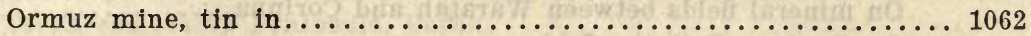

Petterd on tin in..........................1118, 1120, 1121

On tin in Silver Queen mine, at Zeehan............... 1119

Petterd (Twelvetrees and) on Mount Bischoff dikes............. 1149

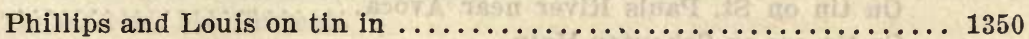

Pioneer, tin at............................... 1062, 1106

Plummer on dividends paid by and future of Mount Bischoff mine...1121a

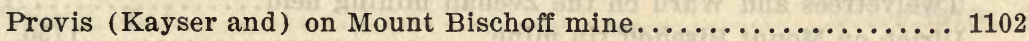

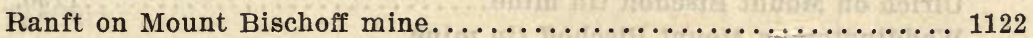

Rath on Mount Bischoff mine...................... 1123

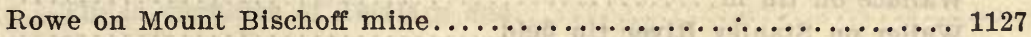

Renison Bell mine, tin in............................ 1146

Report of the Secretary for Mines.................... 1124

Reyer on stream tin from.......................... 1411

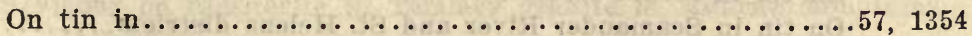

Rickard on tin in Briseis mine, at Derby................ 1125

Ringarooma Valley, tin in...........1062, 1074, 1111, 1129, 1139, 1162

Ritchie on Mount Bischoff tin mine.................... 1126

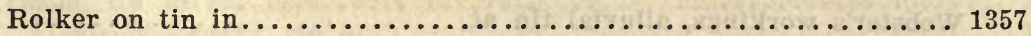

Rowe on Mount Bischoff tin mine...................... 1127

St. Helens district, tin in .........................1153, 1154

St. Pauls Plains, tin in klllas of ..................... 1114

St. Pauls River tin deposit.......................1135, 1137

Sandeman on Mount Bischoff mine and Blue Tier district........ 1128

Scamander River district, tin in..................... 1153

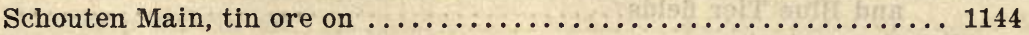

Shaw on Mount Bischoff, Blue Tier, Ringarooma, Gladstone, etc., tin

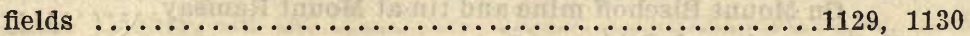

Snowden on Mount Bischoff mine.................... 1131

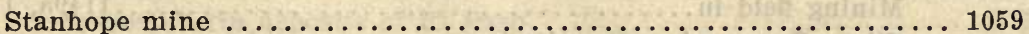

Stanley River tin field, tin in.................1078a, 1112, 1158

Stephen on tin production, $1877-1878 \ldots \ldots \ldots \ldots \ldots \ldots \ldots \ldots \ldots \ldots$

Stokes on Mount Bischoff mine..............729, 730, 1132, 1133

Thureau on Ben Lomond and St. Pauls River tin deposits........ 1135

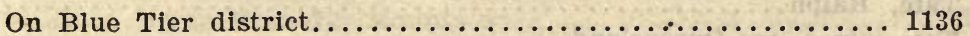

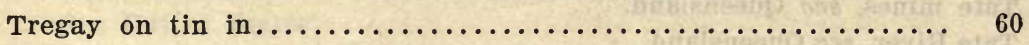


Tasmania-Continued.

Reference

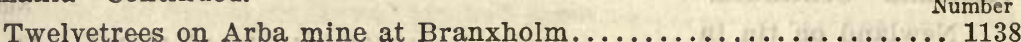

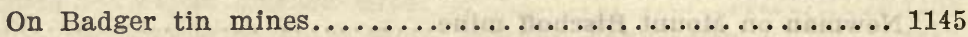

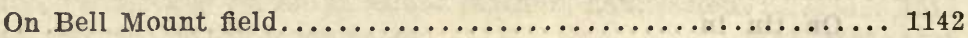

On Bell Mount, Middlesex district ................. 1148

On Blue Tier district......................... 1141

On Coxs Bight tin field........................... 1147

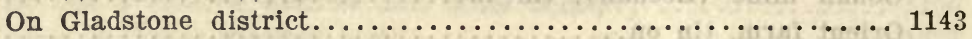

On mineral fields between Waratah and Corinna.......... 1140

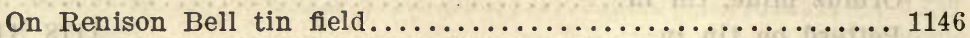

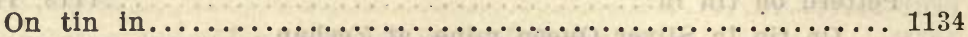

On tin in Ringarooma Valley near Derby............... 1139

On tin on St. Pauls River near Avoca............... 1137

On tin ore on Schouten Main..................... 1144

Twelvetrees and Petterd on Mount Bischoff dikes.............. 1149

Twelvetrees and Ward on the Zeehan mining field..............1149a

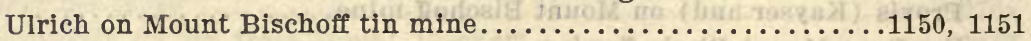

Waddington on Mount Bischoff tin mine.................... 1152

Wallace on tin in.................................. 1134

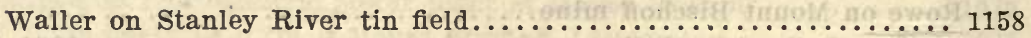

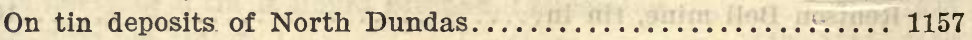

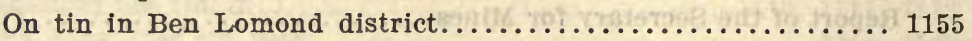

On tin in Mount Heemskirk district................ 1156

On tin in Scamander River and St. Helens districts......... 1153

On tin in St. Helens district........................ 1154

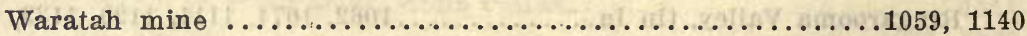

Ward on North Dundas tin field.........................1158a

Webster's workings, alluvial tin at.................... 1140

Wellington on Mount Bischoff mine.................... 1159

White River Bridge, alluvial tin at Ten Mile claim............ 1140

Wickham on Mount Bischoff mine.................. 1160

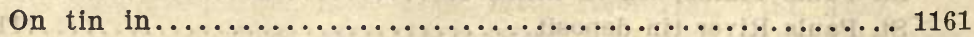

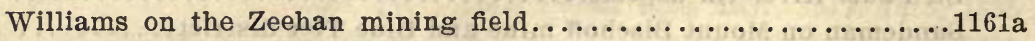

Wilson on Mount Bischoff, Ringarooma, Branxholm, Georges Bay,

and Blue Tier fields.......................... 1162

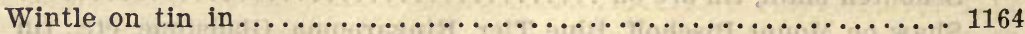

On Mount Bischoff mine and tin at Mount Ramsay........... 1163

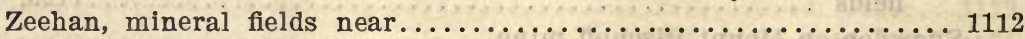

Mining field in ................................. 1141a

Silver Queen mine, stannite in.................... 1119

See also Australia.

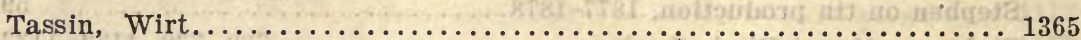

Tatasi, see Bolivia.

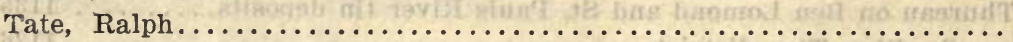

Tate mines, see Queensland.

Tate River, see Queensland.

Tavoy, see Burmah. 
Taxco, see Mexico, Guerrero.

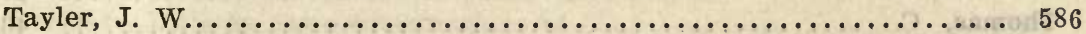

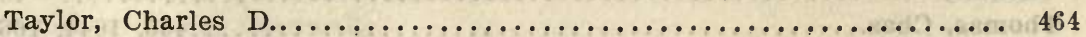

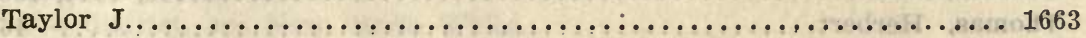

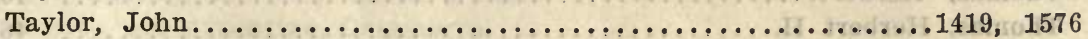

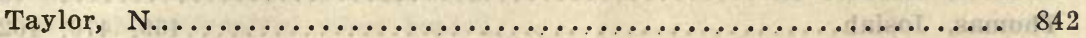

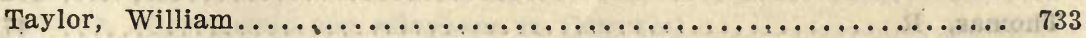

Teallite, Prior on a new sulphostannite of lead from Bolivia........ 1636 Tecca, see Malay Peninsula, Perak.

Telkin

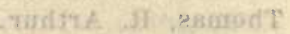

Telom, see Malay Peninsula.

Temescal district, see California.

Tenasserim, see Burmah.

Tenison-Woods, J. E..................307, 734, 735, 736, 737, 863 Teplitz, see Bohemia.

Terrell, S. L.............................................. 1664

Tertiary:

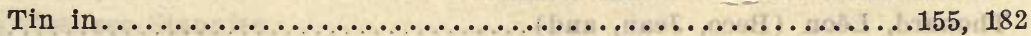

Tin in rhyolites of Tertiary age...................... 751

Tin with galena and pyrite in Tertiary tuffs............... 629

Gascuel on tin in rocks of Tertiary age in Laos............... 643

Lotti on tin deposits in Tertiary intrusives in Tuscany.......... 627

Seymour on cassiterite in Tertiary granite in Mourne Mountains,

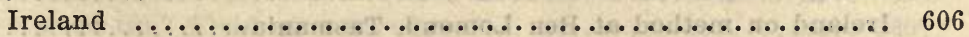

Terubias, see Spain, Salamanca.

Teschemacher, J. E............................... 750

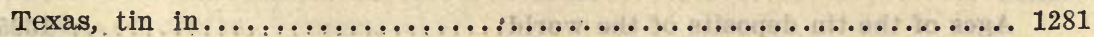

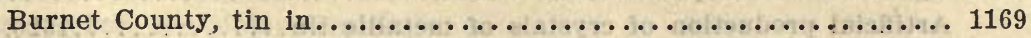

Chauvenet on tin in the Franklin Mountains.................1164a

Comstock on tin in central...............1165, 1166, 1167, 1168

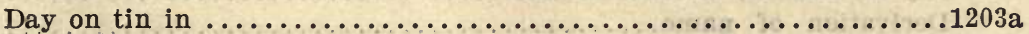

Dumble on tin in Trans-Pecos........................ 1169

El Paso tin deposits.........................1170, 1172, 1216

Franklin Mountains, tin in..............1164a, 1169a, 1170, 1172

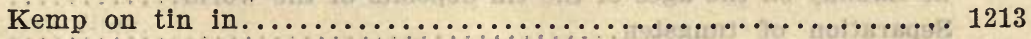

Lakes on tin prospect in Franklin Mountains..............1169a

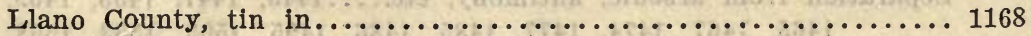

Mason County, tin in................................... 1169

Pavlov on tin deposits of El Paso...................... 1216

Richardson on tin in the Franklin Mountains.............. 1170

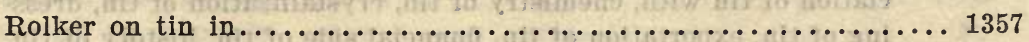

Streeruwitz on tin in West Texas ores.................. 1171

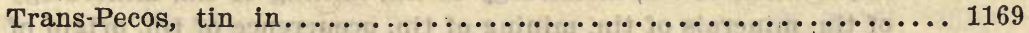

Weed on tin in Franklin Mountains.................... 1172

See United States.

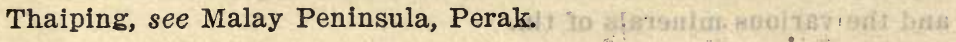




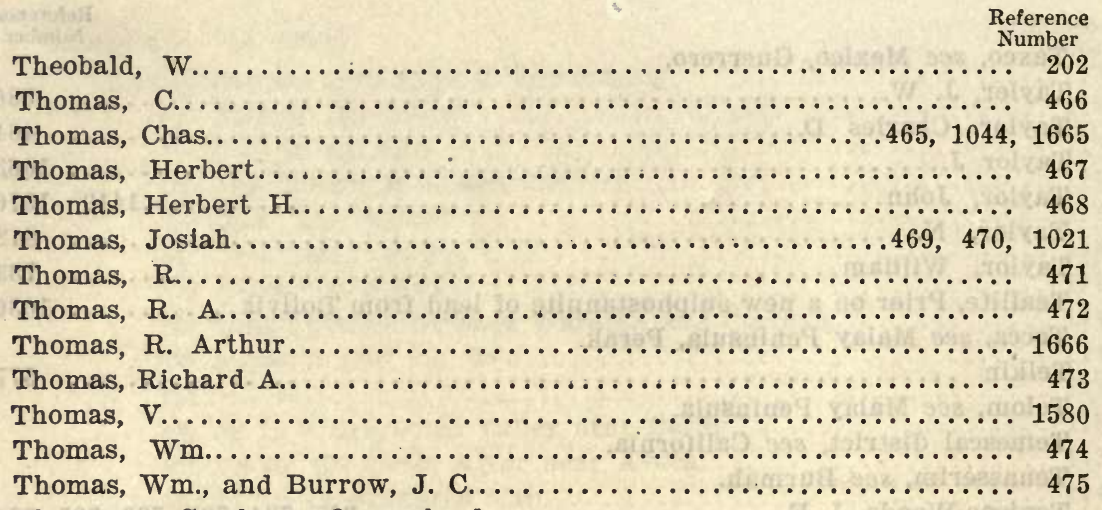

Thompsons Creek, see Queensland.

Thibault, P. J....................... 843, 844, 1577, 1578, 1644

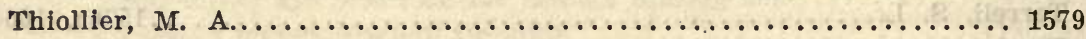

Thistle mine, see New South Wales.

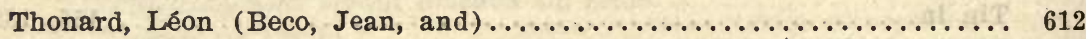

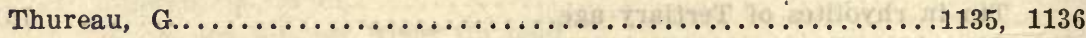

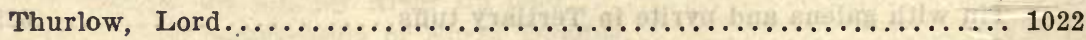

Tilde area, see Nigeria.

Timbarra, see New South Wales.

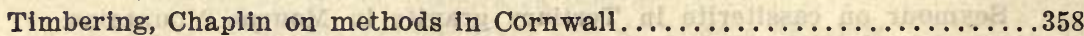

Ireland on method at Ben Lomond, Tasmania............... 1098 Tin:

See also Mining of tin.

Ages of the tin deposits of the world................... 1625

Artificial production of crystals of metallic tin............1626, 1645

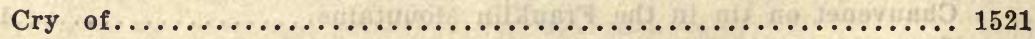

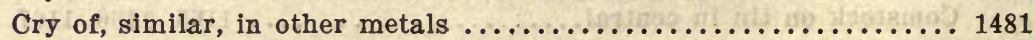

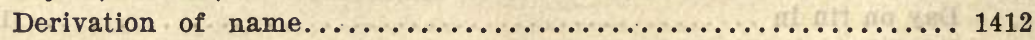

Dimorphous form produced in manufacture of metallic tin crystals.. 1645

Effect of intense cold on ........................... 1492

de Launay on the ages of the tin deposits of the world.......... 1625

Separation of tungsten...................................... 1575

Separation from arsenic, antimony, etc.....1445, 1447, 1455, 1459, $1465,1467,1474,1477,1485,1486,1495,1503,1553,1558$, $1559,1572,1585$

See alloys of tin, analyses of tin, assaying of tin, assays of tin, association of tin with, chemistry of tin, crystallization of tin, dressing of tin, exportation of tin, financial side of tin, history of tin, importation of tin, metallurgy of tin, milling of tin, mineralogy of tin, minerals of tin, mining of tin, occurrence of tin, origin of tin, production of tin, refining of tin, scrap tin, smelting of tin, supply of tin (amount available for future mining), uses of tin, and the various minerals of tin. 
Tinaroo, see Walsh and Tinaroo, under Queensland.

Tincroft mine, see Cornwall.

Tingha district, see New South Wales.

Tinogasta, see Argentina, Catamarca.

Tin ore, phosphorescent when heated...................... 935

Tin oxide, after quartz and allophane in Cornwall.............. 1629

Daubrée on artificial production of . . . . . . . . . . . . . . . 1316

Deville on artificial production of.............................. 1604

Tin plate:

See also "Tin bioxide."

Allan on production of " moire metallique" on..................1429

Flower on history of origin and process of tin plate trade........ 1390

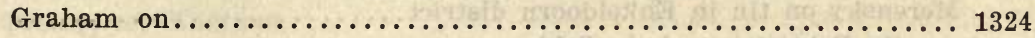

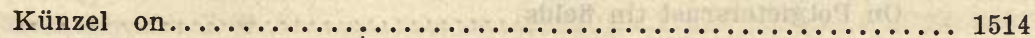

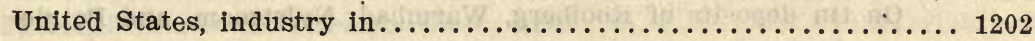

See Scrap tin.

Tin pyrites, see Stannite.

Tinton, see South Dakota, Black Hills.

Titanite, see Association of tin with.

Titanium, Daubrée on artificial production of ................ 1601

See Association of tin with.

Toad's eye tin................................... 356

"Toad's eye wood tin," Field on a variety of................... 1607

Toboali district, see Banka.

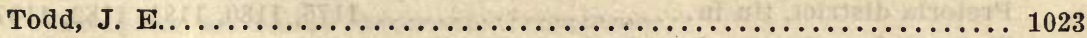

Tomuko, see China, Yunnan.

Tongka Harbor, see Malay Peninsula.

Tonkin, Lacroix on tin in ........................... 516

Topaz, see Association of tin with.

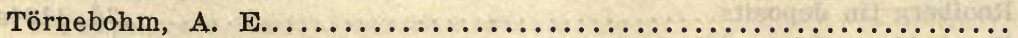

Totoral mine, see Bolivia.

Tourmaline, MacAlister on origin of tin and................. 1341

See Association of tin with.

Trang, see Siam.

Transbaikal region, see Siberia.

Trans-Pecos, see Texas.

Transvaal, tin in

Black Umbelosi River, tin on watershed of.............. 1186

Bushveld near Pretoria, tin in the.........1175, 1180, 1181, 1182, 1186

Bushveld tin deposits ........................... 3 b

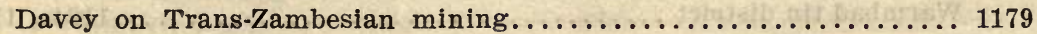

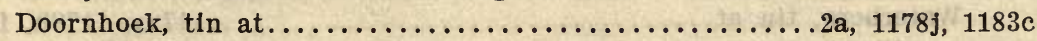

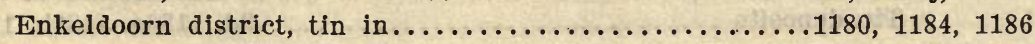

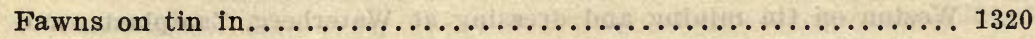


Transvaal-Continued.

Reference Number

Griffith on the Bushveld properties ................... 1180

Groenviei tin fields.........................1178f, 1183a

Groenfontein tin plant.......................... 1178b

Hali on tin near Pretoria and Vlaklaagte...............1181, 1182

Johnson on tin near Potgietersrust.................... 1183

On the Rooiberg, Weynek, Dornhoek, and Potgietersrust tin

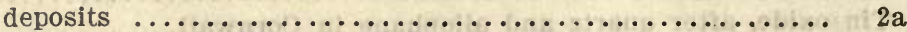

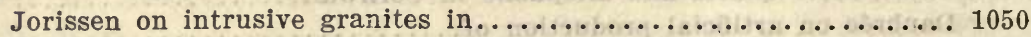

Kynaston on tin deposits of Zaaiplaats in the Waterberg district...1183b

Lawn on the Doornhoek mine.......................1183c

Little Usutu River, tin on watershed of .................. 1186

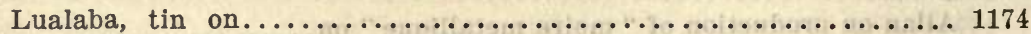

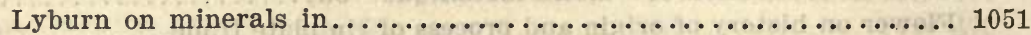

Merensky on tin in Enkeldoorn district................ 1184

On Potgietersrust tin fields.................... 1185

On tin deposits of Rooiberg, Warmbad, Nylstroom, and Potgie-

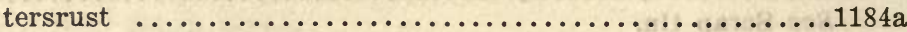

Mills-Davies on tin deposits of ............................

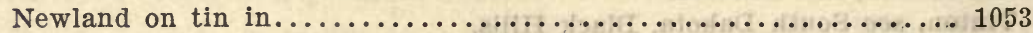

Nylstroom, tin mining at........................... 1184a

Occurrence in various districts of . . . . . . . . . . . . . . . . $1178 \mathrm{~d}$

Potgietersrust, tin near....................1183, 1185, 1189

Tin district..................

Praagh on tin along Transvaal-Swaziland border and in Vlaklaagte

and Enkeldoorn districts..................... 1186

Pretoria district, tin in $\ldots \ldots \ldots \ldots \ldots \ldots \ldots \ldots 1175,1180,1181,1182,1187$

Recknagel on the two deposits in the Rooiberg district..........1186a

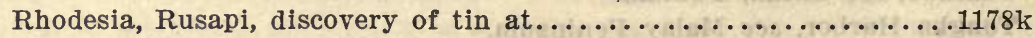

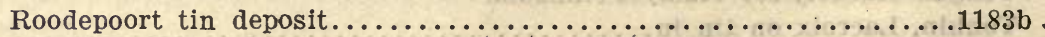

Rooiberg, tin at............... 1178g, 1178i, 1178j, 1185a, 1186a

Rooiberg tin deposits............................ 1184a

Rumbold on Bushveld tin deposits.................. 3 b

Simmersbach on tin in Pretoria district................. 1187

Stewart on tin on the Great Letaba River, Zoutpansberg........ 1188

Steynsdorp Creek, tin on watershed of.................. 1186

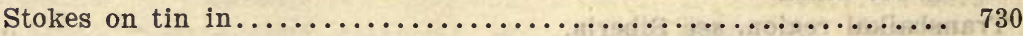

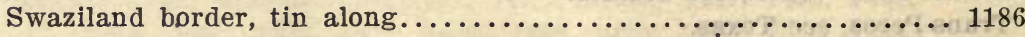

Swinburne on tin at Zaaiplaats near Potgietersrust........... 1189

On Waterberg tin field................................

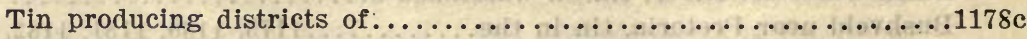

Vlaklaagte, tin mine at.................1178, 1181, 1182, 1186

Warmbad tin district .............................. 1184a, 1185a

Waterberg, tin at............................. 1178h, $1178 \mathrm{i}$

Tin deposits ...................... 1183a, 1183b, 1189a

Weston on tin mining and dressing at Waterberg, Zaaiplaats, and

Rooiberg 
Transvaal-Continued.

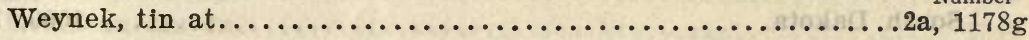

Zaaiplaats tin deposits................ 1178e, 1178h, 1183a, 1183b

Zoutpansberg, tin on the Great Letaba River in.............. 1188

Zwartkloof tin deposit............................ $3 \mathrm{~d}$

See also Africa, Pretoria, and South Africa.

Tras, see Malay Peninsula, Telom.

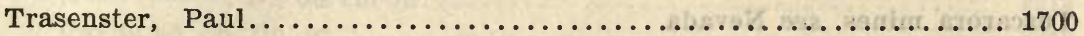

Tras os Montes, see Portugal.

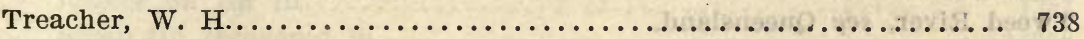

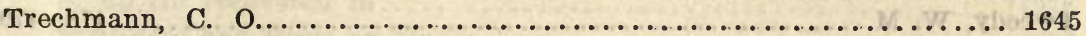

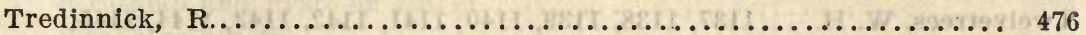

Tregaskis, James................................. 477

Tregay, w...................................60, 1667

Treloy, see England.

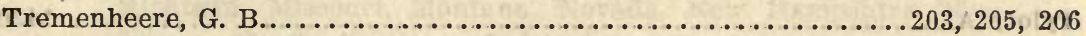

Tremenheere, G. B. (Lemon, Chas., and) .................... 196

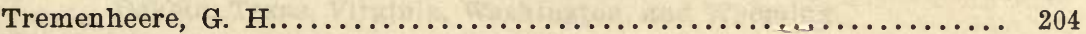

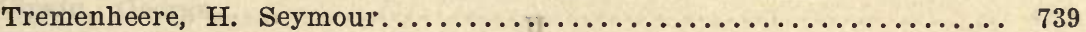

Tremolite, see Association of tin with.

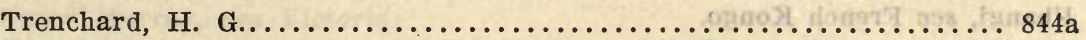

Trengganu, see Malay Peninsula, Tringganu. Trereife, see Cornwall.

Tres Cruces, see Bolivia.

Trethellen tin works, see Cornwall.

Triassic, tin in veins in limestones of the.................. 268 Tringanu, see Malay Peninsula, Tringganu. Tringganu, see Malay Peninsula.

Triphyllite, see Association of tin with.

Tripolite, see Association of tin with.

Trojan war, Plinius on estimation of "white lead" during........... 1408

Tronoh, see Malay Peninsula, Perak.

Truro, see Cornwall.

Trüstedt, Otto

Tsementong, see China, Yunnan.

Tungstate of manganese and iron, see Association of tin with wolframite. Tungsten:

Associated with tin, see Association of tin with.

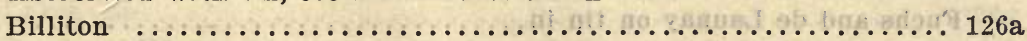

Delvaux de Fenffe on use in iron and steel............... 1476

Fairibault on occurrence of, with tin in Nova Scotia............ 227

Hess on deposits of, with tin in South Dakota................ 1009

Menniche on separation of, from tin ores.................... 1534

Nova Scotia................................... 227

Sadtler on deposits of, with tin in the Black Hills, South Dakota.... 1016

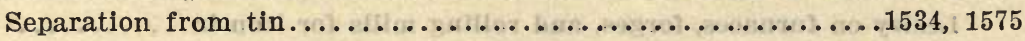


Tungsten-Continued.

South Dakota.

Tasmania .......................................... 1148

Twelvetrees on deposits in tin bearing region, Tasmania........ 1148

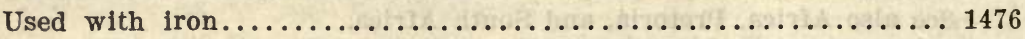

Tuscany, see Italy.

Tuscarora mines, see Nevada.

Tupiza, see Bolivia.

Tweed River, see Queensland.

Tweedy, W. M....................................... 479

Twelvetrees, W. H....1137, 1138, 1139, 1140, 1141, 1142, 1143, 1144, 1145,

$1146,1147,1148,1148 \mathrm{a}$

Twelvetrees, W. H., and Petterd, W. F....................... 1149

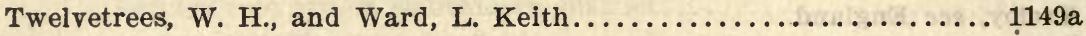

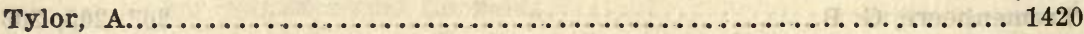

Tyre, tin a current commodity of commerce in............... 1380

\section{U}

Ubangi, see French Kongo.

Uelle, see French Kongo, Welle.

Ulke, Titus.................... 1024, 1245, 1646. See also 1616

Ulrich, G. H. F.............................. 1150, 1151

Uncia vein, see Bolivia.

United Kingdom, see Great Britain, England, etc.

United States, tin in....1190, 1191, 1192, 1193, 1194, 1195, 1196, 1197,

$1198,1199,1298 \mathrm{~b}$

Beck on tin in ................................. 1299, 1300

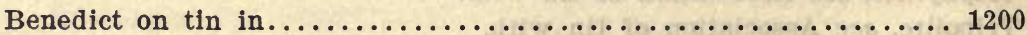

Blake on tin in ..................................... 1202

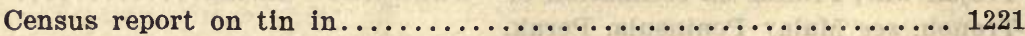

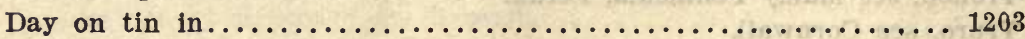

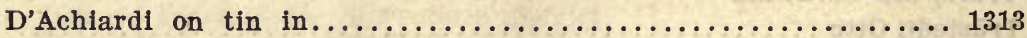

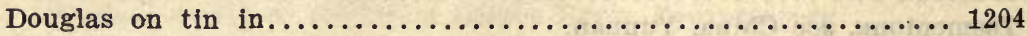

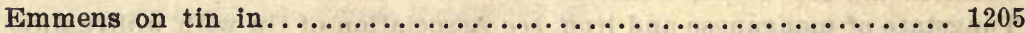

Emmons on geological distribution of tin in............... 1206

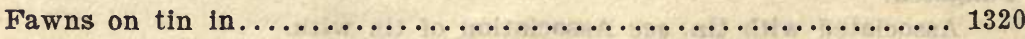

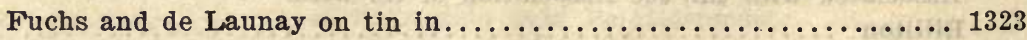

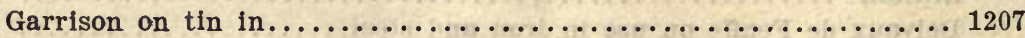

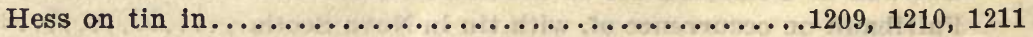

Importation of tin from Bolivia discussed ............... 139

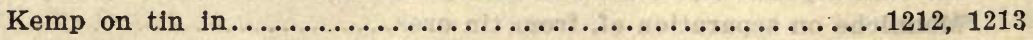

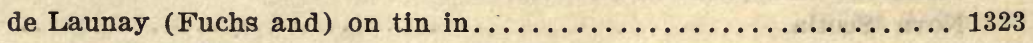

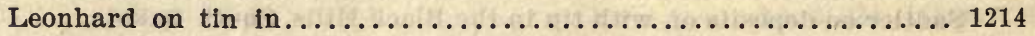

Lesley on furnaces, forges, and rolling mills for iron in......... 793 
United States-Continued.

Lock on tin in . . . . . . . . . . . . . . . . . . . . . 1338

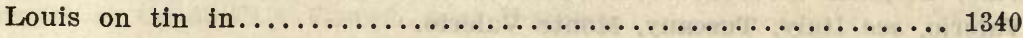

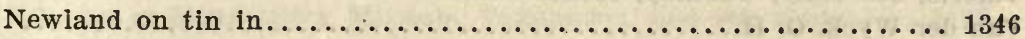

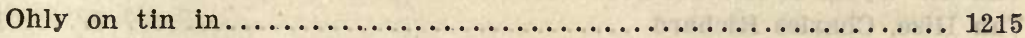

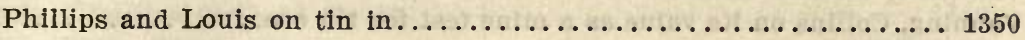

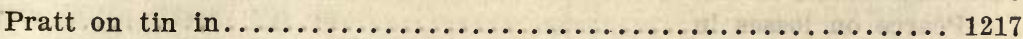

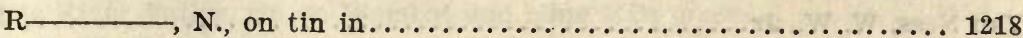

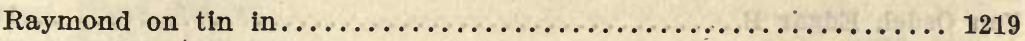

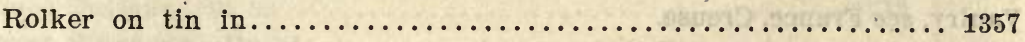

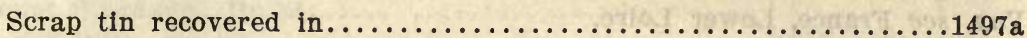

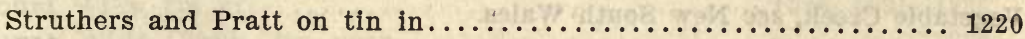

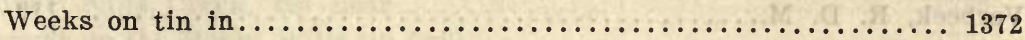

Whitney on statistics of mineral production of ............. 1701

See also Alabama, California, Colorado, Idaho, Maine, Massachusetts,

Michigan, Missouri, Montana, Nevada, New Hampshire, New Jersey, North Carolina, Philippines, South Carolina, South Dakota, Texas, Virginia, Washington, and Wyoming.

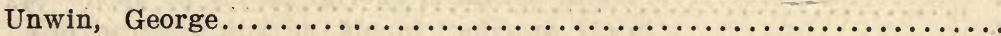

Upper Graupen, see Bohemia.

Upper Murray, see Victoria.

Upper Yarra, see Victoria.

Urais, see Russia.

Uralsk, see Asia.

Uranium, de Launay on occurrence with tin in France.

See Association of tin with.

Uranium phosphate, see Association of tin with.

Ure's Dictionary................................. 1366

Uses of tin:

Appleton on earliest American coin................... 1374

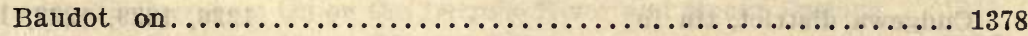

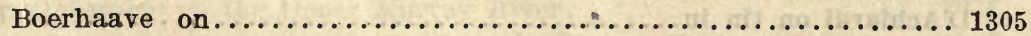

Coating inside of copper utensils in India............... 588

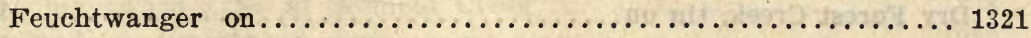

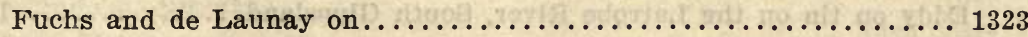

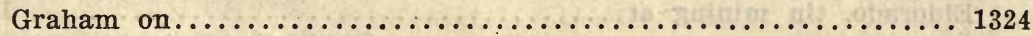

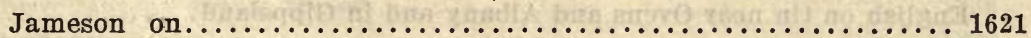

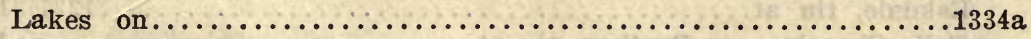

Perak, native uses............................ 747

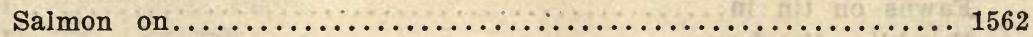

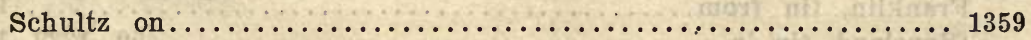

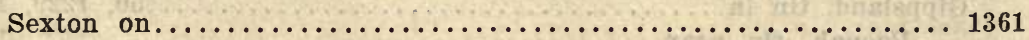

Ussher, W. A. E., and MacAlister, D. A.................... 481

Uwet district, see Nigeria. 
Vale, Stephen S............................... 61

Valerio, see Italy, Tuscany, Monte Valerio.

Van der Wyck, O. H............................... 118

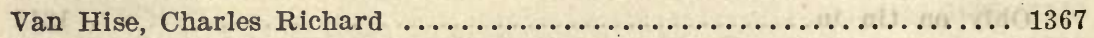

Vanning, Collins on its value as a mine test for tin ore........... 1469

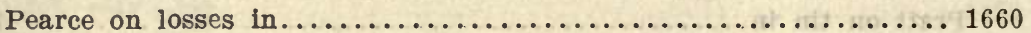

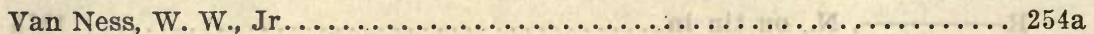

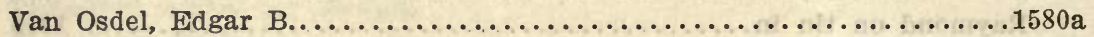

Vauiry, see France, Creuse.

Vay, see France, Lower Loire.

Vegetable Creek, see New South Wales.

Verbeek, R. D. M..................................... 136

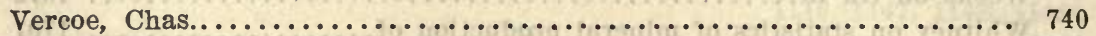

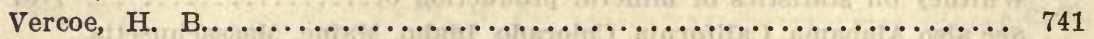

Vesuvianite, see Association of tin with.

Vesuvius, see Virginia.

Veta Estaño, see Bolivia.

Viator

Victoria:

Albany, stream tin near............................ 50

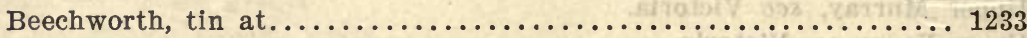

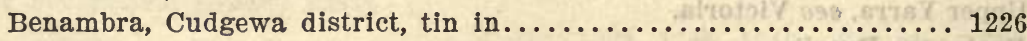

Benedict on tin deposits of ........................... 1301

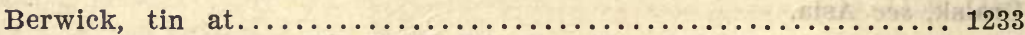

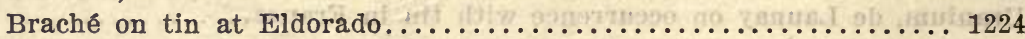

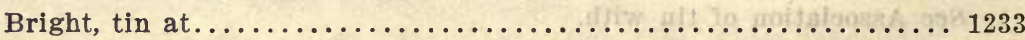

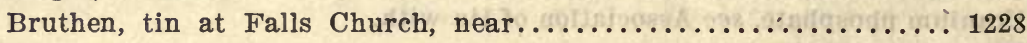

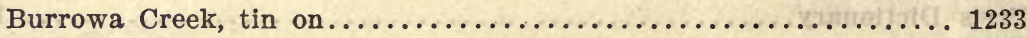

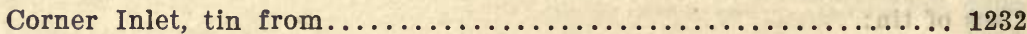

Coghlan on tin in .................................... 1679

Cudgewa district, tin in.................1226, 1229, 1233, 1237

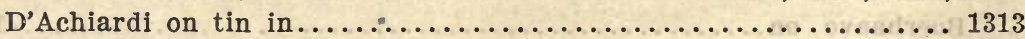

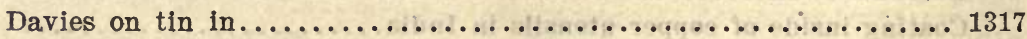

Dry Forest Creek, tin on.......................... 1233

Eddy on tin on the Latrobe River, South Gippsland........... 1225

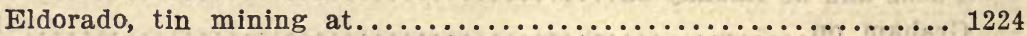

English on tin near Ovens and Albany and in Gippsland......... 50

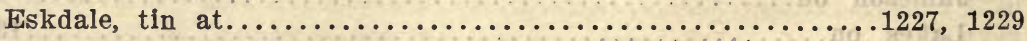

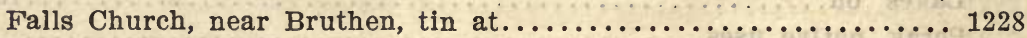

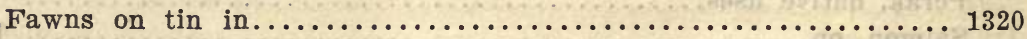

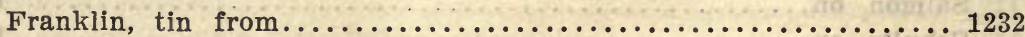

Gippsland, tin in.............................. 1229, 1237

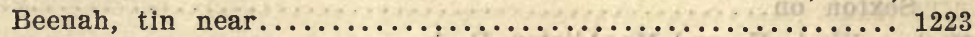

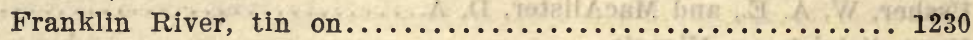

Latrobe River, tin on ...................1225, 1233, 1235

Mount Singapore on Wilsons Promontory............. 1229 
Victoria-Continued.

Gregory on the Mount Cudgewa tin.................... 1226

Herman on tin at Falls Church, near Bruthen.............. 1228

On tin at Mitta Mitta, Eskdale, Tallandoon, and Mt. Elmo.... 1227

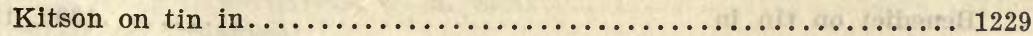

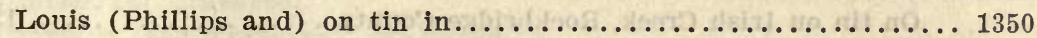

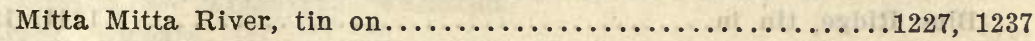

Mitta River Valley, tin on Wombat and Nine Mile creeks......... 1238

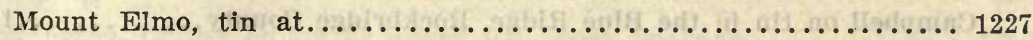

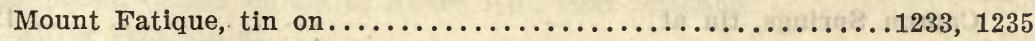

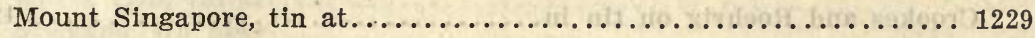

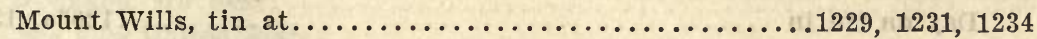

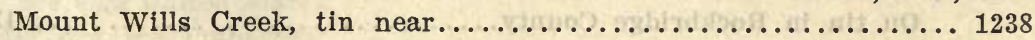

Murray on the Mount Wills tin field................... 1231

On tin in southwest Gippsland.................. 1230

Murray, see Upper Murray.

Newbery on tin from Franklin, Corner Inlet, and Upper Murray.... 1232

Newton on metalliferous minerals of .................... 55

Nicholas on tin at various localities in................... 1233

Northeastern district, Mount Cudgewa, tin at.............. 1229

Eskdale, tin in......................1227, 1229, 1231, 1234

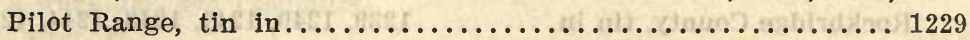

Mount Wills, tin at ..................1229, 1231, 1234

See also Mount Wills Creek.

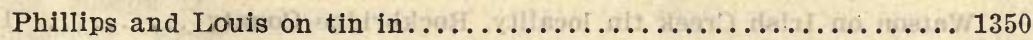

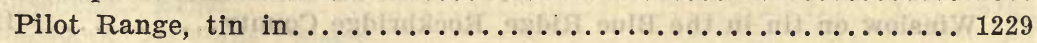

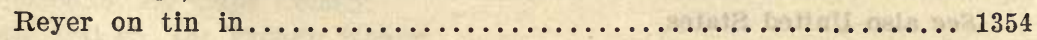

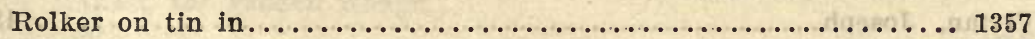

Rosales on the Mount Wills tin field..................... 1234

Sebastopol, discovery of tin at...................... 43

Secretary for Mines and Water Supply, Annual Reports 1899 to date.. 1222

Skene and Smyth on tin on the Latrobe River and Mount Fatique... 1235

Smyth on tin on the Upper Murray River................. 1236

Smyth (Skene and) on tin on the Latrobe River and Mount Fatique.. 1235

Stirling on tin lodes at Wombat Creek................... 1238

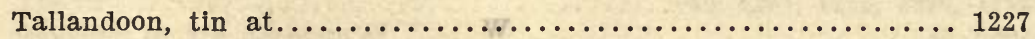

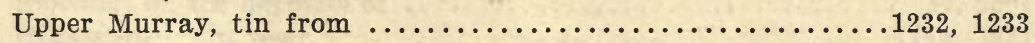

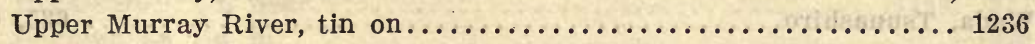

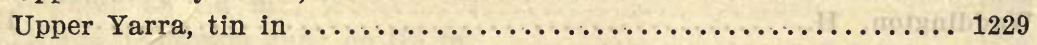

Wombat Creek, tin lodes at........................ 1238

Yarra, see Upper Yarra.

See also Australia.

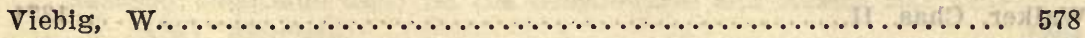

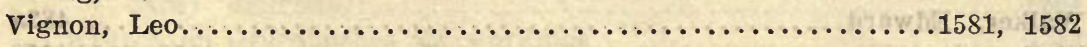

Villeder, see France, Morbihan.

Vilque Chico, see Peru. 
Vilque district, see Peru, Puno.

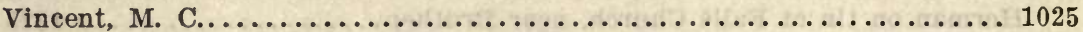

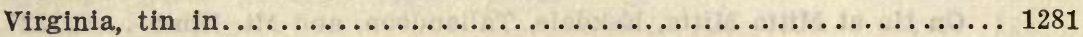

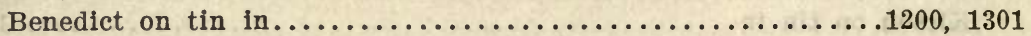

On tin on Irish Creek, Rockbridge County ............. 1239

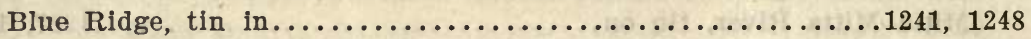

Brown on tin on Irish Creek, Rockbridge County............. 1240

Campbell on tin in the Blue Ridge, Rockbridge County......... 1241

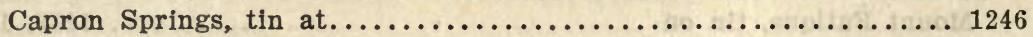

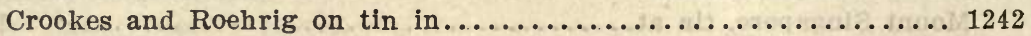

Day on tin in ......................................... 1319

On tin in Rockbridge County................... 1318

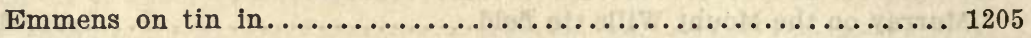

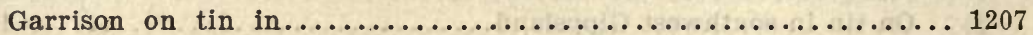

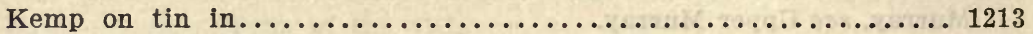

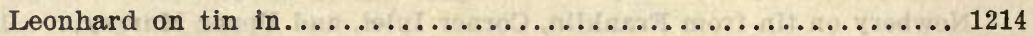

McCreath and Platt on tin in Rockbridge County............. 1243

Nelson County, tin at Nellys Ford................... 1246

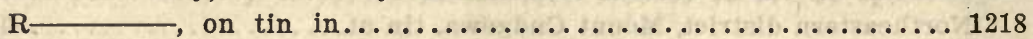

Robertson on tin on Irish Creek, Rockbridge County........... 1244

Rockbridge County, tin in ........1239, 1240, 1241, 1243, 1244, 1248, 1318

Ulke on Cash mine, near Vesuvius..................... 254, 1245

Vesuvius, Cash mine near.................254, 1245, 1246, 1248

Watson on Irish Creek tin locality, Rockbridge County......... 1246

Winslow on tin in the Blue Ridge, Rockbridge County.......... 1248 See also United States.

Vivian, Joseph................................... 481a

Vlaanderen, C. L..................................... 1647

Vlaklaagte, see Transvaal.

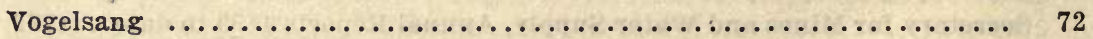

Vogt, J. H. L......................... 1368, 1369, 1370, 1648

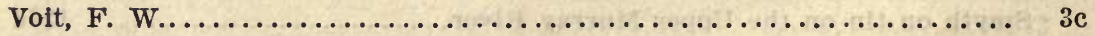

Vulcan mine, see Queensland, Herberton district.

Wada, Tsunashiro............................... 635,636

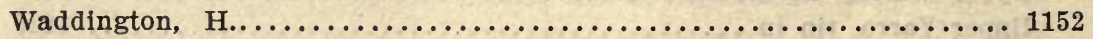

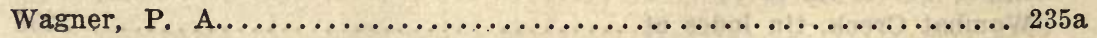

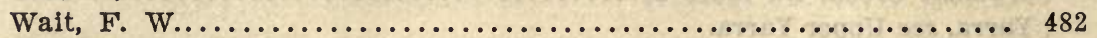

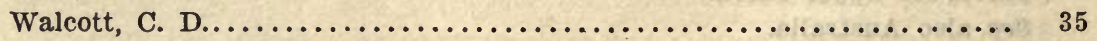

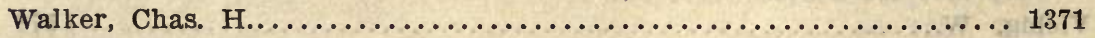

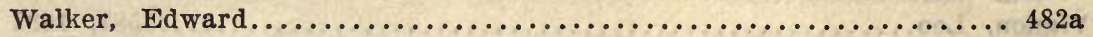

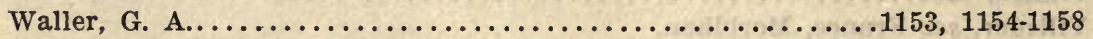

Walsh and Tinaroo field, see Queensland. 
Reference
Number

Waratah, see Tasmania.

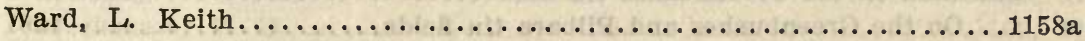

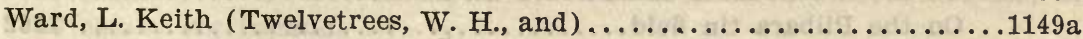

Warmbad, see Transvaal.

Warmbaths, see Transvaal, Warmbad.

Warner, Richard.................................. 1421

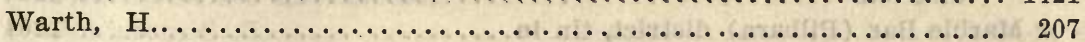

Washington, Collier on tin at Silver Hill, near Spokane.......... 1250

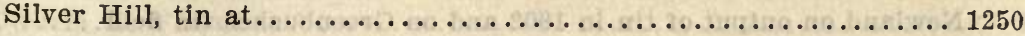

Spokane, tin near.................................. 1250

See also United States.

Waterberg, see Transvaal.

Watson, J. Y............................... 483

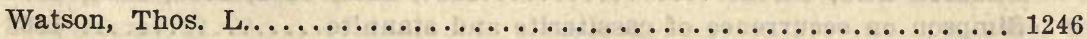

Watsonville, see Queensland.

Waukeroo, see New South Wales.

Wavellite, de Launay on occurrence in France................ 518

Weaver, Thomas...............................608, 609

Webb and Geach.................................. 484

Webster's workings, see Tasmania.

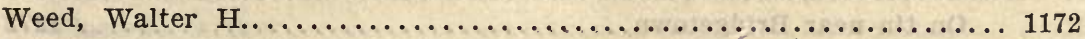

Weedon, Thornhill............................... 939

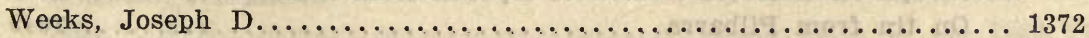

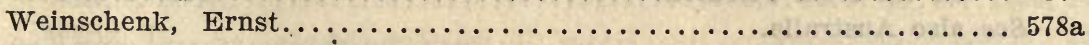

Welbeloond, see Cape Ċolony.

Welle Makwa, see French Kongo.

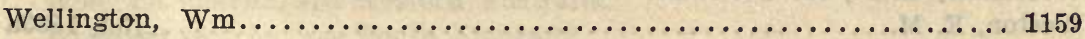

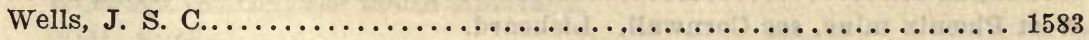

Wendron, see England.

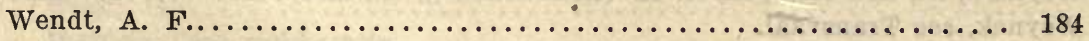

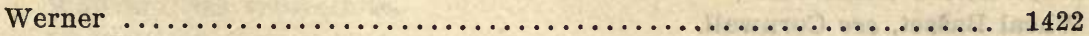

West, H. E.......................................... 485

Western Australia:

Tin in $\ldots \ldots \ldots \ldots \ldots \ldots \ldots \ldots \ldots \ldots \ldots \ldots \ldots .45,1254,1255,1290,1292$

Benedict on tín deposits of ........................ 1301

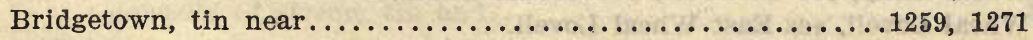

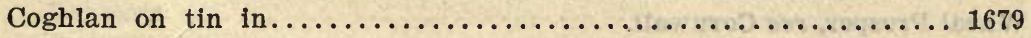

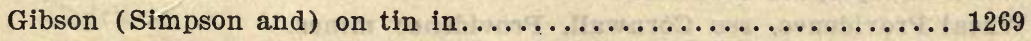

Greenbushes, tin mines at....1251, 1252, 1253, 1256, 1257, 1260, 1261,

$1263,1264,1265,1266,1267,1270,1273$

Jackson (Maitland and) on the Greenbushes and Marble Bar (Pil-

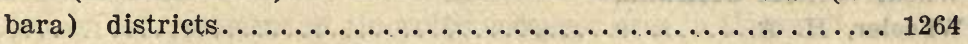

Krusch on Greenbushes tin workings................... 1257

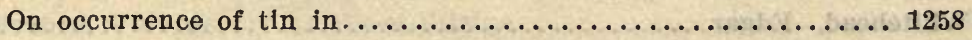

Laplage on tin near Bridgetown on the Blackwood River......... 1259 
Western Australia-Continued.

Reference

Number

Maitland on the Greenbushes tin field.................. 1260

On the Greenbushes and Pilbara tin fields.............. 1261

On the Pilbara tin field......................... 1262

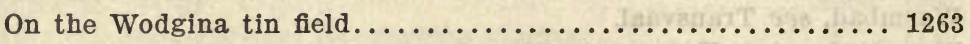

Maitland and Jackson on the Greenbushes and Marble Bar (Pilbara)

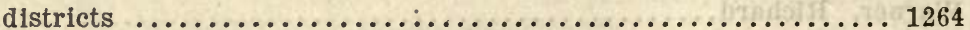

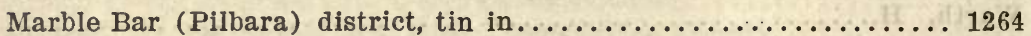

Mulholland on the Greenbushes tin field................. 1265

Newland on output of tin in 1902 and on Greenbushes tin field..... 1266

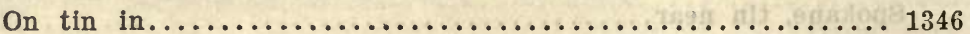

Newton on metalliferous minerals of .................. 55

Pilbarra, distorted cassiterite crystals from............... 1649

Pilbarra field, tin in ...........1256, 1261, 1262, 1263, 1264, 1271

Simpson on occurrence of cassiterite and stannite........... 1268

On tin ore from Greenbushes field.................. 1267

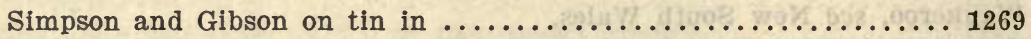

"Stannifer" on Greenbushes tin field.................... 1270

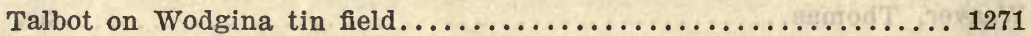

Wodgina district, tin in ........................... 1256, 1271

Woodward on Greenbushes tin field.................... 1273

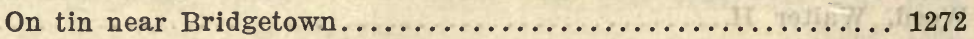

Woolnough on distorted cassiterite crystals from Pilbarra........ 1649

On tin from Pilbarra........................ 1649

See also Australia.

Western district, see Queensland.

West Kitty mine, see Cornwall.

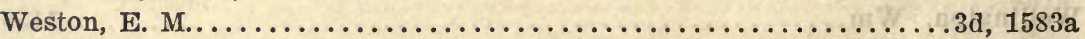

West Phœnix mine, see Cornwall, Liskeard.

Weyland, A., and Kempen, A. R. (Brandenburg, H., and) ......... 1456

Weynek, see Transvaal.

Wheal Basset, see Cornwall.

Wheal Breage, see Cornwall.

Wheal Comfort, see Cornwall, Providence mines.

Wheal Kitty, see Cornwall.

Wheal Laity, see Cornwall, Providence mines.

Wheal Lovell, see East. Wheal Lovell.

Wheal Prosper, see Cornwall.

Wheal Providence, see Cornwall, Providence mines.

Wheal Speed, see Cornwall, Providence mines.

Wheal Uny, see Cornwall.

Wheal Vor, see Cornwall.

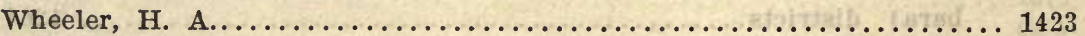

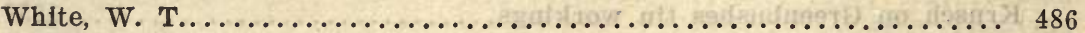

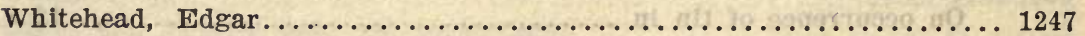

White River Bridge, see Tasmania. 


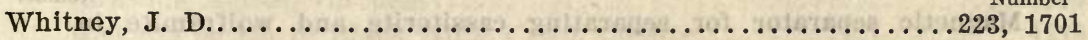

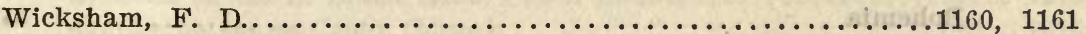

Wicklow, see Ireland.

Wilber, D. F., see No. 1675.

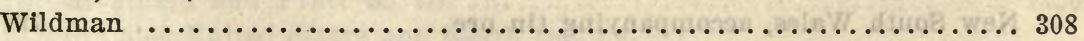

Wild River, see Queensland.

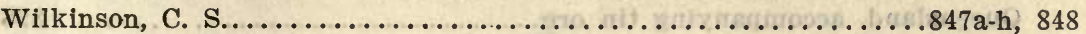

Wilkinson, C. S., and David, T. W. E....................... 849

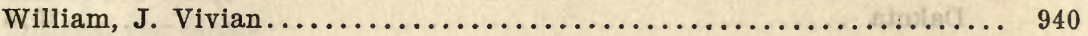

Williams, Archibald............................... 487

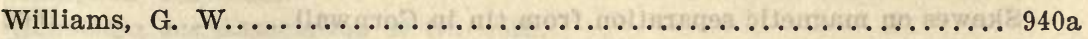

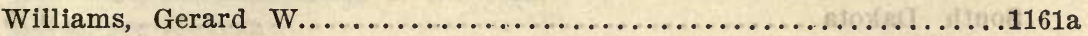

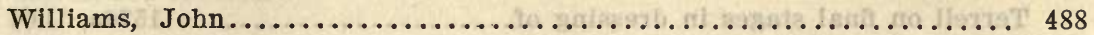

Williams, R. H..............................489, 1668

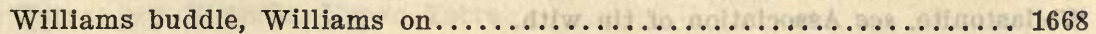

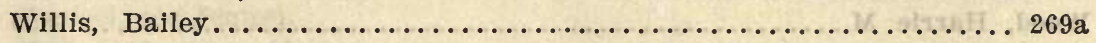

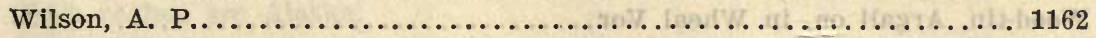

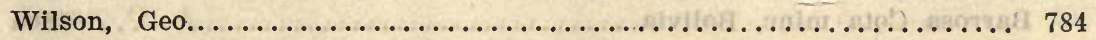

Wilson's Downfall, see. New South Wales.

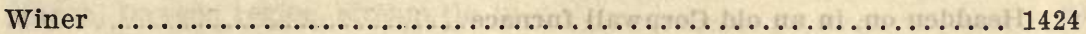

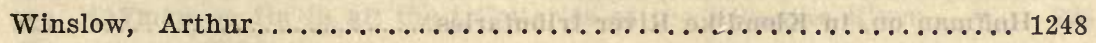

Winslow, see Maine.

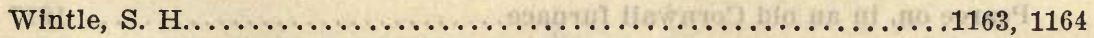

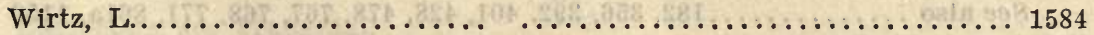

Witmer, Luther Ferree........................... 1585

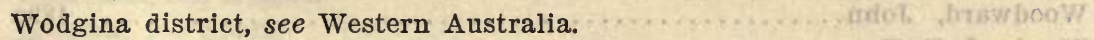

Wodonga district, see South Australia.

Wolf, A. G...................................... 231

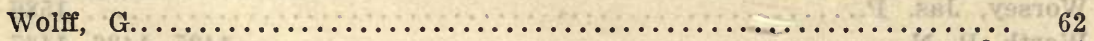

Wolfram, see wolframite.

Wolframite:

Andrews on origin of deposits in New South Wales............. 797

Associated with tin, see Association of tin with.

Barrow on relation of high level terraces of Bodmin Moor to

deposits of stream tin and $\ldots \ldots \ldots \ldots \ldots \ldots \ldots \ldots \ldots \ldots \ldots, 333$

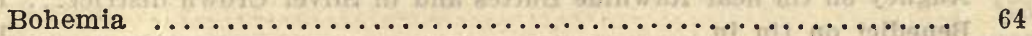

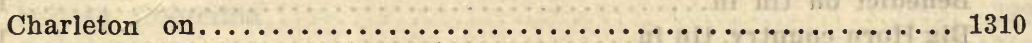

Clotten on occurrence with tin ore in Queensland........... 898

Cornwall .............................. 1479, 1662

Cornwall, Bodmin Moor......................... 333

Dietzsch on treatment of tin-wolfram-copper ores in Cornwall..... 1479

Dressing of tin ores containing............................ 1664

France, with tin ore at Ille-et-Vilaine.................. 514

Kerforne on presence with tin ore at Ille-et-Vilaine, France....... 514 
Wolframite-Continued.

Reference

Magnetic separator for separating cassiterite and wolframite in

Bohemia ...................................... 64

Malacca, with tin ore in placers....................... 682

Metallurgy of................................... 1479

New South Wales, accompanying tin ore................. 797

Origin of deposits................................ 797

Queeusland, accompanying tin ore................... 898

Storms (?) on deposits at Bear Gulch, in tin and gold placers, South

Dakota ..................................... 1015

Separation from tin............................. 1662

Skewes on magnetic separation from tin in Cornwall............ 1662

South Dakota................................... 1015

Terrell on final stages in dressing of.................1576a, 1664

See also Association of tin with.

Wollastonite, see Association of tin with.

Wood, Harrie M................................... 850

Wood-tin, Argall on, in Wheal Vor.......................... 330

Barrosa Cota mine, Bolivia.......................... 180a

Greg and Lettsom on ............................ 1614

Headden on, in an old Cornwall furnace................... 1617

Hoffman on, in Klondike River tributaries................. 228

Majendie on occurrence of .......................... 1342

Pearce on, in an old Cornwall furnace................... 1617

See also ...........182, 356, 392, 401, 428, 478, 767, 768, 771, 861a, 1156

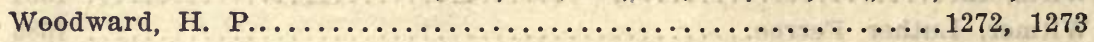

Woodward, John................................. 489a

Woods, J. E. T..................................... 63

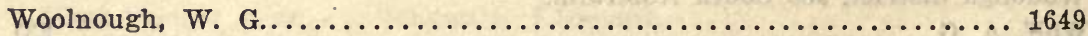

Worsey, Jas. P...................................... 1586

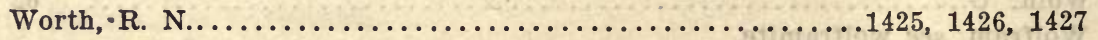

Wray, Leonard, Jr..........................744, 745, 746, 747

Wright, C. R. Adler................................. 1587

Wurtzite, see Association of tin with.

Wyborg, see Russia.

Wyoming:

Aughey on tin near Rawhide Buttes and in Silver Crown district... 1274

Benedict on tin in .................................. 1275

Big Horn country, tin in ............................. 1002

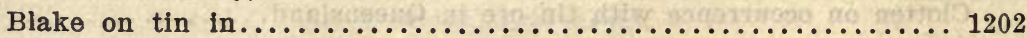

Chance on tin in the Big Horn country.................... 1002

Crook County, tin in............................1016, 1020

Crook County, tin in Black Hills in..................... 1276

Day on tin in the Nigger Hill district..................... 1318

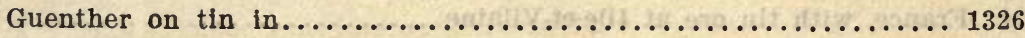

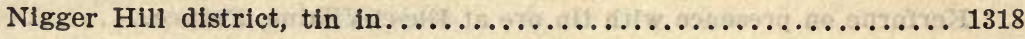


Wyoming-Continued.

Rawhide Buttes, tin near...................... 1274

Ricketts on tin in Black Hilis, Crook County................ 1276

Sadtier on tin in Crook County....................... 1016

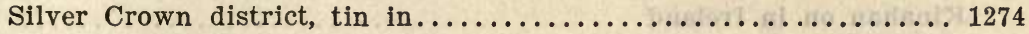

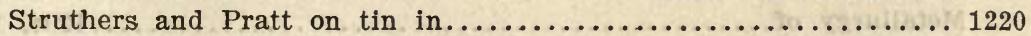

See aiso United States and South Dakota.

\section{$\mathrm{X}$}

Xaija, see Siam.

Xalang, see Siam.

Xamphon, see Siam.

Xenotime, see Association of tin with.

Xeres, see Mexico.

Yarra, see Victoria, Upper Yarra.

Yenisei, see Jenisei.

York region, see Alaska.

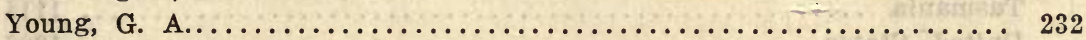

Yttrium, see Association of tin with.

Yukon, Dawson region, stream tin in...................... 23

Hoffman on tin in all the tributaries of the Klondike River..... 228

Yunnan, see China.

Zaaiplaats, see Transvaal.

Zacatecas, see Mexico.

Zamora, see Spain.

Zeehan, see Tasmania.

Zennor, see Cornwall.

Zinc:

Allen on alloy with copper and manganese............... 1431

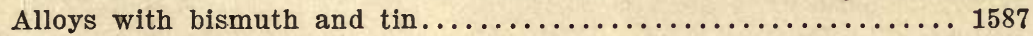

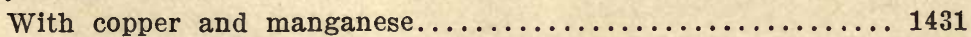

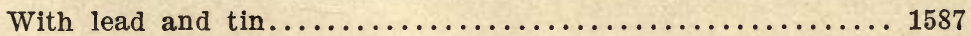

Associated with tin, see Association of tin with.

Beck on occurrence at Schwarzenberg, Germany............. 530

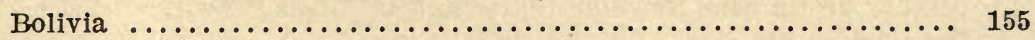

British Columbia............................... 229

Campagne on mines of . . . . . . . . . . . . . 1309

Cry of as indication of fitness of certain beams............ 1481

Douglas on metallurgy of .......................... 1204

Emmons on occurrence in United States and genesis of minerals of. . 1206

Germany, Freiberg ......................... 560

Germany, Schwartzenberg...................... 530

Hydrolysis of salts of, in presence of iodides and iodates....... 1537 
Zinc-Continued.

Reference

Ingalls, Argall, and Garde on zinc resources of British Columbia, and their exploitation......................... 229

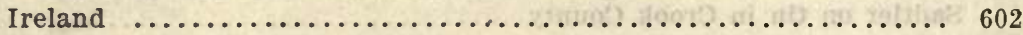

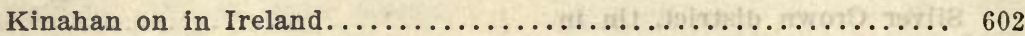

Metallurgy of..................................... 1549

Moody on hydrolysis of salts of, in presence of iodides and iodates. . 15.27

Moore on occurrence with tin in killas of St. Pauls Plains, Tasmania. 1114

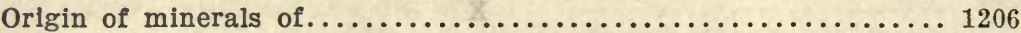

Perret on metallurgy of ............................ 1549

Pilz on deposits in Cartagena, Spain...................... 1040

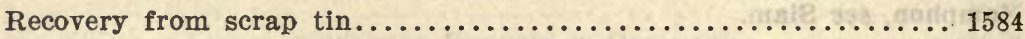

Richter on characteristics and working, and on relations with tin

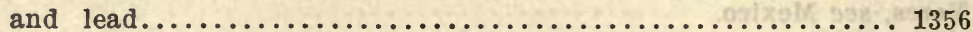

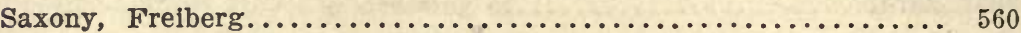

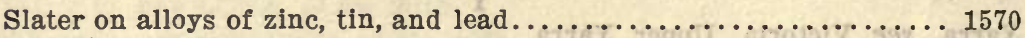

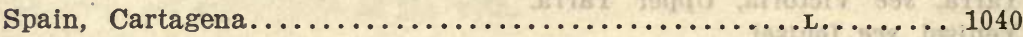

Sulphides of associated with tin in Bolivia................. 155

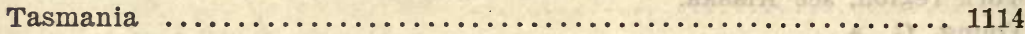

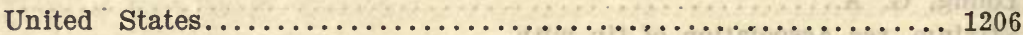

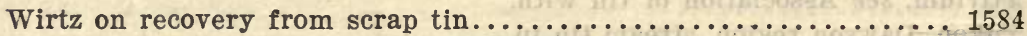

Wright on alloys of lead, tin, and zinc and bismuth, zinc, and tin... 1587

Zinc-blende, Müller and Richter on tin in at Freiberg, Germany...... 560

See Association of tin with.

Zinc sulphides, see Association of tin with.

Zinnwald, see Saxony.

Zinnwaldite, see Association of tin with.

Zircon, see Association of tin with.

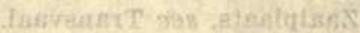

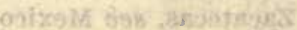

Zirkel, Ferdinand................................. 490

Zoutpansberg, see Transvaal.

Zwartkloof, see Transvaal. 







\section{UNIVERSITY OF CALIFORNIA LIBRARY}

BERKELEY

Return to desk from which borrowed.

This book is DUE on the last date stamped below. MINER|AL TECHINOLOGY LIBRARY

DEC 17195 


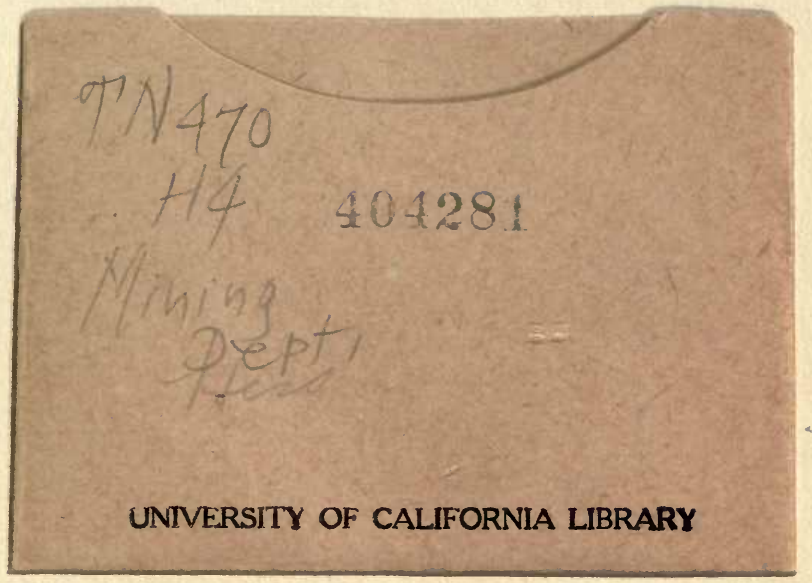


